Universidade de Brasília

Faculdade de Direito

\title{
ENTRE CONTINUIDADE E RUPTURA: UMA NARRATIVA SOBRE AS DISPUTAS DE SENTIDO DA CONSTITUIÇÃO DE 1988 A PARTIR DO DIREITO DE GREVE
}

Ricardo Machado Lourenço Filho

Brasília

2014 
Ricardo Machado Lourenço Filho

\section{ENTRE CONTINUIDADE E RUPTURA: UMA NARRATIVA SOBRE AS DISPUTAS DE SENTIDO DA CONSTITUIÇÃO DE 1988 A PARTIR DO DIREITO DE GREVE}

Tese de Doutorado apresentada ao Programa de Pós-Graduação em Direito da Faculdade de Direito da Universidade de Brasília, para obtenção do título de Doutor em Direito, Estado e Constituição.

Orientador: Prof. Dr. Cristiano Paixão

Brasília

2014 
Após sessão pública de defesa desta Tese de Doutorado, o candidato foi considerado aprovado pela Banca Examinadora.

Professor Doutor Cristiano Paixão

Orientador

Professor Doutor Menelick de Carvalho Netto

Membro

Professora Doutora Gabriela Neves Delgado

Membro

Professor Doutor Márcio Túlio Viana

Membro Externo

Professor Doutor Airton Lisle Cerqueira Leite Seelaender

Membro Externo

Professor Doutor Ricardo José Macedo de Britto Pereira

Suplente

Brasília, 18 de novembro de 2014. 
Para Noemia. 


\section{$\underline{\text { Agradecimentos }}$}

Várias circunstâncias marcaram a elaboração e a conclusão desta tese (como o fato de ter residido em três estados da Federação num lapso de menos de dois anos). As reflexões aqui apresentadas remontam a antes mesmo do ingresso no curso de Doutorado em Direito do Programa de Pós-Graduação da Faculdade de Direito da UnB, em março de 2010. Diversas pessoas participaram, de forma direta ou indireta, da trajetória percorrida.

Agradeço a meus pais, Ricardo e Edimê, e a meus irmãos, Bruno e André, que sempre acompanharam com interesse minha vida acadêmica.

Um obrigado especial à Noemia, minha companheira, cujo amor tem me ensinado a olhar além do horizonte. Seu sorriso tem me guiado desde que estamos juntos. Sua companhia é fundamental. Agradeço também aos pequenos Ana Paula, Hannah, Igor, Ian e Fernando, que têm uma alegria contagiante.

Obrigado aos amigos (e "compadres") de todos os tempos: Sérgio Peres, Érica, Paulo Roberto, Vanessa Matos, Hugo Carneiro ("Maranhas”), Gabriel Bourguignon, Luciano Rodrigues, Júlia e Isabela Rodrigues, “Jão” Henrique. Aos amigos da Unb, com quem tive a oportunidade de trocar algumas reflexões sobre a pesquisa: Mariana Cirne, Carolina Ferreira, Douglas, Daniela, Paulo Blair, Renato Bigliazzi e Leonardo Barbosa. Agradecimento especial à amiga Aline Lisboa, que se dispôs a ler o texto e dialogar sobre a pesquisa.

Ao amigo, professor e orientador Cristiano Paixão, a quem considero um exemplo de dedicação à docência e à pesquisa. Agradeço pela experiência compartilhada nas inúmeras pesquisas desde a graduação e pelo apoio na minha vida profissional.

Aos amigos "mineiros", com quem partilhei momentos únicos quando do ingresso na magistratura trabalhista: Anderson Rico ("Baiano"), Raphael Brolio ("Pata"), Alexandre Toledo, Ricardo Tupy, Lenício Pimentel, André Barbieri, Daniela Mori, Juliana Petenate, Rachel Freire e Marcos Dani.

À Ministra Maria Cristina Irigoyen Peduzzi, com quem muito aprendi nos anos em que trabalhei em seu gabinete e que sempre torceu pelas minhas investidas acadêmicas.

Aos professores do Programa de Pós-Gradução em direito da Faculdade de Direito da Universidade, em especial a Argemiro Martins Cardoso, Cláudia Roesler, Guilherme Scotti, Alexandre Bernardino Costa e José Geraldo de Sousa Júnior. 
Agradeço também aos professores Menelick de Carvalho Netto e Airton Seelaender, pelas observações realizadas na banca de qualificação da tese e que foram essenciais para o desenvolvimento da pesquisa.

Aos amigos dos grupos de pesquisa da UnB "Sociedade, Tempo e Direito", "Percursos, Narrativas e Fragmentos: História do Direito e do Constitucionalismo" e "Trabalho, Constituição e Cidadania".

Agradeço aos amigos da Secretaria da Faculdade de Direito da UnB, em especial a Helena, Lionete, Carlinhos, Diogo, João e Euzilene, pela constante atenção e disponibilidade.

À equipe da CGEDM, do Tribunal Superior do Trabalho, pelo auxílio indispensável na consulta e disponibilização do processo do dissídio coletivo digitalizado e das notas taquigráficas das sessões de julgamento. 


\section{$\underline{\text { Resumo }}$}

O objetivo desta tese é construir uma narrativa sobre as disputas de sentido da Constituição de 1988, tendo como eixo de investigação o direito de greve. A preocupação da pesquisa diz respeito aos usos do texto constitucional. As práticas atuais sobre a greve, sobretudo as que podem ser constatadas nas decisões da Justiça do Trabalho, em especial do Tribunal Superior do Trabalho, indicam a necessidade de construção de um discurso constitucional sobre o direito de greve. A Constituição de 1988 tem como uma de suas dimensões fundamentais a tensão entre continuidade e ruptura com o regime anterior. $\mathrm{O}$ direito de greve reflete essa tensão. Trata-se aqui de compreender a Constituição em perspectiva histórica. Na Assembleia Nacional Constituinte de 1987/1988, a greve era um dos temas centrais de discussão. Diversos constituintes e representantes sindicais, entre outros, se ocuparam em indicar as práticas com as quais se pretendia romper a partir da promulgação do novo texto constitucional, como a intervenção da Justiça do Trabalho nas greves. Com o advento da Constituição, é necessário observar quais usos são dados a ela, quais construções de sentido são realizadas, quais disputas por seu significado têm lugar. A greve dos petroleiros, deflagrada em maio de 1995, permite essa investigação. A reação do Poder Público traz à tona elementos próprios do regime anterior à Constituição, como o recurso às Forças Armadas, ou o discurso de defesa da "segurança nacional". A intervenção do Tribunal Superior do Trabalho é um dos aspectos que mais chama a atenção na greve de 1995, havendo indícios de que a Corte atuou de maneira comprometida com a política econômica do governo. $\mathrm{O}$ exame das decisões do TST propicia a observação de algumas construções de sentido que têm balizado, até hoje, as práticas da Justiça do Trabalho nas greves, como a imposição de multas às entidades sindicais. $\mathrm{O}$ texto constitucional per se não tem força para alterar a realidade. $\mathrm{A}$ elaboração de um discurso adequado à Constituição de 1988 demanda a revisão de determinados usos, práticas e atitudes. O direito de greve comporta várias leituras, seja como direito à violência, expressão da rebeldia do trabalho, direito de resistência. Cuida-se de uma reação às operações dos sistemas funcionais da sociedade moderna (como o direito, a política e economia), reação essa engendrada mediante a ruptura do cotidiano da prestação dos serviços. O que é decisivo é a compreensão da greve como abertura a possibilidades comunicativas (de protesto, de denúncia, de crítica). Isso exige uma estratégia de ruptura com as atuais normas de leitura da Constituição. 


\section{$\underline{\text { Abstract }}$}

The aim of this thesis is to elaborate a narrative of the struggles about the meaning of the 1988 Constitution, using, as line of investigation, the right to strike. The concern relates to the uses of the constitutional text. Current practices on strike, especially those that may be found in decisions of Labour Justice, in particular those of the Superior Labour Court, indicate the need of the construction of a discourse about the constitutional right to strike. The 1988 Constitution has as one of its fundamental aspects the tension between continuity and rupture with the previous regime. The right to strike reflects this tension. The point is to understand the Constitution in historical perspective. At the National Constituent Assembly of $1987 / 1988$, the strike was one of the central topics of discussion. Various constituents and union represents, among others, were engaged in indicating the practices with which they were intending to break since the new Constitution was promulgated, as the intervention of Labour Justice in strikes. With the Constitution, it is necessary to observe what uses are given to it, what meaning constructions are carried out, which disputes over its sense take place. A strike carried out by the workers of Petrobrás, in May 1995, allows this investigation. The reaction of the Public Power itself brings out elements of the previous regime, before the Constitution, such as the use of the military, or the discourse about defense of "national security". The intervention of the Superior Labour Court is one of the aspects of the 1995 strike that call attention. There are evidences that the Court acted in a way compromised with the government's economic policy. An analysis of the Court's decisions provides the observation of some constructions of meaning that have marked, until today, the practices of the Labour Justice about strikes, such as the imposition of fines on unions. The constitutional text per se does not have the strength to change reality. The development of an appropriate speech about the 1988 Constitution demands a revision of certain uses, practices, attitudes. The right to strike support various readings, such as right to violence, rebellion of work expression, the right to resistance. It is a reaction to the operations of the functional systems of modern society (such as law, politics and economy), and this reaction is manifested by the disruption of everyday service. What is decisive is the understanding of the strike as opened communicative possibilities (of protest, complaint, critics). This requires a strategy of disruption with the current standards of reading the Constitution. 


\section{Sumário}

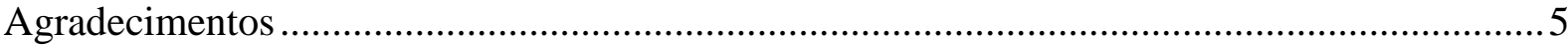

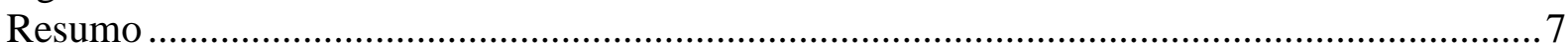

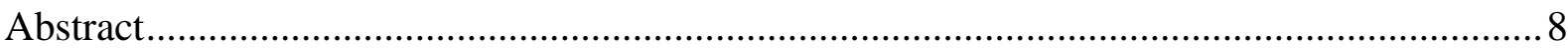

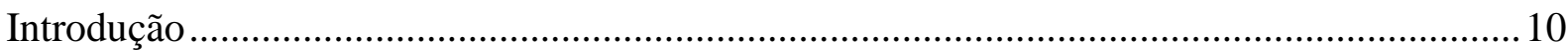

Capítulo 1: As discussões na Assembleia Nacional Constituinte de 1987/1988 sobre o direito

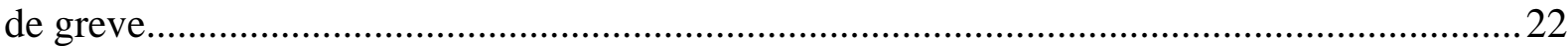

1.1. Antecedentes e instalação da Assembleia Nacional Constituinte .................................22

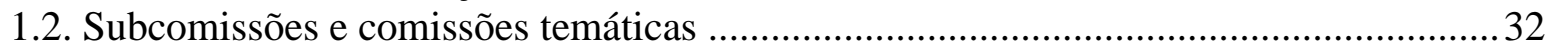

1.2.1. Subcomissão dos Direitos dos Trabalhadores e Servidores Públicos ..................... 33

1.2.2. As audiências públicas promovidas pela Subcomissão e a participação da

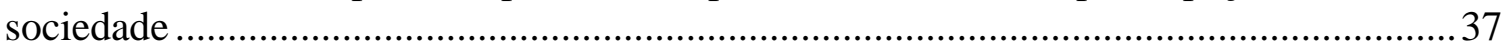

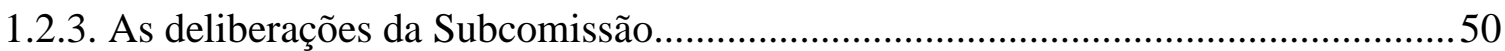

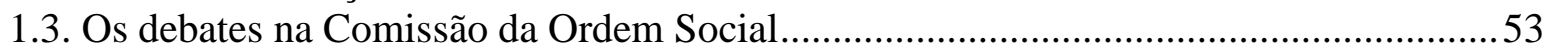

1.4. Os debates no âmbito da Comissão da Soberania e dos Direitos e Garantias do Homem

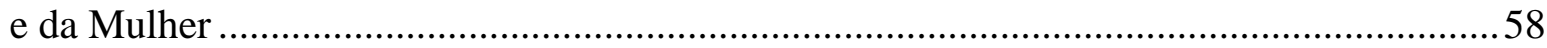

1.5. O percurso na Comissão de Sistematização .............................................................. 70

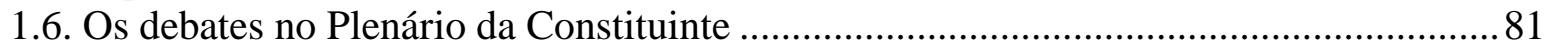

Capítulo 2: A greve dos petroleiros de 1995 e a decisão do Tribunal Superior do Trabalho -

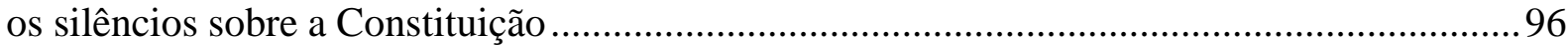

2.1. Antecedentes: a negociação e os acordos firmados em 1994 ........................................96

2.2. A greve de 1995: a resistência dos petroleiros e a postura do Poder Público............... 103

2.3. O primeiro julgamento pelo TST: abusividade da greve e invalidade dos acordos..... 123

2.4. O segundo julgamento da greve pelo TST e as tentativas de encerramento do conflito

2.5. A decisão do Comitê de Liberdade Sindical da OIT

2.6. A execução das multas aplicadas e a ação dos trabalhadores e dos sindicatos pela

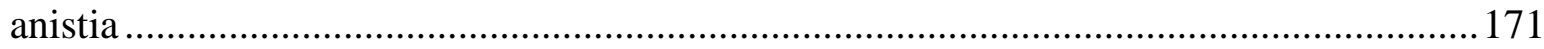

Capítulo 3: O direito de greve como espelho dos desafios da Constituição de 1988 ............. 178

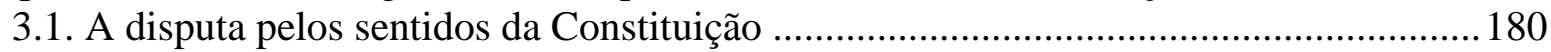

3.2. A atuação da Justiça do Trabalho nas greves e o papel dos tribunais...........................196

3.3. O direito de greve como abertura a possibilidades comunicativas ...............................222

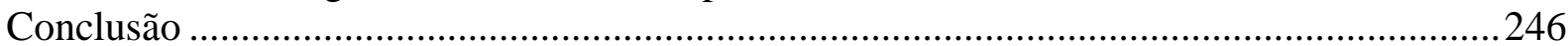

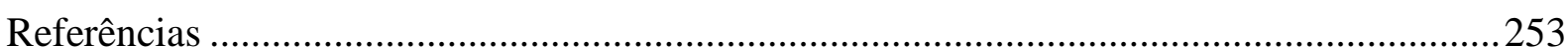

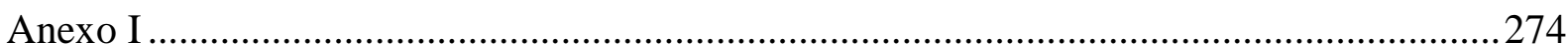

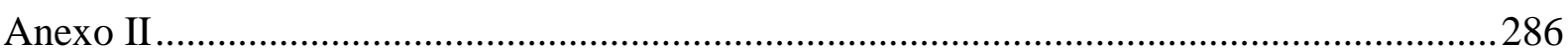




\section{$\underline{\text { Introducão }}$}

Em junho de 2014, os metroviários do Estado de São Paulo deflagraram greve. A imprensa noticiou os transtornos causados, em particular os problemas no trânsito da cidade de São Paulo decorrentes da paralisação do metrô. A Polícia Militar foi mobilizada pelo governo estadual para impedir a realização de piquetes em uma das estações. Os grevistas insistiam, protestavam, faziam outros piquetes. Mas não houve muito tempo para o conflito. Em poucos dias, a Justiça do Trabalho foi acionada. No quinto dia da greve, o Tribunal Regional do Trabalho da $2^{\mathrm{a}}$ Região, além de ter convocado audiências de conciliação entre as partes, já havia proferido duas decisões: uma liminar - no terceiro dia, atendendo a pedido do Ministério Público do Trabalho - estabelecendo um contingente mínimo de trabalhadores em atividade (100\% nos horários de pico e $70 \%$ nos demais, sob pena de multa de $\mathrm{R} \$ 100.000,00$ por dia); e uma definitiva (embora ainda recorrível), julgando abusiva a greve dos metroviários e determinando o imediato retorno dos grevistas à atividade, sob pena de multa de $\mathrm{R} \$ 500.000,00 .^{1}$ De acordo com o Desembargador relator do processo, no Tribunal Regional, "o direito de greve não pode ser balizado em autoritarismo ou no exercício arbitrário de escolhas subjetivas. Não houve atendimento mínimo à população, gerando grande transtorno, inclusive no âmbito da segurança pública".2

Em outra situação, o Tribunal Superior do Trabalho, órgão de cúpula da Justiça do Trabalho, julgou abusiva a greve realizada por professores e auxiliares administrativos de importante universidade do país em protesto diante da não-nomeação para o cargo de reitor do candidato que figurara no topo da lista tríplice - fora nomeada a candidata menos votada. Para o Ministro relator do caso, “a Constituição da República de 1988, em seu art. 9ª assegura o direito de greve, competindo aos trabalhadores decidir sobre a oportunidade de exercê-lo e os interesses que devam por meio dele defender". Ainda segundo o relator, "todavia, embora o direito de greve não seja condicionado à previsão em lei, a própria Constituição (art. 114, § $1^{\circ}$ ) e a Lei $n^{\circ} 7.783 / 1989$ (art. $3^{\circ}$ ) fixaram requisitos para o exercício do direito de greve (formais e materiais), sendo que a inobservância de tais requisitos constitui abuso do direito de greve (art. 14 da Lei $n^{\circ}$ 7.783)". E prosseguia o Ministro: "em um tal contexto, os

\footnotetext{
${ }^{1}$ Até a conclusão desta pesquisa, o Tribunal Regional do Trabalho ainda não havia publicado o acórdão da sessão de julgamento em que a greve dos metroviários fora declarada abusiva. Não obstante, as informações respectivas podem ser buscadas no sítio do Tribunal na internet (www.trt2.jus.br), a partir das notícias divulgadas no período de 4 a 10 de junho de 2014. Outros dados podem ser encontrados nos sítios dos jornais Folha de São Paulo (www.folha.uol.com.br) e Estado de São Paulo (www.estadao.com.br) do mesmo período. 2 Retirado do sítio do Tribunal Regional do Trabalho da $2^{\text {a }}$ Região na internet, http://www.trt2.jus.br/indicenoticias-em-destaque/18606-metro-trt-2-declara-greve-dos-trabalhadores-abusiva (acesso em 21.6.2014).
} 
interesses suscetíveis de serem defendidos por meio da greve dizem respeito a condições contratuais e ambientais de trabalho, ainda que já estipuladas, mas não cumpridas; em outras palavras, o objeto da greve está limitado a postulações capazes de serem atendidas por convenção ou acordo coletivo, laudo arbitral ou sentença normativa da Justiça do Trabalho $(\ldots)^{\prime 3}$

Esse raciocínio deixa evidente a íntima relação entre o exercício do direito de greve e a intervenção da Justiça do Trabalho no Brasil. Como os dois casos acima permitem identificar, a Justiça Especializada tem atuado, nas greves, de várias maneiras: pela imposição de contingentes mínimos de trabalhadores em atividade, pelo estabelecimento de multas, pela declaração de abusividade com determinação de imediata retomada dos serviços. Além disso, há as ações de interdito proibitório, ajuizadas ao argumento de defesa do direito de propriedade do empregador em face dos grevistas. Outro aspecto fundamental é o fato de que a intervenção do Poder Judiciário se dá a partir da provocação unilateral de uma das partes do conflito (em regra, o empregador) ou do Ministério Público do Trabalho. As respostas dadas pela Justiça do Trabalho mantêm velada uma postura de negação ou, pelo menos, de busca pela diminuição do conflito na sociedade.

Diante do art. $9^{\circ}$ da Constituição de 1988, que assegura o direito de greve com uma amplitude inédita na história do país, ${ }^{4}$ o que se percebe, em inúmeras decisões da Justiça do Trabalho, é a maior importância dada à Lei 7.783/1989, articulada de maneira a estabelecer limites e restrições ao direito de greve. A lei ordinária adquire uma normatividade preponderante. A questão subjacente, porém, diz respeito ao significado da Constituição. Falta o desenvolvimento de um discurso constitucional sobre o direito de greve.

Um dos caminhos para a construção desse discurso constitucional pode ser a investigação sobre os usos da Constituição de 1988, que tem, como uma de suas dimensões principais, a tensão entre ruptura e continuidade com relação ao regime anterior. Trata-se de compreender a Constituição em perspectiva histórica. Duas indagações centrais podem, então, ser colocadas: com quais práticas e discursos se buscou romper a partir da Constituição de

\footnotetext{
3 BRASIL. Tribunal Superior do Trabalho. Seção de Dissídios Coletivos. Recurso Ordinário $\mathrm{n}^{\circ} 51534$ 84.2012.5.02.0000, Rel. Ministro Walmir Oliveira da Costa. Diário Eletrônico da Justiça do Trabalho, Brasília, DF, 20.6.2014.

${ }^{4}$ Vale conferir sua redação: "é assegurado o direito de greve, competindo aos trabalhadores decidir sobre a oportunidade de exercê-lo e sobre os interesses que devam por meio dele defender. $\S 1^{\circ}$ A lei definirá os serviços ou atividades essenciais e disporá sobre o atendimento das necessidades inadiáveis da comunidade. $\S 2^{\circ}$ Os abusos cometidos sujeitam os responsáveis às penas da lei" (BRASIL. Constituição (1988). Constituição da República Federativa do Brasil. Diário Oficial da União, Brasília, DF, 5.10.1988).
} 
1988? E, uma vez promulgado o texto, como foi ele interpretado, aplicado, utilizado diante das possibilidades abertas para o exercício daquelas práticas e daqueles discursos?

A hipótese da presente pesquisa é a de que o direito de greve reflete essa tensão da Constituição de 1988 entre ruptura e continuidade. Isso conduz a outra série de questionamentos: quais práticas e quais discursos, pertinentes à greve, se pretendeu interromper com a Constituição? Qual o sentido do art. $9^{\circ}$ do texto constitucional? E quais usos tem sido dado à Constituição em face das oportunidades de recurso àquelas práticas e àqueles discursos? Como o texto constitucional vem sendo utilizado nas intervenções da Justiça do Trabalho nas greves? Seria possível falar, nesse aspecto, em um governo de juízes?

Lançadas essas questões, é necessário começar a pesquisa com a Assembleia Nacional Constituinte de 1987/1988. A Constituinte ocorreu num período marcado por uma significativa mobilização popular, cujo ápice foi o movimento das Diretas Já. As reivindicações se voltavam ao reconhecimento de direitos até então negados ou bastante restringidos, à ampliação da cidadania, da democracia e de participação política. Aliás, um dos mecanismos de participação política foram justamente as greves que caracterizaram o contexto, sobretudo a partir de 1978, com as paralisações deflagradas no ABC paulista. A força da sociedade civil organizada se dirigiu, posteriormente, à ANC, acompanhando de perto os trabalhos que resultaram no novo texto constitucional. Uma das palavras mais recorrentes dos discursos que circularam na Assembleia Constituinte era a de mudança.

$\mathrm{Na}$ área das relações coletivas de trabalho e, de maneira mais particularizada, no que diz respeito ao direito de greve, foram inúmeras as vozes que explicitavam as práticas que se pretendia modificar a partir da nova constituição, numa perspectiva de ruptura com a ordem anterior. Entre essas práticas estavam a intervenção da Justiça do Trabalho, o condicionamento do direito a partir de uma legislação ordinária que impedia ou dificultava seu exercício e as restrições quanto às atividades essenciais. ${ }^{5}$ A Constituição foi promulgada, em 5 de outubro de 1988, com o desafio da mudança, e marcada pela presença popular. ${ }^{6}$

\footnotetext{
${ }^{5}$ A Constituição de 1967, emendada em 1969, proibia a greve no serviço público e nas atividades essenciais (art. 157, § 7º da Carta de 1967 e art. 162 da EC 1\%/1969). Cf. BRASIL. Constituição (1967). Constituição do Brasil. Diário Oficial da União, Brasília, DF, 24.1.1967.

${ }^{6}$ Em seu discurso, na sessão de promulgação da Constituição, o constituinte Ulysses Guimarães (PMDB), Presidente da ANC, destacou o aspecto da mudança, remetendo às palavras que utilizara quando tomou posse no cargo de Presidente, enfatizando, ainda, a participação popular nos trabalhos da Assembleia. Transcrevem-se os seguintes trechos: “dois de fevereiro de 1987: 'ecoam nesta sala as reivindicações das ruas. A Nação quer mudar, a Nação deve mudar, a Nação vai mudar'. São palavras constantes do discurso de posse como Presidente da Assembléia Nacional Constituinte. Hoje, 5 de outubro de 1988, no que tange à Constituição, a Nação mudou. (...)A Constituição mudou na sua elaboração, mudou na definição dos poderes, mudou restaurando a Federação, mudou quando quer mudar o homem em cidadão, e só é cidadão quem ganha justo e suficiente salário, lê e escreve, mora, tem hospital e remédio, lazer quando descansa. (...)A Assembléia Nacional Constituinte rompeu
} 
O resultado dos embates sobre o sentido da nova constituição, na Assembleia Nacional Constituinte, foi um texto que garante o direito de greve e prevê que cabe aos trabalhadores decidir quando e porque exercê-lo. Mas qual o significado dessa inovação constitucional? Como ela se relaciona com os desafios da Constituição de 1988 ?

A proposta da pesquisa é examinar os discursos dos constituintes e dos demais atores que participaram da Assembleia, especificamente no que diz respeito às discussões sobre o direito de greve. Busca-se também identificar em que medida a movimentação popular, com a reivindicação por democracia, por reconhecimento de direitos, por cidadania, influenciou os trabalhos da ANC, o que pode fornecer uma importante dimensão das disputas entre continuidade e ruptura com o regime anterior à Constituição.

É preciso, em seguida, analisar os usos do texto constitucional, tendo como pano de fundo o direito de greve. E o ponto de observação selecionado é a greve nacional dos petroleiros realizada em 1995. Cuida-se de um dos movimentos trabalhistas mais relevantes na história recente do país. A greve durou aproximadamente 30 dias, com significativos impactos em várias regiões. O recurso às Forças Armadas, que ocuparam algumas refinarias, ativou um elemento da memória próprio do regime anterior à Constituição de 1988. Embora as negociações tenham se dado entre o governo e a Petrobrás, a Justiça do Trabalho, por meio do Tribunal Superior do Trabalho, teve uma atuação muito acentuada. Aqui será possível examinar parte das formas de intervenção da Justiça Especializada nas greves e como o texto constitucional é articulado.

A ideia é investigar as construções de sentido sobre a Constituição, adotando, como eixo de pesquisa, o direito de greve. O movimento dos petroleiros de 1995, quando considerada a intervenção da Justiça do Trabalho, traz à tona a tensão entre permanência e ruptura com determinadas práticas relacionadas à greve. É importante pontuar o papel que o Tribunal Superior do Trabalho exerceu nesse conflito, o que coloca o problema da gestão das greves pelo Poder Judiciário.

contra o "Establishment", investiu contra a inércia, desafiou tabus. (...) Foi de audácia inovadora a arquitetura da Constituinte, recusando anteprojeto forâneo ou de elaboração interna. O enorme esforço é dimensionado pelas 61.020 emendas, além de 122 emendas populares, algumas com mais de um milhão de assinaturas, que foram apresentadas, publicadas, distribuídas, relatadas e votadas, no longo trajeto das subcomissões à redação final. A participação foi também pela presença, pois diariamente cerca de dez mil postulantes franquearam, livremente, as onze entradas do enorme complexo arquitetônico do Parlamento, na procura dos gabinetes, comissões, galeria e salões. Há, portanto, representativo e oxigenado sopro de gente, de rua, de praça, de favela, de fábrica, de trabalhadores, de cozinheiras, de menores carentes, de índios, de posseiros, de empresários, de estudantes, de aposentados, de servidores civis e militares, atestando a contemporaneidade e autenticidade social do texto que ora passa avigorar" (BRASIL. Assembleia Nacional Constituinte. Ata da 340 a Sessão da Assembleia Nacional Constituinte, Brasília: Senado Federal, Secretaria Especial de Editoração e Publicações. Subsecretaria de Anais, 1988, documento eletrônico - XXV, p. 322). 
O objetivo da pesquisa é, portanto, apreender a Constituição mediante a investigação dos usos, das práticas e dos discursos engendrados a partir dela. E, antes disso, busca-se reconstruir os desafios que permearam a sua própria elaboração, isto é, o momento de exercício do poder constituinte que lhe deu origem. Daí a opção pela história constitucional. Essa decisão deve ser esclarecida.

Gustavo Zagrebelsky observa que o pressuposto necessário para qualquer compreensão de direito constitucional é responder a perguntas como: para que serve, aqui e agora, uma constituição? Ou para que um direito constitucional? A história e, em particular, a história constitucional podem atuar como fator de compreensão do direito. ${ }^{7}$

De acordo com Zagrebelsky, a constituição estabelece um vínculo entre passado e futuro. Nos Estados Unidos, o "mito" da vontade dos pais fundadores, como objeto e razão das investigações de direito constitucional, marca ainda hoje os debates sobre a interpretação constitucional. Assumindo a vontade constituinte confiada a um texto como ponto de inflexão entre um "antes" a-constitucional ou anticonstitucional e um "depois" constitucional, a ciência jurídica da constituição, ou seja, o direito constitucional, se expressa como o instrumento para assegurar a ruptura e a propensão à fundação de um "desde então até adiante". Por outro lado, segundo as concepções constitucionais da Revolução, em França, a constituição não tem um passado, mas, tão somente, produz futuro. As constituições se propõem a fazer história em seu futuro, mas sem ter uma história "em suas costas". A ideologia dos revolucionários está contida em uma posição "a-histórica" ou "anti-histórica". É uma visão da constituição sem passado, pois essa última surge de uma fratura, mas também sem futuro, ou, mais precisamente, com futuro concentrado e contraído na aceleração representada pelo ato constituinte e que pode tão somente descuidar ou combater a história como força constituinte. ${ }^{8}$

Zagrebelsky aponta, contudo, uma mudança na realidade atual. Houve uma ruptura, uma alteração na prestação funcional da constituição, que, de ato criativo, transformou-se em texto responsivo. A posição do sujeito perante a constituição também foi

\footnotetext{
7 Ver ZAGREBELSKY, Gustavo. Historia y constitución. Tradução de Miguel Carbonell. Madrid: Minima Trotta, 2005. Ernst-Wolfgang Böckenförd, por sua vez, aponta que a história constitucional é um ramo da história e do direito constitucional. Trata-se de condição necessária para a adequada compreensão do direito constitucional vigente. Para ele, a constituição transcende os textos constitucionais e sua interpretação, daí a importância da história constitucional, em cujos marcos é necessário examinar os pressupostos, o contexto e os efeitos do texto constitucional (cf. BÖCKENFÖRD, Ernst-Wolfgang. "La constitución: entre la historia y el derecho". Entrevista con E-W Böckenförd, por Joaquín Valera Suanzes-Carpegna. Trad. por Benito Alaez Corral. In: Historia constitucional - revista eletrônica, $\mathrm{n}^{\mathbf{0}}$ 5, 2004, p. 334 - disponível em http://hc.rediris.es/05/indice.html, acesso em 10.4.2013).

${ }^{8}$ Cf. ZAGREBELSKY, Gustavo. Historia y constitución., p.51/55.
} 
modificada. A postura agora é a da interrogação (ao invés de simples obediência). A constituição que exigia sujeição ao seu projeto político social imperativamente estabelecido dá espaço à constituição à qual nos dirigimos para encontrar respostas que podem ser compartilhadas aos interrogantes que surgem dos casos difíceis da vida constitucional. A razão fundamental dessa mudança é a queda da soberania, a qual arrastou o poder constituinte. A constituição não pode mais ser considerada como o ponto de partida de uma força unívoca e incondicionada. Ela agora se converteu em um ponto de chegada e de convergência do pluralismo político e social. ${ }^{9}$

A constituição é observada a partir da realidade - e não o contrário - e isso faz com que sejam postas questões como a legitimidade da própria constituição. De acordo com Zagrebelsky, essa legitimidade está relacionada à capacidade da constituição de oferecer respostas adequadas, ou, mais especificamente, à capacidade do direito constitucional de encontrar tais respostas na constituição. A constituição per se não diz, mas nós a fazemos dizer. É nesse marco contextual, segundo aquele autor, que devemos recolocar as questões metodológicas do direito constitucional como ciência e, entre elas, a relação entre a constituição e a história.

Os princípios têm um papel fundamental na relação da constituição com o passado, o presente e o futuro. As normas constitucionais de princípio correspondem à formulação sintética das matrizes histórico-sociais do ordenamento jurídico. Indicam as raízes, mas, também, uma direção. Oferecem um ponto de referência no passado e, simultaneamente, orientam o futuro. ${ }^{10}$

A interpretação constitucional não é um ato pontual e a-histórico. Pelo contrário, considerando uma constituição baseada em princípios, a interpretação é o ato que relaciona um passado constitucional assumido como valor e um futuro que se nos apresenta como problema para resolver na linha de continuidade. O futuro nos aparece à luz de uma précompreensão, à luz dos princípios constitucionais. Todavia, essa pré-compreensão não pode ser senão uma pós-compreensão à luz, novamente, dos princípios que nos permitem atingir a consciência histórico-cultural do acontecimento constitucional de que somos partícipes, no transcurso das épocas políticas e sociais.

Conforme a conclusão de Zagrebelsky,

\footnotetext{
${ }^{9}$ Cf. ZAGREBELSKY, Gustavo. Historia y constitución, p. 81/82.

10 Para Zagrebelsky, "os princípios dizem, por um lado, de que passado se provém, em que linhas de continuidade o direito constitucional atual quer estar imerso; por outro, dizem a que futuro está aberta a constituição. Os princípios são, ao mesmo tempo, fatores de conservação e de inovação, de uma inovação que consiste na realização sempre mais completa e adequada às circunstâncias do presente do gérmen 'primeiro' que constitui o princípio" (In: Historia y constitución. p. 89).
} 
as constituições de nosso tempo observam o futuro considerando firme o passado, ou seja, o patrimônio de experiência histórico-constitucional que querem salvaguardar e enriquecer. Se poderia dizer também: passado e futuro se ligam em uma única linha e, tal como os valores do passado orientam a busca pelo futuro, assim também as exigências do futuro obrigam a uma contínua pontualização do patrimônio constitucional que vem do passado e, portanto, a uma incessante redefinição dos princípios da convivência constitucional. A 'história' constitucional não é um passado inerte, senão a contínua reelaboração das raízes constitucionais do ordenamento que nos é imposta no presente pelas exigências constitucionais do futuro. ${ }^{11}$

A abordagem de Gustavo Zagrebelsky evidencia o papel da investigação histórica para a compreensão da Constituição, do direito constitucional e, em última análise, do próprio constitucionalismo moderno. ${ }^{12}$

Ignacio Fernández Sarasola destaca que, para a história constitucional, a constituição é um produto histórico e, como tal, definido pelo contexto. ${ }^{13}$ A constituição resulta do constitucionalismo como movimento político e, como ele, origina-se com o objetivo de limitar o Estado. Estão abarcados pela história constitucional os distintos tipos de constituições em que se traduziu o constitucionalismo moderno, ou seja, liberais, sociais e democráticas. Além disso, na abordagem da história constitucional, não se pode deixar de lado as normas que dispõem sobre a organização e o funcionamento dos órgãos superiores do estado, bem como sobre os direitos e as liberdades fundamentais. Ainda que tais leis não se identifiquem com a constituição, elas a desenvolvem.

É necessário ter em conta que as constituições utilizam elementos do regime político e da cultura jurídica que lhe são anteriores. Seria equivocado fazer tábua rasa do ordenamento jurídico (e administrativo) precedente. Ou seja, há um elemento, na constituição, de preservação, implícita ou explícita, das instituições pretéritas, mesmo que adaptadas à nova realidade normativa. ${ }^{14}$

Daí porque Joaquín Varela Suanzes-Carpegna defende que a história constitucional deve ser desenvolvida a partir de duas perspectivas: a normativo-institucional e

\footnotetext{
${ }^{11}$ ZAGREBELSKY, Gustavo. Historia y constitución, p. 91 (destaque acrescentado).

${ }^{12}$ Horst Dippel faz um alerta provocador, ao afirmar que "a historia do constitucionalismo moderno é uma historia que necessita ser escrita" (DIPPEL, Horst. "Constitucionalismo moderno. Introducción a uma historia que necesita ser escrita”. In: Historia Constitucional - revista electrônica, n. 6, 2005, p. 199 - disponível em http://hc.rediris.es/06/index.html - acesso em 10.4.2013 - tradução livre).

${ }^{13}$ Cf. SARASOLA, Ignacio Fernández. "La historia constitucional: método e historiografía a la luz de um bicentenario Hispánico”. In: FHI-Forum historiae iuris, n.11, jun. 2009.

14 Ver SARASOLA, Ignacio Fernández. "La historia constitucional: método e historiografía a la luz de um bicentenario Hispánico", parágrafos 18 a 28.
} 
a doutrinal. ${ }^{15}$ Cabe ao historiador do constitucionalismo "interligar as normas, as instituições e as doutrinas constitucionais com a sociedade na qual se inserem. Essa é uma conexão que lhe obriga a conhecer, ainda que apenas de forma instrumental, a realidade histórica de seu conjunto, sobretudo a política e a intelectual”. Por isso, o ponto de partida da investigação não pode ser a data de aprovação do texto constitucional. ${ }^{16}$

Segundo Antonio Manuel Hespanha, a missão da história do direito, enquanto disciplina, é "problematizar o pressuposto implícito e acrítico das disciplinas dogmáticas, ou seja, o de que o direito dos nossos dias é o racional, o necessário, o definitivo". ${ }^{17} \mathrm{O}$ pesquisador português observa que "a história do direito realiza esta missão sublinhando que o direito existe sempre ‘em sociedade’ (situado, localizado) e que, seja qual for o modelo usado para descrever as suas relações com os contextos sociais (simbólicos, políticos, econômicos, etc.), as soluções jurídicas são sempre contingentes em relação a um dado envolvimento (ou ambiente). São, neste sentido, sempre locais". ${ }^{18}$

Hespanha se preocupa com a apresentação das estratégias científicas e da metodologia de uma história crítica do direito. A primeira dessas estratégias é "instigar uma forte concepção metodológica" nos historiadores, isto é, problematizar a perspectiva de que a narrativa histórica corresponderia ao relato do que efetivamente aconteceu. Entretanto, "os acontecimentos históricos não estão aí, independentes do olhar do historiador, disponíveis para serem descritos. Pelo contrário, eles são criados pelo trabalho do historiador (...)". Por isso, se essa compreensão poderia, por um lado, lançar o historiador no universo de puro relativismo, por outro, é necessário ter em conta que "o rigor histórico reside mais numa

15 Cf. SUANZES-CARPEGNA, Joaquín Varela. "Algumas reflexões metodológicas sobre a história constitucional". In: RIHGB, a. 169 (440):09-28, jul/set, 2008, p. 11.

16 Ver SUANZES-CARPEGNA, Joaquín Varela. "Algumas reflexões metodológicas sobre a história constitucional", p. 14.

17 Paolo Grossi aponta, ainda, que o historiador do direito pode assumir, junto ao operador do direito positivo, um papel de desmitificador de certezas jurídicas, isto é, "servir como sua consciência crítica, revelando como complexo o que na sua visão unilinear poderia parecer simples, rompendo as suas convicções acríticas, relativizando certezas consideradas absolutas, insinuando dúvidas sobre lugares comuns recebidos sem uma adequada confirmação cultural" (GROSSI, Paolo. Mitologias jurídicas da modernidade. Trad. de Arno Dal Ri Júnior. Florianópolis: Fundação Boiteux, 2004, p. 11).

${ }^{18}$ HESPANHA, Antonio Manuel. Cultura Jurídica Européia - Síntese de um Milênio. Florianópolis: Fundação Boiteux, 2005, p. 21 (ambas as citações). Como observa Ricardo Marcelo Fonseca, "pode-se vislumbrar a história do direito como um saber voltado para o presente, ao invés de fechar-se num passado que só toma sentido em si mesmo. Pode-se encarar o saber histórico-jurídico sobretudo como instrumento de análise e de compreensão, que respeite a efetiva lógica da mudança, das contradições e das diacronias próprias do passado. Pode-se proceder a uma análise interessada na inserção do direito na sociedade e na tarefa de desvelar o seu sentido na lógica da mudança permanente onde hoje vivemos, fazendo da disciplina um instrumento de crítica e desmascaramento da juridicidade vigente, ao invés de ser dela um parceiro e um cúmplice, muitas vezes de modo inocentemente ingênuo" (FONSECA, Ricardo Marcelo. Introdução teórica à história do direito. $1^{\mathrm{a}}$ ed., $2^{\mathrm{a}}$ reimpressão, Curitiba: Juruá, 2011, p. 115). 
coerência interna do discurso - numa observância de 'regras de arte' convencionais - do que numa adequação à 'realidade' histórica". ${ }^{19}$

A outra estratégia é definir como objeto da história o direito em sociedade, o que conduz a uma história do direito estreitamente vinculada à observância dos vários contextos com os quais e nos quais o direito opera, como a cultura, as estruturas sociais, as tradições literárias e a religião.

As normas jurídicas não podem ser adequadamente compreendidas a partir da simples leitura de seu texto. Elas devem ser integradas aos complexos normativos que compõem a organização da vida em sociedade. Como afirma Hespanha - e isso vale para a constituição e o direito constitucional -, "o direito tem um sentido meramente relacional (ou contextual). O papel da regulação jurídica não depende das características intrínsecas das normas do direito, mas do papel que lhes é assinado por outros sistemas normativos que formam o seu contexto. Estes sistemas são inúmeros" e mostram a necessidade de apreensão dos chamados "poderes "periféricos". ${ }^{20}$ Para deixar claro: "periféricos" ao direito oficial, que é descentrado pela teoria política mais recente num conjunto inorgânico de mecanismos discretos e sutis de disciplina social. ${ }^{21}$

A proposta é a de abordar o direito como um produto social, o que significa considerar que a produção do direito é também um processo social. Na assertiva de Hespanha, “a ideia é a de relacionar o direito com os espaços sociais (...), explicando a partir daí os efeitos (jurídicos) produzidos", o que certamente é aplicável para a análise, mais específica, da história constitucional (que é também história do direito). Aqui fica evidente o aspecto da autonomia do direito em relação aos eventos e fenômenos não jurídicos presentes nas relações sociais. Isso quer dizer que o discurso jurídico possui um papel conformador sobre outros discursos. Em suas palavras, "o imaginário jurídico - produzido pelas condições específicas dos discursos e rituais do direito - pode mesmo modelar imaginários sociais mais abrangentes, bem como as práticas sociais que deles decorram". ${ }^{22}$

Coerente com essas premissas de investigação no campo da história do direito e, mais especificamente, da história constitucional, o marco teórico adotado, na presente

\footnotetext{
${ }^{19}$ HESPANHA, Antonio Manuel. Cultura Jurídica Européia - Síntese de um Milênio, p. 34.

${ }^{20}$ HESPANHA, Antonio Manuel. Cultura Jurídica Européia - Síntese de um Milênio, p. 35.

${ }^{21}$ Nesse campo se inserem alguns estudos de Michel Foucault, que, como destaca Hespanha, se referiu "ao caráter molecular do poder, à sua omnipresença na sociedade ('pan-politização') e à necessidade de a teoria política se assumir, para captar o poder em toda a sua extensão, como uma 'micro-física' do poder" (p. 36). Daqui decorre, ainda, a tendência dos historiadores do direito de expandir o seu campo de pesquisa, para além do direito oficial, voltando seu olhar para os demais fenômenos de normação da vida em sociedade.

22 HESPANHA, Antonio Manuel. Cultura Jurídica Européia - Síntese de um Milênio, p. 39 e 40, respectivamente (destaquei).
} 
pesquisa, é a teoria dos sistemas funcionalmente diferenciados de Niklas Luhmann. ${ }^{23}$ Para Luhmann, a Constituição corresponde ao mecanismo que possibilita o acoplamento estrutural entre os sistemas do direito e da política. Trata-se de uma inovação improvável da sociedade moderna e que surgiu no contexto das revoluções burguesas do século XVIII, em especial, nos Estados Unidos da América e em França. Pelo acoplamento estrutural, a Constituição viabiliza a separação entre direito e política - de maneira que uma decisão do Estado poderá ser considerada ilegal (não-direito), por exemplo - mas, ao mesmo tempo, cria as condições para a religação entre os sistemas - uma vez que, v.g., a política demanda a legitimidade por meio do direito e esse último, por sua vez, necessita da força coercitiva fornecida pela política para impor suas decisões. Em última análise, a Constituição conduz ao funcionamento autopoiético de ambos os sistemas, o que significa, para o direito, mais condições para o exercício de sua função, qual seja, garantir direitos, e, para a política, mais condições para a tomada de decisões coletivamente vinculantes, a partir das propostas e dos objetivos do governo, tensionado pela opinião pública. ${ }^{24}$

A proposta de abordagem de Luhmann leva à investigação sobre como os sistemas funcionais (o direito, a política e a economia, por exemplo) operam a partir da Constituição, como observam o texto constitucional e produzem decisões a partir dele. Cuidase de marco teórico que permite apreender a Constituição e o direito em perspectiva histórica, mediante a ativação da memória dos sistemas funcionais. ${ }^{25}$

A pesquisa está organizada em três capítulos.

\footnotetext{
${ }^{23}$ A produção de Niklas Luhmann é bastante abrangente. Para uma compreensão básica sobre sua teoria, é possível consultar as obras LUHMANN, Niklas. La sociedad de la sociedad. Trad. de Javier Torres Nafarrate. México: Herder e Universidad Iberoamericana, 2007; LUHMANN, Niklas. El derecho de la sociedad. Trad. de Javier Torres Nafarrate, con la colaboración de Brunhilde Erker, Silvia Pappe y Luis Felipe Segura. México: Herder, 2005, $2^{\text {a }}$ edição; LUHMANN, Niklas, e DE GIORGI, Raffaele. Teoria della società. $11^{\circ}$ ed. Milano, Italy: FrancoAngeli, 2003; LUHMANN, Niklas. Sociologia do Direito. Vol. I. Trad. de Gustavo Bayer. Rio de Janeiro: Tempo Brasileiro, 1983; LUHMANN, Niklas. Sociologia do Direito. Vol. II. Trad. Gustavo Bayer. Rio de Janeiro: Tempo Brasileiro, 1985; LUHMANN, Niklas. The differenciation of society. Trad. de Stephen Holmes e Charles Larmore. New York: Columbia University Press, 1982; e PAIXÃO, Cristiano. Modernidade, Tempo e Direito. Belo Horizonte: Del Rey, 2002.

${ }^{24}$ Ver LUHMANN, Niklas. "La costituzione come acquisizione evolutiva". In: ZAGREBELSKY, Gustavo, PORTINARO, Píer Paolo, LUTHER, Jörg (Orgs.). Il Futuro della Constituzione. Torino: Einaudi, 1996, pp. $83 / 128$.

${ }^{25}$ Cf. LUHMANN, Niklas. La sociedad de la sociedad, p. 455/460; DE GIORGI, Raffale. "A Memória do Direito". In: Direito, Tempo e Memória. Trad. de Guilherme Leite Gonçalves. São Paulo: Quartier Latin, 2006, pp. 49/73. As obras de Niklas Luhmann demonstram importante afinidade da teoria com a investigação histórica. Um relevante exemplo disso, desenvolvido a partir da perspectiva luhmanniana, no campo da história constitucional, é PAIXÃO, Cristiano e BIGLIAZZI, Renato. História constitucional inglesa e norte-americana: do surgimento à estabilização da forma constitucional. Brasília: Editora UnB: Finatec, 2008.
} 
O capítulo 1 volta-se à Assembleia Nacional Constituinte de 1987/1988. Serão investigados os antecedentes da Constituinte, como a mobilização popular que se fez sentir de maneira mais evidente ao final da década de 1970 e que culminou com as Diretas Já, e o processo de sua instalação, incluindo a deliberação sobre o regimento interno. Passa-se, depois, ao exame dos debates e votações na ANC, começando com as subcomissões e as comissões temáticas. A pesquisa é concentrada nos documentos da Assembleia Constituinte, em especial nas atas de suas reuniões. ${ }^{26}$ Há o acompanhamento do percurso seguido pelos debates sobre o direito de greve, passando pela Comissão de Sistematização até chegar às discussões no Plenário da Constituinte, com a aprovação do texto constitucional. Busca-se fazer uma reconstrução dos discursos que circularam na ANC sobre o direito de greve e que estampavam os desafios postos à nova Constituição.

O capítulo 2 se destina ao exame da greve dos petroleiros de 1995 e da intervenção do Tribunal Superior do Trabalho no conflito. Para compreender de forma mais adequada o movimento dos petroleiros, será necessário observar os antecedentes dessa paralisação, em especial as negociações com o governo e a Petrobrás no ano de 1994. Após, passa-se à análise da postura assumida pelo Poder Público diante da greve, incluindo o recurso às Forças Armadas. A investigação é dirigida, sobretudo, à ação da Justiça do Trabalho, a partir da leitura do processo de dissídio coletivo suscitado perante o Tribunal Superior do Trabalho e das notas taquigráficas das sessões de julgamento da Corte. Há o material colhido a partir de depoimentos de pessoas que acompanharam de perto o conflito e o processo perante o TST. Os argumentos das partes no processo serão apresentados, bem como a fundamentação das decisões do Tribunal. Serão enfocadas também as repercussões da intervenção da Justiça do Trabalho, como o pronunciamento da Organização Internacional do Trabalho, por meio de seu Comitê de Liberdade Sindical, e as execuções das multas aplicadas às entidades sindicais profissionais e as demissões de vários grevistas.

O capítulo 3 tem por objetivo, a partir das informações reunidas nos capítulos precedentes, enfrentar as indagações postas com base na forma de intervenção da Justiça do Trabalho nas greves. Pretende-se refletir sobre os desafios da Constituição de 1988 e sobre a própria função da Constituição, considerando-se as relações entre os sistemas jurídico e político. Será aprofundada a questão pertinente à necessidade de desenvolvimento de um

\footnotetext{
${ }^{26}$ Parte significativa dos Diários da Assembleia Nacional Constituinte foi consultada a partir de documento, em mídia digital (CD), produzido pela Subsecretaria de Anais da Secretaria Especial de Editoração e Publicações do Senado Federal, por ocasião da comemoração dos vinte anos da Constituição de 1988. Os diários analisados por esse meio estão referidos com a indicação de "documento eletrônico". Os demais foram consultados a partir do sítio da Câmara dos Deputados na internet (http://www2.camara.leg.br/documentos-epesquisa/publicacoes/publicacoes-e-estudos), que contém a íntegra dos documentos da Assembleia Constituinte.
} 
discurso constitucional sobre o texto de 1988. Em seguida, examina-se a atuação da Justiça do Trabalho nas greves e o papel dos tribunais, passando-se por aspectos mais contemporâneos, como a modificação decorrente da Emenda Constitucional 45/2004 (que alterou o dispositivo que prevê a propositura de dissídio coletivo na Justiça do Trabalho). É analisada também a problemática atinente a um governo dos juízes - ao menos no que toca aos conflitos trabalhistas de dimensão coletiva. Há a tentativa de articular uma outra leitura sobre o direito de greve, tendo por fundamento o art. $9^{\circ}$ da Constituição, em que a greve será encarada, antes de tudo, como abertura a possibilidades comunicativas, inclusive de protesto. 


\section{Capítulo 1: As discussões na Assembleia Nacional Constituinte de 1987/1988 sobre o direito de greve}

\subsection{Antecedentes e instalacão da Assembleia Nacional Constituinte}

A Assembleia Nacional Constituinte de 1987/1988 foi convocada por uma alteração na Carta então vigente, outorgada em 1967 e alterada em 1969. A Emenda Constitucional no 26 de 1985 estabelecia que, a partir de $1^{\circ}$ de fevereiro de 1987, os membros da Câmara dos Deputados e do Senado Federal se reuniriam em Assembleia Nacional Constituinte e a Constituição seria promulgada após aprovação de seu texto, em dois turnos de discussão e votação, pela maioria absoluta dos membros da Assembleia. ${ }^{27}$

A promulgação da nova Constituição teria um impacto fundamental na transição brasileira em direção à ordem democrática. Estava em curso o processo de ruptura com a ordem autoritária construída pela ditadura militar. Uma importante característica do contexto foi a mobilização popular que antecedeu a convocação da Constituinte e acompanhou os trabalhos de elaboração do novo texto constitucional. Essa é uma referência necessária para a compreensão da tensão, presente na Constituição de 1988, entre ruptura e continuidade com o regime anterior.

Com a Carta aos Brasileiros, lida em 1977, no Pátio das Arcadas da Faculdade de Direito da Universidade de São Paulo, do Largo de São Francisco, já é possível perceber a movimentação de diversos setores da sociedade apontando a necessidade de mudança da ordem instituída. ${ }^{28}$ Algumas organizações se destacaram na defesa dos direitos humanos, do

\footnotetext{
${ }^{27}$ Cf. artigos $1^{\circ}$ e $3^{\circ}$ da Emenda Constitucional 26/1985 (BRASIL. Constituição (1967). Emenda Constitucional $\mathrm{n}^{\circ}$ 26, de 27 de novembro de 1985. Convoca Assembléia Nacional Constituinte e dá outras providências. Diário Oficial da União, Brasília, DF, 28.11.1985).

${ }^{28}$ A leitura da Carta aos Brasileiros, pelo Professor da Faculdade de Direito da USP, Goffredo Telles Jr., ocorreu no dia 8 de agosto de 1977. A Carta foi subscrita (antes e depois de sua leitura) por inúmeros juristas. Segundo depoimentos de pessoas que participaram de maneira mais próxima de sua preparação - entre eles, Flávio Bierrenbach, Almino Affonso e José Carlos Dias -, a elaboração e a leitura da Carta ocorreram no contexto da comemoração do sesquicentenário da Faculdade de Direito da USP, evento que tinha como coordenador o Professor Alfredo Buzaid, que fora Ministro da Justiça da ditadura militar. A ideia da Carta está relacionada, em sua origem, ao desagrado diante dessa escolha e à tentativa de fazer algo que contrastasse com a programação oficial da Faculdade. A respeito, ver SCHUBSKY, Cássio, BIERRENBACH, Flávio, AFFONSO, Almino. Estado de direito já!: os trinta anos da Carta aos Brasileiros. São Paulo: Lettera.doc., 2007. Com relação à sua repercussão, Eugênio Bucci nota que "a expressão Diretas Já é um eco óbvio do Estado de Direito Já, chamamento que encerra a Carta aos Brasileiros” (p. 91). Sobre a importância da Carta, José Eduardo Faria, em depoimento publicado no mesmo livro, observou que: "é difícil avaliar se a Carta aos Brasileiros foi, naquele momento, um fator que mudou todo um processo. Mas que ela foi um evento bastante significativo, não há dúvida alguma; ela se somou a uma série de outros eventos que resultaram não apenas na queda da ditadura, em 1985, mas na convocação da Assembleia Constituinte, em 1986, e na reconstitucionalização do Brasil, em 1988.
} 
Estado de Direito e no combate à censura, como a Igreja Católica, a Ordem dos Advogados do Brasil - OAB e a Associação Brasileira de Imprensa - ABI. ${ }^{29}$

O movimento das Diretas Já marcou a intensificação da mobilização política da sociedade civil, voltada então para as eleições diretas para Presidente da República, reivindicação presente no Congresso a partir de Proposta de Emenda à Constituição, apresentada pelo deputado federal do PMDB, Dante Oliveira. Apesar de rejeitada a Emenda no Congresso Nacional - faltaram 22 dos 320 votos necessários -, a campanha pelas Diretas mostrou-se exitosa ao realizar uma concentração política bastante significativa. Na descrição de Thomas Skidmore,

o presidente, o Planalto, a liderança do PDS e os militares foram todos apanhados com a guarda baixa. Não podiam interromper nem ignorar a robusta campanha que empolgava o país. Alguns elementos eram familiares, como o tom emocional e os apelos no sentido de pressões diretas sobre o Congresso. Mas a campanha também tinha seu aspecto peculiar. Era o ressurgimento do espírito cívico com uma dimensão sem precedentes, acrescendo que nenhum candidato estava pedindo voto para si mesmo. Ao contrário, o objetivo era restaurar o direito de voto. Era uma dramática mensagem da sociedade civil que firmemente reconquistava a sua voz $^{30}$

Com a rejeição da Emenda Dante Oliveira, em 25 de abril de 1984, as forças sociais que haviam sido mobilizadas dirigiram-se à convocação de uma assembleia constituinte. O cenário foi acrescido pela eleição de Tancredo Neves, em 15 de janeiro de 1985, pelo colégio eleitoral, vencendo o candidato do governo, Paulo Maluf, que obteve 180 votos, contra 480 daquele. A população, de maneira geral, depositava inúmeras esperanças em Tancredo Neves, considerado um "salvador" do país. Segundo Skidmore, "o presidente eleito era visto pelos brasileiros como um novo Moisés, com a missão de conduzir o país do deserto da desesperança para uma nova Canaã. Cada brasileiro via em Tancredo a encarnação de suas aspirações. E isto lhe deu mais legitimidade do que a conferida a qualquer presidente eleito na história do país". 31

Gravemente enfermo, porém, Tancredo Neves não pode tomar posse em 15 de março de 1985. A crise institucional foi solucionada com a posse do Vice-Presidente eleito, José Sarney, que passou a exercer o governo de forma temporária. No dia 21 de abril, veio a

Enxergo uma linha de continuidade da Carta aos Brasileiros, em 1977, à promulgação da Constituição, em 1988" (p. 101/102).

${ }^{29}$ Cf., a propósito, MOREIRA ALVES, Maria Helena. Estado e Oposição no Brasil (1964-1984). Bauru, SP: EDUSC, 2005, p. 242/262.

${ }^{30}$ SKIDMORE, Thomas. Brasil: de Castelo a Tancredo, 1964-1985. Trad. de Mario Salviano Silva. Rio de Janeiro: Paz e Terra, 1988, p. 471/472 (destaque no original).

${ }^{31}$ SKIDMORE, Thomas. Brasil: de Castelo a Tancredo, 1964-1985, p. 491. 
notícia da morte de Tancredo, acompanhada por uma forte mobilização popular. Questionavase se a chamada Nova República poderia sobreviver sem ele. A ironia era evidente. Após todas as esperanças e expectativas projetadas em Tancredo, a transição brasileira para a democracia e a recente Nova República seriam conduzidas por José Sarney, que, pouco tempo antes, havia sido o líder do partido de sustentação do governo militar (Aliança Renovadora Nacional - ARENA e Partido Democrático Social - PDS).

A convocação de uma assembleia constituinte fez parte do primeiro discurso proferido por José Sarney após a morte de Tancredo Neves. ${ }^{32}$ Mas a sociedade civil organizada se empenhava para ver em ação uma constituinte convocada de maneira originária e exclusiva, e não congressual e confundida com as eleições parlamentares, como era a proposta do governo. No final, entretanto, prevaleceu essa última. ${ }^{33}$

A questão trabalhista estava entre as principais preocupações do novo governo. Era, aliás, um ponto fundamental de pauta do próprio PMDB, principal partido de oposição ao governo antes de Sarney. Em manifesto ainda de 1982, o partido propunha uma nova "estratégia de desenvolvimento social" e defendia a reforma da legislação trabalhista, de maneira a alcançar a "autonomia sindical". Entre os aspectos importantes da proposta, estava a restauração do direito de greve. Tancredo Neves, ainda durante a campanha presidencial, em 1984, discursara no sentido de definir como objetivo a revisão da legislação trabalhista, de modo a liberar os sindicatos da intervenção do Estado e ampliar o espaço para a realização de

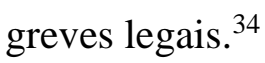

O direito de greve se consolidava como instrumento de participação política dos trabalhadores. Esse processo remonta às greves do ABC paulista iniciadas no ano de $1978 \mathrm{e}$ ao surgimento do chamado Novo Sindicalismo (ou sindicalismo autêntico), radicado nas grandes indústrias daquela região. ${ }^{35} \mathrm{O}$ grupo de dirigentes sindicais que integravam o Novo Sindicalismo defendia negociações coletivas diretas, liberdade e autonomia sindicais e direito

\footnotetext{
32 O trecho do discurso é o seguinte: "vamos construir a democracia, capaz de liberar as energias criadoras da juventude e assegurar a liberdade política. O objetivo maior do nosso projeto nós o atingiremos com a realização da Assembléia Nacional Constituinte, livre e soberana, aspiração legítima de toda a sociedade". A referência à Constituinte ocorreu após José Sarney dizer que as mudanças reclamadas serão realizadas, prometendo que o governo daria prioridade aos pobres, combateria a inflação, lutaria pelo fortalecimento da iniciativa privada e pelos direitos humanos, implantaria a reforma agrária e buscaria sobrevivência digna aos trabalhadores, além da retomada do desenvolvimento e do nível de emprego. O discurso foi integralmente transcrito no periódico Folha de São Paulo, de 22.4.1968.

${ }^{33}$ Sobre o processo de organização popular em torno da convocação da Constituinte e a tramitação da PEC 43/1985, posterior Emenda Constitucional 26/1985, ver MICHILES, Carlos et al. Cidadão constituinte: a saga das emendas populares. Rio de Janeiro: Paz e Terra, 1989, p. 23/33.

${ }^{34}$ Cf. SKIDMORE, Thomas. Brasil: de Castelo a Tancredo, 1964-1985, p. 556/557.

35 Os municípios do Estado de São Paulo incluídos no chamado ABC compreendem Santo André, São Bernardo do Campo, São Caetano do Sul e Diadema.
} 
de greve, além de combaterem a legislação sindical repressiva e o sindicalismo atrelado ao Estado. $^{36}$

O Novo Sindicalismo veiculava pretensões relacionadas ao modelo estatal de gestão das relações de trabalho. Isso estava presente nas paralisações do ABC: o direito de greve fora exercido também com o propósito de articular e defender reivindicações que suplantavam o dia a dia dos locais de trabalho, projetando-se na ordem social e de Estado. Para Maria Helena Moreira Alves, “o 'novo movimento sindical' deve ser considerado parte da oposição democrática como um todo; sua plataforma de reivindicações evidencia seu compromisso político com a democracia e a liberdade de organização". ${ }^{37}$

Embora as greves do $\mathrm{ABC}$ e as que se seguiram na década de 1980 tenham projetado os trabalhadores no cenário político-econômico nacional, não foram eles, junto com seus sindicatos, chamados à "mesa de negociações" da transição democrática. ${ }^{38} \mathrm{O}$ controle da abertura, promovido pelo governo, implicava a manutenção da exclusão de determinados grupos sociais. Daí a importância da greve como instrumento dos trabalhadores para manifestação de seus interesses e a defesa de sua participação no espaço político, tendo sido essa uma característica significativa do período. ${ }^{39}$

Na Assembleia Nacional Constituinte, o direito de greve seria uma questão fundamental. Vale lembrar que as inúmeras greves deflagradas, sobretudo a partir de 1978, desafiavam a legalidade, cujos parâmetros eram definidos pela Lei $n^{\circ} 4.330$, de $1^{\circ}$ de junho de 1964, que, ao regulamentar o direito de greve, estabelecia várias formalidades de difícil

\footnotetext{
${ }^{36}$ Diversos autores indicavam uma conotação política por parte do Novo Sindicalismo, o que seria confirmado pela formação do Partido dos Trabalhadores, cujos líderes tiveram significativos vínculos com as entidades sindicais do ABC paulista e principalmente com a CUT. Cf. ANTUNES, Ricardo, O Novo Sindicalismo no Brasil. Campinas: Pontes, 1995; TAVARES DE ALMEIDA, Maria Hermínia. Crise Econômica e Interesses Organizados: O sindicalismo no Brasil nos anos 80. São Paulo: Editora da Universidade de São Paulo, 1996; e RODRIGUES, Leôncio Martins. "A composição social das lideranças do PT”. In: Partidos e Sindicatos escritos de sociologia política. São Paulo: Ática, 1990, p. 7/33.

${ }^{37}$ MOREIRA ALVES, Maria Helena. Estado e Oposição no Brasil (1964-1984), p. 291. As greves do ABC e a inserção dos trabalhadores nas discussões políticas da transição democrática são temas abordados também em PAIXÃO, Cristiano, LOURENÇO FILHO, Ricardo. "Greve como prática social: possibilidades de reconstrução do conceito a partir da Constituição de 1988”. In: SENA, Adriana Goulart de, DELGADO, Gabriela Neves, e NUNES, Raquel Portugal. Dignidade humana e inclusão social: caminhos para a efetividade do direito do trabalho no Brasil. São Paulo: LTr, 2010, p. 408/424. Alguns documentários foram produzidos sobre essas greves. Entre outros, é possível mencionar $A B C$ da greve. Direção de Leon Hirszman. São Paulo: VF, 1990. DVD (85 min), NTSC, son., color. Port.; e Linha de montagem. Direção de Renato Tapajós. São Paulo: Tapiri Cinematográfica, 2007, DVD (90 min), NTSC, son., color. Port.

${ }^{38}$ Cf. NORONHA, Eduardo. "A explosão das greves na década de 80". In: BOITO JR., Armando (Org.). $O$ Sindicalismo brasileiro nos anos 80. Rio de Janeiro: Paz e Terra, 1991; e MOREIRA ALVES, Maria Helena. Estado e Oposição no Brasil (1964-1984), p. 318 e ss.

39 Ver SOUSA, Nair Heloísa Bicalho de. "Novos sujeitos sociais: a classe trabalhadora na cena histórica contemporânea". In: SOUSA JÚNIOR, José Geraldo e AGUIAR, Roberto A. R (Orgs.). Introdução Crítica ao Direito do Trabalho. Brasília: Universidade de Brasília, 1993 (Série o direito achado na rua, vol. II).
} 
cumprimento. ${ }^{40}$ Além disso, eram tipificadas como crime condutas como promover, participar ou insuflar greve ou lock-out com desrespeito à lei; ou iniciar a greve ou o lock-out, ou aliciar participantes quando estranhos à profissão ou atividades econômicas (art. 29, I e IV). A Constituição de 1967, emendada em 1969, proibia a greve no serviço público e nas atividades essenciais, enquanto a Lei de Segurança Nacional previa como delito a promoção de greve nesses setores com o fim de coagir qualquer dos Poderes da República (art. 32 do Decreto-Lei no 314/1967). Esse último diploma ainda previa o vago tipo penal de incitar publicamente "à subversão da ordem político-social" ou "à desobediência coletiva das leis". ${ }^{41}$

A Consolidação das Leis do Trabalho estabelecia penalidades aos empregados que, de forma coletiva e sem prévia autorização do tribunal competente, abandonassem o serviço, ou desobedecessem a qualquer decisão proferida em dissídio. As penalidades consistiam em suspensão do serviço por até seis meses, ou dispensa do emprego; perda do cargo de representação profissional, caso estivessem em seu desempenho; e suspensão, pelo prazo de dois a cinco anos, do direito de serem eleitos para cargo de representação profissional (art. 723). Eram estipuladas multas para o caso de a suspensão do serviço ou a desobediência às decisões dos Tribunais do Trabalho ter sido ordenada por associação profissional, sindical ou não (art. 724). Outro dispositivo preceituava que "aquele que, empregado ou empregador, ou mesmo estranho às categorias em conflito, instigar a prática de infrações previstas neste Capítulo ou houver feito cabeça de coligação de empregadores ou de empregados incorrerá na pena de prisão prevista na legislação penal, sem prejuízo das demais

\footnotetext{
${ }^{40}$ Como a exigência, constante do art. 10, de interregno mínimo de 5 dias para as atividades acessórias e 10 dias para as atividades fundamentais, entre a notificação do empregador e a deflagração da greve (cf. BRASIL. Lei $\mathrm{n}^{\circ}$ 4.330, de $1^{\circ}$ de junho de 1964. Regula o direito de greve, na forma do art. 158, da Constituição Federal. Diário Oficial da União, Brasília, DF, 3.6.1964. Retificações publicadas no Diário Oficial da União, Brasília, DF, em 15.6.1964 e 19.6.1964). O problema desse condicionante é que, a depender da intensidade do conflito entre trabalhadores e empregadores, a greve pode adquirir um caráter de espontaneidade determinante. A primeira grande greve do regime militar, instaurado em 1964 no país, ocorreu em Osasco, em abril de 1968, deflagrada pelos metalúrgicos da Companhia Belgo Mineira. Francisco Weffort enfatiza o caráter espontâneo com que essa greve se estendeu na Sociedade Brasileira de Eletrificação, também em Contagem, logo após seu início na Companhia Belgo-Mineira. Segundo o autor, a paralisação correspondeu praticamente a "uma explosão do malestar que lavrava desde há algum tempo na empresa. Não teria havido nenhuma reunião formal para programar a greve que praticamente foi decidida no momento mesmo de sua eclosão" (WEFFORT, Francisco. "Participação e conflito industrial: Contagem e Osasco, 1968”. In: Cadernos Cebrap 05. São Paulo: Cebrap, 1972, p. 39). Examinando as greves do ABC paulista, Ricardo Antunes mostra que, em especial a de 1978, ela surgiu de uma decisão espontânea dos trabalhadores. É certo que o sindicato teve um papel importante, sobretudo, nas negociações, mas a eclosão das greves e a definição de seus rumos não tiveram uma direção política, dependendo muito mais da vontade dos próprios operários. Ver ANTUNES, Ricardo. A rebeldia do trabalho - o confronto operário do ABC paulista: as greves de 1978/1980. $2^{\text {a }}$ ed. Campinas: Unicamp, 1992, p. 35/36.

${ }^{41}$ Cf. BRASIL. Decreto-Lei no 314, de 13 de março de 1967. Define os crimes contra a segurança nacional, a ordem política e social e dá outras providências. Diário Oficial da União, Brasília, DF, 13.3.1967. Com relação à criminalização de condutas relacionadas à greve, cf. FRAGOSO, Christiano. Repressão Penal da Greve: uma experiência antidemocrática. São Paulo: IBCCRIM, 2009.
} 
sanções cominadas" (art. 725). O texto legal ainda previa que o estrangeiro que incorresse nessas condutas, após o cumprimento das penalidades, seria expulso do País. ${ }^{42}$

Havia, também na Consolidação das Leis do Trabalho, a regulamentação do processo de dissídio coletivo, pelo qual os Tribunais do Trabalho julgavam os conflitos coletivos, inclusive em caso de greve. $\mathrm{O}$ art. 856, a propósito, estabelecia que a "instância" (ou seja, o dissídio coletivo) seria instaurado mediante representação escrita ao Presidente do Tribunal. E acrescentava: "poderá ser também instaurada por iniciativa do presidente, ou, ainda, a requerimento da Procuradoria da Justiça do Trabalho, sempre que ocorrer suspensão do trabalho". Nessa hipótese, portanto, o Tribunal poderia se manifestar de ofício sobre o conflito coletivo. ${ }^{43}$

Antes mesmo de iniciados os trabalhos da Constituinte, o governo José Sarney buscou apresentar um projeto de lei de greve. Em agosto de 1986, foi enviado ao Congresso Nacional, pela Mensagem 368/1986, o Projeto de Lei $n^{\circ}$ 8.059/1986, elaborado pelo Ministro do Trabalho, Almir Pazzianotto Pinto, e que tratava de negociações coletivas e direito de greve. O PL do governo suavizava algumas das rigorosas exigências para deflagração da greve então previstas na Lei 4.330/1964, como o quórum de deliberação em assembleia, o qual era reduzido de $2 / 3$ dos associados para metade mais um, em primeira convocação, e de $1 / 3$ para $1 / 5$, em segunda convocação. O projeto também reduzia o prazo para notificação dos empregadores e do sindicato patronal (de 5 dias para 72 horas) e eliminava a exigência de indicação prévia e por escrito das reivindicações. Era mantida a possibilidade de declaração da ilegalidade da greve - embora com menos hipóteses; a paralisação por motivos alheios às relações de trabalho permanecia sendo caso de ilegalidade; e continuava a vedação à greve nos serviços públicos e nas atividades essenciais, fato passível de caracterização de falta grave. O PL 8.059/1986, diferentemente da Lei 4.330/1964, previa expressamente que o Tribunal do Trabalho decidiria sobre a legalidade ou ilegalidade da greve. ${ }^{44}$

Na Exposição de Motivos, elaborada pelo Ministro do Trabalho, Almir Pazzianotto Pinto, há indicação de que o Projeto de Lei seria resultado de "amplo debate nacional", sendo recebidas sugestões de entidades sindicais e de outras organizações da

\footnotetext{
${ }^{42}$ Ver BRASIL, Decreto-Lei ${ }^{\circ}$ 5.452, de $1^{\circ}$ de maio de 1943. Aprova a Consolidação das Leis do Trabalho. Diário Oficial da União. Rio de Janeiro, DF, 9.8.1943. Os artigos 723 a 725 da CLT foram revogados, de maneira expressa, pela Lei ${ }^{\circ}$ 9.842/1999 (BRASIL. Lei ${ }^{\circ}$ 9.842, de 7 de outubro de 1999. Revoga os arts. 723, 724 e 725 do Decreto-Lei no 5.452, de $1^{\circ}$ de maio de 1943, que aprova a Consolidação das Leis do Trabalho. Diário Oficial da União. Brasília, DF, 8.10.1999).

${ }^{43}$ Cf. BRASIL, Decreto-Lei ${ }^{\circ} 5.452$, de $1^{\circ}$ de maio de 1943 (CLT). A maioria dos dispositivos da CLT que tratam do procedimento do dissídio coletivo permanece em vigor até hoje.

${ }^{44}$ Cf. o texto do Projeto de Lei 8.059/1986 em BRASIL. Diário do Congresso Nacional (Seção I). Brasília, 7 de agosto de 1986, p. 7269/7271.
} 
sociedade civil, como a OAB e o IAB (Instituto dos Advogados Brasileiros), além de associações comerciais, parlamentares e juristas. Também subsidiaram o texto projetos de lei então em trâmite na Câmara dos Deputados e no Senado Federal. ${ }^{45}$

A proposta do Projeto de Lei seria valorizar a ação dos sindicatos (profissionais e econômicos) no que dizia respeito ao seu "poder de representação", tendo por atribuição fundamental buscar, "pelo entendimento", soluções pertinentes às relações de trabalho. O objetivo seria avançar em direção à autonomia sindical. E o direito de greve estaria imbricado à negociação coletiva:

o anteprojeto admite a greve, ao lado do dissídio coletivo e da arbitragem extrajudicial, como um recurso legítimo a que o sindicato profissional pode recorrer, satisfeitas determinadas exigências, mas respeitada, obviamente, a restrição constitucional à paralisação de serviços públicos e das atividades essenciais, as quais ao mesmo anteprojeto compete definir. Esta concepção de uma unidade integrada entre a negociação e o dissídio, arbitragem extrajudicial e a greve, é o traço inovador e prático da legislação que se propõe, rompendo-se com o equívoco entendimento da greve como direito a ser tratado isoladamente, como se fora um fim em si mesmo, independente do processo de negociação direta, e não um instrumento a ser empregado, circunstancialmente, pelos trabalhadores. ${ }^{46}$

Pela Exposição de Motivos se percebe que o projeto se ateve aos limites impostos pela Carta então vigente, tanto que a observância das restrições constitucionais às paralisações de serviços públicos e das atividades essenciais é colocada como "óbvia". Por outro lado, a proposta do governo teve por finalidade assegurar que a greve correspondesse, "efetivamente, a um sentimento da categoria profissional reivindicante". ${ }^{47}$

O Projeto de Lei do governo, de autoria do Ministro Pazzianotto, adquiria ares de legalização do direito de greve. ${ }^{48}$ Entretanto, o consenso sobre esse aspecto se revelava bastante frágil, consoante a análise de Thomas Skidmore:

Os chefes militares, por exemplo, há muito olhavam os sindicatos com desconfiança e se opunham ao enfraquecimento do poder do governo sobre os grevistas. Os industriais de São Paulo também não participavam da ideia de se criar maiores facilidades para as greves. Eles estavam satisfeitos com a lei em vigor que dava aos empregadores permanente vantagem bastando que

\footnotetext{
${ }^{45}$ BRASIL. Diário do Congresso Nacional (Seção I). Brasília, 7 de agosto de 1986, p. 7274.

${ }^{46}$ BRASIL. Diário do Congresso Nacional (Seção I). Brasília, 7 de agosto de 1986, p. 7274 (destaquei). Nesse trecho, fica claro que o Ministro do Trabalho colocava no projeto sua concepção sobre o direito de greve e de como ele deveria ser exercido pelos trabalhadores.

${ }^{47}$ BRASIL. Diário do Congresso Nacional (Seção I). Brasília, 7 de agosto de 1986, p. 7274.

${ }^{48}$ Embora enviado ao Congresso Nacional em agosto de 1986, o projeto foi tornado público em junho do mesmo ano.
} 
a lei fosse estritamente aplicada. Tanto os militares como os industriais paulistas argumentavam agressivamente contra o que denunciavam como excessiva liberalização do projeto de lei de Pazzianotto. O ministro foi pressionado também por centenas de líderes e associados de sindicatos que consultara. Todos queriam que o governo se afastasse da política sindical para que os órgãos de representação dos trabalhadores pudessem exercer o mesmo direito de greve há muito possuído pelos seus colegas das nações industrializadas. ${ }^{49}$

A esse tempo, veio a público o anteprojeto de Constituição elaborado pela Comissão Provisória de Estudos Constitucionais, também chamada "Comissão de Notáveis", ou, ainda, "Comissão Afonso Arinos" ${ }^{50} \mathrm{O}$ anteprojeto previa o direito irrestrito de greve, inclusive nos serviços essenciais. ${ }^{51}$

Entretanto, o resultado do trabalho da Comissão, entregue ao Presidente da República em 18 de setembro de 1986, não foi encaminhado ao Congresso. Parte significativa da sociedade era contrária ao procedimento preordenado de simples discussão de um anteprojeto pela Assembleia Nacional Constituinte. Por outro lado, o anteprojeto da “Comissão dos Notáveis" provocou reações de correntes ditas "conservadoras", ou seja, comprometidas com a manutenção do statu quo, na medida em que seu texto consagrava inúmeras mudanças importantes - como a atinente ao direito de greve, por exemplo. Mesmo não tendo sido enviado ao Congresso, o anteprojeto da Comissão influenciou os debates da Constituinte, tendo sido referido por inúmeros parlamentares. ${ }^{52}$

\footnotetext{
${ }^{49}$ SKIDMORE, Thomas. Brasil: de Castelo a Tancredo, 1964-1985, p. 567/568. Ainda segundo o historiador, "o projeto da nova lei de greve era inegavelmente um anticlímax. O governo levara quinze anos para produzir um documento extremamente cauteloso. Seu destino dependeria de um complexo jogo de forças no Congresso e no país. E a lei seria obedecida se fosse aprovada?" (p. 569).

${ }^{50}$ Estabelecida pelo Decreto $\mathrm{n}^{\circ}$ 91.450, de 18.7.1985, tratava-se apenas de uma Comissão Provisória de Estudos Constitucionais, formada com o propósito de realizar pesquisas e estudos para subsidiar os trabalhos da Assembleia Nacional Constituinte. Contudo, a Comissão foi além e se ocupou da elaboração de um anteprojeto de constituição (BRASIL, Decreto no 91.450, de 18 de julho de 1985. Institui a Comissão Provisória de Estudos Constitucionais. Diário Oficial da União, Brasília, DF, 22.7.1985).

${ }^{51}$ O Anteprojeto "Afonso Arinos" dispunha o seguinte: "art. 33. É assegurado o direito de greve, nos termos do art. 345 e dos seus $\S \S 1^{\circ}$ e $2^{\circ}$. (...) Art. 345. É reconhecido o direito de greve. $\S 1^{\circ}$. Para o seu pleno exercício, serão estabelecidas providências e garantias necessárias que assegurem a manutenção dos serviços essenciais à comunidade. $\S 2^{\circ}$. As categorias profissionais dos serviços essenciais que deixarem de recorrer ao direito de greve farão jus aos benefícios já obtidos pelas categorias análogas ou correlatas". Embora o anteprojeto tivesse um tom de liberalização do direito de greve, o $\S 2^{\circ}$ do art. 345 , relativo aos serviços essenciais, era um incentivo à não realização de paralisações. Cf. BRASIL. Presidência da República. Anteprojeto Constitucional, elaborado pela Comissão Provisória de Estudos Constitucionais, instituída pelo Decreto ${ }^{\circ}$ 91.450, de 18 de julho de 1985. Diário Oficial da União, Suplemento Especial ao no 185, Brasília, DF, 26.9.1985.

${ }^{52}$ Ver CARVALHO NETTO, Menelick de. "A Revisão Constitucional e a Cidadania: A Legitimidade do Poder Constituinte que deu Origem à Constituição da República Federativa de 1988 e as Potencialidades do Poder Revisional Nela Previsto". In: Fórum Administrativo. Ano I. No 7. Belo Horizonte: Setembro de 2001; BONAVIDES, Paulo e ANDRADE, Paes de. História Constitucional do Brasil. $8^{\mathrm{a}}$ ed. Brasília: OAB Editora, 2006; e MICHILES, Carlos et al. Cidadão Constituinte - a saga das emendas populares, p. 34/35.
} 
Em junho de 1987 - após já terem iniciado os trabalhos da ANC -, o governo encaminhou ao Congresso Nacional, pela Mensagem 166/1987, novo projeto de lei, o de $n^{\circ}$ 164/1987, que tratava das organizações sindicais, das negociações coletivas e do direito de greve. Eram poucas as diferenças entre o PL 164/1987 e o PL 8.059/1986. Além do incremento do quórum para deliberação em Assembleia Geral sobre a greve, em segunda convocação (aumentada de 1/5 para 1/3), o novo projeto previa que, ao ser comunicado da decisão sobre a deflagração da greve (o que também constava do projeto anterior), o Ministério do Trabalho designaria imediatamente mesa-redonda, convocando as partes envolvidas no conflito. Outra mudança significativa: enquanto o PL 8.059/1986 estabelecia que, uma vez declarada a ilegalidade da greve, o Tribunal determinaria o retorno ao trabalho, o PL 164/1987 ia além, dispondo que seria determinado, pelo Tribunal, o retorno, "sob pena de multa diária sobre o sindicato, sem prejuízo da responsabilidade individual por desobediência à decisão judicial". ${ }^{53}$

A Exposição de Motivos do PL 164/1987 é subscrita pelo Ministro do Trabalho, Almir Pazzianotto Pinto, e pelo Consultor Geral da República, J. Saulo Ramos. ${ }^{54}$ Nela, é referido o PL 8.059/1986, que regularia o direito de greve e a negociação coletiva. A Exposição de Motivos apresenta a premissa de que o desenvolvimento das relações coletivas de trabalho, numa sociedade democrática, se projeta em três dimensões fundamentais, intimamente relacionadas: organização sindical, negociação coletiva e direito de greve. Discorre-se sobre a organização sindical brasileira e a mudança do Estado Liberal ao Estado Social, passando-se à informação de que o anteprojeto buscaria "refletir em seu texto as grandes reivindicações da sociedade civil, que postula o repúdio do corporativismo, enquanto elemento doutrinário, informador da nossa organização sindical”. O anteprojeto é apontado como um momento de inflexão, introduzindo o sentido da liberdade na prática sindical. Não obstante - talvez porque já em tramitação no Congresso o PL 8.059/1986 -, não há referência expressa à negociação coletiva ou à greve. ${ }^{55}$

Será visto, à frente, como a atuação do governo e, em especial, o projeto de lei elaborado com a participação do Ministro do Trabalho repercutirão nos trabalhos da

\footnotetext{
${ }^{53}$ Cf. o texto do Projeto de Lei 164/1987 em BRASIL. Diário do Congresso Nacional (Seção I). Brasília, 19 de junho de 1987, p. 2051/2054. É interessante notar que a previsão de multa ao sindicato, caso não cumprida a ordem do Tribunal de retorno ao trabalho, não constava da Lei 4.330/1964. Mais do que isso: também não consta da atual Lei 7.783/1989. Ainda assim, a aplicação de (elevadas) multas às entidades sindicais, em situações de greve, tornou-se uma prática frequente na jurisprudência trabalhista.

${ }_{54}$ A parte final da Exposição de Motivos faz referência, ainda, à "valiosa colaboração" de Amauri Mascaro Nascimento, José Maciel Neves e Francisco Zabulon de Figueiredo.

${ }^{55}$ Cf. BRASIL. Diário do Congresso Nacional (Seção I). Brasília, 19 de junho de 1987, p. 2054/2055.
} 
Assembleia Nacional Constituinte. Antes disso, porém, é pertinente examinar as etapas iniciais do funcionamento da ANC.

Com a instalação da Constituinte ${ }^{56}$, que teria o desafio de elaborar a Constituição sem um texto base ou um anteprojeto, inúmeras forças sociais se voltaram à discussão em torno do regimento interno da Assembleia. Era necessário assegurar mecanismos que garantissem meios de participação da sociedade na construção da nova ordem constitucional. Os instrumentos de participação seriam as emendas populares.

Durante a fase de elaboração do regimento interno da Constituinte, seu relator, o senador Fernando Henrique Cardoso (PMDB), sofreu importante pressão para que incluísse no texto a iniciativa popular, isto é, a possibilidade de apresentação de emendas populares ao projeto de constituição. Ao final, o art. 24 do Regimento Interno da ANC consagrou essa demanda da sociedade civil organizada: "essa nova forma de participação popular - mais avançada do que o recebimento de sugestões e a realização de audiências com entidades da sociedade civil, também previstos no regimento - correspondeu a um real avanço qualitativo. E, com essa vitória, criaram-se condições favoráveis a um maior nível de participação da sociedade no processo constituinte". 57

A mobilização popular não parou com a aprovação do regimento interno da Assembleia Nacional Constituinte. As sessões dessa última foram diariamente acompanhadas, seja pela televisão ou pelo rádio, seja presencialmente. ${ }^{58}$ Por diversas vezes, as discussões e votações contaram com a participação in loco de representantes da sociedade civil. Sessões da Constituinte foram interrompidas em razão das manifestações - frequentemente por meio de vaias - com relação aos rumos dos trabalhos de elaboração da nova Constituição. ${ }^{59}$

\footnotetext{
${ }^{56}$ Para um roteiro dos trabalhos da Assembleia Nacional Constituinte, ver OLIVEIRA, Mauro Márcio. Fontes de informações sobre a Assembléia Nacional Constituinte de 1987 - quais são, onde buscá-las e como usá-las. Brasília: Senado Federal, Subsecretaria de Edições Técnicas, 1993.

57 MICHILES, Carlos et al. Cidadão Constituinte - a saga das emendas populares, p. 55. Cf. Resolução $\mathrm{n}^{\circ}$ 2/1987, que dispõe sobre o Regimento Interno da Assembleia Nacional Constituinte. In: BRASIL. Diário da Assembleia Nacional Constituinte, vol. 330, Resolução nº 2/1987, Brasília, Centro Gráfico do Senado Federal, 1987.

${ }^{58} \mathrm{O}$ art. 76 do RI da ANC previa que "as emissoras de rádio e televisão cederão, diariamente, ao Serviço de Divulgação, para apresentação de programa informativo, contendo exposição de Constituintes e a síntese dos trabalhos da Assembléia Nacional Constituinte, dois horários, de 5 (cinco) minutos cada um (...)”. O art. 77, por sua vez, dispunha que "a Presidência da Assembléia poderá requisitar, das concessionárias de rádio e televisão, horário de, no máximo, 60 (sessenta) minutos, para a divulgação de fato relevante, de interesse da Assembléia Nacional Constituinte". Cf. BRASIL. Diário da Assembleia Nacional Constituinte, vol. 330, Resolução $\mathrm{n}^{\circ}$ 2/1987, p. 31.

${ }^{59}$ Não obstante o art. 40 do RI da ANC estabelecesse que "será permitido, a qualquer pessoa, assistir às sessões, das galerias, desde que esteja desarmada e guarde silêncio, vedada manifestação de aplauso ou reprovação ao que se passar no recinto ou fora dele”. Cf. BRASIL. Diário da Assembleia Nacional Constituinte, vol. 330, Resolução $n^{\circ} 2 / 1987$, p. 21 . Outro caminho importante para a participação popular foi a possibilidade de envio de sugestões à Constituição pelos cidadãos brasileiros. Elas foram reunidas pelo Prodasen em um banco de
} 
É chegado o momento de verificar como essa movimentação da sociedade influenciou os trabalhos da Assembleia Nacional Constituinte e, mais especificamente, as discussões relativas ao direito de greve.

\title{
1.2. Subcomissões e comissões temáticas
}

Ao se propor a discutir os modos de realização de uma Constituinte, o seu alcance e os seus limites, José Eduardo Faria lança uma observação que vai encontrar ressonância na ANC de 1987/1988 e nos usos da nova Constituição:

\begin{abstract}
Qualquer que seja o procedimento adotado para a formulação e de votação de uma nova ordem constitucional, ele obviamente cria relações de favorecimento ou de exclusão para determinados temas, grupos ou interesses. Isso se dá à medida que tal procedimento confere a esses temas, grupos ou interesses um tratamento preferencial, assegurando-lhes prioridade no tempo, maiores possibilidades de realização, etc. Em outras palavras, não há procedimentos neutros - as próprias regras destinadas a regular a própria Constituinte não são meros formalismos processuais; pelo contrário, enquanto tais, elas prejulgam o possível conteúdo de uma nova Carta e o possível resultado do respectivo processo de reordenação institucional do país. ${ }^{60}$
\end{abstract}

O Regimento Interno da Assembleia Nacional Constituinte estabelecia que as discussões e votações que levariam ao texto final da Constituição começariam pelas 24 subcomissões temáticas, que, por sua vez, compunham, a cada grupo de 3, as 8 comissões temáticas. Essas últimas receberiam os anteprojetos daquelas e procederiam à elaboração de anteprojetos, a serem enviados à Comissão de Sistematização, da qual participariam os relatores e presidentes das subcomissões e comissões, além de 49 titulares, com os respectivos suplentes. Em seguida, o projeto de Constituição seria encaminhado ao Plenário da ANC, para votação em dois turnos.

Se, por um lado, a composição da Constituinte não se mostrava muito favorável aos interesses populares, diante da participação de vários parlamentares do "partido do governo" ou "partido da ordem", por outro, a divisão dos trabalhos em comissões e subcomissões temáticas, ao pretexto de aumentar a participação de cada constituinte na

dados, o "Sistema de Apoio Informático à Constituinte - SAIC. A respeito, ver MONCLAIRE, Stéphane (Coord.). A constituição desejada - SAIC: as 72.719 sugestões enviadas pelos cidadãos brasileiros à Assembléia Nacional Constituinte. Brasília: Senado Federal, Centro Gráfico, 1991.

${ }^{60}$ FARIA, José Eduardo. A crise constitucional e a restauração da legitimidade. Porto Alegre: Sergio Antonio Fabris Editor, 1985, p. 19 (destaque acrescentado). 
elaboração do texto constitucional, permitiu a ampliação e a diversificação da agenda constituinte, que recebeu conotação plural. Essa decisão, tomada quando da elaboração do Regimento Interno, certamente contribuiu para o resultado final dos trabalhos da ANC. ${ }^{61}$

A investigação sobre o direito de greve pode iniciar, portanto, pelas discussões ocorridas nas subcomissões temáticas. Como os constituintes definiam o direito de greve? Como entendiam que esse direito deveria ser garantido (ou não) na constituição? E, ainda, como os constituintes (e outros atores que participaram das discussões) situavam o direito de greve no processo de mudança constitucional? O objetivo é examinar os debates e os discursos que circularam na ANC de 1987/1988 a partir dessas questões.

O ponto de partida é a subcomissão cujo próprio nome parece indicar ser ela um locus importante da pesquisa: a Subcomissão dos Direitos dos Trabalhadores e Servidores Públicos (VII-A), vinculada à Comissão da Ordem Social (VII). Seu presidente foi Geraldo Campos e o relator, Mário Lima (ambos do PMDB). ${ }^{62}$

\subsubsection{Subcomissão dos Direitos dos Trabalhadores e Servidores Públicos}

A $5^{\text {a }}$ Reunião da Subcomissão dos Direitos dos Trabalhadores e Servidores Públicos teve como tema de debate o direito de greve. Mário Lima fez uma explanação inicial, pontuando, em ordem cronológica, as leis brasileiras até a Lei 4.330/1964 para, então, destacar o momento de mudança:

(...) o País mudou. Veio a Nova República, as greves estão aí e temos a obrigação de incluir no texto da Constituição dispositivos que realmente dê

${ }^{61}$ Cf. PILATTI, Adriano. A Constituinte de 1987-1988 - Progressistas, conservadores, ordem econômica e regras do jogo. Rio de Janeiro: Editora Lumen Juris, 2008, p. 44. Vale a transcrição do seguinte discurso do Presidente da ANC, Ulisses Guimarães (PMDB), proferido quando de sua participação na reunião da Comissão da Ordem Social em que foram apresentados os relatórios das respectivas Subcomissões: "minhas Senhoras e meus Senhores: desejo aqui confidenciar que, quando a criatividade brasileira, a imaginação brasileira engendrou esta carpintaria constitucional, esta engenharia institucional, para elaborar o nosso texto magno, tive certo receio. E claro que acreditávamos que o documento cívico fundamental desta Nação seria elaborado nos moldes tradicionais, desde 1824, no Brasil e em todo o mundo, através de um texto préelaborado, mas, principalmente, de uma chamada grande Comissão. E aqui, mais uma vez, pôs-se uma das características da cultura brasileira, da sociedade brasileira, o seu espírito - repito - de criatividade, como freqüentemente abandona o inercial e envereda por caminhos inortodoxos; daí, surgiu, principalmente, pela iniciativa dos Constituintes que aqui chegavam pela primeira vez, a idéia que se consubstanciou no Regimento, de vários patamares, vários pisos, vários estágios, como se fosse depurando o texto final da Constituição. Entre eles, basicamente, aproveitando todos os Constituintes, as 24 Subcomissões" (BRASIL. Assembleia Nacional Constituinte. Ata da $2^{a}$ Reunião da Comissão da Ordem Social. Brasília: Senado Federal, Secretaria Especial de Editoração e Publicações. Subsecretaria de Anais, 1987, documento eletrônico, p. 11).

${ }^{62}$ Os debates e discursos foram reproduzidos tal como publicados nas atas da Assembleia Nacional Constituinte, sem realização de quaisquer correções ortográficas ou gramaticais. Feita essa explicação, não será registrada a expressão "sic" diante de eventuais erros de português nas transcrições. 
aos trabalhadores o que há em todas as democracias, em todos os países industrializados do mundo. E não se vá entender que um País que se orgulha de ser a $8^{\mathrm{a}}$ economia do mundo vá dificultar, ou inviabilizar, ou conceder, de maneira equivocada, o direito de greve. Esta, a minha opinião pessoal. (...) $\mathrm{O}$ País está vivendo estes dias de insegurança justamente por causa dessa lei que, na verdade, a pretexto de regular o direito, inviabiliza e impede que se exerça esse direito. E toda lei antinatural tende a ser desrespeitada e tende a ser desconhecida. ${ }^{63}$

Na Subcomissão, os constituintes não apenas apresentaram seus conceitos sobre a greve, como expressaram sua opinião sobre a forma com que o direito deveria ser assegurado no texto constitucional, marcando o momento de mudança. Houve várias manifestações que repudiavam as práticas de intervenção estatal (inclusive por meio da Justiça do Trabalho) nas paralisações e a proibição da greve em determinadas atividades, bem como defendiam uma constituição que garantisse o direito sem permitir sua regulamentação posterior por legislação ordinária, o que seria o mesmo que autorizar a negação do direito. É perceptível, em alguns discursos, a intenção de romper com certas práticas relacionadas à greve.

Para Paulo Paim (PT), a constituição deveria assegurar a liberdade de greve, e não o direito de greve, pois, nessa última expressão, seria possível sua regulamentação futura. ${ }^{64}$ Segundo Domingos Leonelli (PMDB), por sua vez, a ANC talvez pudesse se "inspirar na simplicidade da Constituição Portuguesa", não entrando em detalhes quanto à regulamentação do direito e proibindo eventual legislação ordinária que viesse a dificultar seu exercício. ${ }^{65}$

63 BRASIL. Assembleia Nacional Constituinte. Ata da $5^{a}$ Reunião da Subcomissão dos Direitos dos Trabalhadores e Servidores Públicos. Brasília: Senado Federal, Secretaria Especial de Editoração e Publicações, Subsecretaria de Anais, 1987, documento eletrônico, p. 29. Embora defensor do direito de greve, o relator Mário Lima disse ser contra a greve política, isto é, "a greve sem motivação nas suas finalidades, que é trazer para o trabalhador melhores salários e melhores condições de trabalho" (In: BRASIL. Assembleia Nacional Constituinte. Ata da $10^{a}$ Reunião da Subcomissão dos Direitos dos Trabalhadores e Servidores Públicos. Brasília: Senado Federal, Secretaria Especial de Editoração e Publicações, Subsecretaria de Anais, 1987, documento eletrônico, p. 121).

${ }^{64} \mathrm{O}$ constituinte fez alusão ao anteprojeto de constituição redigido pelo jurista Fábio Konder Comparato, que utiliza a expressão "liberdade de greve" e propõe sua regulamentação constitucional nos seguintes termos: "art. 50 - Aos trabalhadores e funcionários públicos, de qualquer gênero ou categoria, é assegurada a liberdade de paralisar, coletivamente, a prestação de trabalho ou do serviço funcional. $\S 1^{\text {o }}-$ A manifestação de greve, enquanto perdurar, acarreta a suspensão dos contratos de trabalho, ou da relação de emprego público. $\S 2^{\circ}-\mathrm{A}$ lei não poderá restringir ou condicionar o exercício dessa liberdade ao cumprimento de deveres ou ônus. $\S 3^{\circ}-\mathrm{O}$ abuso em manifestação de greve acarreta a responsabilidade civil, penal e administrativa; mas em caso algum a paralisação coletiva do trabalho será considerada, em si mesma, um crime". Para Comparato, "a garantia assegurada à liberdade sindical e à de greve - as quais se reforçam mutuamente - já dispensaria boa parte da regulação pública das relações de trabalho. Na verdade, a melhor proteção aos interesses dos trabalhadores é a autoproteção. Mas em país subdesenvolvido, marcado por fundas desigualdades de condições de vida, numa sociedade em que mais da metade da população vive em situação miserável, seria funestamente utópico dispensar a regulação pública das condições de trabalho. O anteprojeto lança mão, pois, de ambos esses instrumentos de proteção ao trabalhador". Cf. COMPARATO, Fábio Konder. Muda Brasil - uma constituição para o desenvolvimento democrático. São Paulo: Brasiliense, 1986, p. 87 e 59, respectivamente.

65 A Constituição Portuguesa, em seu art. 58, como invocado pelo constituinte, estatuía que "I - é garantido o direito à greve; II - compete aos trabalhadores definir o âmbito de interesses a defender através da greve, não 
Havia uma forte preocupação, por parte dos constituintes, com a regulamentação do direito de greve, sobretudo porque, em outros momentos da história brasileira - como na vigência da Constituição de 1946 -, a disciplina legal da greve tornou inócua a previsão constitucional. ${ }^{66}$ Era bem delineado o cenário de práticas que deveriam ser interrompidas, alteradas. É bastante significativo da postura de boa parte dos constituintes da Subcomissão o seguinte discurso de Célio de Castro (PMDB):

Nas nossas democracias precárias, periféricas, evidentemente a aliança do capital, do grande capital com o Estado, se faz presente para perverter o direito de greve. É comum, no movimento sindical, quando da verificação objetiva de greve, a primeira providência do patronato, quando existe uma greve - uma forma de negociação, embora, radicalizada - é chamar a polícia, é convocar o aparelho do Estado, para se colocar, aí, o aparelho do Estado, que deveria, no mínimo, ter uma função de árbitro, ele se coloca logo do lado do capital contra os trabalhadores. E ao lado da polícia ou do organismo repressivo do Estado vão-se colocando todas aquelas formas de que o Estado periférico se utiliza para tentar inviabilizar na prática o direito de greve. $E$ $a$ própria interpretação de textos, que foram aqui citados pelo nobre Relator, textos que são verdadeiras caricaturas do direito de greve, de que a Justiça do Trabalho lança mão para decretar a ilegalidade de movimentos grevistas. Neste sentido, me ocorre reafirmar aquele pensamento aqui já exposto, que a Constituição deve, sinteticamente, caracterizar o direito e a liberdade de greve como um direito e uma liberdade auto-regulada. ${ }^{67}$

O constituinte Edmilson Valentim ( $\mathrm{PC}$ do $\mathrm{B}$ ) se pronunciou no mesmo sentido, conceituando a greve como a expressão do trabalhador no sistema capitalista, "a única arma (...) que realmente o trabalhador tem para poder pressionar um patrão, um empresário ou o próprio Estado que se negou a negociar de maneira decente, de maneira coerente". Em sua opinião, "na esmagadora maioria, os movimentos grevistas são precedidos de descasos por

podendo a lei limitar este âmbito; III - é proibido o 'lockout'”. De acordo com Domingos Leonelli, sintetizando a proposta de outros parlamentares, "o debate na Constituição a respeito dessa questão pode fazer referência à legislação atualmente existente para negá-la. À Constituição cabe apenas, no meu modo de entender, assegurar o direito à greve e proibir qualquer lei que venha dificultar o exercício desse direito" (BRASIL. Assembleia Nacional Constituinte. Ata da $5^{a}$ Reunião da Subcomissão dos Direitos dos Trabalhadores e Servidores Públicos, p. 29).

${ }^{66}$ A referência à Constituição de 1946 já havia constado do pronunciamento inicial de Mário Lima: “em 46, com o Marechal Dutra na Presidência da República, Sua Excelência baixa o Decreto-Lei no 9.070, em 15 de março de 46, que, na prática, concede o direito de greve, mas o inviabiliza, porque cria um ritual tão complicado que nenhuma categoria consegue fazer uma greve considerada legal sem observar o que esse decreto-Lei preceitua. E, naquele clima de euforia de termos derrotado o nazi-fascismo, a Constituição de 46 reconhece, de maneira expressa, no seu art. 158, o direito de greve. Diz o art. 158: 'É reconhecido o direito de greve, cujo exercício a lei regulará.' Passada a euforia de termos derrotado o nazi-fascismo, nos esquecemos de regular o direito de greve, e ficou vigendo o Decreto-Lei $\mathrm{n}^{\circ}$ 9.070. Ele, na prática, não concedia o direito de greve" (BRASIL. Assembleia Nacional Constituinte. Ata da $5^{a}$ Reunião da Subcomissão dos Direitos dos Trabalhadores e Servidores Públicos, p. 29).

67 BRASIL. Assembleia Nacional Constituinte. Ata da $5^{a}$ Reunião da Subcomissão dos Direitos dos Trabalhadores e Servidores Públicos, p. 30 (destaque acrescentado). 
parte dos patrões, do Estado, descasos, às vezes, humilhantes”. E enfatizou que o direito de greve deve ser autoaplicável, sem necessidade de futura regulamentação. ${ }^{68}$

A proibição da greve em atividades essenciais foi combatida. Augusto Carvalho (PCB) propunha que, nos serviços públicos essenciais, assim definidos pelo Congresso Nacional, a deflagração da greve seria precedida de divulgação, na forma estabelecida pelos próprios trabalhadores. ${ }^{69}$ Wilma Maia (PDS), por sua vez, apresentou proposta em que a intervenção do Estado, em greves deflagradas em atividades essenciais, ocorreria apenas no caso de terem sido configurados prejuízos à sociedade..$^{70}$

Foi lembrado que, muitas vezes, a greve atropela a lei. Como disse Max Rosenmann (PMDB): “no Brasil, temos sentido ao longo dos anos, principalmente nos últimos anos, que, independente de haver regulamentos, leis, que proíbam a prática de greve, ela vem ocorrendo, até mesmo em atividades essenciais".71

O constituinte Júlio Costamilan (PMDB) recordou que o direito de greve já estava previsto na Constituição então vigente, de maneira que o problema que se colocava era justamente o de como respeitar esse direito. ${ }^{72}$ Os constituintes se deparavam com a questão da garantia efetiva, prática, do direito de greve, ou seja, não queriam que o texto constitucional se tornasse "letra morta". Talvez daí viesse a preocupação em estabelecer, na Constituição,

68 BRASIL. Assembleia Nacional Constituinte. Ata da $5^{a}$ Reunião da Subcomissão dos Direitos dos Trabalhadores e Servidores Públicos, p. 32. O constituinte lembrou a necessidade de melhoria no campo da negociação coletiva, assim relatando sua proposta: "É reconhecido aos trabalhadores em geral, inclusive aos funcionários públicos, o direito de greve. Isto tem que ser auto-aplicável, porque é um direito que já está difinido na Constituição e, por isso, não há necessidade de se regular, de lei complementar, com relação ao direito de greve. É necessário, sim, talvez, algum aperfeiçoamento na questão dos acordos, os procedimentos dos acordos das convenções. Esse princípio precisa estar caracterizado na nova Constituição" (p. 32).

69 BRASIL. Assembleia Nacional Constituinte. Ata da $5^{a}$ Reunião da Subcomissão dos Direitos dos Trabalhadores e Servidores Públicos, p. 31.

70 BRASIL. Assembleia Nacional Constituinte. Ata da $5^{a}$ Reunião da Subcomissão dos Direitos dos Trabalhadores e Servidores Públicos, p. 32.

71 BRASIL. Assembleia Nacional Constituinte. Ata da $5^{a}$ Reunião da Subcomissão dos Direitos dos Trabalhadores e Servidores Públicos, p. 31. Rosenmann levantou, ainda, dois pontos importantes sobre a greve, isto é, a legitimidade para sua deflagração e a possibilidade de realização de piquetes: "há dois pontos que aqui levanto, e desejo ouvir a opinião dos demais Companheiros, se possível, - a questão da legitimidade da deflagração - é um ponto muito importante no estabelecimento da greve a deflagração e a legitimidade dessa deflagração, dos trabalhadores que estejam realmente estabelecendo o clima de greve, e a outra questão a utilização do piquete, porque todos nós somos contra qualquer tipo de truculência policial, contra qualquer tipo de truculência governamental, contra qualquer tipo de interferência, mas também acredito eu que não poderemos ser favoráveis a outros tipos de truculência entre os próprios trabalhadores" (BRASIL. Assembleia Nacional Constituinte. Ata da $5^{a}$ Reunião da Subcomissão dos Direitos dos Trabalhadores e Servidores Públicos, p. 32).

72 Nas palavras do constituinte: "já consta na Constituição o direito de greve. A maneira como deve ser respeitado esse princípio é que nesta oportunidade, nesta Constituinte, estamos sendo desafiados, para que efetivamente saibamos e tenhamos a competência para que o texto constitucional reproduza com fidelidade a segurança que o trabalhador precisa ter, para que o seu exercício de greve seja efetivamente pleno, e possa, com todas as condições, fazer valer o seu direito". In: BRASIL. Assembleia Nacional Constituinte. Ata da $5^{a}$ Reunião da Subcomissão dos Direitos dos Trabalhadores e Servidores Públicos, p. 33. 
um texto que não comportasse limitação por legislação posterior, ou mesmo interpretação que significasse a restrição do direito (como visto acima, na manifestação de Célio de Castro).

Na mesma reunião, encerrando-a, o presidente da Subcomissão, Geraldo Campos

(PMDB), deixou transparecer, mais uma vez, a experiência que se pretendia fosse evitada:

Em 46 a Constituição também assegurou o direito de greve, mas remeteu a regulamentação para a lei ordinária. E essa regulamentação anulou por inteiro. Para se fazer uma greve, de acordo com a lei, que a regulamentou, era preciso convocar uma assembléia com dois terços, se não me engano, da categoria, com editais publicados, confirmados daí a tantos dias, era como se dizia naquela ocasião. A Lei de Greve era a verdadeira negociação do direito de greve. ${ }^{73}$

Após as discussões iniciais, os constituintes passaram a ouvir os representantes da sociedade civil organizada que foram convidados a participar das várias audiências promovidas pela Subcomissão. ${ }^{74}$

\subsubsection{As audiências públicas promovidas pela Subcomissão e a participacão da sociedade}

73 BRASIL. Assembleia Nacional Constituinte. Ata da $5^{a}$ Reunião da Subcomissão dos Direitos dos Trabalhadores e Servidores Públicos, p. 35. Ainda para Geraldo Campos, era necessário "exercitar o direito de greve de maneira não condicionada".

${ }^{74} \mathrm{Na} 4^{\mathrm{a}}$ Reunião da Subcomissão, foi apresentada, a partir das deliberações entre os constituintes, a relação de entidades e pessoas que seriam ouvidas nas audiências públicas: CUT - Central Única dos Trabalhadores; CGT - Central Geral dos Trabalhadores; USI - União Sindical Independente; DIEESE - Departamento Intersindical de Estatística e Estudos Sócio Econômicos; DIAP - Departamento Intersindical de Assessoria Parlamentar; DIESAT - Departamento Intersindical de Estudos e Pesquisas de Saúde e dos Ambientes de Trabalho; Confederação Nacional dos Trabalhadores na Agricultura; Confederação Nacional dos Trabalhadores no Comércio; Confederação Nacional dos Trabalhadores na Indústria; Confederação Nacional dos Profissionais Liberais; Confederação Nacional dos Trabalhadores em Comunicações e Publicidade; Confederação Nacional dos Trabalhadores em Empresas de Crédito; Confederação Nacional dos Trabalhadores nos Transportes Marítimos, Aéreo e Fluvial; Confederação Nacional dos Trabalhadores nos Estabelecimentos de Educação e Cultura; Confederação dos Servidores Públicos do Brasil; Confederação Nacional dos Trabalhadores nos Transportes Terrestres; Confederação Nacional dos Trabalhadores Aposentados; Ministro do Trabalho, Almir Pazzianotto; Ministro da Administração, Aluízio Alves; Associação Nacional de Ensino Superior - ANDES; Federação das Associações de Servidores das Universidades Brasileiras - FASUBRA; Confederação de Professores do Brasil ( $1^{\circ}$ e $2^{\circ}$ Graus) - CPB; Federação Nacional dos previdenciários - FENASP; União Brasileira de Informática Pública - UBIP; e uma representante da mulher trabalhadora. Cf. BRASIL. Assembleia Nacional Constituinte. Ata da $4^{a}$ Reunião da Subcomissão dos Direitos dos Trabalhadores e Servidores Públicos. Brasília: Senado Federal, Secretaria Especial de Editoração e Publicações, Subsecretaria de Anais, 1987, documento eletrônico, p. 17. Na $5^{\text {a }}$ reunião, foi aprovada a convocação da Confederação Nacional dos Trabalhadores Aposentados, e, na $8^{\mathbf{a}}$, a convocação da Confederação Nacional dos Pescadores. Cf. BRASIL. Assembleia Nacional Constituinte. Ata da $5^{a}$ Reunião da Subcomissão dos Direitos dos Trabalhadores $e$ Servidores Públicos, p. 26 e BRASIL. Assembleia Nacional Constituinte. Ata da $8^{a}$ Reunião da Subcomissão dos Direitos dos Trabalhadores e Servidores Públicos. Brasília: Senado Federal, Secretaria Especial de Editoração e Publicações, Subsecretaria de Anais, 1987, documento eletrônico, p. 88. Na $18^{\mathrm{a}}$ reunião, a Subcomissão deliberou por convidar entidades patronais, o que resultou na participação, na $20^{\mathrm{a}}$ reunião, da Confederação Nacional do Comércio (cf. BRASIL. Assembleia Nacional Constituinte. Ata da $20^{a}$ Reunião da Subcomissão dos Direitos dos Trabalhadores e Servidores Públicos. Brasília: Senado Federal, Secretaria Especial de Editoração e Publicações, Subsecretaria de Anais, 1987, documento eletrônico). 
A participação da sociedade, nas discussões da Subcomissão dos Direitos dos Trabalhadores e Servidores Públicos, começou com o Departamento Intersindical e de Assessoria Parlamentar - DIAP, que se fez presente pelo advogado Ulisses Riedel Resende. ${ }^{75}$

$\mathrm{O}$ representante do DIAP manifestou estranheza quanto ao projeto de lei encaminhado pelo governo ao Congresso Nacional, relativo ao direito de greve e à organização sindical. Para Ulisses Riedel, o envio do projeto de lei era uma manobra de distração, tanto para os trabalhadores quanto para os constituintes. O projeto teria por objetivo criar uma situação "constituída", ou seja, uma lei, produzida de acordo com as limitações da Carta então vigente, o que corresponderia a uma capitis diminutio do Poder Constituinte. ${ }^{76}$

Ulisses Riedel destacou alguns pontos sobre o direito de greve, tendo como referência o projeto de lei do governo. O primeiro deles foi "a intervenção precipitada da Justiça do Trabalho", isto é, a utilização da Justiça Especializada como instrumento para impedir um "legítimo direito de paralisação". O DIAP propunha a garantia do direito de greve, que não poderia ser restringido pela legislação, nem poderia ser limitado mediante intervenção das autoridades públicas. Era formulada a sugestão de que a propositura de dissídio coletivo fosse proibida desde a deflagração da greve e enquanto ela perdurasse (em contraposição, o projeto do governo estabelecia que "a greve cessará com a decisão da Justiça do Trabalho"). ${ }^{77}$

Outro aspecto ressaltado por Ulisses Riedel foi a previsão, no projeto de lei do governo, da possibilidade de sanções civis aos sindicatos e sanções penais à direção dessas entidades. A motivação do projeto, no primeiro caso, seriam decisões da Justiça do Trabalho que indeferiam pedidos de aplicação de multa aos sindicatos, ao argumento de que não havia

\footnotetext{
75 O representante do DIAP esclareceu que o Departamento não tinha opiniões próprias, mas, sim, buscaria instrumentalizar o que seriam as opiniões do movimento sindical. Cf. BRASIL. Assembleia Nacional Constituinte. Ata da $7^{a}$ Reunião da Subcomissão dos Direitos dos Trabalhadores e Servidores Públicos. Brasília: Senado Federal, Secretaria Especial de Editoração e Publicações, Subsecretaria de Anais, 1987, documento eletrônico, p. 62.

76 Segundo o representante do DIAP, "o trabalho do Ministério do Trabalho e do Poder Executivo não é de elaborar leis, e muito menos de elaborar leis que estejam ligadas diretamente ao aspecto constitucional, que se constitui em prerrogativa única e exclusiva dos Constituintes, de V. Ex.as. Respeitosamente entendemos que corresponde a uma verdadeira capitis diminutio para o Poder Constituinte, que estas matérias de natureza constitucional estejam, neste momento, sendo redigidas pelo Poder Executivo. E, mais ainda, redigidas de portas fechadas. Não como aqui, onde estamos, neste momento, convidados por V. Ex.as para prestar depoimento, para dar declarações, para trazer contribuições. Mas não! Entre paredes, sem que se conheça o teor daquilo que está sendo elaborado. De maneira que gostaríamos de, inicialmente, colocar a nossa posição no que diz respeito a essa atuação governamental dessa elaboração paralela ao Poder Constituinte" (BRASIL. Assembleia Nacional Constituinte. Ata da $7^{a}$ Reunião da Subcomissão dos Direitos dos Trabalhadores e Servidores Públicos, p. 58).

77 BRASIL. Assembleia Nacional Constituinte. Ata da $7^{a}$ Reunião da Subcomissão dos Direitos dos Trabalhadores e Servidores Públicos, p. 58/59.
} 
lei nesse sentido. Já a previsão de sanções penais permitia, em tese, que um piquete fosse considerado ilícito penal. ${ }^{78}$

Em seguida, foi ouvido o representante da central União Sindical Independente USI, Antônio Pereira Magaldi, que trouxe a proposta de que a constituição deveria garantir a proteção ao direito de greve, "que deve ser amplo e irrestrito, ressalvado, em legislação ordinária", quanto às "entidades sindicais que representam empregados que prestam serviços sociais ao público", o direito desses empregados de "decidirem em assembléia, a continuidade da greve, desde que não cause prejuízo aos usuários". ${ }^{79}$ Para Antônio Pereira Magaldi, a proteção ao direito de greve deve ser ampla e irrestrita, mas a população deve ser "ressalvada" 80 em se tratando de paralisação em atividades essenciais - como eletricitários e médicos, por exemplo -, sendo resguardado o direito dos trabalhadores, reunidos em assembleia, de resolverem essa situação. ${ }^{81}$

A proposta da USI, quanto ao direito de greve, foi questionada pelos constituintes Paulo Paim (PT) e Célio de Castro (PMDB). O primeiro fez a seguinte observação:

(...) eu lembraria a V. S. ${ }^{a}$ que a USI é uma entidade representativa dos trabalhadores. Pergunto se a USI entende - e sugiro ao Plenário que se converse sobre esse assunto - que os trabalhadores de categorias essenciais não teriam o direito de greve. Entendo que uma central sindical deve ter plena confiança na classe trabalhadora e deixar que ela decida se deve ou não entrar em greve. Tenho certeza - e foi amplamente discutido aqui, ontem, - de que essas categorias saberão manter trabalhadores em postos importantes que não prejudiquem a população. Lembrava, ontem - e repito aqui hoje - que, recentemente, na França, houve uma greve em que parou, inclusive, a energia. A população mesmo fez a sua passeata quanto ao movimento e, no fim, chegaram a um entendimento. Acho que não cabe a nós das centrais sindicais proibir o direito de greve à classe trabalhadora. Entendo que deve haver uma correlação de forças entre empregado e empregador. ${ }^{82}$

78 BRASIL. Assembleia Nacional Constituinte. Ata da $7^{a}$ Reunião da Subcomissão dos Direitos dos Trabalhadores e Servidores Públicos, p. 59.

79 BRASIL. Assembleia Nacional Constituinte. Ata da $7^{a}$ Reunião da Subcomissão dos Direitos dos Trabalhadores e Servidores Públicos, p. 61. Na transcrição dos debates da Constituinte, a proposta da USI está confusa, tendo sido assim redigida: "O direito de greve. Também eu escolhi para discutir nessa oportunidade. Garantir, na próxima Constituição, a proteção ao direito de greve, que deve ser amplo e irrestrito, ressalvado, em legislação ordinária, as entidades sindicais que representam empregados que prestam serviços sociais ao público. O direito de seus empregados decidirem em assembléia, a continuidade da greve, desde que não cause prejuízo aos usuários". É apenas com a leitura das discussões que se seguiram que se torna possível apreender, de forma mais precisa, o sentido da proposta da Central.

${ }^{80}$ Expressão utilizada pelo próprio representante da USI.

81 BRASIL. Assembleia Nacional Constituinte. Ata da $7^{a}$ Reunião da Subcomissão dos Direitos dos Trabalhadores e Servidores Públicos, p. 64.

82 BRASIL. Assembleia Nacional Constituinte. Ata da $7^{a}$ Reunião da Subcomissão dos Direitos dos Trabalhadores e Servidores Públicos, p. 64. 
Célio de Castro insistiu na indagação posta por Paulo Paim e exortou o representante da USI a rever a proposta da entidade. Relatou que, em reunião anterior, a Subcomissão havia "determinado", por unanimidade, que o direito de greve era substantivo, merecendo redação, no texto constitucional, que não permitisse condicionantes, inclusive no que diz respeito às "categorias de serviços essenciais". 83

Ao final, Antônio Magaldi, concordando com as observações, adotou a proposta apresentada pelo DIAP - como visto, de garantia do direito de greve, sem restrição por lei ordinária ou intervenção de autoridades públicas.

Também o representante da Confederação Nacional dos Trabalhadores na Indústria - CNTI, Olyntho Candido de Oliveira, diretor da entidade, pronunciando-se em nome da confederação e dos trabalhadores (consultados "à porta de fábrica"), expressou a opinião de que o direito de greve deveria "ser usado na sua amplitude de direito e não regulamentado". Isso porque "quando a greve é regulamentada não é direito". ${ }^{84}$

A Confederação Nacional dos Trabalhadores de Comunicação e Publicidade CNTCP, representada por Alceu Portocarrero, igualmente defendeu a proposta apresentada pelo DIAP. ${ }^{85} \mathrm{O}$ representante da Confederação se referiu às mensagens encaminhadas pelo Poder Executivo sobre os projetos de lei envolvendo estrutura sindical, negociação coletiva e direito de greve. A preocupação era a de que a legislação ordinária acabasse condicionando o texto constitucional a ser redigido. Além disso, Alceu Portocarrero tratou da relação entre a

83 BRASIL. Assembleia Nacional Constituinte. Ata da $7^{a}$ Reunião da Subcomissão dos Direitos dos Trabalhadores e Servidores Públicos, p. 67. O constituinte Ronan Tito (PMDB), durante os debates, posteriormente às manifestações dos representantes sindicais, argumentou no sentido de que o trabalhador não deve ser tutelado, nem deve ser considerado irresponsável. Ele pareceria ter em vista a proposta da USI. Em suas palavras: "a nossa função, o tempo todo, e, ontem, fiz uma provocação aqui propositada, a respeito da questão da greve, porque, quando se fala em greve, a gente fala modus in rebus: 'vamos devagar com o andor'. Nas greves? Como se os trabalhadores fossem irresponsáveis, que fizessem greve para colocar a população em situação difícil. Fui Secretário do Trabalho dois anos, num dos períodos mais difíceis, que foi logo depois da ditadura, quando começou o estado democrático, pipocou greve para todos os lados, mas eu, com toda a sinceridade não vi uma greve que não tivesse razão de ser. Presenciei mais de mil greves, participei de mais de mil greves e acho que o nosso trabalhador está bastante adulto. Não se venha aqui requerer tutelar o trabalhador: 'Ah, ele vai fazer isso, ele vai fazer aquilo', como se os patrões fossem todos homens responsáveis - acredito que são - e que os trabalhadores fossem irresponsáveis - aí eu não aceito" (BRASIL. Assembleia Nacional Constituinte. Ata da $7^{a}$ Reunião da Subcomissão dos Direitos dos Trabalhadores e Servidores Públicos, p. 65).

84 BRASIL. Assembleia Nacional Constituinte. Ata da $12^{a}$ Reunião da Subcomissão dos Direitos dos Trabalhadores e Servidores Públicos. Brasília: Senado Federal, Secretaria Especial de Editoração e Publicações, Subsecretaria de Anais, 1987, documento eletrônico, p. 142.

85 A proposta de redação do texto constitucional era a seguinte: "greve, que não poderá sofrer restrições na legislação, sendo vedada às autoridades públicas, inclusive judiciárias, qualquer tipo de intervenção que possa limitar esse direito. É proibido o lock out" (BRASIL. Assembleia Nacional Constituinte. Ata da $7^{a}$ Reunião da Subcomissão dos Direitos dos Trabalhadores e Servidores Públicos, p. 77). 
greve e o direito para lembrar que a greve é deflagrada ainda que proibida pelo direito (ou pela lei). ${ }^{86}$

A Confederação Nacional dos Profissionais Liberais - CNPL, representada por José Augusto de Carvalho, também criticou a restrição por lei do direito de greve, inclusive nas atividades essenciais:

Não se pode admitir que, a esta altura da evolução da sociedade brasileira, o Governo ainda restringe de tal modo o direito de greve que só, excepcionalmente, ela pode ser conduzida de acordo com a lei. Veja bem: a lei que estabelece atividades essenciais para o direito de greve. $\mathrm{O}$ trabalhador sabe quais são as atividades essenciais. Exemplo disso são as greves dos profissionais da Medicina, em que param, mas os serviços essenciais da Medicina não param. Exemplos disso são greves que se fazem em atividades consideradas, hoje, na legislação, essenciais, como metalurgia e outras, em que aquelas atividades que não podem parar, os próprios trabalhadores vão lá e se encarregam de mantê-la funcionando, para que não cause um prejuízo maior. Agora, que a greve causa um desconforto à população, isso é inevitável. Porque se ela não causar prejuízos à população, ela não será greve. ${ }^{87}$

O problema da restrição da greve em atividades consideradas por lei essenciais foi repisado por Orlando Coutinho, representante da Confederação Nacional dos Trabalhadores em Transportes Terrestres - CNTTT. Segundo ele, a primeira reivindicação da categoria, constante do documento "À Constituinte e à Constituição", fruto de Congresso realizado pelos trabalhadores associados à entidade, era "o direito de greve irrestrito" ${ }^{88}$

Orlando Coutinho buscou no direito internacional o conceito de atividade essencial, defendendo que deveria ser assim considerada apenas aquela relacionada à vida, à

\footnotetext{
${ }^{86}$ Em suas palavras, "parece-me que tudo isso, se for decidido agora pelo Legislativo deste País, é forçar com que a própria Constituição, que ainda está sendo discutida, seja condicionada a essa legislação ordinária, que vem a ser aprovada, para depois ser introduzida como princípio. Parece-me que há uma inversão da lógica, parece-me que deve ser descartado tudo em razão da Constituição. Se a lei de greve que está aí, que surgiu nos piores anos das liberdades sindicais, primeiro com a Lei $\mathrm{n}^{\circ} 4.330$ e, depois, com o Decreto-Lei $\mathrm{n}^{\mathrm{o}} 1.632$, e perdurou desde 67 até os dias de hoje, ela pode perdurar por mais alguns meses, para que a Constituição defina isso, sem redundância, e em caráter definitivo. Mesmo porque, o projeto que está para vir como mensagem ainda proíbe a greve nos serviços essenciais. Eu me pergunto e pergunto a V. Ex. ${ }^{a}$ : não será mais uma legislação que já começa como letra morta? Quem, neste País, assegura que, proibida a greve nas atividades essenciais, elas não continuarão ocorrendo? Estão ocorrendo cada vez com mais freqüência, em todas as atividades essenciais!" (BRASIL. Assembleia Nacional Constituinte. Ata da $8^{a}$ Reunião da Subcomissão dos Direitos dos Trabalhadores e Servidores Públicos. Brasília: Senado Federal, Secretaria Especial de Editoração e Publicações, Subsecretaria de Anais, 1987, documento eletrônico, p. 86). O Decreto-Lei 1.632, de 4.8.1978, dispunha sobre a proibição de greve nos serviços públicos e em atividades essenciais de interesse da segurança nacional.

87 BRASIL. Assembleia Nacional Constituinte. Ata da $10^{a}$ Reunião da Subcomissão dos Direitos dos Trabalhadores e Servidores Públicos, p. 106.

${ }^{88}$ Cf. BRASIL. Assembleia Nacional Constituinte. Ata da $12^{a}$ Reunião da Subcomissão dos Direitos dos Trabalhadores e Servidores Públicos. Brasília: Senado Federal, Secretaria Especial de Editoração e Publicações, Subsecretaria de Anais, 1987, documento eletrônico, p. 136
} 
saúde e à segurança dos indivíduos. Lembrou que os serviços de transportes eram reputados essenciais para fins de greve, que era, então, vedada. Para o representante da Confederação, "confunde-se o conforto, o comodismo das pessoas com a essencialidade". Mas ele reconhece que certas atividades seriam essenciais. Entretanto, “compete à própria organização sindical, por dever constitucional e legal, manter em operação o mínimo indispensável para que a vida, a saúde e a segurança de cada cidadão não possam ser prejudicadas". ${ }^{89}$

A Confederação defendeu "a liberdade com responsabilidade", a ser transferida ao sindicato. Além disso, para a entidade, a intervenção da Justiça do Trabalho, decorrente da propositura de dissídio coletivo, tornaria inócuo o direito de greve. ${ }^{90}$

Posição semelhante foi adotada pela Confederação Nacional dos Trabalhadores dos Transportes Marítimo, Aéreo e Fluvial - CONTTMAF, que esteve presente na Subcomissão, por seu presidente, Aluízio Ribeiro. A Confederação propôs o pleno direito de greve, enfatizando que, mesmo nas atividades essenciais, ele deveria ser autoaplicável. Tal como o fizera o representante da CNTTT, Aluízio Ribeiro invocou a responsabilidade dos próprios grevistas em contraposição à limitação do direito de greve. ${ }^{91}$

\footnotetext{
89 BRASIL. Assembleia Nacional Constituinte. Ata da $12^{a}$ Reunião da Subcomissão dos Direitos dos Trabalhadores e Servidores Públicos, p. 137.

${ }^{90}$ Eis a manifestação de Orlando Coutinho: "Esse direito de greve, quando nós colocamos, pois, como irrestrito, está no sentido de transferir para o sindicato a liberdade com responsabilidade para que haja a ordem necessária ao convívio da sociedade. E ele só existirá, também, concretamente, a partir do momento em que se impeça, como hoje ocorre, a existência de uma arbitragem obrigatória, uma faculdade que têm os empresários ou até mesmo o Ministério Público do Trabalho, integrante da estrutura do Poder Executivo, de submeter, compulsoriamente, as partes a uma arbitragem perante a Justiça do Trabalho como forma de impedir o exercício do direito de greve. E para esse aspecto, embora ele devesse ser alvo de apreciação de uma outra Subcomissão desta mesma Assembléia Nacional Constituinte, é que nós gostaríamos de chamar dos membros desta Subcomissão, para que o capítulo do direito dos trabalhadores e dos servidores públicos, a par de assegurar o direito de greve, contenha, também, um dispositivo que torne esse direito de greve eficaz, impedindo que a ação do empresário ou do próprio Poder Executivo, suscitando aquilo que se chama de ação de dissídio coletivo, para tornar inócua a existência do direito" (In: BRASIL. Assembleia Nacional Constituinte. Ata da $12^{a}$ Reunião da Subcomissão dos Direitos dos Trabalhadores e Servidores Públicos, p. 137). A mediação compulsória pelo Ministério do Trabalho está prevista no art. 616 da CLT, que se revela incompatível com a atual Constituição na parte em que veda a intervenção do poder público na organização sindical (art. $\left.8^{\circ}, \mathrm{I}\right)$.

${ }^{91}$ De acordo com o representante da Confederação, "a nossa posição em relação ao direito de greve é, como a que foi destacada anteriormente, em reunião a que assistimos, a de que esse direito deve ser pleno. E sendo, como destacou, com muita propriedade, o Constituinte Célio Castro, uma atividade eminentemente essencial ligada diretamente à questão de vida, esse direito de greve pode e deve ser realmente auto-aplicável. E as limitações do próprio exercício da greve devem ser uma responsabilidade do próprio trabalhador, responsabilidade essa que vem sendo exercida justamente no desdobramento das greves. (...) vemos que os trabalhadores de vários setores, de variado nível de instrução, todos eles têm demonstrado, à sociedade, antes de tudo, que têm consciência profissional, têm consciência dos limites que deve ter a greve" (In: BRASIL. Assembleia Nacional Constituinte. Ata da $16^{a}$ Reunião da Subcomissão dos Direitos dos Trabalhadores e Servidores Públicos. Brasília: Senado Federal, Secretaria Especial de Editoração e Publicações, Subsecretaria de Anais, 1987, documento eletrônico, p. 203).
} 
A Central Geral dos Trabalhadores - CGT, representada por Lourenço do Prado, também defendeu o direito irrestrito de greve. Para a Central, a greve estava vinculada à negociação coletiva, vale dizer, a greve era condição de exercício da negociação coletiva:

Negociação coletiva e direito de greve. Muito se tem falado, ultimamente, sobre a importância da negociação coletiva de trabalho, da liberdade para torná-la efetiva e dos meios indispensáveis para que seja viável na prática das discussões entre patrões e empregados. Prega-se mesmo que o negociador deve ser hábil e tecnicamente preparado, quem sabe até mesmo com recursos ou treinamentos feitos no exterior. Entretanto, pouco ou nada se tem feito de efetivo, mesmo na Nova República, para que isso seja conseguido. Neste sentido, a primeira coisa a ser feita seria a revogação da legislação limitativa das condições de negociação, consubstanciada sobretudo na legislação disciplinadora do exercício do direito de greve, e como sabemos, a dificuldade de todas as formas possíveis, sendo ainda particularmente agravada pela existência do Decreto-lei $\mathrm{n}^{\mathrm{o}} 1.632$, do Governo Geisel, que considera como atividades essenciais e, portanto, susceptíveis de paralisação, atividades que os trabalhadores nunca aceitaram como tais, como é o caso, por exemplo, dos bancários. Por isso, a proposta da CGT, arrimada em seu último congresso, está posta nos seguintes termos: que seja revogada a atual legislação restritiva ao direito de greve e em particular, aos decretos herdados do regime militar, do Decreto-lei $\mathrm{n}^{\circ} 1.632$, de 1979, que pró́be a greve nos setores considerados por ele essenciais, e também da Lei $\mathrm{n}^{\circ}$ 4.330, de 1964, que regulamenta a forma de fazer greve, objetivando dificultar ao máximo o legítimo direito dos trabalhadores. Deve ser encaminhada ao Congresso Nacional legislação alternativa ao direito de greve, e que a Constituinte soberanamente disponha sobre a questão; que o movimento sindical desencadeie intensa pressão e assegure, por todos os meios ao seu alcance, ampla liberdade de greve. Deve ser livre e irrestrito o direito de greve no Brasil. ${ }^{92}$ (p. 261 o Decreto Lei 1632 é de 1978)

Já a Central Única dos Trabalhadores - CUT, por seu presidente, Jair Meneguelli, apresentou o entendimento de que nenhum tribunal teria competência para julgar a greve. Em suas palavras:

não há arbitragem e não há tribunal que tenha competência para julgá-la. Ou nós incentivamos a que capital e trabalho resolvam entre si, as suas divergências, as suas diferenças, ou estaremos estabelecendo alguma coisa que, sem dúvida nenhuma vai pender para este ou para aquele lado. E nós já sabemos para que lado vai pender. A greve tem que ser resolvida entre os trabalhadores e os empresários que tenham competência para administrá-la e não tiveram competência para impedi-la. ${ }^{93}$

92 BRASIL. Assembleia Nacional Constituinte. Ata da $20^{a}$ Reunião da Subcomissão dos Direitos dos Trabalhadores e Servidores Públicos, p. 261.

93 BRASIL. Assembleia Nacional Constituinte. Ata da $20^{a}$ Reunião da Subcomissão dos Direitos dos Trabalhadores e Servidores Públicos, p. 273. 
A Confederação Nacional dos Servidores Públicos do Brasil - CSPB formulou como importantes reivindicações o direito à livre sindicalização e o direito de greve. Para seu representante, Archimedes Pedreira Franco, mesmo em greves deflagradas em atividades essenciais, os servidores não têm permitido a ocorrência de prejuízos. Archimedes Pedreira Franco destacou que o reconhecimento do direito de sindicalização e do direito de greve corresponderia à materialização de uma realidade:

Reconhecer o direito de sindicalização e o direito à greve, na Assembléia Nacional Constituinte de 1987, não seria mais do que materializar a realidade do dia de hoje. Se são proibidos na lei, na prática isso não ocorre. São sucessivas as greves que ocorrem a nível estadual, municipal e federal, e nenhuma outra medida tem sido aplicada além do diálogo para a solução do problema. No momento em que a sindicalização for encarada como uma realidade, como um fato concreto, seguramente, o diálogo será mais fácil e isso permitirá que se reduzam, na prática, os movimentos de paralisação. ${ }^{94}$

A falta de correspondência entre a lei e a realidade também foi destacada pelo professor Osvaldo de Oliveira Maciel, da Associação Nacional dos Docentes do Ensino Superior - ANDES, o qual enfatizou que a associação exercia os direitos que a legislação lhe negava, como, por exemplo, o direito de greve. ${ }^{95}$ Disse, ainda, que a pauta sindical da ANDES era curta e contemplava, entre outros pontos, a defesa do "direito irrestrito de greve".

Até aqui é perceptível a existência de consenso entre as entidades sindicais que se manifestaram expressamente sobre o direito de greve. ${ }^{96}$ Embora os mais variados aspectos relacionados à greve não tenham sido, em sua integralidade, abordados por todas as entidades,

\footnotetext{
94 Assembleia Nacional Constituinte. Ata da $16^{a}$ Reunião da Subcomissão dos Direitos dos Trabalhadores e Servidores Públicos, p. 197. O representante da Confederação Nacional dos Servidores Públicos do Brasil defendeu também a greve por parte de policiais militares, civis e dos bombeiros: "se a greve for permitida para essas organizações, entendemos que elas irão preservar o princípio da defesa de situações consideradas essenciais, como fazem os médicos, como fazem outras categorias profissionais, porque no momento que decretam a greve preservam um mínimo indispensável para a defesa da sociedade, da qual essas categorias também fazem parte. A proibição gera a contestação; a proibição e a repressão levam determinadas categorias à prática de violências. De sorte que, pessoalmente, sou favorável a que policiais militares vinculados aos Estados e policiais civis também vinculados aos Estados, tenham o mesmo direito de sindicalização e greve" (In: Assembleia Nacional Constituinte. Ata da $16^{a}$ Reunião da Subcomissão dos Direitos dos Trabalhadores e Servidores Públicos, p. 207).

95 Segundo Osvaldo de Oliveira Maciel, “a nossa entidade nacional não pediu licença ao Estado para se constituir, ela não depende da contribuição ou de benesses do Estado; eis que ela é mantida unicamente pela contribuição voluntária, que é um ato da vontade política de seus associados e de seus militantes, e ela tem exercido, na prática, os direitos que a legislação autoritária, regressiva e atrasada que até hoje está em vigor, cerceia, que é o direito de greve, por exemplo, entre outros o direito de livre associação, de filiação aos organismos internacionais" (In: Assembleia Nacional Constituinte. Ata da $16^{a}$ Reunião da Subcomissão dos Direitos dos Trabalhadores e Servidores Públicos, p. 200).

${ }^{96}$ Houve entidades que não se manifestaram de forma explícita nas audiências realizadas pela Subcomissão, como foi o caso da Confederação Nacional dos Pescadores, da União Brasileira de Informática Pública e da Confederação Nacional do Comércio (única entidade patronal ouvida pela Subcomissão).
} 
suas visões eram compatíveis. ${ }^{97}$ Considerem-se as maiores Centrais Sindicais da época, a CGT e a CUT. Elas tinham posições divergentes quanto a questões fundamentais relacionadas à organização sindical - como a escolha entre unicidade ou liberdade sindical, por exemplo, ou, ainda, a manutenção ou não da contribuição sindical -, mas não apresentaram divergência em suas propostas sobre o direito de greve (pelo contrário, suas sugestões eram complementares). Apesar da exceção, inicial apenas, da USI, os representantes do movimento sindical brasileiro, chamados a participar das audiências promovidas pela Subcomissão, defendiam, praticamente em uníssono, o direito de greve irrestrito e autoaplicável.

A visão externada pelas entidades sindicais estava em sintonia com a maioria dos constituintes que integravam a Subcomissão dos Direitos dos Trabalhadores e Servidores Públicos. A situação foi diferente quando participaram das reuniões os Ministros do Trabalho, Almir Pazzianotto Pinto, e da Administração, Aluízio Alves.

Desde as primeiras reuniões da Subcomissão, em que parte significativa dos debates foi despendida com a definição das pessoas e entidades que seriam convidadas a participar das audiências públicas, ficou expresso o incômodo dos constituintes com o projeto de lei encaminhado pelo Ministro do Trabalho ao Congresso Nacional. A tramitação do projeto - paralela aos trabalhos da Assembleia Constituinte - era vista pelos parlamentares como uma ameaça (ou, pelo menos, um grande inconveniente). Por isso, era indispensável o convite ao Ministro.

Paulo Paim (PT) se referiu ao projeto de lei do Ministro do Trabalho como "um absurdo, é pior do que esse que está aí, na verdade", pois proporia "até polícia particular para as empresas, para reprimir trabalhadores". E arrematou: "é importante que ele [Ministro do Trabalho] venha aqui o mais rápido possível para darmos, digamos 'uma prensa' nele até que ele retire esse projeto e deixe que os constituintes encaminhem um outro". ${ }^{98} \mathrm{O}$ incômodo com o PL do Ministro do Trabalho também foi expressado por Edmilson Valentim (PC do B), que

\footnotetext{
97 Além das entidades já mencionadas, podemos acrescentar: a Confederação Nacional dos Trabalhadores em Empresas de Crédito, por seu presidente Wilson Gomes de Moura, que se manifestou propondo o reconhecimento do direito de greve (Assembleia Nacional Constituinte. Ata da $7^{a}$ Reunião da Subcomissão dos Direitos dos Trabalhadores e Servidores Públicos, p. 62); o representante da Confederação Nacional dos Trabalhadores no Comércio, Antônio Alves de Almeida, presidente da entidade, que expressou que sua categoria entendia que o direito de greve deveria ser amplo, não devendo existir lei que o proibisse ou o limitasse (Assembleia Nacional Constituinte. Ata da 10 ${ }^{a}$ Reunião da Subcomissão dos Direitos dos Trabalhadores e Servidores Públicos, p. 104); entendimento semelhante foi apresentado pela Confederação Nacional dos Trabalhadores da Agricultura - CONTAG, representada por José Francisco da Silva (Assembleia Nacional Constituinte. Ata da $20^{a}$ Reunião da Subcomissão dos Direitos dos Trabalhadores e Servidores Públicos, p. 260).

98 BRASIL. Assembleia Nacional Constituinte. Ata da $3^{a}$ Reunião da Subcomissão dos Direitos dos Trabalhadores e Servidores Públicos. Brasília: Senado Federal, Secretaria Especial de Editoração e Publicações, Subsecretaria de Anais, 1987, documento eletrônico, p. 16. A referência do constituinte parece ser ao PL 164/1987, examinado acima.
} 
se referiu à atitude do Ministro como "inconcebível". 99 Já para a constituinte Wilma Maia (PDS), o projeto do Ministro Pazzianoto era uma interferência do governo nos trabalhos da Constituinte, uma tentativa de influenciar o pensamento dos constituintes. ${ }^{100}$

O Ministro do Trabalho participou da $13^{\text {a }}$ reunião da Subcomissão. Pazzianotto destacou a necessidade de mudanças significativas, dizendo que era necessário tratar do presente, em razão do futuro, mais precisamente, "do passado e do presente, com os olhos voltados para a construção do futuro". ${ }^{101} \mathrm{Em}$ sua opinião, as questões "mais fundamentais" seriam a organização sindical, o direito de greve, a negociação coletiva e o poder normativo da Justiça do Trabalho. Sobre a greve, enfatizou que a decisão sobre a mudança, entre o que estipulava a Constituição de 1946, o que previa a Carta de então (que proibia a greve nos serviços públicos e nas atividades essenciais) e uma nova redação cabia exclusivamente à Assembleia Nacional Constituinte.

Não demorou muito para que o Ministro fosse questionado sobre o projeto de lei encaminhado ao Congresso Nacional. O constituinte Domingos Leonelli (PMDB) fez a Almir Pazzianotto a "sugestão política" para que ele provocasse o Presidente da República a sustar, durante a elaboração da Constituição, a tramitação, no Congresso Nacional, do projeto que tratava da greve e das negociações coletivas, pois a legislação elaborada teria que se balizar na Constituição então vigente. ${ }^{102}$

\footnotetext{
${ }^{99}$ Em suas palavras, "acho que no momento em que estamos reunidos em Assembléia Nacional Constituinte e especificamente na subcomissão dos Direitos dos Trabalhadores trabalhando para uma nova lei de greve, numa ótica de discussão democrática que, inclusive, será a lei que prevalecerá, porque estará na Constituição, é inconcebível que o ministro remeta uma lei de greve ao Congresso no sentido de se mudar a legislação atual, até porque, se ela mudar, será temporária. Então - fico preocupado com essa atitude, já vamos chamar o ministro aqui, foi decidida a convocação do ministro para se discutir não só sobre a lei de greve, mas sobre assuntos gerais - eu sugeriria, e submeto à discussão dos constituintes, que nós, da subcomissão dos Direitos dos Trabalhadores, enviássemos um comunicado, ou tomássemos um posicionamento em relação a essa atitude do ministro do Trabalho com relação à Lei de Greve". BRASIL. Assembleia Nacional Constituinte. Ata da $5^{a}$ Reunião da Subcomissão dos Direitos dos Trabalhadores e Servidores Públicos, p. 16. Pelo discurso de Paulo Paim e Edmilson Valentim, fica evidente um uso atécnico ou informal de certas expressões. Tanto um como outro usam o termo "lei" para se referir à constituição (o que não é de todo incorreto, na medida em que a constituição é um texto legal, embora superior às demais leis).

100 BRASIL. Assembleia Nacional Constituinte. Ata da $5^{a}$ Reunião da Subcomissão dos Direitos dos Trabalhadores e Servidores Públicos, p. 32.

101 E completou o Ministro: "se não houvesse a necessidade de graves mudanças, se não houvesse a imperiosidade de profundas alterações, não teria razão de ser da própria Assembléia Nacional Constituinte. Bastaria o trabalho rotineiro, sempre profundo, do Congresso Nacional. Na medida em que as grandes lideranças políticas, democráticas, propuseram que se elegesse uma Assembléia Nacional Constituinte, isto significou que toda lei fundamental do País está a exigir uma nova reflexão e uma grande reformulação" (In: BRASIL. Assembleia Nacional Constituinte. Ata da $13^{a}$ Reunião da Subcomissão dos Direitos dos Trabalhadores e Servidores Públicos. Brasília: Senado Federal, Secretaria Especial de Editoração e Publicações, Subsecretaria de Anais, 1987, documento eletrônico, p. 149).

102 Nas palavras do constituinte, “(...) o Governo, mandando para o Congresso uma lei, hoje, tem que fundamentá-la, tem que balizá-la, tem que se limitar à Constituição atual. Não tem sentido, portanto, usar a roupa velha da Constituição, usar o pano velho para fazer uma roupa nova de uma legislação que deverá surgir - se surgir -, se esta Constituição não for completamente auto-aplicável - com um tecido novo, com os elementos
} 
Paulo Paim, por sua vez, indagou o Ministro sobre dispositivos do projeto de lei, afirmando que a Subcomissão entendia que "o direito de greve deve ser irrestrito". E fez apelo semelhante ao de Domingos Leonelli, para que a decisão, sobre o direito, fosse deixada à Assembleia Constituinte. ${ }^{103}$

Almir Pazzianotto, em resposta, procurou diminuir a importância do projeto de lei e de sua tramitação, exaltando o papel da Assembleia Nacional Constituinte e seu poder de “dispor". Suas palavras iniciais foram as seguintes:

Esta Assembléia Nacional Constituinte não pede nada ao Governo. Essa é uma colocação equivocada e que, certamente, não tem o beneplácito dos seus Pares. Não há por que pedir. A Assembléia Nacional Constituinte decide, ela é o poder maior, ela pode fazer tabula rasa dos direitos adquiridos; talvez não o faça por apego aos princípios gerais do Direito, a tradição, a história, a necessidade de que o Direito tenha um embassamento e uma consolidação que permitem que resista mesmo às mudanças de regime, às mudanças de Governo, no que tange às questões essenciais do cidadão e à própria organização do Estado. Mas a Assembléia Nacional Constituinte não pede, ela dispõe. Esta contradição já me despertou a atenção em mais de um momento. ${ }^{104}$

E complementou quanto ao texto da Constituição:

O regime democrático vive um debate de projetos de leis e de mudanças. Porque se a lei fosse definitiva, convocar-se-ia o Poder Legislativo e, uma vez cumprida a sua tarefa, todos os Srs. Parlamentares voltariam para suas casas. A lei existe para ser alterada. E há uma coisa curiosa, Constituinte Paulo Paim, é que essa alteração pode ser feita de forma indolor, pela jurisprudência. Ou os Srs. imaginam que ao concluírem a Constituição, este será um texto hermético, cristalizado, definitivo, irretocável, virginal, sacro, perene? Não é nada disso. E a sua virtude maior resultará da capacidade de adaptar-se às mudanças objetivas, da sociedade, às mudanças concretas da economia de um país em transformação permanente; se há necessidade de alterações de redação de artigos e parágrafos. ${ }^{105}$

Ao final, porém, após a insistência do constituinte Paulo Paim, o Ministro do Trabalho disse que anotaria o pedido e o submeteria ao Presidente da República como

novos de uma nova Constituição" (BRASIL. Assembleia Nacional Constituinte. Ata da $13^{a}$ Reunião da Subcomissão dos Direitos dos Trabalhadores e Servidores Públicos, p. 155).

103 Cf. BRASIL. Assembleia Nacional Constituinte. Ata da $13^{a}$ Reunião da Subcomissão dos Direitos dos Trabalhadores e Servidores Públicos, p. 157.

104 BRASIL. Assembleia Nacional Constituinte. Ata da $13^{a}$ Reunião da Subcomissão dos Direitos dos Trabalhadores e Servidores Públicos, p. 157.

105 BRASIL. Assembleia Nacional Constituinte. Ata da $13^{a}$ Reunião da Subcomissão dos Direitos dos Trabalhadores e Servidores Públicos, p. 158. 
manifestação da Subcomissão. ${ }^{106}$

O Ministro da Administração participou da $14^{\mathrm{a}}$ reunião, pronunciando-se de forma contrária ao reconhecimento do direito de greve dos servidores públicos. Para Aluízio Alves, a proteção à comunidade devia prevalecer em detrimento da proteção ao servidor público - ou seja, em última análise, o interesse no serviço justificaria a restrição ao direito de greve. Embora longo, o trecho a seguir é elucidativo:

Eu sou contra o direito de greve do funcionário público e explico o porquê. O direito de greve é um instrumento que se dá ao trabalhador para, através do seu sindicato, levar o seu patrão a conceder reivindicações que ele está negando no processo de negociação. Como não chegaram a um acordo patrões e empregados, estes fazem greve e o patrão, muitas vezes para evitar o seu prejuízo - a fábrica parada, a casa comercial parada - faz a concessão, negocia sob a pressão econômica.

No caso do funcionário público, porém, não há este patrão. Se o funcionário entrar em greve, quem é prejudicado é a comunidade para cujo serviço foi contratado. Se ele é médico e deixa de trabalhar no hospital público, quem está sendo prejudicado é o doente; se é professor, quem está sendo prejudicado é o estudante. Esta é a primeira razão.

Como segunda razão, acho que chegaríamos a um impasse facilmente, se tivesse direito de greve. No caso de uma greve, a negociação é entre patrão e empregado. Chega um momento em que o empregador cede, concede tal ou qual benefício. E como isso poderia ocorrer na Administração Pública? Vamos admitir que ele quisesse um aumento de $100 \%$ e o Ministério da Administração o concedesse. E aí? Seria o suficiente? Não. Teria que ir ainda à área econômica a fim de que dissesse se haveria verba ou não para pagar - Ministério do Planejamento - e se haveria dinheiro para pagar Ministério da Fazenda. Não tinha. Como ficaria o compromisso assumido pelo Ministério da Administração com os grevistas? Vamos admitir que os dois Ministros dissessem que haveria verba e dinheiro para pagar, mas, ao ir ao Presidente da República, este dissesse por uma razão política qualquer, que não concederia o aumento naquelas bases, porque criaria precedente, ou por outro motivo qualquer. Então outro impasse. Mas vamos admitir que o Presidente da República, por uma razão política qualquer, dissesse "Não concedo. Não quero conceder esse aumento nessas bases, que me vai criar precedentes para isso ou para aquilo". É outro impasse. Mas vamos admitir que o Presidente da República quisesse conceder. Teria que vir uma lei para o Congresso. Vamos admitir que o Congresso, ou não desse os $100 \%$, ou desse mais de $100 \%$. Portanto, falta o elemento negociador. Já na iniciativa

\footnotetext{
${ }^{106} \mathrm{O}$ apelo para a sustação da tramitação do projeto de lei foi reiterado pelos constituintes Augusto Carvalho e Célio de Castro. Esse último, talvez em resposta às observações de Pazzianotto, relatou a "posição majoritária" da Subcomissão no sentido de que o direito de greve deveria ser assegurado como "direito auto-aplicável, não passível de modificação por legislação ordinária posterior que viesse a negá-lo na prática”, ou diminuí-lo por intervenção de autoridades, inclusive judiciárias. Cf. BRASIL. Assembleia Nacional Constituinte. Ata da $13^{a}$ Reunião da Subcomissão dos Direitos dos Trabalhadores e Servidores Públicos, p. 163. O apelo feito pelos constituintes ao Ministro do Trabalho retrata a disputa de força entre o Poder Executivo, de um lado, e o Poder Legislativo e a Assembleia Nacional Constituinte, de outro. Como o governo já havia encaminhado os dois projetos de lei ao Congresso Nacional, uma decisão do próprio Poder Legislativo poderia, em tese, retardar ou mesmo sustar sua tramitação. Entretanto, diante da influência do governo, talvez essa decisão se tornasse inviável sem o apoio do Executivo.
} 
privada, não; é entre patrão e empregado. No Governo, não; quem decide, afinal, é o Congresso Nacional. Não posso, amanhã dizer: "Vocês acabem com a greve, que vou conceder os $100 \%$, garantidos por mim, pelos ministros, pelo Presidente, pela Câmara e pelo Senado". Há, a meu ver, uma confusão de valores e de mecanismos que se aplicam à iniciativa privada e não se aplicam ao funcionário público, tanto que sou a favor do direito de greve na administração indireta, na empresa pública, porque, ela executa a sua tarefa pública pelos processos da iniciativa privada. É uma empresa pública, é uma fundação. Por quê? Porque a diretoria de uma fundação pode conceder um aumento, a diretoria do Banco do Brasil pode conceder um aumento, e está concedido. Ela é a última palavra. No caso do funcionário público, não, a última palavra é uma lei do Congresso. Avaliem se eu chegar e dizer "Suspendam essa greve que esse aumento será concedido, essa vantagem será concedida". Isso dependendo ainda de uma votação do Congresso. E se não fosse aprovada, ou se demorasse a ser aprovada - seis meses, dois meses, um ano - e a greve tivesse sido encerrada na base de um compromisso que eu não podia assumir. Esta é uma das razões pelas quais sou contra o direito de greve. ${ }^{107}$

O relator da Subcomissão, Mário Lima (PMDB), fez o contraponto à posição do Ministro. Recorrendo à realidade do país, o constituinte indagou se não seria o caso de pensar mecanismos diferentes para os funcionários públicos, alertando para o risco de se esquecer "o fundamental, que é a proteção ao homem". ${ }^{108}$

A resposta de Aluízio Alves foi direta: "não. O fundamental não é a proteção ao funcionário. No caso, o fundamental é a proteção à comunidade à qual o funcionário deve servir. Não podemos dizer que o fundamental do serviço público é a proteção do funcionário público, mas o fundamental é o serviço que o funcionário tem que prestar à comunidade". 109

O constituinte Mansueto de Lavor (PMDB) não ficou convencido com o argumento do Ministro e fez oposição. Para ele, o direito de greve deveria ser assegurado a todos com base no princípio de isonomia. E complementou: "pura e simplesmente, negar ao servidor da administração pública, federal, estadual ou qualquer que seja a esfera, o direito de greve, será, não apenas uma enorme frustração, mas, parece-me, que o direito dos

107 BRASIL. Assembleia Nacional Constituinte. Ata da $14^{a}$ Reunião da Subcomissão dos Direitos dos Trabalhadores e Servidores Públicos. Brasília: Senado Federal, Secretaria Especial de Editoração e Publicações, Subsecretaria de Anais, 1987, documento eletrônico, p. 173.

108 De acordo com o relator da Subcomissão, "hoje, na realidade, o funcionário público, os trabalhadores das chamadas atividades essencias só são lembrados disso na hora de sofrerem determinadas restrições. $\mathrm{O}$ trabalhador da área essencial só é lembrado que é essencial quando é proibido de fazer greve quando ele vai negociar, vai para um tribunal, que faz os dissídios com os mesmos prazos, com as mesmas impossibilidades de realizar. Assim, V. Ex. ${ }^{a}$ não acha que teria que se pensar numa sistemática também um pouco diferente, já que se pensa em se privar esses trabalhadores funcionários públicos dos direitos que são dados aos trabalhadores comuns, que podem ter o direito de greve, de se sindicalizarem? Eles não teriam que ter um mecanismo um pouco diferente? No final, acho que vamos terminar esquecendo o fundamental, que é a proteção ao homem" (In: BRASIL. Assembleia Nacional Constituinte. Ata da $14^{a}$ Reunião da Subcomissão dos Direitos dos Trabalhadores e Servidores Públicos, p. 174).

109 Cf. BRASIL. Assembleia Nacional Constituinte. Ata da $14^{a}$ Reunião da Subcomissão dos Direitos dos Trabalhadores e Servidores Públicos, p. 174. 
trabalhadores, na nova Carta Constitucional, terá um cerceamento inexplicável em face da nova realidade do País". 110

O Ministro Aluízio Alves insistiu em sua argumentação, diferenciando as características e o objetivo da Administração Pública e enfatizando a questão dos obstáculos à negociação coletiva. ${ }^{111}$

Na participação dos Ministros do Trabalho e da Administração, é perceptível o embate com a visão dos constituintes sobre o direito de greve, sobretudo quando tomada em consideração a disputa entre romper ou não com o regime anterior à Constituição que seria elaborada. Mesmo Almir Pazzianotto, que, em seu discurso, referiu à necessidade de mudanças - com "os olhos voltados para a construção do futuro" -, não recuou facilmente diante dos apelos dos constituintes para que fosse encaminhado à Presidência da República pedido de sustação da tramitação do projeto de lei relativo à greve, à negociação coletiva e à organização sindical. Mais do que isso, o Ministro procurou justificar como própria do regime democrático a tramitação do projeto, ainda que paralela aos trabalhos da Constituinte.

Com o fim das audiências públicas, a Subcomissão passaria à etapa das deliberações, tendo por objetivo elaborar o anteprojeto de Constituição que seria remetido à Comissão da Ordem Social.

\subsubsection{As deliberacões da Subcomissão}

Na $21^{\text {a }}$ reunião da Subcomissão dos Direitos dos Trabalhadores e Servidores Público, Mário Lima (PMDB) apresentou seu relatório. A Subcomissão havia recebido 1.394 sugestões de normas constitucionais, o que correspondia a $14,15 \%$ do total de sugestões encaminhadas à ANC - foi a Subcomissão que mais sugestões recebeu. O relator destacou que a maioria absoluta dos membros da Subcomissão subscrevera a sugestão de $\mathrm{n}^{\mathbf{0}}$ 6292.8, correspondente à manifestação das Centrais Sindicais e das Confederações Nacionais de

\footnotetext{
110 Cf. BRASIL. Assembleia Nacional Constituinte. Ata da $14^{a}$ Reunião da Subcomissão dos Direitos dos Trabalhadores e Servidores Públicos, p. 174.

111 Para Aluízio Alves, “o mecanismo do serviço público não pode ser confundido com o mecanismo da iniciativa privada, tanto que sou favorável a que se dê o direito de greve aos empregados da União, aos empregados públicos que estejam enquadrados em fundações, naquelas instituições que são próprias da iniciativa privada. Na repartição pública, aí, sim, sou contra, porque entendo que os objetivos e as características são diferentes, e não vejo como se conceder o direito de greve, que só poderá ser evitado mediante um compromisso patronal, que ninguém tem condições de assumir, pois esse compromisso depende de lei a ser votada pela soberania do Congresso Nacional". O Ministro encerrou dizendo do seu dever de sua "opinião franca, quando perguntado sobre o problema" (In: BRASIL. Assembleia Nacional Constituinte. Ata da $14^{a}$ Reunião da Subcomissão dos Direitos dos Trabalhadores e Servidores Públicos, p. 175).
} 
Trabalhadores, apoiando o texto articulado pelo DIAP. ${ }^{112}$

Pela redação do anteprojeto apresentado por Mário Lima, o direito de greve seria previsto nos seguintes termos:

Art. $2^{\circ}$ - A Constituição assegura aos trabalhadores e aos servidores públicos civis, federais, estaduais e municipais, independente de lei, os seguintes direitos, além de outros que visem à melhoria de sua condição social:

(...)

XVI - greve que não poderá sofrer restrições na legislação, sendo vedado às autoridades públicas, inclusive judiciárias, qualquer tipo de intervenção que possa limitar esse direito; é proibido o locaute; ${ }^{113}$

O relatório esclarece o entendimento que fundamentou o anteprojeto:

A greve deve ser entendida como a única forma de pressão verdadeiramente eficaz de que o trabalhador dispõe para fazer valerem as suas reivindicações, em contraposição ao variado poder de pressão do empresariado.

Tal como reconhecido hoje, o direito de greve encontra-se frustrado na prática.

Fiel ao desejo unânime da classe trabalhadora, inclusive dos servidores públicos, a Subcomissão, por expressiva maioria, optou pelo reconhecimento do direito de greve sem restrição de qualquer espécie.

$\mathrm{O}$ respeito aos direitos gerais da comunidade cabe aos próprios trabalhadores grevistas, sob as penas da lei comum. ${ }^{114}$

Foram apresentadas duas emendas ao art. $2^{\circ}$ do anteprojeto, ambas alterando o caput do dispositivo. A primeira delas, de autoria do constituinte Max Rosenmann (PMDB), propunha excluir a expressão "independente de lei". Vale notar que o preceito se desdobrava em 34 incisos e o objetivo da referida expressão era o de que a constituição dispusesse de forma concreta, sem princípios meramente programáticos, sobre os direitos dos trabalhadores. ${ }^{115} \mathrm{Ou}$ seja, a expressão "independente de lei” se referia aos vários direitos

112 Cf. BRASIL. Assembleia Nacional Constituinte. Comissão da Ordem Social. Subcomissão dos Direitos dos Trabalhadores e Servidores Públicos, vol. 188, Brasília, Centro Gráfico do Senado Federal, 1987, p. $2 / 3$. Segundo o relatório, quanto ao direito de greve, a proposta de $n^{\circ} 6292.8$ foi integralmente aprovada e incorporada ao anteprojeto.

113 Cf. BRASIL. Assembleia Nacional Constituinte. Comissão da Ordem Social. Subcomissão dos Direitos dos Trabalhadores e Servidores Públicos, vol. 188, p. 14.

114 BRASIL. Assembleia Nacional Constituinte. Comissão da Ordem Social. Subcomissão dos Direitos dos Trabalhadores e Servidores Públicos, vol. 190, Brasília, Centro Gráfico do Senado Federal, 1987, p. 6.

115 Como constou do relatório: "entendeu-se que a nova Constituição deve dispor concretamente sobre o direito dos trabalhadores e servidores públicos civis e militares, não permitindo que restem princípios que sejam 'letra morta' na nova Carta constitucional. (...) Por outro lado, nesse mesmo sentido, é indubitável que o povo se sentiria traído e frustrado com a apresentação de uma nova Carta Magna com princípios meramente programáticos. O povo está por demais desiludido, não merecendo nova frustração. Tecnicamente, não há porque se deixar para a lei ordinária, princípios que devem ficar claramente definidos na Constituição" (In: BRASIL. Assembleia Nacional Constituinte. Comissão da Ordem Social. Subcomissão dos Direitos dos 
previstos no art. $2^{\circ}$ do anteprojeto. Para opinar contrariamente à emenda de Max Rosenmann, Mário Lima utilizou como exemplo o direito de greve e a experiência da Constituição de 1946. Segundo o relator, a supressão sugerida enfraqueceria o artigo. A emenda foi, ao final, rejeitada, por 18 votos a $7 .{ }^{116}$

A segunda emenda era do constituinte Paulo Paim (PT), que pretendia incluir a expressão "e a todos os demais" no caput do art. $2^{\circ}$. A proposta foi aprovada à unanimidade, ficando o dispositivo assim redigido: "a Constituição assegura aos trabalhadores e aos servidores públicos civis, federais, estaduais e municipais, $e$ a todos os demais, independentemente de lei, os seguintes direitos, além de outros que visem à melhoria de sua condição social (...)".117

Na reunião de 25 de maio de 1987, a Subcomissão aprovou o anteprojeto que seria enviado à Comissão da Ordem Social. $\mathrm{O}$ tom de mudança foi destacado pelo relator:

Acho que estamos escrevendo uma fase nova na vida política deste País. Se as outras Comissões - admito que também levaram a sua missão com dedicação, com a seriedade com que levamos nesta Subcomissão, o nosso País estará definitivamente ingressando numa nova era. Não será uma nova era meramente formal, mas será uma nova era para este País, onde haverá mais justiça social, mais progresso e mais igualdade para todos. ${ }^{118}$

Vários constituintes enalteceram o trabalho da Subcomissão, enfatizando a importância da defesa dos direitos dos trabalhadores. A depender dos constituintes que integravam a Subcomissão, as conquistas seriam inúmeras - além do direito irrestrito de greve, o anteprojeto previa o direito à duração laboral de 40 horas semanais, ao adicional noturno de 50\%, com hora noturna reduzida de 45 minutos, e a estabilidade no emprego, entre outros. Ao mesmo tempo, porém, sabiam que ainda havia um longo caminho a percorrer até a

Trabalhadores e Servidores Públicos, vol. 188, p. 3).

116 O objetivo de Max Rosenmann seria garantir aos congressistas, no futuro, o direito de legislarem. Em suas palavras, "a nossa colocação se prende realmente ao fato de uma vez estabelecida uma Constituição com os termos que estamos aprovando, estabelecermos como um direito constitucional. Se pretendermos amanhã, dentro da dinâmica da sociedade, ampliar o salário-família, ampliar o salário mínimo, ampliar qualquer outra relação subsequente desse artigo, necessitaríamos, sem dúvida nenhuma de uma reforma constitucional; porque está claro que a independência de lei está estabelecida e não haverá lei que possa se contrapor a esses princípios, evitando, portanto, a possibilidade do legislador legislar em torno de todos os assuntos atinentes ao direito do trabalhador". Cf. BRASIL. Assembleia Nacional Constituinte. Ata da $24^{a}$ Reunião da Subcomissão dos Direitos dos Trabalhadores e Servidores Públicos. Brasília: Senado Federal, Secretaria Especial de Editoração e Publicações, Subsecretaria de Anais, 1987, documento eletrônico, p. 310/311.

117 BRASIL. Assembleia Nacional Constituinte. Comissão da Ordem Social. Subcomissão dos Direitos dos Trabalhadores e Servidores Públicos, vol. 191, Brasília, Centro Gráfico do Senado Federal, 1987, p. 3 (destaque acrescentado).

118 BRASIL. Assembleia Nacional Constituinte. Ata da 25a Reunião da Subcomissão dos Direitos dos Trabalhadores e Servidores Públicos. Brasília: Senado Federal, Secretaria Especial de Editoração e Publicações, Subsecretaria de Anais, 1987, documento eletrônico, p. 345. 
elaboração do texto final da nova Constituição. ${ }^{119}$

\subsection{Os debates na Comissão da Ordem Social}

No discurso de vários constituintes, em especial dos que integravam a Comissão da Ordem Social (sendo que alguns deles também compunham a Subcomissão dos Direitos dos Trabalhadores e Servidores Públicos), é possível observar a ideia de que o papel da Assembleia Nacional Constituinte seria elaborar uma Constituição para os trabalhadores - não se tratava, portanto, simplesmente de disciplinar as relações laborais. ${ }^{120}$

Isso é perceptível no seguinte trecho do discurso do Presidente da Comissão, Edme Tavares (PFL), proferido na reunião em que foram entregues os anteprojetos elaborados pelas respectivas Subcomissões: "aos trabalhadores das cidades e do campo esperamos legar uma Constituição, que não só consolide suas conquistas, mas as amplie, de modo que a relação trabalho/capital seja humanizada, que valorize sobretudo o trabalho, considerando-o

\footnotetext{
119 Como expressou o constituinte Francisco Küster: "esta Subcomissão respondeu à altura aos anseios e expectativas dos trabalhadores e dos servidores públicos. Mas outros embates ainda virão, e é fundamental que permaneçamos engajados nessa luta em torno desses mesmos objetivos, para que não venham os representantes dos grandes capitais, nacionais e internacionais, dos entreguistas, dos lesa-pátria, que aqui se fazem presentes também nesta Assembléia Nacional Constituinte, formarem os seus lobbies e fazerem com que nas Comissões Temáticas e na de Sistematização conquistas havidas nesta Subcomissão sejam subtraídas. Se tal acontecer, temo pelos trabalhos da Assembléia Nacional Constituinte" (BRASIL. Assembleia Nacional Constituinte. Ata da $25^{a}$ Reunião da Subcomissão dos Direitos dos Trabalhadores e Servidores Públicos, p. 347 - destaque no original).

${ }^{120}$ Essa constatação torna compreensível a opção inicial da Subcomissão dos Direitos dos Trabalhadores e Servidores Públicos de convidar apenas entidades profissionais - i.e., de trabalhadores - para as audiências públicas, considerando-se, ainda, a exiguidade do tempo para realização dessas audiências. O constituinte Max Rosenmann (PMDB) levantou a questão sobre a convocação de entidades patronais, ao que o Presidente da Subcomissão, Geraldo Campos (PMDB), respondeu que, em "reunião informal", ocorrida no dia anterior, ficara decidido que não seriam levadas propostas de convites a entidades patronais. Diante da insistência de Rosenmann, com o apoio de Stélio Dias (PFL), a proposta foi submetida à votação e rejeitada. Entre os argumentos para rejeição da proposta, estava o maior acesso que os empresários teriam à Constituinte, diferentemente dos trabalhadores. Como observou o constituinte Júlio Costamilan (PMDB): "Acho que todos nós, constituintes, estamos habilitados e somos conhecedores do pensamento dos empresários, porque, acima de tudo, têm condições de divulgar o seu pensamento, através da imprensa, do rádio, da televisão e dessa possibilidade que o poder econômico lhes permite de encaminhar aos constituintes toda uma série de subsídios. Eu tenho condições, no meu Gabinete, de oferecer vários instrumento que me foram encaminhados pelos empresários, da minha cidade, do meu Estado e do País também. Então, por isso, Sr. Presidente, parece me que a diferença se estabelece até nesta subcomissão. Os empresários como o poder incomparavelmente maior do que os trabalhadores, para fazerem chegar até aqui as suas reivindicações. Acho que, em face disto, e entendo que, se tivéssemos disponibilidade de tempo, poderíamos auscultar também o pensamento dos empresários, não teríamos por que não fazê-lo, e tendo sido feito, ontem, detidamente um exame desta questão, sendo visíveis as dificuldades que os trabalhadores têm de fazer chegar a um organismo como este, a um fórum como este, as suas postulações, e mais do que isso, as dificuldades que têm para fazer com que essas postulações se transformem em realidade, em lei, sou de posição muito clara: eu me situo naquilo que foi decidido ontem, isto é votarei de acordo com o que se estabeleceu ontem à noite, na escolha das entidades, com todo o respeito que devo às organizações empresariais" (BRASIL. Assembleia Nacional Constituinte. Ata da $4^{a}$ Reunião da Subcomissão dos Direitos dos Trabalhadores e Servidores Públicos, p. 21).
} 
como fator fundamental do desenvolvimento". ${ }^{121}$ Essa mesma linha discursiva foi seguida por Mário Lima (PMDB), ao entregar o relatório e o anteprojeto elaborados pela Subcomissão dos Direitos dos Trabalhadores e Servidores Públicos. ${ }^{122}$

A constatação acima é importante para marcar o pano de fundo das discussões sobre os direitos dos trabalhadores, entre eles, o direito de greve.

A Comissão, que tinha por relator o constituinte Almir Gabriel (PMDB), começou seus trabalhos com as discussões sobre os anteprojetos elaborados pelas três Subcomissões que a integravam, Subcomissão dos Direitos dos Trabalhadores e Servidores Públicos, Subcomissão de Saúde, Seguridade e do Meio Ambiente e Subcomissão dos Negros, Populações Indígenas, Pessoas Deficientes e Minorias.

Em relação ao anteprojeto da Subcomissão dos Direitos dos Trabalhadores e Servidores Públicos, o constituinte Edmilson Valentim (PC do B), defendendo o trabalho lá produzido, ressaltou que, no que dizia respeito a "um avanço social" e a "um avanço político de participação", o anteprojeto garantia "questões fundamentais" quanto à estabilidade no emprego, à duração laboral de 40 horas semanais e ao direito de greve, assegurando-se, ainda, a sua aplicação imediata. O pronunciamento do constituinte retratava uma das principais preocupações que haviam circulado na Subcomissão: o reconhecimento de que os direitos trabalhistas, incluído o direito de greve, deveriam constar da Constituição como

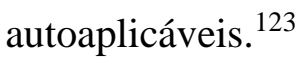

Na 9 ${ }^{a}$ reunião da Comissão, realizada em 12 de junho de 1987, iniciaram-se as discussões do relatório e do substitutivo apresentados por Almir Gabriel. Em seu discurso, o constituinte marcou o sentido de ruptura com a ordem anterior, afirmando, ao final, o caráter instrumental da Constituição. Para Almir Gabriel, não era o caso de apenas reformular a Carta vigente, mas, sim, elaborar uma nova Constituição. Em suas palavras:

Eu diria, como um dos pontos essenciais para entendermos esse relatório, que todos deveremos ter em mente que o que se propõe não é reformular a Constituição vigente; propõe-se fazer uma nova Constituição.

\footnotetext{
121 BRASIL. Assembleia Nacional Constituinte. Ata da $2^{a}$ Reunião da Comissão da Ordem Social. Brasília: Senado Federal, Secretaria Especial de Editoração e Publicações, Subsecretaria de Anais, 1987, documento eletrônico, p. 8.

122 "Fizemos um trabalho que não deve ser perfeito, mas é um trabalho que traduz o que realmente pensa e o que sonha o trabalhador brasileiro, o que sonha o trabalhador a serviço do Estado. Tentamos resgatar o muito que o trabalhador e o funcionário público perderam nos 21 anos de regime excepcional, de regime ditatorial" (BRASIL. Assembleia Nacional Constituinte. Ata da $2^{a}$ Reunião da Comissão da Ordem Social, p. 9).

${ }^{123}$ Cf. BRASIL. Assembleia Nacional Constituinte. Ata da $5^{a}$ Reunião da Comissão da Ordem Social. Brasília: Senado Federal, Secretaria Especial de Editoração e Publicações, Subsecretaria de Anais, 1987, documento eletrônico, p. 44.
} 
A proposta, portanto, que aqui se encerra, não é uma proposta no sentido de se fazer com que o velho melhore. A proposta que aqui se encerra tende a estabelecer um novo pacto social, tende a estabelecer uma nova ordem social, tende a dar ao Presidente da República, aos dirigentes maiores de cada um dos nossos Estados e Municípios a base legal para que se forme uma sociedade realmente melhor, para que se possa mudar a nossa sociedade, para que o Brasil realmente mude. ${ }^{124}$

No substitutivo apresentado por Almir Gabriel, o art. $2^{\circ}$ e o inciso sobre o direito de greve tinham redações diferentes das recebidas na Subcomissão dos Direitos dos Trabalhadores e dos Servidores Públicos:

Art. $2^{\circ}$. São assegurados aos trabalhadores urbanos, rurais e aos servidores públicos, federais, estaduais e municipais, os seguintes direitos, além de outros que visem à melhoria de sua condição social:

(...)

XXII - greve, nos termos do $\S 1^{\circ}$ deste artigo.

(...)

$\S 1^{\circ}$ - o direito de greve será exercido nas seguintes condições:

I - compete aos trabalhadores definir a oportunidade e o âmbito de interesses a defender por meio da greve;

II - serão estabelecidas providências e garantias que assegurem a manutenção dos serviços essenciais à comunidade. ${ }^{125}$

Já no segundo substitutivo do relator, após o oferecimento de emendas pelos constituintes da Comissão, foi apresentada a seguinte redação ao dispositivo que tratava do direito de greve:
Art. $2^{\circ}(\ldots)$
XXIII - greve, competindo aos trabalhadores decidir sobre a oportunidade e o âmbito de interesses que deverão por meio dela defender, bem como, sobre as providências e garantias asseguradoras da continuidade dos serviços essenciais à comunidade; ${ }^{126}$

Na justificação do segundo substitutivo, Almir Gabriel fez constar que o direito de greve estaria definido "de forma abrangente, com ressalva para as situações em que o interesse maior da sociedade implique a preservação de funcionamento dos serviços

\footnotetext{
124 BRASIL. Assembleia Nacional Constituinte. Ata da $9^{a}$ Reunião da Comissão da Ordem Social. Brasília: Senado Federal, Secretaria Especial de Editoração e Publicações, Subsecretaria de Anais, 1987, documento eletrônico, p. 84.

${ }^{125}$ BRASIL. Assembleia Nacional Constituinte. Comissão da Ordem Social, vol. 183, Brasília, Centro Gráfico do Senado Federal, 1987, p. 2/3. Perceba-se, ainda, a exclusão dos trabalhadores domésticos do caput do art. $2^{\circ}$. ${ }^{126}$ BRASIL. Assembleia Nacional Constituinte. Comissão da Ordem Social, vol. 185, Brasília, Centro Gráfico do Senado Federal, 1987, p. 5.
} 
indispensáveis". 127

A redação proposta parecia conferir maior liberdade com relação ao exercício do direito de greve, na medida em que consagrava a competência dos próprios trabalhadores para decidir sobre a oportunidade e os interesses que motivariam sua deflagração. Além disso, o preceito atribuía aos trabalhadores a decisão sobre as providências necessárias à continuidade dos serviços essenciais à comunidade. ${ }^{128}$ Por outro lado, a supressão da expressão "independente de lei" do caput do art. $2^{\circ}$, bem como a inexistência de vedação explícita pareciam abrir margem para a posterior regulamentação legal desse e de outros direitos trabalhistas.

O constituinte Paulo Paim (PT) apresentou emenda ao substitutivo para inserir no caput do art. $2^{\circ}$ a expressão “independente de lei”. A justificativa já era conhecida dos que integraram a Subcomissão dos Direitos dos Trabalhadores e Servidores Públicos:

Outra explicação também fundamental: a expressão "independente de lei". Houve uma ampla discussão na Subcomissão dos Direitos dos Trabalhadores e Servidores Públicos para que tudo que fosse aprovado no art. $2^{\circ}$ se tornasse autoaplicável. Quer dizer, aquilo que aqui aprovarmos, independente de lei, não poderá ser alterado. Conseqüentemente, de fato será aplicado. A preocupação dos trabalhadores é que ao longo da História estamos acostumados a ter belas Constituições; só que, na verdade, as legislações ordinárias acabam não acontecendo $\mathrm{e}$ as vantagens conseguidas na Constituição acabam não se tornando realidade. ${ }^{129}$

Segundo o relator Almir Gabriel, porém, muitos dos direitos previstos no art. $2^{\circ}$ demandavam complementação, como, por exemplo, o adicional noturno, o seguro desemprego, o piso salarial e a gratificação natalina (não foi mencionado o direito de greve). ${ }^{130}$ Para o constituinte Odacir Soares (PFL), a emenda de Paulo Paim seria prejudicial

${ }^{127}$ BRASIL. Assembleia Nacional Constituinte. Comissão da Ordem Social, vol. 185, p. 3.

${ }^{128}$ Especificamente quanto aos serviços essenciais, o substitutivo do relator da Comissão, Almir Gabriel, recebeu o apoio de Mário Lima, sobretudo porque atribuía aos próprios trabalhadores a responsabilidade pela manutenção das atividades essenciais. Para Mário Lima, "a emenda do ilustre relator, na minha opinião, sana a deficiência do meu anteprojeto, quando ele confia aos trabalhadores, ao seu patriotismo, ao seu senso de responsabilidade, o dever de zelar pelo funcionamento das atividades essenciais. Creiam, Srs. Constituintes, que o País não se arrependerá em confiar nos seus trabalhadores, porque mesmo nos períodos do arbítrio jamais faltou ao trabalhador brasileiro serenidade e patriotismo no desempenho das suas missões, nas fábricas espalhadas por todo este País. (...) Havendo greve, os trabalhadores e os patrões se entenderão. Havendo greve sem condicionamentos, sem limitação, sem falsas verdades, não haverá tumulto, e sim, paz. Srs. Constituintes, tenho certeza de que não haverá quem leve o trabalhador para o confronto, para a desordem. Por isso, considero o texto do ilustre relator melhor do que aquele que elaborei na fase inicial dos trabalhos" (BRASIL. Assembleia Nacional Constituinte. Ata da $9^{a}$ Reunião da Comissão da Ordem Social, p. 138).

${ }^{129}$ BRASIL. Assembleia Nacional Constituinte. Ata da $9^{a}$ Reunião da Comissão da Ordem Social, p. 113.

130 Em suas palavras: "Se colocarmos a expressão 'independente de lei' muitas das coisas que aqui estão colocadas como direitos dos trabalhadores acabarão - no nosso entendimento - não podendo ser realmente realizadas, na medida em que a regulamentação de cada um desses direitos se torne absolutamente indispensável 
aos trabalhadores, pois todos os direitos do art. $2^{\circ}$ necessitariam de complementação via legislação ordinária ou legislação complementar e não seriam autoaplicáveis "do ponto de vista prático". 131

Coube a outro constituinte, Célio de Castro (PMDB), que integrara a Subcomissão dos Direitos dos Trabalhadores e dos Servidores Públicos, defender a emenda. O trecho a seguir evidencia a dificuldade de aproximação entre as perspectivas dos parlamentares:

(...) essa foi uma das discussões mais profundas que se travou na Subcomissão dos Direitos dos Trabalhadores e Servidores Públicos. A colocação da expressão "independente de lei" é fundamental parar que se garanta a autoaplicabilidade desse direito. Evidentemente, seria um absurdo não se regulamentassem direitos. Não pode a lei geral jogar por terra esses direitos considerados auto-aplicáveis. É uma conquista que discutimos profundamente e devemos manter, para que não sejam revogados, por lei ordinária, conquistas históricas dos trabalhadores. ${ }^{132}$

O relator insistiu em seu posicionamento quanto a não serem autoaplicáveis os direitos previstos, enquanto o constituinte Salatiel Carvalho (PFL) disse ser evidente que a legislação ordinária não poderia contrariar o texto constitucional. ${ }^{133}$ Ruy Nedel (PMDB, corroborando a opinião do relator, afirmou ser "praticamente certo" que a Constituição estabeleceria a figura do "defensor do povo" e da "inconstitucionalidade por omissão" - ou seja, a emenda proposta seria desnecessária. ${ }^{134}$

Submetida à votação, a emenda de Paulo Paim foi rejeitada, por 30 a 33.

A Comissão da Ordem Social aprovou, então, o anteprojeto de Constituição que seria remetido à Comissão de Sistematização. No que tange ao direito de greve, constou do anteprojeto a mesma redação conferida no segundo substitutivo do relator Almir Gabriel. ${ }^{135}$

Comparando os dois textos, i.e., o da Subcomissão dos Direitos dos Trabalhadores e Servidores Públicos e o da Comissão da Ordem Social, vê-se que o primeiro deixava em evidência as práticas que os constituintes desejavam que fossem superadas, marcando, de

para viabilizá-los" (BRASIL. Assembleia Nacional Constituinte. Ata da $9^{a}$ Reunião da Comissão da Ordem Social p. 114).

${ }^{131}$ Cf. BRASIL. Assembleia Nacional Constituinte. Ata da $9^{a}$ Reunião da Comissão da Ordem Social, p. 114.

${ }^{132}$ BRASIL. Assembleia Nacional Constituinte. Ata da $9^{a}$ Reunião da Comissão da Ordem Social, p. 114.

${ }^{133}$ Segundo Salatiel Carvalho, "o mais importante é o principio constitucional. É evidente que nenhuma lei que vier posteriormente pode contrariar o que estiver na Constituição. Se a Constituição está garantindo um direito, um princípio ao trabalhador, nenhuma lei ordinária, sob pena de ser barrada pela inconstitucionalidade, poderá ser aprovada. De forma que é desnecessário frisar a expressão 'independente de lei'. Portanto, é o principio constitucional que está garantindo" (BRASIL. Assembleia Nacional Constituinte. Ata da $9^{a}$ Reunião da Comissão da Ordem Social, p. 114).

${ }^{134}$ BRASIL. Assembleia Nacional Constituinte. Ata da $9^{a}$ Reunião da Comissão da Ordem Social, p. 114.

${ }^{135}$ BRASIL. Assembleia Nacional Constituinte. Comissão da Ordem Social, vols. 185 e 186, Brasília, Centro Gráfico do Senado Federal, 1987, p. 6. 
forma mais explícita, a ruptura com a ordem jurídico-institucional anterior (por isso a proibição a restrições por lei e a vedação às autoridades públicas, inclusive as judiciárias, de qualquer tipo de intervenção que pudesse limitar o direito de greve). O segundo texto, aprovado na Comissão, sem se referir de maneira expressa ao que deveria ser proibido, assegurava um caráter procedimental ao direito de greve: os trabalhadores decidiriam quando e porque deflagrar a paralisação, sendo responsáveis pelas providências a serem adotadas de modo a garantir a continuidade das atividades essenciais. Ainda que de forma indireta, o dispositivo proposto reconhecia a maturidade dos trabalhadores para o exercício do direito, afastando a tutela estatal e tornando questionável, em tese, a intervenção da Justiça do Trabalho no conflito.

Os debates sobre o direito de greve continuariam na Comissão de Sistematização. Antes, contudo, é necessário examinar as discussões ocorridas nas demais Subcomissões e Comissões da Assembleia Nacional Constituinte.

\subsection{Os debates no âmbito da Comissão da Soberania e dos Direitos e Garantias do Homem e da Mulher}

O direito de greve também foi tema de debate e deliberação no âmbito da Comissão da Soberania e dos Direitos e Garantias do Homem e da Mulher, tanto na Comissão em si, quanto em duas de suas Subcomissões, a saber, a Subcomissão dos Direitos e Garantias Individuais e a Subcomissão dos Direitos Políticos, dos Direitos Coletivos e Garantias.

Nas audiências públicas realizadas por essa última Subcomissão, presidida por Maurílio Ferreira Lima (PMDB) e que tinha como relator Lysâneas Maciel (PDT), o direito de greve foi abordado pelo jurista José Martins Catharino, que defendeu a necessidade de a nova Constituição garantir a "impunidade" do grevista, enfatizando que "quando se fizer uma norma jurídica deve-se pensar no seu tempo de duração, do contrário, teremos a revolta dos fatos contra a mesma". ${ }^{136}$

Já na fase de apresentação do relatório, Lysâneas Maciel destacou que "mais do que nunca temos em mãos elementos suficientes para elaborar uma Constituição com material e reivindicações realmente populares". No primeiro anteprojeto, o direito de greve foi previsto

\footnotetext{
${ }^{136}$ BRASIL. Assembleia Nacional Constituinte. Ata da 10ª Reunião da Subcomissão dos Direitos Políticos, dos Direitos Coletivos e Garantias. Brasília: Senado Federal, Secretaria Especial de Editoração e Publicações, Subsecretaria de Anais, 1987, documento eletrônico, p. 48. Especificamente quanto a essa reunião, foi publicada apenas a ata, sem as notas taquigráficas, o que prejudica a apreensão de todo o conteúdo do discurso de Martins Catharino.
} 
no âmbito do direito de manifestação coletiva, numa redação abrangente:

Art. 28. É assegurado a todos o direito de manifestação coletiva em defesa de seus interesses, incluída a paralisação do trabalho de qualquer categoria, sem exceções.

$\S 1^{\circ}$ - As manifestações públicas independem de licença prévia da autoridade local.

$\S 2^{\circ}$ - Os abusos cometidos sujeitam seus responsáveis às penas da lei. ${ }^{137}$

Lysâneas Maciel expôs a motivação da proposta:

O moderno Estado Social de Direito supõe a livre manifestação coletiva dos cidadãos em defesa dos seus interesses, sejam estes de ordem econômica, cultural, ecológica e social, nas várias esferas de organização, desde a comunitária até a nacional. Trata-se, na verdade, de instrumento imprescindível à efetiva participação dos vários grupos e movimentos sociais na vida do País.

Não há porque excluir desse direito os trabalhadores organizados em entidades representativas, sem qualquer exceção.

Os que temem a greve como instrumento de luta dos trabalhadores, em nome de uma suposta desordem pública, esquecem-se de que os líderes trabalhistas prestam contas à própria categoria quando a greve é mal conduzida ou utilizada. Não se reelegem, e esta é a forma de controle mais eficaz.

Quanto a possíveis abusos praticados no curso das manifestações, entendemos que os responsáveis ficarão sujeitos às penas da lei. ${ }^{138}$

O direito de greve, em última análise, era previsto como instrumento de participação política do trabalhador, integrando um campo maior, pertinente ao direito de livre manifestação coletiva dos cidadãos.

Quando a Subcomissão passou às deliberações sobre o anteprojeto, o constituinte João Menezes (PFL) formulou destaque à sua emenda, que pretendia acrescentar, ao caput do dispositivo acima, a expressão "de acordo com a lei". Embora o preceito tratasse do direito à manifestação, de forma geral, João Menezes tinha por preocupação o direito de greve e a possível ocorrência de abusos. ${ }^{139}$

\footnotetext{
${ }^{137}$ BRASIL. Assembleia Nacional Constituinte. Comissão da Soberania e dos Direitos e Garantias do Homem e da Mulher. Subcomissão dos Direitos Políticos, dos Direitos Coletivos e Garantias. Vol. 74. Brasília: Centro Gráfico do Senado Federal, 1987, p. 11.

${ }^{138}$ BRASIL. Assembleia Nacional Constituinte. Comissão da Soberania e dos Direitos e Garantias do Homem e da Mulher. Subcomissão dos Direitos Políticos, dos Direitos Coletivos e Garantias. Vol. 74, p. 8/9.

${ }^{139}$ Segundo o autor da emenda: "apenas acrescentei 'de acordo com a lei'. Do contrário, todo mundo pára, não há lei para resolver isso. Todo mundo que resolver parar, pára: a Câmara funciona e ninguém vem trabalhar hoje; trata-se de direito coletivo. Não há lei para regular. Parece engraçado, mas é verdade. Então, emendei e entreguei à Mesa. Acrescentei apenas 'de acordo com a lei'. Quer dizer, a pessoa vai parar, mas há uma lei que regulamenta" (BRASIL. Assembleia Nacional Constituinte. Ata da $16^{a}$ Reunião da Subcomissão dos Direitos Políticos, dos Direitos Coletivos e Garantias. Brasília: Senado Federal, Secretaria Especial de Editoração e Publicações, Subsecretaria de Anais, 1987, documento eletrônico, p. 125).
} 
A proposta de emenda foi atacada pelo constituinte João Paulo (PT), que lembrou os riscos de a constituição simplesmente atribuir a regulamentação de determinado direito à legislação infraconstitucional:

Sr. Presidente, Srs. Constituintes, no que toca principalmente ao que se refere ao direito de greve, todas as vezes em que essa questão foi remetida para a legislação complementar o foi muito mais para suprimir o direito do que para regulamentar o exercício. Teríamos que partir de um direito primário, que é o de recusar o seu trabalho. Se não houver isso, seja em qualquer circunstância, em qualquer categoria, seja individual ou coletivamente, teremos o trabalho forçado. Verificar uma forma de não faltar para as comunidades o serviço essencial a elas é um dever da categoria que vai deflagrar greve. Querer orientar-se pela exceção é inadmissível. O exercício da greve foi suprimido por vários dispositivos legais, chegando até ao absurdo de se colocar a atividade bancária como um serviço essencial à segurança nacional, dando aos banqueiros prerrogativas, além das que já têm de expropriar toda a riqueza nacional. Isso foi feito excepcionalmente e essa legislação excepcional sobrevive até hoje. $\mathrm{O}$ direito de greve e o direito de paralisar o trabalho pertencem àqueles que o exercitam. Não se pode remeter à legislação complementar esse exercício, que é um direito individual e coletivo contido na Constituição. Ele tem que estar contido aqui, sem qualquer restrição, a ser remetido para a legislação complementar. ${ }^{140}$

O relator da Subcomissão afirmou que a preocupação de João Menezes estaria contemplada no $\S 2^{\circ}$ do dispositivo - que remetia à lei a previsão da responsabilidade em caso de abuso do direito - e concordou com as ponderações feitas por João Paulo, destacando que a legislação brasileira mais recente havia sido elaborada no sentido de negar o direito de greve.

A proposta de João Menezes foi rejeitada pela Subcomissão, por 11 votos a 1. O anteprojeto foi, então, remetido à Comissão Temática com sua redação original. ${ }^{141}$

Na Subcomissão dos Direitos e Garantias Individuais, presidida pelo constituinte Antonio Mariz (PMDB), o tema da greve foi suscitado, em audiência pública, pelo VicePresidente da Comissão de Justiça e Paz da CNBB, José Geraldo de Sousa Júnior. O representante da CNBB fez considerações sobre "a constituição social da cidadania e os instrumentos de participação direta e de iniciativa populares como garantia de cidadania". ${ }^{142}$ José Geraldo de Sousa Júnior apresentou sugestões de princípios que deveriam ser traduzidos

\footnotetext{
${ }^{140}$ BRASIL. Assembleia Nacional Constituinte. Ata da $16^{a}$ Reunião da Subcomissão dos Direitos Políticos, dos Direitos Coletivos e Garantias, p. 125.

${ }^{141}$ No texto final, o direito à manifestação, incluindo o direito de greve, constou do art. 30 do anteprojeto. Cf. BRASIL. Assembleia Nacional Constituinte. Comissão da Soberania e dos Direitos e Garantias do Homem e da Mulher. Subcomissão dos Direitos Políticos, dos Direitos Coletivos e Garantias. Vol. 77. Brasília: Centro Gráfico do Senado Federal, 1987, p. 12.

${ }^{142}$ BRASIL. Assembleia Nacional Constituinte. Ata da $12^{a}$ Reunião da Subcomissão dos Direitos e Garantias Individuais. Brasília: Senado Federal, Secretaria Especial de Editoração e Publicações, Subsecretaria de Anais, 1987, documento eletrônico, p. 119.
} 
na Constituição, por serem instrumentos de participação popular direta, mesmo no sistema representativo, além de consistirem em iniciativas populares que teriam aptidão para assegurar os direitos de cidadania.

Entre as sugestões levadas pela Comissão de Justiça e Paz da CNBB, estavam as seguintes:

\begin{abstract}
"Aplicabilidade direta e vinculativa dos preceitos constitucionais sobre direitos, liberdades e garantias" - o que significa a recusa às normas programática, autoaplicabilidade dos princípios constitucionais referentes a direitos, liberdades e garantias. Na greve, por exemplo, que só pode ser definida no âmbito dos interesses dos próprios trabalhadores.

(...)

"Proibição de leis restritivas de direitos, liberdades e garantias, relativamente eu alcance do conteúdo constitutivo dos preceitos constitucionais". Como no caso da greve, por exemplo. ${ }^{143}$
\end{abstract}

No anteprojeto apresentado pelo relator, Darcy Pozza (PDS), a proposta, contudo, era prever o direito de greve nos seguintes termos: "São direitos e garantias individuais: (...) XXII - a greve, nos termos da lei". ${ }^{44}$

O constituinte José Genoino (PT) apresentou emenda ao anteprojeto, com inúmeras alterações. Entre as mudanças sugeridas, uma dizia respeito à greve, outra à sindicalização, visando a evitar que fossem simplesmente previstas "na forma" ou "nos termos" "da lei". O receio era exatamente o de que a regulamentação legal viesse a negar o direito estabelecido na Constituição. ${ }^{145}$

143 BRASIL. Assembleia Nacional Constituinte. Ata da $12^{a}$ Reunião da Subcomissão dos Direitos e Garantias Individuais, p. 121. A CNBB subscrevia princípios constantes do projeto de Constituição elaborado pelo jurista Fábio Konder Comparato.

${ }^{144}$ Havia, ainda, um dispositivo que estabelecia que "os direitos e garantias constantes desta Constituição têm aplicação imediata. Conceder-se-á mandado de injunção, para garantir direito nela assegurado, não aplicado em razão de ausência de norma regulamentadora, podendo ser requerido em qualquer Juízo ou Tribunal” (§ 35). No relatório, Darcy Pozza afirmou que teve em vista, além das constituições de outros países, as constituições anteriores do Brasil, entre elas, as de 1891, 1934, 1946 e a de 1964. Ao final, anotou que "a preocupação marcante em todo o trabalho foi o respeito à tradição do Direito Constitucional brasileiro. As sugestões apresentadas, entretanto, representam aquilo que de mais atual existe na sociedade para a qual a norma se dirige. Por conseguinte, mesclamos a tradição e o moderno, tendo como alvo o presente e o futuro democráticos". Essa última assertiva é, pelo menos, questionável, diante da redação proposta para o direito de greve, bem como para a liberdade sindical, eis que prevista "a livre sindicalização, na forma da lei". Cf. BRASIL. Assembleia Nacional Constituinte. Comissão da Soberania e dos Direitos e Garantias do Homem e da Mulher. Subcomissão dos Direitos e Garantias Individuais. Vol. 78. Brasília: Centro Gráfico do Senado Federal, 1987, p. 15/16, 6 e 10, respectivamente (destaque acrescentado).

145 Segundo José Genoino, "é uma tradição das Constituições brasileiras, sempre que tratam do direito, elas dizerem, em seguida, 'na forma da lei', e, depois, surge uma lei que elimina o direito. Acho que o direito não pode ser regulamentado dessa maneira e deve estar redigido da seguinte maneira: direito de greve, ponto; direito de sindicalização, ponto. Se colocar a expressão 'na forma da lei', é como ter na Constituição 'é livre a sindicalização, salvo a lei ordinária', porque depois surge a CLT e acaba com e liberdade de sindicalização. Até o Governo se está dando conta de que isso é uma barbaridade" (BRASIL. Assembleia Nacional Constituinte. Ata 
Na $26^{\text {a }}$ reunião da Subcomissão, realizada em 23 de maio de 1987, procedeu-se ao debate do substitutivo do relator, o qual mantinha a redação original do anteprojeto quanto à greve e à sindicalização - ou seja, a emenda recebera parecer contrário do relator. José Genoino fez uso da palavra para expressar sua discordância e acentuar o risco de continuidade de uma prática própria de períodos autoritários:

A maneira como estão abordados os direitos - são direitos coletivos e que estão abordados aqui como direitos individuais - à sindicalização e à greve, acrescentando a expressão "na forma da lei", é a repetição dos textos constitucionais que nos períodos autoritários e antidemocráticos foram usados exatamente para a normalização do direito, que é a negação do próprio direito. ${ }^{146}$

O encaminhamento da votação contou com a participação do constituinte Francisco Küster (PMDB), que integrava a Subcomissão dos Direitos dos Trabalhadores e Servidores Públicos e destacou que, nessa última, os direitos de greve e de sindicalização haviam sido tratados de maneira que o Estado não teria o direito de intervir nem em um, nem em outro. O constituinte disse ser uma "intromissão" da Subcomissão dos Direitos e Garantias Individuais fazer encaminhamentos para essas questões. ${ }^{147}$

O relator da Subcomissão, porém, insistiu na manutenção do anteprojeto, entendendo ser desnecessária a supressão sugerida. ${ }^{148}$

A emenda foi rejeitada, com 6 votos favoráveis e 9 contrários.

Concluídos os anteprojetos das Subcomissões, chegava a hora de serem debatidos na Comissão da Soberania e dos Direitos e Garantias do Homem e da Mulher, presidida por Mário Assad (PFL). O relator da Comissão era José Paulo Bisol (PMDB).

Na reunião posterior à da entrega daqueles documentos, a Comissão passou à sua discussão. Com relação ao anteprojeto oriundo da Subcomissão dos Direitos e Garantias

da $12^{a}$ Reunião da Subcomissão dos Direitos e Garantias Individuais, p. 247).

146 BRASIL. Assembleia Nacional Constituinte. Ata da $26^{a}$ Reunião da Subcomissão dos Direitos e Garantias Individuais, Brasília: Senado Federal, Secretaria Especial de Editoração e Publicações, Subsecretaria de Anais, 1987, documento eletrônico, p. 260.

147 BRASIL. Assembleia Nacional Constituinte. Ata da $26^{a}$ Reunião da Subcomissão dos Direitos e Garantias Individuais, p. 284.

148 Nas palavras de Darcy Pozza, "quanto à livre sindicalização e à greve, parece-me importante permanecer com a expressão 'nos termos da lei' ou 'na forma da lei', porque essa matéria será também regulamentada em outra Subcomissão, na própria legislação ordinária. O direito à livre sindicalização é do indivíduo, o direito à greve também, os trabalhadores são indivíduos, portanto, não vejo o porquê da supressão". Também encaminhou contrariamente o constituinte José Fernandes (PDT) que, embora tenha destacado que o tema seria pertinente a outra Subcomissão - a dos direitos e garantias coletivos -, entendia que a emenda de Genoino não conferiria "maior liberdade ao assunto" (BRASIL. Assembleia Nacional Constituinte. Ata da $26^{a}$ Reunião da Subcomissão dos Direitos e Garantias Individuais, p. 284). 
Individuais, o constituinte João Paulo (PT), que a havia integrado, expressou, mais uma vez, sua discordância, tendo sido aparteado por Samir Achôa (PMDB). Deu-se, então, um intenso debate entre os dois constituintes, do qual transcrevem-se os seguintes excertos:

JOÃO PAULO: Estranho profundamente o que está escrito nos itens XXII e XXIII, do texto final da Subcomissão dos Direitos e Garantias Individuais. Fala-se aqui na livre sindicalização, na forma da lei; fala-se aqui da greve, nos termos da lei. Apresentei, no entanto, sugestões a Subcomissão, apresentei emendas, para que se não colocasse a expressão "na forma da lei". A liberdade de sindicalizar-se não pode sofrer restrição alguma, é uma decisão. Em regulamentação alguma pode-se prever pena. Mas, então, que não se remeta à legislação ordinária, como aconteceu no passado, a regulamentação. Que pelo menos fique integralmente no texto a que se refere o Anteprojeto da Subcomissão o que se pretende, para que seja uma colocação limpa, cristalina, que não implique a interpretação de um subterfúgio, de uma vontade maléfica de remeter para a legislação ordinária não com a finalidade de regulamentar, mas com a intenção de extinguir ou de restringir o direito.

(...)

SAMIR ACHÔA: Eu, como advogado, e até como cidadão comum, desconheço a forma pela qual será regulamentada a sindicalização. Ora, se é na forma da lei, vamos lutar juntos para que essa lei seja justa, para que ela preveja todas as possibilidades, mas também dê garantias. Tenho visto, em nosso País, até na questão da greve, sindicatos tomarem posições ao arrepio dos mais legítimos... São pessoas preparadas para agüentar um, dois, três dias, quando aqueles desavisados se retiram - $1 \%$ da categoria contrariando a própria categoria. Ora, não adianta poesia, não adianta falar em direitos, quando esses direitos existem apenas para alguns. Temos de ser realistas. No Brasil, as greves decretadas nem sempre atendem aos interesses da categoria, mas aos interesses políticos de alguns. Sou favorável à greve, mas também à regulamentação rigorosa dela, até porque há aqueles que nunca se guiaram pelo espírito democrático da maioria. Democracia, para mim, é decisão de maioria, respeitados os direitos das minorias. Fala-se em liberação total, sem uma forma legal. Quero, porém, uma legislação que estabeleça até restrições à greve em serviços essenciais, porque não se pode sacrificar a população de um modo geral. A greve hospitalar, por exemplo, deve ser proibida. Quando o cidadão abraça uma dessas carreiras, tem de saber que lhe é proibido fazer greve. Se não estiver contente, que vá embora, mas não coloque em risco toda uma comunidade, em nome de reivindicações justas, até, mas que devem ser buscadas nos Tribunais, eis que a greve é apenas um instrumento a mais, além daquele da Justiça. O que é a greve? A greve é uma forma mais adequada para o imediatismo de que se necessita. Por isso defendo a greve. Mas, na medida em que ela prejudica a comunidade, deve haver, como há em qualquer país do mundo, restrição à greve. Nos países mais democráticos do mundo, os serviços essenciais não são passíveis de greve. Quando se fala que uma lei deverá regulamentar a sindicalização e as greves, não entendo que haja, portanto, a própria regulamentação da greve. $\mathrm{O}$ puro e simples conceito estabelecido na Constituição não pode ser auto-aplicável, porque tomaria sem efeito a proposta, tão bem definida, de V. Ex. ${ }^{\mathrm{a}}$.

JOÃO PAULO: (...) Quanto à questão da greve, concitaria o meu colega Constituinte Samir Achôa a estudá-la profundamente. Vou citar um 
exemplo, não muito recente. Em 1979, nos Estados Unidos da América do Norte eclodiu a greve que durou 110 dias, dos trabalhadores das minas de carvão, setor essencial à segurança nacional - estou traduzindo, aqui, as palavras do Presidente Jimmy Carter. Essa greve entrou pelo inverno, quando o carvão, que além de manter as empresas siderúrgicas, tinha de manter também todo o sistema de aquecimento utilizado nos Estados Unidos. No octogésimo dia da greve, invocando um dispositivo legal que só pode ser aplicado por determinação da Suprema Corte dos Estados Unidos, ele queria aplicar a lei, não para tornar a greve ilegal, como se faz neste País, mas para suspendê-la durante oitenta dias, como prevê a legislação, para que as partes pudessem negociar. Em não havendo acordo nesses oitenta dias, novamente seria restabelecido o movimento grevista. Ele solicitou à Suprema Corte, mas esta não concordou. Chegou-se a um acordo...

SAMIR ACHÔA: Permite-me V. Ex. ${ }^{a}$ um aparte?

JOÃO PAULO: Se o aparte de V. Ex. ${ }^{a}$ for de meio minuto...

SAMIR ACHÔA: Acho que deveria haver a definição do que é serviço essencial. Não considero a categoria dos funcionários públicos, por exemplo, na sua totalidade, serviço essencial, nem a dos mineiros. Mas é necessário que a lei defina isso. O prontosocorro, porém, é essencial; a energia elétrica, também. Então, temos de definir. Quem estiver trabalhando nessas áreas não poderá entrar em greve, procurará a Justiça para reivindicar os seus direitos. E a população, na minha opinião, pensa como eu.

JOÃO PAULO: Só sabe definir esta questão quem vem a sentir o problema. $\mathrm{O}$ direito de greve é um direito irrestringível, inalienável, seja em que categoria for. A categoria diretamente ligada ao interesse da comunidade tem de pensar numa maneira de não prejudicá-la. Mas se V. Ex. ${ }^{a}$ limita o direito... Isso é uma prerrogativa e uma responsabilidade da própria categoria, não da elite brasileira.

(...)

Agora, se querem fazer alguma regulamentação, alguma restrição, que façam claramente, que não se deixe para a legislação ordinária, para ser votada às escondidas, como acontece muitas vezes no Congresso Nacional. A Constituição não pode remeter essa questão para a legislação ordinária.

(...)

Este é o meu entendimento, Sr. Presidente. Não se pode embuçar a escravidão no nosso País. Quem quiser limitar ou restringir a greve, em qualquer categoria, quer que essa categoria, fique submissa às intenções dos poderosos desta terra. O trabalhador não é irresponsável, Constituinte Samir Achôa; ele sabe exercitar o seu direito. V. Ex. ${ }^{a}$ não queira qualificar o trabalhador de irresponsável, querendo restringir os seus direitos.

SAMIR ACHÔA: Permite V. Ex. ${ }^{\text {, }}$ Sr. Presidente? O Constituinte João Paulo pós palavras em minha boca. Estou dizendo que sou favorável à greve, mas não posso aceitar que essa liberalidade total atinja os foros da irracionalidade. Entendo que a greve é um direito legítimo, mas externo.

JOÃO PAULO: Trabalhador não é irracional, Constituinte Samir Achôa.

SAMIR ACHÔA: Existem trabalhadores e trabalhadores; existem Deputados e Deputados.

JOÃO PAULO: Existem trabalhadores e exploradores, trabalhadores e dominadores.

(...)

V. Ex. ${ }^{a}$, Constituinte Samir Achôa, se responsabiliza pela sua parte; nós nos responsabilizamos pela nossa.

SAMIR ACHÔA: Existem trabalhadores, na grande maioria responsáveis, e existem os irresponsáveis. 
JOÃO PAULO: V. Ex.` não queria punir o irresponsável punindo a maioria, punindo todos. ${ }^{149}$

Para o constituinte João Paulo, a preocupação fundamental parecia ser a garantia do direito de greve, enquanto o constituinte Samir Achôa parecia ter em vista, antes de tudo, o estabelecimento de garantias contra possíveis abusos no exercício desse direito, sobretudo em atividades consideradas essenciais - o pressuposto da argumentação é a ocorrência de abuso e uma atuação irresponsável por parte dos trabalhadores (não por acaso, a greve, segundo o constituinte, deveria ser proibida nos serviços essenciais).

José Paulo Bisol defendeu, então, a greve como princípio de liberdade (sem, porém, emitir opinião sobre um ou outro anteprojeto). ${ }^{150}$ Já o constituinte João Menezes criticou o anteprojeto recebido da Subcomissão dos Direitos Políticos, dos Direitos Coletivos e Garantias. Para ele, era o caso de incluir a expressão "de acordo com a lei”, para evitar que virasse "bagunça", sendo necessárias normas que estabelecessem os limites dentro dos quais se pudesse exercer o direito de greve. ${ }^{151}$

O contraponto foi feito pelo constituinte João Paulo, que recordou a experiência da Constituição de 1946, quando a legislação ordinária proibiu o direito de greve para determinadas categorias profissionais. Mencionou, ainda, a Lei 4.330/1964. ${ }^{152}$

149 BRASIL. Assembleia Nacional Constituinte. Ata da $4^{a}$ Reunião da Comissão da Soberania e dos Direitos e Garantias do Homem e da Mulher, Brasília: Senado Federal, Secretaria Especial de Editoração e Publicações, Subsecretaria de Anais, 1987, documento eletrônico, p. 17/19.

${ }^{150}$ Para o relator da Subcomissão, "Existem problemas sobre os quais se tem de pensar com humildade. Gostaria de tecer considerações, ainda em caráter sugestivo, sobre o assunto da greve, mas não quero ser extenso. Apenas quero registrar que o princípio da liberdade de greve, sendo um princípio de liberdade, é o melhor. O princípio da liberdade é sempre o melhor. Mas isso não significa que não devam ser considerados o bem e o mal que uma greve de categoria que exerce serviço essencial possa causar à sociedade" (BRASIL. Assembleia Nacional Constituinte. Ata da $4^{a}$ Reunião da Comissão da Soberania e dos Direitos e Garantias do Homem e da Mulher, p. 19).

${ }^{151}$ João Menezes afirmou o seguinte: “o art 30 diz: 'É assegurado a todos o direito de manifestação coletiva em defesa de seus interesses, incluída a paralisação do trabalho de qualquer categoria, sem exceções.' Tudo bem, todos podem parar. Não há mais lei alguma regulando nada. Mas tem que haver a expressão 'de acordo com a lei'. Senão, isso vai virar uma bagunça total. Todos têm direito de fazer greves, mas há que haver normas dentro das quais se possa fazer greve, exercer o direito de greve, a função legal. Mas, exercer direito de greve não significa chegar à violência. Tem de haver normas que determinem e enquadrem esse posicionamento. Senão, passaremos a ser um país sem lei." (BRASIL. Assembleia Nacional Constituinte. Ata da $6^{a}$ Reunião da Comissão da Soberania e dos Direitos e Garantias do Homem e da Mulher, Brasília: Senado Federal, Secretaria Especial de Editoração e Publicações, Subsecretaria de Anais, 1987, documento eletrônico, p. 27).

152 Para João Paulo, "no que diz respeito à lei de greve, novamente levanta-se aqui a necessidade de uma legislação ordinária. Se constatar, nesta Constituição, o remetimento das questões nela gravadas para a legislação ordinária, vamos cair nos vícios do passado e regredir à Constituição de 1946, em que constava unicamente o direito de greve, sem que fosse remetido à legislação ordinária. No entanto, no Governo do Presidente Dutra foi sancionado um decreto-lei que proibiu a greve em alguns setores considerados essenciais, sendo admitida apenas para aquelas atividades consideradas acessórias. Ora, ao longo do tempo, percebemos, com grande atraso, que nos países desenvolvidos a greve deixou de ser um crime, passou a ser uma liberdade, para depois se constituir num direito consolidado. A maioria dos países - e não apenas os desenvolvidos - democráticos, abertos, onde o trabalho não é uma imposição ou escravidão, onde o patrão não pode demitir sumária e arbitrariamente o 
Encerrados os debates iniciais, o relator José Paulo Bisol apresentou seu Substitutivo. O direito de greve estava previsto no art. $4^{\circ}$, no capítulo "Dos Direitos Coletivos", inciso V, intitulado "A manifestação coletiva”. A redação era a seguinte:

Art. $4^{\circ}$ - São direitos e liberdades coletivos invioláveis:

(...)

V - A manifestação coletiva.

a) É livre a manifestação coletiva em defesa de interesses grupais, associativos e sindicais;

b) é livre a paralisação do trabalho, seja qual for a sua natureza e a sua relação com a comunidade, não podendo a lei estabelecer exceções;

c) na hipótese de paralisação do trabalho, as organizações de classe adotarão as providências que garantam a manutenção dos serviços indispensáveis à segurança da comunidade;

d) os abusos cometidos sujeitam seus responsáveis às penas da lei;

e) a manifestação de greve, enquanto perdurar, não acarreta a suspensão dos contratos de trabalho ou da relação de emprego público;

f) a lei não poderá restringir ou condicionar o exercício dessa liberdade ao cumprimento de deveres ou ônus, salvo o disposto nas alíneas "c", "d" e "g" deste inciso;

g) o abuso em manifestação de greve acarreta a responsabilidade civil, penal e administrativa; mas em caso algum a paralisação coletiva do trabalho será considerada, em si mesma, um crime. ${ }^{153}$

O substitutivo de José Paulo Bisol consagrava as principais reivindicações e sugestões sobre o direito de greve, formuladas tanto pelos representantes da sociedade civil organizada, quanto pelos constituintes mais ligados ao movimento sindical brasileiro: a greve estava prevista de forma ampla, os próprios interessados cuidariam das providências a serem adotadas na continuidade dos serviços indispensáveis à segurança da sociedade (era deixada de lado a expressão "atividades essenciais), não haveria suspensão do contrato de trabalho, não seria possível a restrição do direito por lei ou o seu condicionamento (ressalvadas as exigências estabelecidas no próprio texto constitucional) e a greve, em hipótese alguma, seria considerada crime.

O texto recebeu críticas, como a de José Mendonça de Morais (PMDB) ${ }^{154}$ e de

trabalhador, tem uma legislação complementar que apenas reforça o direito do exercício de greve. Então, remeter-se essa questão à legislação ordinária é inadmissível. Tivemos aqui, a propósito, em 1964, a edição da Lei $\mathrm{n}^{\circ}$ 4.330, da qual foi Relator o Presidente desta Constituinte, Deputado Ulysses Guimarães" (BRASIL. Assembleia Nacional Constituinte. Ata da $6^{a}$ Reunião da Comissão da Soberania e dos Direitos e Garantias do Homem e da Mulher, p. 29).

${ }^{153}$ BRASIL. Assembleia Nacional Constituinte. Comissão da Soberania e dos Direitos e Garantias do Homem e da Mulher. Vol. 66. Brasília: Centro Gráfico do Senado Federal, 1987, p. 7.

${ }^{154}$ De acordo com o constituinte, "no que se refere ao direito de greve, estabelecido no texto, tenho a indagar se o Poder Judiciário não poderá jamais dirimir questões a este respeito. Algo que aparece aqui é que a greve é liberalizada, respondendo seus organizadores, é claro, pelos excessos se aqueles que os motivarem. Acho que é da lei e da norma do nosso comportamento social, quando não respeitamos os direitos fundamentais" (BRASIL. 
João Menezes. Esse último fez o seguinte questionamento:

A letra b do inciso V estabelece: "b) é livre a paralisação do trabalho, seja qual for a sua natureza e a sua relação com a comunidade, não podendo a lei estabelecer exceções." Quer dizer, amanhã deixa-se parado um serviço público qualquer por trinta dias, o País entra em colapso, e ninguém pode fazer nada, porque não há lei para regular a questão. Então, cada um faz o que quer. Se os funcionários da Constituinte entrarem em greve amanhã, como funcionarão os nossos trabalhos? Qual é a lei que vai obrigá-los a trabalhar? Não há regulamento nenhum. Parece-me que isso pode gerar uma conturbação social - se é que isto vai avante, o que não acredito que venha a ocorrer.

Travou-se, então, um debate entre José Genoino e João Menezes:

JOSÉ GENOINO: Na letra b, o autor fala que "é livre a paralisação do trabalho". E um conceito correto, porque é um direito que deve ser usado de maneira livre. Mas a letra c diz o seguinte: "Na hipótese de paralisação do trabalho, as organizações de classe adotarão as providências que garantam a manutenção dos serviços indispensáveis à segurança da comunidade."

JOÃO MENEZES: Mas, como, Sr. Constituinte, se a greve é feita pela própria classe? A Constituição é um instrumento que servirá de base para reger a vida de todos os brasileiros! Ninguém aqui é de esquerda, de direita ou de centro! Não importa que eu seja de centro, da direita ou da esquerda. Quero chegar o quanto possível ao que acho que seja a realidade do cotidiano. Este é o instituto que temos aqui.

JOÃO PAULO: Permite-me V. Ex. ${ }^{a}$ um aparte?

JOÃO MENEZES: Pois não.

JOÃO PAULO: Nobre Constituinte, quem V. Ex. ${ }^{a}$ queria que fizesse a greve? Não é a própria classe que tem de fazê-la?

JOÃO MENEZES: Ela pode fazê-la, mas o assunto tem de der regulamentado. Todo mundo pode fazer greve, mas temos de regulamentála. Imaginem se todos os funcionários do serviço de água, por exemplo, permanecessem em greve durante trinta dias. As forças que querem a desordem no País atingiriam seu intento. Esse é o nosso ponto de vista.

JOÃO PAULO: Mas, de acordo com a alínea g, "o abuso em manifestação de greve acarreta a responsabilidade civis. penal e administrativa".

JOÃO MENEZES: Mas quem irá caracterizar o abuso, se não há lei, não há exceção?

JOÃO PAULO: Então, impede-se ou restringe-ser o direito.

JOÃO MENEZES: Constituição não é brincadeira, mas um documento sério. Vamos adiante. ${ }^{155}$

No texto do substitutivo, era adotada a regra que atribuía responsabilidade aos próprios envolvidos na greve quanto à manutenção dos serviços indispensáveis à segurança da

Assembleia Nacional Constituinte. Ata da $6^{a}$ Reunião da Comissão da Soberania e dos Direitos e Garantias do Homem e da Mulher, p. 47).

${ }^{155}$ BRASIL. Assembleia Nacional Constituinte. Ata da 10a Reunião da Comissão da Soberania e dos Direitos e Garantias do Homem e da Mulher, Brasília: Senado Federal, Secretaria Especial de Editoração e Publicações, Subsecretaria de Anais, 1987, documento eletrônico, p. 66 (para ambas as transcrições). 
comunidade. Havia a possibilidade de sanção ao abuso, caso verificado. Os questionamentos pareciam pressupor o oposto, ou seja, o abuso, a irresponsabilidade dos grevistas, por isso, a regulamentação seria necessária.

A responsabilidade dos trabalhadores foi, em seguida, ressaltada pelo constituinte João Paulo como argumento contrário à intervenção do Estado, incluída a Justiça do Trabalho, nos conflitos. A referência à Lei 4.330/1964 explicita a experiência que se pretendia evitar:

eu, como operário, trabalhador de uma fábrica há quarenta anos, não posso aceitar que se invista contra o direito de greve, como se pretende aqui nesta Constituinte. O que é a nossa sociedade, hoje? É uma sociedade capitalista. O sindicato é tipicamente uma entidade da sociedade capitalista. E o que é hoje a empresa, nesta sociedade capitalista em que vivemos? É o poder absoluto, exclusivo - utiliza esse poder, usa e abusa desse poder. E o que os sindicatos pretendem? Que se exercitem os direitos dos trabalhadores dentro da sociedade capitalista em que estamos inseridos. O que cabe aos sindicatos e trabalhadores? Primariamente, negociar aquilo que é vital para sua sobrevivência, que é o seu salário. Isso deve ser feito exclusivamente entre o empregador e o empregado, sem a ingerência do Estado. Esse deve ser o exercício democrático entre as partes. Não podemos mais admitir que o Estado avance numa questão que não é da sua atribuição e resolva os conflitos todos na base da violência. Para isso existe uma legislação específica. Aliás, o pai do nobre Constituinte Luiz Viana Neto, num livro sobre Castello Branco, citou o relator dessa lei - a Lei $n^{\circ} 4.330$. Foi o Presidente desta Constituinte, Deputado Ulysses Guimarães. A Lei $n^{\circ} 4.330$ simplesmente inviabiliza o exercício democrático da greve, porque permite a ingerência do Estado na discussão do direito do trabalhador. O Judiciário, por exemplo, um dos poderes do Estado, sem o consentimento do trabalhador, sempre tem influído nessa área, em geral emitindo decisões a favor do empregador. O que será, então, deste País? Será uma degradação maior do que aquela em que estamos? Porque a Lei $n^{o} 4.330$ confere à Justiça o poder de julgar a legalidade ou a ilegalidade da greve. Isso, definitivamente, não podemos admitir! A questão tem que estar claramente definida na Constituição. E no texto constitucional está dito: "A responsabilidade é de quem exercita o direito". Se é mal exercitado, que a lei coíba, como está explicitada na Constituição. Mas que outra pessoa, que não a parte diretamente interessada no problema, interfira, isso não podemos aceitar! Uma outra parte ter ingerência em assunto que cabe ao empregado e ao empregador é absolutamente inadmissível! Aceito até que um dissídio se instaure no âmbito da Justiça do Trabalho. Mas quando solicitado por ambas as partes! De oficio, pelo procurador ou pela própria Justiça do Trabalho jamais! Pelo empregador apenas, não. Então, não se tem que remeter para a legislação ordinária. Desconheço, em todos esses quarenta anos de trabalho, em diversas empresas, ação predadora por parte do assalariado. Quando ocorreu foi por infiltração de agentes provocadores, que estão impunes até hoje. Portanto, isso é inadmissível. Ou a greve é uma liberdade, como nos países desenvolvidos, nos povos civilizados, ou não se tem liberdade. Meio direito não podemos admitir de forma alguma. Que se conduzam as relações entre o capital e o trabalhador, em nosso país, para o livre exercício da negociação - e o direito de greve, aliás, vem exatamente para propiciar esse equilíbrio. Não se pode admitir que uma legislação complementar, sob a 
alegação de que vem para regulamentar o exercício do direito de greve - e isso já tive oportunidade de dizer algumas vezes - casse ou venha a tolher parcialmente esse direito. Apelo, pois, para a consciência dos nobres companheiros aqui presentes, no sentido de envidarmos esforços para que esta Constituinte venha a oferecer condições de vida participativa à nossa sociedade. Que não haja extremismos de direita - hoje mais exercitados do que qualquer outro - nem extremismos de esquerda. E isso só é possível através da ampla participação de todos, sem exclusão de quem quer que seja. ${ }^{156}$

Na 13 ${ }^{a}$ Reunião, em 12 de junho de 1987, a Comissão deliberou sobre a nova redação conferida pelo relator ao substitutivo, após o exame das emendas oferecidas pelos constituintes. Houve pequena alteração no dispositivo que tratava da greve. ${ }^{157}$

Em razão do cronograma dos trabalhos da Assembleia Nacional Constituinte, não houve tempo hábil para que a Comissão discutisse e deliberasse, item por item, o segundo substitutivo. Passou-se, então, à votação (aprovação ou não) do texto elaborado pelo relator, que recebeu 41 votos favoráveis e 17 contrários. Logo depois, a Comissão decidiu sobre os destaques oferecidos às emendas.

Com relação ao direito de greve, o constituinte João Menezes (PFL) apresentou destaque às alíneas "b", “c", "d" e "g" do inciso V (que tratava, como visto, da "manifestação coletiva"). João Menezes tinha por objetivo retirar a vedação à paralisação do trabalho por iniciativa dos empregadores. ${ }^{158} \mathrm{O}$ relator José Paulo Bisol fez a defesa do texto, enfatizando a

\footnotetext{
156 BRASIL. Assembleia Nacional Constituinte. Ata da $10^{a}$ Reunião da Comissão da Soberania e dos Direitos e Garantias do Homem e da Mulher, p. 78.

${ }^{157} \mathrm{Na}$ nova redação, a alínea "b" vedava a paralisação do trabalho de iniciativa dos empregadores ("é livre a paralisação do trabalho, seja qual for a sua natureza e a sua relação com a comunidade, excluída a iniciativa de empregadores, não podendo a lei estabelecer outras exceções"); a alínea " $\mathrm{f}$ " passava a fazer referência apenas às alíneas "c" e "d"; e a alínea "g" recebeu texto mais conciso, para estabelecer apenas que "em caso algum a paralisação coletiva do trabalho será considerada, em si mesma, um crime" (BRASIL. Assembleia Nacional Constituinte. Comissão da Soberania e dos Direitos e Garantias do Homem e da Mulher. Vol. 68. Brasília: Centro Gráfico do Senado Federal, 1987, p. 6.

158 Vale atentar para o seguinte trecho do discurso de João Menezes: "Por que os empregadores não podem também paralisar? Se os empregadores podem e a Constituição é igual para todos, os empregadores também têm o direito de poder paralisar. Parece-me que aqui estamos usando o princípio de tratar desigualmente seres iguais. Esse princípio não pode ser aceito. Devemos estabelecer igualdade para todos. Se é livre a paralisação do trabalho, tem de ser para todos. Todo mundo pode exercer a paralisação do trabalho de acordo com a letra $b$. É esta a razão de termos pedido destaque para essa emenda. Não podemos admitir que se estabeleça aqui preferência a quem quer que seja. Não podemos estar aqui fomentando luta de classes entre trabalhadores e empregadores. Temos de marchar em igualdade de condições, estabelecendo o melhor relacionamento possível entre as classes sociais. Do contrário, iremos para a anarquia, que não serve a ninguém, muito menos a este País. Precisamos fazer uma Constituição que realmente estabeleça direitos iguais para pessoas iguais, estabeleça direitos iguais para todos". O constituinte Farabulini Júnior (PTB) falou em defesa do substitutivo do relator: "Sr. Presidente, somos dos que defendem a liberdade total para o trabalhador, enquanto deseja promover a greve, e somos contrários ao lockout, à despedida em massa. Cumpre-nos dar ao trabalhador a única possibilidade de que dispõe: a de paralisar o trabalho, para fazer a reivindicação que deseja. A reivindicação do trabalhador deve estar consignada em lei com clareza, como aqui se encontra: 'É livre a paralisação do trabalho, seja qual for sua natureza'. Quanto aos serviços essenciais, o Poder Público, no caso dos hospitais, de postos de saúde, puericultura e tudo o mais, na verdade o Poder Público precisa manter seus serviços, e fazê-lo tão bem a ponto
} 
consciência social e política dos trabalhadores:

Acho que a questão é muito simples, ou se admite que direito de greve é um direito constitucional - e direito constitucional significa algo mais amplo que qualquer direito subjetivo - ou não se quer o direito de greve. isto é. finge-se que se quer, coloca-se na Constituição e permite-se que a lei disponha o contrário. A situação atual é que a greve é um direito constitucional, mas a legislação retira esse direito. Queremos eliminar esse absurdo. Mas aqui há um aspecto muito importante, que talvez não tenha sido alcançado por alguns. Entendemos que os trabalhadores do Brasil atingiram um nível de consciência social e política tão maduro, que têm condições de fazer greve até em serviços essenciais, e cuidar de como se fazem as coisas, sem que ocorram problemas para a comunidade. Este texto, aqui, confia na consciência social e política do trabalhador brasileiro, em última análise, confia na consciência social e política do povo brasileiro. ${ }^{159}$

O substitutivo do relator, em sua nova redação, foi mantido, com 34 votos a favor, 1 contra (justamente do constituinte que requereu o destaque) e uma abstenção. O anteprojeto da Comissão ${ }^{160}$ foi encaminhado à Comissão de Sistematização, onde prosseguiriam os trabalhos da Constituinte.

\subsection{O percurso na Comissão de Sistematizacão}

O Regimento Interno da Assembleia Nacional Constituinte previa que o relator, na Comissão de Sistematização, elaboraria um Anteprojeto, reunindo os textos aprovados nas Comissões temáticas. Esse Anteprojeto foi apresentado pelo relator Bernardo Cabral (PMDB) em 26 de junho de 1987. Pelo Regimento, os constituintes teriam prazo para apresentação apenas de emendas de adequação e, em seguida, o relator apresentaria um Projeto de Constituição, cuja deliberação preliminar competiria à Comissão de Sistematização. Depois, o Projeto seria encaminhado para discussão no Plenário e oferecimento de emendas de mérito, inclusive populares. Encerrado o prazo das emendas, o Projeto retornaria à Comissão, para

de igualmente atender às reivindicações dos funcionários públicos desses setores. Agora, no que tange ao Iockout, à despedida em massa, concordo plenamente com o Sr. Relator, no sentido de que não podemos, de modo algum, autorizá-los. Para os grupos de pressão, os grupos econômicos, que podem lançar mão do lockout, esta é a melhor medida, pois fecham a fábrica e os trabalhadores não têm como exigir seus direitos" (BRASIL. Assembleia Nacional Constituinte. Ata da $13^{a}$ Reunião da Comissão da Soberania e dos Direitos e Garantias do Homem e da Mulher, Brasília: Senado Federal, Secretaria Especial de Editoração e Publicações, Subsecretaria de Anais, 1987, documento eletrônico, p. 151 (para ambas as transcrições).

${ }^{159}$ BRASIL. Assembleia Nacional Constituinte. Ata da $13^{a}$ Reunião da Comissão da Soberania e dos Direitos e Garantias do Homem e da Mulher, p. 151.

${ }^{160}$ Cf. BRASIL. Assembleia Nacional Constituinte. Comissão da Soberania e dos Direitos e Garantias do Homem e da Mulher. Vol. 69. Brasília: Centro Gráfico do Senado Federal, 1987. 
apreciação das emendas e devolução do texto ao Plenário, para votação em dois turnos. ${ }^{161}$

No Anteprojeto de Constituição, Bernardo Cabral incorporou, no que diz respeito ao direito de greve, a redação proposta pela Comissão da Soberania e dos Direitos e Garantias do Homem e da Mulher. ${ }^{162} \mathrm{O}$ texto foi mantido no Projeto de Constituição apresentado em julho de $1987 .{ }^{163}$

A Comissão de Sistematização, presidida pelo constituinte Afonso Arinos (PFL), passou à fase de apresentação de emendas. Entre essas últimas, estavam as emendas populares. O direito de greve foi objeto das emendas de $\mathrm{n}^{\circ} 54,66,74$ e 114.

A emenda popular $\mathrm{n}^{\circ} 54$ (no cadastro da ANC: 1p20717-7) foi subscrita pela CUT, pelo Movimento dos Trabalhadores Rurais Sem Terra - MTST e pela Comissão Pastoral da Terra - CPT. A redação sugerida para a nova Constituição, quanto à greve, era a seguinte:

A constituição assegura aos trabalhadores em geral e aos servidores públicos civis, federais, estaduais e municipais, independente de lei, os seguintes direitos, além de outros que visem à melhoria de sua condição social: (...) XVI - greve, que não poderá sofrer restrições na legislação, sendo vedado às autoridades públicas, inclusive judiciárias, qualquer tipo de intervenção que possa limitar esse direito. ${ }^{164}$

A emenda popular $\mathrm{n}^{\circ} 66$ (1p20746-1) foi formulada por parlamentares e advogados, em trabalho organizado pelo DIAP, e contava com a participação de várias entidades sindicais (como CGT, CUT e USI, além de confederações). No que dizia respeito à greve, a emenda repetia os termos da emenda 54, mas trazia importante justificativa, sinalizando para uma prática que deveria ser evitada:

${ }^{161}$ Cf. os artigos 19/20 do Regimento Interno da ANC, in BRASIL. Diário da Assembleia Nacional Constituinte, vol. 330, Resolução nº 2/1987.

${ }^{162}$ A redação do dispositivo sobre o direito de greve era a seguinte: “Art. 17. São direitos e liberdades coletivos invioláveis: (...) V - A manifestação coletiva. a. é livre a manifestação coletiva em defesa de interesses grupais, associativos e sindicais; b. é livre a greve, competindo aos trabalhadores decidir sobre a oportunidade e o âmbito de interesses que deverão por meio dela defender, excluída a iniciativa de empregadores, não podendo a lei estabelecer outras exceções; c. na hipótese de greve, as organizações de classe adotarão as providências que garantam a manutenção dos serviços indispensáveis ao atendimento das necessidades inadiáveis da comunidade d. os abusos cometidos sujeitam seus responsáveis às penas da lei; e. a manifestação de greve, enquanto perdurar, não acarreta a suspensão dos contratos de trabalho ou da relação de emprego público; f. a lei não poderá restringir ou condicionar o exercício dessa liberdade ao cumprimento de deveres ou ônus, salvo o disposto nas alíneas "c" e "d" deste item; g. em caso algum a paralisação coletiva do trabalho será considerada, em si mesma, um crime" (BRASIL. Assembleia Nacional Constituinte. Comissão de Sistematização. Anteprojeto de Constituição. Vol. 219 (errata no vol. 220). Brasília: Centro Gráfico do Senado Federal, 1987, p. 8).

${ }^{163}$ Cf. BRASIL. Assembleia Nacional Constituinte. Comissão de Sistematização. Projeto de Constituição. Vol. 223. Brasília: Centro Gráfico do Senado Federal, 1987.

${ }^{164}$ BRASIL. Assembleia Nacional Constituinte. Comissão de Sistematização. Emendas Populares - vol. 2. Vol. 231. Brasília: Centro Gráfico do Senado Federal, 1987, p. 56. 
a greve é um fato social que não comporta limitação legal. A história revela paralisações desde escravos, no tempo da escravidão até greve de magistrados. Na sistemática brasileira a Justiça do Trabalho é utilizada como instrumento cerceador do direito de greve. É imprescindível que não se permita a manutenção dessa situação, delegando-se à Justiça do Trabalho o seu magno papel de fazer efetivamente justiça social. O locaute não deve ser admitido, porque dirige-se ao Estado e não às relações de trabalho. ${ }^{165}$

Já a emenda 74 (1p20791-6), de responsabilidade do Sindicato dos Trabalhadores Rurais de Minas Gerais (STR/MG), do Sindicato dos Trabalhadores nas Indústrias de Extração de Ferro e Metais Básicos e de Minerais Não-Metálicos de Patos de Minas METABASE/MG e da Associação dos Pequenos Produtores do Cerrado de MG, previa apenas que "aos trabalhadores serão assegurados: (...) IV - direito de greve, últimos casos".

A emenda 114, a cargo da Associação Profissional dos Empregados Domésticos de São Paulo e da Associação Profissional dos Empregados Domésticos de Santa Catarina, propunha, entre outros dispositivos, um que estipulava: "assegurado ao trabalhador o direito de greve, sem qualquer restrição na legislação". 166

Na 11ª Reunião Extraordinária, em 11 de setembro de 1987, a Comissão de Sistematização debateu o Projeto de Constituição e o parecer do relator às emendas oferecidas ao Anteprojeto. Como indicado, nessa fase dos trabalhos, seriam admitidas apenas emendas de adequação. Não obstante, foram apresentadas inúmeras emendas de mérito, todas rejeitadas pelo relator, com fundamento no Regimento Interno. Bernardo Cabral, entretanto, eximiu-se de defender o Projeto de Constituição naquela etapa, até para que se passasse aos debates no Plenário, segundo o roteiro previsto. ${ }^{167}$

165 BRASIL. Assembleia Nacional Constituinte. Comissão de Sistematização. Emendas Populares - vol. 2. Vol. 231, p. 69.

166 BRASIL. Assembleia Nacional Constituinte. Comissão de Sistematização. Emendas Populares - vol. 2. Vol. 231, p. 74 (sic) e 102, respectivamente. A emenda 114, no entanto, foi indeferida pelo relator, "de acordo com as informações da Secretaria" (p. 102).

$167 \mathrm{Na}$ exposição de motivos ao Projeto de Constituição, o relator escreveu o seguinte, indicando certo descompromisso com o próprio Projeto e com o material recebido das Comissões Temáticas: "reitero afirmação que fiz, quando do oferecimento do Anteprojeto: as regras regimentais, que balisam minha ação, cercearam a liberdade de iniciativa do Relator. Tal como a grande maioria dos Senhores Constituintes, também detectei, no Anteprojeto, a par de virtudes e inovações elogiáveis, inconsistências, superfetações, desvios e, acima de tudo, a ausência de um fio condutor filosófico. (...) É de uma pontiaguda evidência, pois, que o resultado dessa multifacetada contribuição só poderia ser um documento complexo, extenso, não uniforme. (...) Abrir-se-á, entretanto, logo após este segmento de compatibilização e adequação, o instante mais frutuoso de nossos misteres: em Plenário, sem limitação de conteúdo, formularão Vossas Excelências, estou certo - e então sim - as Emendas que traduzam ou possam vir a traduzir os anseios da sociedade. A elas se somarão, na época, as chamadas Emendas Populares, verdadeira manifestação das aspirações da cidadania. Sensível a todo este notável repositório, ao qual farei aditar não só algumas idéias importantes dos trabalhos das Comissões Temáticas, como ainda a consideração ao veiculado em Emendas que agora, por motivos regimentais, não puderam ser apreciadas, e, ademais, por convicções pessoais, este Relator elaborará Substitutivo, à apreciação dos meus eminentes pares. E aí sim, este será trabalho de minha lavra, cuja defesa haverei de assumir, de um lado, sem o mais leve constrangimento, e, de outro, sem qualquer resistência às críticas e contribuições construtivas." (BRASIL. 
Logo no início dessa Reunião, o constituinte Fernando Henrique Cardoso (PMDB) pediu a palavra para noticiar à Comissão o acordo entabulado naquele dia e no dia anterior, entre as lideranças partidárias, para que fosse aprovado o Projeto de Constituição tal como apresentado pelo relator Bernardo Cabral. O acordo previa que o conjunto de emendas oferecidas - de mérito ou de adequação - fosse encaminhado à Mesa da Assembleia Constituinte para que, uma vez renumeradas e readequadas ao novo texto do Projeto, retornassem à deliberação da Comissão, após a etapa de discussões no Plenário. ${ }^{168}$

Após algumas discussões entre os parlamentares, basicamente sobre os termos do acordo e sua compatibilidade ou não com o Regimento Interno da ANC, a Comissão de Sistematização procedeu à votação. O Projeto de Constituição foi aprovado com 76 votos favoráveis e 15 contrários. Os destaques solicitados às emendas rejeitadas foram, em sua grande maioria, retirados pelos constituintes, à exceção de dois, apresentados por constituintes do PFL, e que, submetidos à votação, foram rejeitados. ${ }^{169}$

Com esse procedimento, a ANC avançou para a etapa seguinte dos trabalhos: o oferecimento de emendas em Plenário e o retorno do Projeto de Constituição à Comissão de Sistematização, ocasião em que o relator teria a oportunidade de apresentar seu Substitutivo.

E o Primeiro Substitutivo do relator da Comissão de Sistematização, chamado por ele mesmo de Cabral 1, foi publicado em agosto de 1987. No total, haviam sido oferecidas 20.770 emendas por constituintes e 86 emendas populares (válidas). ${ }^{170} \mathrm{O}$ direito de greve foi tratado no art. 10, numa redação diferente das propostas na fase das Comissões Temáticas. O texto era o seguinte:

é livre a greve, na forma da lei, vedada a iniciativa patronal, competindo aos trabalhadores decidir sobre a oportunidade e o âmbito de interesses que deverão por meio dela defender.

Parágrafo único. Na hipótese de greve, serão adotadas as providências que garantam a manutenção dos serviços indispensáveis ao atendimento das necessidades inadiáveis da comunidade. ${ }^{171}$

Assembleia Nacional Constituinte. Comissão de Sistematização. Projeto de Constituição. Vol. 226. Brasília: Centro Gráfico do Senado Federal, 1987, p. 45).

168 Ver BRASIL. Assembleia Nacional Constituinte. Ata da $11^{a}$ Reunião Extraordinária da Comissão de Sistematização, Brasília: Senado Federal, Secretaria Especial de Editoração e Publicações, Subsecretaria de Anais, 1987, documento eletrônico, p. 212. Manifestaram-se, confirmando o acordo, os líderes do PFL, Alceni Guerra, PDS, Virgílio Távora, PL, Adolfo Oliveira, PT, Plínio Arruda Sampaio, PSB, Jamil Haddad, PDC, Mauro Borges, PC do B, Haroldo Lima, PCB, Roberto Freire, e PDT, Brandão Monteiro. Rejeitou o acordo o líder do PTB, Gastone Righi. Estava ausente o do PMB, Antônio Farias.

169 Cf. BRASIL. Assembleia Nacional Constituinte. Ata da $11^{a}$ Reunião Extraordinária da Comissão de Sistematização, p. 219/226.

${ }^{170}$ Cf. BRASIL. Assembleia Nacional Constituinte. Comissão de Sistematização. Projeto de Constituição. Primeiro Substitutivo do Relator e Parecer. Vol. 235, Brasília: Centro Gráfico do Senado Federal, 1987, p. 3.

${ }^{171}$ BRASIL. Assembleia Nacional Constituinte. Comissão de Sistematização. Projeto de Constituição. Primeiro 
O dispositivo sobre a greve foi enxuto e a discutida expressão "na forma da lei" voltou a aparecer no texto, muito embora não tenha constado de nenhum dos anteprojetos encaminhados pelas Comissões Temáticas. A pergunta que se impõe é: até que ponto as discussões e votações havidas no âmbito dessas Comissões foram consideradas pelo relator Bernardo Cabral?

Examinando as emendas dos constituintes e as emendas populares, tem-se que, dentre as primeiras, inúmeras propunham alterações nos dispositivos do Projeto que cuidavam da greve, várias delas com o intuito de sintetizar o texto constitucional, remetendo a matéria relativa à greve à legislação ordinária. ${ }^{172}$ Entre tais emendas, chama à atenção a de $n^{\circ}$ 1p14326, de autoria do constituinte Olavo Pires (PMDB). O objetivo da proposta era conferir a seguinte redação ao preceito que trataria do direito de greve:

é livre a greve, competindo aos trabalhadores decidir sobre a oportunidade e o âmbito de interesse que deverão por meio dela defender, excluída a iniciativa dos empregadores, não podendo a lei estabelecer outras exceções, a adesão do trabalhador à greve é livre e constitui decisão pessoal de cada um, garantida pela lei e que não será induzida, nem forçada por quaisquer meios coercitivos, físicos ou morais, de quem quer que seja. ${ }^{173}$

A justificativa da proposta indicava a concepção do constituinte sobre o direito de

greve:

No Brasil, defasado no seu desenvolvimento em comparação com outras nações, é preciso estimular, antes de mais nada, o trabalho, a iniciativa e a assunção de riscos. A greve é sempre uma exceção, jamais pode ser considerada regra. Aliás é sintomático que os regimes de orientação socialista ou comunista, que se serviram de greves para ascender ao poder, tomam o cuidado de proibi-las tão logo dominam a situação. Por outro lado, é recorrente o fato de que a greve é decretada, muitas vezes, por minorias, não representativas da verdadeira massa trabalhadora, que, muitas vezes, prefere continuar a trabalhar. Daí preconizar-se que a adesão à greve seja ato voluntário de cada trabalhador, no qual ninguém deve interferir por meios

Substitutivo do Relator e Parecer. Vol. 235, p. 20. Diferentemente do que ocorrera na fase anterior, não houve negativa de autoria por parte de Cabral. Pelo contrário, em suas justificativas, o relator fez constar que "longe de ser um trabalho personalista, este Substitutivo é resultado de tudo quanto pude ouvir e de tudo quanto me convenci" (p. 3).

172 Com relação às emendas populares, não receberam, até esse momento, parecer do relator, pois, como foi explicado quando da apresentação do primeiro substitutivo, não houve defesa oral por parte das entidades que as subscreveram. Cf. BRASIL. Assembleia Nacional Constituinte. Comissão de Sistematização. Projeto de Constituição. Primeiro Substitutivo do Relator e Parecer. Vol. 235, p. 3.

${ }^{173}$ BRASIL. Assembleia Nacional Constituinte. Comissão de Sistematização. Projeto de Constituição. Emendas oferecidas em Plenário (Constituintes e Eleitores). Vol. 229. Brasília: Centro Gráfico do Senado Federal, 1987, p. 23. 
coercitivos, físicos ou morais, admitida sempre a divulgação ampla das razões e justificativas da greve, de modo a permitir que, pela via meramente racional e individualmente voluntária, cada trabalhador decida soberanamente sobre a sua participação no movimento. Os chamados piquetes, quando impedem a locomoção, a circulação, o acesso ao local de trabalho por aqueles que não aderem à greve, constituem violência à liberdade individual que não pode ser tolerada pelo sistema jurídico. ${ }^{174}$

A emenda recebeu do relator Bernardo Cabral parecer pela aprovação parcial. É certo que diversas outras emendas também receberam parecer favorável de Cabral. Entretanto, no caso dessa emenda em especial, o relator expressou sua compreensão sobre como deveria ser o texto constitucional, com relação ao direito de greve. Em suas palavras:

Após acurada reflexão, concluímos que relativamente ao direito de greve, apenas quatro pontos fundamentais devem figurar como preceitos constitucionais

1 - a liberdade de exercício do direito

2 - a atribuição aos trabalhadores da definição sobre a oportunidade e o âmbito de interesses a defender por meio de greve;

3 - a preservação da continuidade de funcionamento dos serviços destinados a atender as necessidades inadiáveis da comunidade;

4 - a regulamentação do direito pela lei respeitando aqueles parâmetros constitucionais.

Como a Emenda preconiza a liberdade do exercício do direito de greve, mas sob outra fórmula que não aquela acima explicitada, somos pela aprovação parcial. ${ }^{175}$

O que significaria a expressão "acurada reflexão"? O relator não faz referência a alguma emenda específica ou mesmo discussão anterior que teria motivado a citada "reflexão" e a mudança quanto ao projeto antes apresentado. Em suma: o material produzido pelas Comissões Temáticas pode ter sido, em boa parte, ignorado por Bernardo Cabral.

Na 14 Reunião Ordinária da Comissão de Sistematização, realizada em 27 de agosto de 1987, o constituinte Paulo Paim (PT) defendeu a Emenda Popular n ${ }^{\circ}$ 54, enquanto Ulisses Riedel de Resende, Diretor Técnico do DIAP, manifestou-se a favor da Emenda $\mathrm{n}^{\circ} 66$. Ambos atacaram o Substitutivo apresentado pelo relator da Comissão. Segundo Paulo Paim, o material que deveria estar no texto, como aprovado na Subcomissão dos Direitos dos Trabalhadores e Servidores Públicos, havia sido arbitrariamente retirado por Bernardo Cabral,

\footnotetext{
${ }^{174}$ BRASIL. Assembleia Nacional Constituinte. Comissão de Sistematização. Projeto de Constituição. Emendas oferecidas em Plenário (Constituintes e Eleitores). Vol. 229, p. 23.

175 BRASIL. Assembleia Nacional Constituinte. Comissão de Sistematização. Parecer sobre as Emendas oferecidas em Plenário ao Projeto de Constituição. Vol. 234, Brasília: Centro Gráfico do Senado Federal, 1987, p. 424 (destaque acrescentado).
} 
inclusive com relação ao direito de greve. ${ }^{176}$ Segundo Paulo Paim:

Foi aprovado também na Subcomissão dos Direitos dos Trabalhadores e servidores públicos, e sumiu do texto do substitutivo, por obra e arte do Sr. Constituinte Bernardo Cabral, o pleno direito de greve.

(...) na verdade, a posição do Sr. Relator desta Comissão, Constituinte Bernardo Cabral, fere e desrespeita tudo aquilo que foi discutido na Subcomissão que tratou dos direitos dos trabalhadores e na própria Comissão da Ordem Social. Questões como estabilidade, quarenta horas semanais de trabalho, direito de greve, aposentadoria para o homem e para a mulher, tanto no campo como na cidade, respeitando o tempo de serviço e não a idade, foram aprovadas por unanimidade.

Gostaria de perguntar, se estivesse presente, ao Relator Bernardo Cabral onde colocou as decisões aprovadas, por unanimidade, na Subcomissão dos Direitos dos Trabalhadores e Servidores Públicos e na Comissão da Ordem Social. E mais: no meu entendimento, esse relatório apresentado é fruto do lobby do capital, dos latifundiários e dos grandes empresários. Ele não representa em nada os interesses da classe trabalhadora. ${ }^{177}$

O Substitutivo do relator também foi combatido pelo constituinte Juarez Antunes (PDT), diante da "poda" feita quanto aos direitos dos trabalhadores. ${ }^{178}$ Por sua vez, o Diretor do DIAP, Ulisses Riedel de Resende, ao discursar em defesa da Emenda Popular $\mathrm{n}^{\circ}$ 66, criticou - com tom de sarcasmo até - o texto elaborado pelo relator da Comissão e denunciou o fato de ter sido suprimido o que fora aprovado, em especial na Subcomissão dos Direitos

\footnotetext{
${ }^{176}$ Além da mudança quanto ao direito de greve, o Substitutivo do relator suprimia o direito à estabilidade no emprego, cujo preceito passara a prever o direito a contrato de trabalho protegido contra despedida imotivada ou sem justa causa, nos termos da lei, bem como retirava a duração semanal do trabalho de 40 horas, pois o novo texto previa apenas 8 horas diárias de labor.

${ }^{177}$ Em seu discurso, Paulo Paim ainda fez a seguinte denúncia: "Queríamos registrar, como denúncia, o que está acontecendo em Volta Redonda. onde já foram demitidos mais de 80 trabalhadores, dentre os quais mais de 13 dirigentes sindicais, inclusive o nobre Constituinte Juarez Antunes, do PDT, preso no dia da greve geral. Estamos sabendo que neste momento o Exército está ocupando o quinto andar da sede do sindicato, em Volta Redonda. É lamentável que não tenhamos direito de greve e que haja, ainda, a interferência do Estado e do Exército quando os trabalhadores se mobilizam em torno dos seus direitos. Gostaria de registrar ainda que li no jornal esta semana que, em São Paulo, os trabalhadores também foram à greve. Depois de duas semanas, foram demitidos em massa. Foram reprimidos pela polícia de São Paulo. As empresas não pagaram os 37,4\% que os trabalhadores ganharam na Justiça, mas, aproveitando-se do fato de a greve ter sido declarada ilegal, demitiram os trabalhadores" (BRASIL. Assembleia Nacional Constituinte. Ata da $14^{a}$ Reunião da Comissão de Sistematização, Brasília: Senado Federal, Secretaria Especial de Editoração e Publicações, Subsecretaria de Anais, 1987, documento eletrônico, p. 361/362).

178 Para o constituinte, "congratulo-me com o companheiro Paulo Paim. Somos dirigentes sindicais e estamos estarrecidos com essa poda feita pelo Relatar Bernardo Cabral nos direitos dos trabalhadores, um vexame. S. Ex. ${ }^{a}$ e seu grupo não estão pensando numa nova Constituição, mas numa já ultrapassada. Nunca se viu nesta Casa indivíduo com horizonte tão estreito como o de Bernardo Cabral, muito afinado com seu partido, que hoje é contra o povo. É de estarrecer! Nós, que defendemos os trabalhadores de quaisquer partidos, temos que nos reunir para tomar uma posição, porque é uma vergonha o que se passa nesta Casa. Tudo foi cortado. Está pior do que a Constituição anterior. É o que há de mais retrógrado e obscurantista. E é o compromisso de Bernardo Cabral e seus pupilos da Comissão de Sistematização" (BRASIL. Assembleia Nacional Constituinte. Ata da $14^{a}$ Reunião da Comissão de Sistematização, p. 363).
} 
dos Trabalhadores e Servidores Públicos e na Comissão da Ordem Social. ${ }^{179}$ Já o constituinte Luiz Gushinken (PT) acusou o relator de ceder a pressões do capital, desprezando o que seria exigido pelo setor majoritário da sociedade, i.e., os trabalhadores. ${ }^{180}$

E qual seria a posição de Bernardo Cabral diante dos ataques ao Substitutivo? A resposta não é simples. O relator não compareceu a diversas reuniões da Comissão de Sistematização - como se percebe, aliás, no pronunciamento acima de Paulo Paim. Bernardo Cabral e seu grupo de relatores adjuntos se reuniam fora das dependências do Congresso. E, de fato, inúmeras articulações entre os grupos de constituintes ocorriam em paralelo, na tentativa de alcançar soluções de consenso sobre os temas mais polêmicos. ${ }^{181}$

As reuniões da Comissão de Sistematização prosseguiam com o debate do Substitutivo apresentado por Bernardo Cabral.

$\mathrm{Na}$ defesa das emendas populares vinha à tona a vontade de mudança. A Emenda Popular 117 tratava das Forças Armadas e foi defendida pela Presidenta da União Nacional dos Estudantes, Gisele Mendonça. O intento da proposta era o de que as Forças Armadas se afastassem da vida política e institucional do país. Isso deveria ser garantido no texto constitucional, mediante a definição expressa das atribuições dos militares. ${ }^{182}$

\footnotetext{
${ }^{179}$ Em suas palavras, "Sr. Presidente, Sr.as e Srs. Constituintes, meus Companheiros, creio que, se fizermos um instante de silêncio e tivermos os ouvidos bem apurados, seremos capazes de ouvir o esposar de champanha na sede da Fiesp, da CNI, da CNA de outros órgãos comprometidos com os interesses da classe empresarial, de poder econômico selvagem. É só prestar bem atenção, pois iremos perceber que eles estão em festa; uma vez que aquilo que se conseguiu a duras penas, através do trabalho de V. Ex.as em debates cuidadosos, em exposições minuciosas, em votações sentidas emocionadas, tornadas na Subcomissão dos Direitos dos Trabalhadores e Servidores Públicos, na Comissão da Ordem Social, com o apoio das mais expressivas lideranças do Congresso Nacional, numa única penada foi suprimido do texto do projeto que nos é agora apresentado. No entanto, penso que eles se enganam. Não vou perder a esperança e não me colocarei numa posição pessimista, achando, como alguns, que o poder de decisão estará nas mãos de alguns grupos e algumas elites. Lembro aos eminentes Parlamentares que a decisão final dependerá do voto de V. Ex.as, de quem será cobrado o comportamento. Não se enganem nem imaginem que alguém vai poder dizer que foi por causa de uma cúpula, de um agrupamento e esconder-se atrás de votos e de posições desconhecidas, porque, na verdade, as nossas propostas, seja através da emenda popular, seja através daquelas já apresentadas pelos Constituintes, deverão ser votadas, e será cobrado o voto "não" (BRASIL. Assembleia Nacional Constituinte. Ata da 14a Reunião da Comissão de Sistematização, p. 363).

${ }^{180}$ Cf. BRASIL. Assembleia Nacional Constituinte. Ata da $14^{a}$ Reunião da Comissão de Sistematização, p. 364.

${ }^{181}$ A relatoria auxiliar organizada por Bernardo Cabral o acompanhou até o final dos trabalhos da Constituinte. Participaram desse grupo os constituintes Wilson Martins (PMDB), Nelson Jobim (PMDB), Fernando Henrique Cardoso (PMDB), Adolfo de Oliveira (PL) e Antonio Carlos Konder Reis (PDS). Quando a figura do relator adjunto foi institucionalizada, a função foi exercida por José Fogaça (PMDB), Adolfo de Oliveira e Antonio Carlos Konder Reis. Cf. COELHO, João Gilberto Lucas. "O processo constituinte”. In: GURAN, Milton (coord. editorial). O processo constituinte 1987-1988. Brasília: AGIL, 1988, p. 51. Segundo Adriano Pilatti, Cabral e seu grupo de relatores se reuniam em gabinete do Banco do Brasil. O relator deixou de comparecer a 17 das reuniões ocorridas entre 14 de julho e 24 de setembro de 1987 (data em que se iniciaram as votações do segundo substitutivo). Cf. PILATTI, Adriano. A Constituinte de 1987-1988, p. 157.

${ }^{182}$ A emenda propunha dois artigos para a constituição. O primeiro disporia que "as Forças Armadas destinamse à defesa da pátria contra a agressão externa e a assegurar a integridade do território nacional". O outro estabeleceria que "as Forças Armadas não poderão intervir na vida política do país". Cf. BRASIL. Assembleia Nacional Constituinte. Comissão de Sistematização. Emendas Populares - vol. 2. Vol. 231, p. 106.
} 
A Emenda Popular merece destaque, não apenas pela ênfase à necessidade de mudança institucional, mas, sobretudo, pela associação entre a ação das Forças Armadas e o direito de greve. Gisele Mendonça ressaltou a atuação do Exército durante uma greve geral deflagrada em plena Nova República, referindo-se expressamente aos poderes exercidos pelo General Leônidas Pires Gonçalves. ${ }^{183} \mathrm{O}$ constituinte Edmilson Valentim (PC do B) também recordou a atuação dos militares durante a greve geral da Companhia Siderúrgica Nacional deflagrada naquele ano. ${ }^{184}$

Após um acordo entre os líderes partidários, além de Afonso Arinos e Bernardo Cabral, o Presidente da ANC, Ulysses Guimarães (PMDB) comunicou que haveria a apresentação de dois substitutivos pelo relator. Em setembro de 1987, o Segundo Substitutivo, ou Cabral 2, foi entregue. O relator deu parecer favorável à aprovação da Emenda Popular 54. A estabilidade no emprego retornou, mas foi mantida a duração laboral de 8 horas diárias. $\mathrm{O}$ dispositivo sobre o direito de greve também foi modificado, retirando-se a expressão "na forma da lei”. O texto recebeu a seguinte redação:

É livre a greve, vedada a iniciativa patronal, competindo aos trabalhadores decidir sobre a oportunidade e o âmbito de interesses que deverão por meio dela defender.

$\S 1^{\circ}$ - Na hipótese de greve, serão adotadas providências pelas entidades sindicais que garantam a manutenção dos serviços indispensáveis ao atendimento das necessidades inadiáveis da comunidade.

$\S 2^{\circ}$ - Os abusos cometidos sujeitam seus responsáveis às penas da lei. ${ }^{185}$

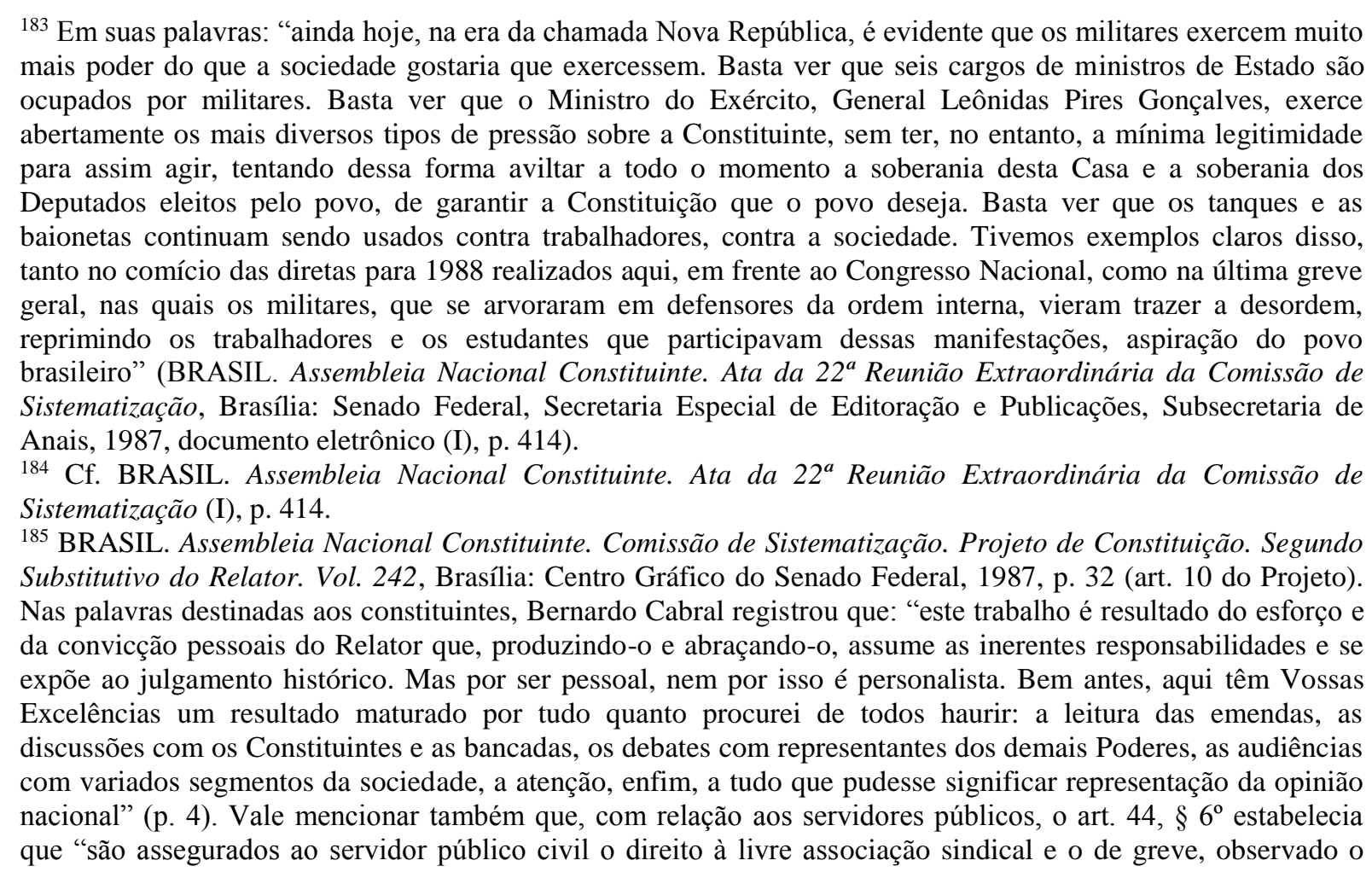


A partir da $32^{\mathrm{a}}$ Reunião Extraordinária, a Comissão de Sistematização passou à discussão do Primeiro e do Segundo Substitutivos do relator, título por título. ${ }^{186} \mathrm{O}$ direito de greve era lembrado nas discussões sobre outros direitos, como a estabilidade no emprego. ${ }^{187}$

O constituinte Luiz Inácio Lula da Silva (PT) ofereceu destaque supressivo ao $§ 2^{\circ}$ do art. 10 do Segundo Substitutivo (destaque 420/1987). A proposta foi defendida por Plínio Arruda Sampaio (PT), que expressou o risco de o referido dispositivo dar margem à restrição do direito de greve, por meio de lei e a despeito do texto constitucional. Além disso, o $\S 2^{\circ}$ parecia ser desnecessário, pois, em caso de abuso, o responsável sempre responderia nos termos da lei. Segundo o constituinte:

A greve passa a ser uma liberdade que os trabalhadores exercitarão no limite dos direitos garantidos nesta Constituição. Esta Constituição garante direitos às pessoas e às coletividades. Esta Constituição pune os abusos, seja através do ilícito civil, seja através do ilícito penal. Para isto existe uma legislação civil e um Código de Processo Civil, para isto existe uma legislação penal e um Código de Processo Penal. De tal maneira que o preceito do $\S 2^{\circ}$ é excrescente, abundante, desnecessário, porque todos os abusos cometidos sempre sujeitam os responsáveis às penas da lei. O inconveniente que vemos, além do aspecto formal de que a Constituição não deve conter dispositivos desnecessários, o inconveniente de fundo que vemos nesse parágrafo é que, de certa maneira, ele abre caminho para uma lei de greve que introduza restrições que a Constituição não quis introduzir, que ele vá além da liberdade que foi concedida e estabeleça casuisticamente uma série de abusos que seriam reprimidos. E é por isto, Sr. Presidente, que vários Constituintes de vários Partidos estão concordes em que é necessário eliminar do texto esta expressão, por desnecessária e por criar o pretexto para que, futuramente, em uma conjuntura menos democrática, se possa fazer uma lei que limite, aquilo que os Constituintes de 87, recolhendo as aspirações da classe trabalhadora e recolhendo as aspirações da sociedade brasileira, que quer viver na democracia e que quer dar aos trabalhadores a oportunidade de uma cidadania plena, decidiram conceder-lhes nesta data histórica de hoje. ${ }^{188}$

disposto nos artigos $9^{\circ}$ e 10 desta Constituição" (p. 40).

${ }^{186} \mathrm{O}$ direito de greve estava previsto no Título II, "Dos direitos e liberdades fundamentais", Capítulo II, “Dos direitos sociais".

${ }^{187}$ O constituinte Luiz Inácio Lula da Silva (PT), pronunciando-se sobre emenda que tratava sobre o direito à estabilidade no emprego, lembrou que o direito de greve era um dos cinco pontos fundamentais pelos quais a classe trabalhadora lutava há mais de meio século. Na mesma ocasião, o constituinte José Serra (PMDB), defendendo o Primeiro Substitutivo quanto ao direito à estabilidade no emprego, afirmou que os trabalhadores da iniciativa privada não deveriam ter o mesmo tratamento que os do setor público, e, em contrapartida, estariam sendo ampliados os instrumentos de atuação dos sindicatos, entre eles, o direito de greve. Cf. BRASIL. Assembleia Nacional Constituinte. Ata da $32^{a}$ Reunião Extraordinária da Comissão de Sistematização, Brasília: Senado Federal, Secretaria Especial de Editoração e Publicações, Subsecretaria de Anais, 1987, documento eletrônico (II), p. 330 e 333, respectivamente.

188 BRASIL. Assembleia Nacional Constituinte. Ata da $32^{a}$ Reunião Extraordinária da Comissão de Sistematização (II), p. 535. 
A contradita coube ao constituinte Gerson Peres (PDS), para quem a previsão constitucional de punição do abuso era necessária para que houvesse seu controle jurisdicional, considerado "parte essencial". O dispositivo seria importante à proteção da sociedade. Para Gerson Peres:

\begin{abstract}
A greve é um movimento consagrado, respeitado e adotado por todos nós, mas é um movimento de classe, de grupo, que defende interesses. Ela pode ser justa e correta e, também, pode ser injusta e incorreta. Os Tribunais, inclusive, podem declará-la ilegal. A greve também pode servir de instrumento de abuso para defesa de interesses de classe. Ora, é neste exato momento que devemos deixar na Constituição que o abuso cometido sujeita os responsáveis às penas da lei, porque, admitamos, que pode um grupo de trabalhadores fazer uma greve ilegal e que prejudique os interesses da comunidade e até do próprio Estado, e a Constituição não preveja nada que realmente apene esses cidadãos que utilizam a greve para defender interesses que não estão amparados na lei. A greve não é um instrumento anárquico, a greve não é um instrumento para se criar condições que inviabilizem o estado de direito. Pelo contrário, a greve é um elemento que contribui para as conquistas sociais dos trabalhadores, mas dentro do respeito ao direito da sociedade, ao direito do Estado, e os abusos cometidos devem ser apenados pelos Tribunais. Tirar o controle jurisdicional sobre os abusos é propiciar parece-me - um instrumento que poderá servir ao estado anárquico, causando sérios prejuízos à tranquiilidade e ao desenvolvimento do País. Portanto, Sr. Presidente, pedi aos Colegas que atentassem bem para a necessidade da permanência desse dispositivo. É nesse dispositivo que a sociedade está protegida. Sem ele a sociedade não está protegida. Dê-se a greve como livre, mas que se reprimam os abusos dela decorrentes. ${ }^{189}$
\end{abstract}

O constituinte Jorge Hage (PMDB) se pronunciou favoravelmente ao destaque, apontando o risco de criação de novas limitações além das existentes na legislação civil e penal. $\mathrm{O} \S 2^{\circ}$ do art. 10 seria, portanto, desnecessário. ${ }^{190}$

189 BRASIL. Assembleia Nacional Constituinte. Ata da $32^{a}$ Reunião Extraordinária da Comissão de Sistematização (II), p. 536. O constituinte Egídio Ferreira Lima (PMDB), por sua vez, entendeu que o $\S 2^{\circ}$ do art. 10 devia permanecer, pois "não tomamos o melhor caminho nas votações da Comissão de Sistematização", uma vez que estava sendo tornada analítica a constituição (p. 536).

190 Jorge Hage anotou que a expressão sobre a punição dos abusos foi retirada, de forma equivocada, do primeiro anteprojeto de constituição, apresentado por Bernardo Cabral, estando inserido em dispositivo que tratava da "manifestação coletiva". Para o constituinte, "foi colada, trazida e justaposta aqui, agora na condição de parágrafo, aquela expressão: 'Os abusos cometidos, sujeitos ou responsáveis à pena da lei', absolutamente desnecessária, redundante, descabida, que pode, entretanto, induzir à criação de novas limitações que não as da legislação civil e penal, que serão sempre aplicáveis aos abusos de qualquer espécie, que jamais poderão ser retirados, como dizia o nobre Constituinte Gerson Peres, da apreciação judicial. De forma alguma. Jamais poderão ser retirados, uma vez que é o art. 5', 'Dos Direitos Individuais e Coletivos', que diz: 'A lei não poderá excluir da apreciação judicial qualquer lesão, ou ameaça ao Direito’. É evidente que qualquer espécie de abuso jamais deixará de ser penalizado pela legislação. De sorte que o dispositivo é, de um lado, absolutamente inócuo, redundante, desnecessário; de outro, impreciso, não diz a quem se dirige. Abusos de quem? Do cidadão? Do sindicato? Da entidade sindical? Do Poder Público ao reprimir a greve? É um absurdo, pode gerar qualquer tipo de interpretação e só contribui para confundir o texto constitucional que em todas as suas demais dimensões só tem merecido aqui os mais amplos e generalizados elogios de todos os segmentos políticos desta Constituinte." (BRASIL. Assembleia Nacional Constituinte. Ata da $32^{a}$ Reunião Extraordinária da Comissão de 
O relatou procedeu à defesa do texto. Bernardo Cabral afirmou que a previsão de punição aos abusos, além de ser bilateral (ou seja, seria possível o abuso por parte de quem reprimia a greve), conferia seriedade à garantia do direito de greve. Segundo o relator:

\begin{abstract}
é preciso que se prove a seriedade, e é o que este texto está querendo fazer: vamos fazer a greve, vamos permitir que os trabalhadores decidam de sua oportunidade, vamos deixar que adotem as providências para que se garanta a manutenção dos serviços indispensáveis e vamos definir as responsabilidades. De quem? De quem faz a greve e comete o abuso, ou daquele que pega o "Urutu" e vai terminar com a greve? Essa responsabilidade precisa ser bem colocada. Não é só o grevista que comete o abuso; aquele que o reprime também pode chegar a tanto. É preciso que se ressalte aqui que este texto está dando a certeza de que tudo que não for, de forma alguma, abuso, não será punido. Não podemos extirpar isto do texto, pois, se assim o fizermos, ficaremos com o texto mutilado, capenga, zarolho, porque se tirou a consequiência exata do caput. ${ }^{191}$
\end{abstract}

Realizada a votação, o destaque foi rejeitado, tendo recebido 23 votos favoráveis e 63 contrários. ${ }^{192}$

Em outubro de 1987, foi apresentado o Substitutivo da Comissão de Sistematização às emendas de Plenário. $\mathrm{O}$ art. 11 do Projeto preservava a redação do art. 10 do Segundo Substitutivo do Relator. ${ }^{193}$

Em novembro de 1987, foi apresentado o Projeto de Constituição (A), sendo mantidos os dispositivos sobre o direito de greve (tanto para os trabalhadores em geral quanto para os servidores públicos). ${ }^{194}$ O Projeto foi encaminho ao Plenário da Assembleia Nacional Constituinte, para discussão em dois turnos.

\title{
1.6. Os debates no Plenário da Constituinte
}

Sistematização (II), p. 536).

191 BRASIL. Assembleia Nacional Constituinte. Ata da $32^{a}$ Reunião Extraordinária da Comissão de Sistematização (II), p. 538.

192 Os constituintes José Fogaça e Fernando Henrique Cardoso formularam declaração de voto, com o seguinte teor: "em defesa do direito dos trabalhadores, e como fator de fortalecimento da extraordinária conquista obtida no caput do art. 10 do Substitutivo 2 do Projeto de Constituição, voto contrariamente à supressão do parágrafo $2^{\circ}$ O parágrafo $2^{\circ}$ delimita a punição. Neste país, de greve, por si só, não será mais punida. Os abusos poderão ser praticados por brigadas facistas antigreve; inclusive pelas autoridades. A punição dos abusos, mesmo dos grevistas, dá solidez e seriedade ao direito de greve. Fica assegurado que tudo que não for abuso não pode ser objeto de punição. Desconhecer tal fato significa enfraquecer o extraordinário avanço, significa vulneralizá-lo. Por fim, é necessário manter o $\S 2^{\circ}$ porque ele limita à lei comum a punição aos abusos. E impede que uma Lei de Segurança, autoritária e facista, venha se sobrepor" (BRASIL. Assembleia Nacional Constituinte. Ata da $32^{a}$ Reunião Extraordinária da Comissão de Sistematização - II, p. 539).

${ }^{193}$ Enquanto o art. $45, \S 6^{\circ}$, repetia o texto do art. $44, \S 6^{\circ}$, do Segundo Substitutivo, sobre o direito de greve dos servidores públicos. Cf. BRASIL. Assembleia Nacional Constituinte. Substitutivo da Comissão de Sistematização. Vol. 244. Brasília: Centro Gráfico do Senado Federal, 1987.

${ }^{194}$ Ver BRASIL. Assembleia Nacional Constituinte. Projeto de Constituição (A). Vol. 251. Brasília: Centro Gráfico do Senado Federal, 1987. 
Dois aspectos são relevantes para a compreensão do percurso seguido pela Assembleia Nacional Constituinte nas discussões de Plenário do Projeto de Constituição. O primeiro deles é a formação do grupo autointitulado Centrão. O segundo, o papel nas votações dos acordos entre as lideranças partidárias.

A articulação de constituintes que deu origem ao Centrão começa ainda ao final dos trabalhos da Comissão de Sistematização. Trata-se de um grupo de parlamentares que representavam a maioria da ANC (ou seja, 280 membros) e reivindicavam uma mudança no Regimento Interno, ao argumento de que eram necessários mecanismos supostamente mais democráticos de votação para evitar, no Plenário, uma "ditadura da minoria" (essa minoria seriam os integrantes da Comissão de Sistematização). ${ }^{195}$

Após diversas controvérsias e negociações, o Centrão conseguiu a aprovação da reforma do Regimento Interno - o que atrasou o calendário dos trabalhos da Constituinte (a proposta do Centrão foi apresentada em 10 de novembro de 1987 e o novo texto foi aprovado apenas em 5 de janeiro de 1988). ${ }^{196}$

O resultado da reforma foi a extinção da Comissão de Sistematização - ou seja, o Projeto aprovado em Plenário não retornaria a ela -, substituída pela simples figura do relator. Para o texto final, houve a criação da Comissão de Redação. Entre outras conquistas, o Centrão conseguiu a prerrogativa de apresentar, no prazo regimental, substitutivos a títulos inteiros do Projeto de Constituição (A), havendo preferência automática para votação de suas emendas (por possuírem maior número de subscritores), a ser realizada por capítulos. ${ }^{197}$

Com relação ao segundo aspecto acima pontuado, as lideranças partidárias tiveram um papel mais intenso durante as discussões do Plenário. Elas foram relevantes na definição de votos de inúmeros parlamentares que não conheciam em detalhe boa parte das matérias submetidas a votação - situação bem diferente se compararmos com os trabalhos das

\footnotetext{
195 João Gilberto Lucas Coelho assim sintetiza a tese dos membros do Centrão: "o principal argumento de seus integrantes era quanto ao processo de votação em primeiro turno. O projeto de Constituição-A, da Comissão de Sistematização, seria votado por títulos ou capítulos. Uma vez votado um destes, em bloco, passariam a ser apreciados os destaques, que, pelo Regimento, poderiam ser apresentados por 35 constituintes, e as emendas. Um destaque para retirar um dispositivo, por exemplo, teria de ser aprovado por, no mínimo, 280 votos, já que o texto base recebera previamente sua aprovação. Este sistema regimental possibilitava a argumentação mais simplista, diante da opinião pública, de que posto o Projeto da Sistematização, seriam necessários 280 votos para rejeitar um dispositivo e não para aprová-lo, o que representaria uma 'ditadura de minoria'. O argumento, embora plausível diante de situações pontuais graves, não levava em consideração a votação prévia que todo o texto de um título ou capítulo receberia” (COELHO, João Gilberto. “O processo constituinte”, p. 53).

${ }^{196}$ Para um exame detalhado do surgimento do Centrão, dos acordos e do processo que conduziu à alteração do Regimento Interno, ver PILATTI, Adriano. A Constituinte de 1987-1988, p. 195/225.

197 Cf. COELHO, João Gilberto. "O processo constituinte", p. 53 e BRASIL. Diário da Assembleia Nacional Constituinte, vol. 340, Resolução n 3/1988, Brasília, Centro Gráfico do Senado Federal, 1988.
} 
Subcomissões e Comissões Temáticas, em que seus integrantes, em regra, tinham familiaridade com os assuntos em deliberação e, com frequência, representavam interesses de determinados setores da sociedade. ${ }^{198}$

A atuação das lideranças era refletida no encaminhamento das votações. Porém, ela se expressou de forma acentuada também na articulação e celebração de acordos. Por diversas vezes, os constituintes, no momento das votações, faziam referência expressa aos acordos entre as lideranças. ${ }^{199}$

Passa-se, então, aos debates no Plenário da Assembleia Nacional Constituinte.

Iniciado o prazo para oferecimento de emendas, os parlamentares do Centrão ofereceram projeto de constituição. O direito de greve era previsto da seguinte forma: “é assegurado o direito de greve, nos termos da lei, que ressalvará aquelas decididas sem prévia negociação. A lei limitará o direito de greve quando se tratar de serviços ou atividades essenciais e inadiáveis à comunidade. Compete aos trabalhadores decidir sobre a oportunidade e os interesses trabalhistas da categoria que devam, por meio dela, defender". 200

A proposta do Centrão incluía a transformação do $\S 2^{\circ}$ do projeto da Comissão de Sistematização em parágrafo único, estabelecendo que "os abusos cometidos e os danos causados sujeitam os responsáveis às penas da lei". ${ }^{201}$

Além da emenda do Centrão, não faltaram sugestões que tornassem mais restrito o direito de greve, considerando-se a redação aprovada pela Comissão de Sistematização. O constituinte Inocêncio Oliveira (PFL), por exemplo, apresentou emenda modificativa

\footnotetext{
198 Ver PILATTI, Adriano. A Constituinte de 1987-1988, p. 197. A figura do líder partidário se fez presente desde o início dos trabalhos da ANC. Na $2^{\mathrm{a}}$ Sessão da Constituinte, presidida por José Carlos Moreira Alves, Presidente do Supremo Tribunal Federal, Plínio de Arruda Sampaio (PT) levantou questão de ordem, afirmando que os senadores eleitos em 1982 (os senadores biônicos) não poderiam participar da ANC e, por conseguinte, da votação a respeito de seu presidente. Foi apoiado pelo constituinte Roberto Freire (PCB). As questões de ordem foram contraditadas por Fábio Lucena (PMDB, senador eleito em 1982) e Gastone Righi (PTB). Logo depois, o constituinte José Lourenço pediu a palavra na condição de "Líder", a qual lhe foi concedida por Moreira Alves. Em seguida, o Presidente do STF indagou aos demais líderes se queriam fazer uso da palavra (cf. BRASIL. Diário da Assembleia Nacional Constituinte. Ata da $2^{a}$ Sessão. Brasília: Senado Federal, Secretaria Especial de Editoração e Publicações, Subsecretaria de Anais, 1987, documento eletrônico - I, p. 9/10). Como observa Adriano Pilatti, com essa atitude, Moreira Alves "reconheceu a existência de líderes partidários no processo constituinte, o que assegurou às pequenas bancadas a mesma capacidade de expressão das demais, ao incorporar aos trabalhos constituintes prática universal nos legislativos" (PILATTI, Adriano. A Constituinte de 1987-1988, p. 25).

199 Alcançar os termos dos acordos entre as lideranças foi uma limitação da pesquisa. No exame das notas taquigráficas e das atas publicadas nos diários da Assembleia Constituinte, tem-se, quando muito, o resultado dos acordos, mas dificilmente são expostas as bases da negociação (que, em regra, não ocorria de forma aberta).

${ }^{200}$ BRASIL. Assembleia Nacional Constituinte. Trabalho comparativo entre o projeto de constituição (A) com as emendas substitutivas oferecidas pelo "Centrão" e os destaques sobre o texto e as emendas individuais, populares e coletivas. Vol. 276. Brasília: Centro Gráfico do Senado Federal, 1988, p. 79 (destaque acrescentado). ${ }^{201}$ BRASIL. Assembleia Nacional Constituinte. Trabalho comparativo entre o projeto de constituição (A) com as emendas substitutivas oferecidas pelo "Centrão" e os destaques sobre o texto e as emendas individuais, populares e coletivas. Vol. 276, p. 80.
} 
propondo que "é livre a greve, cujo exercício será regulado em lei que resguardará a ordem pública, as liberdades individuais, o direito de propriedade, os serviços essenciais nas empresas e na comunidade". Já o constituinte Pedro Ceolin (PFL) ofereceu emenda para prever que, "vedada a iniciativa patronal, é reconhecido o exercício do direito de greve, no âmbito das relações trabalhistas, competindo aos trabalhadores decidir sobre sua oportunidade. $\S 1^{\circ}$ - É proibida a greve nas atividades essenciais e nos serviços públicos, na forma da lei". 202

Pelas propostas acima, é possível identificar algumas ideias que permanecem em circulação quando se trata da greve: a pretensa vinculação da paralisação a interesses apenas trabalhistas (excluindo, assim, greves por outras razões, políticas, por exemplo), a conexão entre greve e ofensa a direito de propriedade e a proibição da greve nos serviços públicos. ${ }^{203}$

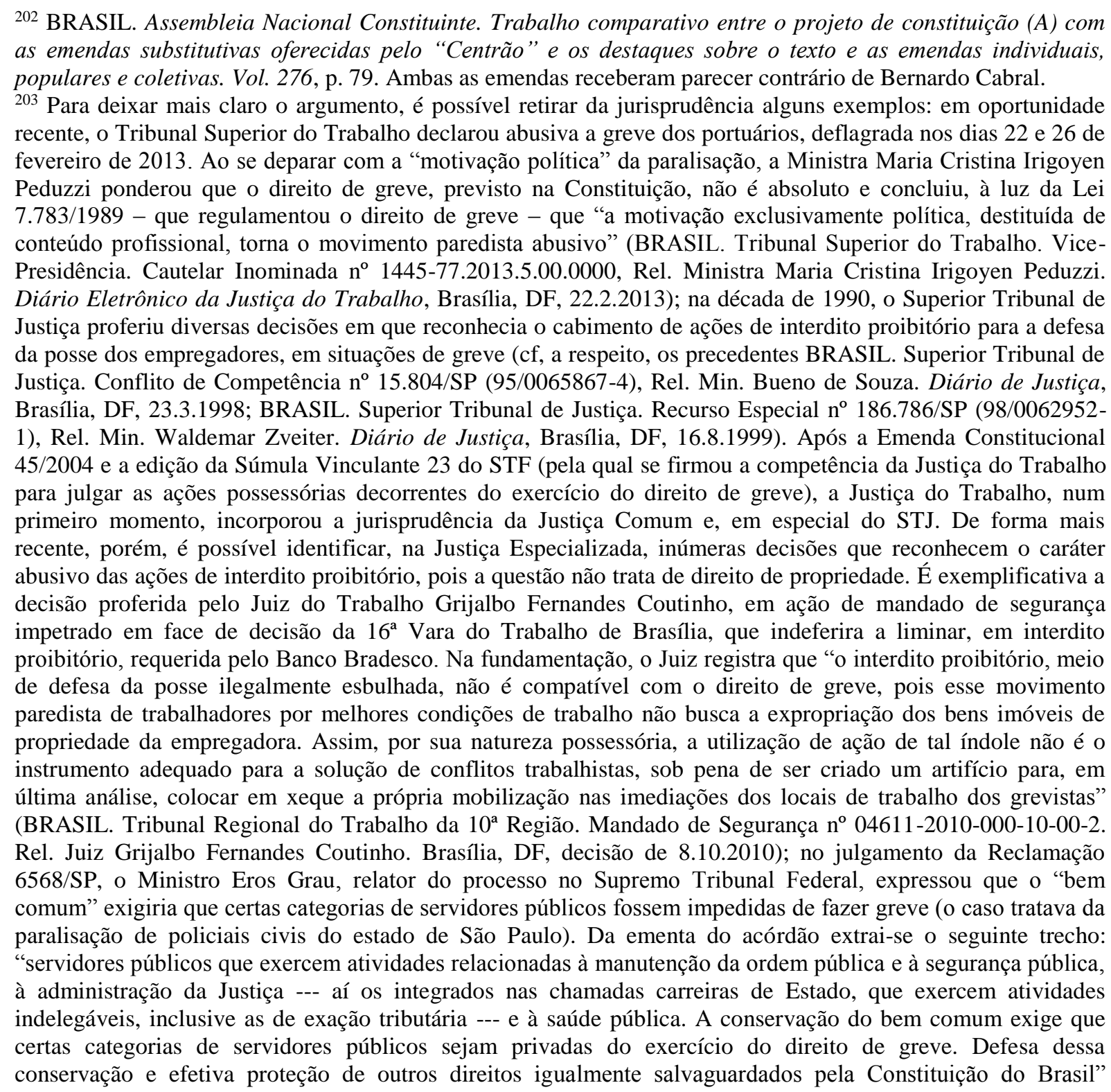


Na sessão de 23.2.1988, o Plenário da Constituinte iniciou a votação do Capítulo II do Título II do Projeto de Constituição (que incluía o direito de greve), deliberando sobre a Emenda Substitutiva 2.038, formulada pelo Centrão e assinada pelo constituinte Afif Domingos (PL). Num primeiro momento, caberia aos constituintes decidir entre a aprovação ou não da referida emenda substitutiva como um todo, para, em seguida, passar à votação dos destaques sobre cada matéria. Os líderes de partido fizeram seus pronunciamentos. Ficou evidente a existência de acordo entre alguns líderes no sentido de aprovar a emenda substitutiva do Centrão.

O primeiro a usar a palavra foi Gastone Righi, pelo PTB. O constituinte atacou tanto o acordo que resultou na proposta do Centrão quanto o projeto elaborado pela Comissão de Sistematização. ${ }^{204} \mathrm{Na}$ mesma linha, Roberto Freire, pelo PCB, encaminhou a votação de seu partido contrariamente à emenda substitutiva, defendendo, por outro lado, o projeto da Comissão de Sistematização. Roberto Freire destacou que a emenda proposta pelo Centrão não passou pelas discussões ocorridas durante o processo constituinte.

Agora votaremos um projeto alternativo, oriundo de uma articulação e que não passou por discussão nas comissões, não foi produto de trabalhos constituintes, não recebeu o respaldo da discussão em Plenário e da votação dos Constituintes, não recebeu o beneplácito de um processo de debates. $\mathrm{O}$ Substitutivo do "Centrão" que é um retrocesso - embora não possa, ele próprio, retroceder a nossa realidade -, já representa a manutenção de conquistas que podem não ser as desejadas, ou aquelas que aqui conquistamos na Comissão de Sistematização, mas também não são aquelas que desejavam os reacionários e retrógrados, que emprestam à classe dominante brasileira uma característica de autoritarismo ímpar, nas sociedades capitalistas com o grau de desenvolvimento da nossa. Não são conquistas que inviabilizem o processo de crescimento capitalista, ou que não tenham parâmetro, ou não apresentem analogia com aquelas obtidas por trabalhadores em sistemas capitalistas outros com o mesmo grau de desenvolvimento do brasileiro. Não se inviabiliza o próprio sistema capitalista com as conquistas que hoje pretendemos inserir na Constituição do País.

É importante salientar isso, para demonstrar o grau de autoritarismo, de reacionarismo e de e tentativa de manter uma superexploração dos trabalhadores, como pretende a classe dominante brasileira, aqui representada por articuladores de lideranças do chamado "Centrão". (... $)^{205}$

(BRASIL. Supremo Tribunal Federal. Reclamação no 6568/SP. Rel. Ministro Eros Grau. Diário de Justiça, Brasília, DF, 25.9.2009).

${ }^{204} \mathrm{O}$ excerto a seguir é significativo: “queremos, inicialmente, declarar que o PTB não foi consultado e, portanto não apóia esse acordo que tem curso em plenário. O PTB está contra ele e não concorda em transacionar, ainda mais pela maneira absolutamente insensata e irresponsável como foi feito" (BRASIL. Assembleia Nacional Constituinte. Ata da $206^{a}$ Sessão da Assembleia Nacional Constituinte, Brasília: Senado Federal, Secretaria Especial de Editoração e Publicações, Subsecretaria de Anais, 1988, documento eletrônico (XIII), p. 261).

${ }^{205}$ BRASIL. Assembleia Nacional Constituinte. Ata da $206^{a}$ Sessão da Assembleia Nacional Constituinte (XIII), p. 262 . 
O constituinte Luiz Inácio Lula da Silva discursou pelo PT, também encaminhando de forma contrária à emenda substitutiva do Centrão. Além de dizer que a emenda significava um "retrocesso", o constituinte denunciou o fato de que os partidos de esquerda não haviam sido chamados para participar do acordo. ${ }^{206}$ Completando o coro dos partidos excluídos, Brandão Monteiro usou a palavra como líder do PDT e encaminhou pela rejeição da emenda substitutiva, uma vez que seu partido não participara da negociação. ${ }^{207}$

Mário Covas, ao conduzir a votação por parte do PMDB, confirmou a existência de acordos com relação a boa parte do texto proposto pelo Centrão, esclarecendo que não houve ajuste quanto a alguns temas. ${ }^{208}$

Num total de 512 votos, a emenda substitutiva recebeu 339 favoráveis, 163 contrários, havendo 10 abstenções.

A proposta do Centrão foi aprovada. Porém, ainda ocorreriam as votações dos destaques. A deliberação favorável à emenda substitutiva do Centrão não impedia que a Constituinte voltasse a discutir o direito de greve.

${ }^{206}$ Luiz Inácio Lula da Silva atribuiu responsabilidade, ainda, ao Presidente da ANC. O seguinte trecho de seu discurso merece destaque: "o projeto do 'Centrão' significa um retrocesso daquilo que foi o motivo da vinda da grande maioria dos Constituintes a esta Casa - a promessa efetiva de que lutaríamos para que a classe trabalhadora tivesse um mínimo de direitos sociais, porque, de acordo com o projeto do 'Centrão', a classe trabalhadora está predestinada a ter apenas deveres; os direitos ficam outra vez com o poder econômico no País. (...) Terminamos, Sr. Presidente, dizendo que V. Ex. ${ }^{a}$ também tem responsabilidade perante a História do País e perante a classe trabalhadora. Esse acordo - firmado possivelmente à uma hora da manhã, em sua residência, Sr. Presidente, sem que os partidos de esquerda tenham sido chamados - na verdade não passa de uma empulhação a tudo aquilo que prometemos em praça pública à classe trabalhadora brasileira" (BRASIL. Assembleia Nacional Constituinte. Ata da $206^{a}$ Sessão da Assembleia Nacional Constituinte - XIII, p. 262/263).

207 Após a votação, o PDT formulou declaração de voto, denunciando o acordo. O principal ponto de inconformismo era o fim da estabilidade no emprego: “(...) por todos esses fatos, o Partido Democrático Trabalhista, não pode aderir ao acordo celebrado pelo PMDB como Centrão para derrogar a proibição da demissão imotivada. Acordo pressupõe concessões recíprocas, transigências de lado a lado até que se encontre um ponto de equilíbrio entre as posições divergentes. O que houve não foi acordo, foi uma capitulação do PMDB às imposições da Fiesp e do Centrão. Nós participamos de inúmeras reuniões e tentativas de acordo porque não nos interessava apostar no impasse. Mas a intransigência sempre esteve do lado do Centrão que parece ter interesse em criar impasses na Constituinte. Por esse motivo, o PDT que procurou em todos os momentos, fazer um acordo e preservar os direitos dos trabalhadores, não pode com seu voto coonestar essa capitulação em detrimento dos reais interesses dos trabalhadores e do povo brasileiro. Que cada um assuma a sua responsabilidade perante os trabalhadores brasileiros e perante a história" (BRASIL. Assembleia Nacional Constituinte. Ata da $206^{a}$ Sessão da Assembleia Nacional Constituinte - XIII, p. 266).

${ }^{208}$ Eis o discurso do constituinte Mário Covas: "no momento, tendo em vista o fato de que V. Ex. ${ }^{a}$ [o Presidente da ANC] irá colocar em votação o conjunto, quero dizer que, em relação à grande parte do texto global, houve acordos, embora parciais. Para que eles possam ser cumpridos, votaremos a favor, votaremos 'sim'. Mais do que isso, há certos textos sobre os quais não houve acordo; por isso o PMDB oportunamente se manifestará sobre eles com total liberdade para votar" (BRASIL. Assembleia Nacional Constituinte. Ata da 206 Sessão da Assembleia Nacional Constituinte, p. 263). O constituinte Osvaldo Lima Filho (PMDB) apresentou declaração de voto, justificando porque não seguiu o encaminhamento de votação do seu partido: "Não poderei acompanhar a Liderança do meu Partido, o PMDB, que realizou um acordo com as forças retrógradas da Constituinte para limitar a garantia de emprego a uma ilusória indenização permissiva do abuso da demissão imotivada do trabalhador sem qualquer fundamento ético ou jurídico" (BRASIL. Assembleia Nacional Constituinte. Ata da $206^{a}$ Sessão da Assembleia Nacional Constituinte - XIII, p. 266). 
O tema foi efetivamente objeto de votação na sessão de $1^{\circ}$ de março de 1988 , tendo sido oferecida uma proposta de texto, resultante da fusão de algumas emendas. A fusão era subscrita pelos constituintes Eliel Rodrigues (PMDB), Augusto Carvalho (PCB), Luiz Inácio Lula da Silva (PT), Inocêncio de Oliveira (PFL), Octávio Elísio (PMDB), Mário Covas (PMDB), Haroldo Lima (PC do B) e Adolfo Oliveira (PL).

A redação sugerida era a seguinte:

Art. 11. É assegurado o direito de greve, competindo aos trabalhadores decidir sobre a oportunidade e os interesses que devam por meio dele defender.

$\S 1^{\circ}$ Quando se tratar de serviços ou atividades essenciais definidos em lei, esta disporá sobre o atendimento das necessidades inadiáveis da comunidade.

$\S 2^{\circ}$ Os abusos cometidos sujeitam os responsáveis às penas da lei.

O texto decorria de um acordo entabulado durante a própria sessão da Constituinte. A fusão foi apresentada na hora, e não previamente. ${ }^{209}$ Isso suscitou manifestações contrárias e protestos, como os do constituinte João Menezes (PFL), que insistiu com o Presidente da ANC para que a votação fosse adiada e a constituição não fosse votada "na marra". João Menezes se referiu várias vezes ao fato de que o texto da emenda, resultado da fusão, não era conhecido por significativa parcela dos constituintes, ressaltando que a greve, no Brasil, deixara de ser "administrativa" para se tornar revolucionária, no sentido de "desestabilizar o Poder". ${ }^{210}$

\footnotetext{
${ }^{209}$ O presidente Ulysses Guimarães chegou a suspender a sessão por cerca de $1 \mathrm{~h}$ para viabilizar a elaboração do texto, fruto do acordo entre alguns constituintes. Cf. BRASIL. Assembleia Nacional Constituinte. Ata da $213^{a}$ Sessão da Assembleia Nacional Constituinte, Brasília: Senado Federal, Secretaria Especial de Editoração e Publicações, Subsecretaria de Anais, 1988, documento eletrônico (XIV), p. 41.

${ }^{210}$ Nas palavras de João Menezes, "todos sabemos o que está acontecendo em relação à greve neste País: hoje ela deixou de ser administrativa para ser revolucionária, com o sentido de desestabilizar o Poder. A demonstrar isso, esta aí a greve dos ferroviários e dos aeronautas, feitas justamente no momento preciso para causar aborrecimento e mal-estar à população. Pergunto aos que estão falando neste plenário: Qual de V. Ex.as conhece o texto que se vai votar aqui? Nem 10\% o conhecem. Vamos falar a verdade: a Constituição está sendo votada 'na marra', o que não pode ocorrer. V. Ex.as não conhecem o que está escrito aqui. Uma emenda forjada ou arrumada não pode ser discutida nem introduzida numa Constituição, se não passar por um exame realmente sincero de todos seus meios. (...) Não sei que direitos foram assegurados às classes sociais. Não sei até onde foi o direito de greve. Não sei se o direito de greve proposto vai levar o País a uma convulsão. Amanhã será o Congresso o responsável por tudo isto. Chamo a atenção de V. Ex.as: não permitamos que a votação se realize hoje. Os líderes que resolveram remendar o dispositivo, que tiraram uma palavra de cada emenda e colocaram outra de sua cabeça tinham de dar oportunidade para que a Constituinte examinasse o assunto. Faço um apelo para que a Assembléia Nacional Constituinte não vote hoje esse artigo. Peço ao meu eminente amigo, Presidente Ulysses Guimarães, que resolveu levar nossos trabalhos 'na marra', não tratar assim esse problema fundamental, que pode levar o País a não sei que destino. Vamos pensar um pouco, vamos ser responsáveis. Representamos 140 milhões de brasileiros, e não podemos resolver problema desta gravidade apenas com um convescote de 4 ou 5 pessoas. Registro o meu protesto e faço um apelo para que V. Ex.as não votem hoje esse dispositivo, porque todos estamos votando sem saber de que se trata. Eu não sei, V. Ex.as não sabem" (BRASIL. Assembleia Nacional Constituinte. Ata da $213^{a}$ Sessão da Assembleia Nacional Constituinte - XIV, p. 42).
} 
A fusão foi defendida por Jarbas Passarinho (PDS), para quem a emenda representava o "ponto de vista de uma imensa maioria" do Plenário. O constituinte apontava a necessidade de um texto que "ordenasse a vida brasileira", uma vez que a legislação antigreve era desrespeitada. Era preciso assegurar o direito de greve, mas, ao mesmo tempo, proteger a sociedade dos abusos. ${ }^{211}$ José Lourenço (PFL) também se pronunciou a favor da emenda, pois o texto refletiria o que seria possível naquele momento do país. Para o parlamentar, era importante que a constituição a ser elaborada fosse cumprida. ${ }^{212}$

O constituinte Cardoso Alves (PMDB) combateu a emenda, em razão da amplitude com que o direito de greve estaria sendo previsto, inclusive retirado do âmbito de apreciação dos tribunais. Para ele, a greve deveria ser proibida nos chamados "serviços essenciais". Em suas palavras:

Os tribunais não decidem mais nem sobre a oportunidade nem sobre a legitimidade dos interesses. Os tribunais ficarão calados. Não haverá mais greve ilegal. Os trabalhadores decidem sobre a legalidade da sua própria greve. A Justiça foi posta de lado. Os tribunais ficarão silentes. Se depois de uma calamidade pública, como a do Rio de Janeiro, serviços essenciais como a limpeza pública, como a saúde pública, como os transportes se declararem em greve, o juiz da oportunidade serão os trabalhadores destes serviços e não mais o Poder Judiciário. Não haverá mais o poder de polícia. O caput do artigo reza a segurança absoluta para o direito de greve. Todas as demais leis que restrinjam, que ab-roguem, que derroguem, que disciplinem o direito de greve ficarão automaticamente revogadas. É em vigor, de maneira clara,

\footnotetext{
211 Segundo o constituinte, "a emenda que acabamos de fazer aqui parece definir exatamente o ponto de vista de uma imensa maioria desta Casa. Haverá os que são contrários, fora de dúvida. Fui Ministro do Trabalho, e, nesta condição, até tive a alegria de, algumas vezes, defender greves como a realizada no Paraná, e, outras vezes, enfrentar greves, porque eram ilegais diante de uma lei extremamente restritiva - a Lei $n^{\circ} 4.330$. O Brasil real, a que há pouco se referiu um Constituinte na reunião com V. Ex. ${ }^{a}$, Sr. Presidente, mostra claramente que hoje até o 'decretão' chamado antigreve, da época do Presidente Ernesto Geisel, é inteiramente desrespeitado. Devemos chegar a alguma coisa que pelo menos ordene a vida brasileira. Nessa ordenação, em primeiro lugar, precisamos assegurar o direito de greve (Palmas.), que é, de fato, uma garantia para todos nós. Em segundo, defender a comunidade, a sociedade, quando sofre as penas de um direito excessivo, daquilo que não está regulamentado. Foi isto que propusemos, e o Líder do PMDB, em boa hora, acolheu. (Palmas.)" (BRASIL. Assembleia Nacional Constituinte. Ata da $213^{a}$ Sessão da Assembleia Nacional Constituinte - XIV, p. 42).

212 José Lourenço aludiu ao acordo que resultou no texto apresentado: "a lei qualifica como serviços essenciais, por exemplo, os transportes públicos. Mas eu pergunto: Ela é cumprida? Hoje, em Brasília, estão em greve os serviços de transporte coletivo. A Constituição a proíbe, mas, quando ela não possui a força e o respaldo da vontade popular, é difícil impô-Ia à Nação, porque o povo a repudia, o povo não a cumpre, e corremos o risco com o qual convivemos hoje e com o qual não devemos continuar a conviver. Devemos fazer uma lei que seja amada pela Nação e não repudiada pelo povo. Deveremos fazer uma Carta constitucional que tenha os aplausos da grande maioria e não permanentemente o esquecimento da maioria da Nação. Sr. Presidente e Srs. Constituintes, depois de conversar com diversos colegas do meu partido, com as mais altas expressões da Assembléia Nacional Constituinte, com os homens que refletem a média do pensamento da grande maioria desta Casa, com o colega Jarbas Passarinho, que possui enorme experiência de Ministro de Estado e de Parlamentar, chegamos a um entendimento com o grupo representado pelo Constituinte Mário Covas. Acho que este entendimento vai ao encontro não daquilo que um ou outro quer, mas daquilo que é possível no conceito de maioria e de respaldo nacional. É isso que buscamos, é isso que fazemos e compreendemos" (BRASIL. Assembleia Nacional Constituinte. Ata da $213^{a}$ Sessão da Assembleia Nacional Constituinte - XIV, p. 42).
} 
insofismável e absoluta, pelo caput do artigo, o direito de greve, seja ela de cunho reivindicatório, de cunho de solidariedade ou de cunho político.

(...)

A greve, Sr. Presidente, é um meio, não um fim. A greve é o último meio, a derradeira forma, a mais violenta, pela qual os trabalhadores lutam para a consecução dos seus direitos. Na realidade, o direito é a paz, e o meio de obtê-lo é a luta. Greve é a derradeira luta. Primeiro, deverá haver conversação, entendimento, troca de idéias, enfim, será preciso exaurir as potencialidades da inteligência, e somente depois de esgotados todos os meios dissuasórios e pacíficos ocorrerá a greve. Que dizer da greve em trabalhos essenciais e de segurança? A greve, Sr. Presidente, deverá produzir efeito entre patrões e trabalhadores, entre reivindicantes e reivindicados. A sociedade, a grande massa social, a grande população não pode ser atingida pela greve. Isso é antidemocrático. (Palmas.) Isso não é conforme a inteligência dos homens. Nenhuma Constituição do mundo permite greve em serviços essenciais.

(...)

Ora, Sr. Presidente, hoje, a exemplo de quase todas as constituições do mundo, a nossa, no art. 162, proíbe o direito de greve. Mesmo assim, os coveiros, lixeiros, médicos, enfermeiros, educadores, transportadores, encarregados de energia declararam-se em greve, com grande prejuízo para a sociedade. ${ }^{213}$

Bernardo Cabral rebateu os argumentos de Cardoso Alves e deu parecer favorável à fusão das emendas. De acordo com o constituinte, a previsão de que a lei definiria os "serviços essenciais" e de que os abusos sujeitariam os responsáveis às penas legais garantiria a possibilidade de intervenção do Poder Judiciário:

quero rebater a opinião do Constituinte Cardoso Alves. Greve não é meio, nem fim. S. Ex. ${ }^{a}$ declara que greve é fim. Não é verdade. Ela é o único instrumento de que o trabalhador dispõe para se contrapor e reivindicar atendimento às suas necessidades.

(...)

Diz-se que o acordo formulado por eminentes Constituintes - de logo, devo declarar que dele não participei, e nem por isto me sinto desprestigiado fará com que os tribunais fiquem calados. Mas isto também não é verdade. Não se pode tirar qualquer ilação deste texto no sentido de que os tribunais ficarão à margem, ou à distância. Por quê? Porque o caput assegura o direito de greve. Este é o enunciado. Mas os $\S \S 1^{\circ}$ e $2^{\circ}$ completam o caput. E por isso tem dois "esses"; signus seguens. Quer dizer, é o que se segue, o que completa, o que esclarece e põe em causa tudo o que se quer. O que diz o $\S$ $1^{\circ}$ ? "Quando se tratar de serviços ou atividades essenciais definidos em lei". Portanto a lei é que vai elencar esses serviços e dispor sobre aquilo que disse

213 BRASIL. Assembleia Nacional Constituinte. Ata da $213^{a}$ Sessão da Assembleia Nacional Constituinte (XIV), p. 43. O discurso do constituinte Cardoso Alves põe em evidência um aspecto fundamental do direito de greve, garantido na forma do art. $9^{\circ}$ da Constituição de 1988. O texto constitucional comporta a leitura de que, uma vez que a oportunidade de deflagração da greve e os interesses que serão por meio dela defendidos são decisões dos próprios trabalhadores, o Poder Judiciário não detém competência, em termos constitucionais, para declarar ilegal uma greve (ao menos não com base no momento em que a paralisação foi deflagrada ou no conteúdo da reivindicação). Entretanto, não tem sido essa a opção do Poder Judiciário. É o caso do Tribunal Superior do Trabalho, órgão de cúpula da Justiça do Trabalho. A questão será retomada no capítulo 3. 
o Constituinte Jarbas Passarinho, com a autoridade de quem foi Ministro do Trabalho e sentiu na pele as agrurar de dever proibir uma greve, ou não fazêlo. Mas quando isso não ficasse escrito devidamente, o $\S 2^{\circ}$ é textualmente claro: (...)

Esses abusos não foram, até hoje, definidos na lei. A partir de agora, o serão. ${ }^{214}$

O constituinte Mário Covas defendeu o acordo feito, que corresponderia aos anseios da maioria dos constituintes, anunciando que o PMDB votaria a favor do texto proposto. $^{215}$ Já o constituinte Bonifácio de Andrada (PDS) formulou declaração de voto contrário à fusão, pela forma em que estava sendo previsto o direito de greve, em especial por permitir paralisações políticas e por remeter à legislação ordinária a questão sobre as atividades essenciais. $^{216}$

Num total de 493 votos, a emenda resultante da fusão recebeu 436 votos favoráveis e 38 contrários (houve 19 abstenções), sendo aprovada.

Daí em diante, o texto votado pelo Plenário da Constituinte sofreu apenas pequenas alterações. No segundo turno, foi oferecida à ANC a redação que viria a ser o atual art. $9^{\circ}$ da Constituição de 1988. Ainda nessa fase, porém, foram apresentadas emendas sobre o direito de greve, entre elas, as que objetivavam que o texto constitucional se limitasse a dizer: "é assegurado o direito de greve". ${ }^{217}$

A Assembleia Constituinte continuaria com os debates sobre os direitos dos trabalhadores, incluído o direito de greve. Circularam mais uma vez ideias que buscavam limitar esse direito. E a prática dos acordos entre lideranças continuou tendo livre curso.

Na sessão de 27 de julho de 1988, o projeto de Constituição foi submetido à votação, em bloco, em segundo turno, ressalvados os destaques. $\mathrm{O}$ acordo entre as lideranças, com o respectivo encaminhamento da votação, conduziu à aprovação do projeto com 403

\footnotetext{
${ }^{214}$ BRASIL. Assembleia Nacional Constituinte. Ata da $213^{a}$ Sessão da Assembleia Nacional Constituinte (XIV), p. 43.

${ }^{215}$ Cf. BRASIL. Assembleia Nacional Constituinte. Ata da $213^{a}$ Sessão da Assembleia Nacional Constituinte (XIV), p. 43.

${ }^{216}$ Eis o teor do voto do constituinte: "o nosso voto é contrário ao texto da fusão de emendas assinada pelos ilustres constituintes Luiz Inácio Lula e Mário Covas, referente ao direito de greve, porque segundo à técnica adotada nas Constituintes Modernas, como da Espanha e Itália, poderá nas suas entrelinhas permitir as paralisações políticas, digo, paralisação com fins políticopartidários. Além disto transfere o problema dos serviços essenciais para a lei ordinária mantendo até que esta seja votada o princípio geral da greve plena, com autoaplicabilidade. Por considerar o assunto serí́ssimo e por defender a greve dos trabalhadores e por ser contra a greve política, que nos opomos ao texto acima focalizado, julgando que não é do interesse do País nesta hora que vivemos" (BRASIL. Assembleia Nacional Constituinte. Ata da $213^{a}$ Sessão da Assembleia Nacional Constituinte - XIV, p. 46).

${ }^{217}$ Ver, a propósito, as emendas oferecidas pelos constituintes Jarbas Passarinho (PDS) e Eliel Rodrigues (PMDB), as quais receberam parecer contrário do relator Bernardo Cabral. Ver BRASIL. Assembleia Nacional Constituinte. Projeto de Constituição (B), $2^{a}$ Turno. Preâmbulo e Títulos I e II. Emendas e destaques organizados por dispositivos. Vol. 308. Brasília: Centro Gráfico do Senado Federal, 1988, p. 74/76.
} 
votos favoráveis, 13 abstenções e 55 votos contrários. ${ }^{218}$

No dia seguinte, a Frente Nacional de Entidades Sindicais, Democráticas e Populares levou documento à Assembleia Constituinte, referindo-se aos direitos dos trabalhadores, consoante o projeto submetido à votação no segundo turno. Constava do documento que "o pouco conquistado não pode ser suprimido". Tais entidades manifestavam preocupação também quanto ao direito de greve, pois não queriam que se tratasse de "apenas um princípio genérico", e, sim, da "garantia real e efetiva do direito de greve". ${ }^{219}$

A Constituinte voltaria a discutir a greve em agosto de 1988, a partir dos destaques às emendas oferecidas ao projeto de Constituição. Todos os destaques (6 no total) tinham por objetivo reduzir a redação do art. $9^{\circ}$ para que constasse apenas que "é assegurado o direito de greve". 220

O constituinte Aloysio Chaves (PFL), ao defender sua emenda, afirmou que sua finalidade era permitir o reconhecimento de certos limites ao direito de greve, como a deflagração por interesses de natureza política, econômica ou de solidariedade:

(...) na redação do dispositivo, depois de se assegurar o direito de greve, acrescentou-se: "...competindo aos trabalhadores decidir sobre oportunidade e os interesses que devam, por meio dele, defender". Esta norma aproximase um pouco da redação do art. 58 da Constituição portuguesa, a única que conheço que inclui norma semelhante. Mas a reprodução foi infeliz, porque o plágio é imperfeito, daí o defeito grave de redação. De sorte que a nossa emenda, quando declara apenas que é assegurado o direito de greve, assegura-o na sua plenitude, e não afeta absolutamente o disposto no $\S 1^{\circ}$, que estabelece que a lei definirá os serviços ou atividades essenciais e disporá sobre o atendimento das necessidades inadiáveis da comunidade. Se consultarmos a Constituição italiana, que tem sido tão citada, tão reproduzida aqui, verificaremos que ela assegura o direito de greve na forma que a lei estabelece. Assim também dispunha a antiga Constituição francesa e as de vários países. Da maneira como está redigido o caput do art. $9^{\circ}$, os trabalhadores poderão deflagrar uma greve antes de iniciar-se a negociação coletiva, no curso de uma convenção coletiva ou depois que o conflito coletivo tenha sido julgado pela Justiça do Trabalho. E a greve poderá ter por objeto tanto interesses pertinentes às respectivas relações de trabalho como outros de natureza política, econômica ou de solidariedade. A

\footnotetext{
${ }^{218}$ Sobre a votação do projeto e as manifestações das lideranças partidárias, que noticiaram o acordo firmado, Cf. BRASIL. Assembleia Nacional Constituinte. Ata da $307^{a}$ Sessão da Assembleia Nacional Constituinte, Brasília: Senado Federal, Secretaria Especial de Editoração e Publicações, Subsecretaria de Anais, 1988, documento eletrônico (XXI), p. 264/269.

219 BRASIL. Assembleia Nacional Constituinte. Ata da 308 ${ }^{a}$ Sessão da Assembleia Nacional Constituinte, Brasília: Senado Federal, Secretaria Especial de Editoração e Publicações, Subsecretaria de Anais, 1988, documento eletrônico (XXI), p. 281. Várias entidades sindicais subscreveram o documento, entre elas a CUT e a CGT, além de confederações e federações.

${ }^{220}$ Cf. BRASIL. Assembleia Nacional Constituinte. Ata da 316 Sessão da Assembleia Nacional Constituinte, Brasília: Senado Federal, Secretaria Especial de Editoração e Publicações, Subsecretaria de Anais, 1988, documento eletrônico (XXII), p. 351.
} 
Organização Internacional do Trabalho, pelo Comitê da Liberdade Sindical, dispôs de maneira clara a esse respeito, ao estabelecer que a greve tem essas limitações, inerentes ao seu exercício, como uma arma de defesa dos trabalhadores, de reivindicação dos trabalhadores, geralmente, para recuperar ou melhorar sua remuneração. Não se pode, portanto, elastecer isso em uma Constituição, de forma imprecisa e inadequada como o foi. Inclusive a redação atual não atende ao que se recomenda no pacto internacional sobre direitos econômicos, sociais e culturais, aprovado pela ONU, em 1966, como regulamentação dos direitos sociais consagrados na Declaração Universal dos Direitos do Homem, de 1948. Portanto, se a Assembléia Nacional Constituinte estabelecer a norma nestes termos: "é assegurado o direito de greve", e mantiver o $\S 1^{\circ}$, que se refere aos serviços essenciais, não afetará absolutamente os direitos dos trabalhadores, não cerceará, não restringirá, não limitará, não excluirá! É a legislação ordinária que estabelecerá depois as normas e procedimento que são indispensáveis. Em qualquer hipótese, terão de ser aprovadas pelo Congresso Nacional. Portanto, ponderando dessa maneira, peço à Assembléia Nacional Constituinte que vote favoravelmente à emenda destacada. ${ }^{221}$

O constituinte Egídio Ferreira Lima (PMDB) se posicionou de forma contrária às emendas. Após destacar a importância do direito de greve e do texto do projeto, lembrou que havia previsão de responsabilidade quanto aos abusos. Egídio Ferreira Lima ressaltou a dificuldade de se distinguir uma greve essencialmente trabalhista de uma política:

Os Constituintes brasileiros de 1987/1988 foram felicíssimos no texto que se encontra no Projeto, composto do art. $9^{\circ}$ e dos dois parágrafos que o completam. É um texto preciso, breve, enxuto; objetivo, orgânico e que disciplina toda a matéria de maneira magistral. Diz o caput" desse artigo: "Art $9^{\circ}$. É assegurado o direito de greve, competindo aos trabalhadores decidir sobre a oportunidade e os interesses que devem por meio dele defender." Essa segunda parte, que se pretende suprimir, tem dois lados: o verso e o reverso, o arbítrio da classe trabalhadora, do sindicato, do operário quanto á oportunidade e à conveniência de deflagrar a greve, mas, dentro desse arbítrio, a fixação da responsabilidade quanto aos abusos, aos crimes que possam vir a cometer. Tanto assim que o $\S 2^{\circ}$ do art. $9^{\circ}$ diz, de maneira clara: "Os abusos cometidos sujeitam os responsáveis às penas da lei." Não se alegue que, livre para determinar a oportunidade, a conveniência da greve, o operário iria deflagrar greves políticas. Essa alegação.é preconceituosa.

É muito difícil distinguir uma greve meramente reivindicadora de direitos trabalhistas, de greve com conotação política. Sr. Presidente, toda reivindicação por salário, por aviso-prévio, por conquistas trabalhistas contém forte conteúdo político. Nessa concepção, nessa visão, conseqüentemente, toda greve é também política, e nem por isso condenável. O preceito ainda prevê, no $\S 1^{\circ}$ : "A lei definirá os serviços ou atividades essenciais e disporá sobre o atendimento das necessidades inadiáveis da comunidade." O direito de greve é assegurado sem restrições. Nele se insere também o direito de exercê-lo por parte dos funcionários e servidores públicos. Aqui, não se faz mais do que reconhecer um fato social já

221 BRASIL. Assembleia Nacional Constituinte. Ata da $316^{a}$ Sessão da Assembleia Nacional Constituinte (XXII), p. 352. 
sedimentado e concreto. Tem razão o Senador Jarbas Passarinho quando diz que o direito de greve aos funcionários e servidores públicos está nas ruas, é uma evidência, e não tem como fechar os olhos a essa evidência, a esse fato. 222

O constituinte João Menezes (PFL) também defendeu sua emenda, entendendo que o texto do projeto consagrava o direito absoluto de greve. $\mathrm{O}$ parlamentar recorreu a inúmeros dados sobre paralisações no país para afirmar que produziam desequilíbrio social. Em suas palavras:

Aquilo que caracteriza o texto de uma Constituição é a outorga genérica do direito. Em se tratando de um tema tão complexo e extenso como é o da greve, temerário seria manter a redação aprovada no primeiro turno da Assembléia Nacional Constituinte. Na forma como se encontra, estabelece o direito absoluto que poderá gerar no cotidiano graves consequiências que não interessam ao bemestar da comunidade.

Srs. Constituintes, vamos prestar um pouco de atenção à frieza dos números. (...) Será possível que esses números nada representam para os Srs. Constituintes? Será possível não acreditarmos que a paralisação total existente no País está causando desequilíbrio social, que as classes trabalhadoras estão sendo prejudicadas, que o Brasil e todas as suas classes produtoras, quaisquer que sejam, estão sendo prejudicados porque a paralisação é imensa?

(...)

Portanto, este assunto é de responsabilidade dos Srs. Constituintes. Vamos todos fazer greve agora para ver se a Constituinte conclui seus trabalhos? (Apupos nas galerias). É assim que está este País. Precisamos ter coragem de dizer isto. Estes são os números frios que ficarão inscritos nos Anais da Assembléia Nacional Constituinte e que vêm representando a desordem, a anarquia e a falta de progresso com a paralisação total da Nação. Somos um homem do povo, representamos o povo e sabemos o quanto este sofre pela irresponsabilidade daqueles que fomentam as greves, mas que se escondem atrás de uma cortina. Espero que V. Ex. ${ }^{a}$ aprovem essa emenda supressiva. ${ }^{223}$

A votação foi encaminhada pelas lideranças. Primeiro a usar a palavra, o constituinte Inocêncio Oliveira (PFL) disse que não houve acordo entre PFL, PMDB, PDS, PTB, PL e PDC e, em razão disso, recomendou que os componentes da bancada de seu partido não participassem da votação. Já os líderes de PSB, PSDB, PDT, PC do B, PL, PMDB, PCB, PT e PTB indicaram que suas bancadas votariam em oposição às emendas.

Entretanto, não houve quórum para realização da votação. A deliberação ficou

222 BRASIL. Assembleia Nacional Constituinte. Ata da $319^{a}$ Sessão da Assembleia Nacional Constituinte, Brasília: Senado Federal, Secretaria Especial de Editoração e Publicações, Subsecretaria de Anais, 1988, documento eletrônico (XXII), p. 538 (o discurso foi publicado posteriormente).

223 BRASIL. Assembleia Nacional Constituinte. Ata da $316^{a}$ Sessão da Assembleia Nacional Constituinte (XXII), p. 352/353. O constituinte foi interrompido várias vezes em razão das vaias da plateia nas galerias do Congresso Nacional. 
para a sessão posterior, em 16 de agosto de 1988.

Antes da nova votação, os constituintes Raquel Cândido (PFL) e Paulo Paim (PT) denunciaram os ataques aos direitos sociais e, em especial, ao direito de greve. ${ }^{224}$

O relator Bernardo Cabral colocou-se de forma contrária às emendas. A maioria dos líderes partidários fez, mais uma vez, o encaminhamento da votação, referindo-se ao acordo firmado ainda em primeiro turno: PCB, PT ("mantendo o acordo"), PC do B, PDT (remetendo ao "extraordinário acordo alcançado no primeiro turno"), PL (que registrou ter participado do acordo no primeiro turno), PMDB (cujo líder, Nelson Jobim, declarou que "houve várias tentativas de novo entendimento sobre o texto e foram frustradas. O PMDB mantém-se íntegro ao acordo primitivo e vota "não"”) e o recém-formado PSDB orientaram contra as emendas. Por sua vez, PFL e PDS indicaram a favor.

As emendas foram rejeitadas, tendo obtido apenas 112 votos favoráveis, em contraste com os 287 contrários (houve 8 abstenções). ${ }^{225}$

\footnotetext{
${ }^{224}$ Além de se referirem aos direitos sociais, as palavras da constituinte Raquel Cândido evidenciam as tentativas de acordo quanto ao texto do projeto de Constituição: "Sr. Presidente, Srs. Constituintes, hoje pela manhã tive o cuidado de participar de parte das rodadas das negociações relativas ao direito de greve. $\mathrm{E}$ ali vi, nitidamente, os sócios ocultos da Nova República, sediados na Assembléia Nacional Constituinte, manipulando, reiteradas vezes, aquilo que já foi objeto de voto, aquilo que já foi objeto de acordo. Esses sócios ocultos que lutam pela volta do passado deixam a desejar o que estamos tracejando para o novo momento histórico do nosso País. O direito de greve - como está sendo questionado - será usado como uma forma de manipulação política. Ora, Srs. Constituintes, toda vez que um sindicato se reúne para reivindicar os seus direitos, ele está agindo politicamente. Portanto, não cabe este questionamento com relação ao direito de greve que será inserido na nova Constituição do País. A era da modernidade tem sido questionada pela conservadorismo, e da forma mais retrógrada maginável, com alguns até se esquecendo de honrar seus compromissos nestes dezoito meses da Assembléia Nacional Constituinte. É importante que os Srs. Constituintes que estão a escrever este novo texto constitucional tenham a certeza de que estamos embarcando num novo avião, e que aqueles que não tomarem esse avião ficarão no salão de espera da história deste País". O constituinte Paulo Paim, por sua vez, fez o seguinte discurso: "Sr. Presidente, Sras e Srs. Constituintes, em primeiro lugar, gostaria de esclarecer que os setores conservadores estão atacando o direito de greve, assegurado no projeto, de uma forma até mesmo inverídica. Em nenhum momento o projeto assegura o pleno direito de greve. É preciso lembrar que o inciso II desse artigo diz que os abusos serão punidos na forma da lei. Só isso, Sr. Presidente, já está limitando o direito de greve”. (BRASIL. Assembleia Nacional Constituinte. Ata da $318^{a}$ Sessão da Assembleia Nacional Constituinte, Brasília: Senado Federal, Secretaria Especial de Editoração e Publicações, Subsecretaria de Anais, 1988, documento eletrônico - XXII, p. 381/383).

${ }^{225}$ Cf. BRASIL. Assembleia Nacional Constituinte. Ata da $318^{a}$ Sessão da Assembleia Nacional Constituinte (XXII), p. 409. Houve, de imediato, manifestações contrárias por parte da sociedade. O constituinte Edison Lobão (PFL), na sessão de 18.8.1988 (dois dias após a votação), recomendou a leitura dos editoriais de dois importantes periódicos do país, os quais criticavam a opção da Assembleia Constituinte quanto à greve. $\mathrm{O}$ constituinte fez referência aos editoriais dos jornais $O$ Globo e Jornal do Brasil. O do primeiro, intitulado "A porta da anarquia", começava dizendo que "A aprovação pela Assembléia Constituinte do direito de greve irrestrito para todas as categorias de trabalhadores, em todas as circunstâncias, sob quaisquer pretextos, ontem consumada no segundo turno de votação, significa a porta aberta à desordem e ao caos". Já o do segundo, com o título de "Signo do risco", afirmava, em determinado momento, que "O direito de greve como aprovado pela Constituinte não tem precedente em qualquer nação. Em todos os países, existem limites que evitam risco de vida ou de segurança da sociedade". Ambos foram integralmente transcritos nos diários da Constituinte. Cf. BRASIL. Assembleia Nacional Constituinte. Ata da 320 ${ }^{a}$ Sessão da Assembleia Nacional Constituinte, Brasília: Senado Federal, Secretaria Especial de Editoração e Publicações, Subsecretaria de Anais, 1988, documento eletrônico (XXV), p. 549/550
} 
É possível inferir que, como as lideranças não chegaram a um novo acordo, optaram pela manutenção do acordo anterior, firmado ainda no primeiro turno. Essa hipótese permite avançar outra: passada a etapa da Comissão de Sistematização e com a formação do Centrão, a aprovação de temas sensíveis ficou dependente da possibilidade de celebração de acordos entre as lideranças partidárias. Cabe, então, o seguinte questionamento: até que ponto as discussões ocorridas anteriormente e os discursos proferidos durante as audiências públicas foram (ou não) deixados de lado?

Aquela votação encerrava o percurso das discussões sobre o direito de greve na Assembleia Nacional Constituinte de 1987/1988. Na sessão de 22 de setembro de 1988, o Projeto D foi votado e aprovado com 474 votos favoráveis, 15 contrários e 6 abstenções. ${ }^{226} \mathrm{~A}$ nova Constituição foi promulgada na 341 a sessão da ANC, realizada em 5 de outubro de 1988. Estava lançado um marco fundamental para a história do direito de greve no país. ${ }^{227}$ Mas como a Constituição seria interpretada e aplicada, em especial pelos tribunais?

A nova Constituição ampliou o direito de greve no país. O texto tem um sentido procedimental, alargando as possibilidades dos atores sociais, mais especificamente dos trabalhadores, que tem reconhecida a decisão sobre quando e porque deflagrar uma greve. Entretanto, a expansão do direito de greve correspondeu à expansão das formas de intervenção do Poder Judiciário na greve. É o que será observado no próximo capítulo, com a greve dos petroleiros de 1995.

\footnotetext{
${ }^{226}$ O líder do PT, Luís Inácio Lula da Silva, em seu discurso destacou a conquista do direito de greve, mas encaminhou a votação contrariamente ao Projeto de Constituição, ao argumento de que, na perspetiva do PT, "a essência do poder, a essência da propriedade privada, a essência do poder dos militares, continua intacta nesta Constituinte" (BRASIL. Assembleia Nacional Constituinte. Ata da 340 ${ }^{a}$ Sessão da Assembleia Nacional Constituinte - XXV, p. 256).

${ }^{227}$ Este o teor do art. $9^{\circ}$ da Constituição de 1988: "é assegurado o direito de greve, competindo aos trabalhadores decidir sobre a oportunidade de exercê-lo e sobre os interesses que devam por meio dele defender. $\S 1^{\circ} \mathrm{A}$ lei definirá os serviços ou atividades essenciais e disporá sobre o atendimento das necessidades inadiáveis da comunidade. $\S 2^{\circ}$ Os abusos cometidos sujeitam os responsáveis às penas da lei”.
} 


\section{Capítulo 2: A greve dos petroleiros de 1995 e a decisão do Tribunal Superior do Trabalho - os silêncios sobre a Constituição}

A Constituição de 1988 ampliou as possibilidades de exercício do direito de greve no Brasil. Todavia, é possível verificar o incremento das formas de intervenção do Poder Judiciário nas greves e, mais do que isso, o protagonismo assumido por esse Poder, em especial pela Justiça do Trabalho, na repressão a greves e ao movimento sindical. Exemplo disso é a vedação à realização de paralisações por motivos políticos, bem como a imposição de multas às entidades sindicais.

O propósito deste capítulo é analisar, a partir da greve de 1995 dos trabalhadores da Petrobrás, as construções de sentido sobre a Constituição de 1988, sobretudo a interpretação que lhe foi conferida pelo Tribunal Superior do Trabalho. A preocupação é com os usos da Constituição. Além disso, busca-se destacar os contornos do protagonismo do Poder Judiciário com relação ao direito de greve, uma vez que, mais direito correspondeu a mais intervenção. $\mathrm{O}$ exame da greve da Petrobrás pode conferir uma importante perspectiva para a compreensão desse protagonismo do Poder Judiciário, ao mesmo tempo em que marca a permanência de uma tensão com o passado da ditadura militar no país. Ou seja, percebe-se aqui a tensão entre ruptura e continuidade com o regime anterior à Constituição de 1988.

Para compreender a greve de 1995 dos petroleiros, é necessário examinar os principais fatos relacionados à campanha salarial e à negociação do ano anterior.

\subsection{Antecedentes: a negociacão e os acordos firmados em 1994}

A campanha salarial dos petroleiros, em 1994, não resultou em acordo coletivo. A negociação foi infrutífera. O país vivenciava a implantação do Plano Real, com a perspectiva de estabilização da economia. Mas os trabalhadores apresentavam perdas em decorrência das regras de conversão da moeda (de cruzeiro real para URV). O governo controlava as negociações coletivas nas empresas públicas federais, estabelecendo condicionantes para a concessão de aumentos reais de salário. Petroleiros e Petrobrás assumiam posturas muito divergentes, o que inviabilizava uma conciliação. ${ }^{228}$

\footnotetext{
${ }^{228}$ Cf., a respeito, SILVA, Sayonara Grillo Coutinho Leonardo de. Relações coletivas de trabalho. São Paulo:
} LTr, 2008, p. 279. 
Deflagrada a greve em 27 de setembro daquele ano - dias antes das eleições para Presidente da República, marcadas para 3 de outubro -, o conflito foi a dissídio no Tribunal Superior do Trabalho, provocado pela Petrobrás. Em decisão liminar, o Presidente da Corte, Min. Orlando Teixeira da Costa, determinou a manutenção de $30 \%$ dos petroleiros em atividade. Pela imprensa, empresa e representantes dos trabalhadores se manifestaram. O então Presidente da Petrobrás, Joel Rennó, após reunião com os Ministros de Minas e Energia, Delcídio Gomez, e da Fazenda, Ciro Gomes, afirmou que funcionários poderiam ser demitidos caso a paralisação fosse considerada ilegal pelo Tribunal. Já a Federação Única dos Petroleiros - FUP anunciou, por sua diretoria, que os petroleiros não retornariam ao trabalho ainda que a Corte julgasse a greve ilegal e abusiva. ${ }^{229}$

No dia 30 de setembro, o processo de dissídio coletivo foi a julgamento e o Tribunal Superior do Trabalho declarou abusiva a greve, ao fundamento de que não havia sido observado o art. 11 da Lei 7.783/1989. ${ }^{230}$ O Ministro Relator, Indalécio Gomes Neto, enfatizou também que uma unidade da Petrobrás (a refinaria Gabriel Passos) fora ocupada pelos grevistas, o que caracterizaria abuso no exercício desse direito. Para o relator, o direito de greve "não pode transbordar para a prática de atos que interfira no exercício de outros direitos pelo seu titular, como é o caso do direito de propriedade, visto que a apropriação de unidade da empresa, sem dúvida, perturba essa garantia fundamental". ${ }^{231}$

A Corte concedeu reajuste salarial de $13,5389 \%$, percentual que já havia sido pago pela empresa - a reivindicação profissional era de 108,36\%. O TST determinou o retorno dos grevistas ao trabalho, a partir de $1^{\text {o }}$ de outubro, sob pena de multa de $\mathrm{R} \$$ $50.000,00$ por dia.

\footnotetext{
${ }^{229}$ Folha de São Paulo de 29 e 30.9.1994. Ver também Jornal do Brasil de 29 e 30.9.1994.

230 "Art. 11. Nos serviços ou atividades essenciais, os sindicatos, os empregadores e os trabalhadores ficam obrigados, de comum acordo, a garantir, durante a greve, a prestação dos serviços indispensáveis ao atendimento das necessidades inadiáveis da comunidade. Parágrafo único. São necessidades inadiáveis, da comunidade aquelas que, não atendidas, coloquem em perigo iminente a sobrevivência, a saúde ou a segurança da população" (BRASIL. Lei $\mathrm{n}^{\circ} 7.783$, de 28 de junho de 1989. Dispõe sobre o exercício do direito de greve, define as atividades essenciais, regula o atendimento das necessidades inadiáveis da comunidade, e dá outras providências. Diário Oficial da União. Brasília, DF, 29.6.1989). Prevaleceu, no julgamento, a posição do Ministro Presidente, Orlando Teixeira da Costa. Cf. BRASIL. Tribunal Superior do Trabalho. Seção de Dissídios Coletivos. Dissídio Coletivo no 131.024/1994. Rel. Ministro Indalécio Gomes Neto. Diário de Justiça, Brasília, DF, 11.11.1994. Segundo Orlando Teixeira da Costa, "houve total descumprimento da lei e um desprezo pela população que tinha que ter assegurado o direito ao abastecimento. Essa greve quis atingir intencionalmente à população" (Jornal do Brasil de $\left.1^{\circ} .10 .1994\right)$.

${ }^{231}$ BRASIL. Tribunal Superior do Trabalho. Seção de Dissídios Coletivos. Dissídio Coletivo no 131.024/1994. Rel. Ministro Indalécio Gomes Neto.
} 
O Coordenador Geral da Federação, Antonio Carlos Spis, informou que os petroleiros voltariam às refinarias apenas se parte das reivindicações fosse atendida e que a orientação seria pela continuidade da greve. ${ }^{232}$

Poucos dias depois do julgamento do dissídio coletivo, começaram as negociações com o Presidente da República, Itamar Franco, que determinou a suspensão, por 24h, das demissões dos grevistas (já anunciadas pela Petrobrás, diante da recusa de retorno ao trabalho). Foi marcada uma reunião para o dia 5 de outubro, em Juiz de Fora/MG, com a presença de Itamar Franco, do Presidente da Central Única dos Trabalhadores - CUT, Vicente Paulo da Silva, o Vicentinho, o Coordenador Geral da FUP, e os Ministros da Fazenda, de Minas e Energia e do Trabalho.

Governo e CUT celebraram um acordo. O Presidente da República se comprometeu a não demitir os trabalhadores, em retaliação à greve, enquanto os petroleiros adiariam as negociações sobre as cláusulas econômicas, aceitando o reajuste de 13,54\% previsto em lei. A avença previa que os dias parados seriam descontados, metade em duas parcelas mensais e o restante, compensado com horas extras. $\mathrm{O}$ acordo estipulou, ainda, que a empresa liberaria sete sindicalistas para atividades ligadas à FUP.

No mesmo dia (5), à noite, a FUP decidiu encerrar a greve, sugerindo aos sindicatos que recomendassem o fim da paralisação nas respectivas assembleias gerais, recomendação essa que foi acatada. ${ }^{233}$

Como resultado da reunião havida em Juiz de Fora/MG, veio a público, cerca de um mês depois, a notícia de novo acordo, com a participação dos Ministros de Minas e Energia, Delcídio Gomez, e do Trabalho, Marcelo Pimentel. Pelo ajuste, garantia-se o pagamento de um salário extra em dezembro de 1994 e outro em janeiro de 1995, a título de antecipação da inflação expurgada no Plano Bresser, de 1987. O acordo previa estabilidade no emprego, liberação de dirigentes sindicais e anistia aos trabalhadores dispensados na greve de setembro/outubro, como combinado na reunião entre o Presidente da República e o Presidente da CUT. Noticiou-se que, com o ajuste, teria sido evitada nova greve. ${ }^{234}$

Logo em seguida, porém, começaram as divergências internas no governo que findava - a essa altura, já haviam ocorrido as eleições presidenciais, vencidas por Fernando Henrique Cardoso, que fora Ministro da Fazenda de Itamar Franco e era considerado o principal responsável pelo plano de estabilização econômica - e que levaram a um

\footnotetext{
232 Jornal do Brasil e Folha de São Paulo de $1^{\circ} .10 .1994$.

${ }^{233}$ Folha de São Paulo de 5 e 6.10.1994.

${ }^{234}$ Jornal do Brasil de 11.11.1994.
} 
questionamento público do acordo. A Petrobrás pretendia demitir 15 trabalhadores que teriam participado de atos de sabotagem durante a paralisação. Mas o acordo celebrado cancelava os inquéritos administrativos. O Ministro do Planejamento, Beni Veras, declarou à imprensa que iria recorrer ao Presidente Itamar Franco para tentar reverter o acordo, que seria "abusivo" e feriria "a filosofia do plano de estabilização econômica". ${ }^{235}$ Além disso, a Secretaria de Coordenação e Controle das Estatais não teria sido ouvida sobre os termos do acordo. Segundo o ministro, "não é justo que concedamos aos empregados da Petrobrás o que está sendo negado às demais categorias. Isso é uma afronta a todos os demais trabalhadores". O problema era o precedente que seria criado para outras empresas estatais. ${ }^{236}$

O Presidente da República se dispôs a rediscutir o acordo com os petroleiros, temendo que empregados de outras estatais fizessem reivindicações semelhantes, colocando em risco o Plano Real. Itamar Franco afirmou ter havido precipitação na definição das cláusulas do ajuste. O Ministro de Minas e Energia, Delcídio Gomez, deixando evidente a dissidência interna, negou que tivesse sido precipitado o acordo e se pronunciou no sentido de que não haveria repercussão negativa no Plano Real. O Ministro do Trabalho, Marcelo Pimentel, declarou que tinha autorização do Presidente da República para negociar os pontos essenciais do acordo com os petroleiros, inclusive sobre as perdas do Plano Bresser. Para Pimentel, o que poderia colocar em risco o plano de estabilização econômica seria uma nova greve da Petrobrás. ${ }^{237}$

235 O Programa de Estabilização Econômica foi criado pela Lei 8.880, de 27.5.1994, que instituiu também a Unidade Real de Valor (URV), para servir exclusivamente como padrão de valor monetário (BRASIL. Lei $\mathrm{n}^{\circ}$ 8.880, de 27 de maio de 1994. Dispõe sobre o Programa de Estabilização Econômica e o Sistema Monetário Nacional, institui a Unidade Real de Valor (URV) e dá outras providências. Diário Oficial da União. Edição Extra. Brasília, DF, 28.5.1994. Retificado no Diário Oficial da União de $1^{\circ}$.6.1994). O Plano Real e os critérios para conversão das obrigações em Real foram regulamentados pela Lei 9.069, de 29.6.1995 (BRASIL. Lei $\mathrm{n}^{\circ}$ 9.069, de 29 de junho de 1995. Dispõe sobre o Plano Real, o Sistema Monetário Nacional, estabelece as regras e condições de emissão do REAL e os critérios para conversão das obrigações para o REAL, e dá outras providências. Diário Oficial da União. Brasília, DF, 30.6.1995).

${ }^{236}$ Folha de São Paulo de 11 e 12.11.1994. Cf. também SILVA, Sayonara Grillo Coutinho Leonardo de. Relações coletivas de trabalho. São Paulo: LTr, 2008, p. 280. Entre os argumentos contrários ao acordo, estaria um parecer da Advocacia Geral da União - AGU, publicado em 14 de outubro, no sentido de que as entidades da administração federal, inclusive indireta, pagassem passivos trabalhistas relativos a planos econômicos tão somente após terem recorrido até a última instância do Poder Judiciário (o acordo, como visto, previa o pagamento de dois salários adicionais em razão de perdas do Plano Bresser). Outro ponto controvertido eram as regras para conversão do $13^{\circ}$ salário adiantado em janeiro e fevereiro daquele ano. A Secretaria da Administração Federal estudava a questão para decidir se a conversão da URV deveria seguir o índice de $1^{\circ}$ de março ou de 30 de junho (esse último o estabelecido no acordo dos petroleiros e mais vantajoso, porque implicava saldo maior a receber).

${ }^{237}$ Folha de São Paulo de 14 e 15.11.1994. Pelo que foi divulgado na imprensa, o Ministro do Trabalho, de início, afirmou que não concordava com todos os pontos do acordo, esclarecendo que o ajuste não previa estabilidade no emprego, na medida em que permaneceria a possibilidade de a empresa demitir por razões de ordem econômica, financeira, técnica ou disciplinar. Em seguida, porém, Marcelo Pimentel explicou que não proporia modificações no acordo, entendendo que nova greve dos petroleiros seria mais prejudicial. Cf. Jornal do Brasil de 14, 15 e 17.11.1994. 
O Ministro da Fazenda, Ciro Gomes, aumentava o coro dos que entendiam que o acordo deveria ser revisto, declarando que sequer tinha conhecimento do ajuste com os petroleiros. Itamar Franco atribuía a responsabilidade do acordo a Gomez (Minas e Energia) e a Pimentel (Trabalho), afirmando que revisaria os termos que fossem contrários ao Plano Real, à primeira negociação com a CUT (em Juiz de Fora/MG) e à decisão da Justiça do Trabalho. ${ }^{238}$ Em reunião com alguns ministros, o Presidente da República insistiu, por outro lado, que não aceitaria demissões sumárias dos petroleiros acusados de sabotar instalações da empresa, ou seja, deveria ser assegurado a eles o amplo direito de defesa. ${ }^{239}$

A FUP convocou assembleias nos postos de trabalho com o objetivo de colocar em deliberação a deflagração de greve imediata, nacional e por tempo indeterminado, caso fosse revogado o acordo com o governo. O Coordenador da Federação, Antonio Carlos Spis, considerava "ultrajante" a discussão governamental sobre o acordo salarial. A mobilização dos trabalhadores também foi anunciada pela CUT. ${ }^{240}$

No dia 16 de novembro, sobreveio um fato importante. O Tribunal Superior do Trabalho cancelou os enunciados 316 e 317 de sua jurisprudência, que reconheciam o direito dos trabalhadores ao IPC de junho de 1987 (relativo ao Plano Bresser) e à URP de fevereiro de 1989 (referente ao Plano Verão), respectivamente. ${ }^{241}$ A Corte cancelou também o enunciado 323, que previa que a suspensão do pagamento das URPs de abril e maio de 1988 afrontava direito adquirido dos trabalhadores. ${ }^{242}$ A decisão do TST era relevante porque sinalizava que, caso os petroleiros questionassem em juízo o direito às diferenças do Plano Bresser - que fora objeto do acordo com o governo - havia maior chance de perderem. ${ }^{243}$

\footnotetext{
${ }^{238}$ Folha de São Paulo de 16.11.1994.

239 Jornal do Brasil de 17.11.1994.

${ }^{240}$ Folha de São Paulo de 15 e 17.11.1994.

${ }^{241}$ O enunciado 316 previa que: "IPC DE JUNHO/1987. DECRETO-LEI No 2.335/1987 (PLANO BRESSER).
} EXISTÊNCIA DE DIREITO ADQUIRIDO É devido o reajuste salarial decorrente da incidência do IPC de junho de 1987, correspondente a 26,06\% (vinte e seis vírgula zero seis por cento), porque este direito já se havia incorporado ao patrimônio jurídico dos trabalhadores quando do advento do Decreto-Lei $n^{\circ}$ 2.335/1987" (BRASIL. Tribunal Superior do Trabalho. Enunciado 316. Diário de Justiça, Brasília, DF, 29.9.1993). E o enunciado 317: “URP DE FEVEREIRO/1989. LEI No 7.730/1989 (PLANO VERÃO). EXISTÊNCIA DE DIREITO ADQUIRIDO A correção salarial da URP de fevereiro de 1989, de 26,05\% (vinte e seis vírgula zero cinco por cento), já constituía direito adquirido do trabalhador, quando do advento da Medida Provisória $\mathrm{n}^{\circ}$ 32/1989, convertida na Lei no 7.730/1989, sendo devido o reajuste respectivo" (BRASIL. Tribunal Superior do Trabalho. Enunciado 317. Diário de Justiça, Brasília, DF, 29.9.1993).

${ }^{242} \mathrm{O}$ texto do enunciado 323 era o seguinte: "DIFERENÇAS SALARIAIS. PLANOS ECONÔMICOS. LIMITE Os reajustes salariais decorrentes dos chamados 'gatilhos' e URPs, previstos legalmente como antecipação, são devidos tão-somente até a data-base de cada categoria” (BRASIL. Tribunal Superior do Trabalho. Enunciado 323. Diário de Justiça, Brasília, DF, 4.1.1994).

${ }^{243}$ Enquanto isso, a Secretaria de Coordenação e Controle das Estatais divulgava que a concessão de parcelas relativas ao Plano Bresser prejudicava o Plano Real, sobretudo por constituir precedentes para outras categorias, noticiando que já havia pressões por parte dos eletricitários, telefônicos e carteiros. Cf. Jornal do Brasil de 17.11.1994 (2 $2^{\mathrm{a}}$ edição). 
Itamar Franco convocou reunião com os representantes dos petroleiros e o Ministro do Trabalho. Os pontos do acordo a serem revistos eram a reposição das perdas do Plano Bresser (com a supressão dos dois salários antes garantidos), a forma de cálculo do desconto da primeira parcela do $13^{\circ}$ salário (a observar a data do pagamento) ${ }^{244}$ e a cláusula de anistia aos grevistas (diante da existência de inquéritos administrativos para apuração de atos de sabotagem). $\mathrm{O}$ argumento do governo, pelo que foi publicizado, seria a decisão do TST (sobre o Plano Bresser).

Não houve acordo, porém, entre os sindicalistas e o governo, que se fizera presente pelos Ministros de Minas e Energia, Delcídio Gomez, e do Trabalho, Marcelo Pimentel. O Coordenador da FUP alertou sobre a possibilidade de greve, com risco de desabastecimento de combustíveis e gás de cozinha. O Ministro do Trabalho, em resposta, afirmou que, "se entrarem em greve, a Petrobrás entrará com dissídio de greve junto ao TST imediatamente". ${ }^{245}$ Para Marcelo Pimentel, sem a sua assinatura, o acordo original não tinha validade (o documento estava assinado apenas por Delcídio Gomez, embora, pelo que foi

\footnotetext{
${ }^{244} \mathrm{O}$ acordo celebrado com o governo previa o pagamento, aos petroleiros, da segunda parcela do $13^{\circ}$ salário segundo a URV de 30 de junho, e não de fevereiro, mês em que foi paga a primeira parcela. A alteração incrementava em 38\% o valor da segunda parcela. Cf. ROMÃO, Frederico Lisboa. A greve do fim do mundo: petroleiros 1995 - expressão fenomênica da crise fordista no Brasil. Tese de Doutorado. Universidade Estadual de Campinas, Instituto de Filosofia e Ciências Humanas, [s.n.], 2006, p. 340.

245 Vale atentar para o "uso" que é feito do Poder Judiciário. O discurso (ameaça) do Ministro do Trabalho demonstra a confiança que havia no TST, no sentido do papel do Tribunal em intervir na greve e declará-la abusiva. Em entrevista concedida ao Programa de História Oral do Tribunal Superior do Trabalho, Marcelo Pimentel, que compusera a Corte, como Ministro togado, de 4.10.1978 a 4.5.1994, deixou claro que sua nomeação para o Ministério do Trabalho teve por objetivo garantir a execução do Plano Real por meio do controle das reivindicações dos trabalhadores: "o convite formulado para assumir o Ministério do Trabalho objetivou dar uma orientação mais técnica ao órgão de maneira que se pudesse impor a execução do Plano [Real] sem grandes dificuldades, principalmente, evitando-se reivindicações muito pesadas dos trabalhadores. Nós conseguimos, salvo a exceção da divergência com os petroleiros, ajudar a conduzir as coisas em termos de que o Plano se estabilizasse a ponto de produzir os resultados que todos usufruem na economia nacional. Eliminou-se a inflação galopante. Era um governo nitidamente técnico e, a nossa atuação foi sem qualquer veleidade política. Sem ser político entrei e sem ser político saí". Indagado especificamente sobre a greve dos petroleiros, Marcelo Pimentel permite entrever o papel desempenhado pelo TST: "foi uma das piores greves que enfrentamos. Consultor Jurídico do Ministério do Trabalho durante 16 anos atuei em inúmeros conflitos. Inclusive na primeira dirigida pelo ilustre presidente Lula da Silva. Mas enfrentar greve não é importante. Opor-se a elas quando se desvirtuam para ter objetivos políticos é outra coisa. Nitidamente, a dos petroleiros era uma disputa política entre eles. Daí porque houve maior dificuldade para que se chegar a um termo satisfatório. Foi muito longa e muito pesada. Com a colaboração do TST, foram adotadas algumas decisões mais firmes no sentido de que as greves não tivessem natureza política e não se prolongasse indefinidamente. Exemplo: a multa aos sindicatos que as patrocinavam contra decisão da Justiça" (destaque no original). Cf. BRASIL, Programa de História Oral do Tribunal Superior do Trabalho. Transcrição da entrevista do projeto de história oral do TST. Ministro Marcelo Pimentel. Transcrição de Luiza Brito Lemos. Brasília, 11.6.2012 (disponível em http:// www.tst.jus.br/documents/10157/3517647/Transcri\%C3\%A7\%C3\%A3o+da+Entrevista+do+Projeto+de+Hist\% C3\%B3ria+Oral+do+TST+-+REVISADO+PELO+Ministro+Marcelo+Pimente+21.pdf - acesso em 13.1.2014 sic).
} 
divulgado pela imprensa, o Ministro do Trabalho tivesse sido o negociador do ponto mais polêmico, i.e., as perdas do Plano Bresser). ${ }^{246}$

Foi realizada nova reunião entre os sindicalistas e o governo, no Ministério do Trabalho, novamente sem sucesso. A essa altura, o governo pretendia rever todos os pontos do acordo, inclusive sobre a estabilidade no emprego. Os petroleiros deflagraram a greve, a partir da $0 \mathrm{~h}$ do dia 23, declarando estarem preparados para não deixar faltar combustíveis e gás de cozinha. A Petrobrás, de imediato (como antecipado por Marcelo Pimentel), propôs o dissídio no Tribunal Superior do Trabalho, enquanto o governo proibiu a empresa de fazer alguma concessão enquanto perdurasse a paralisação. O Ministro do Trabalho afirmou que, em caso declaração da ilegalidade da greve e de sua manutenção, com atos que impedissem a entrada dos que quisessem trabalhar, o Presidente da República poderia convocar as Forças Armadas, que iriam intervir nas refinarias "para defender os interesses da população" e "manter a ordem nas unidades de produção da Petrobrás". ${ }^{247}$

O Presidente, em exercício, do Tribunal Superior do Trabalho, Ministro José Ajuricaba da Costa e Silva, em decisão liminar, determinou que 30\% dos petroleiros fossem mantidos em atividade, a partir de 25 de novembro, sob pena de multa de $\mathrm{R} \$ 100.000,00$ por dia. A Federação Única dos Petroleiros anunciou que não atenderia a determinação judicial, enquanto a Petrobrás, por sua vez, iniciou a convocação nominal dos trabalhadores. ${ }^{248}$

O Presidente da República, a despeito da declaração da FUP, comunicou ao Presidente da Petrobrás, Joel Rennó, que abrisse a negociação com o Presidente da CUT, Vicentinho - o governo federal não participaria mais das negociações. A empresa e os petroleiros chegaram a um acordo provisório: a paralisação seria encerrada e a Petrobrás desistiria do pedido de declaração de abusividade da greve, concordando em reabrir as negociações sobre todos os pontos, inclusive as cláusulas econômicas. Antonio Carlos Spis concedeu entrevista declarando que os aspectos polêmicos, como o Plano Bresser, seriam deixados de lado, para que fossem decididos pelo Poder Judiciário. Segundo o Coordenador da FUP, o TST ficou desmoralizado, desde a greve deflagrada em setembro, pois havia sido desobedecida a determinação de manutenção de $30 \%$ de funcionários em atividade. ${ }^{249}$

\footnotetext{
${ }^{246}$ Folha de São Paulo de 18 e 22.11.1994.

${ }^{247}$ Folha de São Paulo de 23 e 24.11.1994. Ver também Jornal do Brasil de 22 e 23.11.1994. É interessante notar que, no dia seguinte à deflagração da greve, a imprensa já noticiou que "greve de petroleiros ameaça abastecimento" (Jornal do Brasil, manchete de capa da edição de 23.11.1994).

${ }^{248}$ O Procurador-Geral do Ministério Público do Trabalho, João Pedro Ferraz dos Passos, declarou que a greve era abusiva, pois a reivindicação dizia respeito a um acordo que juridicamente não existia, porque a Petrobrás não o assinara. Cf. Folha de São Paulo de 25.11.1994.

${ }^{249}$ Folha de São Paulo de 25, 26 e 28.11.1994 e Jornal do Brasil de 23, 24 e 25.11.1994.
} 
O acordo entre a Petrobrás e os líderes sindicais foi firmado ao mesmo tempo em que era realizada a audiência de conciliação convocada pelo Presidente do Tribunal Superior do Trabalho. O ajuste foi denominado de Protocolo e assinado por José Lima de Andrade Neto, Superintendente Adjunto do Serviço de Recursos Humanos (SEREC) da Petrobrás, e Rosemberg Evangelista Pinto, diretor da FUP (Joel Rennó e Antonio Carlos Spis estavam em Brasília, em audiência no TST). Com a celebração do Protocolo, a greve foi encerrada, sem consulta prévia em assembleias gerais. A Petrobrás assumia o compromisso de retomar as negociações e manter o acordo coletivo de 1993/1994, observada a sentença normativa do TST, e a efetuar a adequação dos níveis salariais, corrigindo os interníveis, o que resultaria em reajustes de $3 \%$ a $18 \%$ para os petroleiros. ${ }^{250}$

Mas as negociações não foram retomadas, contrariando o que havia sido acertado no Protocolo - mantido em sigilo. A FUP denunciou punições a grevistas suspensos ou dispensados sem direito de defesa. Encerrado o prazo para a retomada das negociações, a Petrobrás requereu dilação do prazo. A Federação tentou mobilizar os trabalhadores, sinalizando a possibilidade de retorno à greve. No fim de dezembro, a diretoria da FUP procurou o Presidente da empresa em sua sede, no Rio de Janeiro, mas não obteve resposta Rennó havia viajado. Não havia mais tempo para uma nova paralisação - em poucos dias assumiria um novo Presidente da República. ${ }^{251}$

A mobilização dos petroleiros colocou na ordem do dia a discussão sobre os monopólios estatais, entre eles o do petróleo. Ainda em novembro de 1994, o vencedor das eleições, Fernando Henrique Cardoso, declarou que encaminharia ao Congresso Nacional, em fevereiro, proposta de emenda constitucional para flexibilizar os monopólios estatais. ${ }^{252}$ Essas questões - os acordos não cumpridos, as idas e vindas das greves dos petroleiros ${ }^{253}$, a quebra dos monopólios - iriam ressurgir na paralisação de 1995. E, mais uma vez, a Justiça do Trabalho seria provocada a intervir na greve.

\subsection{A greve de 1995: a resistência dos petroleiros e a postura do Poder Público}

\footnotetext{
${ }^{250}$ Cf. ROMÃO, Frederico Lisboa. A greve do fim do mundo: petroleiros 1995 - expressão fenomênica da crise fordista no Brasil, p. 343/344.

${ }^{251}$ Ver ROMÃO, Frederico Lisboa. A greve do fim do mundo: petroleiros 1995 - expressão fenomênica da crise fordista no Brasil, p. 344/345.

${ }^{252}$ Folha de São Paulo de 26.11.1994.

253 A atuação da FUP foi marcada por decisões de começo e suspensão da greve, durante o processo de negociação com o governo, mesmo sem consulta prévia às bases. Talvez isso tenha desgastado a diretoria da Federação, no final de 1994, o que possivelmente influenciou a forma pela qual a FUP encarou a decisão do TST, em 1995, e sua disposição em manter a greve. Cf. ROMÃO, Frederico Lisboa. A greve do fim do mundo: petroleiros 1995 - expressão fenomênica da crise fordista no Brasil, p. 346.
} 
A greve dos petroleiros, deflagrada no começo de maio de 1995, estava inserida, num primeiro momento, num contexto mais amplo de paralisações dirigidas pela Central Única dos Trabalhadores - CUT. Mas se ela se iniciou no bojo da atuação da Central, adquiriu, em seguida, destaque próprio, sobretudo pelas peculiaridades da situação dos petroleiros, em face dos antecedentes vistos há pouco.

Em 1995, começou um novo governo, tendo sido eleito à Presidência da República Fernando Henrique Cardoso, que fora Ministro da Fazenda de Itamar Franco (e sucedido, na pasta, por Ciro Gomes). Foi à frente desse Ministério que Fernando Henrique Cardoso lançou o Plano Real, fundado, basicamente, numa gerência mais eficiente de recursos monetários, controle do déficit público e num plano de reforma do Estado. O sucesso do Plano Real garantiu expressiva popularidade ao então Ministro. Candidato à presidência pelo PSDB - partido que integrava desde sua fundação, durante a Assembleia Nacional Constituinte de 1987/1988 -, Fernando Henrique Cardoso foi eleito, em outubro de 1994, em primeiro turno, derrotando o candidato do PT, Luiz Inácio Lula da Silva (FHC obteve 54,2\% dos votos, enquanto Lula apenas $27 \%){ }^{254}$

Como Fernando Henrique Cardoso antecipara antes mesmo de sua posse no cargo, o governo apresentou, no Congresso Nacional, no começo de 1995, propostas de alterações constitucionais para acabar com o monopólio estatal em determinadas atividades, entre elas, exploração de petróleo e gás e telecomunicações. No campo das relações de trabalho, o discurso do governo era de flexibilização, isto é, permitir que as forças do mercado regulassem o processo de contratação, dispensa e definição do custo da mão de obra. A redução desse custo contribuiria para a diminuição dos índices de desemprego, segundo o governo e os empresários. O caráter do governo, em especial quanto ao movimento sindical, seria definido principalmente pelo programa de reformas da Constituição de $1988 .{ }^{255}$ Além disso, era necessário dar continuidade ao Plano Real e a postura adotada era de restrição à autonomia coletiva dos sindicatos. ${ }^{256}$

\footnotetext{
${ }^{254}$ Ver TEIXEIRA DA SILVA, Francisco Carlos. "Brasil, em direção ao século XXI”. In: LINHARES, Maria Yedda (org.). História geral do Brasil. $9^{\mathrm{a}}$ ed. Rio de Janeiro: Elsevier, 1990, 15 a reimpressão, p. 416/417.

${ }^{255} \mathrm{Cf}$, a propósito, MARTINS, Heloísa de Souza \& RODRIGUES, Iram Jácome. "O sindicalismo brasileiro na segunda metade dos anos 90”. In: Tempo Social. Rev. Sociol. USP, São Paulo, 11 (2): 155-182, out.1999 (editado em fev. 2000), p. 156 e 166/167.

256 Sayonara Grillo Leonardo Coutinho da Silva observa que, "com o governo Fernando Henrique foram se descortinando políticas e propostas de reforma trabalhista, não necessariamente de desregulamentação, mas de reorientação das regras jurídicas existentes. Um deslocamento em direção a uma mudança na produção das regras jurídicas (...) ocorreu não apenas pela extensão do papel da negociação coletiva (...), mas pela tentativa de desmaterialização da própria autonomia coletiva em processo contínuo de construção e de afirmação no país".
} 
A CUT coordenou, nos primeiros dias de maio de 1995, a realização de uma greve contrária às reformas constitucionais anunciadas pelo governo. A Força Sindical, por sua vez, prometeu fazer greve em defesa das reformas. Essa foi a informação que ganhou destaque, por exemplo, no jornal Folha de São Paulo. É significativo notar que na mesma página em que foram referidas as greves promovidas pela CUT e (em polo oposto) pela Força Sindical, há uma breve notícia da paralisação anunciada para o dia seguinte (3 de maio) na Refinaria do Vale do Paraíba, onde, entre as reivindicações dos petroleiros, estava um aumento de $12 \%$ que teria sido negociado com a direção da Petrobrás em novembro de 1994. ${ }^{257}$

Esse fato parece indicativo de que, num primeiro momento, não foi dada tanta atenção aos petroleiros, talvez diante da amplitude prometida pela paralisação coordenada pela Central Única dos Trabalhadores. ${ }^{258}$

A greve dirigida pela CUT teve início no dia 3 de maio, contando com a participação de petroleiros, telefônicos, eletricitários, previdenciários e funcionários públicos das universidades federais. Entre as reivindicações, estavam protestos diante das reformas constitucionais propostas pelo governo, incluindo a quebra de monopólios estatais e as privatizações do setor elétrico e dos Correios. ${ }^{259}$ Tratava-se, portanto, de uma "greve unificada", envolvendo a participação das entidades sindicais das estatais e do funcionalismo público. Segundo constou do Boletim da Federação Única dos Petroleiros "Primeira Mão",

As propostas enviadas por FHC no Congresso de mudança da Constituição e da legislação representam um duro ataque às conquistas dos trabalhadores e aos direitos da cidadania.

\footnotetext{
A autora nota, ainda, que preponderou "a restrição da autonomia coletiva como política de governo no primeiro ano de gestão, com o objetivo imediato de assegurar a continuidade do Plano Real”. (SILVA, Sayonara Grillo Coutinho Leonardo da. Relações coletivas de trabalho, p. 276).

${ }^{257}$ Folha de São Paulo de 2.5.1995. O periódico Jornal do Brasil ressaltou tão somente a liderança da CUT em greve que mobilizaria cerca de 500 mil funcionários de empresas estatais (Jornal do Brasil de 3.5.1995). Uma exceção foi $O$ Estado de São Paulo, que conferiu maior ênfase à paralisação dos petroleiros - cuja pauta incluía o cumprimento dos acordos celebrados em 1994, além do protesto contra as privatizações e as reformas constitucionais - e só então referiu se tratar de uma mobilização coordenada pela CUT. Cf. a edição de 3.5.1995. ${ }^{258}$ Se a greve dos petroleiros não recebeu tanta atenção diante da mobilização organizada pela CUT, entre as categorias paradas, os trabalhadores da Petrobrás se destacavam: "durante esses primeiros dias, a greve dos petroleiros fora focada como apenas mais uma em meio a tantas greves que estão a ocorrer, não obstante ser disponibilizado a ela um espaço maior na mídia. A greve na Petrobrás, por suas peculiaridades, é colocada em destaque, seja pela responsabilidade com o abastecimento de gás, gasolina e óleo diesel, seja pela abrangência nacional da categoria, pelos custos vultuosos da paralisação, seja por ser a que consegue maior adesão da categoria" (ROMÃO, Frederico Lisboa. A greve do fim do mundo: petroleiros 1995 - expressão fenomênica da crise fordista no Brasil, p. 363).

${ }^{259}$ Um dia após a deflagração da greve, a Comissão Especial da Câmara dos Deputados aprovou, por maioria, a emenda constitucional que encerrava o monopólio estatal do petróleo - era o passo para que a emenda fosse, em primeiro turno, ao plenário da Câmara. O líder do governo na Câmara, Deputado Luiz Carlos Santos (PMDB), considerava se tratar da "emenda mais polêmica do conjunto da ordem econômica" (Jornal do Brasil de 5.5.1995).
} 
O governo quer acabar com a aposentadoria por tempo de serviço, desmontar a Previdência, acabar com a estabilidade do funcionalismo, aprofundar o programa de privatização, flexibilizar os monopólios do petróleo e das telecomunicações (atalho para futura privatização) e reduzir investimentos em saúde e educação. ${ }^{260}$

De acordo com a CUT, a greve, em seu primeiro dia, teria mobilizado cerca de 300 mil trabalhadores do setor público. A paralisação foi expressiva entre os petroleiros segundo o diretor da Federação Única dos Petroleiros, David Soares de Souza, nove das dez refinarias haviam sido atingidas pela paralisação -, sem que houvesse modificação na produção. A estimativa era de que $85 \%$ dos 50 mil petroleiros do país participavam da greve, que também foi significativa entre os eletricitários ( $80 \%$ dos 60 mil trabalhadores do setor). Nas universidades, os dados eram de 50\% de grevistas entre os 103 mil funcionários e, entre os previdenciários, $35 \%$ de 230 mil. $^{261}$

Fernando Henrique Cardoso determinou o corte de ponto dos trabalhadores que aderissem à greve promovida pela CUT. O porta-voz da Presidência da República, embaixador Sérgio Amaral, declarou que "a greve é um direito dos trabalhadores, desde que não transgridam os limites da lei”. O Ministro de Minas e Energia, Raimundo Brito, afirmou, por sua vez, que Petrobrás e Eletrobrás estavam orientadas a não ceder à paralisação de seus empregados e a recorrer à Justiça, requerendo a ilegalidade da greve. Em suas palavras, "não

${ }^{260}$ Cf. "Primeira Mão", Boletim da Federação Única dos Petroleiros de 24.4.1995. Pelas atas das assembleias realizadas pelos Sindicatos de petroleiros, é possível constatar a aprovação de uma pauta "unificada" e de outra específica dos trabalhadores da Petrobrás. Ver, por exemplo, a ata do Sindicato dos Trabalhadores na Indústria da Destilação e Refinação de Petróleo no Estado do Ceará (BRASIL. Tribunal Superior do Trabalho. Seção de Dissídios Coletivos. Dissídio Coletivo no 177.734/1995. Processo, Brasília, DF, p. 186/187). A pauta "unificada" previa greve: "A - contra as reformas constitucionais, do Estado e administrativas neoliberais de FHC; pela defesa da estabilidade do funcionalismo público e contra as privatizações; contra a flexibilização dos monopólios do petróleo e das telecomunicações; B - em defesa da aposentadoria por tempo de serviço e da previdência pública; C - por uma política salarial com reposição mensal conforme ICV do DIEESE; D - por uma política de reposição das perdas salariais segundo reivindicação das categorias (os petroleiros estão com perdas de $22,94 \%$ pelo ICV); E - cumprimento dos acordos e termos de compromisso firmados pelo governo e dirigentes de estatais; F - contra as mudanças nas datas de pagamento dos salários; $\mathrm{G}$ - reintegração dos demitidos na reforma administrativa do governo Collor".

${ }^{261}$ Folha de São Paulo de 3 e 4.5.1995. De acordo com Frederico Lisboa Romão, as reivindicações da CUT e das federações e dos sindicatos a ela filiados foram apresentadas em documento protocolado no dia 27 de abril de 1995 na Presidência da República. Com a pauta, foram entregues também as reivindicações específicas de cada categoria. As dos petroleiros eram as seguintes: "1-Cumprimento do Protocolo assinado em 25/11/94 (item3): 'Amparada na cláusula 105 da Sentença Normativa do Processo TST DC-131.024/94.0, a Petrobrás adequará a atual relação de interníveis, no prazo de 20 dias, visando a promover eventuais ajustes'. O prazo se expirou em 15/12, o pagamento deve ser retroativo a setembro de 94. 2- Reposição das perdas salariais pelo ICV-Dieese (estimativa de set/94 a abril/95) - 23,63\%96. 3- Reintegração dos companheiros demitidos por participação em movimentos reivindicatórios. 4- Cumprimento da Lei de Anistia aos companheiros demitidos durante o governo Collor, com a readmissão imediata. 5- Efetivos mínimos, com uma política de contratações antecipadas, através de concursos públicos. 6- Pagamentos dos passivos trabalhistas. 7- Suspensão imediata da implantação do GDP, das flexibilizações de normas e multifunções" (ROMÃO, Frederico Lisboa. A greve do fim do mundo: petroleiros 1995 - expressão fenomênica da crise fordista no Brasil, p. 352/353). 
há porque ceder. A greve é política e extemporânea”. Para Raimundo Brito, a paralisação seria "coisa da CUT contra as reformas na Constituição". ${ }^{262}$

A Força Sindical, importante central presidida por Luiz Antônio de Medeiros e que tinha, como um de seus dirigentes, Paulo Pereira da Silva, o Paulinho, Presidente do Sindicato dos Metalúrgicos de São Paulo ${ }^{263}$, tomava a iniciativa de promover uma greve a favor das propostas de reforma constitucional do governo, em oposição à paralisação deflagrada pela CUT. ${ }^{264}$ A greve envolveria trabalhadores metalúrgicos e dos setores têxteis, de alimentação e do comércio. A central sindical procurou a adesão dos empregadores. A paralisação teria, ainda, o apoio do Presidente da República ${ }^{265}$ e seria uma greve contra os “privilegiados". ${ }^{266}$ Não era, porém, um discurso novo. De acordo com Armando Boito Jr., entre os operários que integravam a base daquela Central, "há uma forte oposição ao

${ }^{262}$ Folha de São Paulo e Jornal do Brasil de 4.5.1995. Há já aqui um primeiro indício da confiança do governo na declaração de ilegalidade da greve pela Justiça do Trabalho.

${ }^{263}$ A base de sustentação da Força Sindical era justamente o Sindicato dos Metalúrgicos de São Paulo/SP, que havia sido presidido por Luiz Antônio de Medeiros, um dos responsáveis pela formulação do "sindicalismo de resultados" ou, segundo Adalberto Cardoso, "sindicalismo pragmático". Sobre a formação da Força Sindical, cf. CARDOSO, Adalberto Moreira. A trama da modernidade: pragmatismo sindical e democratização no Brasil. Rio de Janeiro: Revan: IUPERJ-UCAM, 1999, p. 185 e ss; e ANTUNES, Ricardo. O Novo Sindicalismo no Brasil. Campinas: Pontes, 1995, p. 38/41. Com relação à reorganização das centrais sindicais brasileiras na década de 1980, ver RODRIGUES, Leôncio Martins. "As tendências políticas na formação das centrais sindicais". In: BOITO JR., Armando (Org.). O Sindicalismo brasileiro nos anos 80. Rio de Janeiro: Paz e Terra, $1991,35 / 39$.

${ }^{264}$ Havia, nesse momento, uma aproximação entre a Força Sindical e o governo. Durante as comemorações do $1^{\mathrm{a}}$ de Maio daquele ano, o Ministro do Trabalho, Paulo Paiva, participou de evento organizado pela Força Sindical, ocasião em que defendeu a retirada de certos direitos da Constituição - como a licença-maternidade e as férias de 30 dias acrescidas de $1 / 3$-, a serem objeto de negociação coletiva entre os interessados. Mas a proposta do Ministro causou reações contrárias. Cf. O Estado de São Paulo de 2 e 3.5.1995. A postura da Força Sindical, sobretudo em relação ao governo, seria alterada no ano seguinte, quando a Central passou da ênfase na negociação para o enfrentamento. Ver, a respeito, MARTINS, Heloísa de Souza \& RODRIGUES, Iram Jácome. "O sindicalismo brasileiro na segunda metade dos anos 90", p. 162/163.

${ }^{265}$ Revista Isto é de 10.5.1995 e Folha de São Paulo de 4.5.1995. Segundo a Isto é, Paulinho, da Força Sindical, teria entrado em contato com o Presidente da República para lhe comunicar sobre a greve em defesa das reformas constitucionais e "Fernando Henrique percebeu que havia no relato de Paulinho uma oferta de greve à seu favor. Imediatamente, assinou embaixo" (sic). Ao final, a greve promovida pela Força Sindical ocorreu no dia 11 de maio e foi considerada um "ato público" em favor das reformas constitucionais. Cf. O Estado de São Paulo de 12.5.1995.

${ }^{266}$ De acordo com o diretor da Força Sindical, o Paulinho, o trabalhador "da base" das categorias envolvidas na greve promovida pela CUT não saberia de seu conteúdo político e participaria da paralisação por reajustes salariais. Segundo ele, apenas "uma casta de privilegiados" estaria preocupada com o fim do monopólio do petróleo, telecomunicações e privatização. Afirmou que Vicentinho [Presidente da CUT] estaria "refém" desses "privilegiados". Cf. Folha de São Paulo e O Estado de São Paulo de 4.5.1995. Essa ideia de que se tratava de uma greve de "privilegiados" encontrou eco em outros órgãos da imprensa. A Revista Veja, de 10.5.1995, publicou a seguinte reportagem: "sob o pretexto de fazer reivindicações salariais, os grevistas da CUT pretendem assustar os congressistas que estão votando a reforma da Constituição. Petroleiros, eletricitários, telefônicos e previdenciários em greve são contra a privatização e o fim dos monopólios, porque desfrutam de condições privilegiadas no ninho estatal. Ganham mais do que os outros trabalhadores brasileiros e têm mordomias de padrão sueco, desconhecidas na iniciativa privada. Com sua greve pretendem passar aos congressistas a idéia de que a opinião pública está contra as reformas". Numa reunião com empresários que manifestavam apoio às propostas de reformas, no dia 11 de maio, o próprio Presidente da República declarou que "é uma greve para defender reserva de mercado e o privilégio de uns poucos" (Revista Isto é de 17.5.1995). 
trabalhador do setor público, considerado, tal qual no discurso oficial dos governos neoliberais, um privilegiado responsável por grande parte das dificuldades econômicas enfrentadas pela população", sentimento esse ("anti-servidor público") que seria estimulado por Luiz Antônio de Medeiros e Paulo Pereira da Silva. ${ }^{267}$

No mesmo dia 3, a Petrobrás ajuizou ação de dissídio coletivo no Tribunal Superior do Trabalho. O processo teve um peso fundamental no desenvolvimento da greve dos petroleiros de 1995 e em suas consequências. E, por isso, é importante seu exame. Para tanto, é o caso de ter em mente o alerta de Carlo Ginzburg de que a evidência (nesta investigação, o processo judicial) deve ser encarada como um documento em si histórico, cuja compreensão demanda referências ao contexto externo. ${ }^{268}$

A ação foi proposta em face da Federação Única dos Petroleiros e de mais 21 sindicatos. ${ }^{269} \mathrm{Na}$ petição inicial, a empresa conferiu o seguinte recorte à situação: em agosto de 1994, expirou a vigência do acordo coletivo de trabalho de 1993/1994; não tendo sido exitosa a tentativa de edição de nova norma coletiva e, diante da iminência da greve, "viu-se a

\footnotetext{
267 Ainda segundo Boito Jr., a Força Sindical "nasceu no início do governo Collor, contando com o apoio político e financeiro desse governo e de grandes empresários. A maioria dos sindicalistas que a lideram integraram o grupo de sindicalistas pelegos, isto é, governistas, ao longo da década de 1980, e continuaram tendo uma atuação governista na década dos governos neoliberais. Mas seria um erro supor que apenas o peleguismo explica o neoliberalismo da Força Sindical. Há indicadores de que as ideias de privatização e desregulamentação passaram a ser aceitas entre os operários que compõem a base da Força Sindical" (BOITO JR., Armando. "Neoliberalismo e corporativismo de Estado no Brasil". In: ARAÚJO, Angela Maria Carneiro. Do corporativismo ao neoliberalismo - Estado e trabalhadores no Brasil e na Inglaterra. Boitempo: São Paulo, 2002 , p. $59 / 87$ (p. 67 e 66 , respectivamente).

${ }^{268}$ De acordo com Ginzburg, para estudar a realidade como um texto é necessário atentar para que nenhum texto é compreensível sem referência a realidades extratextuais. Cf. GINZBURG, Carlo. "Checking the Evidence: The Judge and the Historian”. In: Critical Inquiry. Vol. 18, N. 1, (Outono, 1991), pp. 79/92 (p. 84).

${ }^{269}$ São eles: Sindicato dos Trabalhadores na Indústria de Destilação e Refinação de Petróleo de Cubatão, Santos e São Sebastião; Sindicato dos Trabalhadores na Indústria da Extração de Petróleo nos Estados de Alagoas; Sindicato dos Trabalhadores na Indústria da Destilação e Refinação do Petróleo de Porto Alegre, Canoas, Osório e Tramandaí; Sindicato dos Trabalhadores na Indústria da Extração, Estocagem e Transferência do Petróleo, seus Derivados e Gás Natural do Estado da Bahia; Sindicato dos Petroleiros do Estado da Bahia; Sindicato dos Trabalhadores na Indústria da Destilação e Refinação do Petróleo de Campinas e Paulínia; Sindicato dos Trabalhadores na Indústria da Destilação e Refinação de Petróleo de Duque de Caxias; Sindicato dos Trabalhadores na Indústria da Destilação e Refinação de Petróleo no Estado do Ceará; Sindicato dos Trabalhadores na Indústria da Destilação e Refinação de Petróleo no Estado do Amazonas; Sindicato dos Trabalhadores na Indústria da Destilação de Petróleo de Mauá; Sindicato dos Trabalhadores na Indústria da Destilação e Refinação de Petróleo de Minas Gerais; Sindicato dos Trabalhadores na Indústria da Extração do Petróleo nos Estados do PA/AM/MA/AP; Sindicato dos Trabalhadores na Indústria de Refinação, Destilação, Exploração e Produção de Petróleo nos Estados do Paraná e Santa Catarina; Sindicato dos Trabalhadores na Indústria da Destilação e Refinação do Petróleo no Estado do Rio de Janeiro; Sindicato dos Trabalhadores na Indústria da Destilação e Refinação do Petróleo no Estado do Rio Grande do Norte; Sindicato dos Trabalhadores na Indústria da Destilação e Refinação do Petróleo de São José dos Campos; Sindicato dos Trabalhadores na Indústria da Destilação e Refinação do Petróleo de Barueri e Guarulhos, São Caetano do Sul e São Paulo; Sindicato dos Trabalhadores na Indústria de Exploração, Perfuração, Extração e Produção de Petróleo nos Municípios de São Mateus, Linhares, Conceição da Barra e Jaguaré no Estado do Espírito Santo; Sindicato dos Trabalhadores da Indústria de Petróleo do Estado de Pernambuco; Sindicato dos Trabalhadores nas Indústrias e Empresas Petroquímicas, Químicas, Plásticas e Afins - Bahia; Sindicato dos Trabalhadores na Indústria de Produtos Petroquímicos, Plásticos e Similares do Estado de Sergipe.
} 
Empresa obrigada a suscitar dissídio coletivo (Processo TST-DC-131.024/94.0)”, tendo, em seguida, sido deflagrada a paralisação; o Tribunal Superior do Trabalho determinou o imediato retorno dos trabalhadores ao serviço e proferiu sentença normativa, publicada em 14 de novembro de 1994 e ainda em vigor; a despeito disso, ou seja, muito embora vigente a referida sentença normativa, os suscitados deflagraram "novo movimento grevista", paralisando praticamente todas as unidades da empresa.

Não há referência, na narrativa da Petrobrás, aos acordos celebrados em 1994. Foram invocados, por outro lado, os dispositivos legais que disciplinam a greve em atividades essenciais, em especial os artigos $9^{\circ}$, 10, I, e 11 da Lei 7.783/1989, alegando-se a sua não observância pelos grevistas. A empresa sustentou também que o Sindipetro de Pernambuco não fez a comunicação prévia ao empregador, o sindicato de Amazonas não o fez em prazo legal, todos os suscitados não informaram os usuários dos serviços acerca da greve e o comunicado à Petrobrás teria sido desrespeitado na Refinaria Gabriel Passos, em Betim/MG (onde a paralisação iniciara antes do previsto).

A Petrobrás afirmou que se tratava de "greve manifestamente abusiva". Pediu a declaração de abusividade da paralisação, "com a determinação de imediato retorno dos grevistas aos seus postos de trabalho", e a fixação de multa de R \$100.000,00 (cem mil reais), por dia, "para a hipótese de descumprimento da determinação de retorno ao trabalho". 270

É importante notar que, na petição inicial, não há remissão à Constituição de 1988 e a seu art. $9^{\circ}$, que trata do direito de greve. A leitura do processo per se não permite identificar se a ausência foi proposital, i.e. estratégica, ou se foi uma simples omissão por parte do advogado da empresa. De uma forma ou de outra, não deixa de ser um silêncio significativo - até pela proximidade temporal com a promulgação da Constituição.

A petição inicial da empresa não apresentava ao Tribunal aspectos relevantes da divergência com os petroleiros e seus sindicatos. Basta cotejar aquela peça com os documentos juntados pela própria Petrobrás. Entre eles, estavam os comunicados feitos pelas entidades sindicais à direção da empresa, onde eram apontadas as razões pelas quais optava-se pela greve. No comunicado enviado pela FUP à Petrobrás, em 27 de abril de 1995, por exemplo, estava expressa a pauta reivindicatória dos petroleiros, tendo como primeiro ponto o “cumprimento do item 3 do Protocolo assinado em 25/11/94 - 'A PETROBRÁS adequará a

\footnotetext{
${ }^{270}$ BRASIL. Tribunal Superior do Trabalho. Seção de Dissídios Coletivos. Dissídio Coletivo no 177.734/1995.
} Processo, p. 5/7. 
atual relação de interníveis, no prazo de 20 dias, visando a promover eventuais ajustes'. Este acordo é complementar ao que dispõe a cláusula 105 da Sentença Normativa do TST". ${ }^{271}$

As notificações encaminhadas pelas entidades sindicais à empresa afirmavam o atendimento do "disposto pelo art. 13 da lei 7.783/89, em consonância com o artigo $9^{\circ}$ da Constituição Federal". Já nesse momento, portanto, havia a invocação, pelos sindicatos, do novo texto constitucional.

Instaurado o dissídio, o processo foi concluso ao Presidente do Tribunal Superior do Trabalho, Ministro José Ajuricaba da Costa e Silva, que proferiu despacho, designando para 6 de maio (um sábado) audiência de "instrução e conciliação". Em seguida, o Ministro examinou, em caráter liminar, os pedidos formulados pela empresa:

Outrossim, tendo em vista a informação contida na inicial de que os Suscitados paralisaram o trabalho em quase todas as unidades da Suscitantes sem atendimento das exigências previstas na Lei 7.783 , de 29.06 .89 , no que diz respeito aos serviços ou atividades essenciais executadas pela mesma Suscitante, PETRÓLEO BRASILEIRO S/A, considerando que tal fato, de elevada gravidade para a população, já vem sendo divulgado pela imprensa escrita, falada e televisionada e considerando, ainda, o disposto nos Arts. $9^{\circ}$, 10, Inciso I, e 13, da referida lei, DETERMINO (...) (sic).

O Ministro José Ajuricaba ordenou aos integrantes da categoria dos petroleiros, mediante suas entidades sindicais, que suspendessem imediatamente o processo de paralisação total das unidades da Petrobrás, e, por acordo com a empresa, "mantenham em atividade equipes de empregados, observada a frequência de $30 \%$ (trinta por cento) dos trabalhadores com a necessária qualificação para isso indispensável, asseguradas as condições essenciais de segurança do pessoal e do patrimônio da empresa, de tal maneira que a população não venha a sofrer consequências negativas por falta de gás e combustível".

O Ministro determinou também que "a Petrobrás, na defesa do interesse público", fizesse a convocação nominal ao trabalho, observados os limites acima, das equipes de empregados necessárias ao "rigoroso" atendimento da ordem de retorno, sendo vedada a exigência de efetivo superior a $30 \%$ quanto a cada um dos grupos em que se dividia o contingente de funcionários da empresa.

\footnotetext{
${ }^{271}$ Os demais itens da pauta eram: "2 - a reposição das perdas salariais pelo ICV-DIEESE estimativa de set/94 a abril/95 - 23,63\%; 3 - a reintegração dos demitidos por participação em movimentos reivindicatórios; 4 - ao cumprimento da Lei de Anistia aos companheiros demitidos durante o governo Collor, com a consequente readmissão imediata; 5 - a recomposição dos efetivos mínimos, com uma política de contratações antecipadas, através de concursos públicos; 6 - ao pagamento dos passivos trabalhistas; 7 - a suspensão imediata da implantação do GDP (Gerênciamento de Desempenho de Pessoal), das 'flexibilizações de normas' e implementação das multifunções (polivalência)". Cf. BRASIL. Tribunal Superior do Trabalho. Seção de Dissídios Coletivos. Dissídio Coletivo no 177.734/1995. Processo, p. 35/36.
} 
Foi fixada multa de $\mathrm{R} \$ 100.000,00$, por dia e por entidade sindical ou unidade responsável, podendo ser aplicada tanto à empresa quanto aos sindicatos, em caso de descumprimento da ordem judicial. ${ }^{272}$

Vários aspectos chamam atenção na decisão do Presidente do TST: (i) na fundamentação normativa, não há referência à Constituição, a decisão tem por motivação preceitos legais apenas; ${ }^{273}$ (ii) a decisão é baseada nas alegações da empresa e no que é transmitido pela imprensa, sem que os suscitados tenham sido ouvidos; (iii) há a noção de que a greve não deve gerar transtornos ("consequências negativas") à população, por isso foi fixado um mínimo de contingente de atividades/trabalhadores a permanecer em serviço; e (iv) a perspectiva de que, no conflito entre as partes e diante da paralisação deflagrada, a "defesa do interesse público" incumbia à Petrobrás, que deveria, para tanto, fazer a convocação nominal dos trabalhadores.

Um dia após o início da greve e já depois da decisão liminar do Presidente do Tribunal Superior do Trabalho, o Presidente da República editou decreto com o objetivo de punir servidores públicos em greve. ${ }^{274}$ Embora o decreto não fosse aplicável à expressiva maioria dos grevistas (à exceção dos funcionários das universidades federais), ele dava uma importante amostra da postura que o governo adotaria diante das paralisações.

Segundo informações das próprias federações, a greve havia crescido entre petroleiros, eletricitários, funcionários das universidades federais e previdenciários.

${ }^{272}$ Cf. BRASIL. Tribunal Superior do Trabalho. Seção de Dissídios Coletivos. Dissídio Coletivo no 177.734/1995. Processo, p. 52/53.

${ }^{273}$ Não obstante, desde a promulgação da Constituição de 1988, a interpretação do art. $9^{\circ}$, sobre o direito de greve, parecia ser uma preocupação para os ministros do Tribunal Superior do Trabalho. O Ministro Marcelo Pimentel, em texto publicado na edição de 1988 da Revista do Tribunal, intitulado "A Nova Constituição e suas implicações na legislação trabalhista brasileira", escreveu: "praza aos céus que a entrega aos sindicatos do poder discricionário de decidir quando e como vão fazer greve não leve a Nação para o caos" (PIMENTEL, Marcelo. "A Nova Constituição e suas implicações na legislação trabalhista brasileira". In: Revista do Tribunal Superior do Trabalho, vol. 57, 1988, p. 69/77 (p. 73); na edição de 1989, o Ministro Orlando Teixeira da Costa publicou artigo com o título "Do abuso de direito na greve". O texto inicia com a seguinte assertiva: "A Constituição da República de 1988 assegura o direito de greve, mas prevê que 'os abusos cometidos', quando do seu exercício, 'sujeitam os responsáveis às penas da lei' (art. $9^{\circ}$, caput e $\left.\S 2^{\circ}\right)^{\circ}$ ". O autor procura, então, examinar a aplicação da "teoria civilista do abuso de direito" com relação à greve (COSTA, Orlando Teixeira da. "Do abuso de direito na greve". In: Revista do Tribunal Superior do Trabalho, vol. 58, 1989, p. 91/94 - p. 91).

${ }^{274}$ Trata-se do Decreto 1.480, de 3.5.1995, que dispõe sobre os procedimentos a serem observados em casos de paralisações dos serviços públicos federais, enquanto não regulado o art. 37, VII, da Constituição. De acordo com o art. $1^{\circ}$ do decreto, as faltas dos servidores regidos pela Lei 8.112/1990 decorrentes da participação em paralisação de serviços públicos não poderão, em nenhuma hipótese, ser objeto de abono, compensação ou cômputo para fins de contagem de tempo de serviço ou de qualquer vantagem que o tenha por base. Incumbiria, ainda, à chefia imediata transmitir ao órgão de pessoal a relação dos servidores cujas faltas se enquadrem na hipótese prevista no decreto, discriminando os ocupantes de cargos em comissão e os que percebem função gratificada, que seriam imediatamente exonerados (BRASIL. Poder Executivo. Decreto $\mathrm{n}^{\circ} 1.480$, de 3 de maio de 1995. Dispõe sobre os procedimentos a serem adotados em casos de paralisações dos serviços públicos federais, enquanto não regulado o disposto no art. 37, inciso VII, da Constituição. Diário Oficial da União. Brasília, DF, 4.5.1995). 
Especificamente quanto aos petroleiros, nas diversas refinarias em que houve adesão à paralisação, entre as reivindicações estava a correção dos níveis salariais, que fora objeto do acordo celebrado com a empresa em 1994.

A CUT, entretanto, decidiu rever sua posição. A Central havia circulado a informação de que negociaria com o governo tão somente se fossem retiradas as propostas de reforma constitucional - àquela altura, estava na pauta do Congresso Nacional a discussão sobre a quebra do monopólio do gás canalizado. Pelo novo posicionamento, tomado em reunião no dia 5 de maio, a CUT se dispôs a negociar com o governo a reforma constitucional, mesmo que as propostas de emenda do Poder Executivo não fossem retiradas do Congresso. ${ }^{275} \mathrm{Com}$ isso, a Central recuou e passou a exercer o papel de mediadora entre os grevistas e o governo. ${ }^{276}$

A partir desse momento, é perceptível que a mobilização promovida pela CUT perdeu importância. A atenção se voltou para as categorias que permaneciam em greve, em razão de pautas próprias (coincidentes, em parte, ou não, com a da CUT), como os eletricitários e, em especial, os petroleiros.

Para os grevistas da Petrobrás, estava em jogo o cumprimento dos acordos firmados com o governo em 1994, o que marcaria a reivindicação de aumentos salariais. Mas a pauta também incluía o protesto diante das reformas constitucionais, entre as quais, a quebra do monopólio da exploração do petróleo e derivados. ${ }^{277}$ Assim,

${ }^{275}$ Folha de São Paulo de 6.5.1995. Como esclarece Romão, a "posição [de negociar com o governo a reforma constitucional] foi defendida e capitaneada pela 'Articulação Sindical', corrente de que faz parte Vicentinho, então Presidente da Central. A decisão foi aprovada mesmo tendo a discordância dos sindicalistas ligados a outras forças, como a Convergência Socialista, a CSC, e a CUT pela base. Foi uma reunião bastante polêmica. A posição de sentar com o governo ia de encontro ao espírito da greve puxada pela Central, ainda mais porque havia setores dentro da CUT defendendo a decretação da greve geral já naqueles dias" (ROMÃO, Frederico Lisboa. A greve do fim do mundo: petroleiros 1995 - expressão fenomênica da crise fordista no Brasil, p. 368).

${ }^{276}$ Revista Isto é de 17.5.1995.

277 É possível que, para os grevistas, a questão do aumento salarial tivesse maior relevância. Três petroleiros entrevistados pelo $O$ Estado de São Paulo dão a entender exatamente isso. José Antonio de Souza Narciso, da Refinaria de Duque de Caixas (Reduc), no Rio de Janeiro, declarou que "o arrocho salarial é muito grande e nem com tanto tempo de empresa [20 anos] consigo ganhar um salário digno" (...) "estou dando prioridade à alimentação". Hideo Honda, da Refinaria de Paulínia, em São Paulo (Replan), também com 20 anos de empresa, afirmou que participaria de uma paralisação voltada especificamente contra o fim do monopólio da Petrobrás. Para ele, "essa é uma outra bandeira, mas no momento nosso movimento é pela questão salarial". Já para Miguel Jefinny, aposentado e dirigente do Sindipetrosul, do Rio de Grande do Sul, em primeiro lugar, a greve deveria ser instrumento para aumentar os rendimentos dos petroleiros e, "em segundo plano, o movimento combate as reformas constitucionais". Cf. O Estado de São Paulo de 5.5.1995. De acordo com o advogado Cézar Britto, entrevistado pelo autor desta pesquisa e que atuou na defesa dos sindicatos profissionais, no dissídio coletivo proposto no TST, a greve de 1995 tinha como conteúdo a questão da privatização da Petrobrás. Em suas palavras: "a Petrobrás, para o brasileiro, é uma propriedade pessoal, o Brasil se sente dono da Petrobrás. A cor verde e amarela, o nome, Petróleo brasileiro, a campanha do monopólio que resultou na propriedade fez com que nós incorporássemos a Petrobrás como algo nosso. Então a estratégia de privatizar a Petrobrás era um pouco mais delicada do que nas outras empresas. Por isso mudar o nome, de Petrobrás, de Petróleo brasileiro, para Petrobrax, tirar a cor a verde e amarela, vai ser azul, e acabar com a resistência dos trabalhadores petroleiros." 
quando as principais categorias do setor público entram em greve em 03 de maio de 1995, o que estava em jogo verdadeiramente eram as políticas que o governo pretendia por em prática. No caso dos petroleiros, a esta vontade geral se juntava a frustração dos acordos feitos com a empresa no ano anterior e até então não postos em prática. O que explica o fato de que, quando os outros trabalhadores decidem por fim às suas greves por falta de mobilização das bases, os petroleiros decidem continuar sozinhos no movimento. ${ }^{278}$

Em poucos dias, surgiram as notícias sobre as consequências da paralisação. A questão do abastecimento de gás de cozinha e de derivados de petróleo foi fundamental na greve dos petroleiros. Ainda no segundo dia da paralisação, que avançava, a Petrobrás divulgou nota indicando que "o abastecimento de petróleo e derivados está dentro da normalidade". ${ }^{279}$ De acordo com Paulo Motoki, diretor do Departamento Nacional de Combustíveis (DNC), a situação dos estoques de combustível e outros derivados de petróleo era "muito confortável". Para o diretor, o que estava em poder das distribuidoras seria suficiente para suportar de 15 a 20 dias de greve e, ainda que a paralisação durasse todo esse tempo, faltaria combustível apenas se a greve fosse total. ${ }^{280}$

Já no dia seguinte (6 de maio) vem a notícia que contrariava os prognósticos da véspera. A Petrobrás afirmou que a greve reduzira em 55\% a produção de petróleo no país. Além disso, a empresa comunicou a importação de gás de cozinha, querosene para a aviação e gasolina, em decorrência da paralisação.

Nesse mesmo dia foi realizada a audiência de conciliação e instrução no Tribunal Superior do Trabalho. A ata lavrada retrata - lembrando sempre o seu papel de intermediação ${ }^{281}$ - os discursos do preposto da suscitante, i.e., a empresa, e do representante

(BRITTO, Cézar. Depoimento sobre a greve dos petroleiros de 1995. Entrevistador: Ricardo Machado Lourenço Filho. Brasília, julho de 2014. Arquivo de som M4A).

${ }^{278}$ NEVES, Paulo S. C. "O sindicalismo na indústria petrolífera no Brasil: tendências recentes". In: Scripta Nova - Revista Electrónica de Geografía y Ciencias Sociales. Universidad de Barcelona. ISSN: 1138-9788. Depósito Legal: B. 21.741-98. Vol. VI, núm. 119 (101), 1 de agosto de 2002 (documento eletrônico), p. 7.

${ }^{279}$ Jornal do Brasil de 4.5.1995.

${ }^{280}$ Folha de São Paulo de 5.5.1995. Em outra declaração, Paulo Motoki deixa claro que a Petrobrás já previa a greve e teria se preparado: "a Petrobrás se preparou com antecedência, pois a greve já estava prevista, e por isso a situação é bem menos grave que em novembro" (O Estado de São Paulo de 3.5.1995). Na edição de 31.5.1995, a Revista Veja publicou reportagem sobre o plano de estoque de combustíveis levado a cabo pela Petrobrás antes mesmo da deflagração da greve, em 3 de maio. A preparação do governo teria incluído a transferência de combustível da Petrobrás para as distribuidoras privadas, a importação de petróleo e derivados e a contratação de trabalhadores substitutos. Ver, a respeito, Revista Veja de 31.5.1995.

${ }^{281}$ Como anota Carlo Ginzburg, "na passagem da palavra falada para a escrita, entonações, hesitações, silêncios e gestão se perdem" (In: GINZBURG, Carlo. The Judge and the Historian - marginal notes on a late-twentiethcentury miscarriage of justice. Translated by Antony Shugaar. New York: Verso, 1999, p. 19 - tradução livre). 
da FUP e dos demais sindicatos suscitados, além das participações do Ministro Presidente do Tribunal e do membro do Ministério Público do Trabalho.

É necessário indicar, nesse ponto, uma distinção no que diz respeito às funções do juiz e do historiador, como ressaltado por Carlo Ginzburg. ${ }^{282}$ Para o julgador (no Brasil), as alegações de cada parte provam o fato narrado tão somente naquilo que sejam desfavoráveis aos interesses da própria parte (ou seja, desde que se tratem de confissão). ${ }^{283}$ Para o historiador, porém, todos os discursos empregados pelos participantes do processo têm um papel importante, ou seja, têm interesse de investigação, independentemente de constituírem ou não evidência (prova) em termos processuais. ${ }^{284}$

Na audiência, o Ministro Presidente do TST tentou obter uma conciliação entre as partes. Indagado, o preposto da empresa, Clotário Francisco Cardoso, declarou "que a Petrobrás nada tinha a oferecer, no momento, objetivando tal conciliação”. Diferente foi a resposta do preposto da Federação, Antônio Carlos Spis (presidente da entidade), que afirmou sua inclinação em fazer acordo, uma vez que a discussão dizia respeito justamente a acordo anterior, firmado em setembro de 1994, e que não teria sido cumprido pela empresa.

José Ajuricaba, uma vez não alcançada a conciliação, recebeu a defesa dos suscitados e procedeu ao interrogatório das partes, a começar pela empresa. Clotário Francisco Cardoso foi indagado sobre os acordos celebrados em 1994 e seu cumprimento pela Petrobrás, bem como sobre o atendimento ou não da determinação judicial do dia 3 de maio de 1995. O preposto informou que a empresa não se sentia obrigada a cumprir o acordo do dia 10 de novembro de 1994, pois não teria sido parte na avença, e que, por outro lado, estava sendo cumprida, de forma integral, a obrigação decorrente do acordo de 25 de novembro de 1994, quanto à manutenção das cláusulas do acordo coletivo de trabalho de 1993/1994 que não conflitassem com as da sentença normativa de 1994. Com relação ao item 3 do Protocolo de 25 de novembro de 1994, Clotário Cardoso disse o seguinte:

\footnotetext{
282 Cf. GINZBURG, Carlo. The Judge and the Historian - marginal notes on a late-twentieth-century miscarriage of justice, p. 12/18.

283 Como preceitua o art. 348 do Código de Processo Civil brasileiro: "há confissão, quando a parte admite a verdade de um fato, contrário ao seu interesse e favorável ao adversário (...)” (BRASIL. Lei no 5.869, de 11 de janeiro de 1973. Institui o Código de Processo Civil. Diário Oficial da União. Brasília, DF, 17.1.1973).

${ }^{284}$ Segundo Carlo Ginzburg, "um historiador tem o direito de detectar um problema onde um juiz pode encontrar uma 'ausência de fundamentos procedimentais' ('absence of grounds for proceedings') (GINZBURG, Carlo. The Judge and the Historian - marginal notes on a late-twentieth-century miscarriage of justice, p. 17, tradução livre). É importante esclarecer que a proposta da presente pesquisa não é fazer um "julgamento" do julgamento do dissídio coletivo, mas proceder à reconstrução histórica - tendo por eixo de investigação os usos da Constituição - dos discursos que circularam no processo, no que diz respeito, em particular, ao direito de greve.
} 
que a Suscitante entende haver cumprido a obrigação assumida no item $3^{\circ}$ do Protocolo de 25 de novembro de 1994, uma vez que determinou a realização de estudos para a adequação da relação de interníveis então existentes, os quais concluíram não haver necessidade de qualquer adequação da referida relação, que os referidos estudos foram encaminhados ao Ministério das Minas e Energia, no fim do ano passado, ou no começo do corrente ano, que o acionista majoritário da Suscitante, que é o Governo Federal, entendeu, após recebidos os estudos acima referidos, que não havia necessidade de quaisquer ajustes para adequação da relação de interníveis a que se refere a cláusula $3^{\mathrm{a}}$ do Protocolo firmado em 25 de novembro de 1994, acima mencionado, que o depoente, que é Superintendente do Serviço de Recursos Humanos da PETROBRÁS, entende que havia possibilidade financeira de adequação da relação de interníveis, tendo em vista os estudos feitos neste sentido pela Suscitante, mas, sob o ponto de vista técnico, os ajustes daí decorrentes seriam inexpressivos e não justificavam uma alteração das escalas salariais existentes, que o que se pretendia, através da cláusula $3^{\text {a }}$ do Protocolo de 25 de novembro de 1994 acima mencionado, era uma modificação das escalas salariais, que entende que os estudos feitos pela PETROBRÁS em relação à adequação dos interníveis, e encaminhados ao Ministério de Minas e Energia, deveriam ter sido por este remetidos à CCE Comissão de Coordenação das Empresas Estatais, mas não sabe informar se isto foi feito por aquele Ministério, que até o presente momento o Ministério de Minas e Energia não comunicou à Suscitante se aprovava ou não as conclusões dos referidos estudos, que os estudos referidos previam alterações nos níveis salariais que eram tecnicamente desprezíveis, que o depoente e o advogado da Suscitante, Dr. Ruy Jorge Caldas Pereira, estavam presentes, quando da assinatura do termo de acordo de 15 de novembro de 1994, unicamente para assessorarem, quando solicitados, o Ministro das Minas e Energia (...) que a reunião da qual resultou o termo de acordo de 10 de novembro de 1994 começou por volta de dezoito horas e se prolongou até às duas horas e trinta minutos da manhã seguinte, que o Presidente da PETROBRÁS não esteve presente em nenhum momento à referida reunião, que os estudos feitos pela PETROBRÁS para adequação da relação de interníveis, acima referidos, em nenhum momento foram apresentados à Federação Única dos Petroleiros, ou a qualquer um dos Sindicatos Suscitados, porque, se a Suscitante o fizesse, estaria despertando expectativas na categoria que só poderiam ser autorizadas e aprovadas pelo acionista controlador da empresa, que é o Governo Federal, representado pelo Ministério das Minas e Energia, que a PETROBRÁS não assinou o termo de acordo de 10 de novembro de 1994, firmado entre o Governo Federal e a Federação Única dos Petroleiros, porque não convocada para participar dos entendimentos e negociações que resultaram no referido acordo. $^{285}$

Vale atentar para a assertiva do preposto, de que a empresa entendia que o item 3 do Protocolo assinado em 25 de novembro de 1994 havia sido cumprido, ou seja, até esse momento, a própria Petrobrás não questionava a validade do acordo, nem o fato de que tinha obrigações dele decorrentes (embora demonstrasse querer debater quais eram essas obrigações). E quanto ao ajuste de 10 de novembro de 1994, o depoimento de Clotário

${ }^{285}$ BRASIL. Tribunal Superior do Trabalho. Seção de Dissídios Coletivos. Dissídio Coletivo no 177.734/1995. Processo, p. 131/132. 
Cardoso foi contraditório: afirmou que ele e o advogado da empresa participaram da reunião (embora apenas como assessores), mas declarou que a empresa não assinou o acordo pois não fora convocada a participar dos entendimentos. Além disso, o preposto fornece importantes indícios sobre a relação entre a Petrobrás e o Ministério das Minas e Energia: as decisões de adequação salarial (como no caso dos interníveis) deveriam ser autorizadas justamente por esse Ministério, que atuava como representante do acionista majoritário da empresa, i.e., da União. ${ }^{286} \mathrm{O}$ representante da empresa reconheceu, ainda, que os estudos realizados sequer haviam sido apresentados à Federação ou às demais entidades sindicais.

Clotário Cardoso foi interrogado sobre o cumprimento da determinação do Presidente do TST, narrando em quais unidades a ordem judicial estava sendo cumprida, e, em quais, não (como nas refinarias de Duque de Caxias, Porto Alegre, Curitiba, Paulínia, São José dos Campos, Cubatão e Mataripe), inclusive diante do fato de, em algumas delas, não ter sido alcançado acordo com o sindicato profissional.

O Ministro José Ajuricaba passou à oitiva de Antônio Carlos Spis, representante da FUP e dos sindicatos suscitados. $\mathrm{O}$ dirigente afirmou que a própria FUP recomendara às demais entidades o contato com as Procuradorias Regionais do Trabalho para a celebração de acordo com o objetivo de que fosse atendida a ordem do TST. Spis relatou que a Federação, em reuniões com o Serviço de Recursos Humanos da Petrobrás, cobrou os estudos feitos para adequação da relação de interníveis. O Coordenador da FUP informou ter ouvido de Clotário Cardoso, bem como de Joel Rennó, Presidente da empresa, que os estudos teriam concluído pela possibilidade de aporte salarial da ordem de $12 \%$ a $18 \%$ para os petroleiros, e que a Petrobrás teria disponibilidade financeira para fazer frente a essas despesas. Spis declarou, no entanto, que as entidades sindicais não receberam qualquer comunicação escrita sobre a conclusão de tais estudos, não obstante a empresa tivesse enviado ofício indicando que eles foram remetidos ao Ministério de Minas e Energia, para aprovação.

Com relação aos acordos, Spis afirmou que os petroleiros não estavam em greve, nem havia ameaça de nova paralisação, quando foi celebrado o ajuste de 10 de novembro de 1994. Narrou que a determinação de retorno imediato ao trabalho, oriunda do DC 131.024/1994, foi cumprida. Segundo Spis, o Ministro Marcelo Pimentel não firmou o ajuste de 10 de novembro de 1994, até porque não esteve presente até o término da reunião, às 2 h30 da manhã do dia seguinte (a reunião começara no dia 9 e terminara no dia 10). O dirigente

\footnotetext{
${ }^{286}$ Deve ser lembrado que o acordo do dia 10 de novembro de 1994 foi assinado exatamente pelo então Ministro de Minas e Energia, Delcídio Gomez, e, por outro lado, pela FUP, como se verifica do documento juntado ao processo (cf. BRASIL. Tribunal Superior do Trabalho. Seção de Dissídios Coletivos. Dissídio Coletivo ${ }^{\circ}$ 177.734/1995. Processo, p. 111 e 152).
} 
sindical relatou, ainda, que Joel Rennó participara de parte da referida reunião. Como a Petrobrás não cumpriu o ajuste, de acordo com Spis, os petroleiros deflagraram greve em 23 de novembro de 1994, a qual foi encerrada pelo acordo firmado no dia 25 de novembro. ${ }^{287}$

Sobre a ordem judicial do dia 3 de maio, Antonio Spis se manifestou no sentido de que, nas unidades em que houve acordo, estava sendo cumprido o percentual estabelecido (30\%). Nas demais unidades, estavam ocorrendo "entendimentos e negociações" para que a determinação fosse integralmente cumprida. Spis esclareceu que os "efetivos" produziam GLP, óleo diesel e derivados de petróleo, de maneira a garantir a manutenção dos produtos essenciais, não havendo paralisação total em nenhuma refinaria. $\mathrm{O}$ dirigente negou, mais uma vez, que houvesse paralisação total em alguma região, não constituindo obstáculo à formalização de acordo a rejeição da empresa em informar os estoques locais dos produtos ou mesmo a exigência de jornada de 12 horas. ${ }^{288}$

O Ministro José Ajuricaba chegou a suspender a reunião por mais de uma hora para tentar uma conciliação entre as partes, mas sem êxito. Atendendo a pedido dos suscitados, José Ajuricaba determinou à Petrobrás que juntasse os estudos realizados acerca da adequação da relação de interníveis salariais. ${ }^{289}$

As partes aduziram suas alegações finais. A Petrobrás reiterou que se cuidava de uma greve abusiva, porque não observado o comando judicial e porque não atendidas as formalidades legais. Sustentou que: "trata-se, como notório, de uma greve de natureza exclusivamente política, convocada e deflagrada em conjunto com outras categorias, desprovida, na realidade, de qualquer conteúdo de reivindicação trabalhista". A empresa reduzia o Protocolo de 25 de novembro de 1994 a "uma manifestação de intenções no sentido de reabertura de negociações e de estudos com vistas a procederem-se eventuais ajustes nas tabelas salariais". De toda forma, a Petrobrás realizara os estudos necessários, concluindo pela viabilidade de "pequenos ajustes nos interníveis", mas não obteve autorização do Governo Federal para tanto. A greve seria abusiva porque deflagrada na vigência de sentença normativa. Sobre as consequências da paralisação, a empresa referiu à nota que "acabara" de ser encaminhada à imprensa acerca do funcionamento de diversas refinarias. ${ }^{290}$

${ }^{287}$ BRASIL. Tribunal Superior do Trabalho. Seção de Dissídios Coletivos. Dissídio Coletivo no ${ }^{\circ}$ 177.734/1995. Processo, p. 133/134.

${ }^{288}$ BRASIL. Tribunal Superior do Trabalho. Seção de Dissídios Coletivos. Dissídio Coletivo no 177.734/1995. Processo, p. 134/135.

${ }^{289} \mathrm{O}$ resultado dos estudos consta das p. 140/144 do processo. Os estudos em si não foram juntados.

${ }^{290}$ A nota tinha o seguinte conteúdo: "Com referência à greve dos petroleiros, a Petrobrás informa que as refinarias Gabriel Passos, em Betim/MG, de Capuava, em Mauá/SP, e de Manaus/AM, e as unidades de Xisto, em São Mateus do Sul, no Paraná, e a Fábrica de Asfalto de Fortaleza/CE estão operando e atendendo às necessidades da população por ela abastecida. As demais refinarias, Alberto Pasqualini, no Rio Grande do Sul, 
As alegações finais dos suscitados foram mais breves. Alegaram que a greve tinha amparo no art. 14 da Lei de Greve, ${ }^{291}$ diante do descumprimento do acordo no que dizia respeito à adequação dos interníveis salariais, como ficara incontroverso no depoimento do preposto. Para os suscitados, o acordo exigia as adequações nas tabelas de salário. Afirmaram também que a ordem judicial estava sendo atendida: “(...) fiel cumprimento das determinações deste Tribunal, no seguinte sentido, garantir o contingente de $30 \%$ de trabalhadores quando não houver acordos regionais, preservação dos equipamentos e atendimento às necessidades da população e que até o momento não há notícia de que esteja faltando qualquer derivado de petróleo em qualquer região do país”. Requereram, por fim, que fosse determinado o imediato cumprimento do acordo, sob pena de multa, além da decretação da legalidade da greve. ${ }^{292}$

Dada a palavra ao Ministério Público do Trabalho, o Subprocurador Geral do Trabalho, Ives Gandra da Silva Martins Filho, opinou pela declaração de abusividade da greve e pela procedência das reivindicações dos petroleiros. Para o membro do MPT, o depoimento do preposto da Petrobrás indicava o descumprimento do acordo firmado em 25 de novembro de 1994. Além disso, quanto às formalidades legais, especificamente quanto ao pré-aviso para a deflagração da greve, o movimento fora amplamente divulgado pela imprensa, de maneira que tanto a população quanto a empresa ("que imediatamente começou a adotar as medidas necessárias ao aumento de produção para formação de estoques para enfrentar a greve”)

Duque de Caxias, no Rio de Janeiro, Presidente Getúlio Vargas, no Paraná, Landulpho Alves, na Bahia, e Paulínia, Cubatão e Henrique Lages, em São Paulo, encontram-se paradas. Os empregados dessas refinarias não acataram a ordem judicial do TST para retornarem ao trabalho, e os estoques de GLP (gás de cozinha) da região de Campinas poderão atingir níveis preocupantes se as refinarias de Paulínia e Henrique Lages não voltarem a operar imediatamente. Nesse caso, a Petrobrás, terá de reduzir as entregas às companhias distribuidoras. Os níveis de refino situam-se em 180 mil barris por dia, correspondendo a $12 \%$ da capacidade instalada. A produção de petróleo é de 90 mil barris por dia, ou 38\% da produção normal, enquanto o fornecimento de gás natural situa-se em 7,5 milhões de metros cúbicos por dia, 70\% da disponibilidade normal" (BRASIL. Tribunal Superior do Trabalho. Seção de Dissídios Coletivos. Dissídio Coletivo no 177.734/1995. Processo, p. 136). A nota encaminhada pela empresa gera uma perplexidade: como visto há pouco, a decisão do Ministro Presidente do TST estava fundamentada nas alegações da Petrobrás e no que era noticiado pela imprensa. Ocorre que a nota ora referida mostra, como também indicado no tópico anterior deste trabalho, que parte significativa das informações que a imprensa exibia sobre a greve dos petroleiros vinha justamente da empresa e do governo. Em outras palavras, é possível que a decisão liminar do TST tenha se baseado em grande parte em alegações da própria Petrobrás, de forma direta ou indireta.

291 “Art. 14. Constitui abuso do direito de greve a inobservância das normas contidas na presente Lei, bem como a manutenção da paralisação após a celebração de acordo, convenção ou decisão da Justiça do Trabalho. Parágrafo único. Na vigência de acordo, convenção ou sentença normativa não constitui abuso do exercício do direito de greve a paralisação que: I - tenha por objetivo exigir o cumprimento de cláusula ou condição; II - seja motivada pela superveniência de fatos novo ou acontecimento imprevisto que modifique substancialmente a relação de trabalho" (BRASIL. Lei no 7.783, de 28 de junho de 1989. Dispõe sobre o exercício do direito de greve, define as atividades essenciais, regula o atendimento das necessidades inadiáveis da comunidade, e dá outras providências).

${ }^{292}$ BRASIL. Tribunal Superior do Trabalho. Seção de Dissídios Coletivos. Dissídio Coletivo no 177.734/1995. Processo, p. 137. 
foram comunicadas. Teriam sido atendidos os artigos 14, I, e 13 da Lei de Greve ${ }^{293}$ - não há referência, no parecer, à Constituição de 1988. O Subprocurador observou, porém, que as informações obtidas pelas Procuradores Regionais do Trabalho apontavam para o descumprimento da ordem judicial em algumas regiões - daí a abusividade da greve. Com relação às reivindicações dos petroleiros, Ives Gandra Martins Filho opinou pela determinação de cumprimento do acordo pela Petrobrás. ${ }^{294}$

O julgamento do dissídio coletivo foi marcado para 9 de maio. O relator seria o Ministro Ursulino Santos.

Na defesa apresentada pela FUP, que representava todas as entidades sindicais rés, os acontecimentos de 1994 eram assim narrados: com o malogro das tentativas de negociação, em setembro, houve a deflagração da greve no dia 27 desse mês e o ajuizamento de dissídio coletivo pela empresa; mesmo após a sentença normativa do TST, continuaram as reivindicações quanto a cláusulas preexistentes e às que já haviam sido acordadas com a empresa durante o processo de negociação (todas teriam sido suprimidas pelo Tribunal); com a intervenção do governo federal, foi estabelecido um acordo público, em 5 de outubro, com a participação do então Presidente da República, Itamar Franco, e dos Ministros de Estado, Ciro Gomes, Marcelo Pimentel, Delcídio Gomez e Mauro Durante; diante do não cumprimento do acordo pela Petrobrás, os petroleiros organizaram nova greve, para o dia 11 de novembro ${ }^{295}$, mas, antes de seu início, foi firmado novo acordo coletivo, assinado por Delcídio Gomes, então Ministro de Minas e Energia, e contando com a participação de gerentes e do Presidente da empresa, Joel Mendes Rennó, além do Ministro do Trabalho, Marcelo Pimentel; a Petrobrás descumpriu mais uma vez o acordo, ao argumento de que não fora firmado por representante legal da empresa; os petroleiros entraram em greve no dia 23 de novembro, o que ensejou a propositura de novo dissídio coletivo pela Petrobrás; no mesmo dia da audiência de conciliação, em 25 de novembro, celebrou-se novo acordo, ficando estabelecida a suspensão do movimento pelos petroleiros e a desistência do processo por parte da empresa. A Federação sustentava que, passados cinco meses, a Petrobrás não cumpriu a cláusula que

\footnotetext{
293 "Art. 13. Na greve, em serviços ou atividades essenciais, ficam as entidades sindicais ou os trabalhadores, conforme o caso, obrigados a comunicar a decisão aos empregadores e aos usuários com antecedência mínima de 72 (setenta e duas) horas da paralisação" (BRASIL. Lei no 7.783, de 28 de junho de 1989. Dispõe sobre o exercício do direito de greve, define as atividades essenciais, regula o atendimento das necessidades inadiáveis da comunidade, e dá outras providências).

${ }^{294}$ BRASIL. Tribunal Superior do Trabalho. Seção de Dissídios Coletivos. Dissídio Coletivo no 177.734/1995. Processo, p. 137/138.

${ }^{295}$ Há aqui contradição entre o que foi alegado pela FUP na peça de defesa e o depoimento de Antonio Carlos Spis na audiência do dia 6 de maio (quando o dirigente negou que houvesse ameaça de nova paralisação à época da celebração do acordo de 10 de novembro).
} 
previa a adequação dos interníveis, isto é, a reformulação da tabela dos níveis salariais, o que implicaria aumento de remuneração em torno de $12 \%$. $^{296}$

A FUP contestava também a implementação, pela empresa, do sistema de "Gerenciamento de Desempenho de Pessoal - GDP”, que contrariaria a própria sentença normativa proferida pelo TST no DC - 131.024/94.0. Ao tratar da legalidade da greve, a defesa da Federação invocava o art. 14, parágrafo único, I, da Lei de Greve e relatava que todos os requisitos legais haviam sido cumpridos. Afirmava que a ordem judicial do Presidente do TST também estava sendo atendida. Apresentava, por fim, a pauta de reivindicações. ${ }^{297}$

A defesa foi acompanhada dos documentos pertinentes aos acordos de 1994, bem como das comunicações dos sindicatos, da empresa e do Ministério Público do Trabalho sobre o cumprimento (ou não) da determinação do Presidente do TST. ${ }^{298}$

296 O Protocolo assinado em 25 de novembro de 1994 estabelecia: “1) Prosseguimento das conversações entre a PETROBRÁS e a FEDERAÇÃO ÚNICA DOS PETROLEIROS e os SINDICATOS visando a assinatura de um novo Acordo Coletivo a vigir até agosto de 1995; 2) A PETROBRÁS garante a manutenção das cláusulas do Acordo Coletivo 93/94, que não conflitem com as cláusulas deferidas pela Sentença Normativa do TST Processo DC - 131.024/94.0, até a assinatura do novo acordo; 3) Amparada na cláusula 105 da Sentença Normativa do processo TST DC - 131.024/94.0, a PETROBRÁS adequará a atual relação de interníveis, no prazo de 20 dias, visando a promover eventuais ajustes; 4) A aplicação das cláusulas anteriores ficará condicionada às seguintes condições: a) suspensão imediata da greve com retorno ao trabalho a partir do turno de 23:30 horas; b) desistência por parte da Petrobrás do dissídio coletivo no TST-DC-46.945/94.3 suscitado junto ao TST, com a concordância da FUP e SINDICATOS, em face do encerramento do movimento grevista neste ato" (BRASIL. Tribunal Superior do Trabalho. Seção de Dissídios Coletivos. Dissídio Coletivo nº 177.734/1995. Processo, p. 82 e 146 - o documento estava assinado por José Lima de Andrade Neto, Superintendente Adjunto do Serviço de Recursos Humanos da Petrobrás, e por Rosemberg Evangelista Pinto, diretor da FUP). A cláusula 105 da sentença normativa do processo 131.024/94.0 previa que "dentro do prazo de vigência do Acordo, a Companhia analisará a atual relação internível das escalas salariais, visando a possibilidade e promover eventuais adequações de caráter exclusivamente técnico, vinculados à manutenção do equilíbrio remuneratório interno". Logo abaixo do texto da cláusula, vem a observação de que "a empresa, à folha 34, concorda com a pretensão" (BRASIL. Tribunal Superior do Trabalho. Seção de Dissídios Coletivos. Dissídio Coletivo $\mathrm{n}^{\circ}$ 177.734/1995. Processo, p. 22).

297 Cf. BRASIL. Tribunal Superior do Trabalho. Seção de Dissídios Coletivos. Dissídio Coletivo $\mathrm{n}^{\circ}$ 177.734/1995. Processo, p. 80/88. A pauta é a mesma apresentada nas comunicações endereçadas à empresa pelas entidades sindicais, como visto acima, e tem como primeiro tópico o cumprimento do item 3 do protocolo assinado em 25 de novembro de 1994 com a empresa.

298 As respostas à ordem do TST foram variadas. O Sindicato dos Trabalhadores na Indústria de Destilação e Refinação do Petróleo de Porto Alegre, Canoas, Osório e Tramandaí - Rio Grande do Sul, por exemplo, afirmou "ser absolutamente inócua a determinação com relação às plantas instaladas no âmbito do RS, eis que mantida a frequência de contingente de trabalhadores superior ao índice de 30\%, determinados nos itens I e II do referido despacho" (BRASIL. Tribunal Superior do Trabalho. Seção de Dissídios Coletivos. Dissídio Coletivo $\mathrm{n}^{\circ}$ 177.734/1995. Processo, p. 97). Já o Sindicato dos Trabalhadores na Indústria de Destilação e Refinação de Petróleo no Estado de Minas Gerais alegou que "a direção da Refinaria Gabriel Passos [em Betim/MG], em desacato à mesma Ordem Judicial, (...) insiste em convocar nominalmente, um número de empregados que ultrapassa, em muito, o percentual estipulado por esta Corte" (BRASIL. Tribunal Superior do Trabalho. Seção de Dissídios Coletivos. Dissídio Coletivo no 177.734/1995. Processo, p. 99). Havia também documento elaborado pelo Chefe da Divisão de Suprimento de Petróleo e Combustíveis da Petrobrás, datado de 5 de maio de 1995, indicando o estado crítico do abastecimento de GLP, diesel e querosene de aviação (BRASIL. Tribunal Superior do Trabalho. Seção de Dissídios Coletivos. Dissídio Coletivo no 177.734/1995. Processo, p. 112). Outro documento emitido pela própria Petrobrás indicava que, na Refinaria de Presidente Bernardes, não houve acordo 
Chama atenção, mais uma vez, a inexistência de referência à Constituição de 1988 - muito embora, como já assinalado, algumas comunicações que as entidades sindicais haviam enviado à Petrobrás, sobre a decisão de deflagração da greve, invocassem de maneira expressa o art. $9^{\circ}$ do texto constitucional. Ao afirmar a legalidade da greve, em sua defesa, a FUP construía argumentação baseada apenas no texto da Lei 7.783/1989.

Enquanto o processo de dissídio coletivo foi interrompido, aguardando-se o julgamento da greve, vieram a público outras notícias sobre a questão do abastecimento de derivados de petróleo. No dia 7, foi anunciado que São Paulo, a partir do dia seguinte, poderia ficar sem gás de cozinha e, a partir do dia 10, poderia faltar também combustível para a aviação. Os estados do sul e do centro-oeste poderiam ficar sem GLP a partir do dia 8 do mesmo mês. $\mathrm{O}$ argumento era o de que, a despeito dos estoques de gás de cozinha, a greve impedia sua distribuição em quantidade suficiente. Havia também, de acordo com a empresa, risco de desabastecimento de óleo diesel. ${ }^{299}$

Em 8 de maio, a Petrobrás divulgou nota indicando que os estoques de GLP eram "muito baixos". O Diretor do Departamento Nacional de Combustíveis, Paulo Motoki, em notícia publicada no dia 9 - mesmo dia do julgamento do dissídio coletivo pelo Tribunal Superior do Trabalho -, desdizendo sua própria afirmação de 4 dias antes, declarou que o estoque de gás de cozinha seria suficiente para apenas uma semana mais. ${ }^{300}$

E, ao longo da greve dos petroleiros, foram diversas as informações sobre os problemas de abastecimento de petróleo e derivados, bem como sobre os transtornos causados à população. Por inúmeras vezes, os jornais publicaram as fotos de carros nas filas dos postos de gasolina, ou de pessoas carregando botijões de gás após horas em longas filas. Em determinado momento, a imprensa divulgou que o governo admitia a possibilidade de racionamento de combustíveis. ${ }^{301}$ Poucos dias depois, as próprias distribuidoras de

com o sindicato profissional, na medida em que a empresa entendia que para o cumprimento da ordem judicial, com o contingente fixado, seria necessário modificar o regime de trabalho, de turnos de 6h (usualmente praticado) para o de 12h (em caráter de emergência) (BRASIL. Tribunal Superior do Trabalho. Seção de Dissídios Coletivos. Dissídio Coletivo no 177.734/1995. Processo, p. 118).

${ }^{299}$ Folha de São Paulo de 6 e 7.5.1995. Cf. também Jornal do Brasil de 6 e 9.5.1995. A essa altura, a estimativa era a de que $95 \%$ dos empregados da Petrobrás teriam aderido à paralisação, segundo informações da própria CUT. Ver O Estado de São Paulo de 6.5.1995.

${ }^{300}$ Folha de São Paulo de 8 e 9.5.1995. Os elementos já relatados - como a própria contradição do Diretor do Departamento Nacional de Combustíveis - são indícios de que a falta de combustíveis e derivados de petróleo podem ter decorrido de ação das próprias distribuidoras (independentemente da greve deflagrada, portanto) - o que foi confirmado cerca de três anos depois.

${ }^{301}$ Folha de São Paulo de 17.5.1995 (disponível em http://www1.folha.uol.com.br/fsp/1995/5/17/brasil/21.html e http://www1.folha.uol.com.br/fsp/1995/5/17/brasil/22.html, acesso em 22.1.2014), Jornal do Brasil de 17 e 18.5.1995 e O Estado de São Paulo de 12.5.1995. Ainda no começo da greve, reportagens do Jornal do Brasil destacavam os prejuízos causados a algumas indústrias em decorrência da greve dos petroleiros (ver edição de 9.5.1995). E pouco antes do final da paralisação, o Estado de São Paulo noticiou que "Varejistas dizem que 
combustíveis iniciaram um racionamento. Alguns postos fecharam por falta de combustível. ${ }^{302}$ Enfatizavam-se às dificuldades enfrentadas pela população, diante das informações sobre a falta de gás de cozinha e de combustíveis. Em um periódico, com tom alarmista, lia-se: "com 17 dias completados na sexta-feira 19, a greve dos petroleiros tem custado aos brasileiros sacrifícios só enfrentados por populações submetidas a racionamento de guerra". ${ }^{303}$ O porta-voz da Presidência da República, embaixador Sérgio Amaral, afirmou que "a greve está causando prejuízo ao país e à população". 304

O Presidente da Petrobrás, Joel Rennó, publicou artigo, alguns dias após o começo da paralisação, sustentando que "os movimentos grevistas, sobretudo quando conduzidos por lideranças ultrapassadas e agitando bandeiras reivindicatórias exorbitantes e inviáveis, não contam com a aprovação da população e dos nossos legisladores”. Em outra passagem, destacou os transtornos causados: "além de contrariarem interesses econômicos e estratégicos do país, tornam-se punitivos das camadas mais carentes do povo, bastando pesar os seus perversos efeitos no suprimento do gás de cozinha e no transporte coletivo". 305

A ênfase nos prejuízos causados pela paralisação dos petroleiros - sobretudo por parte da direção da empresa - e, posteriormente, no fato de que a greve não seria aprovada pela população (i.e., pelos não-grevistas) parecia cumprir uma função menos informativa do que estratégica. Ela confluiu para a formação de uma opinião pública que - como será visto certamente teve um peso significativo no desenlace da greve e da disputa de força entre os grevistas e o governo.

É nesse contexto que o processo de dissídio coletivo foi a julgamento na Seção de Dissídios Coletivos do Tribunal Superior do Trabalho em 9 de maio de 1995.

situação é calamitosa", com a seguinte chamada: "empresários varejistas dizem que a crise do abastecimento de combustíveis atinge praticamente todo o Estado; no Rio, os proprietários de postos afirmam que a situação é de pré-colapso" (edição de $\left.1^{\circ} .6 .1995\right)$.

${ }^{302}$ Folha de São Paulo de 22.5.1995 (disponível em http://www1.folha.uol.com.br/fsp/1995/5/22/brasil/9.html, acesso em 29.1.2014).

${ }^{303}$ Revista Isto é de 24.5.1995. Em uma montagem, essa mesma revista colocava em uniformes militares, de tom cinza azulado, o presidente da CUT, o coordenador da FUP e José Maria de Almeida, presidente do PSTU, diante de uma mesa tática. Na parte superior da página, em uniforme militar típico do exército brasileiro, em cor verde oliva, uma montagem com o presidente da Petrobrás, o Ministro de Minas e Energia e o Presidente da República. Frederico Lisboa Romão observa que "a questão do desabastecimento de combustíveis e gás de cozinha tratada pela mídia desde o início da greve, passou a ganhar maior destaque depois da nota da Petrobrás no dia 08.05; daí em diante torna-se seguidamente manchetes nos jornais: fotos de filas quilométricas de populares em busca de botijão; de pessoas em simples bicicletas transportando 7 botijões; depoimentos de cidadãos falando da dificuldade de comprar o gás de cozinha; possibilidade de racionamento, cotas de limite máximo de botijão por pessoa, botijão sendo vendido com ágio de quase 100\%" (ROMÃO, Frederico Lisboa. $A$ greve do fim do mundo: petroleiros 1995 - expressão fenomênica da crise fordista no Brasil, p. 386).

${ }^{304}$ Folha de São Paulo de 17.5.1995 (disponível em http://www1.folha.uol.com.br/fsp/1995/5/17/brasil/21.html, acesso em 22.1.2014).

${ }^{305}$ Folha de São Paulo de 19.5.1995 (disponível em http://www1.folha.uol.com.br/fsp/1995/5/19/opiniao/9.html, acesso em 28.1.2014). 


\subsection{O primeiro julgamento pelo TST: abusividade da greve e invalidade dos acordos}

No começo da sessão de julgamento, antes de passar ao exame da greve dos petroleiros, o Ministro José Ajuricaba, Presidente da Corte, fez um registro, pertinente a questão que já havia sido levantada em sessão anterior do Tribunal. O Ministro Presidente se referiu a matéria, veiculada pelo Jornal do Brasil, com críticas ao Poder Judiciário e à Justiça do Trabalho. Para o ministro, o periódico havia sido injusto nas observações, além de impreciso e incorreto quanto à Justiça do Trabalho. José Ajuricaba ressaltou o crescimento no número de processo ao longo da primeira metade da década de 1990, assim como, por outro lado, o grande volume de processos solucionados pelo TST. O ministro acentuou a agilidade da Corte em "processos de interesse da coletividade", como o que estavam prestes a julgar. ${ }^{306}$

Feito o registro, o Ministro Ermes Pedro Pedrassani indagou o Ministro Presidente se esse último permitiria que os fotógrafos fizessem os registros e depois se retirassem. José Ajuricaba respondeu que eles haviam sido colocados à distância, tendo recomendado que não adentrassem no recinto de julgamento. E observou: "creio que não podemos impedir que eles estejam presentes para assistir". 307

A Corte passou ao exame da ação de dissídio coletivo. Após uma discussão inicial sobre alguns documentos juntados pela Petrobrás, relativos aos estudos para adequação das tabelas dos interníveis, ${ }^{308}$ o Ministro Ursulino leu o relatório e, depois da sustentação oral dos advogados das partes, ${ }^{309}$ deteve-se na análise de uma questão preliminar, pela qual era arguida a ilegitimidade do Sindipetro - PE para figurar no processo, ao argumento de que os trabalhadores por ele representados não participavam do movimento grevista.

\footnotetext{
${ }^{306}$ Cf. as notas taquigráficas da sessão de julgamento do dia 9 de maio de 1995 , referente ao processo TST-DC177.734/1995 (BRASIL. Tribunal Superior do Trabalho. Seção de Dissídios Coletivos. Dissídio Coletivo no 177.734/1995. Notas taquigráficas da sessão de julgamento. Brasília, DF, 9.5.1995, p. 2/3). Merece transcrição o seguinte trecho: "vale salientar que este Tribunal tem procurado agilizar a solução dos processos de interesse da coletividade. Aos dissídios coletivos como este que vamos julgar no início da sessão, da Petrobrás contra os petroleiros, como o dissídio coletivo dos eletricitários - todos de atividades cuja paralisação acarreta prejuízos para a coletividade - tem-se dado prioridade absoluta, trabalhando-se até mesmo em dias de sábado, como ocorreu com instrução do processo de dissídio dos eletricitários, que se verificou no sábado passado. Tudo isto é feito pela Justiça do Trabalho com a preocupação de atender à coletividade; conseqüentemente, é um ramo do Poder Judiciário que não merece, data vênia, as críticas acerbas, injustas e falsas muitas vezes, que se tem feito a este Orgão do Poder Judiciário" (p. 3). A manifestação do Presidente do Tribunal contou com o apoio dos advogados das partes e do Procurador Geral da Justiça do Trabalho, João Pedro Ferraz dos Passos.

307 Ver notas taquigráficas da sessão de 9 de maio de 1995, p. 6.

${ }^{308} \mathrm{Na}$ audiência de instrução, havia sido determinado à suscitante que juntasse os referidos estudos, que teriam sido encaminhados ao Ministério de Minas e Energia. A Petrobrás juntou apenas uma tabela, sem comprovação de que seria o mesmo documento enviado ao Ministério. Os suscitados impugnaram o documento. O Ministro Relator, porém, rejeitou a impugnação, no que foi acompanhado pelos demais ministros.

${ }^{309}$ As sustentações orais dos advogados não foram transcritas nas notas taquigráficas.
} 
A preliminar foi rejeitada pelo ministro relator, uma vez que a greve extrapolava a jurisdição de outros Tribunais Regionais do Trabalho e a empresa possuía quadro de carreira organizado em âmbito nacional, em razão do que eventual decisão sobre as reivindicações profissionais seria aplicada a todos os trabalhadores, mesmo nas bases territoriais de sindicatos que não haviam aderido à paralisação. ${ }^{310}$

Prosseguindo no julgamento, o Ministro Ermes Pedro Pedrassani suscitou a ilegitimidade da Federação Única dos Petroleiros - FUP para figurar no polo passivo do processo. $\mathrm{O}$ ministro questionou se a Federação reuniria as características de uma entidade sindical. O relator, por sua vez, leu dispositivos do estatuto da Federação, observando que "não é uma organização sindical daquelas que surgem pelo tipo confederativo, que é usado pela legislação brasileira. É o mesmo que um Movimento dos Sindicatos Democráticos de Brasília. É uma Confederação dos Sindicatos Democráticos. Nomes criados assim, são nomes fictícios". 311 Mas Ursulino Santos disse que não estava dando importância a essa circunstância, pois os sindicatos estavam representados nos autos.

Dá-se no processo, nesse instante, uma discussão relevante para a compreensão da dimensão do julgamento. ${ }^{312}$ Diante dos esclarecimentos do Ministro Ursulino, o Ministro Pedrassani externou a preocupação no sentido de que não fosse constituído precedente quanto ao reconhecimento da legitimação da FUP, "porque, se ela não integra o sistema sindical brasileiro, não pode estar aqui. E a circunstância de estarem elencados também os sindicatos não a legitima do mesmo modo".313

O advogado da FUP, Carlos Alberto Boechat Rangel, pediu a palavra para prestar um esclarecimento. Informou que existia uma Federação Nacional dos Petroleiros, mas que, àquela altura, estava em processo de extinção. De acordo com o advogado, em segundo grau, a única entidade representativa era a FUP, cujo processo de registro, no Ministério do Trabalho, ainda estava em andamento. ${ }^{314}$

310 Cf. BRASIL. Tribunal Superior do Trabalho. Seção de Dissídios Coletivos. Dissídio Coletivo $\mathrm{n}^{\circ}$ 177.734/1995. Processo, p. 350, e notas taquigráficas da sessão de 9 de maio de 1995, p. 17/18.

${ }^{311}$ BRASIL. Tribunal Superior do Trabalho. Seção de Dissídios Coletivos. Dissídio Coletivo no 177.734/1995. Notas taquigráficas da sessão de julgamento, 9.5.1995, p. 19/20 ( sic).

312 Chamou atenção para esse fato, em entrevista concedida ao autor desta pesquisa, o advogado Cézar Britto, procurador do Sindicato dos Petroleiros de Sergipe e integrante do núcleo de defesa da FUP no dissídio coletivo perante o TST (Cf. BRITTO, Cézar. Depoimento sobre a greve dos petroleiros de 1995).

${ }^{313}$ Notas taquigráficas da sessão de julgamento de 9 de maio de 1995, p. 21.

${ }^{314}$ Até hoje se trata de uma questão controvertida no âmbito do direito do trabalho saber se o reconhecimento da entidade sindical (inclusive federações e confederações) pelo Ministério do Trabalho é necessário para que seja atribuída personalidade sindical à entidade. A problemática tem fundamento na Constituição, cujo art. $8^{\circ}$, I, estabelece que "a lei não poderá exigir autorização do Estado para a fundação de sindicato, ressalvado o registro no órgão competente, vedadas ao Poder Público a interferência e a intervenção na organização sindical" (BRASIL. Constituição (1988). Constituição da República Federativa do Brasil). O Tribunal Superior do 
Após o esclarecimento do advogado, o Ministro Almir Pazzianotto recordou a jurisprudência do Tribunal no sentido de que os sindicatos, ao comparecerem perante o TST, não tinham representatividade nacional que os habilitasse a ajuizar dissídio coletivo ou responder a dissídio coletivo perante a Corte Superior - pois eram organizações regionais. Como a Federação (FUP) não detinha personalidade jurídica sindical, a questão que se colocava seria "romper" ou não com a jurisprudência do Tribunal. Em caso positivo, o resultado seria a fixação de nova orientação, permitindo que sindicatos estaduais, municipais ou intermunicipais atuassem junto ao TST. Para manter a jurisprudência, a solução seria, segundo o ministro, convocar a CNTI (Confederação Nacional dos Trabalhadores da Indústria). ${ }^{315}$

Nova discussão, sobre a natureza da FUP, e o Ministro Pedrassani proferiu voto pela ilegitimidade da Federação, sendo acompanhado pelo Relator e pelo Revisor, Ministro José Luiz Vasconcellos (que alertou para a possível incoerência no julgamento, na medida em que fora rejeitada a preliminar de ilegitimidade do Sindicato de Pernambuco).

Usou a palavra Thaumaturgo Cortizo, Ministro Classista representante dos empregados. Cortizo lembrou que, no processo de dissídio coletivo do ano anterior, a FUP

Trabalho mantém entendimento quanto à necessidade do registro perante o Ministério do Trabalho, como consta da Orientação Jurisprudencial 15 da SDC: “A comprovação da legitimidade 'ad processum' da entidade sindical se faz por seu registro no órgão competente do Ministério do Trabalho, mesmo após a promulgação da Constituição Federal de 1988" (BRASIL. Tribunal Superior do Trabalho. Seção de Dissídios Coletivos. Orientação Jurisprudencial no 15. Diário de Justiça, Brasília, DF, 27.3.1998).

315 BRASIL. Tribunal Superior do Trabalho. Seção de Dissídios Coletivos. Dissídio Coletivo no 177.734/1995. Notas taquigráficas da sessão de julgamento, 9.5.1995, p. 24. Em determinado momento da discussão, o representante do Ministério Público do Trabalho observou que a FUP fora apontada como suscitada pela própria Petrobrás. Diante dessa nota, a resposta do Ministro Pazzianoto foi incisiva: "mas, Sr. Presidente, não me consta até hoje que a Petrobrás tenha sido incumbida, pela Constituição e pela lei, de imprimir reconhecimento ou conferir personalidade jurídica a qualquer tipo de associação. Eu não sabia que a Petrobrás tinha essa prerrogativa. Li todo o Estatudo da Petrobrás hoje, li toda a lei que organizou a Petrobrás, do saudoso Presidente Getúlio Vargas e do saudoso Euzébio Rocha, e não encontrei essa prerrogativa que o ilustre Representante do Ministério Público traz à tona. Realmente, confesso minha ignorância: não sabia que a Petrobrás pode imprimir o selo da da legitimidade jurídica sindical" (BRASIL. Tribunal Superior do Trabalho. Seção de Dissídios Coletivos. Dissídio Coletivo $\mathrm{n}^{\circ}$ 177.734/1995. Notas taquigráficas da sessão de julgamento, 9.5.1995, p. 25 sic). Mais à frente, na sessão de julgamento, o Procurador Geral do Trabalho, João Pedro Ferraz dos Passos, rebateu as críticas de Pazzianotto: "Sr. Presidente, eu gostaria de registrar que o Ministério Público, em momento algum, disse que a Petrobrás tem o poder de estabelecer uma representação sindical. Chamei a atenção aqui, inclusive o fiz de forma paralela a V. Exa., para o fato de V. Exa ter dito que a Petrobrás não impugnou a legitimidade. O Ministério Público colocou apenas que 'nem poderia', porque ela chamou a federação a Juízo. O Ministério Público conhece perfeitamente a Constituição e a CLT em relação à organização das entidades sindicais. E mais, ressaltando novamente, não há nesses autos, em nenhum momento, qualquer registro formal de que a FUP tenha-se apresentado para representar as entidades sindicais. Ela veio, porque foi arrolada pela suscitante e respondeu ao chamado do Juízo. (...) Por esta razão, somos da opinião de que a federação deve, nesta hipótese, permanecer no pólo passivo ou, se assim não for entendido, que se chame os sindicatos e que se faça nova instrução para que eles se façam representar. O que não pode é eles ficarem na expectativa de estarem representados em uma audiência de instrução e julgamento e depois, aquele que os representou, ser excluído do pólo passivo e eles ficarem absolutamente sem voz no dissídio coletivo" (BRASIL. Tribunal Superior do Trabalho. Seção de Dissídios Coletivos. Dissídio Coletivo $\mathrm{n}^{\circ}$ 177.734/1995. Notas taquigráficas da sessão de julgamento, 9.5.1995, p. 29 - sic). 
também estivera presente e o caso foi julgado pelo TST. Observou que a Petrobrás firmara acordo - o Protocolo - com essa mesma Federação e notou que não havia registro de que a CNTI tivesse interesse em ingressar no processo. De acordo com o ministro, a exclusão da FUP deveria implicar a inclusão daquela Confederação, o que poderia levar dias. ${ }^{316}$ Cortizo indagou, então: “a Nação pode continuar a esperar mais dias, enquanto nós é que estaríamos procrastinando, então, o movimento paredista em função do ingresso de mais uma entidade e a retirada da Federação Única dos Petroleiros, quando esta mesma Corte, numa assentada passada, admitiu? Entendo, Sr. Presidente, com a devida máxima venia, que não devemos".317 É nesse momento que a Corte decidiu reconhecer a legitimidade da FUP. A reconsideração de voto por parte do Ministro Pazzianotto é significativa:

(...) Entendo, Sr. Presidente, que em matéria de organização sindical e em matéria de movimentos sociais, greves, a legislação possui uma eficácia diminuta, quase que nula, porque são fenômenos muito dinâmicos, ao passo que a legislação, pela sua própria natureza, é estática. As leis costumam resistir à passagem do tempo e à mudança dos fatos, criando até um atrito entre a legislação e a realidade. Que a organização sindical brasileira está caduca, não tenho dúvida alguma: ela está totalmente ultrapassada. Creio de devemos deixar os interessados mais a vontade para determinarem a sua forma de organização. (...) Ainda que, rigorosamente, essa Federação Nacional dos Petroleiros não corresponda precisamente aos poucos artigos que tratam das organizações sindicais a nível superior (...), o fato é que ela tem a adesão dos sindicatos dos trabalhadores. (...) Vou reconsiderar o meu voto, Sr. Presidente, porque temo pela suspensão do julgamento. Creio que isso ocasionaria uma dificuldade maior. ${ }^{318}$

Como constou do voto do Ministro Ursulino Santos (que permaneceu vencido), prevaleceu o entendimento pela legitimidade da Federação, tomado por maioria, "calcado principalmente no exercício de fato, por esta Federação, da representatividade dos sindicatos da categoria profissional, atestado pelo reconhecimento desta representatividade pela própria Suscitante [a Petrobrás], que a listou entre os suscitados e que com ela negociou". 319

\footnotetext{
${ }^{316} \mathrm{Na}$ entrevista já mencionada, o advogado Cézar Britto relatou ter sugerido a Carlos Alberto Boechat Rangel que esclarecesse à Corte que a FUP ainda não tinha registro reconhecido no Ministério do Trabalho. A intenção era justamente a de que, caso o Tribunal declarasse a ilegitimidade da Federação, seria necessário convocar outra entidade de âmbito nacional, o que atrasaria o julgamento e permitiria que a greve se desenvolvesse. Cf. BRITTO, Cézar. Depoimento sobre a greve dos petroleiros de 1995.

317 BRASIL. Tribunal Superior do Trabalho. Seção de Dissídios Coletivos. Dissídio Coletivo no 177.734/1995. Notas taquigráficas da sessão de julgamento, 9.5.1995, p. 31.

${ }^{318}$ BRASIL. Tribunal Superior do Trabalho. Seção de Dissídios Coletivos. Dissídio Coletivo no 177.734/1995. Notas taquigráficas da sessão de julgamento, 9.5.1995, p. $32 / 33$.

${ }^{319}$ BRASIL. Tribunal Superior do Trabalho. Seção de Dissídios Coletivos. Dissídio Coletivo no 177.734/1995. Processo, p. 350. Ficaram vencidos, além de Ermes Pedrassani e Ursulino Santos, os Ministros José Luiz Vasconcellos e Armando de Brito (a SDC era então composta por 12 Ministros).
} 
A premência do julgamento influenciou o reconhecimento da legitimidade da FUP. Isso também ficou expresso no voto do Ministro Roberto Della Manna, Classista representante dos empregadores, que rejeitou a preliminar com base, "principalmente", na "situação de fato que estamos vivendo" e na "preocupação com o problema nacional que estamos enfrentando". 320

O Ministro Relator seguiu para o exame da legalidade da greve. Ursulino Santos rejeitou a alegação de ilegalidade da paralisação por descumprimento do art. $9^{\circ}$ da Lei de Greve e do preceito que exigia a prévia comunicação, com 72 horas de antecedência, ao empregador e aos usuários de serviços essenciais (art. 13). ${ }^{321}$ Mas o Ministro entendeu que, em Minas Gerais, a greve fora iniciada antes do previsto. Ursulino Santos registrou, ainda, a existência de "fortes evidências" de que não estava sendo garantida a prestação de serviços indispensáveis ao atendimento das necessidades inadiáveis da comunidade. ${ }^{322}$

O Ministro Relator rejeitou a assertiva dos suscitados de que teria havido descumprimento da sentença normativa proferida no processo TST-DC-131.024/1994. Isso porque não havia expirado o prazo para observância da cláusula e, além disso, ela não

${ }^{320}$ BRASIL. Tribunal Superior do Trabalho. Seção de Dissídios Coletivos. Dissídio Coletivo no 177.734/1995. Notas taquigráficas da sessão de julgamento, 9.5.1995, p. 36. Percebe-se o anseio dos integrantes da Corte em julgar o dissídio. Some-se a isso o registro feito pelo Ministro Presidente no início do julgamento. São utilizadas expressões como "interesse da coletividade", "problema nacional”, há a preocupação com a "nação". É possível que essa forma de argumentação estivesse relacionada aos ataques que a Justiça do Trabalho e, em especial, o Tribunal Superior do Trabalho vinham recebendo desde a Assembleia Nacional Constituinte de 1987/1988, quando se propôs a extinção do TST. Essas questões se fizeram presentes mesmo após a promulgação da Constituição de 1988 e por boa parte da década de 1990, ora em termos de extinção do Tribunal Superior, ora da própria Justiça do Trabalho, ou, ainda, de redução de sua competência. Em face de tais ataques, tem-se a impressão de que o TST pretendia justificar sua atuação e a da Justiça do Trabalho perante "a coletividade". Sobre a configuração institucional do TST, bem como a respeito das propostas de sua extinção, ver FREITAS, Lígia Barros de. A consolidação institucional do Tribunal Superior do Trabalho (TST) na longa constituinte (1987-2004). Tese de Doutorado. Universidade Federal de São Carlos, 2012.

${ }^{321}$ Os preceitos enunciam, respectivamente: “Art. $9^{\circ}$ Durante a greve, o sindicato ou a comissão de negociação, mediante acordo com a entidade patronal ou diretamente com o empregador, manterá em atividade equipes de empregados com o propósito de assegurar os serviços cuja paralisação resultem em prejuízo irreparável, pela deterioração irreversível de bens, máquinas e equipamentos, bem como a manutenção daqueles essenciais à retomada das atividades da empresa quando da cessação do movimento. Parágrafo único. Não havendo acordo, é assegurado ao empregador, enquanto perdurar a greve, o direito de contratar diretamente os serviços necessários a que se refere este artigo. (...) Art. $13 \mathrm{Na}$ greve, em serviços ou atividades essenciais, ficam as entidades sindicais ou os trabalhadores, conforme o caso, obrigados a comunicar a decisão aos empregadores e aos usuários com antecedência mínima de 72 (setenta e duas) horas da paralisação" (BRASIL. Lei nº 7.783, de 28 de junho de 1989. Dispõe sobre o exercício do direito de greve, define as atividades essenciais, regula o atendimento das necessidades inadiáveis da comunidade, e dá outras providências).

322 Após referir às informações prestadas nos autos pelo Ministério Público do Trabalho, Ursulino Santos remeteu à posição externada pelo Ministro Orlando Teixeira da Costa quando do julgamento do dissídio coletivo, entre as mesmas partes, em 1994 (Cf. BRASIL. Tribunal Superior do Trabalho. Seção de Dissídios Coletivos. Dissídio Coletivo no 131.024/1994. Rel. Ministro Indalécio Gomes Neto). Nas palavras do Ministro Ursulino: “(...) a simples emissão da ordem emanada da Presidência da Corte por si só revela a desobediência ao art. 11 da Lei de Greve, pois que somente este fato autoriza a prática do ato judicial referido, como bem já demonstrou o Ministro Orlando Teixeira da Costa em anterior julgamento de dissídio coletivo envolvendo as mesmas partes" (BRASIL. Tribunal Superior do Trabalho. Seção de Dissídios Coletivos. Dissídio Coletivo $\mathrm{n}^{\circ}$ 177.734/1995. Processo, p. 351). 
estipulava obrigação à empresa de implementação de mudança na relação dos interníveis. ${ }^{323}$ Quanto aos acordos firmados em 5 de outubro (em Juiz de Fora), 10 de novembro e 25 de novembro de 1994, Ursulino Santos entendeu que a Petrobrás não figurava como parte nos dois primeiros, de maneira que o descumprimento dos ajustes pela Petrobrás não impedia "a incidência do art. 14 da Lei no 7.783/89". Com relação ao terceiro acordo, ele "não [vestia] o figurino adequado". O Ministro recorreu a um argumento de caráter formal para afastar a exigibilidade do acordo:

Para emprestar-lhe o caráter de um acordo coletivo de trabalho e exequibilidade, falta-lhe os requisitos mínimos que a lei exige para a celebração, como a deliberação da assembléia da entidade sindical convenente, realizada com o comparecimento dos interessados e observância do "quorum' específico, as cláusulas obrigatórias e o depósito no competente órgão do Ministério do Trabalho. ${ }^{324}$

Segundo o ministro relator, a ausência, nos autos, dos estatutos das entidades sindicais suscitadas impedia a constatação de que as formalidades ali previstas teriam sido cumpridas na deflagração da greve. Pelo exame das notas taquigráficas da sessão de julgamento, vê-se que Ursulino leu as atas das assembleias dos sindicatos profissionais, conferindo o quantitativo de trabalhadores presentes em cada uma delas. Segundo o ministro, “fiz questão de ler o número de participantes, etc., para mostrar a V. Exas. que não foi trazido aos autos qualquer estatuto, a não ser o da” FUP. E complementou: “então, como posso dizer, na qualidade de Relator, que as assembleias gerais obedeceram o estatuto, quando é uma exigência da lei que regulamenta a greve? (...) E quem deveria fazer a prova de que essa assembleia foi realizada de acordo com o estatuto é a parte interessada. Até hoje é a regra: quem alega, aprova". 325

\footnotetext{
${ }^{323}$ Tratava-se da cláusula 105 da sentença normativa, já transcrita - “(...) dentro do prazo de vigência do Acordo, a Companhia analisará a atual relação internível das escalas salariais, visando a possibilidade e promover eventuais adequações de caráter exclusivamente técnico, vinculados à manutenção do equilíbrio remuneratório interno" (BRASIL. Tribunal Superior do Trabalho. Seção de Dissídios Coletivos. Dissídio Coletivo $n^{\circ}$ 177.734/1995. Processo, p. 22).

${ }^{324}$ BRASIL. Tribunal Superior do Trabalho. Seção de Dissídios Coletivos. Dissídio Coletivo no 177.734/1995. Processo, p. 352. Em entrevista, concedida ao autor deste trabalho, um Ministro do Tribunal Superior do Trabalho, embora então não compusesse a Seção de Dissídios Coletivos, chamou atenção para o fato de que a Seção extinguia vários processos de dissídios coletivos por questões formais. Segundo ele, a SDC extinguia processos "por tolices (ex. dissídio extinto porque estavam presentes à assembleia apenas 200 trabalhadores, e não 300)". Está implícito nas palavras do entrevistado que a referência é aos dissídios propostos pelas categorias profissionais. Além disso, a assertiva acima deve ser compreendida a partir da visão mais ampla, expressada pelo mesmo Ministro entrevistado, de que o Tribunal da época "era um tribunal apegado ao empregador, ao governo. Esse era o 'caldo de cultura' daquele tribunal".

${ }^{325}$ BRASIL. Tribunal Superior do Trabalho. Seção de Dissídios Coletivos. Dissídio Coletivo no 177.734/1995. Notas taquigráficas da sessão de julgamento, 9.5.1995, p. 47.
} 
A conclusão do ministro relator trilhava o caminho da abusividade da paralisação:

por todo o exposto, declaro abusivo o movimento grevista e autorizo o desconto dos dias em que houve paralisação do trabalho, com a devida repercussão nos contratos individuais, determinando o imediato retorno dos trabalhadores à atividade, cominando multa diária de R\$100.000,00 (cem mil reais), para cada entidade sindical, na hipótese de manutenção da greve após às 12:00 horas de amanhã, dia 10 de maio de 1995.

As reivindicações dos grevistas foram, em seguida, julgadas improcedentes pelo relator, seja porque o acordo celebrado em 25 de novembro de 1994 não atendia à forma legal ("não cabe determinar a implementação do acordo firmado pelas partes em 25/11/94, por este não se identificar com a forma legal de um convênio coletivo de trabalho"), seja porque as demais reivindicações implicariam revisão da sentença normativa anterior, prolatada em 1994, o que seria vedado pelo art. 873 da CLT. ${ }^{326}$

$\mathrm{Na}$ declaração de abusividade da greve, ficou vencido apenas o Ministro Thaumaturgo Cortizo. Com relação à improcedência das reivindicações, votaram contrariamente ao relator os Ministros Thaumaturgo Cortizo e José Ajuricaba, além do Juiz Convocado Mauro Viola. Com esse placar, a Seção de Dissídios Coletivos do Tribunal Superior do Trabalho julgou ilegal a paralisação dos petroleiros, reputando-a abusiva, autorizou o desconto dos dias parados, determinou o imediato retorno à atividade, sob pena de multa de $\mathrm{R} \$ 100.000,00$ por dia, para cada entidade sindical, e julgou improcedentes as reivindicações profissionais.

Os Ministros Almir Pazzianotto e Armando de Brito apresentaram, por escrito, votos convergentes ao do relator.

A base do voto do Ministro Almir Pazzianotto foi o argumento de que nem o Presidente da República, nem o Ministro de Estado poderiam "agir em nome da Petrobrás, assinando acordo coletivo de trabalho, alteração de acordo coletivo ou de sentença normativa". O Ministro detalhou as normas que regiam o funcionamento interno da empresa, criada pela Lei 2.004, de 3 de outubro de 1953, para concluir que:

esses impedimentos [de atuação pelo Presidente da República ou por Ministro de Estado] parecem-me óbvios, pois sendo a Petrobrás uma

\footnotetext{
326 “Art. 873 - Decorrido mais de 1 (um) ano de sua vigência, caberá revisão das decisões que fixarem condições de trabalho, quando se tiverem modificado as circunstâncias que as ditaram, de modo que tais condições se hajam tornado injustas ou inaplicáveis" (BRASIL, Decreto-Lei $n^{\circ} 5.452$, de $1^{\circ}$ de maio de 1943). A citação precedente corresponde a BRASIL. Tribunal Superior do Trabalho. Seção de Dissídios Coletivos. Dissídio Coletivo no 177.734/1995. Processo, p. 352.
} 
sociedade de economia mista, de capital aberto, com forte participação acionária de pessoas físicas e jurídicas de direito privado, não compete ao Presidente da República interferir na sua vida administrativa, nos seus negócios, nas suas atividades, a não ser na forma e pela maneira previstas em lei. Pelas mesmas razões, não pode o Sr. Presidente emitir cheque, fazer compras ou efetuar vendas em nome e por conta da empresa. ${ }^{327}$

Para Almir Pazzianotto, o primeiro acordo, por ele chamado de "encontro de Juiz de Fora", não estava assinado e conteria cláusulas que "não [poderiam] ser consideradas como integrando acordo coletivo de natureza salarial". Já o segundo "suposto acordo", assinado por Delcídio Gomez, então Ministro de Minas e Energia, "evidentemente, esse documento não vincula a Petrobrás": “nem a Constituição, nem a Lei 2.004/53, nem os Estatutos da Petrobrás, concedem a Ministro de Estado prerrogativas para assumir obrigações em nome das sociedades anônimas de economia mista". O terceiro acordo teria sido subscrito por pessoa - o Superintendente Adjunto do Serviço de Recursos Humanos da Petrobrás - que não possuía poderes para celebrá-lo: “(...) apesar das suas boas intenções, o subscritor desse Protocolo não detinha poderes para realizar essa negociação, nem ela foi ratificada posteriormente pela Presidência da Petrobrás. Nos autos do processo não encontrei documento que me leve a concluir em outra direção". ${ }^{328}$ Em síntese:

Inexistindo o suposto acordo celebrado com o Presidente da República Dr. Itamar Franco, sendo destituído de qualquer validade o documento assinado pelo então Ministro das Minas e Energia, e não havendo sido ratificado o Protocolo que contém o autógrafo do Superintendente Adjunto, devo concluir que a Petrobrás, em momento nenhum, se obrigou ou foi obrigada validamente a reajustar, recalcular salários ou a praticar novos interníveis. ${ }^{329}$

Esse aspecto é importante no voto do Ministro Pazzianotto. Ele fez questão de enfatizar que "não houve acordo algum”. A questão era relevante: “é aconselhável que o acórdão que venha a ser proferido deixe muito claro, porque foi dito da tribuna que houve

\footnotetext{
${ }^{327}$ BRASIL. Tribunal Superior do Trabalho. Seção de Dissídios Coletivos. Dissídio Coletivo no ${ }^{\text {177. }}$ 1734/1995. Processo, p. 355. Merece atenção a utilização do recurso à obviedade, talvez numa tentativa de encerrar a discussão, além de deixar evidente a crítica a entendimento contrário.

${ }^{328}$ Vale notar que a prova dos poderes do Superintendente poderia ser feita apenas pela empresa, mas essa certamente não teria interesse na sua produção. Por outro lado, é possível que, para a própria Petrobrás, fosse natural sua representação por algum superintendente. Na audiência mesma realizada em 6 de maio no TST, a empresa se fez representar justamente pelo Superintendente do Serviço de Recursos Humanos e não consta dos autos qualquer documento (como uma procuração, por exemplo) que conferisse ao superintendente poderes expressos de representação.

${ }^{329}$ BRASIL. Tribunal Superior do Trabalho. Seção de Dissídios Coletivos. Dissídio Coletivo no 177.734/1995. Processo, p. 355. Lembre-se que a Petrobrás, em momento algum do processo, questionou a validade, em especial, do acordo firmado em 25 de novembro de 1994. Pelo contrário, seu preposto, em audiência - o Superintendente Adjunto do Serviço de Recursos Humanos -, afirmou que a empresa entendia ter cumprido o referido ajuste.
} 
dois acordos. Não houve". Segundo Pazzianotto, "houve - perdoem-me a palavra - duas fantasias". Após examinar os preceitos - já mencionados - pertinentes à Petrobrás, o ministro observou que “o Presidente da República (...) não pode assinar acordo coletivo em nome da Petrobrás. Se assinar, Sr. Presidente, Sua Excelência estará dando demonstração do seu desconhecimento, do seu despreparo, da sua, talvez, ingenuidade, das suas concessões políticas, porque Sua Excelência não pode obrigar a Petrobrás". 330

No que dizia respeito ao terceiro acordo, cuja validade também havia sido rejeitada por Pazzianotto, o advogado da FUP pediu a palavra para esclarecer que, em nenhum momento, a Petrobrás contestara a existência ou a validade do ajuste. O Ministro assim rebateu o argumento: “(...) Sr. Presidente, eu, como Juiz, neste tipo de matéria, não prendo demasiadamente àquilo que foi dito ou alegado", referindo-se, logo após, à lei que criara a Petrobrás e a seus estatutos. E concluiu seu raciocínio da seguinte forma:

Uma empresa com essas características não pode ser administrada, comprometida em lance dessa responsabilidade, por um adjunto que não exibiu autorização de ninguém; ou ser comprometida por um Ministro interino acidentalmente guindado á titularidade do Ministério das Minas e Energia; ou até mesmo ser comprometida por um gesto do Presidente da República, que, no fim de seu mandato, resolver desconhecer uma decisão da Justiça do Trabalho. O Presidente resolveu ignorar, tripudiar sobre a decisão da Justiça do Trabalho. Ora, isso é possível? Não, por isso a lei que criou a Petrobrás e previu a existência dos estatutos cerca as medidas da administração de garantias, que não pode desconhecer, embora não tenha sido alegadas. Aqui defendo também um pouco o contribuinte. ${ }^{331}$

${ }^{330}$ BRASIL. Tribunal Superior do Trabalho. Seção de Dissídios Coletivos. Dissídio Coletivo no 177.734/1995. Notas taquigráficas da sessão de julgamento, 9.5.1995, p. 51. Em outro trecho de seu voto, Pazzianotto afirmou que: “(...) não houve acordo coletivo de trabalho algum vinculando a Petrobrás, assinado pelo Presidente Itamar Franco e pelo Ministro de Minas e Energia. Houve dois atos, com máxima vênia, inconsequentes de duas altíssimas autoridades do Poder Executivo: o próprio Chefe do Executivo Federal e um de seus Ministros de Estado. Não deveria ter feito isso. Induziram os trabalhadores e os dirigentes sindicais da Petrobrás em graves equívocos, sem nenhuma consequência jurídica" (p. 52).

${ }^{331}$ BRASIL. Tribunal Superior do Trabalho. Seção de Dissídios Coletivos. Dissídio Coletivo no 177.734/1995. Notas taquigráficas da sessão de julgamento, 9.5.1995, p. 57. A questão dos poderes do Superintendente Adjunto de Recursos Humanos da Petrobrás foi lembrada pelo Procurador-Geral do Trabalho, que o considerava legítimo. O Procurador registrou sua discordância com a posição do Ministro Pazzianotto e observou o seguinte: "Então, por entender que esses poderes estão garantidos para esse cidadão [o Superintendente Adjunto do Serviço de Recursos Humanos] é que o Ministério Público, evidentemente, não vai adotar providências que deveria, se de certa forma concordasse com a fundamentação do voto do Ministro Almir Pazzianotto. Porque, neste caso, eu teria, naturalmente, de pedir a extração de peças ou pegar esse documento e encaminhar ao Ministério Público Federal competente, para que fizesse uma investigação acerca de seu houve ou não usurpação de poderes, porque temos aqui um servidor de alto nível da Petrobrás, que é uma empresa que se reputa séria, e que assinou esse documento perante empregados. Então, ele estaria aqui certamente usurpando poderes que ele não tem. Só pelo fato de o Ministério Público entender que há esses poderes é que ele exarou esse Parecer" (BRASIL. Tribunal Superior do Trabalho. Seção de Dissídios Coletivos. Dissídio Coletivo n 177.734/1995. Notas taquigráficas da sessão de julgamento, 9.5.1995, p. 71). 
O Ministro Pazzianotto rejeitou as reivindicações dos grevistas, algumas delas por fugirem ao âmbito de exercício do poder normativo da Justiça do Trabalho (como o cumprimento da Lei de Anistia, por exemplo), e ressaltou, às entidades sindicais, que estava em vigor a sentença normativa proferida pelo Tribunal em 1994. ${ }^{332}$ Ao final, o Ministro acompanhou o relator, concluindo "pela abusividade do movimento grevista, entre outras coisas, pelo desrespeito à Ordem Judicial que determina, como manda a Constituição e a Lei, a continuidade das atividades essenciais inadiáveis para a comunidade".

O voto escrito do Ministro Pazzianotto contém a primeira referência (expressa) à Constituição naquele julgamento, embora a argumentação, sobre o texto constitucional, não tivesse nenhum desenvolvimento. É interessante, ainda assim, observar que a invocação à Constituição apareceu para destacar a abusividade da greve, porque não observada a ordem constitucional e legal de "continuidade das atividades essenciais inadiáveis para a comunidade". A ênfase dizia respeito aos deveres decorrentes da greve, mas não ao potencial do direito em si, em especial às garantias previstas aos grevistas.

No voto do Ministro Armando de Brito houve a remissão mais direta à Constituição. A posição do Ministro foi também a mais contundente. Ao pedir, na sessão de julgamento, a juntada de seu voto, o ministro afirmou:

Trata-se de um voto em que fala o juiz e fala o cidadão, que está atormentado pela sucessão de greves que estão ocorrendo neste País, que mais parecem movimento estudado, calculado, liderado, enfim, com finalidade política. É o que deploro neste voto convergente, uma vez que estamos em vias de reformar a Constituição, trazendo à baila a necessidade de revermos até o próprio art. $9^{\circ}$ da Constituição, que se presta a tão sérios desvirtuamentos, a ponto de albergar, quiçá, a tese de que a greve política é possível. ${ }^{333}$

Em seu voto, o Ministro Armando de Brito atacou de maneira expressa os dirigentes sindicais, enaltecendo os esforços do governo em enfrentar o problema da inflação,

\footnotetext{
332 Almir Pazzianotto assim advertiu os sindicatos: "impõe-se concluir que a Federação e os Sindicatos por ela coordenados não apreenderam perfeitamente a situação criada após o julgamento do Dissídio Coletivo TST-DC 131.024/94.0, Ac. 1181/94, de 30 de setembro de 1994. Apesar da reunião com o ex-Presidente Itamar Franco, do encontro com o ex-Ministro Delcídio Gomez, e do Protocolo subscrito pelo Superintendente Adjunto, todos inócuos juridicamente, é aquela Sentença que se acha em vigor, e a desistência daquele Processo, ou a modificação daquele julgado, depende de ajuste bilateral válido, no qual a Petrobrás se faça representar em conformidade com as disposições da Lei 2.004/53 e dos seus Estatutos" (BRASIL. Tribunal Superior do Trabalho. Seção de Dissídios Coletivos. Dissídio Coletivo no 177.734/1995. Processo, p. 356).

${ }^{333}$ BRASIL. Tribunal Superior do Trabalho. Seção de Dissídios Coletivos. Dissídio Coletivo no 177.734/1995. Notas taquigráficas da sessão de julgamento, 9.5.1995, p. 58.
} 
o que pode ser tido como um indício do compromisso da Corte com a política econômica (e com o Plano Real):

Estamos vivendo de algum tempo a esta data momentos - longos momentos até - de inquietação e desalento. Tomando ciência pela imprensa, pela ampla publicidade na televisão, ouvindo pronunciamentos do Congresso Nacional, sabemos que está deflagrado um movimento político-sindical para se opor às reformas constitucionais propostas pelo Governo. É clara a incitação aos eventos grevistas e às paralisações-relâmpago.

Eles querem exaurir a sociedade, vencendo-a pelo cansaço. Certos dirigentes sindicais fazem convocações iradas com discursos claudicantes na defesa dos monopólios, que, na realidade, se traduzem na defesa do lesivo sistema corporativista-imobilista enquistado nas estatais e trazendo danos graves à economia nacional. Num ensejo em que o Governo, tentando debelar a inflação, não permite há meses que subam os preços de tarifas públicas; a gasolina, em episódio inédito neste País, até baixou de preço. ${ }^{334}$

Armando de Brito se referiu à greve dos marítimos, julgada abusiva, e à dos rodoviários (essa última deflagrada em Brasília, de domingo para segunda-feira daquela semana) para indicar que "temos o abuso do uso da liberdade. Estamos, pois, ante uma situação de rebeldia contra as instituições, onde já se não obedecem as ordens judiciais de manter em funcionamento 30\% (trinta por cento) das atividades das categorias em greve".

Para o ministro, a "greve política" devia ser encarada como "matéria diretamente ligada à sobrevivência da ordem democrática, ou seja, como verdadeira questão de segurança nacional". ${ }^{335}$ Não seria admissível, em sua ótica, que "150 milhões de brasileiros" ficassem "reféns de 500 mil funcionários grevistas de estatais" (a referência não é, portanto, apenas aos trabalhadores da Petrobrás). ${ }^{336}$ Era particular a situação normativa do país:

Não há lei democrática no mundo que, com tanta liberalidade, tenha cuidado desse tema "greve" em sua Constituição, escrita ou costumeira, de modo a erigir agrupamentos sindicais em um poder de Estado, com potencial para, querendo, e com motivação qualquer, paralisar um País.

Isto só se vê no Brasil. ${ }^{337}$

\footnotetext{
334 Em outra passagem, o Ministro indagou se os político-sindicalistas pretendem "governar o País; mas, inviabilizando-o antes como Nação". Cf., para ambas as citações, BRASIL. Tribunal Superior do Trabalho. Seção de Dissídios Coletivos. Dissídio Coletivo nº 177.734/1995. Processo, p. 357.

${ }^{335}$ Destaca-se o vínculo estabelecido entre manutenção da ordem democrática e segurança nacional, considerado o exercício do direito de greve e eventual paralisação de natureza política. Aqui fica evidente a tensão com o passado da ditadura militar e, ao mesmo tempo, o desafio da Constituição de 1988 de romper com esse passado.

${ }^{336}$ Tais grevistas estariam "liderados por uma central sindical que perdeu as eleições políticas majoritárias para a Presidência da República e que tenta, por este modo, punir os eleitores que a derrotaram e, por via reflexa, ao seu candidato" (BRASIL. Tribunal Superior do Trabalho. Seção de Dissídios Coletivos. Dissídio Coletivo $\mathrm{n}^{\circ}$ 177.734/1995. Processo, p. 357).

${ }^{337}$ BRASIL. Tribunal Superior do Trabalho. Seção de Dissídios Coletivos. Dissídio Coletivo no 177.734/1995. Processo, p. 357.
} 
De acordo com Armando de Brito, era necessário alterar o texto constitucional. ${ }^{338}$ E as sucessivas manifestações "legais e moderadoras da Justiça do Trabalho", nos processos envolvendo o direito de greve, estavam se tornando "desgastantes" para o próprio Poder Judiciário, na medida em que "as direções supra-sindicais politizadas não cumprem as decisões". O Ministro parecia se referir aos desdobramentos do dissídio coletivo dos petroleiros do ano anterior, como se nota na passagem seguinte: "e o pior é que, ainda, por vezes após os julgamentos definitivos, são chamadas [as direções supra-sindicais politizadas] aos conciliábulos nos mais altos escalões do Executivo, numa tentativa vã, a nosso ver, de manter uma pacífica convivência".

O Ministro Armando de Brito reiterou a necessidade de alteração do texto constitucional e ressaltou que os abusos deviam ser punidos de maneira efetiva. Segundo ele:

É necessário, sim, e urgente expungir o texto quase irresponsável inserido no caput do art. $9^{\circ}$ da Constituição, para torná-lo um referencial sério e assegurador de um direito a fim de tornar claro para o leigo em Direito que não é ele absoluto e irrestrito - o da greve por qualquer motivo, em qualquer oportunidade a critério das lideranças.

Esperar que se cometam abusos e mais abusos para reprimir os responsáveis segundo as penas da lei, conforme escrito no $\S 2^{\circ}$ do mesmo art. $9^{\circ}$, é postergar uma solução, é quase projetar uma impunidade, porque, em movimentos de massa, ficam diluídas as responsabilidades, justificando os sindicatos e seus dirigentes que o movimento, que escapou ao seu controle, tinha finalidade econômica - quase sempre um pretexto -, dada a revolta dos trabalhadores com a política das reformas constitucionais, etc, etc. E, assim, na verdade, malgrado os prejuízos para o País e seu povo, sempre os abusos ficam impunes.

E concluiu pela abusividade da greve dos petroleiros - só então houve referência direta ao movimento daquele ano: “é por isso, vislumbrando na greve dos petroleiros mais uma tentativa de sublevar o País, e mais uma vez deplorando as leis brandas ou dúbias que temos, voto pela abusividade da greve dos petroleiros em defesa da sobrevivência da ordem jurídica e da sobrevivência das instituições democráticas que muitos dirigentes timbram por atos ou por omissões em levar à derrocada". 339

\footnotetext{
${ }^{338}$ Em suas palavras: "por essas razões de vivência desses dias, em que organismos sobrevivem de contribuições confederativas e de partidos políticos, é que se devem ter ceifadas da Constituição as normas dúbias em que, com audácia, a organização sindical lastreia suas posições e tumultua, impondo reações no próprio meio obreiro, inconformado com tal ação política deletéria e, portanto, trazendo a insegurança para a vida dos cidadãos e da coletividade" (BRASIL. Tribunal Superior do Trabalho. Seção de Dissídios Coletivos. Dissídio Coletivo no 177.734/1995. Processo, p. 357).

339 BRASIL. Tribunal Superior do Trabalho. Seção de Dissídios Coletivos. Dissídio Coletivo no 177.734/1995. Processo, p. 358.
} 
O voto do Ministro Armando de Brito se voltou diretamente contra a Constituição, afirmando a necessidade de sua modificação no que toca ao direito de greve. Em última análise, há uma declaração de não aplicação do art. $9^{\circ}$ do texto constitucional. A paralisação dos petroleiros, diante disso, seria abusiva, segundo o Ministro, em nome da sobrevivência da ordem jurídica e das instituições democráticas. Valeria a pergunta: quer isso dizer que o direito de greve estaria afastado desses dois campos?

$\mathrm{Na}$ investigação sobre a greve de 1995, é importante questionar sobre as relações entre o Poder Executivo e o Tribunal Superior do Trabalho. Em determinados momentos, parecia haver o compromisso da Corte com a política econômica adotada pelo governo (e combatida pelos trabalhadores), como no voto acima do Ministro Armando de Brito. ${ }^{340}$ Por outro lado, talvez existisse, por parte do Executivo, a confiança de que o TST efetivamente julgaria abusiva a greve. O Ministro do Planejamento, José Serra, indagado sobre as recentes paralisações no país, afirmou que os movimentos grevistas "são normais dentro de um sistema democrático" e que "claro que nós não gostamos das greves na área pública, mas está aí o Tribunal do Trabalho para julgar e é lá que o governo defende a sua posição". 341

Após o julgamento da greve pelo Tribunal Superior do Trabalho, o governo externou a expectativa de que a decisão judicial fosse acatada, com o retorno imediato ao trabalho. ${ }^{342}$ A Federação Única dos Petroleiros, entretanto, decidiu propor, nas assembleias, a

\footnotetext{
${ }^{340} \mathrm{O}$ compromisso do TST com a política econômica do governo não é uma peculiaridade da decisão proferida na greve dos petroleiros de 1995. Em entrevista concedida ao autor desta pesquisa, o então Procurador-Geral do Trabalho, João Pedro Ferraz dos Passos, trazendo à tona o papel do Tribunal Superior e do Ministério Público quanto à política econômica, relatou que: "a pressão no TST era sempre, por quê? Porque existia uma limitação do Tribunal de conceder reajustes salariais, de conceder a correção salarial, mas sempre respeitando a política econômica estabelecida pelo governo, inclusive tinha, na época, o Ministério Público tinha o dever de recorrer de todas as decisões... Quer dizer, era um recurso, que era obrigatório para o Ministério Público, dele recorrer sempre que as decisões do TST concedessem reajuste além da política econômica do governo. Então tínhamos essa obrigação de recorrer independente de acharmos que estava certo ou não. Ultrapassou a política econômica... Então, o Ministério Público, na época, era também um fiscal da política econômica do governo" (PASSOS, João Pedro Ferraz dos. Depoimento sobre a greve dos petroleiros de 1995. Entrevista concedida a Ricardo Machado Lourenço Filho. Brasília, julho de 2014. Arquivo M4A).

${ }^{341}$ Folha de São Paulo de 10.5.1995 (disponível em http://www1.folha.uol.com.br/fsp/1995/5/10/brasil/13.html, acesso em 13.1.2014). A revista Veja assim descreveu a proximidade do governo com o TST: "às vésperas do julgamento, o ministro Almir Pazzianotto ligou para José Serra. Disse que os ministros estavam convencidos de que a paralisação era ilegal, mas temia que Fernando Henrique repetisse a proeza de Itamar e, desprezando a decisão do TST, resolvesse aceitar uma outra reivindicação. Serra tranquilizou o ministro, mas, por segurança, resolveu consultar o presidente. FHC se encontrava em Londres, nas comemorações dos 50 anos do fim da II Guerra Mundial, e mandou avisar que não iria ceder. No mesmo dia, Serra fez chegar a mesma versão não apenas a Pazzianotto, mas a todos os ministros do TST. Conhecendo de antemão o resultado do julgamento, antes mesmo da abertura da sessão, Serra e Brito [Ministro de Minas e Energia] reuniram-se para discutir os passos seguintes." (Veja de 31.5.1995). É curioso que, às vésperas da eclosão da greve, o Ministro do Trabalho, Paulo Paiva, tenha dado uma declaração defendendo a diminuição do poder normativo da Justiça do Trabalho: "é necessário reduzir a esfera do poder normativo da Justiça do Trabalho, para estimular as negociações" (Jornal do Brasil de 3.5.1995).

342 Jornal do Brasil de 10.5.1995.
} 
continuidade da greve e a interrupção total da produção de derivados de petróleo em todas as refinarias. Um dos diretores da entidade, Afonso de Menezes, declarou que, até a véspera da decisão do TST, a produção estava sendo mantida em 30\%. Para Menezes, a decisão do TST fora política, e acusou a Petrobrás de esconder os estoques de derivados de petróleo. A CUT, por seu Presidente, Vicentinho, manifestou-se no sentido de que "qualquer decisão da Federação terá nosso integral apoio".343

Os boletins dos sindicatos evidenciavam a indignação dos grevistas: "abusivo é o governo" e "às favas com o TST", entre outras expressões. ${ }^{344}$ O Sindicato dos Petroleiros do Estado do Rio de Janeiro - SINDIPETRO, por exemplo, publicou nota intitulada "Governo Federal não cumpre acordos salariais e força petroleiros à $3^{\mathrm{a}}$ greve". Após breve narrativa sobre os acordos celebrados em 1994, a entidade enfatizou o "golpe" dado pelo Tribunal: “Golpe - (...) o TST ainda considerou toda a história acima como um 'engodo' no qual os petroleiros caíram. Fomos culpados por termos sido enganados. Ou seja, traídos e, ainda pior, culpados. Só que todos os acordos salariais da história recente da Petrobrás nunca foram assinados pelo Conselho Administrativo ou pelo Presidente da empresa, mas sempre pelo Serviço de Recursos Humanos". 345

A FUP encaminhou às demais entidades sindicais informativo, apontando que foram poucos os recuos da greve. Na maioria dos locais, a decisão das assembleias havia sido pela continuidade da paralisação. ${ }^{346}$

A Petrobrás iniciou a demissão de grevistas, entre eles, vários dirigentes sindicais - o primeiro nome da lista era o do Coordenador da FUP, Antonio Carlos Spis. Para a empresa, os empregados demitidos "agiram em flagrante desrespeito às decisões do TST" e contribuíram para prejudicar "ainda mais a normalidade do abastecimento nacional de derivados de petróleo". Foram demitidos, num primeiro momento, 25 petroleiros e, em

\footnotetext{
${ }^{343}$ Folha de São Paulo de 11.5.1995 (disponível em http://www1.folha.uol.com.br/fsp/1995/5/10/brasil/19.html e http://www1.folha.uol.com.br/fsp/1995/5/11/brasil/13.html, acesso, em 13.1.2014). Vicentinho criticou, ainda, o Tribunal Superior do Trabalho: "em todos os meus anos de sindicalismo nunca vi uma greve ser julgada legal (...) A Justiça do Trabalho é submissa ao Poder Executivo (...) Hoje, o papel do tribunal é estimular conflitos" (Jornal do Brasil de 10.5.1995).

${ }^{344}$ Cf. ROMÃO, Frederico Lisboa. A greve do fim do mundo: petroleiros 1995 - expressão fenomênica da crise fordista no Brasil, p. 374.

${ }_{345}$ Em outra passagem, a entidade defendeu que o então Presidente da República e o Ministro de Minas e Energia tinham poderes para assinar os acordos e criticam a imprensa: "Estelionato - Se o então Presidente Itamar assinou um acordo que não podia assinar, se o ministro das Minas e Energia assinou um acordo que não podia assinar, se um superintendente ligado diretamente à presidência da Petrobrás assinou um acordo que não podia assinar, todos deveriam estar presos como estelionatários. Com certeza, eles tinham poderes para assinar. A exorbitância está sendo do TST. Mas os jornais e tevês passam a ideia de que os vilões da história somos nós, os trabalhadores". A nota foi publicada no Jornal do Brasil de 13.5.1995.

${ }^{346}$ Cf. ROMÃO, Frederico Lisboa. A greve do fim do mundo: petroleiros 1995 - expressão fenomênica da crise fordista no Brasil, p. 374.
} 
seguida, outros $34 .{ }^{347}$ Em algumas unidades, a empresa impediu a saída dos que trabalhavam, ao perceber que não seriam substituídos, o que deu origem a denúncias de cárcere privado e a greves de fome por parte desses petroleiros. ${ }^{348}$

A FUP pronunciou-se, indicando que os grevistas estariam prontos para radicalizar ainda mais o movimento. O Diretor Geraldo Pinto declarou que "com as demissões teremos um enfrentamento de maior grau" e que "a greve será radicalizada porque o governo está truculento". ${ }^{349}$ A Federação dos Petroleiros tentou articular uma dispensa coletiva, que segundo Antonio Carlos Spis, poderia levar à demissão de 40 mil funcionários. ${ }^{350}$ Além disso, a FUP e demais entidades informaram publicamente que garantiam o abastecimento de combustíveis e derivados de petróleo. ${ }^{351}$

Não demorou para que fosse aventado o recurso às Forças Armadas. A Folha de São Paulo publicou notícia de que o Exército poderia ser chamado a intervir nas refinarias de petróleo e nas usinas hidrelétricas para assegurar a integridade física das respectivas instalações (os eletricitários também tiveram sua greve julgada abusiva pelo TST e ameaçavam não cumprir a determinação judicial de retorno ao serviço). Segundo o jornal, um contingente de tropas estava sendo mantido nos quartéis pelos comandos militares do Leste

${ }^{347}$ Folha de São Paulo de 11.5.1995 (disponível em http://www1.folha.uol.com.br/fsp/1995/5/11/brasil/12.html, acesso em 18.1.2014). As listas dos demitidos foram publicadas no Jornal do Brasil de 12 e 13.5.1995.

${ }^{348}$ Ver ROMÃO, Frederico Lisboa. A greve do fim do mundo: petroleiros 1995 - expressão fenomênica da crise fordista no Brasil, p. 390 e O Estado de São Paulo de 5 e 11.5.1995. Na Replan, em Paulínia/SP, 28 empregados que estavam sendo mantidos na refinaria desde o dia 8 de maio começaram uma greve de fome no dia 9 , com o fï de forçar a diretoria a interromper a produção de GLP (Folha de São Paulo de 11.5.1995, disponível em http://www1.folha.uol.com.br/fsp/1995/5/11/brasil/14.html, acesso em 18.1.2014).

${ }^{349}$ Folha de São Paulo de 11.5.1995 (disponível em http://www1.folha.uol.com.br/fsp/1995/5/11/brasil/12.html, $\begin{array}{lllllll}\text { acesso em } & 18.1 .20014) & \text { e } & \text { de } & 12.5 .1995 & \text { (disponível } & \mathrm{em}\end{array}$ http://www1.folha.uol.com.br/fsp/1995/5/12/brasil/21.html, acesso em 21.1.2014). No mesmo dia em que foi anunciada a segunda leva de demissões, a Petrobrás admitiu que estavam completamente paradas as refinarias de Paulínia, São José dos Campos e Cubatão, todas de São Paulo, e as de Araucária (PR) e Duque de Caxias (RJ).

${ }^{350}$ Folha de São Paulo de 12.5.1995 (disponível em http://www1.folha.uol.com.br/fsp/1995/5/12/brasil/24.html, acesso em 21.1.2014) e Jornal do Brasil de 11.5.1995. As demissões promovidas pela Petrobrás geraram controvérsias entre as lideranças dos grevistas. Isso porque "a ala mais radical" defendia a interrupção total da produção de gás de cozinha nas oito refinarias ainda paralisadas, enquanto a outra ala entendia que seria o caso de retomar a produção normal de GLP para evitar que a sociedade se posicionasse contrariamente aos petroleiros. Cf. Folha de São Paulo de 12.5.1995 (disponível em http://www1.folha.uol.com.br/fsp/1995/5/12/brasil/23.html, acesso em 21.1.2014). Mas no boletim divulgado pela FUP aos sindicatos a orientação era de interrupção total da produção, sem que houvesse, porém, prejuízo à população: "nessa nova fase da greve, a parada da produção será total. Onde houver falta de gás de cozinha e gás natural para a população e hospitais, os petroleiros deverão discutir em assembléia como fazer o atendimento de emergência. Afinal a comunidade é, como nós, vítima deste governo" (ROMÃO, Frederico Lisboa. A greve do fim do mundo: petroleiros 1995 - expressão fenomênica da crise fordista no Brasil, p. 376/377).

${ }^{351}$ Em entrevista, ao ser indagado sobre a decisão do TST, na parte em que o Tribunal entendeu que não estava sendo observado o índice de 30\% dos serviços em funcionamento, Antônio Carlos Spis respondeu que: "os petroleiros têm uma visão de como cumprir a necessidade emergencial da população. A visão é a que nós estamos tendo hoje. Não falta nada. Se houver necessidade nós operamos. Assim como rareou gás de cozinha em Brasília nós pusemos a refinaria de Paulínia para operar um determinado momento para suprir a Capital. O que o governo quer, o que o TST pretende é impedir que categorias estatais façam greve. A ordem é absurda por falta de conhecimento da realidade técnica da Petrobrás" (O Estado de São Paulo de 13.5.1995). 
(Rio de Janeiro/RJ), Sudeste (São Paulo/SP), Sul (Porto Alegre/RS), Nordeste (Recife/PE) e Amazônia (Belém/PA e Manaus/AM), à disposição do Ministro do Exército, Zenildo de Lucena. Em entrevista concedida a uma emissora de rádio, o Ministro Chefe da Casa Civil, Clóvis Carvalho, afirmou que "as circunstâncias pedem ações" e o governo não hesitaria em adotá-las.

A Polícia Militar de São Paulo decretou estado de sobreaviso, acionando uma companhia da Tropa de Choque da PM. O Tenente Coronel Antônio Rufino Freire declarou que "estamos à disposição da Petrobrás" e que "os homens irão para a rua desde que a Petrobrás nos acione. Vamos tomar conta do patrimônio para evitar o vandalismo dos grevistas e para evitar atos de calamidade". ${ }^{352}$

No dia seguinte, porém, o Presidente da República negou que as Forças Armadas tivessem articulado algum tipo de intervenção nas greves. ${ }^{353} \mathrm{O}$ embaixador Sérgio Amaral, porta-voz da Presidência da República, alguns dias depois, foi a público, afirmando que "desautoriza[va] qualquer informação de que as Forças Armadas" estariam preparadas para intervir nas refinarias. ${ }^{354}$

No dia 17 de maio, os suscitados (FUP e sindicatos) apresentaram recurso de “embargos infringentes" perante o Tribunal Superior do Trabalho, a ser julgado pela própria Seção de Dissídios Coletivos. ${ }^{355}$ Após reiterar a sua narrativa dos fatos, a argumentação das entidades sindicais foi a seguinte: era válido o acordo firmado, o denominado protocolo, que produzira efeitos entre as partes, na medida em que a Petrobrás desistiu do processo proposto no TST (o DC 146.945/1994) e, por outro lado, houve a suspensão imediata da greve; a desistência do processo foi homologada pelo Tribunal; o protocolo de intenções foi "alçado à condição de acordo homologado nos autos pela desistência da requerente"; 356 como o acordo

\footnotetext{
${ }^{352}$ Folha de São Paulo de 13.5.1995 (disponível em http://www1.folha.uol.com.br/fsp/1995/5/13/brasil/25.html, acesso em 21.1.2014).

${ }^{353}$ Folha de São Paulo de 14.5.1995 (disponível em http://www1.folha.uol.com.br/fsp/1995/5/14/brasil/14.html, acesso em 21.1.2014) e Jornal do Brasil de 14.5.1995.

${ }^{354}$ Folha de São Paulo de 16.5.1995 (disponível em http://www1.folha.uol.com.br/fsp/1995/5/16/brasil/18.html, acesso em 22.1.2014).

${ }^{355} \mathrm{O}$ recurso tinha por fundamento o art. $2^{\circ}$, II, “c”, da Lei 7.701/1988, que permanece em vigor e que dispõe: "Compete à seção especializada em dissídios coletivos, ou seção normativa: (...) II - em última instância julgar: (...) c) os embargos infringentes interpostos contra decisão não unânime proferida em processo de dissídio coletivo de sua competência originária, salvo se a decisão atacada estiver em consonância com precedente jurisprudencial do Tribunal Superior do Trabalho ou da Súmula de sua jurisprudência predominante" (BRASIL. Lei $n^{\circ}$ 7.701, de 21 de dezembro de 1988. Dispõe sobre a especialização de Turmas dos Tribunais do Trabalho em processos coletivos e dá outras providências. Diário Oficial da União. Brasília, DF, 22.12.1988). Havia previsão, ainda, nos artigos 356 e ss do Regimento Interno do TST (BRASIL. Tribunal Superior do Trabalho. Resolução n. 40-A, de $1^{\circ}$ de outubro de 1993. Diário da Justiça, Brasília, DF, 23.11.1993).

${ }^{356}$ BRASIL. Tribunal Superior do Trabalho. Seção de Dissídios Coletivos. Dissídio Coletivo no 177.734/1995. Processo, p. 365.
} 
foi homologado, seu conteúdo "foi ungido pelo fenômeno da 'coisa julgada', e coberto pelo 'manto da imutabilidade'; em caso de eventual vício na prática do ato, o pacto deveria ser considerado válido até que sentença declarasse sua nulidade; ${ }^{357}$ a própria requerente [a Petrobrás] em nenhum momento do processo negou validade ao acordo. Pelo contrário, os elementos de prova indicavam que a suscitante admitia a validade do ajuste; "o não reconhecimento da validade do pacto firmado entre as partes, no mérito, viola os preceitos mencionados na fundamentação e estampados nos artigos civis citados, além do artigo $7^{\circ}$, inciso XXVI, da Carta Política Brasileira"; ${ }^{358}$ a Lei de Greve foi observada, bem como houve o cumprimento da ordem judicial; não havia previsão legal para a imposição de multa às entidades sindicais, o que caracterizaria violação ao art. $5^{\circ}$, II, da Constituição (princípio da legalidade). Com relação ao mérito, os suscitados pediam a exclusão da multa e o provimento do recurso, discorrendo sobre os limites do poder normativo da Justiça do Trabalho. ${ }^{359}$

A Petrobrás impugnou o recurso. Para a empresa, o protocolo de intenções não integrava o acordo firmado entre as partes e homologado pelo Tribunal quando da desistência do DC146.945/1994; a cláusula apontada como descumprida não poderia ser interpretada no sentido de conter obrigação da suscitante de conceder reajuste salarial, sobretudo porque isso dependeria de prévio assentimento "dos órgãos competentes do Poder Executivo"; 360 foram realizados os estudos previstos na cláusula do acordo; a greve foi deflagrada na vigência de sentença normativa; o protocolo de 25 de novembro de 1994 "não é acordo coletivo de trabalho"; 361 “o caráter político, e não reivindicatório, da greve é (...) notório e tem sido, reiteradamente, declarado por dirigentes das entidades sindicais e para-sindicais que a lideram, inclusive nos panfletos distribuídos aos empregados na mobilização para o movimento"; o objetivo da reivindicação econômica era a elevação, "a níveis imprevisíveis", da capacidade de mobilização e reivindicação de outras categorias, mormente de empresas estatais, decorrente de qualquer benefício que fosse resultado da greve, "estimulando, mais ainda, a onda de greves planejada pela CUT como parte de sua atuação política, e colocando em sério risco o processo de estabilização econômica"; “a greve é abusiva porque sua

\footnotetext{
357 BRASIL. Tribunal Superior do Trabalho. Seção de Dissídios Coletivos. Dissídio Coletivo no 177.734/1995. Processo, p. 365.

${ }^{358}$ BRASIL. Tribunal Superior do Trabalho. Seção de Dissídios Coletivos. Dissídio Coletivo no 177.734/1995. Processo, p. 367.

359 Cf. BRASIL. Tribunal Superior do Trabalho. Seção de Dissídios Coletivos. Dissídio Coletivo $\mathrm{n}^{\circ}$ 177.734/1995. Processo, p. 372.

${ }^{360}$ BRASIL. Tribunal Superior do Trabalho. Seção de Dissídios Coletivos. Dissídio Coletivo no 177.734/1995. Processo, p. 379.

${ }^{361}$ BRASIL. Tribunal Superior do Trabalho. Seção de Dissídios Coletivos. Dissídio Coletivo no 177.734/1995. Processo, p. 381.
} 
motivação é claramente política. E a sociedade não pode ficar submetida, sem severa reação das autoridades competentes, inclusive e especialmente do Poder Judiciário, aos riscos incalculáveis que decorrem desse tipo de prática política". ${ }^{362}$

É possível notar a mudança na argumentação da Petrobrás. A suscitante se valeu de determinados pontos da primeira decisão do Tribunal e os utilizou na impugnação ao recurso dos suscitados. Atente-se ao fato de que, a essa altura, os petroleiros já haviam deliberado por não cumprir a determinação judicial de retorno à atividade, e a imprensa, por outro lado, enfatizava a cada dia os transtornos causados pela paralisação.

O Procurador Geral do Trabalho, João Pedro Ferraz dos Passos, apresentou parecer no sentido de que os acordos firmados em 1994 não possuíam valor jurídico, pois não preenchiam os requisitos de validade de uma norma coletiva. Segundo o Procurador, "se o acordo contém promessas, ainda que veladas e de alcance controvertido, e se o descumprimento delas ocasionou conflito entre as partes, com a deflagração da greve, creditese isso à inabilidade, para não dizer irresponsabilidade, de ambas as partes, contabilizando prejuízos econômicos à Nação e impondo sacrifícios à sociedade". ${ }^{363}$ O Procurador opinou pelo desprovimento do recurso, com a manutenção do acórdão.

O processo foi pautado, de início, para o dia 29 de maio de 1995. A Petrobrás, no entanto, ofereceu petição, requerendo a antecipação da sessão de julgamento, diante dos prejuízos decorrentes da greve. ${ }^{364} \mathrm{O}$ pedido da empresa foi acolhido (praticamente sem fundamentação $\left.{ }^{365}\right)$, e a sessão, antecipada para o dia 26 de maio.

Do dia 23 para o dia 24 de maio, ou seja, cerca de dez dias após a negativa de Fernando Henrique Cardoso, o Exército ocupou quatro refinarias (a Replan, em Paulínia/SP, a Revap, em São José dos Campos/SP, a Recap, em Mauá/SP e a Repar, em Araucária/PR). De acordo com o porta-voz da Presidência da República, a determinação de Fernando Henrique Cardoso era a de que o Exército ocupasse as refinarias para garantir o patrimônio e permitir a

\footnotetext{
362 BRASIL. Tribunal Superior do Trabalho. Seção de Dissídios Coletivos. Dissídio Coletivo no 177.734/1995. Processo, p. 381.

${ }^{363}$ BRASIL. Tribunal Superior do Trabalho. Seção de Dissídios Coletivos. Dissídio Coletivo no 177.734/1995. Processo, p. 390.

364 Estes, os motivos deduzidos pela empresa: "pondera (...) a Suplicante que o presente dissídio é relativo a uma greve de seus empregados que já perdura por 3 (três) semanas, provocando drástica redução na produção e refino de petróleo e, de gás natural, comprometendo o abastecimento de produtos essenciais à população. O prolongamento da situação por praticamente mais uma semana, certamente agravará, ainda mais, a situação, acarretando ainda maiores sacrifícios à coletividade. Releva destacar, ainda, o elevadíssimo custo para o País, decorrente da necessidade de maiores importações de derivados de petróleo, com a finalidade de evitar o colapso do abastecimento interno" (BRASIL. Tribunal Superior do Trabalho. Seção de Dissídios Coletivos. Dissídio Coletivo no 177.734/1995. Processo, p. 400/401)

365 A petição foi despachada à caneta: "Defiro o pedido, antecipando o julgamento para..." (BRASIL. Tribunal Superior do Trabalho. Seção de Dissídios Coletivos. Dissídio Coletivo no 177.734/1995. Processo, p. 400).
} 
entrada de quem quisesse trabalhar, com "cautela e segurança". Os militares não participariam de qualquer fase da produção ou refino do petróleo, estando encarregados de ocupar a parte interna das refinarias e cuidar do patrimônio físico. 366

A ação do Exército levou o Ministro de Minas e Energia, Raimundo Brito, a fazer um pronunciamento em cadeia de rádio e televisão. O ministro destacou as decisões do Tribunal Superior do Trabalho proferidas em 1994, bem como a daquele ano, tendo sido julgada abusiva a greve, em curso, dos petroleiros. Não houve referência, em discurso, aos acordos celebrados durante a Presidência de Itamar Franco. Segundo Raimundo Brito, os dirigentes sindicais não respeitaram a decisão da Justiça do Trabalho, o que prejudicou os próprios trabalhadores. Mas diversos petroleiros haviam decidido retornar ao serviço e "as tropas do Exército foram chamadas apenas para assegurar que o retorno dos trabalhadores ocorr[esse] sem incidentes". ${ }^{367}$

\footnotetext{
${ }^{366}$ Folha de São Paulo de 25.5.1995 (disponível em http://www1.folha.uol.com.br/fsp/1995/5/25/brasil/4.html, acesso em 29.1.2014). O Alto Comando das Forças Armadas informou que as tropas tinham por objetivo assegurar a presença de 100 técnicos (25 em cada refinaria) admitidos pela Petrobrás para garantir o "funcionamento mínimo" das unidades. Cf. Jornal do Brasil de 25.5.1995.

367 Vale transcrever a íntegra do pronunciamento do Ministro de Minas e Energia: "Minhas senhoras, meus senhores, estou aqui para esclarecer os fatos e explicar a posição do governo sobre a greve dos petroleiros, que já dura 22 dias, provocando prejuízos à economia e trazendo tantos transtornos à população brasileira. Em setembro de 1994, por decisão do Tribunal Superior do Trabalho, foram estabelecidas, e estão em vigor até 31 de agosto de 1995, as regras que regulamentam as relações entre a Petrobrás e os seus trabalhadores. Apesar disso, as lideranças sindicais levaram os petroleiros a entrar em greve. Como todos sabem, o Tribunal Superior do Trabalho, em sessão realizada no último dia 9 de maio, decidiu que as reivindicações salariais não são procedentes. Até 31 de agosto de 1995, continuam em vigor as regras estabelecidas pelo Tribunal em setembro do ano passado. Todas essas regras estão sendo cumpridas pela Petrobrás. Além disso, por entender que os dirigentes sindicais não cumpriram a exigência legal de manter pelo menos $30 \%$ dos trabalhadores em atividade normal em cada uma das unidades da Petrobrás, o Tribunal julgou a greve abusiva e determinou o regresso imediato dos petroleiros ao trabalho. Mais uma vez, os dirigentes sindicais não respeitaram a decisão da Justiça, prejudicando, inclusive, os próprios trabalhadores. Alguns deles, infelizmente, já foram demitidos, enquanto muitos outros não terão salário a receber amanhã, dia 25 (hoje). A atitude dos sindicatos em não acatar uma decisão da Justiça é preocupante e revela descaso para com a população brasileira. Mas nós não podemos generalizar. Milhares de empregados da Petrobrás, das áreas administrativa, de transporte, de pesquisa e dos campos de petróleo, retornaram ao trabalho. Os petroleiros das refinarias de Manaus e Minas Gerais têm garantido a operação das unidades; parte dos trabalhadores das refinarias da Bahia, do Rio Grande do Sul e do Ceará asseguram, pelo menos, a operação parcial das suas unidades. Ontem à noite e hoje pela manhã, algumas centenas de trabalhadores resolveram voltar a operar as refinarias de Capuava, Paulínia e Vale do Paraíba, em São Paulo, e a do Paraná. As tropas do Exército foram chamadas apenas para assegurar que o retorno dos trabalhadores ocorra sem incidentes. A volta desses petroleiros ao trabalho é uma demonstração de bom senso, de responsabilidade e de respeito à lei. Sobretudo de compromisso com o público. Esta é a tradição dos petroleiros, que construíram esta grande empresa que é a Petrobrás e que tão bons serviços já prestaram ao país. Estamos diante de uma situação em que não deve haver vencidos ou vencedores. Trata-se somente de acatar uma decisão judicial e garantir o menor prejuízo possível à população. Conclamo todos os petroleiros que ainda não voltaram às suas atividades normais que sigam o exemplo da grande maioria que já está trabalhando. Este é o exemplo a ser seguido. Eu garanto a todos que a Petrobrás está aberta às conversações. E isto vai acontecer tão logo os petroleiros cumpram a decisão do Tribunal. Chegou o momento de por fim à greve. Com ela, todos perdemos. Com o diálogo e entendimento, todos ganhamos. É isto que o país inteiro espera de nós" (Folha de São Paulo de 25.5.1995, disponível em http://www1.folha.uol.com.br/fsp/1995/5/25/brasil/12.html, acesso em 29.1.2014).
} 
O Comandante da $5^{a}$ Região Militar, General Antônio Araújo de Medeiros, responsável pelas tropas no Paraná e em Santa Catarina, concedeu entrevista sobre a ação do Exército. No que dizia respeito à função das tropas, que ocupavam a Repar, o General afirmou que "nós estamos lá para garantir a integridade e a segurança da refinaria. Os soldados circulam pelas áreas. Formamos uma espécie de cinturão de segurança”. Antônio Medeiros informou a postura do Exército quanto à segurança das instalações: "como é que eu permito a segurança das instalações? Eu permito impedindo que alguém vá lá e danifique. Então, se eu tiver que atirar, eu vou atirar para manter a integridade das instalações. Isso daí é uma coisa certa". Talvez diante da resposta do General, foi formulada a pergunta: "mas o senhor não teme um confronto como o que ocorreu na CSN (Companhia Siderúrgica Nacional), em 1988, em que dois [na verdade, três] operários foram mortos?”. Para o General, contudo, o episódio da CSN comportava mais de uma leitura: "você se reporta a uma situação que a gente pode analisar por vários ângulos. Eu não vou analisar isso aí para você, não. Você tem uma versão, e eu tenho outra". Antônio Medeiros foi indagado, então, sobre a possibilidade de confronto entre os soldados e os petroleiros. Para ele, "nós vamos evitar ao máximo um confronto. Evitar ao máximo é a lógica. Se tiver, por infelicidade, que acontecer, nós não vamos fugir dele". 368

A entrevista dada pelo General Antônio Araújo de Medeiros traz à tona um aspecto que perpassa como um espectro a paralisação dos petroleiros: a greve dos operários da Companhia Siderúrgica Nacional, em Volta Redonda/RJ, deflagrada em novembro de 1988. ${ }^{369}$ Vale observar como a memória dessa greve é ativada durante a paralisação dos petroleiros, sobretudo após a recusa em cumprir a decisão do Tribunal Superior do Trabalho.

\footnotetext{
368 Entrevista concedida à Folha de São Paulo de 25.5.1995, disponível em http://www1.folha.uol.com.br/fsp/1995/5/25/brasil/11.html, acesso em 29.1.2014).

${ }^{369}$ A greve teve início, mais precisamente, em 7 de novembro de 1988. Os operários ocuparam diversos setores da indústria e organizaram piquetes. No mesmo dia, a Polícia Militar cercou a fábrica. E no dia seguinte à noite, o Exército entrou na Usina, dando lugar a confrontos entre os soldados e os grevistas. Esses últimos se refugiaram na aciaria - setor de produção de aço. No dia 9 de novembro, o Exército investiu contra os operários, utilizando bombas, fuzis, metralhadoras, tanques e carros urutus. A ação dos militares estava fundada em uma decisão judicial de reintegração de posse e em uma ordem do próprio governo. O resultado do confronto foram dezenas de feridos e três operários mortos (Carlos Augusto Barroso, Walmir Freitas Monteiro e William Fernandes Leite), tendo os grevistas saído da Usina no dia 10. A greve ainda perduraria até o dia 23 de novembro. Cf., a respeito, entre outros, GRACIOLLI, Edílson José. Um caldeirão chamado CSN - resistência operária e violência militar na greve em 1988. Uberlândia: Editora da Universidade Federal de Uberlândia, 1997; MANGABEIRA, Wilma. Dilemas do novo sindicalismo: democracia e política em Volta Redonda. Trad. de Vera Pereira. Rio de Janeiro: Relume-Dumará: ANPOCS, 1993; VEIGA, Sandra Mayrink, e FONSECA, Isaque. Volta Redonda, entre o aço e as armas. Petrópolis-RJ: Vozes, 1989; e PAIXÃO, Cristiano, e LOURENÇO FILHO, Ricardo. "Direito de greve entre afirmação e repressão: o caso CSN". In: DELGADO, Gabriela Neves, e PEREIRA, Ricardo José Macêdo de Britto (orgs.). Trabalho, constituição e cidadania: a dimensão coletiva dos direitos sociais trabalhistas. São Paulo: LTr, 2014, pp. 331/347; além de jornais da época, como Folha de São Paulo e Jornal do Brasil.
} 
Esse é certamente um dos elementos que marca a tensão entre ruptura e permanência com o regime anterior à Constituição de $1988 .{ }^{370}$

É significativo que, dois dias após a ocupação das refinarias de petróleo pelo Exército, o periódico Folha de São Paulo, cuja linha editorial demonstrava inclinações a favor das ações do governo e contrariamente aos grevistas ${ }^{371}$, publicou uma reportagem lembrando a greve de 1988 da CSN e o confronto entre soldados e operários. ${ }^{372}$ Segundo Ana Cosenza:

(...) a Folha de S. Paulo apresentou certa apreensão com os resultados da ocupação militar e passou a considerar que também o governo estava fazendo uso político da greve. O jornal paulista logo voltou a defender um acordo entre petroleiros e governo, para colocar fim à greve sem que a democracia brasileira saísse arranhada. Expressiva desta postura da Folha foi a publicação da matéria "Conflito matou 3 operários em 88 ", que lembrava a greve da CSN em Volta Redonda e, na forma como descreveu os acontecimentos, continha uma crítica às atitudes do Exército, da PM e do governo na época. A presença desta matéria entre as notícias sobre a ocupação do Exército nas refinarias da Petrobrás foi um chamado a que governo e petroleiros optassem pelo diálogo e evitassem que a tragédia da CSN se repetisse. ${ }^{373}$

\footnotetext{
370 Não obstante a própria greve da CSN tenha ocorrido cerca de um mês após a promulgação da Constituição.

${ }^{371}$ Ver, a propósito, a página “opinião" da edição de 12.5.1995, intitulada "Afronta”, que, logo no início, afirma: "a decisão da maioria dos petroleiros de dar prosseguimento à greve, radicalizando mesmo o movimento, é gravíssima e merece a mais veemente condenação. Ela representa um desrespeito flagrante e intolerável à Justiça, que, em sentença proferida na última terça-feira, julgou a paralisação abusiva e determinou a volta ao trabalho. A própria interrupção das atividades como instrumento de pressão trabalhista, no caso dos petroleiros, já constitui um recurso que merece reparos. Como bem demonstram os problemas e a incerteza quanto ao abastecimento de gás de cozinha, é a população que acaba sofrendo com a greve, muito mais do que o empregador que -em tese- se pretende atingir (...)" (Folha de São Paulo de 12.5.1995, disponível em http://www1.folha.uol.com.br/fsp/1995/5/12/opiniao/1.html, acesso em 21.1.2014); em outro texto, na página "opinião" da edição de 16.5.1995, intitulado "Afrontando a lei”, tem-se a seguinte assertiva: "o estágio a que chegou a greve dos petroleiros é um absurdo. Ao desrespeitar a decisão judicial que determinou a volta ao trabalho -justa ou injusta, não é o caso de discutir aqui-, a categoria rompeu o preceito básico do Estado de Direito que é o de acatar as sentenças da Justiça. Decisões judiciais não se discutem, cumprem-se". Em outra passagem do mesmo artigo, há uma cobrança ao governo: "causa estranheza também a forma como o Planalto vem tratando essa atitude absurda que apenas prejudica a população. Embora o máximo que possa fazer é demitir grevistas por justa causa e aplicar multas aos sindicatos -R \$ 100 mil por dia parado, o que, de resto, torna esta pena pecuniária inexequível-, ele vem agindo sem o vigor necessário diante da afronta ao Estado de Direito no Brasil. Talvez por temer uma maior radicalização do movimento, as demissões ocorrem em marcha lenta. A questão é de fato delicada, mas uma coisa é certa: não se pode ceder à chantagem, pior ainda quando ela ocorre em desafio a uma decisão da Justiça. Se o governo ceder, estará ele próprio contribuindo para uma flagrante violação ao Estado de Direito. E isso é intolerável" (Folha de São Paulo de 16.5.1995, disponível em http://www1.folha.uol.com.br/fsp/1995/5/16/opiniao/1.html, acesso em 22.1.2014).

372 O título da reportagem era "Conflito matou 3 operários em 88" (Folha de São Paulo de 26.5.1995, disponível em http://www1.folha.uol.com.br/fsp/1995/5/26/brasil/17.html, acesso em 30.1.2014).

373 COSENZA, Ana. "Representações da greve dos petroleiros de 1995 na imprensa: as referências ao período militar e à democracia no discurso jornalístico". In: Proj. História, São Paulo, (29), tomo 1, p. 303-312, dez. 2004, p. 309. O confronto também foi recordado pelo Jornal do Brasil, em reportagem publicada no dia seguinte à ocupação das refinarias pelo Exército. O título da reportagem é "o massacre da CSN" (Jornal do Brasil de 25.5.1995). Na mesma linha, a revista Veja lembrou o caso da CSN, após a ocupação das refinarias pelos militares: "a penúltima intervenção do Exército num conflito trabalhista ocorreu numa usina em Volta Redonda, em 1988, terminou com três operários mortos por soldados do Exército - e o governo José Sarney sangrando" (Veja de 31.5.1995).
} 
A questão da CSN já havia sido aventada antes da intervenção dos militares. Poucos dias depois que a FUP anunciou a recusa em cumprir a decisão do Tribunal Superior do Trabalho e a Petrobrás divulgou as listas dos demitidos, o Presidente da CUT alertou: "lembrem-se de Volta Redonda (...) Se o governo colocar o Exército contra os petroleiros pode provocar um conflito sangrento". ${ }^{374}$ E logo após as primeiras notícias de que o Exército poderia ser mobilizado para ocupar as refinarias, o colunista da Folha de São Paulo, Jânio de Freitas, recordou os fatos ocorridos em Volta Redonda/RJ, em 1988. ${ }^{375}$ O então Presidente do Partido dos Trabalhadores, Luiz Inácio Lula da Silva, a seu turno, defendendo que o governo devia abrir as negociações, afirmava a necessidade de se "evitar que se repita o que ocorreu, em 88, na CSN".376

O governo expressava preocupação semelhante quanto a evitar uma repetição do conflito de Volta Redonda/RJ. ${ }^{377}$ Alguns dias após a ação do Exército nas refinarias, o Ministério do Exército e a Secretaria de Assuntos Estratégicos - SAE teriam feito advertências para que os militares evitassem "ao máximo" confrontos e que não aceitassem provocações dos grevistas. Tais advertências estariam fundadas justamente no "fantasma da CSN (Companhia Siderúrgica Nacional)".378

Quando o Tribunal Superior do Trabalho examinou o recurso dos suscitados no processo de dissídio coletivo, as Forças Armadas já haviam ocupado as quatro refinarias da Petrobrás. O governo não admitia a discussão de reivindicações econômicas com os grevistas, enquanto durasse a paralisação. ${ }^{379}$ A Petrobrás tampouco se mostrava disposta ao diálogo. ${ }^{380}$

\footnotetext{
374 Jornal do Brasil e O Estado de São Paulo de 13.5.1995.

375 No artigo "Os riscos do impasse", o colunista observa que "a situação atual é de impasse. Mas, se não solucionado por entendimento, nem por isso o impasse fica no impasse. Dele termina sempre emergindo um fato que o rompe. Com frequência, um fato cuja força, ou violência mesmo, é prejudicial às duas partes. Foi o que aconteceu em Volta Redonda - para citar um exemplo útil neste momento - quando o Exército acabou matando três operários e por muito tempo carregará o ônus desse ato". Cf. Folha de São Paulo de 16.5.1995, disponível em http://www1.folha.uol.com.br/fsp/1995/5/16/brasil/10.html, acesso em 22.1.2014).

${ }^{376}$ Folha de São Paulo de 16.5.1995, disponível em http://www1.folha.uol.com.br/fsp/1995/5/16/brasil/17.html, acesso em 22.1.2014). Ver também Jornal do Brasil de 17.5.1995.

377 Jornal do Brasil de 25.5.1995.

${ }^{378}$ Folha de São Paulo de 28.5.1995 (disponível em http://www1.folha.uol.com.br/fsp/1995/5/28/brasil/22.html, acesso em 30.1.2014).
}

379 Cf., a respeito, Folha de São Paulo de 24.5.1995 (disponível em http://www1.folha.uol.com.br/fsp/1995/5/24/brasil/4.html, acesso em 29.1.2014).

${ }^{380}$ Em entrevista concedida à Folha de São Paulo, poucos dias antes do julgamento do recurso de embargos infringentes pelo TST, o Procurador-Geral do Trabalho, João Pedro Ferraz dos Passos, disse que tentou uma saída alternativa para encerrar a greve: "queria que as partes sentassem só para ver se conseguiam alguma coisa para que os empregados voltassem ao trabalho. Não tive sucesso. A Petrobrás não senta com grevista. Queria que ela dissesse isto diretamente aos petroleiros e, com isto, eles possivelmente voltariam ao trabalho. Mas não consegui". Indagado sobre o discurso da empresa estava muito duro, respondeu que: "está muito difícil. A disposição é levar às últimas consequências a decisão do TST no sentido de que a greve é ilegal. Não estou 
Não é uma questão simples identificar o que estava por trás da greve e, por outro lado, o que baseava a postura do Poder Público. Além dos acordos firmados em 1994, os indícios apontam para o problema da privatização da Petrobrás (o que era visto como uma ameaça por parte dos trabalhadores) $)^{381}$, a preocupação do governo com os índices inflacionários, associada ao respeito do TST à política econômica adotada, ${ }^{382} \mathrm{e}$ uma investida do Executivo contra o movimento sindical, em especial no caso de greves organizadas por sindicatos vinculados à Central Única dos Trabalhadores - CUT. ${ }^{383}$ Tudo isso pode ter circulado à época, sobretudo nos bastidores e nas comunicações entre os principais atores envolvidos na greve.

\subsection{O segundo julgamento da greve pelo TST e as tentativas de encerramento do conflito}

Na data prevista, em 26 de maio, a Seção de Dissídios Coletivos analisou o recurso dos suscitados. ${ }^{384} \mathrm{O}$ Ministro Pedrassani, mais uma vez, questionou o Presidente sobre a presença da imprensa. José Ajuricaba permitiu que os fotógrafos e cinegrafistas

encontrando disposição por parte da empresa para qualquer sinalização aos empregados em greve" (Folha de São Paulo de 24.5.1995 - disponível em http://www1.folha.uol.com.br/fsp/1995/5/24/brasil/5.html, acesso em 29.1.2014).

381 Esse aspecto já foi destacado acima, tendo surgido em BRITO, Cézar. Depoimento sobre a greve dos petroleiros de 1995.

382 Ponto ressaltado em PASSOS, João Pedro Ferraz dos. Depoimento sobre a greve dos petroleiros de 1995.

$383 \mathrm{Na}$ entrevista concedida ao autor desta pesquisa, João Pedro Ferraz dos Passos, relata a tentativa de conciliação levada a cabo no intervalo entre a primeira e a segunda decisão do TST, deixando explícita a intenção do governo quanto aos grevistas e ao movimento sindical: “(...) eu lembro que na época eu fui muito pressionado para tomar providência a respeito dos trabalhadores. Naquela oportunidade (...), eu tentei inúmeras vezes reunião com a Petrobrás e com o governo, naquela época. Eu era Procurador Geral, tinha uma relação boa com o Ministro do Trabalho, que na época, se não me engano, era o Paulo Paiva, o Ministro do Trabalho, e o Secretário Geral dele era o hoje governador de Minas Gerais, Anastasia. Então eu tinha uma boa relação com o Ministério e fiz algumas reuniões, algumas reuniões com o movimento grevista no meu gabinete, de Procurador Geral, tentando uma negociação. Tinha um líder do movimento grevista, que, se não me engano, era Spis o nome dele. Era um sujeito extremamente radical, dificílimo de negociar. Eu lembro que era advogado de uma das federações de petróleo o Cézar Britto, que foi Presidente da Ordem (...) e o Cézar esteve em algumas reuniões dessas que teve comigo. Mas o elemento era extremamente radical. A última tentativa de acordo antes que o Tribunal fizesse mais uma sessão para analisar o comportamento dos empregados... Eu tentei fazer um acordo e lembro que eu telefonei para o Ministro do Trabalho de então... (...) Então eu liguei para o Ministro do Trabalho e disse: 'olha, eu estou aqui com o movimento, eu gostaria de conversar e quero conversar com a Petrobrás mas não vejo ambiente para conversar com o Presidente da Petrobrás, o Presidente da Petrobrás estava querendo realmente...' E ele [Ministro do Trabalho] disse: 'olha, Procurador, eu lhe aconselho a não levar adiante a sua pretensão de conciliar porque a deliberação do governo é quebrar o movimento sindical' (PASSOS, João Pedro Ferraz dos. Depoimento sobre a greve dos petroleiros de 1995).

384 Às vésperas do julgamento, o Conselho Consultivo da FUP chegou a deliberar sobre a desistência do recurso, concluindo, após votação, por sua manutenção. De acordo com Antonio Carlos Spis, "os petroleiros não têm esperanças no TST e, por isso, chegamos a levantar a hipótese de retirar o recurso. Mas não aceitamos a sentença anterior e decidimos mantê-lo". Em quatro refinarias, os petroleiros aprovaram a desistência do recurso, por considerá-lo inútil. Cf. Folha de São Paulo de 26.5.1995 (disponível em http://www1.folha.uol.com.br/fsp/1995/5/26/brasil/23.html, acesso em 30.1.2014). Durante o julgamento, os grevistas exibiam cartazes à frente do prédio do Tribunal, num dos quais estava escrito: “A greve é legítima. Abusiva é a existência do TST" (O Estado de São Paulo de 27.5.1995). 
permanecessem até que o ministro relator começasse a leitura do voto, podendo ficar os demais jornalistas, pois o julgamento era público. ${ }^{385}$

Feita a leitura do relatório pelo Ministro Hylo Gurgel (novo relator), o Procurador Geral do Trabalho se referiu ao parecer que já constava dos autos. Enfatizou que a questão dizia respeito à validade jurídica dos acordos firmados em 1994, que não atenderiam às formalidades legais para sua caracterização como convenção coletiva. Em suas palavras:

O que importa, neste foro, é o valor jurídico dessas tratativas, em face da decisão antes proferida pelo TST e, como bem colocado na decisão recorrida, tais acordos nenhum abalo provocam na sentença normativa. $\mathrm{O}$ valor moral ou político dos acordos não se submetem agora à decisão dessa Justiça. Quanto a este ponto, nenhum reparo merece o Acórdão embargado. ${ }^{386}$

Em seu voto, o Ministro Hylo Gurgel analisou a validade dos acordos firmados. Com relação ao primeiro deles, de 5 de outubro de 1994, Hylo Gurgel registrou que estava apócrifo, ${ }^{387}$, além de ter sido superado pelo "Termo de Acordo que entre si, firmam o Governo Federal e a Federação Única dos Petroleiros- FUP”, "rubricado" por Delcídio Gomez e Antônio Carlos Spis. Para Hylo Gurgel, entretanto, o então Ministro de Minas e Energia não representava a Petrobrás, ou seja, ninguém assinou pela empresa. E o documento tampouco estava autenticado, o que o inviabilizava como meio de prova - o que, à época, era exigido por lei. Já o "Protocolo firmado entre a Petrobrás e a Federação Única dos Petroleiros", de 25 de novembro de 1994, "ressente-se (...) de formalidade expressamente prevista na Lei, que lhe condiciona a eficácia ao seu cumprimento e, ainda assim, após o transcurso de 03 (três) dias". Hylo Gurgel invocou o art. 614, caput e $\S 1^{\circ}$, da CLT para consignar que não poderia reconhecer o protocolo como "Acordo qualificado juridicamente na área do Direito Coletivo". 388 O ministro registrou seu "estranhamento" pelo fato de as partes não terem conciliado em juízo no segundo processo de dissídio coletivo de 1994:

\footnotetext{
385 BRASIL. Tribunal Superior do Trabalho. Seção de Dissídios Coletivos. Dissídio Coletivo no 177.734/1995. Notas taquigráficas da sessão de julgamento, Brasília, DF, 26 de maio de 1995, p. 2/3.

${ }^{386}$ BRASIL. Tribunal Superior do Trabalho. Seção de Dissídios Coletivos. Dissídio Coletivo no 177.734/1995. Notas taquigráficas da sessão de julgamento, 26 de maio de 1995, p. 6 (sic).

387 O documento, intitulado "Termo de entendimento do governo federal com os petroleiros/CUT" e constante da pág. 147 dos autos, não contém assinatura, nem sequer campo para assinatura. Há, a caneta, as palavras "At: Sérgio" e "Fup", na parte superior, e "Spis - 5/10/94", na parte inferior, acima de dois números de fax. Segundo o relator do processo, "de concluir-se, portanto, que aquele que fez esse documento, não o assinou, de modo que, por si, é apócrifo. Ninguém por ele, se atribuiu responsabilidade, "Sérgio" é prenome e "SPIS", não sei. As pessoas, em juízo, só se identificam por seu nome completo e qualificação" (BRASIL. Tribunal Superior do Trabalho. Seção de Dissídios Coletivos. Dissídio Coletivo no 177.734/1995. Processo, p. 418).

388 O art. 614 da CLT preceitua que: "os Sindicatos convenentes ou as emprêsas acordantes promoverão, conjunta ou separadamente, dentro de 8 (oito) dias da assinatura da Convenção ou Acôrdo, o depósito de uma
} 
E mais se lamenta, quando, à vista dos autos, se percebe que o denominado "Protocolo" foi firmado no mesmo dia em que as partes conciliaram em Dissídio, sob o compromisso de continuarem a negociar.

É estranho que, após encerrado o Dissídio, demonstrando, as partes, disposição de negociar, estabeleçam Acordo, logo depois deixando escapar a oportunidade de fazê-lo em juízo, com segurança. É procedimento difícil de entender-se.

Para o Ministro, se as partes estavam dispostas a negociar, faria mais sentido que firmassem o acordo em juízo, de maneira a fazê-lo "com segurança”. Qual é a compreensão do papel do Tribunal (e mesmo do direito, enquanto subsistema social) subjacente a essa forma de pensamento? Haveria a percepção de que o Poder Judiciário é o espaço da segurança, ou seja, que confere segurança às partes, à sociedade?

Hylo Gurgel observou que o acordo talvez valesse em termos éticos, mas, não, jurídicos, por lhe faltar formalidade legal, e não poderia substituir a sentença normativa então em vigor. Além disso, a Federação não teria agido segundo os poderes outorgados pela categoria profissional, não comprovando a autorização da assembleia geral. ${ }^{389} \mathrm{O}$ documento não atenderia, ainda, ao art. 613 da CLT. ${ }^{390}$

via do mesmo, para fins de registro e arquivo, no Departamento Nacional do Trabalho, em se tratando de instrumento de caráter nacional ou interestadual, ou nos órgãos regionais do Ministério do Trabalho e Previdência Social, nos demais casos. (Redação dada pelo Decreto-lei n ${ }^{\circ} 229$, de 28.2.1967) § $1^{\circ}$ As Convenções e os Acôrdos entrarão em vigor 3 (três) dias após a data da entrega dos mesmos no órgão referido neste artigo (Redação dada pelo Decreto-lei no 229, de 28.2.1967)" (BRASIL, Decreto-Lei no 5.452, de $1^{\circ}$ de maio de 1943. Aprova a Consolidação das Leis do Trabalho).

${ }^{389}$ Segundo o Ministro, “(...) se o centro irradiante do direito de firmar Acordo ou Convenção é a Categoria, se Assembléia Geral houve para delegação de poderes à Federação, não se ateve, ela, Federação, ao que lhe foi outorgado, pois o documento produzido não corresponde ao assim normatizado. E mais, porque elaborado fora do juízo, deveria acompanhar-se da cópia da Assembléia Geral autorizadora, pois o Instrumento Normativo que resulte de vontade das Partes há de ser precedido da delegação de poderes, que só a categoria organizada em Assembléia poderia fazê-lo. Necessário, também, a efetiva participação da categoria na Assembléia, comprovada com lista de presença, tudo como está previsto no art. 612 da CLT". O dispositivo consolidado enuncia que: "os Sindicatos só poderão celebrar Convenções ou Acordos Coletivos de Trabalho, por deliberação de Assembléia Geral especialmente convocada para êsse fim, consoante o disposto nos respectivos Estatutos, dependendo a validade da mesma do comparecimento e votação, em primeira convocação, de 2/3 (dois terços) dos associados da entidade, se se tratar de Convenção, e dos interessados, no caso de Acôrdo, e, em segunda, de 1/3 (um têrço) dos mesmos. (Redação dada pelo Decreto-lei $\mathrm{n}^{\circ}$ 229, de 28.2.1967) Parágrafo único. O "quorum" de comparecimento e votação será de $1 / 8$ (um oitavo) dos associados em segunda convocação, nas entidades sindicais que tenham mais de 5.000 (cinco mil) associados. (Incluído pelo Decreto-lei $\mathrm{n}^{\circ}$ 229, de 28.2.1967)" (BRASIL, Decreto-Lei ${ }^{\circ} 5.452$, de $1^{\circ}$ de maio de 1943. Aprova a Consolidação das Leis do Trabalho).

390 "As Convenções e os Acordos deverão conter obrigatòriamente: (Redação dada pelo Decreto-lei $n^{\circ}$ 229, de 28.2.1967) I - Designação dos Sindicatos convenentes ou dos Sindicatos e emprêsas acordantes; (Incluído pelo Decreto-lei no 229, de 28.2.1967); II - Prazo de vigência; (Incluído pelo Decreto-lei nº 229, de 28.2.1967); III Categorias ou classes de trabalhadores abrangidas pelos respectivos dispositivos; (Incluído pelo Decreto-lei ${ }^{\circ}$ 229, de 28.2.1967); IV - Condições ajustadas para reger as relações individuais de trabalho durante sua vigência; (Incluído pelo Decreto-lei no 229 , de 28.2.1967); V - Normas para a conciliação das divergências sugeridas entre os convenentes por motivos da aplicação de seus dispositivos; (Incluído pelo Decreto-lei no 229, de 28.2.1967); VI - Disposições sôbre o processo de sua prorrogação e de revisão total ou parcial de seus dispositivos; (Incluído pelo Decreto-lei $n^{\circ} 229$, de 28.2.1967) VII - Direitos e deveres dos empregados e emprêsas; (Incluído pelo 
O Ministro Relator considerou abusiva a greve, na medida em que o protocolo não era considerado Acordo [Coletivo de Trabalho], o que tornava aplicável o art. 14 da Lei 7.783/1989. E, segundo as informações prestadas pela Procuradoria, não teria havido o atendimento da ordem emitida pelo Presidente do Tribunal: "a Greve foi, também por isso, abusiva". ${ }^{391}$ A aplicação da multa foi mantida.

Após se pronunciarem relator e revisor, o Ministro Presidente tomou o voto dos demais ministros da Seção de Dissídios Coletivos. Vale destacar a posição do Ministro Almir Pazzianotto, que acompanhou o relator e o revisor, mas fez considerações sobre o compromisso que o protocolo poderia gerar à Petrobrás:

(...) à vista destes últimos esclarecimentos vindos com os embargos - que, na verdade, revestem-se mais de características de embargos de declaração -, passo a entender, com a decisão do Ministro Ursulino Santos, que o documento celebrado pelas partes, em 25 de novembro de 1994, como ajuste obrigacional, não tem características de acordo, convenção ou convênio coletivo, embora possa resultar em compromisso para a empregadora, a Petrobrás, identificável através de novas negociações. ${ }^{392}$

A referência à obrigação por parte da empresa poderia servir de argumento para a reabertura das negociações entre a Petrobrás (i.e., o governo) e a FUP, consistindo em uma "saída" para a greve. Essa articulação contou com a presença dos advogados Carlos Alberto Boechat Rangel e Cézar Britto, que se reuniram, às vésperas da segunda sessão de julgamento, com o Ministro Almir Pazzianotto. A manifestação de Pazzianotto, contudo, não foi incorporada ao voto do relator, nem constou de nenhum documento do processo. ${ }^{393}$

Decreto-lei $\mathrm{n}^{\mathbf{o}}$ 229, de 28.2.1967); VIII - Penalidades para os Sindicatos convenentes, os empregados e as emprêsas em caso de violação de seus dispositivos. (Incluído pelo Decreto-lei no 229, de 28.2.1967). Parágrafo único. As convenções e os Acordos serão celebrados por escrito, sem emendas nem rasuras, em tantas vias quantos forem os Sindicatos convenentes ou as emprêsas acordantes, além de uma destinada a registro. (Incluído pelo Decreto-lei $n^{\circ} 229$, de 28.2.1967)" (BRASIL, Decreto-Lei $n^{\circ} 5.452$, de $1^{\circ}$ de maio de 1943. Aprova a Consolidação das Leis do Trabalho).

${ }^{391}$ BRASIL. Tribunal Superior do Trabalho. Seção de Dissídios Coletivos. Dissídio Coletivo no 177.734/1995. Processo, p. 420.

392 BRASIL. Tribunal Superior do Trabalho. Seção de Dissídios Coletivos. Dissídio Coletivo no 177.734/1995. Notas taquigráficas da sessão de julgamento, 26 de maio de 1995, p. 20.

${ }^{393}$ Essa articulação foi relatada pelo advogado Cézar Britto na entrevista concedida ao autor deste trabalho. Cézar Britto indicou que o Ministro Pazzianotto era o principal interlocutor do governo junto ao Tribunal Superior do Trabalho: "quando termina o [primeiro] julgamento, os trabalhadores permaneceram em greve mas procuraram uma saída jurídica. Foi aí que nós começamos a conversar com os Ministros do TST. A saída foi dar provimento parcial ao nosso recurso para reconhecer que o acordo tinha efeito político possível, embora não tivesse efeito nenhum enquanto acordo coletivo de trabalho. Se reconhecesse que teria efeito moral ou cível, a Petrobrás daria o reajuste e nós acabaríamos a greve, as multas podiam ser pagas ou discutidas. Isso foi mais ou menos acordado em reuniões em que participou o Ministro Pazzianotto. Quando estávamos certo que teríamos mais ou menos isso, o Palácio [do Planalto] mudou de novo o entendimento e, quando nós fomos para o julgamento, o que já tinha sido acordado, que daria provimento para esclarecer essa matéria, nem essa matéria foi esclarecida" (BRITTO, Cézar. Depoimento sobre a greve dos petroleiros de 1995). Carlos Alberto Boechat 
Na discussão sobre a validade dos acordos, a decisão da SDC foi tomada por maioria, ficando vencidos o Ministro José Ajuricaba e o Juiz Convocado Mauro Viola, que votavam pela determinação à empresa para que cumprisse o Protocolo de 25 de novembro de 1994. No restante das questões, a decisão foi à unanimidade. Os Ministros Roberto Della Manna, Armando de Brito e Thaumaturgo Cortizo apresentaram, em apartado e por escrito, votos convergentes.

Roberto Della Manna, Ministro Classista representante dos empregadores ${ }^{394}$, criticou as lideranças sindicais, discorrendo sobre o direito de greve. Seu voto se limitou à abusividade da paralisação. Para o Ministro, "quando uma greve se transforma numa luta entre Sindicato, ou Federação não reconhecida, como a FUP, e a Lei, ela deixa de ser direito e se torna uma arma que se volta contra a própria democracia". Segundo Della Manna, teria havido "desacato e ofensa" ao TST, “Órgão que interpreta e aplica a Lei de Greve”. E, no caso dos petroleiros, "a greve é totalmente política, declarada, inclusive, pelos próprios dirigentes sindicais da CUT e da FUP”. Nas palavras do Ministro:

O Direito de Greve acaba onde começam os direitos da cidadania - greves como esta, que prejudicam a população, principalmente as mais sofridas, além de ilegais, são totalmente absurdas e o mais grave, que não podemos admitir, é o desrespeito aos poderes constituídos, numa demonstração de força das categorias que se servem de seu "monopólio" de serviços para atingir as instituições.

Della Manna adotou as premissas de que: a "Lei é a expressão da vontade geral de um povo", cabendo ao Estado "evitar que sua aplicação rompa a igualdade dos cidadãos perante" a "Lei"; e de que "as questões entre Empregados e Empresas não podem, e não devem, jamais alcançar em suas piores consequências a sociedade como um todo"; para concluir: "por isso que a Lei limita o direito de greve, no caso de serviços essenciais, cuja paralisação, como neste caso, prejudica a população".

O Ministro se dirigiu às lideranças sindicais e aos grevistas, invocando o "bom senso". Há, em seu voto, a intenção de determinar o comportamento desses atores:

Rangel, em entrevista ao periódico Veja, se referiu a essa alternativa para o fim da greve, por meio da remissão à cláusula dos reajustes interníveis. Segundo o advogado, "mantendo isso no voto do relator, pode funcionar como uma brecha de negociação nas assembléias. Podemos dizer para os petroleiros que é uma saída honrosa, que o governo vai continuar estudando até agosto" (Veja de 31.5.1995).

${ }^{394}$ A representação classista na Justiça do Trabalho foi extinta apenas em 1999, com a Emenda Constitucional $n^{\circ}$ 24, que alterou o art. 116 da Constituição de 1988 (ver BRASIL. Constituição (1988). Emenda Constitucional $n^{\circ}$ 24, de 9 de dezembro de 1999. Altera dispositivos da Constituição Federal pertinentes à representação classistas na Justiça do Trabalho. Diário Oficial da União, Brasília, DF, 10.12.1999). 
Portanto, esta greve era, e continua sendo, abusiva, ilegal e ao insistir em manter greves impopulares, essas lideranças radicais estão dando ao Congresso Nacional e ao Governo Federal todas as condições para eliminar os excessos do poder sindical neste País.

Assim espero que essas Lideranças meditem sobre isso e que o bom senso leve os servidores grevistas a retornarem ao trabalho, e que depois discutam suas reivindicações sem radicalizações de ambos os lados. ${ }^{395}$

Antonio Maria Thaumaturgo Cortizo, por sua vez, era Ministro Classista representante dos empregados. Do primeiro para o segundo julgamento pela SDC, ele mudou de posicionamento: deixou de considerar válidos os acordos, bem como passou a reputar abusiva a greve. No voto convergente apresentado quando do segundo julgamento do dissídio, Antonio Cortizo expressou porque entendera válidos os acordos: "havia a necessidade, naquele instante, de se trazer a paz social ao País, em nome da qual, entendi que os acordos eram válidos para que pudéssemos julgar também aquelas reivindicações (...)”. Entretanto, “(...) hoje, entendo que esses acordos não são válidos para serem julgados nos termos da Constituição e das leis vigentes no país, por esta Especializada". O Ministro pediu "vênia não aos Srs. Ministros, mas aos senhores líderes sindicais, neste momento", para acompanhar os Ministros relator e revisor. ${ }^{396}$

Cortizo considerou que a democracia teria três pilares básicos: "a imprensa livre, o Parlamento livre e o Poder Judiciário funcionando em toda sua plenitude". O Ministro se voltou, então, ao descumprimento da ordem judicial de retorno ao serviço pelos petroleiros, ainda assim se desculpando com esses últimos:

Este Tribunal, bem ou mal, decidiu. E uma nação que tem um dos seus pilares básicos rompidos, fatalmente resvalará para o autoritarismo. E não colaboro para o rompimento do Estado de Direito que se consolida no nosso País. Não é com confronto, desobediência, insubordinação ao Poder Judiciário que vamos consolidar a democracia, nem o nosso Estado de Direito. Considerei a greve não abusiva até o julgamento daquela oportunidade. A partir daquele momento, de descumprimento da decisão deste Tribunal, peço perdão aos companheiros petroleiros de todo o País, mas não concordo com descumprimento de decisão judicial, seja ela boa ou ruim. Há recurso dentro do Estado Democrático de Direito para que cada parte tenha o seu direito assegurado. A partir daquela data para cá, não posso admitir que a Nação sofra as consequências pelo não-cumprimento de uma decisão judicial. Se for ruim, recorra-se. Se for boa, então, cumpra-se. Mas é boa só de um lado? Não, companheiros petroleiros, a partir daquela data para

\footnotetext{
${ }^{395}$ BRASIL. Tribunal Superior do Trabalho. Seção de Dissídios Coletivos. Dissídio Coletivo no 177.734/1995. Processo, p. 422 (para todas as citações).

${ }^{396}$ BRASIL. Tribunal Superior do Trabalho. Seção de Dissídios Coletivos. Dissídio Coletivo no 177.734/1995. Processo, p. 423/424 (destaque acrescentado). O revisor era o Ministro José Luiz Vasconcelos.
} 
cá, considero que o movimento de vocês não conta com o meu respaldo, sendo abusivo. Este é o meu voto. ${ }^{397}$

Antonio Cortizo concordou com a aplicação da multa, diante do descumprimento da decisão judicial (de retorno ao serviço). De toda forma, o que salta aos olhos, em seu voto, é a manifestação contrária - apesar de todas as escusas - à posição dos petroleiros de manter a greve a despeito da decisão do Tribunal. A conduta dos grevistas foi colocada fora do âmbito democrático. Na análise de Sayonara Grillo da Silva:

Embora diante de um julgamento de dissídio coletivo, no qual se estava definindo questões atinentes à política econômica, e com todas as especificidades que envolvem o exercício concreto de um poder normativo em que mais do que nunca as cortes se comportam como poder de Estado, a condenação da conduta dos grevistas passa por opô-los não à política econômica, não por afirmar a greve como uma medida de conflito contra o empregador. A culpabilização passa pelo deslocamento do conflito do binômio trabalho e capital para outra relação entre tribunal e grevistas, em que o tribunal é apresentado como lugar neutro e legitimado de decisão, e a greve não mais como um ato de resistência operária e uma medida de pressão dirigida em face do empregador, mas sim como ato de "descumprimento antidemocrático" de uma decisão judicial. ${ }^{398}$

O Ministro Armando de Brito, a seu turno, suscitou - como já o havia feito, na mesma ocasião, o Ministro Pedrassani - a questão da ilegitimidade da FUP. Em suas palavras:

(...) o que se teria de examinar era se trabalhadores não organizados em sindicatos dentro do sistema sindical brasileiro teriam o direito de deflagrar uma greve que tumultua o País, que traz prejuízos incomensuráveis à Nação, em nome de uma suposta negociação instrumentalizada por papéis que foram aqui trazidos como fundamento para legitimar uma greve, o que, evidentemente, não passa de uma simples posição retórica de quem quer dar satisfação à imprensa e à opinião pública. (...) Por isso renovo aqui o meu voto anterior: não reconheço legitimação à entidade. Mas, uma vez que a douta maioria entendeu, ante circunstâncias extraordinárias e eventuais de gravidade de uma crise social que se avizinhava, de examinar a matéria e, portanto, manter a questão nos termos de um litígio trabalhista, estaria pretensamente albergado dentro dos termos constitucionais, que, a meu ver, não é o caso, porque se trata de caso exclusivo de aplicação de disposição do Código Penal, configurado o crime contra a organização do trabalho no procedimento deste aglomerado de dirigentes que se arvora em liderança sindical para decretar a greve, a continuação ou a paralisação da greve. ${ }^{399}$

${ }^{397}$ BRASIL. Tribunal Superior do Trabalho. Seção de Dissídios Coletivos. Dissídio Coletivo no ${ }^{\circ}$ 177.734/1995. Processo, p. 424.

${ }^{398}$ SILVA, Sayonara Grillo Coutinho Leonardo da. Relações coletivas de trabalho, p. 282.

399 BRASIL. Tribunal Superior do Trabalho. Seção de Dissídios Coletivos. Dissídio Coletivo no 177.734/1995. Notas taquigráficas da sessão de julgamento, 26 de maio de 1995, p. 21/22. 
Já no voto que fez juntar ao processo, o Ministro Armando de Brito se voltou, de início, às críticas dirigidas ao Tribunal quando do primeiro julgamento. O Ministro respondeu negativamente às questões, por ele mesmo levantadas, sobre se a Corte estava sendo "intemperant[e] ou intempestiv[a]" e se estaria sendo um "Tribunal que 'profere decisões políticas'”. Segundo Armando de Brito:

Tenho convicção de que, assim como no campo espiritual-religioso do Apostolado, há uma missão didática e de sentido apostólico no sentenciar deste Tribunal. Que tem um compromisso inarredável com o Direito, a Justiça e a Verdade.

Ele, como órgão constitucional integrado também por juízes leigos em Direito, pode nem sempre decidir com o rigorismo de uma pura tecnicidade jurídica, pois tem que exercer o chamado Poder Normativo naquelas questões trabalhistas em que inexiste lei, mas que a necessidade social impõe que se dê uma solução, via sentença. ${ }^{400}$

As expressões usadas são significativas: "missão didática" e "sentido apostólico" na atividade de decidir, com a afirmação subsequente do compromisso da Corte com "o Direito, a Justiça e a Verdade". O Tribunal decidia e, ao decidir, indicava aos atores sociais como deveria agir, como uma espécie de messias que apontava o caminho a ser seguido. ${ }^{401}$

Armando de Brito cobrou dos órgãos públicos, em especial do Ministério Público da União, uma atuação mais "viril” diante das greves. Afinal, “o tão invocado direito de greve deixa de o ser quando o Judiciário declara abusiva a paralisação do trabalho. E se não é direito, o que resta? Crime contra a organização do trabalho, capitulado no art. 201 do Código Penal". ${ }^{402} \mathrm{O}$ Ministro, fazendo referência ao passado brasileiro, chegou a aludir à possibilidade de ações militares:

Eis o meu voto-conclamação, no qual está subjacente o empenho, o zelo, para que se preserve a democracia neste País, com as instituições operantes para, não deixando espaços vazios de poder, ensejar a que novas ações militares indesejadas tenham que ocorrer ante o processo omissivo de uma reação saneadora-corretiva da sociedade civil, refém da baderna, praticada sob roupagens de uma greve, direito social reconhecido pela Constituição,

\footnotetext{
${ }^{400}$ BRASIL. Tribunal Superior do Trabalho. Seção de Dissídios Coletivos. Dissídio Coletivo no 177.734/1995. Processo, p. 426.

${ }^{401} \mathrm{Um}$ ministro entrevistado afirmou que o Tribunal daquela época - e a assertiva tem em vista em especial a SDC - era um Tribunal que não acreditava na greve e que buscava disciplinar a atuação dos empregados e, dentre esses, dos grevistas. Diante dessa postura da Corte, outro ministrou chegou a lhe dizer [ao primeiro] que "o direito de greve acabou".

402 BRASIL. Tribunal Superior do Trabalho. Seção de Dissídios Coletivos. Dissídio Coletivo no 177.734/1995. Processo, p. 427.
} 
mas condicionado frente aos demais interesses e bens jurídicos também por ela albergados. ${ }^{403}$

O Ministro utilizou, na conclusão do voto, uma fórmula argumentativa que se tornou recorrente em decisões judiciais. A construção é feita a partir do reconhecimento de que o direito de greve é garantido pelo ordenamento jurídico (frequentemente com referência à sua natureza constitucional) para, em seguida, mediante a utilização de uma conjunção adversativa, vir a apresentação, com ênfase, das restrições que devem acompanhá-lo. Com isso, a própria discussão sobre a interpretação do art. $9^{\circ}$ da Constituição é colocada de lado. ${ }^{404}$

Concluído o julgamento do dissídio coletivo, os grevistas deliberaram, mais uma vez, não cumprir a decisão do TST. A essa altura, a greve já adquirira uma relevante dimensão. A sociedade fora convocada a discuti-la. A imprensa entrevistou diversas personalidades. Pesquisas de opinião foram realizadas. Entre as questões debatidas, sobressaíam o caráter político ou não da paralisação, a recusa dos petroleiros em cumprir a determinação do TST de retorno ao trabalho e a ocupação das refinarias pelos militares.

Vários juristas e acadêmicos se manifestaram. Celso Ribeiro Bastos, constitucionalista e professor da Pontifícia Universidade Católica de São Paulo (PUC/SP), afirmou que a situação, em face da decisão do TST e da recusa dos petroleiros, poderia "levar o Executivo a não ter outra opção senão criar um Estado de emergência (...) Não há nenhum outro poder legal para fazer os grevistas voltarem ao trabalho". ${ }^{405}$ Segundo Fábio Konder Comparato, professor da Universidade de São Paulo, a desobediência por parte dos petroleiros, em relação ao julgamento do TST, era inadmissível e "os limites de uma greve se estabelecem quando começa a prejudicar outras categorias e o povo em geral". Para Amauri Mascaro Nascimento, também professor da USP, a única saída dos petroleiros seria voltar ao

\footnotetext{
${ }^{403}$ BRASIL. Tribunal Superior do Trabalho. Seção de Dissídios Coletivos. Dissídio Coletivo no 177.734/1995. Processo, p. 427/428 (sublinhado no original).

${ }^{404}$ José Rodrigo Rodriguez propõe a hipótese de que essa construção argumentativa tem por objetivo facilitar o convencimento do destinatário da decisão: "diversos acórdãos trazem a afirmação veemente de que o direito de greve, como todo direito, está sujeito a limites, uma afirmação que, doutrinariamente, é absolutamente evidente. Todos os direitos são limitados pelo simples fato de existirem ao lado de outros direitos. A discussão sobre os direitos inclui, necessariamente, a consideração de seus limites. O que nos surpreende é que os juízes considerem necessário repetir esta afirmação com tanta insistência. A que se deveria este fato? A nossa hipótese é que esta afirmação, exatamente por ser extremamente óbvia, é de fácil aceitação pelo destinatário da decisão. E como o que faz seguir a ela, geralmente, é a afirmação de uma limitação ao direito de greve, a sentença posterior ganha poder de convencimento, derivado da afirmação anterior. O discurso coloca lado a lado uma afirmação de senso comum 'todos os direitos são limitados' e/ou, o 'direito de um termina onde começa o direito do outro' e, logo após, justificando-se nesse raciocínio, busca fundamentar qualquer limite ao direito de greve, eximindo-se de abordar com profundidade a questão da interpretação constitucional do Art. $9^{\circ}$ da Lei Suprema" (RODRIGUEZ, José Rodrigo. Dogmática da Liberdade Sindical - Direito, Política, Globalização. Rio de Janeiro: Renovar, 2003, p. 513).

${ }^{405}$ Folha de São Paulo de 16.5.1995 (disponível em http://www1.folha.uol.com.br/fsp/1995/5/16/brasil/42.html, acesso em 22.1.2014).
} 
trabalho, e o governo não poderia tomar qualquer atitude, sob o risco de desmoralizar o Tribunal. Sylvia Romano, advogada trabalhista, entendia que a recusa dos petroleiros evidenciava a falta de crença no Poder Judiciário e no governo. Em sua opinião, "uma situação como essa é lastimável, pois é o descrédito total das nossas instituições e o governo fica sem força para se impor". 406

A professora de direito constitucional Maria Garcia, também da PUC/SP, afirmou que a desobediência civil é um direito fundamental admitido pela Constituição, a teor do art. $5^{\circ}, \S 2^{\circ}$. De acordo com ela, "qualquer cidadão brasileiro, diante de uma lei injusta ou de ato de autoridade exorbitante, pode pleitear sua nulidade ao Supremo Tribunal Federal (STF), diretamente e sem advogado". Esse procedimento, em seu entender, seria, porém, rejeitado pelo STF, ao menos num primeiro momento. Isso porque "a Justiça é muito formalista e demora a absorver as inovações. Mas é preciso inventar novas formas de defender a cidadania”. A respeito dos petroleiros, a professora opinou que, em primeiro lugar, a decisão do TST deveria ser cumprida, para que pudesse ser rediscutida em grau de recurso ("é como imposto legal. Primeiro pagamos, depois discutimos a legalidade da cobrança"). Além disso, para Maria Garcia, "não conheço o acórdão do TST. Mas se o acordo foi considerado nulo por não ter sido assinado por representantes da Petrobrás, competia ao governo, que fez a negociação, regularizá-lo". ${ }^{407}$

O professor Goffredo da Silva Telles, da USP, via duas desobediências no caso: uma, por parte dos petroleiros em relação à decisão judicial, outra, por parte do governo, que não cumpriu um acordo por ele celebrado. Em suas palavras, "sinto-me angustiado. A situação é delicada. O governo descumpriu o acordo, o TST desconheceu esse acordo firmado de boa-fé, e os petroleiros ignoraram a decisão do tribunal. É preciso bom senso e patriotismo para solucionar essa questão". O problema do acordo com o governo também foi ressaltado por Cássio de Mesquita Barros Jr., professor de direito do trabalho da USP: "a situação é exótica. Decisão judicial cumpre-se. Se ela não está certa, deve ser discutida em grau de recurso. Ao mesmo tempo, o governo assina um acordo e a empresa não o cumpre". ${ }^{408}$ Outro professor de direito do trabalho da USP, Otávio Bueno Magano, questionou a própria decisão do TST: “embora não tenha qualquer simpatia pela greve dos petroleiros, muito menos depois

\footnotetext{
${ }^{406}$ Folha de São Paulo de 17.5.1995 (disponível em http://www1.folha.uol.com.br/fsp/1995/5/17/brasil/30.html, acesso em 22.1.2014).

407 Folha de São Paulo de 21.5.1995 - páginas distintas (disponível em http://www1.folha.uol.com.br/fsp/1995/5/21/cotidiano/3.html http://www1.folha.uol.com.br/fsp/1995/5/21/cotidiano/4.html, acesso em 28.1.2014).

${ }_{408}$ Folha de Sâ Paulo de 21.5.1995 (disponível em http://www1.folha.uol.com.br/fsp/1995/5/21/cotidiano/3.html, acesso em 28.1.2014).
} 
que resolveram desacatar uma decisão judicial, considero as razões da decisão discutíveis. (...) A Petrobrás, apesar de regida pelo seu estatuto, é uma empresa pública e sujeita-se ao controle daquele Ministério". 409

A decisão do TST foi questionada, ainda, por Barbosa Lima Sobrinho, que enviou carta ao Presidente Fernando Henrique Cardoso. Para ele, "a decisão do TST choca a sociedade, traduzindo a legalização da quebra de um contrato, ainda mais quando assinado por um ministro e avalizado por um presidente". 410

Em um importante artigo, cujo título era "para os amigos, tudo; para os inimigos, a lei”, o jurista Dalmo Dallari criticou a incoerência do Poder Executivo, bem como a decisão do Tribunal Superior do Trabalho. Em sua opinião:

Um ponto básico é a incoerência do Executivo federal, que usa dois pesos e duas medidas em termos de exigência de estrito respeito à legalidade. No caso dos petroleiros, a origem do conflito é um acordo celebrado no final de 1994, com a participação do presidente da República, do presidente do Petrobrás e de um ministro de Estado.

Naquela oportunidade foram registrados todos os itens do acordo num documento escrito, assinado, então, pela liderança sindical dos trabalhadores e pelo ministro. As partes interessadas manifestaram livremente sua vontade, não havendo qualquer dúvida quanto ao que foi acordado nem quanto à legalidade das cláusulas ajustadas. É razoável supor que todos os participantes estavam de boa-fé e acreditavam na plena validade do acordo. Além de tudo, estavam presentes autoridades federais que, de fato, poderiam autorizá-lo ou impedi-lo.

Agora, quando deveria ser cumprido o acordo, o presidente da República determinou à Petrobrás que se recusasse a isso, porque o cumprimento não convinha à política econômica do governo. É importante notar que a resistência veio do presidente da República que, inclusive, determinou depois que o presidente da Petrobrás não negociasse com os trabalhadores. Isso deixa fora de dúvida que o presidente da República manda realmente na Petrobrás, o que reforça a convicção de que o acordo de 1994 teve a concordância de quem podia decidir pela empresa. Para justificar o descumprimento, alegou-se que a formalização daquele ajuste não se tinha completado, por ter faltado a manifestação de concordância de órgãos administrativos da Petrobrás, aos quais o estatuto confere essa atribuição.

Considerando exclusivamente os aspectos formais, sem levar em conta que houve manifestação inequívoca da vontade de ambas as partes na atribuição de direitos e responsabilidades, e dando importância absoluta à forma, mesmo numa situação em que ela em nada afetava o compromisso ético e a essência do ajuste jurídico, o Tribunal Superior do Trabalho julgou sem validade o acordo. É inegável que, considerado o assunto de um ponto de vista estritamente formal, a imperfeição consistente na falta de uma formalidade oferece justificativa para o descumprimento. Mas,

409 Folha Se São Paulo de 21.5.1995 (disponível em


evidentemente, isso não é ético e reduz o direito a um jogo de formalidades, muito conveniente para enganar ingênuos de boa-fé. ${ }^{411}$

Outro debate recorrente era se a greve teria ou não motivação política. As opiniões eram variadas: "Toda greve é política. A questão não é discutir se é política ou não. O problema é que os servidores públicos devem encontrar formas de lutar pelos seus direitos sem prejudicar o cidadão" (Mário Covas, então Governador de São Paulo pelo PSDB mesmo partido de Fernando Henrique Cardoso); “A greve não é política, é eminentemente econômica, é por salários. Seria política se fosse contra as reformas do governo, contra a quebra do monopólio da Petrobrás" (Paulo Paim, então Deputado Federal pelo PT do Rio Grande do Sul); "Sim. A greve hoje é política. No início ela era reivindicatória mas perdeu esse caráter" (Ricardo Trípoli, então Presidente da Assembleia Legislativa de São Paulo pelo PSDB); “Acho que a greve é política também. Do ponto de vista da reivindicação, já houve manifestação do TST. Apesar disso, os petroleiros não voltaram ao trabalho. Há indícios de que há conotação política, como a questão da reforma constitucional" (Deputado Federal José Anibal, líder do PSDB na Câmara dos Deputados); "A greve não é política. São reivindicações econômicas e sociais. (...) Dizem que a greve é política porque tentam pegar um gancho na greve na tentativa de jogar a sociedade contra os petroleiros e contra o monopólio. Nós somos contra estas reformas, mas não houve uma discussão dentro da categoria sobre isso" (Luíza Botelho, Diretora da Federação Única dos Petroleiros). ${ }^{412}$

O Jornal do Brasil publicou editorial, intitulado "Arrogância e Desacato", que tratava das greves políticas. Em determino trecho, lia-se o seguinte:

(...) greves políticas pressupõem um nível superior de cidadania e de consciência social, que só a convicção democrática pode oferecer. O Brasil ainda está no primeiro estágio da democracia, com forte dosagem de corporativismo de inspiração paternalística e tinturas autoritárias. A reforma constitucional quer modificar as bases econômicas e sociais sobre as quais se apóiam o atraso econômico e a descontinuidade política. Não é por acaso que o sindicalismo atrasado, que tem medo de democraticar-se na pluralidade, quer manter o passado quando o futuro bate à porta do Congresso. ${ }^{413}$

\footnotetext{
${ }^{411}$ Folha de São Paulo de 2.6.1995 (disponível em http://www1.folha.uol.com.br/fsp/1995/6/02/opiniao/9.html, acesso em 4.2.2014).

${ }^{412}$ Folha de São Paulo de 23.5.1995 (disponível em http://www1.folha.uol.com.br/fsp/1995/5/23/brasil/55.html, acesso em 29.1.2014).

${ }^{413}$ Jornal do Brasil de 12.5.1995.
} 
O próprio Antônio Carlos Spis, Coordenador da FUP, ao ser indagado, rechaçou se cuidar de uma paralisação política: "A greve é contra o arrocho e as reformas. A gente não faz uma greve sem estar ligado à conjuntura. A pauta específica é econômica e social. Nos rotulam como greve política porque somos ligados à CUT e o governo tem como intenção primeira quebrar a CUT, que é a central que preocupa. Não tínhamos intenção alguma de ter um enfrentamento ao governo FHC através da greve". ${ }^{414}$ A par das declarações de Spis, é interessante notar, em um dos cartazes estendidos pelos grevistas, as frases: "Estamos em greve. Contra o arrocho salarial. Contra a política de FHC". 415

Em todas essas opiniões, havia em comum o fato de não ser indagada a validade em si de uma greve política. Trata-se de um importante silêncio. Para os que condenavam a paralisação, uma forma de fazê-lo era considerá-la política (como se fosse um vício que significasse por si); para os que defendiam a greve, tentava-se evitar a qualidade de política (da mesma forma: como se tratasse de um aspecto evidente). A despeito do texto constitucional de 1988 e das discussões que tiveram lugar na Assembleia Nacional Constituinte de 1987/1988, parecia permanecer a mentalidade de que a greve política não seria uma forma legítima de reivindicação. ${ }^{416}$ É válido contrastar essa mentalidade com a perspectiva de que o novo texto constitucional atribuiu aos trabalhadores a decisão sobre porque deflagrar uma greve, não limitando as possibilidades de motivação do movimento.

O componente político de uma greve comporta, além disso, diversos sentidos não se limitando à ideia de um movimento contrário a determinada decisão do governo. Nas entrevistas realizadas com João Pedro Ferraz dos Passos e Cézar Britto, por exemplo, a noção de um aspecto político na greve dos petroleiros de 1995 está associada ao fato de a liderança dos grevistas estar vinculada à CUT, que, por sua vez, era (e é até o presente) o braço sindical

\footnotetext{
${ }^{414}$ Folha de São Paulo de 22.5.1995 (disponível em http://www1.folha.uol.com.br/fsp/1995/5/22/brasil/4.html, acesso em 29.1.2014). De acordo com o entrevistador, Spis teria caído em contradição ao afirmar que a greve seria contra "o arrocho e as reformas" e, ao mesmo tempo, negar que ela fosse política. A assertiva de Spis se opunha à de outro Diretor da FUP, Clarkson Messias Araújo do Nascimento, que, no curso das tentativas de estabelecimento de negociações com o governo, declarara, alguns dias antes, que "a greve só tem como objetivo o cumprimento do acordo, por mais que queiram vinculá-la ao movimento contra as reformas constitucionais" (O Estado de São Paulo de 17.5.1995).

${ }^{415}$ Cartaz do Sindicato dos Petroleiros de Caxias/RJ. Cf. O Estado de São Paulo de 4.5.1995. O próprio Antônio Carlos Spis, quinze anos depois, vai sustentar que "a greve de maio de 1995 foi o maior momento de enfrentamento classista ao governo FHC e às suas políticas neoliberais" (Entrevista concedida ao Portal da FUP na internet, disponível em http://www.fup.org.br/2012/noticias/entrevistas/118, acesso em 12.3.2014).

${ }^{416}$ De acordo com Jacques Le Goff, o nível da história das mentalidades é aquele "que escapa aos sujeitos particulares da história, porque revelador do conteúdo impessoal de seu pensamento, é o que César e o último soldado de suas legiões, São Luís e o camponês de seus domínios, Cristóvão Colombo e o marinheiro de suas caravelas têm em comum". Cf. LE GOFF, Jacques. "As mentalidades: uma história ambígua". In: LE GOFF, Jacques. NORA, Pierre (orgs.). História: novos objetos. Trad. Terezinha Marinho. Rio de Janeiro: Francisco Alves, 1995, p. 71.
} 
do PT, importante partido de oposição ao governo do então Presidente da República, Fernando Henrique Cardoso. ${ }^{417}$

Entre os temas e discussões que circulavam à época do conflito, era frequente, sobretudo na imprensa, a ideia de que a atitude dos petroleiros era intolerável e exigia punição. Após a notícia de que a FUP e os sindicatos filiados decidiram pela continuidade da greve, o Jornal do Brasil, por exemplo, publicou editorial intitulado "Provocação Insensata". Os seguintes trechos são significativos:

Depois que o Tribunal Superior do Trabalho julgou abusiva a greve dos petroleiros, a recusa em voltar ao trabalho saiu do terreno das reivindicações trabalhistas para configurar deliberada afronta à lei. É grave. Desafio à lei passa à categoria de ato revolucionário, e pede pronta punição.

Os insuflados pela CUT - braço sindical do PT, que também se recusa a aceitar a derrota de suas teses na eleição presidencial - devem saber onde estão se metendo ao desafiar a Lei. Greve contra a Justiça é provocação. Sindicalismo praticado neste momento pela CUT saiu do âmbito trabalhista para o perigoso terreno revolucionário.

(...)

O direito de greve existe para que reivindicações de uma parcela social possam contar com apoio da opinião pública. As greves atuais não tiveram sucesso porque a população quer usufruir a estabilidade da moeda. A maioria da população se convenceu de que a continuidade do Plano Real está indexada às reformas na Constituição, para modernizar o país e retirar a sociedade do domínio do corporativismo incrustado na burocracia oficial e nas empresas estatais. ${ }^{418}$

Não faltaram opiniões que fundamentavam a mobilização das Forças Armadas: "Não há alternativa. É o que determina a lei e as instituições. O governo não pode admitir o desabastecimento e a paralisação da economia. Eles (os petroleiros) estão achando que podem paralisar a nação” (Marcelo Allencar, então Governador do Rio de Janeiro pelo PSDB); “A ocupação era inevitável. Na medida em que a refinaria está inteiramente paralisada, alguém precisa tomar conta dela. Ao ocupar a refinaria, o Exército não está cometendo nenhum ato de violência pessoal contra ninguém" (Mário Covas, então Governador de São Paulo pelo PSDB); "Defendo a ocupação das refinarias pelo Exército, mas os soldados deveriam ir desarmados. É lamentável, mas necessária. As palavras agora são moderação, cautela, prudência e cabeça fria para que a gente tenha logo uma solução para essas questões" (Ciro

\footnotetext{
417 Vale conferir o seguinte trecho da entrevista concedida por João Pedro Ferraz dos Passos: "a intenção do governo era naturalmente passar por cima do movimento sindical. Não do movimento sindical, mas daquela facção do movimento sindical que estava apoiando a greve, que era realmente a CUT, a Central Única dos Trabalhadores, porque o braço sindical do governo era outro." (PASSOS, João Pedro Ferraz dos. Depoimento sobre a greve dos petroleiros de 1995).

418 Jornal do Brasil de 10.5.1995.
} 
Gomes, ex-Ministro da Fazenda no governo de Itamar Franco); “O governo demorou para tomar essa atitude. A greve é um direito que tem de ser respeitado, desde que exercida na forma da lei. Conhecida a decisão do TST, não pode persistir a greve e menos ainda a ocupação das refinarias. É um ato de rebelião civil.” (Miguel Reale, Professor Emérito da Faculdade de Direito da USP); “A atitude do governo foi acertada e em consonância com a população, que quer o fim da greve. O governo não pode deixar de cumprir a decisão do TST e tem obrigação de fazer as refinarias funcionarem. O presidente está certíssimo.” (Antônio Carlos Magalhães”, então Senador Federal pelo PFL da Bahia); 419 “(...) A greve está sendo um movimento político de confronto à sociedade e é inteiramente justificável o uso do Exército. Essa não é uma prerrogativa de um governo de exceção ou militar e cabe perfeitamente em um governo democrático. O governo pediu a ocupação para defender o interesse da população" (Mailson da Nóbrega, ex-Ministro da Fazenda); “Acho que foi uma decisão acertada, porque o governo tem o dever de preservar o patrimônio público" (Nelson Marchezan, Deputado Federal pelo PPR do Rio Grande do Sul); "o governo tinha que tomar uma atitude. Está tomando até tarde. Não sei se é correto, mas o governo tem que governar. Os grevistas estão submetendo a população a um sofrimento que me parece desnecessário (...)" (Armando Peralta, Presidente licenciado da Associação Paulista de Supermercados APAS). ${ }^{420}$

A imprensa prosseguia realizando pesquisas de opinião. O Estado de São Paulo divulgou os resultados de pesquisa feita pela InformEstado. Chama atenção a informação de que, entre os entrevistados, 56,3\% consideravam que os trabalhadores que prestavam serviços públicos essenciais não tinham direito de fazer greves políticas (contra $41 \%$ que entendem positivamente), não obstante 79,3\% opinavam que esses mesmos trabalhadores tinham direito de fazer greves econômicas. ${ }^{421}$

A Folha de São Paulo noticiou pesquisa segundo a qual 59\% dos entrevistados (todos de São Paulo) aprovavam a ocupação pelo Exército das quatro refinarias, enquanto $26 \%$ eram contrários. Antes, o mesmo jornal havia publicado outra pesquisa, em que $60 \%$ dos participantes se opunham à greve (21\% apoiavam em parte e $17 \%$, totalmente). Além disso,

\footnotetext{
${ }^{419}$ Folha de São Paulo de 25.5.1995 (disponível em http://www1.folha.uol.com.br/fsp/1995/5/25/brasil/16.html, acesso em 29.1.2014).

420 O Estado de São Paulo de 25.5.1995.

${ }^{421}$ Ainda de acordo com os dados publicados, $84,3 \%$ dos entrevistados achavam que os funcionários das estatais eram privilegiados; $44,3 \%$, que o objetivo das greves eram melhores salários e condições de trabalho, enquanto $33 \%$ acreditavam que eram greves políticas contra Fernando Henrique Cardoso; e 70\% eram favoráveis às privatizações de empresas de serviços essenciais, como saúde, telefonia e energia elétrica $O$ Estado de São Paulo de 14.5.1995.
} 
$55 \%$ consideravam o movimento injusto, enquanto $34 \%$ reputavam-no justo, e $34 \%$ entendiam que, até aquele momento, o governo estava sendo rigoroso na medida certa, 29\% que estava sendo mais rigoroso do que devia e $27 \%$ menos severo do que deveria. Outro dado era o de que, para 53\% dos entrevistados, a greve era política, contra o governo de Fernando Henrique Cardoso (para segundo 36\%, os objetivos eram econômicos, isto é, por melhores salários). ${ }^{422}$

A despeito da intervenção dos militares e da segunda decisão do TST, permanecia o impasse entre o governo e os grevistas. As dificuldades de negociação continuavam. $\mathrm{O}$ governo não aceitava discutir enquanto não houvesse retorno ao trabalho, e os grevistas não retomavam suas atividades enquanto as demissões não fossem canceladas. ${ }^{423}$ Os petroleiros, nas diversas unidades da Petrobrás, mantinham, ora mais, ora menos, a mobilização. No geral, a greve continuava e a FUP tentava abrir canais de comunicação com o governo, buscando interlocutores. $^{424}$

Diversos parlamentares, alguns do próprio PSDB (como o Deputado Federal André Franco Montoro), assim como a Confederação Nacional dos Bispos do Brasil - CNBB tentaram assumir o papel de mediador. ${ }^{425}$ A Petrobrás, por sua vez, anunciou o corte de ponto dos grevistas, que não receberiam os salários dos dias parados. ${ }^{426}$

Logo após o novo julgamento do dissídio pelo Tribunal Superior do Trabalho, que nada acrescentou às tentativas de negociação, o Presidente da República foi à televisão e

422 Folha de São Paulo de 24 e 25.5.1995 (disponível em http://www1.folha.uol.com.br/fsp/1995/5/25/brasil/35.html http://www1.folha.uol.com.br/fsp/1995/5/24/brasil/50.html, respectivamente, acesso em 29.1.2014).

${ }^{423}$ O Presidente da República chegou a declarar que "não [era] o caso" de receber o presidente da CUT, Vicentinho. Em suas palavras, “a questão não é mais com o governo. É com os tribunais. Tá na hora de entender que o Brasil é uma democracia. E numa democracia quando o tribunal, em última instância, fala, acabou” (...) "Os petroleiros, que já fizeram tanta coisa boa pelo Brasil, devem entender que a Justiça disse não" (Jornal do Brasil de 13.5.1995). Alguns dias depois, o porta-voz da Presidência declarou que "O governo não tem o que negociar, e não pode negociar sobre que já foi uma decisão da Justiça. E decisão judicial tem de ser cumprida. Isso, na verdade, não deve ser apenas qualificado como uma greve, mas como uma desobediência à lei" (Jornal do Brasil de 19.5.1995).

${ }^{424}$ Segundo Frederico Lisboa Romão, “a situação das bases em greve é de relativa estabilidade, apesar dos problemas advindos imediatamente após o julgamento do TST, quando algumas bases retornaram ao trabalho; a direção nacional dos petroleiros tinha razoável controle sobre o movimento. O seu trabalho diário era trazer para a greve as bases que saíam. Um fato simbólico é que, algumas vezes, a própria direção da greve, quando percebia o movimento fraquejando em alguma base, defendia a suspensão do movimento naquele local específico. A greve era suspensa ali e, em seguida começava-se um novo trabalho de convencimento para o retorno à greve. Com ações desse tipo, as direções conseguiam evitar o fim da greve por esvaziamento. Essa tática permitiu comprovadamente uma grande flexibilidade no movimento" (ROMÃO, Frederico Lisboa. A greve do fim do mundo: petroleiros 1995 - expressão fenomênica da crise fordista no Brasil, p. 395).

${ }^{425}$ Cf., por exemplo, O Estado de São Paulo de 18.5.1995, Jornal do Brasil de 16 a 19.5.1995 e Folha de São Paulo de 26 a 30.5.1995.

426 Ver, a respeito, Folha de São Paulo de 26.5.1995 (disponível em http://www1.folha.uol.com.br/fsp/1995/5/26/brasil/52.html, acesso em 30.1.2014), Jornal do Brasil de 26.5.1995 e O Estado de São Paulo de 22.5.1995. 
dirigiu um apelo aos grevistas, para que retornassem ao trabalho, indicando, com isso, a disposição do governo e da Petrobrás a dialogar. E, em outra ocasião, Fernando Henrique Cardoso reiterou a possibilidade de negociação assim que as refinarias tivessem sua produção retomada. Segundo ele, "não há razão para manter a greve que está prejudicando o país e a população (...) Não podemos fazer uma democracia sem respeito à lei e à Justiça". 427

O Presidente da República cobrou da Petrobrás que fosse acionada a Procuradoria-Geral da República, no sentido de adotar as providências cabíveis em face dos petroleiros, diante da continuidade da greve e do não cumprimento da decisão judicial. ${ }^{428}$ No dia seguinte, teve-se a notícia de que o Ministro da Justiça, Nelson Jobim, e o ProcuradorGeral da República em exercício, Moacir Antônio Machado da Silva, decidiram que a Polícia Federal, a pedido da Procuradoria, abriria inquérito para apuração de responsabilidades. Para o Procurador, os petroleiros poderiam ser enquadrados nos artigos 201 e 202 do Código Penal. $^{429}$ Após a formalização do requerimento à Polícia Federal, o Ministro da Justiça declarou que "o Ministério Público está fazendo o que a Constituição determina” e “(...) defendendo o interesse da população brasileira". ${ }^{430}$

A empresa, por sua vez, seguia publicando informações de que a greve estaria reduzindo, e a produção, aumentando. ${ }^{431}$ Além disso, a Petrobrás voltou a ameaçar os

\footnotetext{
${ }^{427}$ Folha de São Paulo de 27.5.1995 (disponível em http://www1.folha.uol.com.br/fsp/1995/5/27/brasil/39.html e http://www1.folha.uol.com.br/fsp/1995/5/27/brasil/39.html, respectivamente, acesso em 30.1.2014). O embaixador Sérgio Amaral, porta-voz da Presidência da República, afirmou que "pela segunda vez, a Justiça se pronunciou sobre a greve e é ela que tem competência para dizer se o movimento é justo ou injusto" (...) "Só nos resta obedecer a Justiça; é assim na democracia" ( $O$ Estado de São Paulo de 27.5.1995)

428 O Estado de São Paulo de 30.5.1995 e Folha de São Paulo de 30.5 .1995 (disponível em http://www1.folha.uol.com.br/fsp/1995/5/30/brasil/9.html, acesso em 3.2.2014).

${ }^{429} O$ Estado de São Paulo de 31.5.1995. Os dispositivos legais invocados preveem o seguinte: "Paralisação de trabalho de interesse coletivo. Art. 201 - Participar de suspensão ou abandono coletivo de trabalho, provocando a interrupção de obra pública ou serviço de interesse coletivo: Pena - detenção, de seis meses a dois anos, e multa. Invasão de estabelecimento industrial, comercial ou agrícola. Sabotagem. Art. 202 - Invadir ou ocupar estabelecimento industrial, comercial ou agrícola, com o intuito de impedir ou embaraçar o curso normal do trabalho, ou com o mesmo fim danificar o estabelecimento ou as coisas nele existentes ou delas dispor: Pena reclusão, de um a três anos, e multa" (BRASIL, Decreto-Lei n ${ }^{\circ}$ 2.848, de 7 de dezembro de 1940. Código Penal. Diário Oficial da União. Rio de Janeiro, DF, 31.12.1940. Retificação em 3.1.1941). Além disso, outras entidades, como a Federação do Comércio de Combustíveis - Fecombustíveis e a Companhia Siderúrgica Nacional, ameaçaram propor ações judiciais em face da FUP e dos sindicatos dos petroleiros para obter o ressarcimento dos prejuízos sofridos. Cf. Folha de São Paulo de 30.5.1995 (disponível em http://www1.folha.uol.com.br/fsp/1995/5/30/brasil/11.html, acesso em 3.2.2014).

${ }^{430}$ Folha de São Paulo de 31.5.1995 (disponível em http://www1.folha.uol.com.br/fsp/1995/5/31/brasil/9.html, acesso em 3.2.2014).

${ }^{431}$ Cf., entre outros, $O$ Estado de São Paulo de 30.5.1995. Em entrevista, Antonio Carlos Spis admitiu que havia perspectiva para o fim da greve, uma vez que a empresa teria apresentado documento acerca do início das negociações. Spis negou, porém, que os petroleiros estivessem à procura de uma saída honrosa (Folha de São Paulo de 30.5.1995, disponível em http://www1.folha.uol.com.br/fsp/1995/5/30/brasil/6.html, acesso em 3.2.2014). A situação nas bases dos sindicatos era, efetivamente, de recrudescimento. Em alguns estados, a greve foi suspensa. Ver, a respeito, ROMÃO, Frederico Lisboa. A greve do fim do mundo: petroleiros 1995 expressão fenomênica da crise fordista no Brasil, p. 413.
} 
petroleiros com a possibilidade de novas demissões, a partir do momento em que a paralisação completasse 30 dias. A orientação, vinda da Presidência da República, era de demissão por "abandono de emprego". 432

As tentativas de negociação prosseguiam. O governo sinalizava que não haveria intervenção caso a Petrobrás decidisse rever as demissões, com a volta ao trabalho. ${ }^{433} \mathrm{~A}$ recusa do governo em negociar parecia estar associada ao fato de que o prolongamento da greve desenhava um prognóstico melhor para a proposta de emenda que rompia o monopólio da exploração do petróleo. 434

A Procuradoria Geral do Ministério Público do Trabalho começou a execução da multa aplicada pelo Tribunal Superior do Trabalho às entidades sindicais. ${ }^{435} \mathrm{O}$ valor era de $\mathrm{R} \$$ 2,1 milhões por sindicato, totalizando R $\$ 35,7$ milhões. ${ }^{436}$

No dia 2 de junho, a Federação Única dos Petroleiros anunciou o fim (na sua comunicação: "suspensão") da greve, segundo decisão da maioria das assembleias. De acordo com a FUP, não havia mais possibilidade de negociação e, a cada momento, a paralisação era suspensa em alguma base. Os petroleiros, segundo a entidade, continuariam em "estado de greve" e buscariam a retomada das negociações na semana seguinte. ${ }^{437}$ Mas não havia

\footnotetext{
${ }^{432}$ Folha de São Paulo de 31.5.1995 (disponível em http://www1.folha.uol.com.br/fsp/1995/5/31/brasil/11.html, acesso em 3.2.2014). Essa hipótese era contestada pelos petroleiros. Após assembleia em que foi decidida a continuidade da greve, o Diretor do Sindicato dos Petroleiros de Mauá/SP, disse que o argumento do governo não tinha validade legal (Folha de São Paulo de $1^{\circ} .6 .1995$, disponível em http://www1.folha.uol.com.br/fsp/1995/6/01/brasil/18.html, acesso em 3.2.2014).

${ }^{433}$ Folha de São Paulo de $1^{\circ} .6 .1995$ (disponível em http://www1.folha.uol.com.br/fsp/1995/6/01/brasil/17.html, acesso em 3.2.2014).

${ }^{434}$ Isso foi detectado também pelo Partido dos Trabalhadores, que fazia oposição ao governo. Cf. Folha de São Paulo de 30.5.1995 (disponível em http://www1.folha.uol.com.br/fsp/1995/5/30/brasil/10.html, acesso em 3.2.2014). Ver também ROMÃO, Frederico Lisboa. A greve do fim do mundo: petroleiros 1995 - expressão fenomênica da crise fordista no Brasil, p. 383.

435 João Pedro Ferraz dos Passos, na entrevista concedida para esta pesquisa, relatou ter ocorrido pressão por parte do então Ministro da Justiça, Nelson Jobim, sobre o Ministério Público, inclusive de forma direta na Procuradoria-Geral da República. Teria havido pressão também por parte do Tribunal Superior do Trabalho. Cf. PASSOS, João Pedro Ferraz do. Depoimento sobre a greve dos petroleiros de 1995.

${ }^{436}$ Folha de São Paulo de 1º.6.1995 (disponível em http://www1.folha.uol.com.br/fsp/1995/6/01/brasil/22.html, acesso em 3.2.2014). De acordo com $O$ Estado de São Paulo, "os petroleiros foram a categoria que recebeu até agora a multa mais expressiva fixada pelo TST, desde a criação desse tipo de punição, no ano passado. (...) Os assessores do TST explicam que o valor foi 'expressivo' desta vez porque o Tribunal queria que os petroleiros voltassem ao trabalho imediatamente, já que a greve afetava atividades essenciais. Os ministros do TST levaram em consideração a 'pujança econômica dos sindicatos' dos petroleiros" (edição de 3.6.1995).

${ }^{437}$ Folha de São Paulo de 3.6.1995 (disponível em http://www1.folha.uol.com.br/fsp/1995/6/03/brasil/3.html, acesso em 4.2.2014). Na refinaria de Cubatão/SP, a greve foi encerrada apenas no dia seguinte. A FUP fez a seguinte comunicação às demais entidades: "de posse do quadro nacional de hoje, onde apesar de ainda haver muita disposição em algumas refinarias, a realidade da maioria das bases aponta um caminho que não marca para a continuidade de uma greve forte na categoria, e de que é necessário mantermos a nossa unidade nacional para que não haja divisão, e ainda de que não vemos perspectiva de que possamos encontrar negociação por dentro da greve, a análise da direção da FUP, por unanimidade, é de que devemos SUSPENDER O MOVIMENTO, MANTER O ESTADO DE GREVE e indicar a 3a feira (06.06) para data de inicio das negociações com a companhia" (ROMÃO, Frederico Lisboa. A greve do fim do mundo: petroleiros 1995 -
} 
garantia de cancelamento das demissões. Antônio Carlos Spis afirmou: "vamos à justiça, se for preciso, para anular as demissões". De toda forma, conforme notícia divulgada pelo portavoz da Presidência da República, a empresa estaria liberada para negociar as readmissões. A estimativa de prejuízo era de U\$ 1,5 bilhão. ${ }^{438}$

Alguns órgãos da imprensa comemoravam o fim da greve. O Estado de São Paulo publicou editorial intitulado "Venceu o respeito à Justiça". ${ }^{439}$ A Revista Veja, por sua vez, vaticinava, em tom exultante:

lançando mão de recursos jurídicos e econômicos e de tropas do Exército, além de contar com o apoio de pelo menos dois terços da população, o governo já comemora uma vitória que pode iniciar a ruptura de um equilíbrio de forças que subsiste na política brasileira desde o fim do governo Figueiredo, quando se criou um movimento sindical forte e todos os governos foram obrigados, dessa ou daquela forma, a sentar para negociar com o outro lado. ${ }^{440}$

A questão da opinião pública pode ter contribuído para o encerramento da paralisação. Vários meios de comunicação já haviam divulgado pesquisas que indicavam a reprovação da greve. Isso provavelmente foi um fator de pressão sobre os petroleiros. As pesquisas de opinião criavam um ambiente de vitória e consenso para o governo, em especial para o Presidente da República e sua equipe, e desfavorável aos grevistas. ${ }^{441}$

A mídia atuou de maneira decisiva na construção de uma imagem negativa dos grevistas, bem como na formação de uma opinião pública em torno do governo e de sua

expressão fenomênica da crise fordista no Brasil, p. 417).

${ }^{438}$ O Estado de São Paulo de 3.6.1995. Cerca de três anos mais tarde, a edição de 12.4.1998 da Folha de São Paulo divulgou, em pequena nota, que, "no jornal do DCE da USP, o superintendente de recursos humanos da Petrobrás, José Lima de Andrade Neto, afirmou que o desabastecimento de combustíveis durante a greve dos petroleiros, em 95, foi provocado por sonegação das distribuidoras".

${ }^{439}$ O seguinte trecho é significativo: “o Presidente Fernando Henrique Cardoso não deve, em momento algum, recuar no propósito de reestruturar o Estado brasileiro, ação que começa pelo respeito que os cidadãos e os poderes públicos devem às decisões judiciais. Foi por ter batido os grevistas dentro da Constituição e no campo que eles escolheram - o desafio à Justiça - que o chefe do Estado pôde tratar essa greve como assunto de rotina e não de 'segurança nacional'. (...) Todo esse episódio leva a que se reveja a posição defensiva em que os políticos se colocam diante de grevistas que falam alto: o grevista é um cidadão como outro qualquer, que tem seus direitos e não pode ferir o dos demais, muito menos desafiar a Justiça. Quando os políticos compreenderem isso e pensarem que a próxima greve pode ser contra muitas das coisas erradas que fazem, não terão pressa em mediar e parecer bonzinhos diante dos que são os inimigos da Ordem Jurídica que eles, políticos, juraram defender. Agora é a hora de persistir na postura de que os danos civis que foram causados por uma greve ilegal devem ser reparados." (O Estado de São Paulo de 3.6.1995).

${ }^{440}$ Revista Veja de 31.5.1995.

441 Em tom de vitória, o Ministro de Minas e Energia, Raimundo Brito declarou que "a condução deste movimento, por parte do governo e da Petrobrás, deixa ensinamentos bons para todas as partes envolvidas (...) Aprendemos a operar uma greve no setor estatal" (Revista Isto é de 7.6.1995). 
postura em relação aos petroleiros. ${ }^{442}$ Isso parece ter influenciado os rumos da greve, como se verifica na seguinte análise:

(...) os trabalhadores do petróleo não conseguiram transformar o seu poder de pressão, fruto da mobilização da categoria, em simpatia popular, haja vistas a imagem negativa do movimento junto à população: o movimento deixa a imagem de uma greve corporativista de um grupo de trabalhadores privilegiados que não temiam prejudicar todo o conjunto da população na defesa de seus privilégios. Não resta dúvida pois que foi esta imagem pública negativa o ponto frágil do movimento dos petroleiros. ${ }^{443}$

No Jornal Nacional, da Rede Globo, Adílson Citelli notou, nos dias imediatamente anteriores ao término da greve, o "quase desaparecimento" da voz da Federação Única dos Petroleiros. Havia uma "dominância discursiva" na "locução direta do governo", e "a fala dos sindicalistas, quando surgia, era difusa". O autor observa que "o consenso sobre a incúria dos petroleiros nasceu, portanto, sobre atos comunicativamente coercitivos. A metonímia e a sinédoque tornaram-se figuras condutoras do processo. Todos estavam contra a greve, ainda que o ponto da generalização pudesse ser o depoimento de um motorista com dificuldades para abastecer seu carro e mesmo a dona de casa postada numa longa fila para comprar um botijão de gás". ${ }^{444}$

\footnotetext{
442 Segundo Romão: "A mídia buscou isolar por completo a greve. Com seus artigos, matérias e imagens construiu um cenário bipolar. De um lado estava a população, o conjunto da nação e seu governo, lutando para derrotar o dragão da inflação, para estabilizar a economia. Gente simples e humilde que se sacrificava em nome de um futuro melhor para todos. Do outro lado se encontrava o corporativismo, trabalhadores já privilegiados por seus altos salários, que se preocupavam apenas consigo mesmos. Todos funcionários de uma única empresa que, por sua vez, viviam de costas para o país; uma empresa que apesar de estatal não prestava contas ao povo, sequer pagava devidamente seus impostos. Era a desejo da nação contra os interesses corporativos; a luta do bem contra o mal. As ações da imprensa criaram um consenso contra a greve" (ROMÃO, Frederico Lisboa. A greve do fim do mundo: petroleiros 1995 - expressão fenomênica da crise fordista no Brasil, p. 432).

${ }^{443}$ NEVES, Paulo S. C. "O sindicalismo na indústria petrolífera no Brasil: tendências recentes", p. 8 (documento eletrônico). A capacidade do governo de gerar consenso diante de uma greve e a repercussão disso são também ilustradas na seguinte passagem do texto de Heloísa Martins e Iram Rodrigues: "quatro anos e meio depois [à greve dos petroleiros], na última semana de julho de 99, os caminhoneiros fizeram um movimento que durante quatro dias praticamente parou o País. O governo foi pego de surpresa com a extensão do movimento e, de certa forma, cedeu em, praticamente, todos os pontos reivindicados pelos caminhoneiros. O que mudou nestes quatro anos? Simplesmente, o Executivo se enfraqueceu, está com baixos índices de popularidade, que podem ser comparados com os piores momentos dos governos Sarney e Collor. O Plano Real, principalmente após a desvalorização cambial ocorrida em janeiro de 99 , agravou problemas que já vinham de antes, em particular o desemprego. As melhorias anunciadas no início de 95 ainda não chegaram para a ampla maioria da população. Essa é a principal diferença entre estes dois momentos..." (In: "O sindicalismo brasileiro na segunda metade dos anos 90", p. 159).

${ }^{444}$ CITELLI, Adílson Odair. "Palavras de ordem: a greve dos petroleiros e a reportagem que não houve". In: Comunicação e Educação. São Paulo (4): 82 a 89, set/dez de 1995, p. 86 e 88, respectivamente. Citelli afirma, ainda, que "o expediente técnico de formatar o telejornal pelo princípio da reiteração, isto é, pela repetição, dia após dia, da mesma estrutura de apresentação, igualmente cumpria função educativa. A questão da greve era disposta sempre em três núcleos organizativos: apelo emocional, relato dos fatos, ameaça" (p. 87).
} 
E, subjacente às coberturas jornalísticas dos problemas decorrentes da falta de gás e combustíveis, com ênfase nos prejuízos causados, havia uma posição sobre o próprio direito de greve, previsto na Constituição. Como destaca Ana Cosenza:

A edição das matérias privilegiou, ainda, as informações prestadas por membros do governo, sindicatos patronais e distribuidoras. Ao mesmo tempo, as denúncias feitas pelas entidades dos petroleiros (de que a Petrobrás e as distribuidoras estavam escondendo estoques), posteriormente confirmadas, foram suprimidas ou minimizadas. Nas matérias sobre o problema da falta de gás e combustíveis, também estava subjacente a idéia de que o direito de greve não poderia ser tão amplo quanto o estabelecido pela Constituição de 1988. Os ditos prejuízos à população, destacados nas notícias e reportagens, reforçavam a concepção de que, em alguns setores, o exercício do direito de greve implicaria a supressão de um direito considerado mais importante: $\mathrm{o}$ dos consumidores. ${ }^{445}$

A discussão sobre os limites do direito de greve esteve presente na decisão do Tribunal Superior do Trabalho que julgou a paralisação dos petroleiros. O suposto confronto do direito de greve com outros direitos, como o de ir e vir ou o direito dos consumidores, permanece até hoje um aspecto levantado com frequência em processos judiciais. ${ }^{446}$ Talvez a

${ }^{445}$ COSENZA, Ana. "Representações da greve dos petroleiros de 1995 na imprensa: as referências ao período militar e à democracia no discurso jornalístico", p. 305. O Jornal do Brasil publicou, na edição de 26.10.1995, reportagem sobre o estudo do Tribunal de Contas da União indicando que, durante a greve de maio, as distribuidoras de gás e combustíveis esconderam seus estoques com o objetivo de especular com o produto. De acordo com a nota, "os dados levantados pelos auditores mostram que tinham fundamento as denúncias dos grevistas, que na época da paralisação garantiram que as refinarias estavam produzindo o gás de cozinha. Os dados levantados pelo TCU, a pedido do ministro Adhemar Glisi, mostram que a Petrobrás reduziu em apenas $16,5 \%$ o repasse de combustíveis para as distribuidoras, embora a produção tenha caído 58\% (a diferença veio dos estoques). 'A redução havida na distribuição não seria suficiente para causar os contratempos verificados nas grandes cidades, com a população em busca desses produtos', afirmam os técnicos do tribunal”.

${ }^{446}$ Os $\S \S 1^{\circ}$ e $3^{\circ}$, da Lei 7.783/1989 dispõem respectivamente que: "em nenhuma hipótese, os meios adotados por empregados e empregadores poderão violar ou constranger os direitos e garantias fundamentais de outrem" e "as manifestações e atos de persuasão utilizados pelos grevistas não poderão impedir o acesso ao trabalho nem causar ameaça ou dano à propriedade ou pessoa" (BRASIL. Lei no 7.783, de 28 de junho de 1989. Dispõe sobre o exercício do direito de greve, define as atividades essenciais, regula o atendimento das necessidades inadiáveis da comunidade, e dá outras providências). É exemplificativa de como é colocado o referido confronto entre direitos a decisão proferida pelo então Corregedor Geral da Justiça do Trabalho, Ministro Ives Gandra Martins Filho, no processo CorPar-7603-51.2013.5.00.0000, em que ficou registrado o seguinte entendimento: “(...) considerando que membros do sindicato profissional estariam a impedir o acesso de empregados e clientes às agências bancárias do Banco Requerente, conforme o registro constante das Atas Notariais juntadas à seq. 1, págs. 185-193, e que as fotografias trazidas à colação indicam que parte dos grevistas se postavam à frente do acesso às agências bancárias, dificultando o ingresso de empregados do banco e demais usuários às suas dependências, ficam evidentes o 'fumus boni iuris' e o fundado receio de dano de difícil reparação - 'periculum in mora' - pressupostos aptos à concessão da liminar. Isso porque, embora não haja indícios de que os sindicalistas tenham se utilizado de meios violentos para obter o fechamento das agências, inibindo o trabalho dos bancários que assim o desejassem ou o acesso do público em geral, a intimidação decorrente do ostensivo posicionamento nos lugares de ingresso às agências é suficiente para evidenciar que os grevistas não se orientaram pela norma do art. $6^{\circ}$, $\S \S 1^{\circ}$ e $3^{\circ}$, da Lei 7.783/89" (BRASIL. Tribunal Superior do Trabalho. Corregedoria-Geral da Justiça do Trabalho. Correição Parcial no 7603-51.2013.5.00.0000. Rel. Min. Ives Gandra Martins Filho. Diário Eletrônico da Justiça do Trabalho, Brasília, DF, 10.10.2013). 
origem do debate tenha sido justamente a amplitude com o que o direito está previsto na Constituição de 1988, associando-se às demandas reprimidas no regime anterior. ${ }^{447}$

Passadas quase duas décadas, é interessante perceber como a história da greve de 1995 é recontada por alguns dos envolvidos. Para a Central Única dos Trabalhadores, a paralisação se inseriu na "Campanha nacional contra as reformas neoliberais de FHC", no período de março a maio de 1995, sendo considerada "a principal luta de resistência à política de privatizações do Estado promovida pelo governo Fernando Henrique Cardoso". ${ }^{448}$ Em tom semelhante, a Federação Única dos Petroleiros publicou cartilha, quando completados 15 anos da paralisação, referindo-se à "greve que contestou o neoliberalismo e impediu a privatização da Petrobrás". Sobre os efeitos do movimento, defendeu:

A FUP e seus sindicatos foram submetidos a multas milionárias por terem colocado em xeque os julgamentos viciados do TST, que decretou como abusiva uma greve absolutamente legítima.

Além de evitar a privatização da Petrobrás e desmascarar o autoritarismo do governo, a greve de maio de 1995 despertou um movimento nacional de solidariedade e unidade da classe trabalhadora. Por todo o país, fizemos ecoar um brado que marcou para sempre a categoria: "Somos todos petroleiros". ${ }^{449}$

Apesar da decisão da FUP, em 2 de junho, de "suspender" a paralisação, a greve de 30 dias dos petroleiros ainda produziu várias consequências. A Organização Internacional do Trabalho foi acionada, as multas aplicadas à Federação e aos sindicatos profissionais

\footnotetext{
${ }^{447} \mathrm{O}$ seguinte relato de João Pedro Ferraz dos Passos fornece uma relevante perspectiva de como a questão era colocada para o Poder Judiciário: “(...) no setor privado, as questões foram se acirrando muito mais, porque nós não tínhamos ainda nenhuma legislação que limitasse esses direitos, que dissesse: 'olha, o direito de greve tem que ser exercido dentro desses parâmetros e tal'. Não tinha nada. Então esse foi o período em que o Judiciário tinha que colocar alguns freios e tratar da ilegalidade de greve, legalidade ou ilegalidade de greve, buscando uma legislação que ainda não se sabia se estava ou se não estava recepcionada. Quer dizer, era um outro problema, o Judiciário tinha que verificar, com todo cuidado, quais as disposições, até mesmo as disposições da Consolidação das Leis do Trabalho, que tinham sido recepcionadas e a legislação da greve. Então foi um período que nós tivemos muita dificuldade com essas interpretações. Foi um período também de muita, eu diria, participação política, enfim. Todos aqueles anseios de greve que foram reprimidos durante décadas foram liberados exatamente pela Constituição de 88" (PASSOS, João Pedro Ferraz do. Depoimento sobre a greve dos petroleiros de 1995).

${ }^{448}$ Disponível em http://www.cut.org.br/institucional/68/cronologia-de-lutas, acesso em 12.3.2014.

${ }^{449}$ A expressão "somos todos petroleiros" foi utilizada no dia 31 de maio de 1995, quando a CUT promoveu o "Dia Nacional de Solidariedade à Greve dos Trabalhadores da Petrobrás", com a participação de bancários, metalúrgicos, professores e funcionários públicos. Como era de se esperar, não havia, ao menos no discurso dos dirigentes sindicais, uma ideia de derrota. Em entrevista concedida por Antônio Carlos Spis ao próprio Portal da FUP na internet, ele declarou que: "Em hipótese alguma, a greve foi derrotada. Nós, sim, derrotamos FHC, obrigando-o a tirar a máscara de democrata. Desmoralizamos um presidente que tinha a obrigação de negociar por ser o governo detentor da maioria das ações ON da Petrobrás, uma empresa de economia mista. O acordo assinado com Itamar Franco (presidente que antecedeu FHC) foi cumprido com sobras na Campanha Reivindicatória de 1996" (disponível em http://www.fup.org.br/2012/noticias/entrevistas/118, acesso em 12.3.2014).
} 
foram executadas e se iniciou o percurso no sentido de alcançar a readmissão dos trabalhadores dispensados. É hora de examinar esses desdobramentos.

\subsection{A decisão do Comitê de Liberdade Sindical da OIT}

Após o primeiro julgamento do dissídio coletivo pelo Tribunal Superior do Trabalho, a Central Única dos Trabalhadores, no dia 17 de maio de 1995, formulou queixa ao Comitê de Liberdade Sindical da Organização Internacional do Trabalho. O governo brasileiro pronunciou-se no dia 4 de setembro de 1995.

De acordo com o informe da OIT, ${ }^{450}$ a CUT relatou os fatos ocorridos em 1994 e 1995, desde a deflagração da greve no ano anterior, os acordos firmados com o governo e, finalmente, a decisão do TST. Afirmou que, no dia 11 de maio, a Petrobrás, por determinação do Presidente da República, despediu funcionários da empresa, por justa causa, estando, entre eles, vários dirigentes sindicais. Narrou que, até 15 de maio, já haviam sido dispensados 59 empregados, incluindo dirigentes dos sindicatos e da federação. A greve continuou e foi garantido o percentual de $30 \%$ de produção de gás para abastecimento de hospitais, indústrias e domicílios - segundo a CUT. De acordo com a Central, a postura do governo brasileiro representava uma "flagrante violação" à Constituição nacional, que previa estabilidade no emprego ao dirigente sindical, e à Convenção 98 da OIT, ratificada pelo país (e que consagrava o princípio da negociação coletiva ${ }^{451}$. Além disso, o Tribunal Superior do Trabalho declarou a nulidade de acordo coletivo (de 10 de novembro de 1994) firmado por Ministros de Estado, autoridades hierarquicamente superiores à direção da Petrobrás. Para a CUT, o Poder Executivo rejeitava documento negociado e celebrado pela administração anterior, que fora composta pelo então Presidente da República.

O governo brasileiro, por sua vez, apresentou sua versão dos fatos - de 1994 a 1995 -, fez referência ao art. 114 da Constituição e sustentou que o processo judicial de declaração de abusividade da greve tramitara nos limites do texto constitucional e da Lei 7.783/1989. Informou que, como consequência do caráter abusivo da paralisação, foi autorizado à empresa, segundo a lei, realizar dispensas e substituir os empregados em greve, "tanto para zelar pelo cumprimento da decisão judicial quanto para que fosse respeitado o

450 ORGANIZAÇÃO INTERNACIONAL DO TRABALHO. Caso número 1839 (Brasil): 300. Informe del Comité de Libertad Sindical. 264 Reunión del Consejo de Administración. Genebra: OIT, 1995 (disponível em http://www.ilo.org/dyn/normlex/es/f?p=1000:50002:0::NO:50002:P50002_COMPLAINT_TEXT_ID:2903565\# 1 , acesso em 11.4.2014).

${ }^{451}$ A convenção 98 da OIT está em vigor no Brasil desde a década de 1950, aprovada pelo Decreto-Legislativo $n^{\circ} 49 / 1952$ e promulgada pelo Decreto no $33.196 / 1953$. 
estado de direito"452. Competia à empresa assegurar o abastecimento de produtos indispensáveis à comunidade, como combustíveis e gás de cozinha, cuja falta já estaria sendo sentida pela população, com comprometimento da segurança nacional. Para tanto foram necessárias algumas dispensas. O governo encaminhou ao Comitê as decisões judiciais proferidas nos dias 9 e 26 de maio de 1995.

Vale constatar - mais uma vez - a ausência de remissão ao art. $9^{\circ}$ da Constituição, tanto pela CUT, quanto pelo governo brasileiro. O único texto normativo invocado sobre a greve é a Lei 7.783/1989. A Constituição foi referida apenas quanto à previsão de estabilidade no emprego dos dirigentes sindicais (art. $8^{\circ}$, VIII) e com relação ao poder normativo da Justiça do Trabalho (art. 114). Fica a indagação: por que não há uma discussão sobre a interpretação a ser conferida ao texto constitucional?

Em suas conclusões ${ }^{453}$, o Comitê destacou o fato de que, três dias após o início da greve e enquanto ela se desenvolvia, o Tribunal Superior do Trabalho impôs condições de trabalho às partes, tornando ilegal a atuação dos grevistas. O Comitê ressaltou o princípio, assentando em outros casos, de que "uma disposição que permite que uma das partes do conflito possa unilateralmente solicitar a intervenção da autoridade do trabalho para que essa avoque a solução do conflito representa um risco contra o direito dos trabalhadores de deflagrar a greve e é contrária ao incentivo à negociação coletiva". O Comitê considerou, diante disso, que houve violação ao direito de greve e solicitou ao governo que adotasse providências no sentido de alterar a legislação, de maneira a que a submissão de conflitos coletivos a autoridades judiciais dependesse de comum acordo entre as partes, ou que se tratasse de serviços essenciais em sentido estrito (ou seja, aqueles que, caso interrompidos, pudessem colocar em perigo a vida, a segurança ou a saúde de toda ou de parte da população).

O Comitê de Liberdade Sindical convocou o governo brasileiro a que garantisse o respeito às convenções coletivas celebradas entre sindicatos e empresas, concitando os interlocutores sociais a resolverem os conflitos coletivos por meio da negociação coletiva.

Como houve contradição entre o alegado pela CUT e pelo governo brasileiro quanto ao cumprimento dos $30 \%$ dos serviços mínimos, o Comitê não encontrou condições de formular conclusão a respeito. Por outro lado, tendo em vista que a greve foi julgada abusiva pelo TST, porque estava em vigor instrumento normativo oriundo do próprio Tribunal, e considerando que o Comitê criticou exatamente a submissão unilateral do conflito coletivo à

\footnotetext{
452 Tradução livre (em todas as citações).

${ }^{453}$ O Comitê de Liberdade Sindical elabora e relata suas conclusões a partir das alegações dos envolvidos e dos documentos juntados, ou seja, não há uma instrução em termos processuais.
} 
Corte, bem como diante da circunstância de ter se tratado de um conflito complexo e de grande duração, além dos dois acordos invocados pela CUT (firmados com o governo e a empresa), o Comitê solicitou ao governo que adotasse providências para facilitar o retorno ao trabalho dos dirigentes sindicais e dos demais empregados. ${ }^{454}$

Ao final, o Comitê convidou o Conselho de Administração da OIT a fazer as seguintes recomendações:

a) o Comitê pede ao Governo que tome medidas com vistas à modificação da legislação com o objetivo de que a submissão dos conflitos coletivos de interesses às autoridades judiciais seja possível apenas de acordo entre as partes, ou no caso de serviços essenciais no sentido estrito do termo (aqueles cuja interrupção poderia colocar em risco a vida, a segurança ou a saúde da pessoa em toda ou em parte da população);

b) o Comitê convoca o governo a que garanta que as convenções coletivas entre empresas e sindicatos sejam respeitados. Solicita também que concite aos interlocutores sociais a resolverem os conflitos coletivos por meio da negociação coletiva; e

c) O Comitê solicita ao Governo que tome medidas para facilitar a reintegração em seus postos de trabalho dos 59 dirigentes sindicais e sindicalistas despedidos pela empresa Petrobrás.

A OIT se pronunciou quando a greve dos petroleiros já havia sido encerrada. Não obstante, sua manifestação produziu importantes repercussões ${ }^{455}$ e alguns incômodos. Almir Pazzianotto Pinto, Ministro do Tribunal Superior do Trabalho, publicou artigo, criticando a decisão da OIT.

Após expressar seu respeito à Organização, Almir Pazzianotto afirmava que ela, "talvez induzida por informações incorretamente prestadas", teria se equivocado, supondo que o país ainda fosse "vítima do autoritarismo", razão pela qual [a OIT] ignorou que a decisão tomada quando da greve da Petrobrás havia sido proferida pelo TST, no exercício normal de

\footnotetext{
${ }^{454}$ A recomendação literal foi a de que fosse facilitado o retorno aos postos de trabalho dos "59 dirigentes sindicais e sindicalistas despedidos pela empresa". Entretanto, parece ter havido equívoco por parte do Comitê. Isso porque, segundo consta do próprio relatório do Comitê, a alegação da CUT era de que haviam sido 59 os empregados dispensados, dentre os quais dirigentes dos sindicatos e da federação.

455 Com a edição da Emenda Constitucional 45/2004, o art. 114 foi alterado, passando a exigir o comum acordo para a propositura de dissídio coletivo perante os tribunais trabalhistas. Além disso, foi prevista a possibilidade de o Ministério Público do Trabalho ajuizar o dissídio coletivo em caso de greve em atividade essencial, com possibilidade de lesão ao interesse público. O Tribunal Superior do Trabalho vem se mostrando, porém, refratário a uma interpretação que confira maior efetividade às modificações promovidas pela Emenda Constitucional 45/2004. Desde a promulgação da emenda, a Corte vem construindo jurisprudência no sentido de mitigar a exigência de comum acordo. Tanto é assim que a Corte não exige que haja concordância expressa das partes, bastando a inexistência de oposição pela parte suscitada (cf. BRASIL. Tribunal Superior do Trabalho. Seção de Dissídios Coletivos. Recurso Ordinário no 2030700-36.2006.5.02.0000, Relatora Ministra Kátia Magalhães Arruda. Diário Eletrônico da Justiça do Trabalho, Brasília, DF 10/05/2013). Outro exemplo é o entendimento, constante de alguns precedentes da Corte, no sentido de que, se há greve, independentemente de se tratar ou não de atividade essencial, a propositura do dissídio coletivo prescinde do comum acordo. Esses aspectos serão examinados no próximo capítulo.
} 
competência prevista na Constituição e na lei. Segundo Pazzianotto, a OIT deveria considerar que a Petrobrás detinha o monopólio da extração do petróleo, do refino e da distribuição de derivados, executando atividades essenciais e inadiáveis à população, tal como estabelecido na Constituição e na Lei de Greve. Além disso, o conflito coletivo não foi solucionado por entendimentos diretos "e a deflagração da greve levou a empresa a exercer o seu direito de ação", perante o TST.

Pazzianoto lembrou que, "lamentavelmente (...), a sentença do Tribunal não foi cumprida, e tampouco combatida através do devido processo legal, à disposição dos interessados". Segundo o Ministro, a opção foi a continuidade da greve, acarretando que produtos essenciais, como GLP, faltassem à população, "prejudicando particularmente camadas mais pobres". ${ }^{456}$

Almir Pazzianotto lançou, então, importante observação - para os fins desta pesquisa - sobre o sistema brasileiro de tratamento de conflitos coletivos:

O sistema brasileiro de solução dos conflitos individuais e coletivos de trabalho não será o mais perfeito da face da Terra, e talvez comporte mudanças que dêem maior ênfase aos esforços de autocomposição. Não se deve negar, entretanto, que a Justiça do Trabalho tem constantemente demonstrado eficiência, imparcialidade e equilíbrio, características virtuosas facilmente comprováveis em volumosa quantidade de processos individuais e coletivos instaurados por trabalhadores e sindicatos profissionais.

$\mathrm{O}$ acesso unilateral ao Poder Judiciário tem se mostrado positivo aos assalariados. Cabe, porém, com exclusividade ao Congresso Nacional avaliar a conveniência e a oportunidade da alteração da norma constitucional que o assegura. Enquanto prevalecer o princípio, segundo o qual "a lei não excluirá da apreciação do Poder Judiciário lesão ou ameaça a direito", não se impedirá ao trabalhador, ao empregador ou aos seus sindicatos que recorram à Justiça do Trabalho. ${ }^{457}$

Não obstante a defesa do sistema brasileiro e do papel do Tribunal Superior do Trabalho, não havia, no artigo, nenhuma discussão sobre o direito de greve e de como seu exercício se relacionava com a atuação do Poder Judiciário (vale recordar que o Comitê de Liberdade Sindical associou, em sua manifestação, a intervenção da "autoridade do trabalho", provocada unilateralmente, à violação ao direito de deflagrar a greve). E a afirmada competência constitucional do TST não vinha pensada em consideração ao dispositivo, também da Constituição, que tratava do direito de greve (art. $9^{\circ}$ ). Para além disso, fica também a indagação: até que ponto o princípio da inafastabilidade da jurisdição ou do acesso

${ }^{456}$ PAZZIANOTTO PINTO, Almir. "O governo, a OIT e a Justiça do Trabalho". In: Síntese Trabalhista, ano VII, no 84, junho de 1996, pp. 126/128 (p. 127).

${ }^{457}$ PAZZIANOTTO PINTO, Almir. “O governo, a OIT e a Justiça do Trabalho”, p. 127/128. 
à justiça, invocado no trecho acima, assegura ao Poder Judiciário competência para intervir no exercício do direito de greve?

É chegado o momento de examinar os demais desdobramentos do Dissídio Coletivo 177.734/1995.

\subsection{A execução das multas aplicadas e a aç̃a dos trabalhadores e dos sindicatos pela} $\underline{\text { anistia }}$

Foi visto há pouco que, a despeito das duas decisões do Tribunal Superior do Trabalho, os petroleiros em greve optaram por manter a paralisação. No dia 31 de maio, o Ministério Público do Trabalho requereu à Corte a execução da multa imposta, quando do primeiro julgamento, no valor de R $\$ 2.100 .000,00$ por entidade sindical, diante da suspensão dos serviços entre os dias 11 e 31 daquele mês. O pleito era o de que as entidades fossem citadas para pagar em $48 \mathrm{~h}$, sob pena de penhora de bens suficientes à garantia total daquele montante. O MPT requereu também que a Petrobrás fosse intimada para que, "em benefício da execução, se abstenha de repassar às entidades sindicais, colocando à disposição desse Juízo, quaisquer valores que lhe sejam devidos em decorrência de lei, sentença normativa, convenção ou acordo coletivo de trabalho". ${ }^{458}$

O Presidente do TST, Ministro José Ajuricaba da Costa e Silva, acolhendo o pleito do MPT, determinou a citação da FUP e das demais entidades sindicais, bem como a intimação da Petrobrás, exatamente como requerido. ${ }^{459}$

A FUP interpôs agravo regimental ao despacho da Presidência do Tribunal, pretendendo sua reconsideração e se insurgindo contra o início da execução, uma vez que

\footnotetext{
${ }^{458}$ BRASIL. Tribunal Superior do Trabalho. Seção de Dissídios Coletivos. Dissídio Coletivo no ${ }^{\text {177 }}$ 177.734/1995. Processo, p. 431. De acordo com o Ministério Público do Trabalho, "inobstante aquela decisão [a que cominou a multa], os trabalhadores continuam em greve, como é notório, negando à sociedade a prestação de serviços indispensáveis à saúde, à sobrevivência e à segurança, além de causar graves prejuízos econômicos ao patrimônio nacional, surgindo, daí, também, o inequívoco interesse do Ministério Público em promover a EXECUÇÃO" (p. 430). O requerimento do MPT era acompanhado de uma petição da própria Petrobrás, que lhe fora dirigida, datada de 16 de maio, onde a empresa registrava a continuidade da greve, o que caracterizaria, a seu ver, "desobediência civil", estando, ainda, "perfeitamente configuradas diversas práticas delituosas" (mas não há indicação específica de quais seriam essas práticas). A Petrobrás pedia "a adoção, pelo Ministério Público, das medidas que reputa[sse] necessárias ao fiel cumprimento da lei e da decisão proferida pelo C. Tribunal Superior do Trabalho, bem como à apuração das responsabilidades, nos campos civil e penal" (p. 436). Em anexo à petição da empresa (e à do MPT), havia recortes de jornais sobre os problemas de abastecimento relacionados à greve (lembrando que parte das notícias tinha como fonte a própria Petrobrás ou órgãos do governo federal).

459 BRASIL. Tribunal Superior do Trabalho. Seção de Dissídios Coletivos. Dissídio Coletivo no 177.734/1995. Processo, p. 451/452.
} 
ainda não havia transitado em julgado a decisão que impusera a multa. ${ }^{460}$ José Ajuricaba da Costa e Silva rejeitou o pleito da Federação, invocando vários dispositivos legais que sustentariam a possibilidade de execução naquele caso. Mas o que mais chama a atenção é a parte final do despacho que indeferiu o pedido de reconsideração: "outrossim, apressei-me a deferir o pedido de execução do Ministério Público do Trabalho tendo em vista que, àquela altura, apesar de já existirem duas decisões desta C. Corte declarando a abusividade da greve, e determinando 'o retorno imediato dos trabalhadores à atividade', os Suscitados ainda persistiram em manter a paralisação". ${ }^{461}$ Ou seja, a execução estava sendo autorizada também em razão do descumprimento da ordem de retorno ao trabalho.

Com o início da execução, a Petrobrás suspendeu o repasse de valores às entidades sindicais, e essas últimas foram citadas, cada uma, para pagar o montante de $\mathrm{R} \$$ 2.100.000,00, sob pena de penhora de seus bens. As constrições foram efetivamente realizadas, recaindo sobre equipamentos dos sindicatos (como mesas, cadeiras, máquinas datilográficas), contas bancárias e até mesmo sobre suas sedes. ${ }^{462}$

No decorrer do processo, os suscitados ainda se valeram de inúmeras medidas (embargos de declaração, agravos regimentais, embargos à execução e até recurso extraordinário para o Supremo Tribunal Federal ${ }^{463}$ ). Além das penhoras realizadas sobre os bens das entidades sindicais, a Petrobrás, cumprindo a determinação judicial, passou a depositar em juízo os valores que seriam devidos aos sindicatos.

A execução teve curso até novembro de 1998. Ainda em 1995, os representantes dos petroleiros começaram a atuar, junto ao Poder Legislativo, com o objetivo de buscar anistia às entidades sindicais e aos trabalhadores dispensados. Foi apresentado, no Congresso

\footnotetext{
${ }^{460}$ BRASIL. Tribunal Superior do Trabalho. Seção de Dissídios Coletivos. Dissídio Coletivo no ${ }^{\circ}$ 177.734/1995. Processo, p. 499/501.

${ }^{461}$ BRASIL. Tribunal Superior do Trabalho. Seção de Dissídios Coletivos. Dissídio Coletivo no 177.734/1995. Processo, p. 514. Na sessão de 12 de junho, a SDC negou provimento ao agravo regimental (p. 562/564).

${ }^{462}$ No Espírito Santo, por exemplo, o Sindicato dos Petroleiros teve seu prédio, em São Mateus/ES, e equipamentos (como ar-condicionado e máquina de escrever) penhorados (cf. o auto de penhora e avaliação às p. 629/631 do processo - BRASIL. Tribunal Superior do Trabalho. Seção de Dissídios Coletivos. Dissídio Coletivo $\left.\mathrm{n}^{\mathrm{o}} 177.734 / 1995\right)$.

${ }^{463}$ A discussão levada ao STF dizia respeito apenas à legitimidade do Ministério Público do Trabalho e à retenção dos valores relativos às mensalidades sindicais pela Petrobrás, já na fase de execução das multas aplicadas (p. 1776/1781). O recurso teve seu seguimento negado pelo Presidente do TST, Min. Ermes Pedro Pedrassani, em 5.12.1996 (p. 1816/1819). A Federação interpôs agravo de instrumento, cujo seguimento também foi negado, em 30 de setembro de 1998, pelo Ministro Ilmar Galvão, do Supremo Tribunal Federal, ao argumento de que ambas as questões haviam sido decididas "sob o enfoque exclusivamente infraconstitucional, significando que qualquer ofensa à Carta da República, se existente, somente se daria de forma reflexa e indireta, o que não enseja a abertura da via extraordinária" (TST-AIRE-5975/1997, p. 272 - os autos desse processo foram apensados ao DC-177.734/1995). A FUP ainda apresentou agravo regimental (p. 274/277), que foi desprovido pela $1^{\text {a }}$ Turma do STF, em sessão de 9 de fevereiro de 1999. A decisão transitou em julgado em 19 de maio de 1999. Cf. BRASIL. Tribunal Superior do Trabalho. Seção de Dissídios Coletivos. Dissídio Coletivo no 177.734/1995. Processo.
} 
Nacional, o Projeto de Lei $\mathrm{n}^{\circ}$ 600, de 1995, que previa a concessão de anistia com relação às multas aplicadas pelo Tribunal Superior do Trabalho aos sindicatos, no período de $1^{\circ}$ de maio de 1995 até a publicação da lei. ${ }^{464}$

O texto foi aprovado no Congresso Nacional, mas vetado pelo Presidente da República Fernando Henrique Cardoso. Na mensagem de veto $\mathrm{n}^{\circ} 260$, de abril de 1996, o Chefe do Poder Executivo considerou injustificável a anistia:

o que caracteriza o Estado Constitucional é que nele não existem nem podem existir soberanos: todos, entes públicos ou privados, restam vinculados à Constituição e à lei. Assim como não é dado a órgão do Poder Executivo ou do Poder Legislativo se insurgir contra decisões judiciais definitivas, também não podem os cidadãos ou as suas associações representativas se rebelar contra ordens emanadas de órgãos jurisdicionais.

A mensagem de veto referiu, em seguida, à continuidade da greve, a despeito da decisão do TST: “considerar 'legítima' a insurreição das entidades sindicais contra decisão do egrégio TST, como faz o presente projeto de lei, viola a idéia básica que preside o princípio do Estado de Direito, a idéia de respeito e de observância das normas de direito positivo e das decisões judiciais". Havia, ainda, a preocupação com os limites do direito: "todos os exercentes do direito de liberdade no contexto da vida social não podem perder de vista que liberdade implica responsabilidade, devendo aqueles que escolhem o caminho da violação da lei assumir diretamente as conseqüências pelos seus atos". 465

Cerca de dois anos depois, houve nova investida no sentido da anistia. Ainda sob a presidência de Fernando Henrique Cardoso, foi aprovada a Lei $n^{\circ} 9.689 / 1998$, que concedeu anistia das multas impostas pelo TST. ${ }^{466} \mathrm{O}$ diploma contém regra idêntica à prevista no

\footnotetext{
${ }^{464}$ O projeto era de autoria do deputado Luciano Zica, do PT. Cf. BRASIL, Diário da Câmara dos Deputados. Brasília, DF. 5 de março de 1996. O fundamento do projeto era o seguinte: "a declaração de abusividade e ilegalidade de movimentos grevistas não pode ser utilizada com[o] instrumento para a completa inviabilização da entidade sindical, por definição assegurada pela Constituição”. A justificativa era a de que teria havido o exercício legítimo do direito de reivindicação e que a abusividade não poderia ser caracterizada pelo simples estado de greve. Havia, ainda, o argumento de que a responsabilidade por abusos não poderia ser transferida dos trabalhadores para as entidades sindicais.

465 BRASIL, Presidência da República. Mensagem de veto $n^{o} 260$, de $1^{\circ}$ de abril de 1996. Diário Oficial da União. Brasília, DF, 2.4.1996. O texto do veto refere ainda ao encaminhamento de projeto de lei pelo Executivo acerca da responsabilidade dos sindicatos pelo exercício do direito de greve e da definição de parâmetros para a aplicação de sanções, sobretudo multas, em caso de abuso. Trata-se do Projeto de Lei $\mathrm{n}^{\circ}$ 1.802, de 1996, que propunha a alteração de dispositivos da Lei $\mathrm{n}^{\circ}$ 7.783/89. O projeto foi apensado ao de $\mathrm{n}^{\mathrm{o}} 401$, de 1991 e, em 28 de maio de 2013, recebeu, na Comissão de Trabalho, de Administração e Serviço Público da Câmara dos Deputados, parecer pela sua rejeição.

${ }^{466}$ A lei resultou do Projeto de Lei do Senado no 195/1995, de autoria do Senador José Eduardo Dutra, do PT. O art. $1^{\circ}$ da norma tem a seguinte redação: "É concedida anistia das multas cominadas pelo Tribunal Superior do Trabalho a entidades sindicais representativas da categoria dos trabalhadores na indústria de extração, exploração, estocagem, transferência, perfuração, destilação, produção e refinação de petróleo e seus derivados,
} 
projeto de 1995, que fora vetado integralmente. Fica então a dúvida: o que teria motivado o veto do primeiro projeto, e não o do segundo? Isso foi explicado no veto parcial do Presidente da República, com relação ao parágrafo único do art. $1^{\circ}$ e ao art. $2^{\circ}$ da lei de 1998.

De acordo com a mensagem presidencial, o projeto anterior fora vetado por contrariar o interesse público, desprestigiando as decisões da Justiça do Trabalho, e porque "estimulava a impunidade de sindicatos que promovem irresponsavelmente greves abusivas, em detrimento da sociedade". Os altos valores das multas aplicadas pelo Tribunal foram atribuídos às próprias entidades sindicais, que optaram por continuar com a greve após a decisão do TST. O seguinte trecho da mensagem é significativo:

\begin{abstract}
Mesmo com a determinação judicial de retorno ao trabalho, decidiram as lideranças sindicais prosseguir no movimento, desafiando a Justiça do Trabalho e prejudicando ainda mais a sociedade, que padeceu pela falta de combustível e gás de cozinha durante mais de um mês. Para estancar o movimento paredista, o Ministério Público do Trabalho procedeu à execução das multas impostas pelo TST.

As multas chegaram a valores muito elevados, provocando a insolvência dos sindicatos tendo em vista que eram diárias e o fato de a greve ter se prolongado por muito tempo. Assim, os únicos responsáveis por seu montante foram as lideranças sindicais que insistiram na manutenção indefinida de movimento grevista já reconhecido como ilegal pela Justiça do Trabalho.
\end{abstract}

A Presidência da República optou, porém, por vetar apenas em parte o novo projeto, especificamente quanto ao parágrafo único do art. $1^{\circ}$ e ao art. $2^{\circ}$. Esse previa a vigência da lei a partir de sua publicação, enquanto aquele estabelecia a restituição às entidades sindicais dos valores retidos pela Petrobrás. A justificativa para o não exercício do veto quanto ao restante o projeto era a seguinte:

(...) considerando-se que o elevado montante das multas continua, efetivamente, a inviabilizar o funcionamento dos sindicatos petroleiros, já tendo efeito pedagógico a postura adotada pela Justiça do Trabalho, Ministério Público e Governo na responsabilização dos sindicatos que agiram com flagrante atentado à ordem institucional da sociedade, pode-se sancionar o projeto, desde que vetado o parágrafo único do artigo $1^{\circ} .{ }^{46}$

gás natural e outros similares da indústria petroquímica, química e de plásticos e afins, entre 1o de setembro de 1994 e a data da publicação desta Lei, em decorrência de sentenças judiciais declaratórias de ilegalidade ou abusividade de movimento grevista ou de improcedência de reivindicações de categorias profissionais." (BRASIL. Lei $\mathrm{n}^{\circ}$ 9.689, de 14 de julho de 1998. Concede anistia de multas cominadas pelo Tribunal Superior do Trabalho a entidades sindicais representativas dos empregados da Empresa Petróleo Brasileiro S/A PETROBRÁS, no período em que menciona. Diário Oficial da União, Brasília, DF, 15.7.1998).

${ }^{467}$ BRASIL, Presidência da República. Mensagem de veto $n^{\circ} 858$, de 14 de julho de 1998. Diário Oficial da União, Brasília, DF, 15.7.1998 (destaques acrescentados). Ao final, a mensagem de veto praticamente recomenda que o Congresso Nacional aprove o Projeto de Lei 1.802/1996, que visa a disciplinar a greve nas 
A Lei 9.689 foi editada em 14 de julho de 1998. Em 2 de setembro do mesmo ano, a FUP, representando as demais entidades sindicais, apresentou petição, junto ao Tribunal Superior do Trabalho, requerendo, com fundamento naquela lei, a suspensão de todas as constrições realizadas e a extinção dos processos de execução instaurados. O Ministério Público do Trabalho, pelo Subprocurador Geral do Trabalho Otávio Brito Lopes, expressou sua concordância com o pleito da FUP. ${ }^{468}$

No dia 20 de novembro de 1998, o então Presidente do TST, Min. Wagner Pimenta, diante da anistia reconhecida em lei, acolheu o pedido da Federação e julgou extinto o processo de execução, determinando a desconstituição dos atos de constrição sobre o patrimônio das entidades sindicais. É perceptível o tom de contrariedade do Ministro:

Esta norma [Lei 9.689/1998], não há dúvida, é expressa quanto à concessão de anistia às entidades sindicais representantes dos petroleiros da multa que lhes foi cominada por esta Corte, por terem resistido ao acatamento da decisão, prolatada nos autos do Processo no TST-DC-177.734/95.1, pela qual se determinou o imediato retorno dos seus representados ao trabalho.

Não se pode deixar de reconhecer, no entanto, tratar-se de diploma legal casuístico, pois beneficia, exclusivamente, uma categoria profissional em detrimento de toda a sociedade, prejudicada, por ocasião da greve dos petroleiros de 1995, nas suas necessidades mais básicas, por ação irresponsável e irrefletida de entidades sindicais retrógradas, despreparadas para atuarem sob regime democrático e sem compromisso com os reais interesses da categoria que representam.

Servirá, ainda, de estímulo à prepotência e à arrogância de lideranças sindicais refratárias à legalidade, incentivando-as a agirem em descompasso com a lei, pois, certamente, após este exemplo, sentir-se-ão autorizadas à descumprirem ordens emanadas do Poder Judiciário sempre que tiverem seus interesses contrariados.

A Lei $n^{\circ} 9.689 / 98$, porém, não obstante estas críticas, além de outras que lhe podem ser feitas, afigura-se constitucional, não se podendo negar-lhe eficácia. (.... $)^{469}$

A FUP requereu, ainda, que os valores retidos pela Petrobrás fossem restituídos às entidades sindicais. ${ }^{470} \mathrm{O}$ pedido foi aceito pelo Presidente do Tribunal, que, em 17 de

atividades essenciais. Essa seria a razão para vetar o art. $2^{\circ}$ da Lei 9.689/1998, que estabelecia a vigência da lei a partir de sua publicação. Eis os termos da mensagem: “(...) afigura-se recomendável que, na espécie, se observe o período de vacatio legis de 45 dias, conforme prevê a Lei de Introdução ao Código Civil. Dentro desse lapso temporal, poderá o Congresso Nacional aprovar o Projeto de Lei $\mathrm{n}^{\circ} 1.802$, de 1996, que acresce dispositivos à Lei $\mathrm{n}^{\mathrm{o}} 7.783$, de 28 de junho de 1989, ainda que com alterações, ou proposta equivalente, conferindo disciplina adequada à greve nos serviços ou atividades essenciais. Assim, proponho veto também ao art. $2^{\circ}$ do aludido projeto".

${ }^{468}$ BRASIL. Tribunal Superior do Trabalho. Seção de Dissídios Coletivos. Dissídio Coletivo no 177.734/1995. Processo, p. 1836/1837 e 1863/1866, respectivamente.

${ }^{469}$ BRASIL. Tribunal Superior do Trabalho. Seção de Dissídios Coletivos. Dissídio Coletivo no 177.734/1995. Processo, p. 1870/1871. 
dezembro de 1998, determinou à empresa que se abstivesse de realizar novos bloqueios de valores devidos àquelas entidades, bem como que liberasse, de imediato, o montante que havia sido retido (ou seja, na prática, foi inócuo o veto presidencial ao parágrafo único do art. $1^{\circ}$ da Lei 9.689/1998).

Com relação aos trabalhadores punidos em razão da participação na greve, foi aprovado, no Congresso Nacional, o Projeto de Lei $n^{\circ} 113$, de 1999, que estabelecia anistia a dirigentes, representantes sindicais e trabalhadores punidos em decorrência da participação em ações de reivindicação. A proposta tinha como fundamento a garantia constitucional dos direitos de associação, livre exercício das atividades sindicais e de greve. ${ }^{471}$

A Presidência da República exerceu, novamente, o poder de veto. Em sua justificativa, destaca-se o seguinte excerto:

a anistia dos trabalhadores da Petrobrás punidos por força da decisão judicial que declarou a ilegalidade da greve, sem que se verifique no ordenamento jurídico alteração do posicionamento que submete o direito de paralisação aos limites estabelecidos em lei, terá o condão de incentivar o descumprimento de tais limitações e das decisões judiciais que venham a ser proferidas, o que representará inequívoca desmoralização do Poder Judiciário, a quem incumbe a aplicação da lei ao caso concreto.

O projeto foi, então, vetado por contrariar "o interesse público e o princípio da independência e harmonia dos poderes". ${ }^{472}$

Alguns anos depois, em 2003, sendo Presidente da República Luiz Inácio Lula da Silva (ex-Presidente da Central Única dos Trabalhadores), foi sancionada a Lei $\mathrm{n}^{\circ} 10.790$, de 28 de novembro de 2003, que concedeu anistia aos punidos pela participação nas greves no período de 10 de setembro de 1994 a $1^{\text {o }}$ de setembro de $1996 .{ }^{473}$

\footnotetext{
${ }^{470}$ BRASIL. Tribunal Superior do Trabalho. Seção de Dissídios Coletivos. Dissídio Coletivo no 177.734/1995. Processo, p. 1875/1878.

${ }^{471} \mathrm{O}$ autor do projeto foi o Deputado Federal Jair Meneguelli, do PT. Ver BRASIL. Diário da Câmara dos Deputados. Brasília, 16 de março de 1999.

${ }^{472}$ BRASIL, Presidência da República. Mensagem de veto $n^{\circ} 488$, de 14 de junho de 2002. Diário Oficial da União. Brasília, DF, 17.6.2002.

${ }^{473} \mathrm{O}$ art. $1^{\circ}$ da lei dispõe que: "É concedida anistia a dirigentes, representantes sindicais e demais trabalhadores integrantes da categoria profissional dos empregados da empresa Petróleo Brasileiro S/A - PETROBRÁS, que, no período compreendido entre 10 de setembro de 1994 e 1o de setembro de 1996, sofreram punições, despedidas ou suspensões contratuais, em virtude de participação em movimento reivindicatório, assegurada aos dispensados ou suspensos a reintegração no emprego" (BRASIL. Lei n ${ }^{\circ}$ 10.790, de 28 de novembro de 2003. Concede anistia a dirigentes ou representantes sindicais e trabalhadores punidos por participação em movimento reivindicatório. Diário Oficial da União, Brasília, DF, $\left.1^{\circ} .12 .2003\right)$. Em entrevista a este pesquisador, o advogado Cézar Britto relatou que todos os empregados dispensados acabaram readmitidos e vários deles se tornaram, posteriormente, diretores da Petrobrás. Cf. BRITTO, Cézar. Depoimento sobre a greve dos petroleiros de 1995.
} 
A despeito do reconhecimento da anistia aos sindicatos e aos trabalhadores dispensados, a greve dos petroleiros de 1995 continua a se projetar no tempo, diante de sua importância. Ela é significativa para a história do direito de greve no Brasil e da própria Constituição de 1988. O papel dos tribunais, em especial da Justiça do Trabalho, também pode ser pensando a partir daquele movimento e de tudo que ele implicou. A atuação do Tribunal Superior do Trabalho foi decisiva, mas não isolada. Até que ponto o Poder Judiciário atuou de braços dados com o Poder Executivo?

Segundo Sayonara Grillo da Silva,

a cronologia dos fatos e os argumentos expendidos no acórdão não permitem isentar o Executivo e deslocar apenas para o Tribunal [Superior do Trabalho] a decisão. Há a responsabilidade definida e distinta de cada instância pelas decisões que lhe competem. Mas neste caso, além de o Judiciário exercer um papel de poder de Estado, atuou como co-partícipe da gestão econômica, da gestão de governo. ${ }^{474}$

O julgamento do dissídio coletivo pelo TST e seus desdobramentos trazem à tona a questão sobre os desafios da Constituição de 1988, marcadamente diante da tensão entre ruptura e continuidade em relação ao regime anterior. E mais: quais são os usos da Constituição? Qual é o papel que a Lei 7.783/1989 exerce na interpretação do art. $9^{\circ}$ do texto constitucional? Vale suscitar também a problemática de um governo de juízes. Essas discussões serão examinadas no próximo capítulo.

${ }^{474}$ SILVA, Sayonara Grillo Coutinho Leonardo da. Relações coletivas de trabalho, p. 284. 


\section{Capítulo 3: O direito de greve como espelho dos desafios da Constituiç̃ão de 1988}

No capítulo 1, procurou-se observar os discursos que circularam na Assembleia Nacional Constituinte no que diz respeito ao direito de greve. Havia - ao menos até a etapa da Comissão de Sistematização e, em seguida, das discussões e votações no Plenário - um tom predominante de ruptura com a ordem anterior. Foi explicitado o desejo de proibição das práticas de restrição e repressão às greves - em especial as formas decorrentes da intervenção do Estado. Em determinados discursos, a finalidade era assegurar o direito de maneira que não admitisse regulamentação, por lei ordinária, que viesse a anulá-lo na prática. O objetivo era a garantia do amplo direito (para alguns: liberdade) de greve. ${ }^{475}$ Recorde-se, por exemplo, que, no anteprojeto apresentado pela Comissão da Soberania e dos Direitos e Garantias do Homem e da Mulher, a greve estava prevista em dispositivo que cuidava da "manifestação coletiva" e estabelecia a liberdade de paralisação do trabalho, "seja qual for sua natureza e a sua relação com a comunidade, não podendo a lei estabelecer exceções". ${ }^{476}$

Na fase da Comissão de Sistematização e do Plenário, os trabalhos da Assembleia Nacional Constituinte adquiriram uma dinâmica diferente. Os acordos entre as lideranças assumiram um papel importante na trajetória dos debates e das votações. Isso ocorreu com o direito de greve. O texto que, ao final, resultou no art. $9^{\circ}$ da Constituição decorreu da fusão de algumas emendas, subscrita por constituintes de vários partidos após um acordo entabulado durante a própria sessão da ANC. ${ }^{477}$

Não há, porém, como ignorar os debates ocorridos nas etapas anteriores da Constituinte e que veiculavam os anseios por mudança. A mobilização da sociedade civil que se intensificara no movimento das Diretas Já se voltou para a ANC de 1987/1988. Havia pretensões voltadas para a ampliação do espaço democrático e para o reconhecimento de direitos civis e políticos. A própria Constituinte se inseria no processo de ruptura com a ordem autoritária construída pela ditadura militar. Este, aliás, era o tom dos trabalhos da ANC e um dos desafios da nova Constituição: romper com a ordem anterior. ${ }^{478}$

\footnotetext{
475 Conferir às transcrições, no capítulo 1 , dos discursos dos constituintes e dos representantes das entidades sindicais que participaram das audiências públicas realizadas pelas Subcomissões Temáticas.

476 Ver 1.4 acima.

${ }^{477}$ Cf. 1.6 supra.

478 Sobre essas questões, ver BARBOSA, Leonardo Augusto de Andrade. Mudança Constitucional, Autoritarismo e Democracia no Brasil Pós-1964. Tese (Doutorado em Direito, Estado e Constituição). Faculdade de Direito da Universidade de Brasília. Brasília, 2009; PAIXÃO, Cristiano, e BARBOSA, Leonardo
} 
Uma das qualidades de uma Constituição escrita é o fato de que o texto, exatamente porque texto, é aberto à interpretação. ${ }^{479}$ A pergunta que se impõe é, então: o que fazer com a Constituição? Vem à tona, aqui, o problema dos usos do texto constitucional e da disputa pelo seu significado. Em que medida as vozes da Constituinte, com as pretensões de mudança, de ruptura, de reconhecimento de direitos, repercutiram (e repercutem) nos usos que são feitos do texto constitucional, sobretudo pelos tribunais? ${ }^{480}$

A greve dos petroleiros de 1995 - examinada no capítulo 2 - e, em especial, a decisão do Tribunal Superior do Trabalho permitem constatar como o direito de greve expressa essa tensão entre continuidade e ruptura com a ordem anterior, a qual, em última análise, é uma dimensão importante de compreensão da Constituição de 1988. É significativo que, no julgamento do dissídio coletivo, a Corte tenha mantido silêncio com relação ao texto constitucional e seu art. $9^{\circ}$. Não há discussão, a partir da Constituição, quanto às possibilidades de exercício do direito de greve.

Chama atenção, pelo contrário, o questionamento que um dos ministros do TST faz à própria Constituição. Vale lembrar o voto do Min. Armando de Brito, para quem a "greve política" deveria ser encarada como "verdadeira questão de segurança nacional" e seria "necessário (...) e urgente expungir o texto quase irresponsável inserido no caput do art. $9^{\circ}$ da Constituição". O Ministro concluía pela abusividade da greve "em defesa da sobrevivência da ordem jurídica (...) e das instituições democráticas". ${ }^{481}$

A decisão do TST provoca uma reflexão que tem como ponto de partida constatar que a ampliação do direito de greve na Constituição de 1988 foi acompanhada pela diversificação das formas de intervenção do Poder Judiciário nas greves. Há uma atuação, em particular da Justiça do Trabalho, no sentido de reprimir paralisações, restringir as ações do movimento sindical e impor limites ao direito de greve. É necessário pensar essa questão sob a ótica da relação entre direito e política, ou, em outros termos, entre os sistemas jurídico e político. Pode-se recordar as palavras de ministros de Estado que, diante de uma paralisação,

\footnotetext{
Augusto de Andrade. "Cidadania, democracia e Constituição: o processo de convocação da Assembleia Nacional Constituinte de 1987-1988”. In: DIAS, Maria Tereza Fonseca, e PEREIRA, Flávio Henrique Unes. Cidadania e Inclusão Social - Estudos em homenagem à Professora Miracy Barbosa de Sousa Gustin. Belo Horizonte: Fórum, 2009; e PAIXÃO, Cristiano. "Autonomia, democracia e poder constituinte: disputas conceituais na experiência constitucional brasileira (1964-2014)". In: Quaderni Fiorentini - per la storia del pensiero giuridico moderno. N ${ }^{\circ}$ XLIII, tomo I. Giuffrè Editore, 2014, pp. 415/458.

${ }^{479}$ Cf. CARVALHO NETTO, Menelick de, e SCOTTI, Guilherme. Os direitos fundamentais e a (in) certeza do direito: a produtividade das tensões principiológicas e a superação do sistema de regras. Belo Horizonte: Fórum, 2011, p. 134/135.

${ }^{480}$ Não se trata de interpretar a Constituição a partir da intenção dos constituintes, mas, sim, de buscar uma compreensão mais adequada da dimensão da Constituição de 1988 com relação à ordem precedente.

${ }^{481}$ Ver item 2.3 acima.
} 
simplesmente confiavam na atuação do Tribunal Superior do Trabalho (i.e., confiança de que a greve seria julgada ilegal). ${ }^{482}$ Volta-se à pergunta já formulada: é possível falar, então, em um governo de juízes?

O objetivo deste capítulo é, a partir do material reunido na investigação sobre a Assembleia Nacional Constituinte e sobre a greve dos petroleiros de 1995, examinar essas indagações para, ao final, propor algumas reflexões sobre o papel da Constituição e dos tribunais, bem como a respeito do próprio direito de greve.

\subsection{A disputa pelos sentidos da Constituição}

No contexto da promulgação da Constituição de 1988, o constitucionalista Ives Gandra da Silva Martins veiculou pequeno artigo intitulado "A estabilidade das instituições e a nova Constituição", que foi apresentado em Fórum na Pontifícia Universidade Católica de Minas Gerais, em Belo Horizonte. Em determinada passagem do texto, após enunciar as principais características da nova Constituição, Ives Gandra da Silva Martins pontua alguns aspectos sobre a sua aplicação e interpretação. Segundo ele, "agradando ou não, a futura Carta orientará os destinos da nação, podendo, se for aplicada da forma emocional como transcorrem os debates constituintes, criar um impasse de estabilidade institucional, pela geração de hiperinflação, recessão e desordem social" ${ }^{483}$

Diante disso (ou seja, desse risco), os juristas, para Ives Gandra, poderiam “interpretar a Constituição com seu texto desarmônico", de maneira a "adaptá-lo às reais necessidades e aspirações nacionais mais do que às posições e posturas deste ou daquele grupo de parlamentares". De acordo com o constitucionalista, os próprios parlamentares (que haviam composto a Assembleia Nacional Constituinte), "já sem os holofotes da imprensa acompanhando cada ato ou palavra sua, poderão, em ambiente não emocional, dar um perfil pertinente às necessidades do país".

O Poder Judiciário teria um papel importante na estabilização das instituições e teria a capacidade de rechaçar os perigos decorrentes de um "debate emocional" sobre a Constituição. Em suas palavras:

\footnotetext{
482 Foi o caso do Ministro do Trabalho, Marcelo Pimentel, no governo do Presidente Itamar Franco, e do Ministro do Planejamento, José Serra, já no governo de Fernando Henrique Cardoso, como visto no capítulo 2.

483 MARTINS, Ives Gandra da Silva. "A estabilidade das instituições e a nova Constituição". Manuscrito de 4.11.1988 (disponível em http://www.gandramartins.adv.br/artigo/index/p/137 - acesso em 13.7.2013). Destaques acrescentados.
} 
A partir do dia 5 de outubro encerra-se, definitivamente, o período de elaboração constitucional e se principia o período de adequação da Nação à sua nova ordem, período em que o Poder Judiciário, com a integridade moral e profundos conhecimentos de seus membros, exercerá criativa atividade, permitindo que as instituições se estabilizem e afastando os riscos de convulsões, que o debate emocional poderia acarretar. ${ }^{484}$

O que seriam as "reais necessidades e aspirações nacionais"? O que significa "dar [à Constituição] um perfil pertinente às necessidades do país"? O que seria o "debate emocional" sobre a Constituição? Chama atenção, a propósito, o fato de o "debate emocional" ser colocado em contraponto às "reais necessidades e aspirações nacionais".

As palavras de Ives Gandra da Silva Martins evidenciam a disputa sobre o significado da Constituição de 1988 e mostram os desafios postos, no que diz respeito aos usos do novo texto constitucional. Há a ideia de inauguração de uma nova ordem, mas, nessa nova ordem, segundo aquele autor, a Constituição deveria ser aplicada e interpretada sobretudo pelo Poder Judiciário, composto de membros com "integridade moral" e "profundos conhecimentos" (em oposição aos parlamentares) - no sentido de atender às "necessidades do país".

Não fica claro quais seriam essas necessidades, mas se verifica a preocupação com a "estabilidade das instituições". O discurso do constitucionalista explicita a tensão entre continuidade e ruptura, sob a ótica da luta pelos sentidos da Constituição. A referência à “estabilização das instituições" e à ideia de se evitar o "debate emocional” talvez tenha em vista a forte mobilização popular intensificada no movimento das Diretas Já e canalizada para a Assembleia Nacional Constituinte. Em meio aos anseios de mudança, de ruptura com o regime anterior e de reconhecimento de direitos, o texto de Ives Gandra surge como um anticlímax - é perceptível o pessimismo em relação ao novo texto constitucional, acusado pelo autor de desarmônico e capaz de gerar (i.e., sua interpretação) convulsões sociais.

Ainda para ilustrar o problema, traz-se um exemplo pertinente ao direito de greve. Em um artigo de 2004, intitulado "Ainda as greves selvagens", o professor Miguel Reale escrevia que, quando participante da "Comissão dos Notáveis", em 1986, opinara contrariamente à greve nos serviços considerados essenciais à coletividade, tanto na esfera privada quanto na pública. Em sua visão, a greve, nesse caso, "representava um gravíssimo desequilíbrio nas relações sociais, pelo fato do funcionário e do trabalhador reivindicarem direitos e interesses valendo-se de penosos sacrifícios impostos ao povo". ${ }^{485}$

\footnotetext{
${ }^{484}$ MARTINS, Ives Gandra da Silva. “A estabilidade das instituições e a nova Constituição”, p. 3.

485 REALE, Miguel. "Ainda as greves selvagens". Manuscrito de 9.10.2004 (disponível em
} 
Após indicar os contra-argumentos então apresentados à sua opinião, bem como referir à Lei de Greve, em especial ao seu art. 11 (que prevê a obrigação de sindicatos, empregadores e trabalhadores de garantir a prestação dos serviços indispensáveis ao atendimento das necessidades inadiáveis da população, nas greves em atividades ou serviços essenciais), Miguel Reale observava que:

A esta altura dos acontecimentos, com sucessivas greves nos transportes coletivos, nas atividades bancárias, e após os 91 dias de suspensão dos trabalhos pelos serventuários de justiça, já há experiência bastante para devermos reconhecer quanto foram ilusórias as promessas constitucionais e da legislação ordinária!

Ilusórios são também os dispositivos legais que, na hipótese de não atendimento das disposições das leis e dos tribunais quanto ao "mínimo de serviços a serem prestados", o Poder Público fica obrigado "à prestação dos serviços indispensáveis", bem como a faculdade de recorrer à cooperação de terceiros... ${ }^{486}$

De acordo com o jurista, não são todos os trabalhos que admitem substituição de grevistas. Assim, nas atividades essenciais, a cessação da greve depende apenas da concordância dos trabalhadores. Diante dessa realidade, o autor afirmava que:

Inútil seria pensar na possibilidade de uma reforma constitucional, que revogue o proclamado direito de greve nos casos que estamos analisando, pois há certas prerrogativas que, uma vez estabelecidas, tornam-se definitivas.

Nem creio que novos projetos de lei possam superar a crise em que nos encontramos, como decorrência previsível de excessivo apego a pretensos ideais democráticos e de justiça social.

Ressurgem, assim, as greves selvagens, não mais sob a forma de conflitos e retaliações, mas à custa da coletividade inerme, que somente poderá contar com apelos formulados através dos meios de comunicação. ${ }^{487}$

É nítido o incômodo do autor com os transtornos causados pelas greves apontadas - transportes, atividades bancárias, serviços de justiça. O desejo de mudança constitucional do direito de greve é expressado, não obstante a consciência das barreiras existentes (certamente o dispositivo da Constituição que confere aos direitos e garantias fundamentais a condição de cláusulas pétreas ${ }^{488}$ ). E a crise constatada pelo autor seria motivada pelos "pretensos ideais democráticos e de justiça social”.

\footnotetext{
www.miguelreale.com.br - acesso em 13.7.2013), p. 1 ( sic).

${ }^{486}$ REALE, Miguel. "Ainda as greves selvagens", p. 2.

${ }^{487}$ REALE, Miguel. "Ainda as greves selvagens", p. 2 (destaque acrescentado).

${ }^{488} \mathrm{O}$ art. 60, $\S 4^{\circ}$, IV, da Constituição de 1988 dispõe que "não será objeto de deliberação a proposta de emenda
} 
Tal como no artigo de Ives Gandra Martins Silva, examinado acima - há, aliás, uma importante afinidade entre os textos ${ }^{489}$-, nota-se a disputa pelos sentidos da Constituição e de sua dimensão de ruptura com o regime anterior. ${ }^{490}$ É perceptível a tensão - na verdade, uma oposição - com relação aos anseios democráticos que acompanharam a promulgação da Constituição de 1988 e o período subsequente. Há, em ambos os artigos, uma espécie de malestar diante das potencialidades do novo texto constitucional.

Mas não seria de se esperar que a promulgação da Constituição de 1988 gerasse consenso sobre seus princípios, suas disposições e, sobretudo, sua interpretação. Pelo contrário. Talvez aí, i.e., na capacidade de suscitar dissensos, que, por sua vez, exigem um tratamento democrático na esfera pública, esteja uma importante qualidade da Constituição. De acordo com o professor Menelick de Carvalho Netto, "a virtude de uma Constituição democrática é que ela não permite mecanismos que instituem uma paz de cemitério. Ela precisamente remete à discussão pública os problemas para que possamos, de maneira constante e reflexiva, rever antigos usos e tradições". ${ }^{491}$

Para aprofundar o debate, propõe-se empreender uma reflexão sobre a função da constituição e, em seguida, sobre o significado e os desafios da mudança constitucional.

A teoria dos sistemas apresenta importantes instrumentos para uma abordagem funcional da Constituição. De acordo com Niklas Luhmann, a constituição, ou seja, a forma constitucional, é uma aquisição evolutiva improvável da sociedade moderna. ${ }^{492}$ Para Luhmann, o surgimento da constituição está inserido no contexto das revoluções burguesas do

tendente a abolir: (...) IV - os direitos e garantias individuais".

${ }^{489}$ Tal afinidade não parece casual. Ives Gandra da Silva Martins foi aluno de Miguel Reale. Eles fundaram juntos a Academia Internacional de Direito e Economia, além de terem escrito livros juntos. Conferir a entrevista concedida por Ives Gandra da Silva Martins ao sítio Consultor Jurídico (disponível em http://www.conjur.com.br/2012-nov-11/entrevista-ives-gandra-silva-martins-tributarista-constitucionalista acesso em 12.5.2014).

${ }^{490}$ No caso, em especial, do professor Miguel Reale, há indícios de que possuía relevantes vínculos com o regime anterior à Constituição de 1988. Para exemplificar, Miguel Reale foi nomeado, em 1969, pelo Presidente Arthur da Costa e Silva para a comissão encarregada de rever a Constituição de 1967; de 1969 a 1973, foi reitor da Universidade de São Paulo; e, em 1974, foi nomeado, pelo Presidente Emílio Garrastazu Médici, para o Conselho Federal de Cultura (informações disponíveis em http://www.miguelreale.com.br/ - acesso em 12.5.2014). Airton Seelaender identifica, ainda, a participação de Miguel Reale no Integralismo brasileiro, que opunha à democracia e ao liberalismo o "Princípio da Autoridade" e compartilhava certos valores (em matéria de organização política e financeira, por exemplo) do fascismo europeu de Mussolini, Hitler e Salazar. Sobre essa questão, além da necessidade e da importância de uma investigação sobre os "juristas pró-ditadura" no Brasil e a atuação das faculdades de direito durante os regimes autoritários, ver SEELAENDER, Airton Cerqueira Leite. "Juristas e Ditaduras: uma leitura brasileira". In: FONSECA, Ricardo Marcelo, e SEELAENDER, Airton Cerqueira Leite (Orgs.). História do Direito em perspectiva. Curitiba: Juruá, 2009, pp. 415-432).

491 CARVALHO NETTO, Menelick. "A urgente revisão da teoria do poder constituinte: da impossibilidade da democracia possível" (Prefácio). In: CATTONI, Marcelo. Poder constituinte. Belo Horizonte: Mandamentos, 2006, p. 22.

492 Cf. LUHMANN, Niklas. "La costituzione come acquisizione evolutiva", p. 83/91. Ver também CORSI, Giancarlo. "Sociologia da Constituição". Trad. Juliana N. Magalhães. In: Revista da Faculdade de Direito da

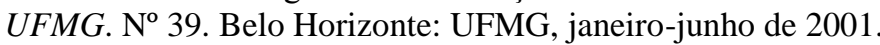


século XVIII, em especial a norte-americana. A constituição, entretanto, não foi simplesmente planejada pelos revolucionários. Ela decorreu de uma necessidade tanto do direito quanto da política. A experiência histórica das colônias, repleta de pressupostos improváveis, conduziu à consolidação da ideia sobre a necessidade de uma lei que funcionasse como parâmetro de conformidade ou não-conformidade ao direito por parte das demais leis e atos jurídicos. $\mathrm{O}$ caráter supralegal da constituição, como critério de validade do restante direito, é o traço mais significativo do constitucionalismo norte-americano. ${ }^{493}$

Segundo Niklas Luhmann, o surgimento da constituição atende a uma situação histórica determinada e está relacionado com as condições políticas norte-americanas. A questão que se colocava estava ligada ao vazio decorrente da declaração de independência quanto à Inglaterra. Os Estados soberanos deveriam ser criados, em primeiro lugar, como Estados individuais e, apenas depois, no conjunto de um Estado nacional. Uma constituição escrita parecia ser o instrumento adequado e eficaz para tanto. A mudança operada, ao lado de seu caráter improvável, adquire a forma de um uso, de uma inovação conceitual: “a Constituição tem início assim que se começa a distinguir o constitucional/inconstitucional do legal/ilegal". 494

O advento da forma constitucional está relacionado também a uma necessidade do sistema político, pertinente ao problema da soberania e à necessidade de imposição de limites ao exercente do poder (que, considerando a experiência das revoluções burguesas, se desloca do monarca ao parlamento e, em seguida, ao povo). A partir do momento em que é possível exercer o poder em conformidade ou não-conformidade com o direito - o que evidencia a

\footnotetext{
${ }^{493}$ De acordo com Cristiano Paixão e Renato Bigliazzi, “a noção moderna de constituição, tal como surgida nos Estados Unidos da América, não tem precedente na história. Não é incorreto - ou nem sequer exagerado afirmar que a formalidade constitucional é uma inovação fundamental introduzida no léxico político-jurídico da modernidade no fim do século XVIII. A consagração dos direitos fundamentais, a divisão de poderes e a limitação do governo são elementos importantes para a compreensão de todo o processo e para a afirmação do constitucionalismo moderno - mas não são determinantes do momento constitucional norte-americano, tampouco seu principal fruto. Na verdade, a própria ideia de que a constituição seja interpretada e vivida como uma norma supralegal, da qual dependa a validade de todos os outros atos normativos numa dada comunidade política, 'é a invocação mais significativa do constitucionalismo na América" (PAIXÃO, Cristiano e BIGLIAZZI, Renato. História constitucional inglesa e norte-americana: do surgimento à estabilização da forma constitucional, p. 92/93).

${ }^{494}$ LUHMANN, Niklas. El derecho de la sociedad, p. 545. Graham Maddox, nesse sentido, observa que os colonos norteamericanos rejeitaram a constituição inglesa amorfa, uma vez que acreditavam que, sobre ela, haviam sido tratados injustamente pelo parlamento, considerado tirânico, bem como que ela não assegurava direitos exigíveis em face de uma legislatura competente para todos os temas. Assim, apenas uma constituição escrita, estabelecendo os limites da autoridade do governo e garantindo direitos justiciáveis aos cidadãos, seria então aceita (MADDOX, Graham. "Constitution". In: BALL, Terence; FARR, James; HANSON, Russell L. Political innovation and conceptual change. New York: Cambridge University Press, 1995, p. 60/61).
} 
independência do sistema político com relação ao jurídico - busca-se, como diz Luhmann, "proteção em uma Constituição". 495

A tese luhmanniana é a de que a constituição corresponde a uma reação à diferenciação entre direito e política, ou seja, "à total separação de ambos os sistemas de funções e à consequente necessidade de uma religação entre eles". ${ }^{496}$ A constituição funciona como mecanismo de acoplamento estrutural entre os sistemas jurídico e político. Isso quer dizer que direito e política se referem um ao outro (ou seja, se irritam de maneira recíproca) por meio dos canais estipulados constitucionalmente (e apenas dessa forma). Pela especificação dos espaços de heterorreferenciabilidade entre os sistemas funcionais, há um significativo incremento de complexidade. ${ }^{497} \mathrm{O}$ acoplamento estrutural gera um efeito tanto de inclusão quanto de exclusão, pois os sistemas se reportam um ao outro apenas na forma constitucional. ${ }^{498}$ Assim, a intervenção política na jurisdição por parte de políticos ou de funcionários corruptos, ou vice-versa, é excluída. O acoplamento rejeita a interferência de um sistema no funcionamento autopoiético (autoproduzido) do outro sistema. ${ }^{499}$

\footnotetext{
${ }^{495}$ LUHMANN, Niklas. "La costituzione come acquisizione evolutiva", p. 105. Hannah Arendt afirma que o verdadeiro significado da constituição não é, de modo algum, "a salvaguarda das liberdades civis, mas sim o estabelecimento de um sistema de poder inteiramente novo". A questão, para os norte-americanos, não era propriamente como limitar o poder, e sim como estabelecê-lo, isto é, como fundar um novo governo. Sua preocupação era a constituição do poder, isto é, a constituição da liberdade política, baseada na "fundação e correta distribuição do poder". A função da constituição, na experiência norte-americana, era justamente a instituição de um sistema de poderes (que controlasse e equilibrasse os poderes da união e os dos estados). A inovação americana está relacionada à abolição da soberania no interior do corpo político da república. Ainda segundo Hannah Arendt, "o verdadeiro objetivo da Constituição Americana não era o de limitar o poder, mas o de criar mais poder e, na realidade, estabelecer e constituir devidamente um centro de poder inteiramente novo, destinado a compensar a república confederada, cuja autoridade se viria a exercer sobre um grande território em expansão, pelo poder perdido através da separação das colônias da coroa inglesa" (ARENDT, Hannah. Sobre a Revolução. Trad. de I. Morais. Lisboa: Antropos, 2001, p. 184 e 189, respectivamente).

496 LUHMANN, Niklas. "La costituzione come acquisizione evolutiva", p. 87. Essa tese tem como desdobramento a constatação de que os sistemas não são congruentes, i.e., não há sobreposição, nem hierarquia entre eles (cf. p. 109).

497 Como esclarece Luhmann, "a política especifica as formas idôneas a levá-la em conta referindo restritivamente ela mesma ao Estado e o concebendo como Estado constitucional. Em contraste com o antigo conceito europeu de societas civilis, se diz agora: sem Estado (constituído) não há nenhuma política. O direito especifica as formas idôneas a levá-lo em conta reconduzindo a si mesmo, mediante a lei constitucional, a um instituto jurídico de conteúdo indeterminado: o poder constituinte do povo. Esse projeto global vem reiterado e implementado nos planos de segundo grau. A política, se busca o sucesso de sua ação, não pode renunciar ao arsenal do direito que deve funcionar juridicamente e de cujo código binário não pode se afastar. $\mathrm{O}$ direito, por meio de uma legislação influenciável politicamente, se adapta às contínuas pressões exercitadas a partir da política e conquista, com isso, a possibilidade de reenviar ao iter político muitos impulsos para sua modificação" (La costituzione come acquisizione evolutiva", p. 111).

${ }^{498}$ A seguinte passagem, com um exemplo da biologia, é elucidativa: "o acoplamento estrutural é uma forma, uma forma constituída de dois lados; em outras palavras: uma distinção. O que inclui (o que se acopla) é tão importante como o que exclui. As formas do acoplamento estrutural são, portanto, restritivas e facilitam, com isso, a influência do ambiente sobre o sistema. As células aceitam somente determinados íons (como sódio ou cálcio) através de suas membranas, e rejeitam outros (como césio ou lítio). Cf. LUHMANN, Niklas. El derecho de la sociedad, p. 508/509 (destaques na origem).

${ }^{499} \mathrm{O}$ sociólogo alemão observa, nesse sentido, os riscos existentes de um funcionamento da política e do direito orientados para a economia: "mais ou menos contemporaneamente, desenvolvem-se outros acoplamentos
} 
Essa constatação é fundamental para a assertiva de Luhmann sobre a função da Constituição: muito embora o acoplamento estrutural conduza a mais possibilidades de irritação entre direito e política, os sistemas permanecem operativamente fechados em torno de seus respectivos códigos (direito/não-direito e poder/não-poder).

A Constituição é observada tanto pelo direito, quanto pela política. Ela é uma estrutura jurídica e, ao mesmo tempo, política. É possível que o sentido jurídico da Constituição tenha um desenvolvimento diverso do seu sentido político. E isso traz importantes consequências para o próprio uso da Constituição. Segundo Luhmann:

a Constituição que conforma e determina o Estado assume um sentido diferente em ambos os sistemas: para o sistema jurídico é uma lei suprema, uma lei fundamental; para o sistema político é um instrumento político no duplo sentido de política instrumental - modificadora de situações - e de política simbólica - não modificadora de situações. Embora as duas visões poderiam parecer contradizer-se semanticamente, resultam compatíveis graças ao fechamento operativo dos sistemas. (...) Desse modo, é possível que se desenvolvam separadamente o sentido jurídico e o sentido político da Constituição, o que se faz evidente em um incremento da irritação recíproca. É, assim mesmo, concebível que em muitos países em vias de desenvolvimento se observe que as Constituições servem, de maneira quase exclusiva, como um instrumento da política simbólica, porque ainda não se obteve êxito em fechar operativamente o sistema jurídico e torná-lo impermeável à influência da política e de outras forças sociais. Mas ainda nesse caso se pode reconhecer o modelo moderno do acoplamento estrutural (...). O uso exclusivamente simbólico das Constituições serve à política para proceder como se o direito a limitasse e a irritasse e para abandonar as verdadeiras relações de poder à comunicação dos entendidos. ${ }^{500}$

Em sentido pleno, porém, a Constituição, como conquista evolutiva, cumpre sua função tão somente sob o pressuposto de uma diferenciação funcional e, por conseguinte, do fechamento operativo dos sistemas jurídico e político. Isso corresponde, como visto, à limitação das formas de irritação recíproca entre os sistemas. A imposição de limites na relação entre o sistema e o ambiente equivale a uma redução de complexidade que, entretanto, é condição necessária de possibilidade para a construção de (mais) complexidade. ${ }^{501} \mathrm{E}$ o incremento de complexidade é justamente o que descreve a democracia. ${ }^{502}$ Para Luhmann:

estruturais que, por meio da propriedade, da liberdade contratual e dos prenúncios de um novo direito das empresas, abrem à economia possibilidades diretas de dispor do direito e, com isso, de mobilizar o poder político em prol do interesse econômico privado. Disso se pode antever o que a diferenciação funcional requer: separação e recíproca impermeabilização dos acoplamentos estruturais entre política, direito e economia" (La costituzione come acquisizione evolutiva", p. 114).

${ }^{500}$ LUHMANN, Niklas. El derecho de la sociedad, p. 548/549. Sobre o uso simbólico da Constituição ver também NEVES, Marcelo. A constitucionalização simbólica. São Paulo: WMF Martins Fontes, 2007.

${ }^{501}$ Cf. LUHMANN, Niklas. El derecho de la sociedad, p. 509.

${ }^{502}$ Ver DE GIORGI, Raffaele. "Problemas da governabilidade democrática". In: Direito, Democracia e Risco - 
As constituições existem como êxitos verdadeiros - em oposição ao mero texto - quando se consegue limitar a influência recíproca entre direito e política mediante os canais previstos na Constituição do Estado e quando se consegue elevar as possibilidades no marco desses acoplamentos. Pode observar-se, então, nessa forma de acoplamento estrutural, que outras possibilidades são efetivamente excluídas. "Outras possibilidades" significa concretamente, por exemplo: utilização de posições jurídicas na economia (riqueza, controle jurídico sobre oportunidades politicamente importantes) para a obtenção de poder político; o terror político; a corrupção política. Na medida em que o sistema político, por uma parte, e o sistema jurídico, por outra, se encontrem vinculados através do poder "privado" da pressão, do terror ou da corrupção, nenhum dos dois - se é que é possível, em absoluto, distingui-los - pode adquirir um elevado grau de complexidade. Por meio das Constituições se alcança, então, devido à limitação das zonas de contato em ambas as partes, um imenso incremento de recíproca irritabilidade maiores possibilidades por parte do sistema jurídico de registrar decisões políticas em forma jurídica, bem como, da mesma forma, maiores possibilidades da parte da política de servir-se do direito para por em prática seus objetivos. O problema é, então, de ambos os lados, a determinação de quais são as formas estruturais com as quais há de se superar um incremento tão drástico de variabilidade. Assim, praticamente podemos afirmar que a democracia é uma consequência da transformação do direito em algo positivo e das possibilidades concomitantes de modificá-lo a cada momento. ${ }^{503}$

Examinar a Constituição pela ótica dos sistemas funcionalmente diferenciados (direito, política e também a economia) conduz à observação das operações dos sistemas e da sua reprodução a partir das limitações impostas em termos constitucionais. É o caso de indagar, mais especificamente, sobre os desafios à Constituição de 1988 em termos de funcionamento dos sistemas jurídico, político e econômico. ${ }^{504}$

vínculos com o futuro. Porto Alegre: Sérgio Antonio Fabris, 1998, pp. 49/64 - p. 53.

${ }^{503}$ LUHMANN, Niklas. El derecho de la sociedad, p. 540/541. É importante esclarecer que, a despeito da linguagem muitas vezes hermética, a teoria da diferenciação funcional do direito e da sociedade, proposta por Niklas Luhmann, mostra-se compatível com os princípios do constitucionalismo, como a limitação do poder político, a proteção aos direitos fundamentais, garantias à democracia, etc. Ver, a respeito, PAIXÃO, Cristiano. Modernidade, Tempo e Direito; e CAMPILONGO, Celso. Política, sistema jurídico e decisão judicial. São Paulo: Max Limonad, 2002, p. 15/25; e NEVES, Marcelo. Entre Têmis e Leviatã: uma relação difícil. São Paulo: Martins Fontes, 2006.

${ }^{504}$ É importante esclarecer que cada sistema opera a partir de um código específico, que organiza a autopoiésis (i.e., a autorreprodução) do próprio sistema. O direito opera com base no código direito/não-direito; a política, poder/não-poder (e também governo/oposição); a economia, ter/não-ter capacidade de disposição. O código não é uma norma, mas uma estrutura que permite identificar as comunicações (operações) que pertencem ao sistema, diferenciando-o do ambiente. As relações entre os sistemas - vale dizer, sua irritação recíproca - podem colocar problemas de "corrupção" de códigos. Na precisa explicação de Celso Fernandes Campilongo, "os problemas de autorreprodução do sistema jurídico decorrem das excessivas pretensões e utilizações que o sistema político - e, particularmente, o Welfare State - faz do direito. O direito passa a ser utilizado para resolver problemas para os quais seu código não pode oferecer respostas ou é absolutamente inadequado. $\mathrm{O}$ sistema político observa o direito da perspectiva do legislador e, consequentemente, opera num grau de complexidade incompatível com os problemas concretos a serem processados pelo código 'direito/não-direito'. Nenhum sistema é transcendente. Não pode assumir operações que escapem ao seu código peculiar. O Estado 
É necessário compreender o significado da mudança constitucional, bem como de seus limites e suas possibilidades. Pode se revelar produtiva, nesse contexto, uma investigação sobre a identidade constitucional da ordem inaugurada em 1988.

Michel Rosenfeld afirma que a identidade constitucional pode se desenvolver durante toda a vida de um regime constitucional. Não obstante, a elaboração da constituição, em regra, tem um papel decisivo na determinação da identidade constitucional de certa constituição. A redação da constituição exige, ao mesmo tempo, a negação de identidades préconstitucionais e a criação de uma nova identidade que, por sua vez, demanda a reincorporação da matéria oriunda do passado pré-constitucional (i.e., anterior à constituição). É significativo que, em especial nos casos em que há mudança de regimes, a feitura da constituição (pode-se dizer o processo constituinte) não resulta, normalmente, numa total renovação da auto-identidade do povo para quem a constituição é elaborada. Ainda assim, é importante que haja mudanças no conteúdo dessa identidade nacional. ${ }^{505}$

No que toca ao processo de elaboração de uma constituição, a criação de uma nova identidade constitucional requer tanto a negação de identidades pré-constitucionais e de aspectos de identidades extra-constitucionais, quanto a reincorporação, em termos de reformulação ou reinterpretação, de aspectos da ordem pré-constitucional e extraconstitucional. Esse processo - de negação e reincorporação - é dinâmico e se desenvolve em termos dialéticos, prolongando-se no tempo mediante a solução de tensões que conduzem a novos conflitos e, em contrapartida, à necessidade de posteriores mudanças na identidade constitucional. ${ }^{506}$ Em razão dessas exigências, Rosenfeld nota que:

Para que uma nova constituição seja bem sucedida, a identidade constitucional lançada em sua feitura deve alcançar um equilíbrio delicado.

não pode dispor do dinheiro e do direito - ou seja, o sistema político não pode valer-se do sistema econômico e do sistema jurídico - ignorando as condições de possibilidade inerentes a tais meios. Direito e economia impõem obstáculos à disponibilidade política. Os três sistemas trabalham com códigos diversos. Não se pode perseguir fins políticos com a utilização do direito e da economia sem que se reconheça os limites da capacidade desses sistemas. A exceção são os casos de 'corrupção' dos respectivos códigos de comunicação, com consequências implacáveis para a manutenção autopoética do sistema" (CAMPILONGO, Celso Fernandes. Política, sistema jurídico e decisão judicial, p. 99/100). Sobre os problemas de corrupção de código entre os sistemas do direito, da política e da economia no Estado de Bem-Estar Social, cf. LUHMANN, Niklas. Teoría Política en el Estado de Bienestar. Introdução e tradução de Fernando Vallespín. Madrid: Alianza Editorial, 1997.

${ }^{505}$ A França pré-revolucionária, por exemplo, já era uma nação, porém caracterizada pela hierarquia feudal e por estados separados, enquanto a França pós-revolucionária se tornou uma nação de cidadãos iguais entre si. Cf. ROSENFELD, Michel. "The problem of 'identity' inconstitution - making and constitutional reform". Manuscrito, p. 8/9.

$506 \mathrm{O}$ caso norte-americano é um exemplo apropriado, no que diz respeito à construção da identidade constitucional, considerando-se os conflitos surgidos a partir do princípio de que "todos os homens nascem iguais" e a realidade da escravidão existente em 1776, quando elaborada a Declaração de Independência. Cf. ROSENFELD, Michel. "The problem of 'identity' inconstitution - making and constitutional reform”, p. 10. 
Por um lado, essa identidade constitucional requer uma suficiente mas não total negação de identidades pré-constitucionais - suficiente para conferir à nova ordem constitucional um começo inovador ( $a$ fresh start), mas não tão radical de maneira a ameaçar o senso de auto-identidade do povo. Por outro lado, a nova identidade constitucional deve transformar e reincorporar suficiente material pré e extra-constitucional, de modo a permitir ao povo se relacionar com a nova constituição como sua constituição, e a permitir a seus intérpretes dotar suas disposições fundamentais (key provisions) de conteúdo que possa conduzir a um amplo senso de legitimidade por toda a comunidade política (polity). ${ }^{507}$

A identidade constitucional tem, não obstante, uma natureza evasiva. A sua determinação, sempre parcial e fragmentada, demandaria a (re)construção de um entrelaçamento entre passado (dos constituintes), presente e futuro (das gerações supervenientes). Mas o passado e o futuro são incertos e podem ser reconstruídos sob várias leituras, inclusive conflitantes entre si. Não se trata, de toda forma, de simplesmente buscar a verdadeira intenção dos constituintes - numa concepção originalista. A identidade constitucional estará sempre aberta à reinterpretação e à reconstrução - sobretudo no caso de uma constituição escrita. ${ }^{508}$

O caráter evasivo e problemático da identidade constitucional se refere à questão indicada há pouco, sobre a sua relação com outras identidades relevantes. O processo pelo qual a identidade constitucional se mantém distinta de outras identidades mas, ao mesmo tempo, as incorpora, ainda que parcialmente, se reflete na redação e na interpretação da constituição. Como observa Rosenfeld, mais uma vez:

ainda que os constituintes tivessem podido escrupulosamente evitar se referir a essas outras identidades ao elaborarem um texto constitucional amplamente fundado, traços das identidades deixadas de fora indubitavelmente se esgueirariam de volta ao corpus constitucional, como um subproduto da interpretação e da elaboração das normas constitucionais.

\footnotetext{
${ }^{507}$ ROSENFELD, Michel. "The problem of 'identity' inconstitution - making and constitutional reform", p. 10 (tradução livre).

508 Nas palavras de Michel Rosenfeld, "para se estabelecer a identidade constitucional através dos tempos é necessário fabricar a tessitura de um entrelaçamento do passado dos constituintes com o próprio presente e ainda com o futuro das gerações vindouras. O problema, no entanto, é que tanto o passado quanto o futuro são incertos e abertos a possibilidades de reconstrução conflitantes, tornando assim imensamente complexa a tarefa de se revelar linhas de continuidade. Ainda que a real intenção dos constituintes fosse plena e claramente acessível, permaneceria em discussão o quanto e em qual medida e extensão ela deveria ser relevante ou vinculante para uma determinada geração subsequente. E, dado que a intenção dos constituintes sempre poderá ser apreendida em diversos níveis de abstração, sempre haverá a possibilidade de a identidade constitucional ser reinterpretada e reconstruída. Pelo menos no que toca às constituições escritas a identidade constitucional é necessariamente problemática em termos da relação da Constituição com ela mesma. Um texto constitucional escrito é inexoravelmente incompleto e sujeito a múltiplas interpretações plausíveis" (ROSENFELD, MICHEL. A identidade do sujeito constitucional. Tradução de Menelick de Carvalho Netto. Belo Horizonte: Mandamentos, 2003, p. 17/18.
} 
Os intérpretes constitucionais não podem se despir completamente de sua identidade nacional ou cultural. Assim é que a questão-chave passa a ser a de como a identidade constitucional pode se distanciar o suficiente das outras identidades relevantes contra as quais ela precisa forjar sua própria imagem, enquanto, ao mesmo tempo, incorpora elementos suficientes dessas identidades para continuar viável no interior de seu próprio ambiente sociopolítico. ${ }^{509}$

O processo de elaboração da constituição é relevante para o tipo de relação que a nova constituição mantém com a identidade pré-constitucional (ou seja, com a ordem anterior). De acordo com Rosenfeld, parece fazer sentido que, se a criação de uma constituição é precedida de uma revolução violenta, a relação entre a nova constituição e a identidade constitucional será diferente, se comparada com uma situação de transição pacífica em direção a uma nova constituição.

O autor propõe quatro modelos de processos de elaboração da constituição: a) o decorrente de revolução, ou modelo baseado na revolução (como nas Revoluções Francesa e Norte Americana do século XVIII); b) o imposto pelos vencedores de uma guerra sobre os vencidos, ou modelo baseado na guerra (como na Alemanha e no Japão, após a Segunda Guerra Mundial); c) o da transição pacífica para uma nova constituição, ou o modelo da transição pactuada (cujo exemplo seria a Espanha, depois da morte de Franco); e d) aquele fundado em tratado transnacional, ou modelo do tratado-constitucional (o exemplo seria a Constituição Europeia ou o Tratado Constitucional para a União Europeia). ${ }^{510}$

O terceiro modelo, proposto por Rosenfeld, é aquele em que há a passagem de um regime autoritário pré-constitucional para uma democracia constitucional. Essa passagem se dá pela negociação entre representantes do regime autoritário, ou seus "herdeiros", e "reformistas" que pretendem a transição para a democracia. ${ }^{511}$

\footnotetext{
${ }^{509}$ ROSENFELD, Michel. A identidade do sujeito constitucional, p. 22/23.

${ }^{510}$ ROSENFELD, Michel. "The problem of 'identity' inconstitution - making and constitutional reform”, p. 11.

${ }^{511}$ De acordo com Rosenfeld, na Espanha pós-Franco, nem os herdeiros do ditador, nem a oposição democrática tinham força suficiente para sobrepujar (mesmo pela violência) seus adversários, e ambos os lados tinham receio de uma guerra incontrolável e de violência. Isso os levou à negociação, por meio de um processo que fez uso de instituições e estruturas existentes, transformando-as de dentro. O consenso alcançado resultou, então, na Constituição de 1978. Outros exemplos desse modelo seriam alguns países do Centro e do Leste Europeu, por volta de 1990, bem como a África do Sul (Ver ROSENFELD, Michel. "The problem of 'identity' inconstitution making and constitutional reform", p. 12). Sobre o caso espanhol, Rafael Aday identifica a ausência de um programa de justiça de transição, faltando os critérios de verdade, justiça e reparação, na medida em que não houve investigação sobre os atos contrários à democracia anterior ao franquismo e violadores de direitos humanos; não foram levados perante a justiça os responsáveis por esses atos contrários aos direitos humanos; e inexistiu uma política de reparação das vítimas, além de ser perceptível um déficit importante quanto às reparações institucionais (como a retirada de símbolos do franquismo em ruas e praças). Cf. ALDAY, Rafael Escudero. "La sombra del franquismo es alargada: el fracaso de la llamada Ley de Memoria Histórica". ln:LOPEZ, Federico Fernández-Crehuet. LOPEZ,DanielJ. Garcia (ed.). Derecho, memoria histórica y díctaduras. Granada: Editorial Comares, 2009, pp. 33-60.
} 
A descrição do terceiro modelo apresentado por Rosenfeld - e do próprio exemplo por ele tomado - guarda pertinência com o caso brasileiro. Utilizando a conceituação de Daniel Aarão Reis, tem-se que, no Brasil, a transição democrática estendeu-se de 1979 a 1988, sendo o marco inicial a revogação dos Atos Institucionais e, final, a promulgação da nova Constituição. ${ }^{512}$ Ela teve seu curso com o controle dos militares, a partir dos ideais, lançados ainda em 1974 pelo então Presidente Ernesto Geisel, de uma transição lenta, gradativa e segura. ${ }^{513}$ Não houve propriamente uma negociação. Os militares conduziram a transição, que foi, todavia, tensionada pela oposição política (como o MDB) e pela eclosão de importantes movimentos sociais ${ }^{514}$, como as greves dos metalúrgicos do $\mathrm{ABC}$ e manifestações que contavam com o apoio da Igreja Católica, por meio da Confederação Nacional dos Bispos do Brasil - CNBB, por exemplo. ${ }^{515}$

\footnotetext{
512 Segundo Daniel Aarão Reis, "no período de transição já não havia ditadura, mas ainda não existia uma democracia". Para esse autor, existe um senso comum, em grande parte reforçado pela historiografia, no sentido de que a ditadura militar brasileira teria se encerrado com a posse do Presidente José Sarney, em 1985. Essa perspectiva, porém, teria por consequência silenciar sobre as bases sociais e políticas (civis) do regime ditatorial - transformando os militares em "bodes expiatórios", ou seja, como únicos responsáveis pela ditadura. (REIS, Daniel Aarão. Ditadura e democracia no Brasil: do golpe de 1964 à Constituição de 1988. $1^{\mathrm{a}}$ ed. Rio de Janeiro: Zahar, 2014, p. 125 (destaques no original) e 126/128.

${ }^{513}$ REIS, Daniel Aarão. Ditadura e democracia no Brasil: do golpe de 1964 à Constituição de 1988, p. 99.

514 A aprovação da Lei de Anistia (Lei 6.683), em 1979, está inserida nesse contexto específico. Para o governo, a anistia deveria assegurar a libertação dos presos remanescentes, permitir o retorno dos exilados e proteger os aparelhos de segurança, então denunciados como implementadores da política de Estado da tortura. No âmbito dos comitês de anistia, contudo, defendia-se a anistia ampla, geral e irrestrita, inclusive, para alguns setores, com o desmonte dos órgãos de segurança e o julgamento dos torturadores (cf. REIS, Daniel Aarão. Ditadura e democracia no Brasil: do golpe de 1964 à Constituição de 1988, p. 132/133). Ao final, a aprovação da lei de anistia foi uma derrota à oposição, pois não foi ampla, geral e irrestrita, como se pretendia. Como observa Thomas Skidmore, "foi uma transação política. Os líderes da oposição sabiam que só podiam passar a um regime aberto com a cooperação dos militares. Poderia haver futuras tentativas de reabrir a questão, especialmente por parte daqueles mais próximos das vítimas da tortura. Mas por enquanto os políticos brasileiros receberam uma lição, para o melhor ou o pior, sobre a arte da "conciliação"” (SKIDMORE, Thomas. Brasil: de Castelo a Tancredo, 1964-1985, p. 426). Sobre a movimentação social pela aprovação da lei de anistia, ver também GRECO, Heloisa Amélia. "Esquecimento, Instituinte vs. Instituído: a luta pela Anistia ampla, geral e irrestrita". In: H. R. Kleber da Silva. A luta pela anistia. São Paulo: Editora Unesp/Arquivo Público do Estado de São Paulo/Imprensa Oficial do Estado de São Paulo, 2009; MEZAROBBA, Glenda. "Anistia e reparação: uma combinação imprópria". In: H. R. Kleber da Silva. A luta pela anistia. São Paulo: Editora Unesp/Arquivo Público do Estado de São Paulo/Imprensa Oficial do Estado de São Paulo, 2009; e SALES, Jean Rodrigues. "Ditadura militar, anistia e a construção da memória social". In: H. R. Kleber da Silva. A luta pela anistia. São Paulo: Editora Unesp/Arquivo Público do Estado de São Paulo/Imprensa Oficial do Estado de São Paulo, 2009. Em agosto de 2010, o Supremo Tribunal Federal julgou improcedente o pedido formulado pelo Conselho Federal da OAB, na ADPF 153, que pretendia a declaração de que o art. $1^{\circ}$, § $1^{\circ}$, da Lei 6.683/1979 - que concede anistia a todos que, em determinado período, cometeram crimes políticos ou crimes conexos a esses (ou seja, crimes de qualquer natureza relacionados a crimes políticos ou cometidos com motivação política) - não fora recepcionado pela Constituição de 1988 (cf. BRASIL. Supremo Tribunal Federal. Arguição de Descumprimento de Preceito Fundamental $\mathrm{n}^{\circ}$ 153. Rel. Ministro Eros Grau. Diário de Justiça Eletrônico, Brasília, DF, 6.8.2010).

515 A respeito das greves dos metalúrgicos do $\mathrm{ABC}$, que tiveram lugar entre 1978 e 1980, cf. ANTUNES, Ricardo. A rebeldia do trabalho - o confronto operário do ABC paulista: as greves de 1978/1980; e ABRAMO, Laís Wendel. $O$ resgate da dignidade: greve metalúrgica e subjetividade operária. Campinas, SP: Editora da Unicamp, São Paulo, OS: Imprensa Oficial, 1999.
} 
Esse tensionamento teve seu ápice nas Diretas Já - e a mobilização política da sociedade, vista nesse movimento, vai ser, adiante, canalizada para a Assembleia Nacional Constituinte. Anthony Pereira observa, entretanto, que, “apesar da campanha das Diretas Já, ocorrida em 1984, quando grandes manifestações de massa exigiram eleições diretas, a transição brasileira para um governo civil foi um processo dominado pelas elites e fortemente controlado, no qual tanto as forças armadas quanto o Judiciário mantiveram quase intocada a totalidade de suas prerrogativas". 516

A própria Constituição de 1988 manteve, em seu artigo 142, a prerrogativa das Forças Armadas de defesa da lei e da ordem. ${ }^{517}$ Não se define, contudo, quando ou como a lei e a ordem são violadas, decisão essa que acaba ficando a cargo das Forças Armadas. Ou seja, são elas mesmas que definem a lei e a ordem. Na análise de Jorge Zaverucha:

ordem não é um conceito neutro e sua definição operacional, em todos os níveis do processo de tomada de decisão política, envolve escolhas que refletem as estruturas política e ideológica dominantes. Portanto, a noção de (des)ordem envolve julgamentos ideológicos e está sujeita a estereótipos e preconceitos sobre a conduta (in)desejada de determinados indivíduos. Além do mais, tal artigo não especifica se a lei é constitucional ou ordinária. ${ }^{518}$

Na greve dos petroleiros de 1995, o recurso às Forças Armadas foi utilizado pelo então Presidente da República, Fernando Henrique Cardoso, que ordenou a ocupação de quatro refinarias pelos militares. Em uma entrevista, posterior à ação do Exército, o Presidente afirmou estar "cumprindo a Constituição". ${ }^{519}$ Vale recordar também as palavras do General Antônio Araújo de Medeiros, Comandante da $5^{\mathrm{a}}$ Região Militar, que, a respeito da função das tropas que ocupavam a Repar, declarou que "nós estamos lá para garantir a integridade e a segurança da refinaria. Os soldados circulam pelas áreas. Formamos uma espécie de cinturão de segurança", e ainda esclareceu: "como é que eu permito a segurança

\footnotetext{
${ }^{516}$ PEREIRA, Anthony. Ditadura e repressão: o autoritarismo e o estado de direito no Brasil, no Chile e na Argentina. Tradução de Patricia Queiroz Carvalho Zimbres. São Paulo: Paz e Terra, 2010, p. 240.

$517 \mathrm{O}$ art. 142, caput, da Constituição dispõe que: "As Forças Armadas, constituídas pela Marinha, pelo Exército e pela Aeronáutica, são instituições nacionais permanentes e regulares, organizadas com base na hierarquia e na disciplina, sob a autoridade suprema do Presidente da República, e destinam-se à defesa da Pátria, à garantia dos poderes constitucionais e, por iniciativa de qualquer destes, da lei e da ordem" (BRASIL. Constituição (1988). Constituição da República Federativa do Brasil - destaques acrescentados).

518 ZAVERUCHA, Jorge. "Relações civil-militares: o legado autoritário da Constituição brasileira de 1988". In: TELES, Edson; SAFATLE, Wladmir (Orgs.). O que resta da ditadura: a exceção brasileira. São Paulo: Boitempo, 2010, pp. $41 / 76$ (p. 49).

${ }^{519}$ Revista Veja de 31.5.1995.
} 
das instalações? Eu permito impedindo que alguém vá lá e danifique. Então, se eu tiver que atirar, eu vou atirar para manter a integridade das instalações. Isso daí é uma coisa certa". ${ }^{520}$

A associação da greve com uma situação que desafia a lei e a ordem esteve presente, ainda, na decisão do TST. O Ministro Armando de Brito, vale recordar, expressou a posição de que a "greve política" deveria ser encarada como "questão de segurança nacional", votando, então, pela abusividade da paralisação dos petroleiros, em prol da defesa da "sobrevivência da ordem jurídica e (...) das instituições democráticas". ${ }^{521}$ Essa ideologia de segurança nacional era própria do regime militar pós-1964, quando ela "servia ao mesmo tempo de quadro de referência organizacional e de justificação para a necessidade de constituir mecanismos repressivos de controle da sociedade civil". ${ }^{522}$ Com a promulgação do novo texto constitucional, chama atenção o uso autoritário desses conceitos - lei, ordem, segurança nacional - num contexto democrático.

Para Daniel Aarão Reis, a Constituição de 1988 acabou consagrando e reforçando uma ordem nacional-estatista, tendo como marcas a centralização de poderes, a hipertrofia do Executivo, a permanência da tutela militar e a manutenção de prerrogativas de representantes dos trabalhadores e o corporativismo sindical. Sendo assim, "a questão era saber em que medida a lógica das tradições nacional-estatista, incorporando notáveis - e inquietantes legados do período ditatorial, não se constituiria no futuro - porque já inscrita no texto constitucional - uma ameaça aos direitos e liberdades formalmente enunciados". 523

Se a experiência brasileira evidencia traços do modelo de mudança constitucional desenhado por Michel Rosenfeld, a advertência feita pelo constitucionalista também soa relevante para a história constitucional do país: “um dos perigos de transições pactuadas é que elas falham em trazer à tona uma suficiente ruptura com o passado pré-constitucional de maneira a tornar viável um caminho exitoso para a constituição emergente". 524

Mas o determinismo causal deve ser evitado. ${ }^{525}$ É necessário atentar para o que o próprio Rosenfeld aponta com relação ao sujeito e à matéria constitucionais: a sua busca

\footnotetext{
${ }^{520}$ Cf. capítulo 2, item 2.3 supra.

${ }^{521}$ Cf. capítulo 2, item 2.3 supra.

522 MOREIRA ALVES, Maria Helena. Estado e Oposição no Brasil-1964-1984, p. 315. Leonel Severo Rocha afirma que o autoritarismo brasileiro do período pós-64, para impor suas decisões, precisa recorrer à força, negando permanentemente os direitos humanos. Daí, segundo o autor, "a necessidade da utilização da ideologia da segurança nacional para justificar a violência empregada e da defesa do desenvolvimento econômico para justificar a concentração do capital nas mãos das classes ricas, o que produziu, a partir desta matriz, um Estado extremamente forte" (ROCHA, Leonel Severo. "Os senhores da lei". In: Epistemologia jurídica e democracia. $2^{\mathrm{a}}$ ed. São Leopoldo: Ed. Unisinos, 2003, p. 122).

${ }^{523}$ REIS, Daniel Aarão. Ditadura e democracia no Brasil: do golpe de 1964 à Constituição de 1988, p. 166.

${ }^{524}$ ROSENFELD, Michel. "The problem of 'identity' inconstitution - making and constitutional reform”, p. 12.

${ }^{525}$ Cf. LUHMANN, Niklas. "Causalidade no Sul”. Trad. de Menelick de Carvalho Netto (para fins acadêmicos).
} 
chega ao encontro de um hiato, um vazio. Isso não afasta, porém, seu caráter indispensável, evidenciando, antes de tudo, a necessidade de sua reconstrução, que jamais será completa e definitiva. Assim, “a identidade do sujeito constitucional só é suscetível de determinação parcial mediante um processo de reconstrução orientado no sentido de alcançar um equilíbrio entre a assimilação e a rejeição das demais identidades relevantes (...)".526

A advertência de Michel Rosenfeld traz à tona, outra vez, o problema dos usos da Constituição e, além disso, da importância de desenvolvimento de um discurso constitucional que permita a invenção e a reinvenção da identidade do sujeito constitucional. Aquele discurso deve ser construído a partir de um texto constitucional, localizado em seu devido contexto, considerando as restrições normativas e fatuais relevantes. Segundo Rosenfeld, "o sujeito constitucional, motivado pela necessidade de superar a sua carência (lack) e inerente incompletude, precisa se dotar do instrumental do discurso constitucional para construir uma narrativa coerente na qual possa localizar uma auto-identidade plausível". 527

Com a Constituição de 1988, surge a necessidade de construção de um discurso constitucional coerente com seu processo de elaboração "democrático, aberto e participativo". ${ }^{528}$ De acordo com Carlos Michiles, a campanha das Diretas Já foi um marco fundamental de reivindicação de democracia. ${ }^{529} \mathrm{E}$, em seguida, a ruptura com o "entulho autoritário" foi buscada mediante uma constituinte. Ainda que surgissem questionamentos à Assembleia Nacional Constituinte eleita em 1986 (pelo fato, por exemplo, de ser um Congresso Constituinte e não uma assembleia exclusiva), o ponto decisivo era o seu aspecto processual. Em suas palavras:

nesse momento de inegável importância histórica para o país, importava mais não a perspectiva estanque da Constituinte em si, mas o seu caráter processual. Ou seja, a mobilização popular que seria despertada com a

In: Revista de Teoria Sociológica. Universidade de Bielefeld, Alemanha, s/d;

526 ROSENFELD, Michel. A identidade do sujeito constitucional, p. 27 . O autor esclarece que não se deve proceder à personificação do sujeito constitucional: "nem os constituintes, nem os intérpretes da Constituição, nem os que se encontram sujeitos às suas prescrições são propriamente o sujeito constitucional. Todos eles formam parte do sujeito constitucional e pertencem a ele, mas o sujeito constitucional enquanto tal só pode ser apreendido mediante expressões de sua auto-identidade no discurso intersubjetivo que vincula todos os atores humanos que estão e serão reunidos pelo mesmo conjunto de normas constitucionais" (ROSENFELD, Michel. A identidade do sujeito constitucional, p. 40).

${ }^{527}$ ROSENFELD, Michel. A identidade do sujeito constitucional, p. 40.

${ }^{528}$ CARVALHO NETTO, Menelick de, e PAIXÃO, Cristiano. "Entre permanência e mudança: reflexões sobre o conceito de constituição". In: MOLINARO, Carlos Alberto; MILHORANZA, Mariângela Guerreiro; PORTO, Sérgio Gilberto (Coords.). Constituição, jurisdição e processo: estudos em homenagem aos 55 anos da Revista Jurídica. Sapucaia do Sul: Notadez, 2007, p. 104.

${ }^{529}$ Daniel Aarão Reis indica algumas manifestações públicas de insatisfação com o regime no período de 1975 a 1978, a começar pela realização, em São Paulo, de protesto pelo assassinato do jornalista Vladimir Herzog. Cf. REIS, Daniel Aarão. Ditadura e democracia no Brasil, p. 119/122. 
realização dessa Constituinte. O seu caráter pedagógico, de aprendizagem política e, principalmente, seu significado na luta pela construção da cidadania do povo brasileiro. ${ }^{530}$

A movimentação popular que se dirigiu para a Assembleia Nacional Constituinte de 1987/1988 é essencial para o reconhecimento da importância desse momento de exercício do poder constituinte e, sobretudo, para a compreensão da própria Constituição. ${ }^{531}$

O desenvolvimento de um discurso constitucional - ou de uma cultura constitucional - "pressupõe abertura para o futuro, construção de uma comunidade política consciente e reflexiva e disposição para o aprendizado com a experiência histórica". ${ }^{532}$ Aliás, os direitos fundamentais estão relacionados justamente com a abertura para o futuro e com o aprendizado diante da experiência histórica. ${ }^{533}$

O texto constitucional per se não é capaz de alterar a realidade, ou mesmo de garantir o funcionamento das instituições e dos sistemas, ou a realização de direitos fundamentais. Para a formulação de um discurso constitucional, adequado ao texto de 1988, é preciso rever certos usos, práticas, atitudes. Pode ser útil, nesse sentido, como afirmam Menelick de Carvalho Netto e Cristiano Paixão, "reiterar um conceito histórico de constituição, que permita estabelecer uma gramática de práticas e usos do texto

\footnotetext{
${ }^{530}$ MICHILES, Carlos. Cidadão Constituinte - a saga das emendas populares, p. 20 e 19, respectivamente. A movimentação popular acompanhou os trabalhos da Constituinte e se fez sentir por meio das emendas populares. Florestan Fernandes indica que a Constituição foi acompanhada pela eclosão do "Povo na História". Uma das vias desse processo foi a "participação popular" na Assembleia Constituinte. Diversas entidades da sociedade civil - como OAB, CNBB e CPT - organizaram listas de assinaturas para endossar emendas populares relevantes. Na observação de Fernandes, "essas listas despencaram sobre a ANC e engendraram uma realidade histórica nova, em matéria de pressão popular" (FERNANDES, Florestan. A Constituição inacabada. São Paulo: Estação Liberdade, 1989, p. 348).

${ }^{531}$ De acordo com Menelick de Carvalho Netto, "a legitimidade da Constituição de 1988 veio de seu inusitado processo de elaboração. O Regimento Interno original do processo constituinte, que prefigurava segundo a prática até então adotada no país uma transição 'pelo alto', terminou tendo que ser totalmente revisto. A 'comissão de notáveis', que já havia elaborado uma proposta de Constituição, trabalhou inutilmente. O procedimento tradicional foi atropelado pela grande força popular já mobilizada no movimento das Diretas Já, e que diante da sua frustração decorrente da não aprovação da Emenda Dante de Oliveira e da morte do presidente eleito pelo Colégio Eleitoral como símbolo da transição para a democracia, Tancredo Neves, exigiu a formulação de um novo procedimento iniciado com a coleta de sugestões populares, ocasionando a abertura e a total democratização do processo constituinte" (CARVALHO NETTO, Menelick. "A urgente revisão da teoria do poder constituinte: da impossibilidade da democracia possível" - Prefácio, p. 25).

${ }_{532}$ CARVALHO NETTO, Menelick de. PAIXÃO, Cristiano. "Entre permanência e mudança: reflexões sobre o conceito de constituição", p. 107.

${ }^{53}$ Cf. LUHMANN, Niklas. La costituzione come acquisizione evolutiva", p. 100; CORSI, Giancarlo. "Sociologia da Constituição", p. 6 (manuscrito); e NEVES, Marcelo. "The symbolic force of human rights". In: Philosophy \& Social Criticism. Vol. 33, n 4, 2007, p. 416.
} 
constitucional". ${ }^{534}$ Esse é um desafio fundamental da Constituição de 1988, que, como lembra Florestan Fernandes, nasceu sob o emblema da ruptura. ${ }^{535}$

$\mathrm{Na}$ construção de um discurso constitucional, assume papel relevante a interpretação e a aplicação dadas ao texto pelos tribunais. Como indica Michel Rosenfeld, as construções hermenêuticas produzidas pelas cortes judiciais são cruciais para a compreensão da identidade constitucional. ${ }^{536}$ Isso conduz ao tópico seguinte, sobre a função dos tribunais e às relações entre os sistemas jurídico e político.

\subsection{A atuaç̃o da Justica do Trabalho nas greves e o papel dos tribunais}

Tomando como ponto de partida a criação, em Portugal, do Supremo Tribunal de Justiça, António Manuel Hespanha lança algumas observações sobre a relação entre direito legislativo e direito judiciário - ou seja, entre esse, resultado do trabalho dos juízes e tribunais, e aquele, fruto da produção do Parlamento composto por representantes do povo soberano. A questão de fundo, segundo o historiador, seria exatamente o papel dos juristas e do seu saber na conformação do direito de um Estado Democrático. ${ }^{537}$

De acordo com Hespanha, as constituições monarquistas não vinculavam o juiz à lei. Assim, no Antigo Regime, é perceptível uma preponderância dos juristas e, em especial, dos juízes e tribunais, denunciados, muitas vezes, pelo não cumprimento das leis. $\mathrm{Na}$ Constituição Portuguesa de 1822, buscou-se adotar medidas para restringir o arbítrio judicial ou assegurar sua disciplina. Havia, então, a imagem de que a justiça era arbitrária, corrupta e corporativa. Pretendia-se, por conseguinte, limitar o direito judiciário, com a criação de uma Corte de Cassação.

A origem do Supremo Tribunal de Justiça português se insere nesse contexto, com o objetivo de constituir uma instância de controle político dos tribunais, e, sobretudo, de garantir a conformidade das sentenças ao direito. Esta era a previsão do texto constitucional: estabelecer a revisão das sentenças diante de uma (genérica) contradição ao direito, e não propriamente de uma violação à lei. O resultado foi a manutenção do que já ocorria no Antigo Regime. Há a possibilidade, segundo Hespanha, de que a anulação da sentença por

\footnotetext{
${ }^{534}$ CARVALHO NETTO, Menelick de. PAIXÃO, Cristiano. "Entre permanência e mudança: reflexões sobre o conceito de constituição", p. 107.

535 FERNANDES, Florestan. A Constituição inacabada, p. 250.

${ }^{536}$ ROSENFELD, Michel. A identidade do sujeito constitucional, p. 18/19.

${ }^{537}$ Cf. HESPANHA, António Manuel. "Governo da lei ou governo dos juízes? O primeiro século do Supremo Tribunal de Justiça em Portugal". In: História Constitucional, n. 12, 2011, pp. $203-237$ (disponível em www.historiaconstitucional.com - acesso em 10.4.2013), p. 203.
} 
ofensa ao direito tenha funcionado contrariamente à nova ordem constitucional. Poderia ocorrer de o STJ anular, porque contrária ao direito, uma decisão que aplicasse a lei, bem como de ratificar uma decisão que violasse de forma clara a lei, mas estivesse de acordo com o direito doutrinal e jurisprudencial. O sistema mantinha, de forma quase intacta, a preponderância dos juristas. António Manuel Hespanha assim explica:

O que acontecia é que esta abertura a um direito para além da lei - ou mesmo contra a lei - correspondia, na verdade, ao quadro de fontes de direito herdado do Antigo Regime, quadro no qual a doutrina e o direito dos tribunais mantinham um lugar central. Era nesse quadro (...) que a mentalidade dos juízes se tinha formado. E, por isso, eles tinham essa concepção alargada de "direito", bem a amplitude da autonomia dos juristas para dizerem o direito como correspondendo à ordem natural das coisas. ${ }^{538}$

Para Hespanha, antes de atuar como garante da nova Constituição e das leis que a acompanharam, o novo Tribunal poderia funcionar como elemento de corrupção da ordem constitucional e jurídica, sujeitando o texto constitucional e as leis a um direito tradicional, com a subsequente conversão do regime de um Estado fundado na soberania do povo para, mais uma vez, um Estado arbitrado pelo conjunto dos juristas. ${ }^{539}$

$\mathrm{O}$ artigo de António Manuel Hespanha traz a questão do governo dos juízes, em que o Estado e o próprio corpo político, cujo exercício do poder se ampara na soberania popular, passam a ser pautados mais por um direito judiciário, criado pelo corpo de magistrados, do que por um direito legislativo, produzido pelo parlamento.

A abordagem de Hespanha interessa à presente pesquisa, não tanto pela experiência portuguesa com o Supremo Tribunal de Justiça, mas, sobretudo, quanto à colocação do problema atinente a um governo dos juízes e suas implicações.

O Tribunal Superior do Trabalho é o órgão de cúpula da Justiça do Trabalho no Brasil. Ele exerce o papel de instância extraordinária - como uma Corte de Cassação - em processos originados nas Varas do Trabalho (onde atua um juízo monocrático), tendo por função zelar pela observância da Constituição e da Lei, bem como a uniformização da

\footnotetext{
${ }^{538}$ HESPANHA, António Manuel. "Governo da lei ou governo dos juízes? O primeiro século do Supremo Tribunal de Justiça em Portugal”, p. 228.

539 Nas palavras do historiador português, "pode dizer-se - não considerando agora questões importantes relativas ao estatuto dos magistrados - que o STJ quase que obtivera todas as condições para transformar a constituição do Estado português num Estado de Juízes. Controlava a legitimidade da lei, nos termos da Constituição da nova República, funcionava como um intérprete da lei dotado de um poder capaz de 'cassar' uma sentença dada contra a interpretação do direito por ele acolhida e (...) disputava ao executivo a jurisdição administrativa, que, desde o Antigo Regime, ele mantivera como 'justiça retida"' (HESPANHA, António Manuel. "Governo da lei ou governo dos juízes? O primeiro século do Supremo Tribunal de Justiça em Portugal", p. 235).
} 
jurisprudência trabalhista. ${ }^{540} \mathrm{O}$ Tribunal detém, por outro lado, competência para julgar determinados processos originariamente, bem como para apreciar recursos, atuando como segundo grau de jurisdição. É o que ocorre, por exemplo, com os processos de dissídio coletivo, em que há o exercício do poder normativo da Justiça do Trabalho, ou seja, a competência, reconhecida a essa esfera do Poder Judiciário, de solucionar conflitos coletivos entre os atores do mundo do trabalho mediante a criação de normas que vão regular as condições laborais entre eles. ${ }^{541}$ A decisão aí proferida é chamada de sentença normativa e o julgamento alcança, em regra, a procedência ou não das reivindicações profissionais e a legalidade ou a abusividade no exercício do direito de greve, quando o caso.

$\mathrm{Na}$ Exposição de Motivos do Decreto-Lei $\mathrm{n}^{\mathrm{o}}$ 1.237, de 2.5.1939, que regulamentou a Justiça do Trabalho - então vinculada ao Poder Executivo ${ }^{542}$ - e reconheceu seu poder normativo, esse último é apresentado como uma condição essencial para que a Justiça do Trabalho desempenhasse a tarefa de dirimir os conflitos entre empregados e empregadores, de maneira a promover a "paz social". 543

Ao longo de sua história, a Justiça do Trabalho foi provocada, em inúmeras ocasiões, a se manifestar e (pretensamente) resolver conflitos coletivos, sobretudo nos casos em que eram deflagradas greves. Essa atuação do Judiciário Trabalhista, encarada como uma forma de intervenção indesejada do Estado, nas paralisações, foi lembrada na Assembleia Nacional Constituinte de 1987/1988. Para exemplificar, no bojo das discussões da Subcomissão dos Direitos dos Trabalhadores e Servidores Públicos sobre a melhor forma de

${ }^{540}$ O art. 896 da CLT preceitua que "cabe Recurso de Revista para Turma do Tribunal Superior do Trabalho das decisões proferidas em grau de recurso ordinário, em dissídio individual, pelos Tribunais Regionais do Trabalho, quando: a) derem ao mesmo dispositivo de lei federal interpretação diversa da que lhe houver dado outro Tribunal Regional do Trabalho, no seu Pleno ou Turma, ou a Seção de Dissídios Individuais do Tribunal Superior do Trabalho, ou contrariarem súmula de jurisprudência uniforme dessa Corte ou súmula vinculante do Supremo Tribunal Federal; b) derem ao mesmo dispositivo de lei estadual, Convenção Coletiva de Trabalho, Acordo Coletivo, sentença normativa ou regulamento empresarial de observância obrigatória em área territorial que exceda a jurisdição do Tribunal Regional prolator da decisão recorrida, interpretação divergente, na forma da alínea a; c) proferidas com violação literal de disposição de lei federal ou afronta direta e literal à Constituição Federal" (BRASIL, Decreto-Lei n ${ }^{\circ} 5.452$, de $1^{\circ}$ de maio de 1943. Aprova a Consolidação das Leis do Trabalho destaque acrescentado).

${ }^{541}$ Como se sabe, a Justiça do Trabalho, dotada de poder normativo, foi criada durante o governo de Getúlio Vargas, constituindo um dos principais pilares da organização sindical então elaborada e mantida quase intocada pela Constituição de 1988. Esses pilares são o reconhecimento do sindicato pelo Estado, a unicidade sindical, a contribuição sindical compulsória e, por fim, o poder normativo da Justiça do Trabalho. Cf. BOITO JR., Armando. O sindicalismo de Estado no Brasil - uma análise crítica da estrutura sindical. Campinas: Editora da Unicamp, São Paulo: Hucitec, 1991. Ver também LOURENÇO FILHO, Ricardo. Liberdade sindical: percursos e desafios na história constitucional brasileira. São Paulo: LTr, 2011.

${ }^{542}$ A Justiça do Trabalho passou a integrar o Poder Judiciário apenas com a Constituição de 1946.

${ }^{543}$ Cf. VIANNA, Oliveira. "Exposição de Motivos da Comissão elaboradora do Projeto de Organização da Justiça do Trabalho". In: Problemas de Direito Corporativo. $2^{\mathrm{a}}$ Ed. Brasília: Câmara dos Deputados, 1983, p. 244. Esclareça-se que, desde 1932, já existiam as Comissões Mistas de Conciliação e Julgamento, instituídas pelo Decreto $\mathrm{n}^{\circ} 21.396$, de 21 de março daquele ano, e que funcionavam com representantes de empregados e empregadores, além de um juiz togado. 
se assegurar, na nova constituição, o direito de greve, o constituinte Célio de Castro observou que "é a própria interpretação de textos (...) textos que são verdadeiras caricaturas do direito de greve, de que a Justiça do Trabalho lança mão para decretar a ilegalidade de movimentos grevistas". 544 Por sua vez, a Confederação Nacional dos Trabalhadores em Transportes Terrestres, por seu representante, ouvido na fase das audiências públicas, expressou a opinião de que, para a entidade, a intervenção da Justiça do Trabalho, em razão da propositura de dissídio coletivo, tornava ineficaz o direito de greve. ${ }^{545}$

A promulgação da Constituição de 1988 e a ampliação do direito de greve, com a previsão específica de que compete aos próprios trabalhadores decidir quando e porque deflagrar a greve, não parecem ter sido acompanhadas de uma interrupção no padrão de intervenção da Justiça do Trabalho. Pouco depois do advento do novo texto constitucional, foi a julgamento, no Tribunal Superior do Trabalho, dissídio coletivo envolvendo empregados da Aeróleo Taxi Aéreo. O relator do processo, Min. Fernando Villar, questionou a competência da Corte para julgar a greve, diante da nova Constituição e de seu art. $9^{\circ}$, entendendo que “desapareceu a competência do Tribunal para declarar a ilegalidade da greve". Mas essa posição não prevaleceu. Por 11 votos a 2, o TST concluiu que permanecia a possibilidade de declaração da ilegalidade da greve. Mais do que isso, como noticiado pela imprensa, o Tribunal decidiu que o "direito de greve não é irrestrito". Predominou, no julgamento, a posição do revisor, Min. Almir Pazzianoto, para quem alguns parâmetros da greve continuavam regulados pela Consolidação das Leis do Trabalho - CLT. Segundo o Ministro, "a nova Constituição não revogou o Título VI da CLT, que trata das convenções coletivas, e que estabelece um rito para a greve, em três etapas, a negociação, a arbitragem e a greve. Quem fizer greve antes de negociar corre o risco de ver sua paralisação declarada ilegal pelo Tribunal". 546

Não parece equivocado, porém, afirmar que, em última análise, a partir da Constituição de 1988, houve uma diversificação da intervenção da Justiça do Trabalho em conflitos coletivos e, em especial, em greves. Trata-se de uma alteração qualitativa, na medida em que foram ampliadas as formas de atuação do Judiciário Trabalhista. E isso com implicações abrangentes.

\footnotetext{
${ }^{544}$ Cf. capítulo 1, item 1.2.1 supra.

${ }^{545}$ Ver capítulo 1, item 1.2.1 supra.

${ }^{546}$ Cf. Folha de São Paulo de 10.11.1988. Chama atenção, ainda, o fato de que, entre os inúmeros dispositivos da Constituição de 1988 carentes de regulamentação, um dos primeiros a ter sua normatividade complementada foi o que trata do direito de greve, com a edição da Lei 7.783, de 28.6.1989.
} 
No julgamento do dissídio coletivo proposto pela Petrobrás, diante da greve dos petroleiros de 1995, o Tribunal Superior do Trabalho estabeleceu um percentual de trabalhadores que deveriam permanecer em atividade, de maneira a assegurar os serviços mínimos indispensáveis ao atendimento das necessidades inadiáveis da população, e impôs o pagamento de multa, no importe de $\mathrm{R} \$ 100.000,00$, em caso de descumprimento da ordem; em seguida, declarou ilegal a paralisação dos petroleiros, determinando o retorno imediato ao trabalho, sob pena de multa, no mesmo valor; e julgou improcedentes as reivindicações profissionais, que tinham amparo em acordo - o Protocolo - cuja validade, até aquele momento, sequer havia sido questionada pela própria empresa.

Atendendo a pedido do Ministério Público do Trabalho, a Corte iniciou a execução das multas impostas às 21 entidades sindicais, no valor de R $\$ 2.100 .000,00$ para cada, o que, em boa parte dos casos, ameaçou o funcionamento dos sindicatos.

Há indícios de que o Tribunal foi utilizado pelo governo como instrumento de gestão de conflitos coletivos, além de ter atuado como copartícipe da política econômica vale recordar as palavras dos Ministros Marcelo Pimentel, em 1994, e José Serra, em 1995, demonstrando a confiança do Poder Executivo de que a Justiça do Trabalho declararia ilegais as paralisações. O padrão intervencionista aplicado pelo TST parecia servir aos interesses do Estado, mormente diante das preocupações em torno do Plano Real e do controle da inflação, associada à postura do governo de investir contra o movimento sindical vinculado ao partido de oposição. Não devem ser descartadas pressões diretas exercidas pelo governo sobre integrantes da Corte. ${ }^{547}$ O Tribunal seguia o papel de promotor da "paz social", indicado na exposição de motivos ao decreto-lei de $1939 .{ }^{548}$

Chama atenção, além disso, o silêncio do Tribunal sobre a Constituição de 1988. O texto constitucional parece ter sido ignorado pela maioria dos ministros da SDC do TST. Não há nenhuma discussão (constitucional) sobre o exercício do direito de greve. A Corte utilizou um padrão de julgamento fundado, de forma exclusiva, na Lei 7.783/1989. Vale

\footnotetext{
${ }^{547}$ Sayonara Grillo Coutinho Leonardo da Silva, que entrevistou os ministros do TST que integraram a Seção de Dissídios Coletivos à época do julgamento do dissídio coletivo da Petrobrás, afirma que: "é importante não perder de vista que por ocasião da implantação do Plano Real, como informou um dos protagonistas dos eventos, havia uma 'interligação muito grande, uma intimidade muito grande entre o Ministério do Trabalho e o TST'. O Entrevistado n. 2 informou que o Ministro do Trabalho foi ao TST e explicou aos ministros que o acordo 'acabaria com o Plano Real'. Eis o seu relato: 'Porque se as empresas privadas vão desrespeitar o Plano Real, fugir da política econômica, se o próprio governo permite que a Petrobrás faça, acabou o Plano Real. E foi aí que o TST resolveu proibir a greve, declarar ilegal e ainda multou o sindicato'." (In: Relações coletivas de trabalho, p. 284).

548 Talvez não seja equivocado acrescentar a esse cenário a postura da Corte, que buscava, em diversos momentos, justificar sua própria existência perante a sociedade, como ficou evidente no pronunciamento do Ministro Presidente do TST, quando da abertura da primeira sessão de julgamento da greve de 1995. Cf. capítulo 2, item 2.3.
} 
recordar que o primeiro relator do processo, Min. Ursulino Santos, declarou a paralisação ilegal, entendendo que: em Minas Gerais, a greve fora deflagrada antes do previsto; havia evidências de que não estava sendo garantida a prestação dos serviços indispensáveis ao atendimento das necessidades inadiáveis da população, segundo o percentual estabelecido pelo Tribunal; como os acordos não tinham validade, os petroleiros não poderiam fazer greve, pois vigente a sentença normativa proferida no processo TST-DC-131.024/1994; e não havia como constatar que as formalidades previstas nos estatutos sindicais haviam sido observadas. ${ }^{549}$ Todos os aspectos ressaltados pelo relator são tratados pela referida lei ordinária. Os limites estabelecidos pela Lei 7.783/1989 adquirem preponderância em relação ao texto constitucional.

A decisão do TST na greve dos petroleiros de 1995 não é, porém, um caso pontual. A intervenção da Justiça do Trabalho, em sede de dissídio coletivo, pela imposição de percentuais mínimos de trabalhadores que devem permanecer em atividade, sob pena de pagamento de multa, tem sido uma constante na jurisprudência trabalhista. Em vários precedentes, a estipulação desses percentuais tem significado proibir a paralisação, a despeito da previsão constitucional. Alguns exemplos podem ser elucidativos.

Em greve dos metroviários de São Paulo, em 2006, o Tribunal Regional do Trabalho da $2^{\text {a }}$ Região determinou, liminarmente, a manutenção de $100 \%$ da frota, nos horários de pico, e de $80 \%$, nos demais horários, sob pena de pagamento de multa no valor de $\mathrm{R} \$ 100.000,00$ por dia. ${ }^{550}$ Diante de paralisação realizada no ano seguinte, também pelos metroviários, o mesmo Tribunal considerou abusiva a greve, impondo à empresa e ao sindicato profissional condenação por danos morais e materiais causados à coletividade. Referindo-se à opção pela paralisação, a relatora do processo entendeu que as partes "preferiram o alarde, o caos, o desrespeito ao cidadão que paga seus impostos e mais uma vez arca com o prejuízo". 551

Em decisão de julho de 2013, numa ação de dissídio coletivo de greve, envolvendo a Empresa Brasileira de Infra-Estrutura Aeroportuária, de um lado, e, do outro, o

\footnotetext{
${ }^{549}$ Cf. capítulo 2, item 2.3.

${ }^{550}$ Cf. BRASIL. Tribunal Regional do Trabalho da $2^{\text {a }}$ Região. Medida Cautelar no 20236200600002005 . Rel. Juiz Nelson Nazar. Diário de Justiça. São Paulo, SP 20.9.2007.

${ }^{551}$ BRASIL. Tribunal Regional do Trabalho da $2^{\text {a }}$ Região. Dissídio Coletivo $\mathrm{n}^{\mathrm{o}}$ 20288200700002002. Rel. Juíza Sonia Maria Prince Franzini. Diário de Justiça, São Paulo, SP, 10.7.2007. Essa restrição excessiva ao direito de greve pode ser observada também fora da Justiça do Trabalho. O Superior Tribunal de Justiça determinou liminarmente a suspensão da greve deflagrada em junho de 2009 pelos servidores do Instituto Nacional do Seguro Social - INSS e, entendendo tratar-se de serviços essenciais, estabeleceu multa no importe de R\$ $100.000,00$ por dia em caso de descumprimento. Cf. BRASIL. Superior Tribunal de Justiça. Agravo Regimental na Medida Cautelar no 15.656 -DF. Rel. Min. Og Fernandes. Diário de Justiça Eletrônico, Brasília, DF, $1^{\circ} .7 .2009$.
} 
Sindicato Nacional dos Empregados em Empresas Administradoras de Aeroportos - SINA, o então Presidente do Tribunal Superior do Trabalho, Min. Carlos Alberto Reis de Paula, determinou a manutenção de $100 \%$ dos trabalhadores das atividades de controle de tráfego aéreo, $70 \%$ dos que atuavam na área de segurança e operação, e 40\% para os demais. ${ }^{552}$

O silêncio a respeito da Constituição, constatado na decisão de 1995, também aparece na jurisprudência trabalhista, sobretudo do TST. Em vários precedentes, percebe-se a ausência de um discurso constitucional sobre o direito de greve. A própria constitucionalidade da Lei 7.783/1989 - que impõe sérias restrições ao exercício do direito - não é debatida. Alguns confrontos entre a Constituição e a Lei de Greve podem ser rapidamente apontados. Por exemplo, enquanto o texto constitucional prevê que os trabalhadores decidirão quando deflagrar a greve, a lei ordinária veda sua realização na vigência de norma coletiva (exceto se o motivo da paralisação for o cumprimento dessa última ou se for motivada pela superveniência de fatos novos ou acontecimento imprevisto que altere, de maneira significativa, as relações laborais), como estatui o art. $14 .{ }^{553}$

Outro ponto problemático diz respeito às ações dos grevistas. $\mathrm{O}$ art. $6^{\circ}$ da Lei $7.783 / 1989$ prevê restrições à conduta desses últimos. ${ }^{554}$ Esse dispositivo tem sido utilizado

552 Cf. BRASIL. Tribunal Superior do Trabalho. Presidência. Decisão cautelar no Dissídio Coletivo no 5842 82.2013.5.00.0000. Rel. Min. Carlos Alberto Reis de Paula. Diário Eletrônico da Justiça do Trabalho, Brasília, $\mathrm{DF}, 1^{\circ} .8 .2013$. Esse último precedente impressiona pelo fato de fazer expressa referência à Constituição e, em seguida, vedar, de forma integral, a greve em determinada atividade.

553 Ver o artigo 14 da Lei 7.783/1989, já transcrito acima. Em um processo julgado pelo TST, os trabalhadores do setor de vigilância de determinada região deflagraram greve, pretendendo que as empresas pagassem o adicional de periculosidade com base no inciso II do art. 193 da CLT, acrescentado pela Lei 12.740, de 8.12.2012 (que assegura o benefício quando o empregado estiver exposto ao risco de "roubos ou outras espécies de violência física nas atividades profissionais de segurança pessoal ou patrimonial"). O Tribunal, contudo, entendeu que o direito do art. 193, II, da CLT não é autoaplicável, dependendo de regulamentação, em razão do que a paralisação seria abusiva, pois havia norma coletiva vigente (assinada em 26.1.2012 e válida até 31.1.2014). A ementa do acórdão assim sintetiza o posicionamento da Corte: "Na vigência de instrumento normativo coletivo, seja autônomo (acordo ou convenção coletiva de trabalho) ou heterônomo (sentença normativa), a lei afasta a declaração da abusividade da greve que tenha por objetivo exigir o cumprimento de cláusula ou condição, ou quando 'motivada pela superveniência de fato novo ou acontecimento imprevisto que modifique substancialmente a relação de trabalho'. No caso, a greve teve como finalidade exercer pressão na categoria patronal para que efetuasse o pagamento imediato do valor do adicional previsto na nova redação do art. 193, II, da CLT, estabelecida pela Lei $\mathrm{n}^{\circ}$ 12.740/2012. Entretanto, o referido benefício não é autoaplicável, porque carece da regulamentação do órgão competente (hoje já regulado pela Portaria $\mathrm{n}^{\circ} 1.885$ do MTE). Nessa condição, o fator motivador da paralisação não se amolda às exceções estabelecidas no art. 14, I e II, da Lei $n^{\circ}$ 7.783/89, que afastariam a declaração de abusividade da greve. (...) (BRASIL. Tribunal Superior do Trabalho. Seção de Dissídios Coletivos. Recurso Ordinário n 116-89.2013.5.05.0000. Relatora Ministra Kátia Magalhães Arruda. Diário Eletrônico da Justiça do Trabalho, Brasília, DF, 15.4.2014).

${ }^{554}$ De acordo com o referido preceito: "São assegurados aos grevistas, dentre outros direitos: I - o emprego de meios pacíficos tendentes a persuadir ou aliciar os trabalhadores a aderirem à greve; II - a arrecadação de fundos e a livre divulgação do movimento. $\S 1^{\circ}$ Em nenhuma hipótese, os meios adotados por empregados e empregadores poderão violar ou constranger os direitos e garantias fundamentais de outrem. $\S 2^{\circ} E_{\text {E vedado às }}$ empresas adotar meios para constranger o empregado ao comparecimento ao trabalho, bem como capazes de frustrar a divulgação do movimento. $\S 3^{\circ}$ As manifestações e atos de persuasão utilizados pelos grevistas não poderão impedir o acesso ao trabalho nem causar ameaça ou dano à propriedade ou pessoa" (BRASIL. Lei $\mathrm{n}^{\circ}$ 
para impedir, por exemplo, a realização de piquetes pelos grevistas. Numa decisão de outubro de 2013, já citada, o então Corregedor Geral da Justiça do Trabalho, Ministro Ives Gandra da Silva Martins Filho, em sede de Correição Parcial, entendeu que a "intimidação decorrente do ostensivo posicionamento nos lugares de ingresso às agências é suficiente para evidenciar que os grevistas não se orientaram pela norma do art. $6^{\circ}, \S \S 1^{\circ}$ e $3^{\circ}$, da Lei $7.783 / 89^{\prime \prime}{ }^{555}$ Não há nenhuma referência ao art. $9^{\circ}$ da Constituição. ${ }^{556}$

A própria definição legal da greve revela-se insuficiente. $\mathrm{O}$ art. $2^{\circ}$ da Lei 7.783/1989 a conceitua como "suspensão coletiva, temporária e pacífica, total ou parcial, de

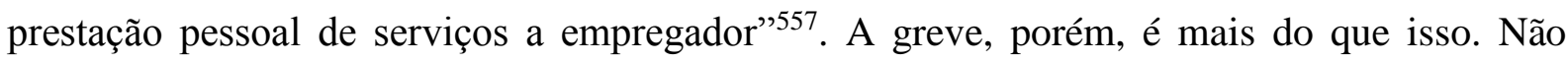
apenas pela noção, simples até, de que há greve sem interrupção do trabalho - como na operação padrão ou operação tartaruga -, mas também porque falta, na lei, a compreensão do direito de greve como forma de reivindicação, de protesto, de resistência, voltado, em potencial, não apenas em face do empregador e da empresa, mas também a outros espaços, como a política e também o direito. Esse aspecto será retomado adiante.

7.783, de 28 de junho de 1989. Dispõe sobre o exercício do direito de greve, define as atividades essenciais, regula o atendimento das necessidades inadiáveis da comunidade, e dá outras providências).

${ }^{555}$ A fundamentação, em parte já aqui mencionada, traz os seguintes motivos: "embora não haja indícios de que os sindicalistas tenham se utilizado de meios violentos para obter o fechamento das agências, inibindo o trabalho dos bancários que assim o desejassem ou o acesso do público em geral, a intimidação decorrente do ostensivo posicionamento nos lugares de ingresso às agências é suficiente para evidenciar que os grevistas não se orientaram pela norma do art. $6^{\circ}$, $\S 1^{\circ}$ e $3^{\circ}$, da Lei $7.783 / 89$. Com efeito, enquanto o $\S 1^{\circ}$ preconiza que em nenhuma hipótese os meios adotados pelos empregados e empregadores poderão violar ou constranger os direitos e garantias fundamentais de outrem, o $\S 3^{\circ}$ é incisivo ao ressaltar que as manifestações e atos de persuasão utilizados pelos grevistas não poderão impedir o acesso ao trabalho nem causar ameaça ou dano à propriedade ou pessoa" (Cf. BRASIL. Tribunal Superior do Trabalho. Corregedoria-Geral da Justiça do Trabalho. Rel. Ministro Ives Gandra Martins Filho. Correição Parcial no 7603-51.2013.5.00.0000). O Ministro destaca que decisões semelhantes já haviam sido adotadas pela Corregedoria Geral da Justiça do Trabalho e cita os precedentes (TST-CorPar-7096-61.2011.5.00.0000, Min. Barros Levenhagen, DEJT de 14/10/11; TSTCorPar-6954-57.2011.5.00.0000, Min. Barros Levenhagen, DEJT de 11/10/11, TST-CorPar-671468.2011.5.00.0000, Min. Barros Levenhagen, DEJT de 05/10/11, TST-RC-2006436-38.2008.5.00.0000, Rel. Min. João Oreste Dalazen, DJ de 24/10/08). É curioso, em todos esses processos, a utilização da Correição Parcial para provocar a manifestação do TST. De acordo com a CLT (art. 709, II) e o Regimento Interno da Corregedoria Geral da Justiça do Trabalho (art. 13), trata-se de instrumento cabível para corrigir erros, abusos e atos contrários à boa ordem processual, quando não houver recurso ou outro meio processual específico. Para o Min. Corregedor, porém, deveria ser aplicado o art. 13 do RICGJT, que autoriza a adoção, pelo Corregedor, as medidas necessárias a evitar lesão de difícil reparação, em situação extrema ou excepcional, de maneira a garantir o resultado útil do processo.

${ }_{556} \mathrm{Em}$ alguns precedentes, a referência à Constituição é seguida do reconhecimento de que o direito é limitado, de maneira que, na construção argumentativa, a limitação ou mitigação ganha mais relevo que a afirmação do direito de greve. Para uma análise dessa jurisprudência do TST, cf. PAIXÃO, Cristiano, LOURENÇO FILHO, Ricardo. "A greve e sua conformação pelo TST: desvelando mentalidades". In: MELO FILHO, Hugo Cavalcanti... [et. al.]. O mundo do trabalho, volume I: leituras críticas da jurisprudência do TST: em defesa do direito do trabalho. São Paulo: LTr, 2009, pp. 65/76. Ver também, sobre o problema desse tipo de argumentação, RODRIGUEZ, José Rodrigo. Dogmática da Liberdade Sindical - Direito, Política, Globalização, pp. 512/517.

${ }^{557}$ BRASIL. Lei ${ }^{\circ} 7.783$, de 28 de junho de 1989. Dispõe sobre o exercício do direito de greve, define as atividades essenciais, regula o atendimento das necessidades inadiáveis da comunidade, e dá outras providências. 
É necessário assinalar, por ora, que a Emenda Constitucional 45/2004 trouxe importantes inovações à atuação da Justiça do Trabalho. Dois aspectos merecem ser examinados para os fins desta pesquisa: a ampliação da competência do Judiciário Trabalhista para abarcar as lides decorrentes do exercício do direito de greve; e as modificações em matéria de poder normativo.

Com o alargamento da competência, diante da nova redação conferida ao art. 114 da Constituição ${ }^{558}$, os processos - especificamente, lides individuais - em que se discutia o exercício do direito de greve passaram a ser examinados pela Justiça Especializada. Isso levou à Justiça do Trabalho as ações - já frequentes no âmbito da Justiça Comum - de interditos proibitórios, em que o requerente (na maioria dos casos, instituições financeiras), pretende o estabelecimento de restrições ao exercício do direito de greve ao argumento de defesa do direito de propriedade do empregador. ${ }^{559}$

Num primeiro momento, a Justiça do Trabalho incorporou, em sua jurisprudência, a prática dos interditos proibitórios, acolhendo os pedidos formulados com fundamento no direito de propriedade (na mesma linha traçada pela Justiça Comum). Em decisão de agosto de 2010, por exemplo, o Tribunal Superior do Trabalho chancelou a utilização de interdito proibitório contra ação grevista deflagrada pelo Sindicato dos Empregados em

\footnotetext{
558 Em sua redação original, o art. 114, caput, da Constituição dispunha que: "compete à Justiça do Trabalho conciliar e julgar os dissídios individuais e coletivos entre trabalhadores e empregadores, abrangidos os entes de direito público externo e da administração pública direta e indireta dos Municípios, do Distrito Federal, dos Estados e da União, e, na forma da lei, outras controvérsias decorrentes da relação de trabalho, bem como os litígios que tenham origem no cumprimento de suas próprias sentenças, inclusive coletivas". Com a Emenda Constitucional 45/2004, o texto passou a ser o seguinte: "Compete à Justiça do Trabalho processar e julgar: I as ações oriundas da relação de trabalho, abrangidos os entes de direito público externo e da administração pública direta e indireta da União, dos Estados, do Distrito Federal e dos Municípios; II as ações que envolvam exercício do direito de greve; III as ações sobre representação sindical, entre sindicatos, entre sindicatos e trabalhadores, e entre sindicatos e empregadores; IV os mandados de segurança, habeas corpus e habeas data , quando o ato questionado envolver matéria sujeita à sua jurisdição; $\mathrm{V}$ os conflitos de competência entre órgãos com jurisdição trabalhista, ressalvado o disposto no art. 102, I, o; VI as ações de indenização por dano moral ou patrimonial, decorrentes da relação de trabalho; VII as ações relativas às penalidades administrativas impostas aos empregadores pelos órgãos de fiscalização das relações de trabalho; VIII a execução, de ofício, das contribuições sociais previstas no art. 195, I, a , e II, e seus acréscimos legais, decorrentes das sentenças que proferir; IX outras controvérsias decorrentes da relação de trabalho, na forma da lei" (BRASIL. Constituição (1988). Emenda Constitucional $\mathrm{n}^{\circ} 45$, de 30 de dezembro de 2004. Altera dispositivos dos arts. $5^{\circ}, 36,52,92,93,95,98,99,102$, 103, 104, 105, 107, 109, 111, 112, 114, 115, 125, 126, 127, 128, 129, 134 e 168 da Constituição Federal, e acrescenta os arts. 103-A, 103B, 111-A e 130-A, e dá outras providências. Diário Oficial da União, Brasília, DF, 31.12.2004 - destaque acrescentado).

559 Após um momento inicial de controvérsia entre a Justiça Comum e a Justiça do Trabalho, o Supremo Tribunal Federal (STF), no julgamento do RE 579.648-5/MG, decidiu que compete à Justiça do Trabalho apreciar o pedido formulado em ação de interdito proibitório fundada no exercício do direito de greve. A Corte amparou a decisão no art. 114, II, da Constituição, preceito alterado pela Emenda Constitucional no 45/2004. Posteriormente, foi editada a Súmula Vinculante $\mathrm{n}^{\circ}$ 23, com a seguinte redação: "a Justiça do Trabalho é competente para processar e julgar ação possessória ajuizada em decorrência do exercício do direito de greve pelos trabalhadores da iniciativa privada" (BRASIL. Supremo Tribunal Federal. Súmula Vinculante $\mathrm{n}^{\circ} 23$. Diário de Justiça Eletrônico, Brasília, DF, 11.12.2009).
} 
Estabelecimentos Bancários de Belo Horizonte e Região. A Corte, aplicando à greve um discurso supostamente consensual de que não há direitos fundamentais “ilimitados", reconheceu que o uso do interdito proibitório não contrariava o texto constitucional. ${ }^{560}$

$\mathrm{O}$ que se verifica, nos processos que chegaram à Justiça do Trabalho, é um uso preventivo de ações judiciais na tentativa de minimizar os efeitos da greve, mitigando o exercício do direito. Busca-se a imposição prévia, pelo Judiciário, de como os grevistas devem agir. Pelas ações de interdito proibitório, o Poder Público acaba se antecipando e definindo os limites dentro dos quais o direito de greve deve ser exercido pelos trabalhadores. Essa postura discrepa da abertura prevista no art. $9^{\circ}$ da Constituição de $1988 .^{561}$

Já são identificáveis, porém, precedentes, também da Justiça do Trabalho, no sentido de não acolher o pedido apresentado nas ações de interdito proibitório, exatamente por caracterizar restrição ao exercício do direito de greve. ${ }^{562}$

O segundo aspecto, decorrente da Emenda Constitucional 45/2004, diz respeito ao poder normativo da Justiça do Trabalho. A Constituição de 1988, em sua redação original,

\footnotetext{
${ }^{560}$ A ementa do acórdão esclarece os fundamentos do Tribunal: "1. O direito de greve, conquanto expressamente garantido pela Constituição Federal em seu artigo $9^{\circ}$, não se encontra despido de qualquer limite, como é ínsito, aliás, aos demais direitos fundamentais. 2. No caso em tela, não obstante o reconhecimento pelas instâncias ordinárias do direito dos trabalhadores em deflagrar o movimento paredista, determinou-se que o sindicato-réu se abstivesse de molestar a posse mansa e pacífica do autor sobre as agências bancárias, medida esta que não afronta o direito previsto no artigo $9^{\circ}$ da Constituição Federal." (BRASIL. Tribunal Superior do Trabalho. $2^{\mathrm{a}}$ Turma. Agravo de Instrumento em Recurso de Revista $\mathrm{n}^{\circ}$ 128040-67.2005.5.03.0114. Rel. Ministro Guilherme Caputo Bastos. Diário Eletrônico da Justiça do Trabalho, Brasília, DF, 20.8.2010).

${ }^{561}$ Sobre a prática dos interditos proibitórios e a jurisprudência do TST, cf. PAIXÃO, Cristiano, LOURENÇO FILHO, Ricardo. "Direito de greve, interditos proibitórios e a centralidade do direito de propriedade: uma visão crítica da orientação do TST" In: COUTINHO, Grijalbo Fernandes, FAVA, Marcos Neves (coordenadores). $O$ que estão fazendo da nova competência Justiça do Trabalho? Análise crítica da jurisprudência do STF, TST e do STJ após a EC 45/2004. São Paulo: LTr, 2011, pp. 319/335.

562 Ver, por exemplo, a decisão do Tribunal Superior do Trabalho, no processo TST-AIRR-18570073.2009.5.02.0383, em que a Corte confirmou o acórdão do Tribunal Regional no sentido de que não houve ameaça ao direito de propriedade pelo fechamento das agências bancárias (BRASIL. Tribunal Superior do Trabalho. $8^{a}$ Turma. Agravo de Instrumento em Recurso de Revista $\mathrm{n}^{\circ}$ 185700-73.2009.5.02.0383. Rel. Ministro Márcio Eurico Vitral Amaro. Diário Eletrônico da Justiça do Trabalho, Brasília, DF, 5.10.2012). Em sentido semelhante, a decisão do Tribunal Regional do Trabalho da $2^{a}$ Região, nos autos do processo TRT/SP-RO ${ }^{\circ}$ 21230920125020312, em que a ementa aponta que: "o direito de greve está assegurado pelo artigo $9^{\circ}$ da CF. Qualquer ordem prévia genérica, ameaçadora, motivada apenas por mera preocupação subjetiva da empresa, caracteriza inegável constrangimento aos empregados grevistas, expressamente vedado pelo $\S 2^{\circ}$ do artigo $6^{\circ}$ da Lei 7783/89 que o regulamenta. Eventuais excessos, com uso de violência ou impedimento físico de entrada nas agências, se acontecerem, deverão ser resolvidos pela força policial à disposição do empregador" (BRASIL. Tribunal Regional do Trabalho da $2^{\mathrm{a}}$ Região. Recurso Ordinário $\mathrm{n}^{\mathrm{o}}$ Rel. 21230920125020312. Rel. Desembargador Manoel Antonio Ariano. Diário Eletrônico da Justiça do Trabalho, São Paulo, SP, 4.10.2013). Há exceções, como o mostram as decisões da Corregedoria Geral da Justiça do Trabalho citadas há pouco. Em um importante julgamento, porém, a $7^{\mathrm{a}}$ Turma do Tribunal superior do Trabalho julgou procedente uma ação civil pública, proposta pelo Ministério Público do Trabalho, em que foi reconhecida a prática abusiva por vários Bancos no ajuizamento de diversas ações de interdito proibitório com o intuito de inviabilizar o livre exercício do direito de greve. A Corte reconheceu a conduta antissindical dos réus, impondo-lhe o pagamento de indenização por danos morais coletivos. Cf. BRASIL. Tribunal Superior do Trabalho. $7^{\mathrm{a}}$ Turma. Recurso de Revista ${ }^{\circ}$ 253840-90.2006.5.03.0140. Rel. Min. Vieira de Mello Filho. Diário Eletrônico da Justiça do Trabalho, Brasília, DF, 20.6.2014.
} 
permitia que qualquer um dos atores envolvidos em um conflito coletivo (entidades sindicais ou empresas) pudesse suscitar, perante o Judiciário Trabalhista, dissídio coletivo. ${ }^{563}$ Isso autorizava que uma das partes, de forma unilateral e, portanto, independentemente da concordância da outra, provocasse o pronunciamento da Justiça Especializada sobre a abusividade ou não de determinada greve, bem como sobre a procedência ou não das reivindicações profissionais que estavam na base do conflito. É o que ocorreu no caso da greve dos petroleiros de 1995, em que o dissídio coletivo foi provocado pela Petrobrás.

A decisão do TST, naquela ocasião, ensejou uma queixa, pela Central Única dos Trabalhadores, perante o Comitê de Liberdade Sindical da Organização Internacional do Trabalho, como visto. Em sua manifestação, após a apresentação das alegações da CUT e do governo brasileiro, o Comitê fez algumas recomendações. Entre elas, estava a de modificação da legislação, de maneira a que os conflitos coletivos fossem submetidos às autoridades judiciais tão somente se houvesse "acordo entre as partes, ou no caso de serviços essenciais no sentido estrito do termo (aqueles cuja interrupção poderia colocar em risco a vida, a segurança ou a saúde da pessoa em toda ou em parte da população)". 564

Na linha da recomendação da OIT, a Emenda Constitucional 45/2004 propiciou relevante alteração no exercício do poder normativo pela Justiça do Trabalho. ${ }^{565}$ Com o novo texto conferido ao art. $114, \S 2^{\circ}$, da Constituição, a propositura do dissídio coletivo estaria submetida à existência de comum acordo entre as partes envolvidas no conflito. ${ }^{566} \mathrm{~A}$ modificação parecia impedir a intervenção da Justiça Especializada em greves e negociações coletivas em caso de provocação unilateral (ou seja, por apenas uma das partes interessadas).

\footnotetext{
$563 \mathrm{O}$ art. 114, $\S 2^{\circ}$, da Constituição de 1988 estabelecia o seguinte: "recusando-se qualquer das partes à negociação ou à arbitragem, é facultado aos respectivos sindicatos ajuizar dissídio coletivo, podendo a Justiça do Trabalho estabelecer normas e condições, respeitadas as disposições convencionais e legais mínimas de proteção ao trabalho". Em complemento, o art. $8^{\circ}$ da Lei de Greve dispõe que: "a Justiça do Trabalho, por iniciativa de qualquer das partes ou do Ministério Público do Trabalho, decidirá sobre a procedência, total ou parcial, ou improcedência das reivindicações, cumprindo ao Tribunal publicar, de imediato, o competente acórdão"

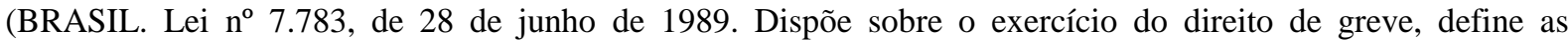
atividades essenciais, regula o atendimento das necessidades inadiáveis da comunidade, e dá outras providências).

${ }_{564}$ Cf. capítulo 2, item 2.4 acima.

565 Embora as modificações trazidas com a Emenda Constitucional 45/2004 estejam em consonância com a recomendação da OIT, caberia uma investigação mais aprofundada sobre até que ponto essa recomendação influenciou na tramitação da PEC que resultou naquela emenda constitucional.

566 Esta, a nova redação do art. $114, \S 2^{\circ}$ : "Recusando-se qualquer das partes à negociação coletiva ou à arbitragem, é facultado às mesmas, de comum acordo, ajuizar dissídio coletivo de natureza econômica, podendo a Justiça do Trabalho decidir o conflito, respeitadas as disposições mínimas legais de proteção ao trabalho, bem como as convencionadas anteriormente" (BRASIL. Constituição (1988). Constituição da República Federativa do Brasil-destaque acrescentado).
} 
Outro ponto importante foi a restrição quanto à atuação do Ministério Público do Trabalho, cuja legitimidade à propositura de dissídio coletivo passou a ser prevista (apenas) para a hipótese de greve em atividade essencial, com risco de lesão ao interesse público. ${ }^{567}$

Indaga-se: como essa inovação legislativa foi interpretada e aplicada pelo Tribunal Superior do Trabalho?

Em pouco tempo, a Corte construiu o entendimento de que o requisito do comum acordo não exigia petição conjunta dos envolvidos no conflito, sendo suficiente a não oposição expressa da parte em face de quem fosse suscitado o dissídio. ${ }^{568}$ Mas o Tribunal foi além. Em caso de greve deflagrada, a Justiça do Trabalho poderia ser provocada por qualquer das partes, independentemente de comum acordo, não havendo, ainda, restrição quanto à legitimidade, de maneira que o Ministério Público do Trabalho poderia propor o dissídio coletivo mesmo na hipótese de paralisação em atividade não prevista em lei como essencial. Em outras palavras: tornando inócua a alteração promovida pela Emenda Constitucional 45/2004, o Tribunal Superior do Trabalho erigiu a greve à condição de porta de entrada para a intervenção da Justiça do Trabalho nos conflitos coletivos.

As seguintes ementas são ilustrativas do entendimento da Corte:

RECURSO ORDINÁRIO EM DISSÍDIO COLETIVO. DISSÍDIO
COLETIVO DE GREVE AJUIZADO PELO SINDICATO
PROFISSIONAL. APRESENTAÇÃO DE AÇO REIVINDICAÇO.
EXIGÊNCIA DO COMUM ACORDO PARA O AJUIZAMENTO. Desde a
edição da Lei $\mathrm{n}^{\circ} 7.783 / 89$, não se distingue entre as empresas, os
empregados e o Ministério Público do Trabalho no tocante à legitimidade e

\footnotetext{
$567 \mathrm{O}$ art. $114, \S 3^{\circ}$, da Constituição passou a enunciar que: "Em caso de greve em atividade essencial, com possibilidade de lesão do interesse público, o Ministério Público do Trabalho poderá ajuizar dissídio coletivo, competindo à Justiça do Trabalho decidir o conflito" (BRASIL. Constituição (1988). Constituição da República Federativa do Brasil).

568 A seguinte ementa é exemplificativa: "RECURSOS ORDINÁRIOS INTERPOSTOS PELO SINDICATO DOS TRABALHADORES EM EMPRESAS FERROVIÁRIAS DE SÃO PAULO, SINDICATO NACIONAL DAS EMPRESAS DE MEDICINA DE GRUPO - SINAMGE E SINDICATO NACIONAL DAS EMPRESAS DE ODONTOLOGIA DE GRUPO - SINOG. ANÁLISE CONJUNTA. MATÉRIA COMUM - FALTA DO MÚTUO CONSENSO PARA O AJUIZAMENTO DO DISSÍDIO COLETIVO. ARTIGO 114, § 2, DA CONSTITUIÇÃO FEDERAL. EXTINÇÃO DO FEITO. Com a edição da Emenda Constitucional n. ${ }^{\circ}$ 45/2004, estabeleceu-se novo requisito para o ajuizamento da ação coletiva de natureza econômica, qual seja, que haja comum acordo entre as partes. Trata-se de requisito constitucional para instauração de instância do dissídio coletivo e diz respeito à admissibilidade do processo. A expressão 'comum acordo', de que trata o mencionado dispositivo constitucional, não significa, necessariamente, petição conjunta das partes, expressando concordância com o ajuizamento da ação coletiva, mas a não oposição da parte, antes ou após a sua propositura, que se pode caracterizar de modo expresso ou tácito, conforme a sua explícita manifestação ou o seu silêncio. No caso dos autos, houve a recusa expressa do suscitado quanto à instauração do dissídio coletivo, a qual foi feita em momento oportuno, ao teor do art. 301, X, do CPC, o que resulta na extinção do processo sem resolução de mérito, ante a falta de pressuposto de desenvolvimento válido e regular do processo. Recurso ordinário provido. (BRASIL. Tribunal Superior do Trabalho. Seção de Dissídios Coletivos. Recurso Ordinário $\mathrm{n}^{\circ}$ 2030700-36.2006.5.02.0000. Relatora Ministra Kátia Magalhães Arruda. Diário Eletrônico da Justiça do Trabalho, Brasília, DF, 10.05.2013 - destaque acrescentado).
} 
ao interesse para provocar a apreciação da Justiça do Trabalho em torno das reivindicações em caso de greve, conforme se depreende do art. $8^{\circ}$. Ademais, a leitura literal da alteração trazida pela Emenda Constitucional no 45/2004 demonstra que se exige expressamente o comum acordo tão somente para o ajuizamento do dissídio coletivo de natureza econômica. De outro lado, o Tribunal Superior do Trabalho, em composição plena, decidiu pelo cancelamento da OJ 12 da SDC, não mais prevalecendo o entendimento no sentido da vedação ao sindicato profissional que deflagre a greve de ajuizar dissídio coletivo de greve para discutir, ao menos e em tese, a qualificação jurídica do movimento (Sessão de 24/04/2010). Por fim, e não menos relevante, a própria Constituição Federal contempla a possibilidade de a Justiça do Trabalho decidir o conflito em dissídio coletivo ajuizado pelo Ministério Público do Trabalho em caso de greve em atividade essencial. Esses quatro fatores convergem para a conclusão no sentido de que, em caso de greve, mesmo que em atividade não essencial, o dissídio coletivo ajuizado por qualquer das partes prescindiria do comum acordo, embora apresentadas as reivindicações pela categoria profissional. Isso porque, ao menos, no dissídio coletivo de greve ajuizado pela categoria patronal, sindicato ou empresa, os trabalhadores podem apresentar as reivindicações, devendo a Justiça do Trabalho apreciá-las, sem a exigência do comum acordo para tanto. Com efeito, não é de se esperar que a empresa ou o sindicato patronal concorde com a apreciação das reivindicações sobretudo porque já está em posição de defesa ante a deflagração da greve que o atinge diretamente. De resto, o conflito perduraria sem que a Justiça do Trabalho pudesse ao menos esforçar-se na solução do litígio, limitando-se a pronunciar sobre eventual abusividade da greve. Recurso a que se nega provimento no particular. ${ }^{569}$

\section{RECURSO ORDINÁRIO. DISSÍDIO COLETIVO DE GREVE} PROPOSTO PELO SINDICATO DA CATEGORIA PROFISSIONAL. 1. LEGITIMIDADE ATIVA. O dissídio coletivo de natureza econômica encontra, hoje, desde a EC n ${ }^{\circ} 45 / 2004$, forte restrição constitucional, em face do pressuposto do comum acordo inserido no art. 114, § $2^{\circ}$, do Texto Máximo da República. Entretanto, havendo o fato social da greve, a regência da ordem jurídica indica em outra direção, em vista do elevado interesse social que existe na célere solução do conflito. Desse modo, no caso de greve, independentemente da área, categoria ou atividade, a legitimidade para propositura do dissídio coletivo é ampla, quer pelo Ministério Público do Trabalho, quer pelo empregador ou seu sindicato, quer pelo sindicato de trabalhadores. Esta é a jurisprudência atual da SDC do TST, que propôs (e alcançou) do Pleno do Tribunal o cancelamento da antiga OJ 12. Não prospera, portanto, a arguição de ilegitimidade ativa. Preliminar rejeitada. ${ }^{570}$

569 Cf. BRASIL. Tribunal Superior do Trabalho. Seção de Dissídios Coletivos. Recurso Ordinário no 201420084.2009.5.02.0000. Relator Ministro Márcio Eurico Vitral Amaro. Diário Eletrônico da Justiça do Trabalho. Brasília, DF, 01.7.2011 (destaque acrescentado).

570 Ver BRASIL. Tribunal Superior do Trabalho. Seção de Dissídios Coletivos. Recurso Ordinário no 2020800 24.2009.5.02.0000. Relator Ministro Mauricio Godinho Delgado. Diário Eletrônico da Justiça do Trabalho, Brasília, DF, 23.11.2012 (destaque acrescentado). Em sentido semelhante, também do TST: BRASIL. Tribunal Superior do Trabalho. Seção de Dissídios Coletivos. Recurso Ordinário no 168400-29.2009.5.04.0000. Relator Ministro Mauricio Godinho Delgado. Diário Eletrônico da Justiça do Trabalho, Brasília, DF, 16.05.2014; e BRASIL. Tribunal Superior do Trabalho. Seção de Dissídios Coletivos. Recurso Ordinário $\mathrm{n}^{\mathrm{o}}$ 11689.2013.5.05.0000. Relatora Ministra Kátia Magalhães Arruda (já mencionado). 
Está subjacente no posicionamento do TST a ideia de que o Poder Judiciário deve ter a oportunidade de examinar o conflito coletivo. A primeira ementa acima o diz expressamente, enquanto a segunda fundamenta a atuação da Justiça do Trabalho no “interesse social (...) na célere solução do conflito". O que está por trás desse raciocínio de que o Poder Judiciário deve intervir? A greve como uma situação de desordem? O (suposto) "interesse social na solução célere do conflito" significa uma autorização para a intervenção da Justiça Especializada? A propósito, há, de fato, esse interesse social? Ou seria ele mesmo um produto da própria decisão judicial? E até que ponto o pronunciamento do Poder Judiciário pode efetivamente solucionar o conflito?

Vozes contraditórias parecem ressurgir aqui. De um lado, a exposição de motivos do decreto-lei que regulamentou a Justiça do Trabalho, em 1939, atribuindo-lhe o papel de garantidora da "paz social" (com todos os pressupostos ideológicos daquele contexto). De outro, os discursos dos constituintes de 1987/1988, que pretendiam vedar a intervenção do Estado (e do Poder Judiciário) no direito de greve, acompanhados das repercussões, no plano internacional, da decisão do TST no dissídio coletivo dos petroleiros de 1995.

É hora de analisar o papel dos tribunais (e dos juízes) e do próprio sistema jurídico. O instrumental para tanto será, mais uma vez, a teoria dos sistemas.

Os tribunais são subsistemas de tipo organizacional do sistema jurídico - ou seja, são sistemas parciais. O que os distingue de todas as demais instituições do sistema é o imperativo de decidir, isto é, a proibição da denegação de justiça (non liquet). Essa regra - de dupla negação - tem várias consequências importantes. Entre elas, o reconhecimento de que os tribunais, sobretudo diante de hard cases, inventam o direito (naquelas hipóteses em que eles não podem simplesmente encontrá-lo). A necessidade de decidir é transformada em liberdade (decisória) - o que não quer dizer ausência de compromisso quanto ao direito vigente, ao texto jurídico. ${ }^{571}$ Esse é o ponto de partida para a construção do universo jurídico, do pensamento jurídico e da argumentação jurídica. Por isso, o direito deve compreender-se como um sistema fechado em si mesmo, onde se pode utilizar uma "argumentação puramente

\footnotetext{
${ }^{571}$ Niklas Luhmann chama isso de o "paradoxo da transformação da coerção em liberdade". Em suas palavras: "quem se vê coagido à decisão e, adicionalmente, à fundamentação de decisões, deve reivindicar para tal fim uma liberdade imprescindível de construção do direito. Somente por isso não existem 'lacunas no direito'. Somente por isso a função interpretativa não pode ser separada da função judicativa. E somente por isso o sistema jurídico pode reivindicar a competência universal para todos os problemas formulados no esquema 'direito ou não-direito"' (LUHMANN, Niklas. "A posição dos tribunais no sistema jurídico". In: Revista da Ajuris. N. 49. Porto Alegre: Ajuris, julho de 1990. Trad. de Peter Naumann, p. 163).
} 
jurídica" - de modo que importam apenas os valores do código (direito/não-direito) com relação ao que será julgado. ${ }^{572}$

Para explicar a posição dos tribunais no sistema jurídico, Niklas Luhmann recorre à distinção centro/periferia. Para o sociólogo alemão, os tribunais ocupam o centro do sistema, de maneira que todos os demais espaços de trabalho (vale dizer: comunicação jurídica) pertencem à periferia - como a conclusão de contratos ou a legislação. A periferia atua como zona de contato do sistema jurídico com os demais sistemas parciais da sociedade (economia e política, por exemplo). É na periferia que as irritações desses demais sistemas sociais são (ou não) formalizadas em termos jurídicos (isto é, traduzidas no código direito/não-direito). ${ }^{573} \mathrm{~A}$ autonomia do sistema é garantida, também na periferia, na medida em que ele não está obrigado a decidir (por essa razão, o sistema não opera como uma simples extensão, sem vontade, de operações que são externas ao direito). Os tribunais, por sua vez, trabalham sob um isolamento cognitivo mais acentuado, e é apenas no centro do sistema onde há coação à decisão. ${ }^{574}$

A atividade interpretativa, atribuída aos tribunais, consiste na "revisão" da consistência de decisões (operações) jurídicas. Trata-se de uma observação de segunda ordem, isto é, de observação de decisões jurídicas (por exemplo, contratos, leis, outras decisões judiciais) que, por sua vez, já observaram o direito. No caso dos tribunais, a especificidade da interpretação é o fato de que os tribunais o fazem em um sentido argumentativo, de maneira a demonstrar a racionalidade presente em sua própria decisão. ${ }^{575}$

Outra consequência importante da distinção centro/periferia diz respeito à operação voltada (ou não) à existência de um consenso. Na periferia do sistema, o consenso é necessário. De outra forma não seria possível a celebração de contratos ou a edição de leis.

\footnotetext{
572 Cf. LUHMANN, Niklas. El derecho de la sociedad, p. 367/381. Segundo Luhmann, a argumentação voltada às consequências - as quais, porém, não são passíveis de conhecimento porque se mostrarão apenas no futuro - é uma saída para a pressão à decisão. Além disso, diante da regra de proibição da denegação da justiça, não há como exigir dos tribunais uma lógica argumentativa que exclua regressos ad infinitum ou círculos viciosos e, também por essa razão, o recurso a determinados princípios é aceitável.

573 O pertencimento de uma operação a um ou outro sistema social é definido em termos comunicativos - até porque a sociedade é constituída de comunicação. Assim, se determinada comunicação é voltada ao código direito/não-direito, será uma operação do sistema jurídico; se tiver por base o código poder/não-poder, pertencerá ao sistema político, e assim por diante. Por isso, na teoria da diferenciação social, a legislação ocupa um lugar - na periferia, é verdade - do sistema jurídico: na medida em que uma lei define um direito (ou um não-direito), essa operação, i.e., essa comunicação passa a pertencer ao sistema jurídico. Ver, a respeito, LUHMANN, Niklas. Sociologia do Direito. Vol. I; LUHMANN, Niklas. La sociedad de la sociedad; LUHMANN, Niklas. "El derecho como sistema social". In: No Hay Derecho. Ano V, no 11. Buenos Aires: Agosto - Outubro de 1994 (Trad. de Paulo Sávio Peixoto Maia, para fins acadêmicos); PAIXÃO, Cristiano. Modernidade, Tempo e Direito; e CAMPILONGO, Celso. Política, sistema jurídico e decisão judicial, p. 75/84. 574 Os procedimentos probatórios - construídos pelo próprio sistema - exemplificam esse isolamento. Cf. LUHMANN, Niklas. El derecho de la sociedad, p. 382/384.
}

${ }^{575}$ LUHMANN, Niklas. El derecho de la sociedad, p. 389. 
No centro do sistema, é diferente. Os tribunais, pressionados pelo dever de decidir, não podem depender, de forma simultânea, do consenso. Mas não é raro identificar decisões judiciais que recorrem a palavras supostamente consensuais. Para citar exemplos aqui já vistos, cumprem esse papel expressões como "interesse social", "segurança nacional", "proteção da lei e da ordem”. O consenso, nesse caso, é criado pela própria decisão judicial. De acordo com Luhmann, "as fórmulas de consenso que os tribunais utilizam (aspirações morais do povo, sensibilidade dos homens mais justos e equitativos) parecem insípidas e rançosas, além do que, no processo, já não se examinam, senão que se comportam como ficção jurídica". 576

As observações feitas na presente investigação constituem indícios de que, após a Constituição de 1988, houve uma expansão - ou, pelo menos, uma diversificação - da atuação do Poder Judiciário nos conflitos trabalhistas, em especial no exercício do direito de greve. Diante dessa postura dos tribunais, sobretudo do Tribunal Superior do Trabalho, vem a indagação sobre a existência de um governo dos juízes.

Num plano mais geral, que extrapola o campo dos conflitos trabalhistas, essa problemática é examinada por Celso Campilongo justamente a partir da teoria dos sistemas. $\mathrm{O}$ autor, ao investigar os limites e as possibilidades do governo representativo, lança a pergunta sobre se o Poder Judiciário estaria se convertendo em espaço privilegiado de recepção de temas próprios da política, substituindo, assim, as instituições representativas. E, diante disso, se a expansão global do poder dos tribunais estaria conduzindo a um governo dos juízes. Campilongo pretende, em face dessas questões, analisar a adequação e a capacidade operativa dos tribunais - e também do sistema jurídico - quanto aos ruídos oriundos do ambiente político. ${ }^{577}$ Para tanto, faz importantes observações - pertinentes para esta investigação sobre as funções de ambos os sistemas parciais. Em suas palavras:

a função do sistema político - tomar decisões coletivas - não se confunde com a do sistema jurídico - garantir direitos. Apesar dessa diferenciação, o sistema político fornece ao sistema jurídico prestações fundamentais, vale dizer, as premissas decisórias (leis) e o reforço da eficácia das decisões

\footnotetext{
${ }^{576}$ LUHMANN, Niklas. El derecho de la sociedad, p. 385. É importante esclarecer que a distinção entre centro e periferia não significa diversidade de posição ou relevância social. Como explica Luhmann, "a diferença de periferia e centro não implica nenhuma diferença de ordem hierárquica ou de importância para a continuação da autopoiesis do sistema. Muito pelo contrário, a diferença é uma forma de dois lados, que demarca a separação desses dois lados e que pode estruturar o próprio sistema apenas como unidade da diferença. Sem periferia não haveria nenhum centro, sem centro não haveria periferia" (LUHMANN, Niklas. "A posição dos tribunais no sistema jurídico", p. 164). Além disso, a distinção centro/periferia também se faz presente em outros sistemas sociais, como a economia e a política. Cf. LUHMANN, Niklas. El derecho de la sociedad, p. 395/399.

577 CAMPILONGO, Celso. "Governo representativo 'versus' governo dos juízes: a 'autopoiese' dos sistemas político e jurídico”. In: O direito na sociedade complexa. São Paulo: Max Limonad, 2000, pp. 79/87.
} 
jurídicas (polícia, prisões, enfim, os meios coercitivos). Igualmente relevantes são as prestações dadas em sentido inverso, isto é, do sistema jurídico ao sistema político, na forma de legitimação das decisões políticas (aplicação das leis) e de oferecimento das premissas para o uso da violência (regulação jurídica do monopólio estatal da força). Por isso, apesar de paradoxal, quanto maior a independência de um sistema maior também a dependência em relação ao outro. ${ }^{578}$

A sociedade mundial é marcada por elevados graus de complexidade e contingência. Complexidade corresponde a excesso de possibilidades, e, contingência, a risco de desapontamento. ${ }^{579}$ A sociedade atual é caracterizada pela inevitabilidade dos riscos. A política reflete isso. ${ }^{580} \mathrm{O}$ processo decisório desse sistema - voltado à produção de decisões coletivamente vinculantes - opera com incertezas (contingência) e riscos (decorrentes de uma eleição, por exemplo). É nesse contexto, segundo Celso Campilongo, que o Poder Judiciário tende a rever os temas da política. A suposição é a de que os tribunais estariam livres dos ônus do processo eleitoral, das contingências que perpassam a dinâmica política e manteriam mais distância dos conflitos, de maneira que contariam com um ambiente de serenidade e, embora não eliminem as incertezas do processo de decisão (que vai oscilar entre direito e não-direito), estariam em condições de manter os riscos dentro de limites toleráveis. ${ }^{581}$

Mas, indaga Campilongo, o sistema do direito estaria apto a atuar como substituto funcional do sistema da política?

A função do sistema político, como já se adiantou, é tomar decisões coletivamente vinculantes. Essa função é exercida pelo uso do poder. Como os demais subsistemas sociais, a política opera (comunicativamente) a partir de um código próprio: poder/não-poder. O centro desse sistema é construído de forma hierárquica, cindido pelo dual governo/oposição. A referência a esses binômios permite a atribuição da operação/comunicação ao sistema político. A comunicação do sistema é preservada a partir da constante variação, seleção e estabilização de decisões coletivamente vinculantes. Um mecanismo básico para a operação

${ }^{578}$ CAMPILONGO, Celso. "Governo representativo 'versus' governo dos juízes: a 'autopoiese' dos sistemas político e jurídico", p. 82.

579 Como explica Niklas Luhmann, “(...) o mundo apresenta ao homem uma multiplicidade de possíveis experiências e ações, em contraposição ao seu limitado potencial em termos de percepção, assimilação de informação, e ação atual e consciente. Cada experiência concreta apresenta um conteúdo evidente que remete a outras possibilidades que são ao mesmo tempo complexas e contingentes. Com complexidade queremos dizer que sempre existem mais possibilidades do que se pode realizar. Por contingência entendemos o fato de que as possibilidades apontadas para as demais experiências poderiam ser diferentes das esperadas; (...) em termos práticos, complexidade significa seleção forçada, e contingência significa perigo de desapontamento e necessidade de assumir-se riscos" (LUHMANN, Niklas. Sociologia do direito, vol. 1, p. 45/46).

580 Até porque cada operação do sistema parcial reproduz o próprio sistema e também a sociedade. Ver LUHMANN, Niklas. "El derecho como sistema social".

${ }_{581}$ CAMPILONGO, Celso. "Governo representativo 'versus' governo dos juízes: a 'autopoiese' dos sistemas político e jurídico", p. 84. 
do sistema, a partir desses códigos, são as eleições, por exemplo. E as decisões do sistema são ativadas a partir de programas teleológicos, isto é, voltados para determinados fins (como os programas políticos ou as propostas de governo). ${ }^{582}$

O sistema político também opera fechado em termos operacionais, como condição para a multiplicação da sua complexidade interna. O binômio governo/oposição e os elementos formais de democracia (como garantias da minoria, autolimitação do poder e alternância entre governo e oposição) permitem o contínuo incremento da complexidade do sistema (ou seja, possibilidades de escolha) e o permanente tratamento da contingência. ${ }^{583}$ Por isso se pode dizer que democracia corresponde à manutenção da complexidade, i.e., abertura das possibilidades decisórias, possibilidade de tomada de decisões que vão conduzir a novas alternativas e novas demandas de decisões. ${ }^{584}$ Vai ficando clara, assim, a estreita correlação entre política e democracia. ${ }^{585}$

A política também replica a diferença centro/periferia. O centro do sistema é ocupado pelo Estado, mas não se trata de um centro condutor da política, mas, sim, de uma diferenciação organizativa. É no centro onde são tomadas as decisões coletivamente vinculantes. Na periferia do sistema, entretanto, operam organizações com base em um grau de complexidade mais elevado. São essas organizações - v.g., os partidos - que preparam e enviam as decisões para o centro do sistema. ${ }^{586}$

O desafio do Estado é justamente a adequação (ou inadequação) dos meios disponíveis para a implementação de decisões coletivamente vinculantes. A expansão da política (e do Estado) pode conduzir a que o sistema ignore os limites que decorrem dos códigos externos ao próprio sistema, como o direito e a economia. Com isso, a política passa

\footnotetext{
${ }^{582}$ Ver CAMPILONGO, Celso. Política, sistema jurídico e decisão judicial, p. 71/72.

${ }^{583}$ Cf. CAMPILONGO, Celso. Política, sistema jurídico e decisão judicial, p. 71/72.

${ }^{584}$ Raffaele De Giorgi identifica dois pressupostos para uma prática democrática concreta, quais sejam, a completa positivação do sistema do direito e a universalização dos meios de comunicação de massa, e observa que, "na nossa sociedade, as possibilidades são maiores do que em qualquer outra: democracia é a contínua multiplicação de possibilidades decisórias, com base no pressuposto da diferenciação que caracteriza a sociedade moderna. Democracia é a capacidade de resistências às pressões ambientais que se opõem à plena diferenciação dos sistemas sociais" (DE GIORGI, Raffaele. "Democracia, parlamento e opinião pública". Direito, Democracia e Risco - vínculos com o futuro. Porto Alegre: Sérgio Antonio Fabris Editor, 1998, pp. 35/47 - p. 42).

${ }^{585}$ Segundo Celso Campilongo, "a democracia é o pressuposto para a manutenção da complexidade, visto que continuamente reproduz as possibilidades de escolha, garante a reversibilidade das decisões e está sempre aberta à renovação dos temas. À democracia compete elaborar a complexidade do sistema político. Essa complexidade, por sua vez, é produzida pela indeterminação estrutural própria dos sistemas diferenciados. Governar a complexidade significa selecionar e escolher entre alternativas. Isso produz decepções. Quanto maior o número de opções, maior também a quantidade de propostas discriminadas no momento da decisão" (CAMPILONGO, Celso. Política, sistema jurídico e decisão judicial, p. 73).

${ }^{586}$ Assim, "na periferia a tematização política das pretensões é mais intensa e o incremento das possibilidades de escolhas mais veloz; no centro estão os mecanismos seletivos e de autocontrole dessas pretensões" (CAMPILONGO, Celso. Política, sistema jurídico e decisão judicial, p. 74).
} 
a demandar desses outros sistemas prestações para as quais eles não são estruturalmente adequados - um exemplo seria a demanda política por atuação do Poder Judiciário na implementação de determinada proposta de gestão econômica, para pensar no caso da greve de 1995 e do papel exercido pelo Tribunal Superior do Trabalho. ${ }^{587}$ Para Campilongo, “desconhecendo ou não conferindo a devida importância a seus limites estruturais, isto é, incapaz de se auto-observar, o sistema político perde o controle sobre suas operações e passa a pedir e oferecer aos demais subsistemas prestações impossíveis de serem satisfeitas". ${ }^{588}$

O sistema jurídico, por sua vez, opera a partir do código direito/não-direito. O fechamento operativo se dá em torno dessa distinção. As decisões são tomadas a partir de programas normativos (como exemplifica Celso Campilongo: precedentes, leis e contratos, regulamentos e a própria jurisprudência). ${ }^{589}$ Tal como os demais sistemas autopoiéticos (ou seja, que se reproduzem a partir de suas próprias operações), também no caso do direito o fechamento operacional é condição para sua abertura cognitiva, de maneira que o sistema pode conectar referências internas com referências externas. Isso se dá por meio da distinção entre expectativas cognitivas e expectativas normativas, ou, em outros termos, na diferença entre fatos e normas. Combinando esses elementos, o sistema aloca os valores direito e nãodireito, identificando as expectativas protegidas das não protegidas pelo direito. ${ }^{590}$

\footnotetext{
${ }^{587}$ Esse expansionismo do sistema político foi um dos problemas que conduziram à chamada crise do Estado de Bem-Estar Social. Ver LUHMANN, Niklas. Teoría Política en el Estado de Bienestar; HABERMAS, Jürgen. Direito e Democracia - entre facticidade e validade. Vol. II. Trad. de Flávio Beno Siebeneichler. Rio de Janeiro: Tempo Brasileiro, 1997; e PAIXÃO, Cristiano. "Os problemas de legitimação no capitalismo tardio e a crise do Estado do Bem-Estar Social. In: SOUSA JUNIOR, José Geraldo (Org.). Na Fronteira: Conhecimento e Práticas Jurídicas para a Solidariedade Emancipatória. Porto Alegre: Síntese, 2003.

${ }^{588}$ CAMPILONGO, Celso. Política, sistema jurídico e decisão judicial, p. 75. Vale conferir, nesse sentido, as observações de Francisco Oliveira sobre o governo Fernando Henrique Cardoso, no Brasil. Segundo aquele autor, a lógica implícita desse governo não seria antiestatista, como prega o neoliberalismo, mas a imposição autoritária da vontade do Executivo sobre as demais formas de representação política e sobre a própria sociedade civil. Em suas palavras, "toda a ideologia antiestatizante, neoliberalizante do governo FHC (...) é fraca para esconder, na verdade, uma intervenção total e desapiedada sobre a sociedade. (...) Dá-se, assim, o primado da política sobre todas as outras esferas, o que constitui um dos traços mais autoritários do capitalismo contemporâneo. (...) Essa tendência revela-se na supremacia de uma política antipolítica, que se resume ao império do Executivo sobre o Legislativo e mesmo sobre o Judiciário (...)" (OLIVEIRA, Francisco de. "A derrota da vitória: a contradição do absolutismo de FHC". In: Novos Estudos CEBRAP, n. 50, março de 1998, pp. 13-21 (p. 16)

${ }^{589}$ Esses programas normativos podem ser alterados. Uma das características do direito positivo, na sociedade moderna, é exatamente sua variabilidade (o não-direito pode se tornar direito e vice-versa). Por isso, segundo Luhmann, a vigência do direito, antes de ser uma simples emanação de uma ordem suprema, como propunha Hans Kelsen, é um símbolo que circula no sistema. Ver LUHMANN, Niklas. "A posição dos tribunais no sistema jurídico", p. 164, nota 32.

${ }^{590}$ Em razão disso, como explica Campilongo, "Justiça (...) não seria a pura correspondência entre a decisão e os interesses externos, mas sim a consistência das operações internas que reconhecem e qualificam os interesses como protegidos ou repelidos pelo direito" (CAMPILONGO, Celso. Política, sistema jurídico e decisão judicial p. 78). Para uma interessante análise dos conceitos de justiça em Luhmann e Jacques Derrida, cf. TEUBNER, Gunther. "Self-subversive Justice: Contingency or Transcendence Formula of Law?". In: Modern Law Review, $\mathrm{n}^{\circ} 72,2009$, pp. 1-23).
} 
É possível começar a identificar, então, os limites do sistema jurídico. $\mathrm{Na}$ observação de Celso Campilongo:

\begin{abstract}
Sua tarefa [do direito] é a de garantir e manter expectativas quanto aos interesses tutelados pelo direito e oferecer respostas, claras e justificadas, no caso de conflito. Daí a definição luhmanniana de direito como 'generalização congruente de expectativas normativas'. Com base em expectativas normativas estabilizadas, os programas do sistema jurídico implementam o valor do código do direito (lícito/ilícito). É assim que o sistema jurídico decide quem tem razão à luz do próprio direito. Dentro desses limites, a forma fundamental do direito é a de um programa condicional respaldado pela força física. Evidentemente, esse programa pode ter conotações morais (conceitos como "boa fé" e "moralidade administrativa") ou preocupações teleológicas (direito do planejamento e demais estratégicas promocionais que fixam o direito como o meio para atingir um fim). Mas isso não significa que o sistema jurídico possa estabelecer qualquer relação de causalidade com a moral e com seus fins políticos. Essas são questões que dependem de outros fatores. A referência jurídica é sempre normativa. É por meio do código direito/não-direito e de seus programas normativos que o sistema pode combinar referências externas e internas. ${ }^{591}$
\end{abstract}

A partir dessas descrições se percebe que as funções dos sistemas são infungíveis, isto é, não são intercambiáveis. ${ }^{592}$ Direito e política estão estruturados de maneira distinta para o tratamento da complexidade presente no ambiente do sistema. A seletividade do direito e da política é diferente. Não é por acaso que o sistema político, que opera de maneira inclusiva (a partir da pretensa incorporação dos cidadãos nas prestações realizadas pelos sistemas funcionais ${ }^{593}$ ), lida com problemas relacionados à justiça distributiva, enquanto o sistema jurídico, com um rigor seletivo mais acentuado, opera com questões pertinentes a justiça corretiva ou procedimental (voltado à forma de obtenção da decisão). ${ }^{594}$

$\mathrm{Na}$ sociedade moderna, caracterizada pela existência de sistemas funcionalmente diferenciados, o sistema político adquire uma estrutura tridimensional, formada por política, administração e público. A comunicação torna-se circular e autorreferente: "o público

${ }^{591}$ CAMPILONGO, Celso. Política, sistema jurídico e decisão judicial, p. 78/79. De acordo com o próprio Niklas Luhmann, "processar expectativas requer um código binário que contém um valor positivo (direito) e um valor negativo (não-direito) e que exclui artificialmente tanto as contradições (o direito não é direito, o que não é direito é direito), como outros valores (utilidade, conveniência política, etc.). Esta codificação tem decisiva importância para a diferenciação do sistema do direito, já que propicia ao sistema sua própria forma de contingência constituída internamente. Tudo o que entra na esfera de relevância do direito é o que é direito ou não-direito e tudo o que não se encaixa neste código é tão-somente significativo apenas se for importante como questão preliminar em decisões acerca do direito e do não-direito" (LUHMANN, Niklas. "El derecho como sistema social", p. 19).

592 Essa infungibilidade de funções é uma característica dos sistemas funcionalmente diferenciados. Cada um exerce uma função com referência a um problema da sociedade. Cf. LUHMANN, Niklas, e DE GIORGI, Raffaele. Teoria della società, p. 303.

${ }^{593}$ Ver LUHMANN, Niklas. Teoría Política en el Estado de Bienestar, p. 48/49.

${ }^{594}$ Cf. CAMPILONGO, Celso. Política, sistema jurídico e decisão judicial, p. 90. 
influencia a política; a política limita a administração e o legislativo; a administração cria vínculos para si e para o público; o público reage a todo o processo. Enfim, uma circularidade de dupla direção, que admite e estimula a contracircularidade". 595

A política, se comparada com o direito, está mais adaptada, em termos estruturais, à produção de consenso. Esta é a regra do sistema: gerar “agregações majoritárias”. Já para o direito, as decisões judiciais, em regra, têm em vista a manutenção de expectativas normativas específicas. A política atua sob o pressuposto de um conjunto de comunicações sociais e de informações, de variabilidade de opiniões e referências cognitivas mais complexas do que o direito. O sistema jurídico, a seu turno, toma por base uma complexidade já reduzida pelo sistema político. ${ }^{596}$

Considerando o ponto de observação escolhido nesta pesquisa - ver os usos da Constituição e as disputas por seu sentido a partir do direito de greve -, em que termos se poderia falar em governo dos juízes? Na perspectiva de que há indícios de que a gestão - vale dizer, o governo - dos conflitos trabalhistas tem passado, antes de tudo, pelo Poder Judiciário, mais especificamente pela Justiça do Trabalho, ou seja, pelo sistema jurídico, e não pelo Estado (Executivo/Legislativo), isto é, o sistema político.

O exercício dessa gestão de conflitos trabalhistas é facilitado pelo próprio sistema jurídico. É significativa, a respeito, a interpretação (descrição) construída pelo TST após a Emenda Constitucional 45/2004 para preservar o exercício do poder normativo, transformando a greve em porta de entrada para a intervenção da Justiça do Trabalho naqueles conflitos. $^{597}$ Uma das consequências desse processo parece ser a apontada por Celso

595 Cf. CAMPILONGO, Celso. Política, sistema jurídico e decisão judicial, p. 90. Ver também LUHMANN, Niklas. Teoría Política en el Estado de Bienestar, p. 65/66.

${ }^{596}$ Cf. CAMPILONGO, Celso. Política, sistema jurídico e decisão judicial, p. 91.

${ }^{597}$ No final do ano de 2010, às vésperas do Natal (e do início do recesso forense - de 20 de dezembro a 6 de janeiro), veio a público a notícia da possibilidade de greve dos aeroviários e aeronautas do país. Diante disso, a Presidência do Tribunal Superior do Trabalho publicou a seguinte nota no sítio do tribunal na internet: "tendo em vista algumas consultas sobre a anunciada greve das categorias dos aeroviários e aeronautas, a Presidência do Tribunal Superior do Trabalho esclarece que se mantém à disposição para, se assim desejarem as partes envolvidas, adotar medidas que possam contribuir para a solução de eventual impasse, sem prejuízo dos entendimentos que vêm sendo mantidos" (disponível em http://www.tst.jus.br/busca-denoticias?p_p_id=buscanoticia_WAR_buscanoticiasportlet_INSTANCE_xI8Y\&p_p_lifecycle=0\&p_p_state=nor mal\&p_p_mode=view\&p_p_col_id=column-2\&p_p_col_count=2\%20\&advanced-search-

display=yes\%20\&articleId $=310199 \% 20 \&$ version $=1.0 \% 20 \&$ groupId $=10157 \% 20 \&$ entryClassPK=310201, acesso em 4.6.2014). No mesmo dia, à noite, o então Presidente da Corte, Min. Milton de Moura França, em decisão cautelar proferida em ação proposta pelo Ministério Público do Trabalho, determinou que fosse mantido em atividade $80 \%$ do efetivo dos aeronautas e aeroviários, sob pena de multa diária de $\mathrm{R} \$ 100.000,00$, "de forma a viabilizar o transporte aéreo em todo o território nacional, no período compreendido entre 23 de dezembro de 2010 e 2 de janeiro de 2011" (disponível em http://www.tst.jus.br/busca-denoticias?p_p_id=buscanoticia_WAR_buscanoticiasportlet_INSTANCE_xI8Y\&p_p_lifecycle=0\&p_p_state=nor mal\&p_p_mode=view\&p_p_col_id=column-2\&p_p_col_count=2\%20\&advanced-searchdisplay $=$ yes $\% 20 \&$ articleId $=310208 \% 20 \&$ version $=1.0 \% 20 \&$ groupId $=10157 \% 20 \&$ entryClassPK $=310210$, acesso 
Campilongo: "o Judiciário deixa de ser visto como o lugar de trivialização, banalização ou neutralização dos conflitos por meio de operações programadas e passa a ser encarado como uma importante arena de exposição, afirmação e condensação dos conflitos através de operações estratégicas". 598

A pressão à decisão força os tribunais a se apoiarem em um direito judicial que, não raras vezes, se fundamenta em ficções jurídicas que reinterpretam de forma equivocada a vontade - i.e., o consenso - em que se baseou a promulgação da Constituição ou de uma lei. Pense-se no exemplo do art. $9^{\circ}$ da Constituição de 1988 , ou do art. 114 , $\S 2^{\circ}$, com a redação dada pela Emenda Constitucional 45/2004. Na construção desse direito judicial, os tribunais criam o próprio interesse social que estariam a defender, e que não passa por qualquer prova empírica durante o procedimento judicial. ${ }^{599}$ Em termos de teoria dos sistemas, pode-se afirmar que, com isso, acabam entrando na construção dos programas decisórios elementos que são alheios ao código direito/não-direito. De acordo com Celso Campilongo,

ainda que a legislação seja vaga, contraditória, passível de várias interpretações ou omissa, o juiz está sempre obrigado a decidir os casos que se lhe apresentam com fundamento no ordenamento jurídico. Ora, esse procedimento ganha uma dimensão política ainda mais importante num contexto em que a Constituição incorpora um extenso elenco de direitos fundamentais. Apesar disso tudo, não é imaginável que o juiz possa decidir à margem de qualquer referência interna ao sistema jurídico. Da perspectiva do direito, elevadas taxas de independência e criatividade não podem representar a substituição das opções oferecidas pela Constituição por uma orientação qualquer - política, econômica, religiosa, etc. - advinda do ambiente externo ao sistema jurídico. Isso caracterizaria uma corrupção dos códigos do direito, ou seja, a utilização de meios de comunicação próprios de outros subsistemas (econômico, político, etc.) para resolver problemas do sistema jurídico. ${ }^{600}$

Se a decisão do TST na greve dos petroleiros de 1995 põe em evidência problemas pertinentes às relações entre direito e política, a diversificação da intervenção da Justiça do Trabalho e o seu papel de gestora dos conflitos trabalhistas trazem à tona, em especial, uma perspectiva de rejeição do próprio conflito social.

No caso do direito do trabalho, em particular, essa questão é relevante. O conflito é inerente, natural, às relações laborais. E ele é produzido tanto no plano individual quanto no coletivo. A dinâmica do conflito não permite, em regra, uma solução legislativa, e o recurso

em 4.6.2014).

${ }^{598}$ CAMPILONGO, Celso. Política, sistema jurídico e decisão judicial, p. 62.

${ }^{599}$ Essa observação também é válida no caso da utilização de expressões como "interesse da Nação", "proteção da ordem" ou "proteção da segurança nacional".

${ }^{600}$ CAMPILONGO, Celso. Política, sistema jurídico e decisão judicial, p. 61/62. 
ao Poder Judiciário é, no mínimo, complicado, na medida em que a solução da divergência demanda a criação (e não a mera aplicação) do direito. É por isso que, para o direito do trabalho, tem tanta importância a negociação coletiva, como mecanismo de autocomposição de conflitos. ${ }^{601}$

A Constituição de 1988 fornece importantes premissas nesse sentido, como, v.g., a garantia aos trabalhadores do direito ao reconhecimento das convenções e acordos coletivos (art. $7^{\circ}, \mathrm{XXVI)}$, a proibição de intervenção e interferência do Poder Público na organização sindical (art. $\left.8^{\circ}, \mathrm{I}\right)$, o reconhecimento de que cabe aos sindicatos a representação dos direitos e interesses da categoria $\left(\operatorname{art} .8^{\circ}, \mathrm{III}\right)$ e o direito de greve $\left(\operatorname{art} .9^{\circ}\right) .{ }^{602}$

O que se percebe na expansão da Justiça do Trabalho é uma suposta premência na solução dos conflitos laborais, que, segundo essa perspectiva, não podem (na verdade, são impedidos de) observar sua dinâmica própria, sobretudo em hipóteses de greve, mas devem, sim, ser resolvidos a partir da atuação do Poder Judiciário, que estaria - segundo uma ficção já examinada - respaldado pelo "interesse social". Essa forma de operação dos tribunais trabalhistas, em especial do Tribunal Superior do Trabalho, contém, entretanto, significativos elementos antidemocráticos.

Qual é o problema do conflito coletivo e de seu prolongamento? Por que o Judiciário deve intervir para resolvê-lo? Por que sua solução - talvez, sobretudo, nos casos de greve - não pode ficar a cargo dos próprios interessados? Subjacente à intervenção da Justiça do Trabalho, há uma negação do conflito social e, em última análise, da greve. Há importantes conotações morais aqui: o conflito (e também a greve) é visto como algo ruim e, portanto,

\footnotetext{
${ }^{601}$ Como observa Márcio Túlio Viana, os conflitos, no campo do trabalho, "estão no coração do sistema. Além disso, como afetam o grupo, tendem a se expressar coletivamente - o que também aumenta a sua eficácia. Em geral, quando coletivos, não buscam a aplicação, mas a (re) construção do Direito. Assim, em princípio, rejeitariam a solução pelo juiz, mas não a do legislador. O problema é que - aberto o conflito - o choque de interesses é tão presente, tão intenso e tão urgente que raras vezes há tempo para que o legislador intervenha; e a consequência, inusitada nos outros ramos jurídicos, é a sua substituição pelas partes, que criam, elas próprias, o Direito que lhes convém. Desaparece, assim, a mediação do Estado. Já não há uma separação entre os agentes que produzem a norma e aqueles que a consomem. Na mesma medida, dilui-se a distinção entre o fato que faz a norma nascer (fonte material) e o modo pelo qual esta se revela (fonte formal). Do mesmo modo que a crisálida traz em seu corpo o DNA da borboleta, o conflito carrega nas entranhas os elementos formadores do novo Direito: quando tudo corre bem, ele próprio - conflito - se transforma em convenção. Os mesmos trabalhadores que, ao se pôr em greve, dizem que 'a regra terá de ser esta!', se vitoriosos dirão, no ajuste com os patrões, que 'a regra, agora, é esta'. Naturalmente, também a reação patronal pode conter elementos da futura norma." (VIANA, Márcio Túlio. "Conflitos coletivos de trabalho". In: Revista do TST. Brasília, vol. 66, no 1, jan/mar de 2000, pp. $116 / 150$ - p. 118/119).

${ }^{602}$ Florestan Fernandes, a propósito, defende o caráter inovador do dispositivo da Constituição de 1988 que assegura o direito de greve, afirmando que "não se pode separar o dispositivo sobre a greve do conjunto de inovações institucionais que atravessaram o muro conservador da Assembleia Nacional Constituinte" (FERNANDES, Florestan. A Constituição inacabada, p. 337).
} 
como um mal que deve ser evitado, de preferência de maneira "célere". Nota-se o recurso a valores superiores, como "interesse social" e "bem comum".

Mas o código mal/bem é próprio do sistema moral e não se confunde com os códigos dos demais sistemas funcionais, em particular do direito e da política. ${ }^{603}$ Numa sociedade marcada por um elevado grau de complexidade, os consensos são cada vez mais improváveis, de maneira que os dissensos e, por conseguinte, os conflitos são legítimos. Daí porque os valores próprios do sistema moral não servem à reprodução do sistema jurídico (ou de qualquer outro subsistema social que não a própria moral), nem podem atuar como critério de fundamentação da democracia, ou, ainda, de preservação da "ordem jurídica". ${ }^{64}$ Isso significa que não deve ser moralmente preferível estar ao lado do governo (ao invés da oposição), ou, para o sistema jurídico em particular, que a constatação de um ilícito, ou seja, de um não-direito, deva evitar qualquer desqualificação no campo da moral. ${ }^{605}$

Como já ficou evidente nas observações acima, a sociedade moderna, de acordo com a teoria dos sistemas de Niklas Luhmann, é caracterizada pela diferenciação funcional, ou seja, a existência de sistemas especializados em funções (direito, política, economia, religião, moral, etc.). Cada subsistema social observa a si próprio e à sociedade a partir do tipo de comunicação que aplica em suas operações, ou seja, de acordo com o código que é específico a cada sistema de função. Uma sociedade assim estruturada não possui vértice, nem centro, e, por conseguinte, não pode ser dirigida por uma instância central, seja ela o direito (e os tribunais), a política ou a moral. ${ }^{606}$ Não há, portanto, "um lugar ou uma instância que

\footnotetext{
${ }^{603}$ Sobre o sistema moral e sua especialização comunicativa em torno do código mal/bem, ver LUHMANN, Niklas, e DE GIORGI, Raffaele. Teoria della società. p. 76/82.

604 Ao rejeitar as críticas à teoria luhmanniana que a acusam de antidemocrática, Celso Campilongo esclarece que: "duvidar da possibilidade do consenso - consenso esse no mínimo improvável nas sociedades altamente diferenciadas e complexas - significa reconhecer legitimidade ao dissenso. (...) Suspeitar de uma fundamentação moral da democracia - por exemplo, de uma justificação da democracia baseada nas noções de bem comum ou de paz - também não parece despropositado. Todos estão de acordo que o bem comum e a paz são valores agregadores. Eles têm a função de criar uma base para a comunicação. Num primeiro exame, não há como negar a 'bondade' desses valores e a 'maldade' da sua negação. O problema reside na especificação operacional e comunicativa desses valores. Para uns, o 'bem comum' pode significar a ampla participação na vida pública, para outros pode representar a não interferência na vida privada. A 'paz', para alguns, tem o sentido de desarmamento, para outros, diversamente, estar fortemente armado é a melhor garantia da 'paz'. Levados ao extremo, os valores morais bloqueiam a comunicação e geram intransigência. Não é desprezível a proximidade tão frequente e promíscua que se verifica entre moralismo e violência" (CAMPILONGO, Celso. Política, sistema jurídico e decisão judicial, p. 124/125).

${ }^{605}$ Ver LUHMANN, Niklas, e DE GIORGI, Raffaele. Teoria della società, p. 307.

606 Cf. LUHMANN, Niklas. "Globalization or world society: how to conceive of modern society?". In: International Review of Sociology of Law, março de 1997, vol. 7, item 1 (manuscrito), p. 11. Ainda segundo Luhmann, "a sociedade mundial alcançou um grau mais elevado de complexidade com contingências estruturais mais elevadas, mais mudanças inesperadas e imprevisíveis (algumas pessoas chamariam isso de 'caos') e, sobretudo, mais dependências e independências interligadas. Isso significa que construções causais (cálculos, planejamentos) não são mais possíveis a partir de um ponto de vista central e 'objetivo'. Eles diferem dependendo dos sistemas que observam, que atribuem efeitos a causas e causas a efeitos, e isso destrói as presunções
} 
represente completamente a sociedade". ${ }^{607}$ Inexiste qualquer hierarquia entre as funções dos subsistemas sociais - ou seja, não há um sistema que vincule todos os demais. ${ }^{608}$

Em tais condições, não há um observador (vale dizer, sistema) privilegiado na sociedade. Nenhum sistema conduz a sociedade. Toda observação implica fazer distinções (que, por sua vez, pressupõem um ponto cego). ${ }^{609} \mathrm{E}$ o resultado dessa operação é contingente, na medida em que poderia ser diverso, a depender do ponto de onde se faz a observação/distinção. $\mathrm{O}$ desafio é a adequada consideração dessa contingência, acompanhada do próprio pressuposto da diferenciação funcional. ${ }^{610}$ Por isso a utilização de supostos valores superiores é problemática. Como esclarece Niklas Luhmann:

os valores só podem descrever a sociedade bem mais complexa por meio de fórmulas extremas e, para tanto, se referem ao que na comunicação normal é presumivelmente inconteste, dado como pressuposto, mas que, precisamente por isso, não é tematizado. Também esse âmbito não questionado é um strange loop movido por um certo embaraço frente à justificação dos ideais supremos na trivialidade da comunicação cotidiana, na qual se pressupõe que paz, liberdade, igualdade, segurança, bem-estar para todos, etc., sejam indubitavelmente um bem. Isto é o que as pessoas querem sentir, aquilo em que os redatores dos programas dos partidos creem, slogans para as eleições políticas, para os discursos políticos, como também, de forma menos direta, para os comentários à Constituição. O que também pode ser verdadeiro, mas precisaria ser verificado. ${ }^{611}$

Ingeborg Maus examina essa questão da atuação dos tribunais a partir da utilização de valores superiores ou próprios da moral, notando que, pela utilização de pontos de vista morais e de valores em sua jurisprudência, a Justiça - i.e., o Poder Judiciário -

ontológicas e lógicas de uma direção central. Nós temos que viver com uma sociedade policêntrica e policontextural" (LUHMANN, Niklas. "Globalization or world society: how to conceive of modern society?", p. 12 - tradução livre).

${ }^{607}$ DE GIORGI, Raffaele. "Democracia, parlamento e opinião pública”. In: Direito, democracia e risco, p. 41.

${ }^{608}$ Ver LUHMANN, Niklas, e DE GIORGI, Raffaele. Teoria della società, p. 304.

${ }^{609} \mathrm{O}$ sistema do direito, por exemplo, observa a realidade a partir de operações que distinguem entre direito e não-direito. Entretanto, o observador não pode ver as distinções que ele mesmo utiliza para observar. Para o direito, isso quer dizer que o sistema, a cada operação, não pode indagar se a distinção entre direito e não-direito é ou não direito. Nas palavras de Celso Campilongo, "esse é o seu ponto de partida ou sua estrutura latente, diria Luhmann. De modo paradoxal: o ponto cego não vê que não vê essa distinção" (CAMPILONGO, Celso. “"Aos que não vêem que não vêem aquilo que não vêem': sobre fantasmas vivos e a observação do direito como sistema diferenciado". In: DE GIORGI, Raffaele. Direito, Tempo e Memória - Apresentação. Trad. de Guilherme Leite Gonçalves. São Paulo: Quartier Latin, 2006, pp. 11/26 - p.18/19.

${ }^{610}$ Luhmann afirma que "a teoria da sociedade, seja ela verdadeira ou falsa, e isso não tem importância aqui, contribui para a autodescrição da sociedade. Ela [a teoria] é comunicada no interior da sociedade para conceber uma descrição da sociedade, incluindo a descrição da descrição. Ela se refere a seu objeto mas também a si mesma como parte de seu objeto - como um subsistema de um subsistema da sociedade. Qualquer comunicação sobre a sociedade é uma operação autológica" (LUHMANN, Niklas. "Globalization or world society: how to conceive of modern society?", p. 14 - tradução livre)

${ }^{611}$ LUHMANN, Niklas. La costituzione come acquisizione evolutiva", p. 126. 
adquire maior legitimação e imuniza suas decisões contra críticas. A referência a princípios "superiores" ao direito escrito (como "interesse social", no caso aqui analisado) acarreta uma suspensão das normas individuais e guia a decisão do caso concreto de maneira inusitada. ${ }^{612}$

A expectativa de que a Justiça atue como instância moral se apresenta também na estrutura legal (conceitos como "má-fé”, "sem consciência”, “censurável”) e na confiança popular. ${ }^{613}$ Em caso de conflitos sociais, a Justiça desponta "como uma instituição que, sob a perspectiva de um terceiro neutro, auxilia as partes envolvidas em conflitos de interesses e situações concretas, por meio de uma decisão objetiva, imparcial e, portanto, justa". 614

Ainda para Ingeborg Maus, a ascensão da Justiça, como instância superior de consciência da sociedade, é acompanhada, em certos ramos do Judiciário, por uma aplicação do direito que não apenas corrige as leis - "em seus momentos ilusórios" - como as inverte. As leis são encaradas como meras previsões e premissas de decisão, sendo desprezadas suas densidades regulatórias. Por outro lado, a partir do momento em que os tribunais juridicizam suas próprias concepções morais, transformando-as em regras jurídicas, o enfrentamento e o debate público de determinadas questões são suprimidos, evitando sua problematização social. Em outras palavras:

Somente quando a jurisprudência trata seus próprios pontos de vista morais como regras jurídicas é que qualquer fato imaginável pode ser identificado como juridicamente relevante e transformado em matéria de decisão judicial. Com isso o poder de sanção do Estado expande-se, vindo de encontro a exigências que, de acordo com o entendimento clássico do Estado de direito, somente valiam como exigências morais, ficando legadas à problematização social imanente. ${ }^{615}$

\footnotetext{
${ }^{612}$ Segundo a autora: "assim, enriquecido por pontos de vista morais, o âmbito das "proibições" legais pode ser arbitrariamente estendido ao campo extrajurídico das esferas de liberdade. Somente a posteriori, por ocasião de um processo legal, é que o cidadão experimenta o que lhe foi "proibido", aprendendo a deduzir para o futuro o "permitido" (extremamente incerto) a partir das decisões dos tribunais. Os espaços de liberdade anteriores dos indivíduos se transformam então em produtos de decisão judicial fixados caso a caso" (MAUS, Ingeborg. "Judiciário como superego da sociedade - o papel da atividade jurisdicional na 'sociedade órfâ"'. In: Novos estudos, Trad. de Martonio Lima e Paulo Albuquerque. N. 58, novembro de 2000, pp. 183/202 (p. 189/190). Essa forma de operar do sistema jurídico, gravado por incertezas, também é apontado por Luhmann. Ver LUHMANN, Niklas. La costituzione come acquisizione evolutiva", p. 127.

${ }^{613}$ A imprensa certamente desempenha um importante papel nesse ponto. Na greve dos Petroleiros de 1995, várias notícias de jornais foram juntadas ao processo. Além disso, como visto no capítulo 2, as notícias veiculadas pela imprensa serviram à construção de um suposto consenso quanto à necessidade de repressão aos grevistas. Ver capítulo 2 supra.

${ }^{614}$ MAUS, Ingeborg. "Judiciário como superego da sociedade - o papel da atividade jurisdicional na 'sociedade órfâ"', p. 190. Merece ser lembrada a opinião, apresentada no item 3.1., de Ives Gandra da Silva Martins, que confia na "integridade moral e nos profundos conhecimentos" dos membros do Poder Judiciário para que a Constituição seja interpretada de maneira a permitir a estabilização das instituições e afastar os riscos de "convulsões" decorrentes do "debate emocional".

${ }^{615}$ MAUS, Ingeborg. "Judiciário como superego da sociedade - o papel da atividade jurisdicional na 'sociedade órfâ"', p. 201.
} 
As práticas e os discursos até aqui analisados - intervenção da Justiça do Trabalho com declaração de abusividade de paralisações e aplicação de multas, utilização de interditos proibitórios, necessidade de atuação da Justiça Especialização para pôr fim ao conflito contém a perspectiva da greve como algo indesejado, que deve ser evitado. A partir do material colhido na presente investigação, é cabível propor uma releitura do direito de greve, na tentativa de contribuir para a construção de um discurso constitucional sobre esse direito. É o objetivo do próximo tópico.

\subsection{O direito de greve como abertura a possibilidades comunicativas}

A Constituição de 1988 reconhece o direito de greve com uma redação inédita na história do país. Talvez o aspecto mais marcante do texto constitucional seja o fato de que não há definição do que seja a greve. Não há sequer a associação - bastante comum - da greve com a ideia de paralisação do trabalho. A principal qualidade do art. $9^{\circ}$ da Constituição parece ser o caráter procedimental com que o direito é assegurado: compete aos trabalhadores decidir quando deflagrar a greve e quais interesses serão por meio dela defendidos. O texto se volta à garantia do procedimento de exercício do direito, cuja condução compete aos trabalhadores. ${ }^{616}$

Pouco tempo após a promulgação da Constituição, o governo federal procurou regulamentar o direito de greve. ${ }^{617}$ Em 27 de abril de 1989, foi editada, pelo então Presidente

${ }^{616}$ Cf. PAIXÃO, Cristiano, LOURENÇO FILHO, Ricardo. "Greve como prática social: possibilidades de reconstrução do conceito a partir da Constituição de 1988". In: SENA, Adriana Goulart de, DELGADO, Gabriela Neves, e NUNES, Raquel Portugal. Dignidade humana e inclusão social: caminhos para a efetividade do direito do trabalho no Brasil. São Paulo: LTr, 2010.

${ }^{617}$ Essa proximidade entre um momento de ruptura ou inovação nos âmbitos do direito e da política e uma nova regulamentação do direito de greve não foi inédita na história brasileira. Como se sabe, o golpe militar de 1964 ocorreu da noite do dia 31 de março para o dia $1^{\circ}$ de abril daquele ano. Em $1^{\circ}$ de junho de 1964 entrou em vigor uma nova lei de greve, a de $\mathrm{n}^{\circ} 4.330$, que resultou da aprovação, no Congresso Nacional, do projeto de lei 1471 de 1948. No dia 17 de abril de 1964 - após a tomada do poder pelos militares -, o deputado Martins Rodrigues, do PSD (que apoiava o golpe militar), proferiu discurso em que leu nota sobre o programa do partido acerca de sua atuação no Congresso. A nota reafirmava "a posição essencial do PSD favorável à necessidade de serem efetuadas reformas e tomadas medidas que visem dar ao Brasil os instrumentos jurídicos e constitucionais indispensáveis ao seu desenvolvimento e ao bem estar do seu povo (...)". Entre os pontos apresentados no roteiro de atuação do partido, constava um pertinente à lei de greve, em que se defendia a importância de aprovação do projeto de lei 1471 de 1948, considerando o parecer apresentado pelo então deputado, Ulysses Guimarães, relator da matéria na Câmara. A nota, nesse ponto, declarava que: "a difícil complementação do art. 158 da Constituição que reconhece o direito de greve tem a participação proeminente de dois parlamentares pessedistas o Senador Jefferson Aguiar autor do Substitutivo aprovado no Senado, e o deputado Ulysses Guimarães, relator da matéria na Câmara dos Deputados. O parecer Ulysses Guimarães situa o remédio da cessação coletiva de trabalho em sua exata perspectiva social de recurso extremo para obtenção de melhoria salarial e de condições de trabalho, incompatível com pressupostos meramente políticos ou de solidariedade, garante aos sindicalistas correta e democrática manifestação de vontade nas assembléias, através de voto secreto e fixação de 'quorum' mínimo para deliberação; [ilegível] o desrespeito à proteção da Lei Magna a propriedade e ao trabalho como 
da República, José Sarney, a Medida Provisória nº 50. A evidenciar seu caráter restritivo, em comparação ao texto constitucional, o art. $1^{\circ}$ da medida provisória estabelecia que "a greve é um direito dos trabalhadores, a quem compete decidir sobre a oportunidade de seu exercício e definir, relativamente aos direitos sociais, os interesses a defender por meio dele". ${ }^{618}$ A redação objetivava a limitação da possibilidade de greves que não tivessem conotações diretamente econômicas ou profissionais.

Após uma reedição, aquela medida provisória foi convertida na Lei 7.783, de 28 de junho de 1989, até agora vigente. Houve significativa modificação no texto. $\mathrm{O}$ art. $1^{\circ}$ da lei preceitua que "é assegurado o direito de greve, competindo aos trabalhadores decidir sobre a oportunidade de exercê-lo e sobre os interesses que devam por meio dele defender". Há uma repetição do art. $9^{\circ}$ da Constituição. Entretanto, o parágrafo único do dispositivo prevê que "o direito de greve será exercido na forma estabelecida nesta Lei”. Abre-se o caminho para a restrição do direito. Em seguida, o art. $2^{\circ}$ conceitua a greve: "para os fins desta Lei, considerase legítimo exercício do direito de greve a suspensão coletiva, temporária e pacífica, total ou parcial, de prestação pessoal de serviços a empregador". 619

O exame do conjunto da Lei 7.783/1989 indica que a finalidade do legislador foi a de disciplinar, isto é, limitar o direito de greve. Ainda que sejam previstos direitos aos grevistas - como a livre divulgação do movimento (art. $6^{\circ}$, I) ou a proibição de rescisão contratual, por parte do empregador, durante a greve (art. $7^{\circ}$, parágrafo único) - o caráter da lei é o de condicionamento do exercício do direito. A preocupação é, antes de tudo, estabelecer restrições. Não bastasse a enumeração das diversas obrigações impostas aos trabalhadores - como a condução da greve pelo sindicato e a necessidade de prévia comunicação ao empregador -, o art. 14 encerra dispondo que "constitui abuso do direito de greve a inobservância das normas contidas na presente Lei (...)". ${ }^{620}$

A tentativa inicial do governo federal de evitar greves que não estivessem diretamente relacionadas a questões econômicas ou profissionais, ou seja, que veiculassem reivindicações políticas, encontrou respaldo na jurisprudência trabalhista, em especial do

'obrigação social', que nenhum brasileiro, por meios violentos, poderá ser obstado de prestar" (BRASIL. Diário do Congresso Nacional. Seção I, de 18 de abril de 1964, p. 2451/2452 - sic).

${ }^{618}$ BRASIL. Medida Provisória n ${ }^{\circ}$ 50, de 27 de abril de 1989. Dispõe sobre o exercício do direito de greve, define as atividades essenciais, regula o atendimento das necessidades inadiáveis da comunidade, e dá outras providências. Diário Oficial da União, Brasília, DF, 28.4.1989 - destaque acrescentado. A Medida Provisória 50 foi reeditada pela de $\mathrm{n}^{\circ} 59$, também de 1989 , sem alteração de texto.

${ }^{619}$ BRASIL. Lei $n^{\circ} 7.783$, de 28 de junho de 1989. Dispõe sobre o exercício do direito de greve, define as atividades essenciais, regula o atendimento das necessidades inadiáveis da comunidade, e dá outras providências. ${ }^{620}$ BRASIL. Lei $\mathrm{n}^{\circ} 7.783$, de 28 de junho de 1989. Dispõe sobre o exercício do direito de greve, define as atividades essenciais, regula o atendimento das necessidades inadiáveis da comunidade, e dá outras providências. 
Tribunal Superior do Trabalho. A Corte possui inúmeros precedentes que apontam a greve política como contrária à ordem constitucional e legal. Entre os mais significativos está a própria decisão na greve dos petroleiros de $1995 .{ }^{621}$

Tudo isso acompanha os discursos e as posturas examinadas anteriormente, como a suposta "necessidade" de intervenção da Justiça do Trabalho, as declarações de abusividade, a imposição de multas, etc.

O objetivo deste tópico será, então, o de apresentar uma outra leitura possível sobre a greve, tomando por pressuposto a importância de construção de um discurso constitucional sobre esse direito. Leitura possível porque, como já se afirmou, observar implica fazer distinções, e o observador mesmo não vê as próprias distinções que utiliza para observar (do contrário incorreria num paradoxo). Por isso, para dizer com Celso Campilongo, é importante "ver que não vemos aquilo que não vemos". 622

${ }^{621}$ Cf. capítulo 2, supra. Vale transcrever também as seguintes ementas do TST: "NA GREVE DOS PORTUARIOS O SYNDARMA E PARTE LEGITIMA PARA AJUIZAR O DISSIDIO. GREVE ABUSIVA POR TER SIDO DECRETADA CONTRA A ORIENTAÇÃO QUE VINHA SENDO DISCUTIDA NO CONGRESSO NACIONAL PARA PRIVATIZAÇÃO OU REGULAMENTAÇÃO DOS PORTOS. NA GREVE PORTUARIA HA DE SER RESPEITADO O FUNCIONAMENTO DOS SETORES QUE GARANTAM O ABASTECIMENTO. GREVE DECLARADA ABUSIVA." (BRASIL. Tribunal Superior do Trabalho. Seção Especialização em Dissídios Coletivos. Recurso Ordinário em Dissídio Coletivo no 52547/1992. Relator Ministro Marcelo Pimentel. Diário de Justiça, Brasília, DF, 20.11.1992); "a greve política não é um meio de ação direta da classe trabalhadora em benefício de seus interesses profissionais, e, portanto, não está compreendida dentro do conceito de greve trabalhista. Entende-se por greve política, em sentido amplo, a dirigida contra os poderes públicos para conseguir determinadas reivindicações não suscetíveis de negociação coletiva. Recurso Ordinário Obreiro parcialmente provido." (BRASIL. Tribunal Superior do Trabalho. Seção Especializada em Dissídios Coletivos. Recurso Ordinário em Dissídio Coletivo no 454136-20.1998.5.01.5555. Relator Ministro Valdir Righetto. Diário de Justiça, Brasília, DF, 6.8.1999); “A greve política não é um meio de ação direta da classe trabalhadora em benefício de seus interesses profissionais e, portanto, não está compreendida dentro do conceito de greve legal trabalhista. Entende-se por greve política, em sentido amplo, a dirigida contra os poderes públicos para conseguir determinadas reivindicações não suscetíveis de negociação coletiva. Correta, portanto, a decisão que declara a abusividade do movimento grevista com tal conotação, máxime quando inobservado o disposto na Lei 7.783/89. Recurso Ordinário conhecido e desprovido. (BRASIL. Tribunal Superior do Trabalho. Seção Especializada em Dissídios Coletivos, Recurso Ordinário em Dissídio Coletivo no 571212-31.1999.5.01.5555. Relator Juiz Convocado Márcio Ribeiro do Valle. Diário de Justiça, Brasília, DF, 15.9.2000 - esse caso cuidava de greve deflagrada pelo Sindicato dos Trabalhadores nas Indústrias Urbanas do Rio de Janeiro com o objetivo de contestar o processo de privatização da Companhia Estadual de Águas e Esgotos - CEDAE); "METROVIÁRIOS. GREVE. ABUSIVIDADE. É abusiva, diante do ordenamento constitucional e infraconstitucional vigente, a greve política insurreicional ou de simples retaliação, destituída de conteúdo profissional. Hipótese em que os metroviários de São Paulo deflagraram greve, por 24 (vinte e quatro horas), em protesto, alegando descumprimento por parte da Companhia do Metropolitano de São Paulo METRÔ (suscitante) de ordem judicial liminar proferida em ação popular, de interesse pessoal de dirigentes sindicais, em que se teria determinado a suspensão do ato de abertura dos envelopes de propostas das empresas concorrentes em processo de licitação tendente à concessão para a iniciativa privada, por meio de Parceria Público Privada (PPP), da nova Linha 4 - Amarela. Abusividade da greve caracterizada quanto ao aspecto da motivação. (...)" (BRASIL. Tribunal Superior do Trabalho. Seção Especializada em Dissídios Coletivos, Recurso Ordinário em Dissídio Coletivo no 2025800-10.2006.5.02.0000. Relator Ministro Fernando Eizo Ono, Diário Eletrônico da Justiça do Trabalho, Brasília, DF, 04.11.2011).

${ }^{622}$ CAMPILONGO, Celso. “'Aos que não vêem que não vêem aquilo que não vêem': sobre fantasmas vivos e a observação do direito como sistema diferenciado", pp. 11/26. 
No conhecido artigo "Zur Kritik der Gewalt", Walter Benjamin afirma que "o direito de greve é o direito de usar a violência para impor determinados fins". Para os trabalhadores, a greve corresponde, então, ao direito de usar a força para alcançar certos objetivos. ${ }^{623}$ Porém, em algumas situações, em especial a de uma greve geral revolucionária, esse direito à violência, ou seja, ao uso da força é considerado uma ameaça. O Estado vai sinalizar que a intenção originária que reconhecera o direito de greve foi mal interpretada. Não é à toa que a greve é, com frequência, apreendida como uma "perturbação da ordem". De acordo com Benjamin, o Estado teme a violência que pode - e é pertinente aqui a ideia de poder - alterar situações jurídicas. Em outras palavras, o Estado vê a ameaça no exercício da greve como violência fundadora do direito. ${ }^{624}$

A construção teórica de Benjamin contém uma preocupação com o direito, suas instituições e à violência que lhes é inerente. A palavra "crítica", do título do artigo, não contém propriamente um juízo de valor, numa ideia de rejeição, mas, sim, um juízo no sentido de exame para obter meios para julgar a violência. ${ }^{625}$ Para Walter Benjamin, o direito monopoliza a violência para salvar a si mesmo. A violência, quando não está nas mãos da ordem jurídica estabelecida, representa uma ameaça, não por seus fins, mas tão somente por sua existência fora do direito. A ameaça vai ficar mais evidente onde a violência - exercida pelos indivíduos - é permitida, de acordo com o próprio ordenamento jurídico. É o caso do direito de greve. ${ }^{626}$ Para o filósofo alemão, uma conduta, ainda que decorrente do exercício de um direito, pode ser nomeada violência, tendo em vista que exerce um direito concedido de maneira a subverter o próprio ordenamento jurídico em razão do qual tal direito foi reconhecido. ${ }^{627}$

Jacques Derrida propõe um exercício de desconstrução ao analisar esse texto de Walter Benjamin. Derrida observa que a expressão violência é utilizada por Benjamin em um sentido muito específico. O título original do ensaio de Benjamin deve ser interpretado com cuidado. Isso porque a palavra Gewalt pode ser traduzida por violência, mas "pode significar

\footnotetext{
${ }^{623}$ BENJAMIN, Walter. "Para una crítica de la violencia". In: Conceptos de filosofia de la historia. $1^{\text {a }}$ ed. La Plata: Terramar, 2007, pp. 113/138 - p. 118. Para o presente trabalho, foram utilizadas as versões espanhola e francesa do texto de Benjamin. Ver essa última em BENJAMIN, Walter. "Critique de la violence". In: Oeuvres. Tome I. Trad. de Maurice de Gandillac, Rainer Rochlitz e Pierre Rusch. Paris: Gallimard, 2000, pp. 210/243.

${ }^{624}$ BENJAMIN, Walter. "Para una crítica de la violencia", p. 118/119.

${ }^{625}$ Cf. DERRIDA, Jacques. Força de lei: o fundamento místico da autoridade. Trad. de Leyla Perrone-Moisés. São Paulo: WMF Martins Fontes, 2007, p. 74.

${ }^{626}$ Ver BENJAMIN, Walter. "Para una crítica de la violencia", p. 117.

${ }^{627}$ BENJAMIN, Walter. "Para una crítica de la violencia", p. 117.
} 
também o domínio ou a soberania do poder legal, a autoridade autorizante ou autorizada: $a$ força de lei" ${ }^{628}$

Benjamin se refere a dois tipos de violência: a que funda o direito e a que $o$ conserva. A greve seria uma manifestação da primeira, isto é, da violência fundadora do direito, aquela que tem ou pretende ter força de lei, como apontado por Derrida. $\mathrm{O}$ direito de greve corresponde, portanto, a um "direito ao direito", ou seja, um direito a modificar ou legitimar determinadas relações de direito. É justamente nesse aspecto que a greve pode ser vista pelo Estado como uma ameaça. Para Benjamin, o Estado teme a modificação de situações jurídicas por meio da greve, que, não obstante, é reconhecida como direito. Trata-se de uma ameaça interna ao próprio direito. ${ }^{629}$

Jacques Derrida indica que a expressão greve geral manifesta a essência do direito de greve. Como já visto, o Estado não avalia bem essa passagem do limite, considerando abusiva a greve, ao argumento de que houve um mal-entendido (a intenção originária não era essa, o direito não foi bem compreendido). Na persistência da greve, mesmo após a condenação por parte do Estado, pode ter lugar uma situação revolucionária, que permite refletir sobre a homogeneidade entre direito e violência, isto é, "a violência como exercício do direito e o direito como exercício da violência”. A violência constitui uma ameaça que é interna ao próprio direito, ou seja, uma ameaça à ordem de direito estatal que concedeu esse mesmo direito à violência, i.e., o direito de greve. Como explica Derrida:

O Estado teme a violência fundadora, isto é, capaz de justificar, de legitimar ou de transformar as relações de direito, e portanto de se apresentar como tendo um direito ao direito. Essa violência pertence assim, de antemão, à ordem de um direito de transformar ou de fundar, mesmo que ela possa ferir nosso sentimento de justiça. Somente essa violência suscita e torna possível uma "crítica da violência", que determina a violência como sendo uma coisa diferente do exercício natural da força. Para que uma crítica, isto é, uma avaliação interpretativa e significante da violência seja possível, devemos primeiramente reconhecer sentido numa violência que não é um acidente sobrevindo do exterior do direito. Aquilo que ameaça o direito pertence já ao direito, ao direito ao direito, à origem do direito. A greve geral fornece, assim, um fio condutor precioso, já que ela exerce o direito concedido para contestar a ordem do direito existente e criar uma situação revolucionária na qual se tratará de fundar um novo direito, se não sempre (...) um novo Estado. ${ }^{630}$

\footnotetext{
${ }^{628}$ DERRIDA, Jacques. Força de Lei - o "Fundamento místico da autoridade", p. 73.

${ }^{629}$ Cf. BENJAMIN, Walter. "Para una crítica de la violencia", p. 119/126.

${ }^{630}$ DERRIDA, Jacques. Força de Lei - o "Fundamento místico da autoridade", p. 81 e 81/82, respectivamente.
} 
Esse momento de fundação - presente, por exemplo, na instituição de todos os Estados - é um instante de interrupção, de suspensão do direito, e, portanto, de um nãodireito. ${ }^{631}$ Mas isso corresponde à história do direito, de acordo com Derrida, sobre o texto de Benjamin. A fundação fica suspensa, relacionada a um ato performativo puro e independente, ou seja, que não presta contas a ninguém. O sujeito desse performativo está diante de uma lei por vir. E a inteligibilidade dessa lei será produzida apenas no futuro e a depender da própria ordem instaurada. Essa inteligibilidade não é, assim, nem neutra, nem não-violenta. Ela corresponde ao discurso de autolegitimação da violência que instituiu a ordem, a lei, e também seus modelos interpretativos. Trata-se de uma violência performativa interna à leitura interpretativa. Isso traz consequências relevantes para a forma de compreensão da greve geral de que trata Benjamin, a qual se apresenta como o direito de contestar a ordem estabelecida e as suas normas de leitura. ${ }^{632}$

Essa interpretação do texto de Benjamin permite compreender a greve como uma estratégia de ruptura, inclusive da ordem jurídica e de suas normas de inteligibilidade. A ideia de interrupção é fundamental para o filósofo alemão. Benjamin propunha a ruptura, a interrupção do ciclo de fundação (violenta) e de decadência do direito (que, segundo ele, enquadrava todos os aspectos da vida no esquema meio/fim). E isso se baseia na noção de uma nova época histórica por vir. ${ }^{633}$ Jeanne Marie Gagnebin, referindo-se à ideia de greve geral desenvolvida por Walter Benjamin, observa que se trata de

uma figura radical da interrupção como resistência à engrenagem política e social; aqui também, somente a tentativa de parar o tempo pode permitir a uma outra história vir à tona, a uma esperança de ser resguardada em vez de soçobrar na aceleração imposta pela produção capitalista. A greve geral para a produção, assim como os relógios em que revolucionários atiram; $e ́ o$ mesmo gesto de interrupção do tempo, de quebra da continuidade histórica. ${ }^{634}$

\footnotetext{
${ }^{631}$ Não se cuida aqui obviamente da distinção direito/não-direito utilizada pela teoria dos sistemas.

${ }^{632}$ DERRIDA, Jacques. Força de Lei - o "Fundamento místico da autoridade", p. 87/88.

${ }^{633}$ Ver BENJAMIN, Walter. "Para una crítica de la violencia", p. 137. A perspectiva da quebra de continuidade da normalidade histórica, à qual se opõe um momento único, particular, de ruptura, parece ter raízes na construção política do tempo, baseada na ideia de estado de exceção, de Carl Schmitt. A influência de Schmitt no pensamento de Benjamin é confirmada pela própria carta que este escreveu àquele, ao lhe informar do envio de uma cópia do livro As origens do Drama Barroco Alemão. Cf., a respeito, BREDEKAMP, Horst. "From Walter Benjamin to Carl Schmitt, via Thomas Hobbes". Trad. Melissa Thorson Hause e Jackson Bond. In: Critical Inquiry, Vol. 25, n. 2, “Angelus Novus": Perspectives on Walter Benjamin), Winter, 1999, pp. 247/266.

${ }^{634}$ GAGNEBIN. Jeanne Marie. História e narração em Walter Benjamin. São Paulo: Perspectiva, 2007, p. 98 (destaques acrescentados).
} 
Axel Honneth, debruçando-se sobre o artigo de Benjamin, nota que o filósofo alemão busca empreender uma crítica ao direito como um todo. ${ }^{635}$ A hipótese que guiaria Benjamin é a de que os padrões e as distinções determinantes para o tratamento da violência, no presente, são oriundas do direito e estão presas ao modelo meio/fim. Tomando em conta as tradições do direito natural e do direito positivo, Benjamin afirma que o direito, por meio do esquema meio/fim, penetra em todos os espaços da vida ética, de maneira que é pleno o domínio da violência jurídica, isto é, da violência que está na base do direito (que funda e também conserva a ordem do direito). Com a influência de Georges Sorel, Benjamin considera que o direito serve apenas à manutenção da ordem de poder estabelecida. ${ }^{636} \mathrm{~A}$ ideia de revolução, segundo Honneth, deve ser compreendida nesse contexto. A ditadura do direito seria derrubada apenas por meio de uma revolução cultural que, num sentido sagrado, divino, pode, de forma imediata, produzir justiça pelo exercício da violência. ${ }^{637}$

Com relação ao direito de greve, utilizado como exemplo por Benjamin, Honneth critica o fato de que não é inequívoco que o reconhecimento legal desse direito signifique um direito ao exercício da violência, sobretudo se se considerar como greve a simples omissão de determinadas ações ou atividades. Ao recorrer ao direito de greve, Benjamin procura demonstrar uma contradição interna da ordem jurídica, na medida em que o Estado se depara

${ }^{635}$ HONNETH, Axel. "Saving the sacred with a philosophy of history - on Benjamin's 'Critique of Violence"'. In: Pathologies of Reason - On the Legacy of Critical Theory. Trad. James Ingram e outros. New York: Columbia University Press, 2009, pp. 88/125.

${ }^{636}$ Essa influência é apontada por Honneth (p. 100/104). Além disso, há certa semelhança no uso que ambos fazem da expressão violência. Georges Sorel, ao tratar da greve geral política, escreve que: "os termos força e violência são empregados ora ao se falar da autoridade, ora ao se falar dos atos de revolta. É claro que os dois casos dão lugar a consequências bem diferentes. Sou de opinião de que seria mais vantajoso adotar uma terminologia que não resultasse em ambiguidade e de que se deveria reservar o termo violência para a segunda acepção. Diríamos portanto que a força tem por objetivo impor a organização de uma certa ordem social na qual uma minoria governa, enquanto a violência tende à destruição dessa ordem. A burguesia empregou a força desde o início dos tempos modernos, enquanto o proletariado reage agora contra ela e contra o Estado pela violência" (SOREL, Georges. Reflexões sobre a violência. Trad. de Paulo Neves. São Paulo: Martins Fontes, 1992, p. 195). ${ }^{637}$ Para Honneth, Benjamin "está convencido de que qualquer instituição da sociedade conduzida segundo o esquema meio/fim deve reduzir os assuntos humanos ao balanceamento de interesses individuais. E o único poder moral que o então autor de trinta anos acredita que pode - em razão de sua pureza, de seu intrínseco caráter absoluto - nos libertar da fatalidade do direito é a violência sagrada de Deus" (HONNETH, Axel. "Saving the sacred with a philosophy of history - on Benjamin's 'Critique of Violence"', p. 125). Jacques Derrida destaca a perspectiva judaica do texto de Benjamin, que "opõe a justa violência divina (judia), que destrói o direito, à violência mítica (da tradição grega), que instaura e conserva o direito" (DERRIDA, Jacques. Força de Lei - o "Fundamento místico da autoridade", p. 62). Assim se compreende a assertiva de Benjamin, de que "fundação do direito é criação de poder e, nessa medida, um ato de imediata manifestação de violência. Justiça é o princípio de toda instauração divina de fins; poder, o princípio de toda instauração mítica do direito", e, também, a conclusão do artigo: “(...) deve ser rejeitada toda violência mítica, a violência fundadora do direito e que se pode chamar governante. Deve ser rejeitada também a violência conservadora do direito, a violência administrativa que está a serviço da violência fundadora. A violência divina, que é insígnia e selo, jamais meio de execução sagrada, pode ser chamada soberana" (BENJAMIN, Walter. "Para una crítica de la violencia", p. 132 e 138, respectivamente). Sobre a noção de origem mítica do direito, cf. também BENJAMIN, Walter. "Sobre a linguagem em geral e sobre a linguagem humana". In: Sobre arte, técnica, linguagem e política. Trad. de Maria Luz Moita. Lisboa: Antropos, pp. 177/196. 
com a ameaça decorrente da violência, que ele mesmo reconhecera, e a enfrenta capturando a violência fundadora do direito. ${ }^{638}$ Mas apenas na perspectiva do trabalho - e, em especial, da tese de que há um pequeno passo entre uma simples paralisação e o uso da violência que pode subverter a ordem jurídica - a proposta se sustenta. E o que Benjamin demonstraria não seria, em última análise, uma contradição do direito, mas uma contradição de determinada situação jurídica. Além disso, indica Honneth, uma greve geral não é um evento regular, nem mesmo necessário na história dos Estados modernos. De toda forma, a tese de Benjamin apontaria para o fato de que a ordem jurídica permitiria, ela mesma, ser ab-rogada, ou seja, ela deveria abrir mão de sua soberania para poderes externos ou mobilizar uma violência que não possui legitimidade constitucional. ${ }^{639}$

Essas leituras - incluindo as pertinentes críticas de Axel Honeth - evidenciam que o texto de Benjamin coloca a greve como uma espécie de provocação ao Estado, ao mesmo tempo que corresponde a uma estratégia de ruptura. A greve tem, ainda, a característica de força de lei, a que se refere Derrida, na medida em que representa a luta pela conquista de direitos. É um instrumento de resistência coletiva dos trabalhadores. Trata-se da "arma mais eficaz que os trabalhadores criaram para fazer face ao poder do capital". Por meio dela, podem os grevistas empreender uma luta pela defesa do direito já posto, ou pela conquista de novo direito. 640

Márcio Túlio Viana, buscando desenvolver os sentidos da greve, propõe observar as traduções que essa palavra adquire. Em inglês, greve é strike, que significa ataque e, na forma verbal, golpear, chocar-se. Em espanhol, a expressão correspondente é huelga, cujo radical é huelgo e que significa alento, fôlego. Finalmente, em italiano, utiliza-se a palavra sciopero, que vem do prefixo sciolto, isto é, livre de ligações ou de vínculos. A partir dessa constatação, Márcio Túlio Viana afirma que a greve:

é strike enquanto violência. Golpeia o contrato de trabalho, pois questiona o que foi ajustado e desobriga o empregado de sua prestação principal. (...) Mas a greve também é huelga: um momento de tomar fôlego, espécie de parênteses na rotina do trabalho. $\mathrm{O}$ trabalhador se desprende - ainda que não de todo - do poder de comando. (...) No mesmo sentido, greve é sciopero,

\footnotetext{
638 Segundo Benjamin, o direito positivo - em oposição ao direito natural - exige um "testemunho" da sua origem histórica. $\mathrm{O}$ direito juridiciza certos fins de maneira a que possam ser realizados pelo poder jurídico, isto é, pela violência. Nesse caso é possível distinguir entre violência sancionada (como o direito de greve) e violência não sancionada pelo direito. A contradição resultaria exatamente da condenação por parte do Estado na hipótese de uma greve geral. Ver BENJAMIN, Walter. "Para una crítica de la violencia”, p. 116/118.

${ }^{639}$ Ver HONNETH, Axel. "Saving the sacred with a philosophy of history - on Benjamin's 'Critique of Violence"', p. 110/111.

${ }^{640}$ Cf. VIANA, Márcio Túlio. Direito de resistência: possibilidades de autodefesa do empregado em face do empregador. São Paulo: LTr, 1996, p. 281 e 285.
} 
que lembra "solto". É a liberdade que volta, não obstante mitigada, temporária e sobretudo contraditória: em termos reais, o trabalhador se coloca fora do contrato, ainda que formalmente dentro dele, e para reentrar nele em seguida. ${ }^{641}$

Num estudo voltado às greves metalúrgicas do ABC paulista, de 1978 a 1980, Ricardo Antunes afirma que a greve manifesta "um momento de rebeldia do trabalho frente à dominação do capital" ${ }^{\prime 42}$. Fica evidente, no texto desse autor, a preocupação com os efeitos da greve no plano da consciência do ser social (i.e., do trabalhador) que a deflagra, especialmente no que diz respeito a seu papel e à força da ação coletiva no sistema capitalista. Em suas palavras, "os possíveis desdobramentos de um processo de greve, no prazo da subjetividade operária, serão nulos, inexistentes ou substancialmente reduzidos, quando a paralisação se integrar no universo das relações imediatas de compra e venda da força de trabalho, sem ferir a materialidade do sistema social". ${ }^{643}$

Ricardo Antunes indica que o estudo dos processos reais das greves poderá indicar se, nessas ocasiões, houve ou não o desenvolvimento da consciência social do proletariado. ${ }^{644}$ Se o sociólogo, por um lado, enfatiza esse aspecto da greve no processo de conscientização do proletariado, ou seja, do seu papel no processo produtivo, mas também de sua força de ação, por meio da contraposição aos interesses do capital, ele igualmente pretende, por outro lado, explorar os limites da greve. Essa última constitui um dos

${ }^{641}$ VIANA, Márcio Túlio. "Da greve ao boicote: os vários significados e as novas possibilidades das lutas operárias". In: DA SILVA, Alessandro; SOUTO MAIOR, Jorge Luiz; FELIPPE, Kenarik Boujikian; e SEMER, Marcelo (coordenadores.). Direitos Humanos: essência do direito do trabalho. São Paulo: LTr, 2007, pp. 88/95 - p. 92/93.

${ }^{642}$ ANTUNES, Ricardo. A rebeldia do trabalho - o confronto operário do ABC paulista: as greves de 1978/1980, p. 189.

643 ANTUNES, Ricardo. A rebeldia do trabalho - o confronto operário do ABC paulista: as greves de 1978/1980, p. 189. Vale transcrever também o seguinte trecho: "na medida em que a greve possibilita ao operariado dar passos no sentido de superar a imediatidade, através da articulação das suas causas e motivações, levando-o a avançar qualitativamente no sentido de aprofundar as contradições do capital em sua totalidade e a pensar na problemática do controle social da produção, na medida em que esta articulação entre interesses postos pela imediatidade e interesses mais globais de transformação social for efetivada - o que somente se concretiza quando a ação grevista é resultado de uma teleologia consciente - a greve estará se constituindo num instrumento real no processo de desenvolvimento da subjetividade do ser social. Se, entretanto, ela não supera o plano da imediatidade e se atém aos aspectos isolados da contradição, se não capta suas múltiplas dimensões, se ela não pauta sua ação conduzida por uma direção política consciente, sua significação será muito mais restrita, podendo inclusive impedir, obscurecer ou até mesmo fazer retroceder o desenvolvimento da consciência de classe" (ANTUNES, Ricardo. A rebeldia do trabalho - o confronto operário do ABC paulista: as greves de 1978/1980, p. 211).

${ }^{644}$ Para Antunes, "com uma direção consciente, inspirada numa concepção que objetiva a emancipação do trabalho, a greve se constituirá em efetivo passo no processo de conscientização do ser social. Será, portanto, através do estudo das greves, em seus processos reais, que se poderá dizer se houve ou não alguma contribuição para o desenvolvimento da consciência social do proletariado" (ANTUNES, Ricardo. A rebeldia do trabalho - $o$ confronto operário do ABC paulista: as greves de 1978/1980, p. 190 - destaque na origem). 
instrumentos de luta dos trabalhadores, mas não o único. De toda forma, há, para o autor, uma vinculação entre greve e transformação social. ${ }^{645}$

Antunes pretende localizar determinadas dimensões fundamentais presentes nas greves. No que diz respeito à natureza delas, ele começa com a distinção sobre a espontaneidade ou a não espontaneidade. O critério essencial, para diferenciar ambos os tipos, é a existência, ou não, de uma direção consciente, a partir da razão dialética, que desencadeia a greve. Assim, a greve espontânea é a que surge do próprio instinto da classe dos trabalhadores, ao nível da consciência do cotidiano, sem, portanto, uma direção consciente deflagradora. Já uma greve não-espontânea constitui um movimento que tem por base uma ação teleológica anterior, sendo politicamente conduzido. ${ }^{646}$

É tematizada também a distinção entre greve política e greve econômica. Ricardo Antunes considera econômicas as greves que veiculam reivindicações parciais, voltadas aos efeitos e não às causas do regime de salários (isto é, ao processo de produção), não atingindo a materialidade do sistema capitalista. Integram o cotidiano da sociedade capitalista e estão no plano da imediatidade das relações contratuais entre capital e trabalho. As greves políticas, por sua vez, são dirigidas ao aparato estatal, atingindo-lhe a base material ou a sua superestrutura jurídico-política.

Como esclarece o autor, é possível, entretanto, que uma determinada greve tenha traços econômicos e também políticos. E tanto uma greve política quanto uma greve econômica podem ser espontâneas. Assim, "se é verdade que na história do movimento operário europeu estas greves, ora econômicas, ora políticas, ocorreram diversas vezes, é preciso acentuar, com toda ênfase, que foi muito comum a interpenetração destas duas modalidades de greves". E acrescenta, em outra passagem, que "uma greve pode, em sua processualidade e movimento, assumir vários conteúdos e mesmo metamorfosear-se". ${ }^{647}$

\footnotetext{
${ }^{645}$ Segundo Ricardo Antunes, “a greve é um instrumento importante, porém, não o único, e sua insuficiência transparece especialmente quando ela é desprovida de uma teleologia consciente e direcionada, quando ela não se fundamenta numa direção portadora da razão dialética, quando ela não se insere num projeto mais global de transformação radical da sociedade" (ANTUNES, Ricardo. A rebeldia do trabalho - o confronto operário do ABC paulista: as greves de 1978/1980, p. 193).

${ }^{646} \mathrm{O}$ autor cuida ainda da greve não-espontânea, consciente e revolucionária, que é aquela movida por uma ação que contém uma análise científica da realidade, fundada na razão dialética, e que visa, em última análise, modificar o controle da produção e da sociedade, passando-o à classe operária. Cf. ANTUNES, Ricardo. A rebeldia do trabalho - o confronto operário do ABC paulista: as greves de 1978/1980, p. 194/198.

${ }^{647}$ ANTUNES, Ricardo. A rebeldia do trabalho - o confronto operário do ABC paulista: as greves de 1978/1980, p. 204 (destaque na origem) e 207, respectivamente. Ricardo Antunes refere, ainda, a outras classificações, utilizando teóricos como Rosa Luxemburgo e K. Kautsky, como greve política revolucionária e greve política reformista, greve geral anarquista e greve política acidental, greve política de massas (dividida em demonstrativa e coercitiva), greve ofensiva ou defensiva e greve geral ou parcial. Mas os elementos essenciais das greves correspondem às dimensões espontânea, não-espontânea, econômica e/ou política. Cf. ANTUNES, Ricardo. A rebeldia do trabalho - o confronto operário do ABC paulista: as greves de 1978/1980, p. 198/206.
} 
Em razão disso, percebe-se que o uso das tipologias requer cuidado. Para Ricardo Antunes, as greves do ABC paulista, deflagradas entre 1978/1980, explicitam essa dupla dimensão (ou seja, política e econômica). Como visto no capítulo 2, na greve dos petroleiros de 1995, também é possível constatar essa dualidade (ao lado das reivindicações voltadas diretamente ao aumento salarial, o movimento se dirigia contra o aparato estatal, em particular, a decisão quanto às reformas constitucionais anunciadas pelo Presidente da República, Fernando Henrique Cardoso, e a quebra do monopólio da Petrobrás quanto à exploração de petróleo e seus derivados).

Outro ponto merece ser destacado quanto às tipologias das greves. Elas não estão alheias ao seu uso, inclusive com conotações políticas. A greve dos petroleiros de 1995 revela isto: o uso político da expressão greve política. Afinal, por que é importante classificar uma greve como política ou não política?

Na greve dos petroleiros de 1995, é possível notar a seguinte situação, a partir das opiniões que circularam na imprensa: os que eram contrários à greve, em regra taxavam-na de política; os que a defendiam, pelo contrário, diziam que não era política. O próprio Antônio Carlos Spis, Coordenador da FUP, disse que a greve era contra "o arrocho e as reformas [propostas por FHC]", mas negou que fosse política. ${ }^{648}$

A disputa pelo sentido da greve contém implícita a luta pelo próprio significado do texto constitucional. Quando o governo declara que uma greve é política, o objetivo pode ser indicar que não é necessário negociar com os grevistas, porque o movimento seria ilegal, não estando abarcado no âmbito do direito assegurado na Constituição. Este, o uso político da expressão greve política ${ }^{649}$ E essa comunicação, feita pelo governo, tem lugar justamente no ambiente interno do sistema político, que é a opinião pública (onde circulam também poder código do sistema - e os programas teleológicos). ${ }^{650}$ No caso da greve de 1995, viu-se como a mobilização da opinião pública teve um papel importante (inclusive na decisão do TST).

Os desenvolvimentos da teoria dos sistemas sobre os movimentos sociais podem contribuir para a compreensão da processualidade da greve e de sua relação com o direito, os sistemas funcionais e a própria sociedade.

\footnotetext{
${ }^{648}$ Cf. capítulo 2, item 2.2, supra.

${ }^{649}$ Ver também PAIXÃO, Cristiano, LOURENÇO FILHO, Ricardo. "Greve como prática social: possibilidades de reconstrução do conceito a partir da Constituição de 1988".

${ }^{650}$ Cf. CAMPILONGO, Celso. Interpretação do direito e movimentos sociais. Rio de Janeiro: Elsevier, 2012, p. 115; e LUHMANN, Niklas. Teoría política nel Estado de Bienestar, p. 61/66. A opinião pública não é um reservatório de consenso, mas uma "forma de reflexão da sociedade, que se apresenta através dos meios de comunicação" (DE GIORGI, Raffaele. "Democracia, parlamento e opinião pública”, p. 45).
} 
Os movimentos sociais são sistemas comunicativos, autopoiéticos, operativamente fechados em temáticas de protesto e de crítica à sociedade. Assemelham-se a direito, política, economia, etc., nesse ponto, ou seja, por serem sistemas. Mas não são sistemas funcionais e infungíveis, nem operam com base em um código como aqueles demais sistemas, ou a partir de uma programação bem especificada (como o direito, com programas normativos, ou a política, com programas teleológicos). ${ }^{651}$

Os movimentos sociais operam, sobretudo, por meio de hetero-observações, isto é, mediante referências ao ambiente. Os sistemas funcionalmente diferenciados, cuja existência é marca característica da sociedade moderna, possuem instâncias e organizações que decidem (como o Estado e os tribunais), com as implicações que disso decorrem: produção de diferenças, ao suposto de gerar igualdade, de exclusões, ao suposto de gerar inclusão. Os movimentos sociais, sentindo-se atingidos, protestam, reclamam, diante dessas decisões e, em alguns casos, dos riscos produzidos por essas mesmas decisões. ${ }^{652}$ Cabe a eles fazer a crítica da sociedade e dos sistemas funcionais, denunciar suas perversões e assimetrias. ${ }^{653}$ Uma vez que a sociedade moderna não possui um centro, um vértice, os movimentos sociais se voltam, sobretudo, para os sistemas que tem um centro, i.e., uma instância decisória, como a política. ${ }^{654}$

Os efeitos das operações dos sistemas funcionais são melhor compreendidos a partir da distinção inclusão/exclusão, que é fundamental para a teoria dos sistemas. A distinção deve ser apreendida em termos comunicativos. Os movimentos sociais abarcam, assim, os excluídos das comunicações dos sistemas funcionais (ou seja, aqueles que não tem capacidade de participar dos processos comunicativos nos subsistemas sociais). ${ }^{655}$ Os sistemas funcionais incluem a todos, mas isso gera assimetrias. ${ }^{656}$ Mesmo quando objetivam 651 Luhmann distingue, ainda, os movimentos sociais dos sistemas de interação e dos sistemas de organização.
Ver LUHMANN, Niklas. La sociedad de la sociedad, p. $673 / 676$.
652 Cf. LUHMANN, Niklas. Risk: a sociological theory. New York: A. de Gruyter, 2006, p. 136/143.
${ }^{653}$ Cf. CAMPILONGO, Celso. Interpretação do direito e movimentos sociais, p. 7/8. Por isso Campilongo
afirma que "os movimentos sociais fazem a crítica da sociedade. Logo, seus alvos são as lacunas, as
inconsistências, as perversões, o mau funcionamento e os efeitos do próprio funcionamento dos sistemas de
função. A sociedade que provoca a mobilização dos movimentos sociais é uma sociedade diferenciada
funcionalmente. É nesse ambiente que os protestos são construídos"; e, em outro trecho: "movimentos sociais
são uma forma da autodescrição da sociedade que reage a problemas criados pela diferenciação social. A teoria
dos movimentos sociais é uma teoria da sociedade" (CAMPILONGO, Celso. Interpretação do direito e
movimentos sociais, p. 63 e 69 , respectivamente).
654 Ver LUHMANN, Niklas. La sociedad de la sociedad, p. 677 (embora o autor se refira a movimentos de
protesto, a observação é válida também aos movimentos sociais, como se verá adiante).
655 De acordo com Niklas Luhmann, em razão da diferenciação social, a regulação da inclusão se dá pelos
sistemas parciais da sociedade, de maneira que os indivíduos participam de todos os sistemas funcionais, a
depender do âmbito funcional e de que código é introduzido na comunicação. Cf. LUHMANN, Niklas. La
sociedad de la sociedad, p. 495 .
656 A inclusão é comunicativa: todos estão incluídos no sistema da economia, na medida em que, para operar esse 
promover inclusão, os sistemas acabam gerando exclusão. As organizações formais dos sistemas - como os tribunais, o Estado, os bancos, as empresas - incluem de forma limitada, ou seja, produzem exclusões. Isso é uma característica da diferenciação funcional da sociedade. Os protestos são organizados em face dessas exclusões. Os efeitos da distinção entre inclusão e exclusão evidenciam as limitações dos sistemas funcionais (que produzem diferenças). ${ }^{657}$ Segundo Raffaele De Giorgi, "o risco da democracia moderna decorre da possibilidade de produzir ampliação das diferenças - e, consequentemente, de produzir novas desigualdades - por meio da compensação do tratamento de outras desigualdades". ${ }^{658}$

De acordo com o tipo de articulação comunicativa que produzem, os movimentos sociais podem ser de protesto ou de desintegração. Os primeiros atacam a diferenciação funcional da sociedade, consideram-se superiores aos códigos dos sistemas funcionais e pretendem desdenhar desses últimos. ${ }^{659}$ Os segundos apostam na diferenciação funcional, acreditam na Constituição e buscam estimular a variabilidade dos sistemas (inclusive o direito). ${ }^{660}$ A diferença operativa e comunicativa entre os tipos de movimentos sociais é assim descrita por Celso Campilongo, a partir da distinção com relação aos sistemas funcionais:

tipo de comunicação, é necessário utilizar o meio do dinheiro (e não que haja igualdade de poder de compra ou de mercado); todos também estão incluídos no direito, tendo em vista que, para sustentar uma expectativa normativa (comunicação jurídica), é necessário indicar o fundamento legal da pretensão (i.e., recorrer ao código direito/não-direito, o que não significa igualdade de fruição de direitos ou atuação conforme a lei). Cf. CAMPILONGO, Celso. Interpretação do direito e movimentos sociais, p. 50/51; e LUHMANN, Niklas. La sociedad de la sociedad, p. 495.

657 Ver CAMPILONGO, Celso. Interpretação do direito e movimentos sociais, p. 51/52. É elucidativo o que ocorre, por exemplo, no campo das políticas públicas: "olhar atento e crítico a seleções de políticas sociais acesso à moradia e ao crédito imobiliário, reforma agrária, programas de acesso à universidade, Bolsa Família, distribuição de medicamentos - revela que inclusão numa política pode representar exclusão dessa mesma ou de outras políticas. Mais investimento em moradias na cidade pode implicar menos verba para reforma agrária. Crédito imobiliário para quem possui até três salários de renda pode representar a exclusão de quem ganha quatro salários" (CAMPILONGO, Celso. Interpretação do direito e movimentos sociais, p. 55).

${ }^{658}$ DE GIORGI, Raffaele. "Democracia, parlamento e opinião pública”, p. 46. Esse risco decorre, em especial, a partir da inclusão de todos no sistema político.

659 Por isso diz Luhmann que o movimento de protesto "se considera a si mesmo a (boa) sociedade" (LUHMANN, Niklas. La sociedad de la sociedad, p. 676).

${ }^{660} \mathrm{O}$ seguinte trecho é explicativo: "movimentos sociais tem uma forma. Como toda forma, possuem dois lados: o lado interior, constituído pelas comunicações de quem protesta, de quem não se conforma, não aceita mudanças e reage a elas ou as propõe e espera por elas; e o lado exterior, contra o qual se protesta, constituído por sistemas de função da sociedade questionados pelos movimentos sociais. A sociedade possui instâncias e organizações que produzem decisões. Os movimentos sociais sentem-se atingidos por essas decisões. Imaginam não ter participado delas. Reclamam. É no modo de armação comunicativa das reclamações que se pode encontrar a diferença entre movimentos de protesto e movimentos de desintegração" (CAMPILONGO, Celso. Interpretação do direito e movimentos sociais, p. 67). Para a teoria dos sistemas, integração corresponde à redução do grau de liberdade interna dos sistemas funcionais, o que pode ocorrer em condições de cooperação ou de conflito. Trata-se de um aspecto dinâmico na relação entre os sistemas, de maneira que uma integração muito forte entre os sistemas pode desencadear conflitos. Da mesma forma, para reagir aos conflitos, é promovida a integração entre os sistemas. Por isso, talvez o problema seja promover a desintegração suficiente entre os sistemas (de maneira a ampliar a liberdade interna dos sistemas). A distinção integração/desintegração tem importante conexão com a diferença inclusão/exclusão. A exclusão de um sistema indica elevada probabilidade de exclusão de outros sistemas, do que decorre que a exclusão integra mais os sistemas do que a inclusão. Como 
Sistemas de funções operam de modo fechado em razão do tipo de código e programas que utilizam. Movimentos sociais não têm essa estrutura. A diferença protesto/tema não tem o vigor da diferença código/programa. Mas os sistemas de funções também possuem meios de comunicação que circulam pelo sistema e que se condensam nas formas. Validade (direito), moeda (economia) e poder (política) são símbolos comunicativos que transitam pelos sistemas e se cristalizam em formas. Movimentos sociais possuem símbolo análogo: os temas combinados com a atitude geral para a reclamação. São "reservatórios de insatisfação" com as fraquezas e consequências negativas da sociedade moderna. Não há nos movimentos sociais - de "protesto" ou de "desintegração" - uma orientação geral para a satisfação. Movimentos sociais não se alinham à turma dos contentes. Aqui, Poliana não tem vez. Mas uma coisa é estar insatisfeito e usar o sistema, aproveitar suas fraquezas, estimular sua variabilidade, buscar sua mudança; outra coisa, bem diversa, é levar a insatisfação ao extremo: corromper a lógica sistêmica, insistir no impasse, bloquear o encadeamento das comunicações. No primeiro caso, pode-se falar num uso criativo dos sistemas funcionais. No segundo, num uso destrutivo, descrente ou descompromissado com os sistemas de funções. No primeiro grupo estão os movimentos de desintegração: insistem no uso de sistemas funcionais. No segundo, os movimentos de protesto: provocam os sistemas como sinal de rejeição". 661

Os movimentos sociais - sejam eles de protesto ou de integração - denunciam e reagem a determinados efeitos dos sistemas funcionais, suas assimetrias, as exclusões produzidas por suas operações. Não é tão importante se, na denúncia, os movimentos sociais têm ou não razão - ou, sobretudo, se um tribunal reconhecerá que a denúncia é conforme ou não ao direito. O fundamental é a possibilidade da denúncia, da reclamação, da reação, ou seja, o seu procedimento, a sua comunicação. Aqui entra a greve.

A greve compartilha dos movimentos sociais a circunstância de ser uma reação às operações dos sistemas funcionais. É a reação na forma de resistência dos trabalhadores em face do empregador ou tomador dos serviços, para dizer com Márcio Túlio Viana. ${ }^{662}$ É a denúncia do "não" ou das exclusões produzidas pelas organizações econômicas (numa negociação coletiva, por exemplo). Mas também pode ser a denúncia dos efeitos e do funcionamento do sistema político. Na greve de 1995, os grevistas se sentiam ameaçados diante da decisão de quebra do monopólio da Petrobrás. A decisão do TST, por outro lado, contém indícios de uma atuação do Tribunal como cogestor da política econômica. De certa

esclarece Luhmann, quem não tem endereço não pode se matricular na escola (na Índia), quem não sabe ler nem escrever terá menos chances no mercado de trabalho, podendo, ainda, ser discutido se deve ou não ter o direito político de votar (como ocorrido no Brasil). Cf. LUHMANN, Niklas. La sociedad de la sociedad, p. 500; e CAMPILONGO, Celso. Interpretação do direito e movimentos sociais, p. 57/58.

${ }^{661}$ CAMPILONGO, Celso. Interpretação do direito e movimentos sociais, p. 69/70.

${ }^{662}$ VIANA, Márcio Túlio. Direito de resistência. 
forma, isso - essa coordenação da Corte ao governo, a evidenciar uma possível articulação do jurídico orientada à programação teleológica da política ${ }^{663}$ - também foi denunciado quando os grevistas se voltaram contra o pronunciamento do Tribunal.

Para além do caso da greve de 1995, é possível identificar outras situações, na perspectiva dos trabalhadores, em que o protesto se manifesta pela greve, denunciando, reclamando, apontando os efeitos do funcionamento dos sistemas funcionais. É o caso, por exemplo, do sentimento de ameaça ou de contrariedade, ou mesmo de resistência, diante de uma decisão política sobre a regulamentação de determinada atividade, ${ }^{664}$ ou sobre a nomeação de um alto funcionário público. ${ }^{665}$

Em outras situações, como exemplifica Campilongo, pode ocorrer que o funcionamento do mercado seja bloqueado por razões políticas, ou que uma invenção desarticule o sistema produtivo e gere uma leva de desemprego. Tais assimetrias são comuns na sociedade moderna. Com frequência, os movimentos sociais protestam diante desses riscos. É possível que os tribunais atuem como importantes observadores nessas hipóteses. O direito pode observar esses conflitos de modo a ver o que os sistemas envolvidos não veem, isto é, os paradoxos e as latências. ${ }^{666}$ Em relação a esses sistemas, o direito atua como observador de segunda ordem. ${ }^{667}$

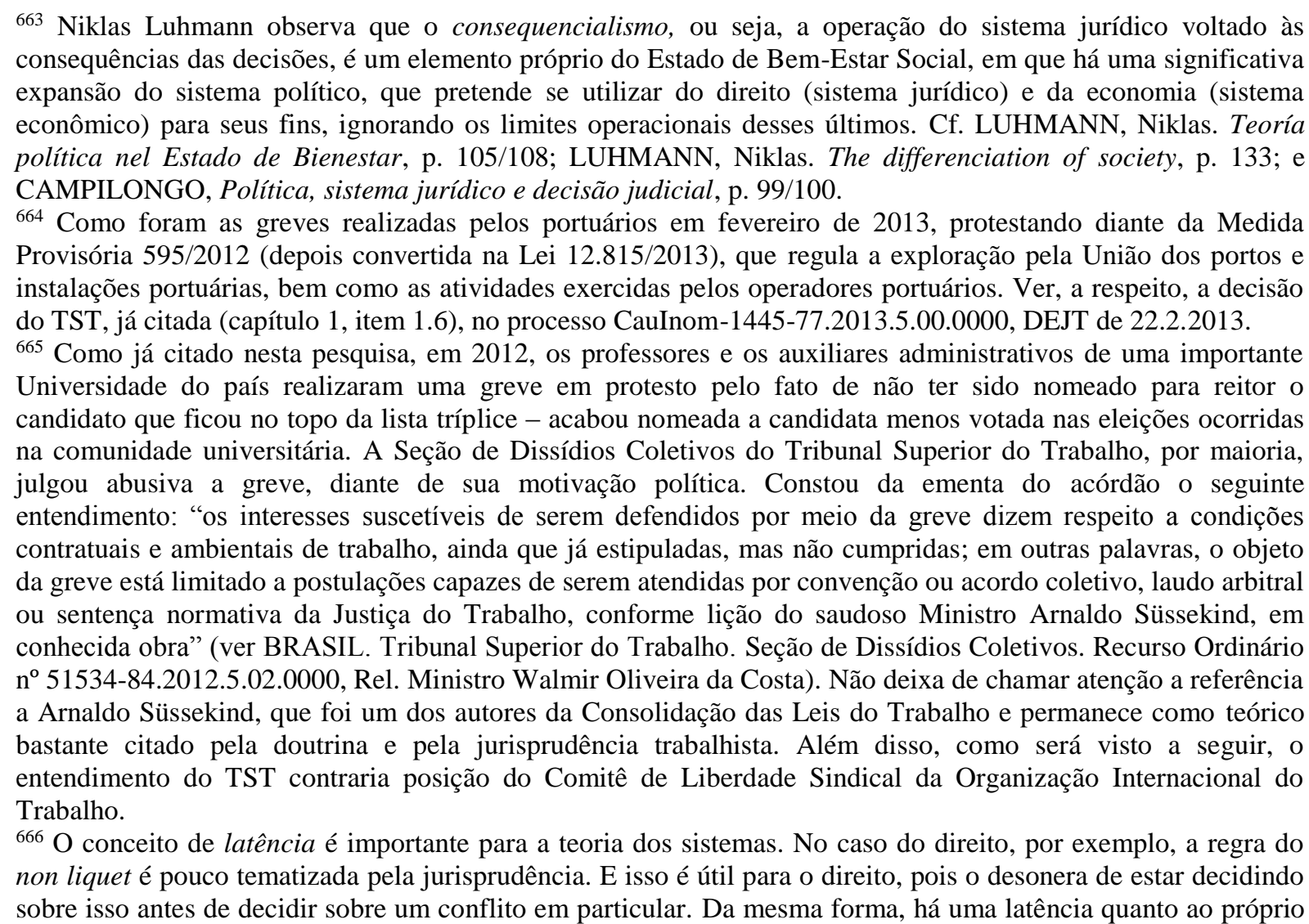


A atuação como observador de segunda ordem, entretanto, não autoriza o direito e os tribunais a substituírem os sistemas conflitantes. ${ }^{668}$ Como observadores de segunda ordem, equidistantes quanto às partes e aos sistemas conflitantes, os tribunais podem ampliar o horizonte de possibilidades de observação, mostrando a contingência do tratamento rígido das alternativas. Por conseguinte, observações concorrentes e alternativas se apresentam na interpretação jurídica, diante da posição dos tribunais, tanto em relação aos movimentos sociais, quanto aos demais sistemas funcionais. A interpretação jurídica produz autoobservação do sistema jurídico, mas também auto-observação da sociedade - sem desconsiderar que os sistemas parciais, bem como as partes que levam o conflito ao sistema jurídico também produzem auto-observações. Para Celso Campilongo, a condição de observador de segunda ordem permanece um desafio aos tribunais, e um campo a ser explorado, mormente quanto aos movimentos sociais. ${ }^{669}$ Esses últimos, por sua vez, podem contribuir para a inserção de novas distinções nas comunicações jurídicas, demandando do sistema novas auto-descrições, ou, ainda, para a ampliação do horizonte de temas e de interpretações do direito, o que, em última análise, aumenta a complexidade do sistema. ${ }^{670}$

O sistema jurídico também pode entrar em conflito com outros sistemas funcionais - a implantação de determinada política econômica pelo governo, por exemplo, pode suscitar a discussão sobre o direito (ou não-direito) dos trabalhadores a diferenças

código direito/não-direito. Como esclarece Raffaele De Giorgi, “se a condição de possibilidade das operações do sistema for sua observabilidade com base na distinção lícito/ilícito, esta condição de possibilidade é o ponto cego de todas as distinções que são utilizadas no sistema. Tal ponto cego não é outra coisa que não a esfera de latência do sistema, em que se constroem seus próprios valores, que são as formas 'que se satisfazem quando um sistema se adapta a uma contínua observação que não pode ser observada'. Estes próprios valores são as distinções que se diferenciam e não se diferenciam” (DE GIORGI, Raffaele. “A memória do direito”, p. 67).

667 Não há um juízo valorativo aqui, isto é, não se trata de atribuir aos tribunais a posição de observador privilegiado. Segundo Raffaele De Giorgi, “na sociedade, não existe lugar para fundamentos, ontologias, talvez nem mesmo, para o espírito absoluto e, tampouco, para a crítica se, por crítica, se entende o uso de uma distinção melhor que as outras. O observador que observa um outro observador não é um observador melhor, mas somente um outro observador que vê a distinção utilizada pelo primeiro e não pode ver sua distinção" (DE GIORGI, Raffaele. "Condições de descrição da complexidade na sociedade mundial". In: Direito, tempo e memória. Trad. de Guilherme Leite Gonçalves. São Paulo: Quartier Latin, 2006, pp. 205/221 - p. 221).

668 Embora, como lembra Campilongo, "muitas vezes, as decisões dos tribunais parecem ignorar essa obviedade. Assumem ônus que o sistema jurídico não é capaz de saldar" (CAMPILONGO, Celso. Interpretação do direito e movimentos sociais, p. 36).

${ }^{669}$ Em suas palavras: “os movimentos sociais (e outros sistemas sociais que operam de 'modo cego', isto é, deixando parte das distinções que os constituem encobertas) laboram num 'realismo inocente'. Um observador de segunda ordem, isto é, um observador que perdeu essa inocência, consequentemente, é capaz de perceber o dogmatismo por trás da comunicação de protestos. Movimentos sociais aparentam unidade. Denunciam a falta de coesão da sociedade, os perigos que isso gera e as inconsistências nas relações intersistêmicas. Tribunais podem se dar conta dos dois exageros. A sociedade, por seu turno, apresenta os movimentos sociais como radicais, incoerentes ou baderneiros. Insiste no respeito aos limites rígidos dos sistemas funcionais. Novo par de extremismos que os tribunais podem ver. Essa 'perda de inocência' encontra nos procedimentos judiciais e no processo decisório dos tribunais um campo de análise a ser explorado" (CAMPILONGO, Celso. Interpretação do direito e movimentos sociais, p. 36/37).

${ }^{670}$ Cf. CAMPILONGO, Celso. Interpretação do direito e movimentos sociais, p. 99/100. 
salariais. Esse conflito pode ser levado aos tribunais pelos movimentos sociais, principalmente mediante uma greve. O problema se apresenta se o direito pretender assumir o papel de outro sistema funcional - atuando, no exemplo, como cogestor da política econômica, o que pode alimentar ainda mais o conflito. ${ }^{671}$

Os movimentos sociais podem se voltar contra o próprio sistema jurídico, denunciando seus efeitos ou funcionamento - como, v.g., uma orientação excessiva do jurídico ao político, ou econômico. Em determinadas hipóteses, em que é apontada a ineficácia de direitos ou invocada uma interpretação alternativa de direitos em disputa, negativas recorrentes por parte dos tribunais podem gerar uma descrença no direito. ${ }^{672}$ Isso não quer dizer que os juízes e tribunais devam buscar consenso para suas decisões, mas, tão somente, que os movimentos sociais, nesse caso, continuam operando: denunciando e reagindo às operações e decisões dos sistemas funcionais. Pode ocorrer, ainda, que movimentos de desintegração, na classificação proposta por Campilongo, se transformem em movimentos de protesto (ou de integração), dirigidos à denúncia dos limites estruturais do sistema jurídico. ${ }^{673}$

A greve pode assumir essas características. Ela pode servir à crítica dos sistemas e, em última análise, da sociedade -, seja ele o direito, a economia ou mesmo a política. A greve corresponde a uma reação, em especial, às operações das organizações dos sistemas econômicos (como as empresas). Não se trata, porém, de atuação passiva. A greve é também denúncia, resistência, para que mudanças sejam promovidas (embora muitas vezes, é verdade,

\footnotetext{
${ }^{671}$ Segundo Celso Campilongo, "se o sistema jurídico toma parte do conflito, qual sua condição de isenção para o arbitramento da contenda entre sistemas? Como, normalmente, o plano operacional do sistema jurídico está preocupado em apreciar conflitos de terceiros, a ruptura de imparcialidade do sistema jurídico fica acobertada pelos requisitos de legitimação das partes para o processo e ausência de inciativa processual dos juízes. Mas, obviamente, não se trata deste problema formal. Os juízes não se dão conta de que, quando assumem papel de substitutos de outros sistemas, na verdade alimentam ou interferem no conflito do qual tomam parte. Causas levadas aos tribunais por movimentos sociais, mas não só por eles, são particularmente potencializadoras deste tipo de paradoxos. Interpretá-los envolve grau de complexidade e de percepção das auto-limitações do sistema jurídico que normalmente passa ao largo, quer da reflexividade da teoria do direito, quer da operacionalidade do processo decisório judicial" (CAMPILONGO, Celso. Interpretação do direito e movimentos sociais, p. 93/94).

${ }^{672}$ Cf. CAMPILONGO, Celso. Interpretação do direito e movimentos sociais, p. 74/76.

${ }^{673}$ A greve de 1995 dos petroleiros, sobretudo com a recusa dos grevistas em acatar a decisão judicial, pode ser observada nessa perspectiva. Segundo Campilongo, "movimentos de desintegração, quando mobilizam o direito, não podem ter certeza da decisão judicial. Não é diferente daquilo que ocorre com qualquer cidadão que procure a Justiça. Muitas vezes, sabem que o pleito funciona como um experimento. Reiteradas tentativas podem redundar em condensação de estruturas jurídicas. Porém, se as derrotas se estabilizam sem perspectivas de variabilidade, desfazem-se as vantagens típicas da legitimação pelo procedimento: temporalização e diferimento das questões. O direito apresentará sua outra face: obstáculo à mudança social. Não se pode perder de vista que essa também é uma característica constitutiva do sistema jurídico. Quando os movimentos de desintegração apreendem isso, podem se desencantar com o direito e migrar para novas formas de protesto, como movimentos de integração que denunciem os limites estruturais do direito" (CAMPILONGO, Celso. Interpretação do direito e movimentos sociais, p. 119).
} 
ela será a resposta ao "não" diante das reivindicações de mudança). ${ }^{674} \mathrm{O}$ que caracteriza a greve, na linha desenvolvida acima, é o tipo de articulação comunicativa produzida: de reivindicação, de resistência, de protesto, de denúncia, de reação, etc., voltando-se aos sistemas funcionais e às suas instâncias decisórias. Nesse sentido, a distinção entre greve política e greve econômica é de menor importância.

A Constituição de 1988 garante essa abertura comunicativa por meio do direito de greve. Por isso são os trabalhadores que vão decidir quando e porque deflagrar a greve. ${ }^{675}$ Também por isso é de menor relevância que o texto constitucional não tenha conceituado esse direito. O que é fundamental é a garantia do procedimento da greve.

Mas o que a diferenciaria de outras formas de protesto ou mesmo de outros movimentos sociais?

Como escreve Márcio Túlio Viana, é possível falar em greve em sentido amplo para indicar protestos, denúncia ou pressão exercidos coletivamente por operários, estudantes, prostitutas, ou, mesmo para se referir a greve de fome, de palavras, de ocupação, de zelo, tartaruga, entre outros significados. Em todos esses casos, há uma prática, que se prolonga por determinado tempo, de ruptura com a rotina. Para o direito, esse conceito de ruptura da rotina pode ser utilizado, considerando-se, porém, o contexto do trabalho. A especificidade da greve é, então, a ruptura do cotidiano da prestação de serviços. ${ }^{676}$

Se a greve compartilha com os movimentos sociais a circunstância de ser uma reação diante das operações dos sistemas funcionais e de suas organizações, i.e., ao seu funcionamento, às suas assimetrias e exclusões, pode-se acrescentar que a reação (ou a resistência, a denúncia, a reclamação, o protesto) se dá a partir da ruptura do cotidiano da prestação de serviços.

Essa peculiaridade, contudo, não restringe o teor das comunicações articuladas na greve. Em outras palavras: não há limitação ao campo profissional ou econômico. A

\footnotetext{
${ }^{674}$ Como observa Márcio Túlio Viana, “(...) é importante notar que há duas formas de resistência - pelo direito já posto e para se pôr o direito. A primeira pode ser exercida pelo indivíduo ou pelo grupo. Já a outra, no campo trabalhista, só pelo grupo. É aí que entra a greve. Embora também sirva de arma contra violações da lei, ela se presta especialmente para fabricar a lei, num contexto em que a lei não se ajusta ao direito ou à justiça" (VIANA, Márcio Túlio. "Da greve ao boicote: os vários significados e as novas possibilidades das lutas operárias", p. 98).

675 Os movimentos sociais, como visto, são sistemas autopoiéticos comunicativos, de maneira que sua reprodução se dá a partir da combinação do protesto e do tema (de protesto) respectivo. Por conseguinte, é o próprio sistema que constrói o tema (embora mediante heterobservações) e dá origem, a partir daí, a uma controvérsia. Daí porque o sistema é aberto cognitivamente quanto ao tema e às ocasiões, mas fechado operativamente quanto à forma de protesto. Cf. LUHMANN, Niklas. La sociedad de la sociedad, p. 682; e LUHMANN, Niklas. Risk: a sociological theory, p. 126/127.

${ }^{676}$ Cf. VIANA, Márcio Túlio. "Da greve ao boicote: os vários significados e as novas possibilidades das lutas operárias”, p. 100/101. Em razão disso, o autor afirma que o conceito legal - do art. 2º da Lei 7.783/1989 - não corresponde à realidade e restringe a norma constitucional.
} 
Constituição de 1988, pelo contrário, assegura a abertura comunicativa por meio da greve, que é reconhecida como direito. Os temas das reivindicações serão decididos pelos grevistas. No plano internacional, essa abertura também é juridicamente garantida.

O Comitê de Liberdade Sindical da Organização Internacional do Trabalho possui entendimentos abrangentes, já tendo decidido que:

os interesses profissionais e econômicos, que os trabalhadores defendem mediante o direito de greve, abrangem não só a obtenção de melhores condições de trabalho ou reivindicações coletivas de ordem profissional, como também envolvem a busca de soluções para questões de política econômica e social e para problemas que se apresentam na empresa e que interessam diretamente aos trabalhadores;

(...)

o direito de greve não deveria limitar-se aos conflitos de trabalho suscetíveis de terminar numa determinada convenção coletiva: os trabalhadores e suas organizações devem poder manifestar, caso necessário, num âmbito mais amplo, seu possível descontentamento com questões econômicas e sociais que guardem relação com os interesses de seus membros;

(...)

a declaração de ilegalidade de uma greve nacional de protesto pelas consequências sociais e trabalhistas da política econômica do governo e sua proibição constituem grave violação da liberdade sindical ${ }^{677}$

A greve é reconhecida pelo ordenamento como um direito. Trata-se de direito que possui vínculo estreito com o sindicalismo e a liberdade sindical. $\mathrm{Na}$ experiência histórica de construção dos direitos fundamentais, a liberdade sindical consolida-se a partir das lutas empreendidas pelos movimentos e pelas organizações de trabalhadores. Ela é afirmada e defendida num contexto conflitivo de construção e desenvolvimento de identidades coletivas dos trabalhadores perante Estado e empregadores. A afirmação da liberdade sindical implica o reconhecimento da existência das classes sociais e de seus antagonismos. A origem da liberdade sindical evidencia que não houve uma derivação pura e simples do direito clássico de associação. É um direito novo, construído historicamente face ao Estado e aos empregadores e oriundo das lutas dos trabalhadores contra a exploração a partir do trabalho. ${ }^{678}$

É possível afirmar que se cuida de um direito reconhecido, positivado, a partir da reação, das denúncias, dos protestos diante das operações e assimetrias produzidas pelas

677 ORGANIZAÇÃO INTERNACIONAL DO TRABALHO. $O$ direito coletivo, a liberdade sindical $e$ as normas internacionais. Vol. II. Trad. e revisão técnica de Kelly Karoline Bepe Fernandes, Sandro Lunard Nicoladeli e Tatyana Scheila Friedrich. São Paulo: LTr, 2013, p. 135, 137 e 139 (parágrafos 526, 531 e 542), respectivamente.

${ }^{678}$ Cf. SILVA, Sayonara Grillo Coutinho Leonardo da. Relações coletivas de trabalho. São Paulo: LTr, 2008, p. $84 / 85$. 
organizações dos sistemas funcionais, sobretudo da economia. ${ }^{679}$ Niklas Luhmann afirma que os movimentos de protesto "observam a sociedade moderna de acordo com suas consequências". O socialismo, que tinha por referência os efeitos da industrialização, foi apenas a primeira ocorrência. ${ }^{680}$

Para Antonio Baylos, o sindicalismo está inscrito em uma dinâmica de emancipação social de grandes massas de trabalhadores, especialmente a partir do século XIX, em relação a um sistema capitalista que os submetia a condições de miséria moral e material e de sujeição política. Os primeiros espaços de dignidade no trabalho foram construídos com a participação indispensável das organizações de trabalhadores. É nesse ponto que ficam mais evidentes os vínculos entre liberdade sindical e direito de greve.

O movimento trabalhista construiu coletivamente um conjunto de direitos no âmbito do trabalho ao mesmo tempo em que exigia a ampliação de direitos políticos reservados exclusivamente às pessoas do sexo masculino e que fossem proprietárias. E, em sua etapa avançada, foi capaz de edificar sobre o trabalho uma estrutura articulada de direitos e prestações sociais que conformaram um verdadeiro status de cidadania, o que, hoje, chamamos de cidadania social.

O direito de greve é o instrumento idôneo para impulsionar a realização desses objetivos e, por isso, desde o reconhecimento jurídico e político da liberdade sindical, integra o conteúdo essencial dessa última e deve ser garantido de forma plena pelos sistemas jurídicos desenvolvidos. ${ }^{681}$

A greve, enquanto direito, engendra o exercício coletivo de uma liberdade, ${ }^{682}$ que adquire, em última análise, o simbolismo da força dos trabalhadores. ${ }^{683}$ Esses dois aspectos -

\footnotetext{
${ }^{679}$ Karl Polanyi, considerando os efeitos da Revolução Industrial, em especial na Inglaterra, refere ao "progresso miraculoso nos instrumentos de produção", acompanhado de "uma catastrófica desarticulação na vida das pessoas comuns" (POLANYI, Karl. A grande transformação: as origens da nossa época. Trad. de Fanny Wrobel. Rio de Janeiro: Campus, 1980, p. 51).

${ }^{680}$ LUHMANN, Niklas. La sociedad de la sociedad, p. 681. Ainda segundo o autor, enquanto o socialismo permaneceu como sendo o único caso, foi possível o desenvolvimento de uma correspondente teoria da sociedade e da sua forma de protesto. Daí o interesse, até hoje, por Karl Marx. Entretanto, a partir do momento em que outras consequências das estruturas da sociedade moderna foram descobertas e vieram à tona, essa "simplificação" tornou-se insustentável (seja como monopólio das formas de protesto, seja como teoria). Ver também LUHMANN, Niklas, e DE GIORGI, Raffaele. Teoria della società, p. 337/338.

${ }^{681}$ BAYLOS, Antonio. "Sobre el Derecho a Huelga". Entrevista concedida à Fundação Sol. Tradução livre. Disponível em http://www.fundacionsol.cl/sobre-el-derecho-a-huelga (acesso em 23.4.2011). A Convenção 87 da OIT estabelece que a liberdade sindical implica, entre outras, a garantia às organizações de trabalhadores e entidades patronais do direito de elaborar os seus estatutos, elegerem livremente os seus representantes, organizar a gestão e a sua atividade, bem como formular o seu programa de ação (art. $3^{\circ}$ ). De acordo com Sayonara Grillo da Silva, o reconhecimento do direito de formulação dos programas de ação do sindicato assegura a decisão acerca da ação direta por meio da greve. Cf. SILVA, Sayonara Grillo Coutinho Leonardo da. Relações coletivas de trabalho, p. 95/96.

${ }^{682}$ Ver SUPIOT, Alain. Critique du droit du travail. Paris: Quadrige/PUF, 2007, p. 144. Nas palavras de Márcio Túlio Viana, "a greve é algo mais que a simples soma do direito de cada um em fazer face à opressão do capital. É exercício coletivo da liberdade de não trabalhar, e, exatamente por ser coletivo, tem algo de próprio, de diferente; não se confunde com o interesse de cada um" (VIANA, Márcio Túlio. Direito de resistência -
} 
a dimensão coletiva e a sua origem histórica - tornam problemática a utilização de instrumentos jurídicos (inclusive de critérios interpretativos) próprios da tutela de direitos e interesses apreendidos a partir de relações individuais. É o caso, por exemplo, do recurso aos interditos proibitórios ${ }^{684}$ ou da aplicação de multas aos sindicatos profissionais. ${ }^{685}$

É interessante considerar as descrições que a Organização Internacional do Trabalho, por meio de seu Comitê de Liberdade Sindical, tem feito com relação ao direito de greve. Embora seja exercida pelos trabalhadores, a greve, como possibilidade comunicativa, não se restringe a questões econômicas ou profissionais.

Trata-se de direito que é indissociável do direito de sindicalização, previsto na Convenção 87 da OIT. ${ }^{686} \mathrm{E}$ ainda que o Brasil não tenha ratificado essa convenção, assinou vários outros documentos internacionais que reconhecem o direito à liberdade sindical, além, é claro, da previsão da Constituição de $1988\left(\operatorname{art} .8^{\circ}\right) .^{687}$

O Comitê de Liberdade Sindical entende que não contraria a liberdade sindical a previsão legal de procedimentos de conciliação e arbitragem como condições prévias à

\footnotetext{
possibilidades de autodefesa do empregado em face do empregador, p. 293).
}

${ }^{683}$ Essa força simbólica é descrita por Eric Hobsbawn com relação ao chamado "dia do trabalhador": "o $1^{\circ}$ de Maio tornou-se uma afirmação anual da presença da classe [trabalhadora] - com mais sucesso onde (...) ele salientou aquela presença por uma afirmação simbólica da força fundamental dos trabalhadores: a ausência ao trabalho através de uma greve de um dia" (HOBSBAWM, Eric. J. Mundos do Trabalho - novos estudos sobre história operária. São Paulo: Paz e Terra, 2005, p. 112).

684 Cf. PAIXÃO, Cristiano e LOURENÇO FILHO, Ricardo. PAIXÃO, Cristiano, LOURENÇO FILHO, Ricardo. "Direito de greve, interditos proibitórios e a centralidade do direito de propriedade: uma visão crítica da orientação do TST".

${ }^{685}$ Em outro caso já citado, o Tribunal Regional do Trabalho da $2^{\text {a }}$ Região (São Paulo) declarou a abusividade da greve deflagrada pelos metroviários, no começo de junho de 2014, e determinou o imediato retorno ao trabalho, sob pena de multa de $\mathrm{R} \$ 500.000,00$ por dia, em caso de descumprimento. Os sindicatos profissionais já haviam recebido multa diária de $\mathrm{R} \$ 100.000,00$, caso fosse descumprida a decisão liminar que determinara o funcionamento de $100 \%$ das atividades do metrô em horários de pico. Cf. notícia do sítio do próprio Tribunal: http://www.trt2.jus.br/indice-noticias-em-destaque/18606-metro-trt-2-declara-greve-dos-trabalhadores-abusiva (acesso em 21.6.2014). Os sindicatos profissionais não acataram de imediato a ordem de retorno ao serviço. Dois dias após o julgamento, o Desembargador Relator determinou o bloqueio das contas bancárias das entidades, no total de $\mathrm{R} \$ 3.000 .000,00$, para o pagamento das penalidades. Ver, a respeito, http://www.trt2.jus.br/indicenoticias-em-destaque/18613-greve-do-metro-trt-2-bloqueia-contas-dos-sindicatos-a-fim-de-assegurar-opagamento-da-multa (acesso em 21.6.2014).

${ }^{686}$ Cf. ORGANIZAÇÃO INTERNACIONAL DO TRABALHO. $O$ direito coletivo, a liberdade sindical $e$ as normas internacionais. Vol. II, p. 135 (parágrafo 523). A despeito de o direito de greve estar vinculado à liberdade sindical, o Comitê já decidiu que "as greves de caráter puramente político e as greves decididas sistematicamente, muito antes que as negociações sejam levadas a cabo, não são atingidas no âmbito dos princípios da liberdade", entretanto, “embora as greves de natureza puramente política não estejam amparadas pelos princípios da liberdade sindical, os sindicatos deveriam poder organizar greves de protesto, especialmente para exercer o direito de criticar a política econômica e social do governo" (ORGANIZAÇÃO INTERNACIONAL DO TRABALHO. O direito coletivo, a liberdade sindical e as normas internacionais. Vol. II, p. 137 - parágrafos 528 e 529).

${ }^{687}$ Entre outros, o Brasil ratificou a Convenção 98 da OIT e é signatário da Declaração de Filadélfia da OIT, de 1946, do Pacto Internacional sobre Direitos Civis e Políticos e do Pacto Internacional dos Direitos Econômicos, Sociais e Culturais - aprovados em 1991 e promulgados, mediante decreto ( $\mathrm{n}^{\circ} 592$ e 591, respectivamente), em 1992. O país também é parte da Declaração Sócio Laboral do Mercosul, de 1998. Todos reconhecem o direito à liberdade sindical. 
declaração da greve, desde que a arbitragem não seja compulsória. ${ }^{688}$ A obrigatoriedade da arbitragem é aceitável tão somente se for solicitada por ambas as partes envolvidas no conflito coletivo, ou, ainda, nas hipóteses que envolverem funcionários públicos que exerçam autoridade em nome do Estado ou nos serviços essenciais em sentido estrito. A possibilidade de que uma das partes leve o conflito, unilateralmente, à autoridade trabalhista ameaça o direito de greve e a proposta de incentivo à negociação coletiva ${ }^{689}$ - o que fornece uma importante perspectiva para reflexão sobre a jurisprudência do Tribunal Superior do Trabalho, vista há pouco.

A definição dos chamados "serviços essenciais" também é relevante em matéria de greve, na medida em que, nessas atividades, são admitidas restrições ou mesmo a sua proibição. De acordo com o Comitê de Liberdade Sindical, "para determinar os casos em que se podia proibir a greve, o critério predominante é a existência de uma ameaça evidente e iminente à vida, à segurança ou à saúde de toda a população ou parte dela". ${ }^{690}$ Mas se trata de conceito fluido, dinâmico, a depender das peculiaridades de cada lugar. ${ }^{691}$ Não são considerados essenciais no sentido estrito do termo os setores do petróleo e do porto, bancos, transporte em geral (incluindo os metropolitanos), geração, transporte e distribuição de combustíveis, correios, coleta de lixo, entre outros. ${ }^{692}$ Entretanto, ainda que não sejam

\footnotetext{
688 "Não pode ser considerado como atentatória à liberdade sindical uma legislação que preveja procedimentos de conciliação e arbitragem (voluntária) nos conflitos coletivos como condição prévia para declaração de uma greve, contanto que o recurso à arbitragem não tenha caráter obrigatório e não impeça a prática, o recurso à greve" (ORGANIZAÇÃO INTERNACIONAL DO TRABALHO. O direito coletivo, a liberdade sindical e as normas internacionais. Vol. II, p. 140 - parágrafo 549).

689 “A arbitragem obrigatória, para pôr fim a um conflito coletivo de trabalho e a uma greve, só é aceitável quando solicitada pelas duas partes envolvidas no conflito ou nos casos em que a greve pode ser limitada, e mesmo proibida, ou seja, nos casos de conflito na função pública com relação a funcionários que exercem funções de autoridade em nome do Estado ou nos serviços essenciais, no sentido estrito do termo, ou seja, serviços cuja interrupção possam pôr em risco a vida ou a segurança de toda a população ou parte dela"; e "disposição que permite que uma das partes do conflito possa, unilateralmente, solicitar a intervenção da autoridade do trabalho, para avocar a si sua solução, apresenta um risco para o direito dos trabalhadores de declarar a greve e é contrária à promoção da negociação coletiva" (ORGANIZAÇÃO INTERNACIONAL DO TRABALHO. O direito coletivo, a liberdade sindical e as normas internacionais. Vol. II, p. 143 - parágrafos 564 e 566, respectivamente).

690 ORGANIZAÇÃO INTERNACIONAL DO TRABALHO. O direito coletivo, a liberdade sindical $e$ as normas internacionais. Vol. II, p. 146 - parágrafo 581. Importante notar que o Comitê indica a apenas possibilidade (e não necessidade) de proibição da greve nesses serviços, e ainda assim desde que asseguradas medidas compensatórias. No ordenamento jurídico brasileiro, a proibição da greve em atividades essenciais parece conflitar com o art. $9^{\circ}$ da Constituição, que admite apenas restrições ao direito, mas não seu impedimento. 691 "O que se entende por serviços essenciais no sentido estrito do termo depende, em grande parte, das condições peculiares de cada país. Por outro lado, esse conceito não é absoluto, uma vez que um serviço não essencial pode converter-se em serviço essencial quando a duração de uma greve ultrapasse um certo período ou um certo alcance, pondo assim em risco a vida, a segurança da pessoa ou a saúde de toda população ou parte dela" (ORGANIZAÇÃO INTERNACIONAL DO TRABALHO. O direito coletivo, a liberdade sindical e as normas internacionais. Vol. II, p. 147 - parágrafo 582).

692 ORGANIZAÇÃO INTERNACIONAL DO TRABALHO. O direito coletivo, a liberdade sindical $e$ as normas internacionais. Vol. II, p. 148/149 - parágrafo 587. Já de acordo com a Lei 7.783/1989, são consideradas
} 
reputadas essenciais, é admissível a manutenção de um quantitativo mínimo de funcionários, desde que, na definição desse mínimo, haja participação das entidades sindicais profissionais com empregadores e autoridades públicas ${ }^{693}$ - o que exclui a possibilidade de estabelecimento unilateral pelo Poder Judiciário.

As posições do Comitê de Liberdade Sindical indicam que a greve gera certos transtornos, que não podem ser utilizados como fundamento para definir certa atividade como essencial em sentido estrito. Ou seja, determinados efeitos são inerentes ao conflito e à deflagração da greve, que, nesses casos, pode levar a uma "perturbação da vida normal da comunidade". ${ }^{694}$ Os piquetes, sem violência, também são admitidos, desde que respeitada a liberdade de trabalho dos não-grevistas. ${ }^{695} \mathrm{E}$ a intervenção da polícia ou das forças armadas é possível apenas em caso de ameaça à ordem pública ${ }^{696}$ - lembrando que se trata, porém, de

essenciais as seguintes atividades: “Art. 10 (...) I - tratamento e abastecimento de água; produção e distribuição de energia elétrica, gás e combustíveis; II - assistência médica e hospitalar; III - distribuição e comercialização de medicamentos e alimentos; IV - funerários; V - transporte coletivo; VI - captação e tratamento de esgoto e lixo; VII - telecomunicações; VIII - guarda, uso e controle de substâncias radioativas, equipamentos e materiais nucleares; IX - processamento de dados ligados a serviços essenciais; X - controle de tráfego aéreo; XI compensação bancária".

693 Este, o entendimento do Comitê: "na definição dos serviços mínimos e do número de trabalhadores que os garantam, deveriam poder participar não só as autoridades públicas, mas também as organizações de trabalhadores e de empregadores interessadas. Com efeito, isso não só permite um equilibrado intercâmbio de pontos de vista sobre o que, numa situação concreta, poder-se-ia considerar como serviços mínimos, limitados ao estritamente indispensável, como também contribui para garantir que a dimensão dos serviços mínimos não tenha, na prática, por resultado a inocuidade da greve, tendo em vista seu escasso impacto, assim como para dissipar possíveis impressões das organizações sindicais de que a ação de greve acabou em frustração em razão dos serviços mínimos concebidos em termos demasiadamente amplos e definidos unilateralmente" (ORGANIZAÇÃO INTERNACIONAL DO TRABALHO. O direito coletivo, a liberdade sindical e as normas internacionais. Vol. II, p. 155 - parágrafo 612).

694 " $O$ fato de vincular as restrições do direito de greve com as dificuldades que provocam no comércio e nos negócios, abrem portas à proibição de uma diversidade de ações reivindicatórias e de greves legítimas. Ainda quando as greves e outras ações conexas têm repercussões prejudiciais para o comércio e os negócios, tais consequências não convertem o setor afetado em um serviço 'essencial', e por onde deveriam manter-se o direito de greve". E, quanto à possibilidade de o empregador convocar empregados (ou seja, mobilizá-lo), o Comitê já entendeu que "mesmo se reconhecendo que a suspensão do funcionamento de serviços ou de empresas, como empresas de transportes, ferroviários e do setor petrolífero, poderia conduzir a uma perturbação da vida normal da comunidade, é difícil admitir que a suspensão desses serviços ou empresas conduza necessariamente a uma grave crise nacional. O Comitê achou, por conseguinte, que a mobilização dos trabalhadores, adotada por ocasião de conflitos nesses serviços, restringia seu direito de greve como meio de defesa de seus interesses profissionais e econômicos" (ORGANIZAÇÃO INTERNACIONAL DO TRABALHO. O direito coletivo, a liberdade sindical e as normas internacionais. Vol. II, p. 150 e 160 - parágrafos 592 e 637, respectivamente).

695 "Os piquetes de greve, que agem de conformidade com a lei, não devem ser objeto de empecilhos por parte das autoridades públicas"; e "o exercício do direito de greve deve respeitar a liberdade de trabalho dos não grevistas quando a legislação assim o dispõe, assim como o direito da direção da empresa de ingressar nas instalações da mesma" (ORGANIZAÇÃO INTERNACIONAL DO TRABALHO. $O$ direito coletivo, a liberdade sindical e as normas internacionais. Vol. II, p. 162 e 163 - parágrafos 648 e 652, respectivamente).

696 “A intervenção do exército nos conflitos laborais não favorece a um clima livre de violência, pressões ou ameaças, que é essencial para o exercício da liberdade sindical”; e "as autoridades só deveriam recorrer à força pública, quando se produz um movimento de greve, se a situação envolvesse uma certa gravidade ou fosse julgada realmente ameaçada a ordem pública" (ORGANIZAÇÃO INTERNACIONAL DO TRABALHO. $O$ direito coletivo, a liberdade sindical e as normas internacionais. Vol. II, p. 161 - parágrafos 641 e 644 , respectivamente). 
conceito indeterminado e, portanto, manipulável. A eventual imposição de multas não pode ter efeito intimidatório ou de inibição das ações sindicais. ${ }^{697}$

Todas essas são leituras significativas do direito de greve e das formas que o protesto por ele engendrado pode adquirir. São observações compatíveis com a Constituição de 1988 e com o sentido procedimental com que a greve foi prevista no art. $9^{\circ}$. É necessário, no entanto, que a abertura assegurada no texto constitucional encontre ressonância nas práticas e nas interpretações (i.e., operações) dos tribunais e do sistema jurídico, de maneira a que seja possível o desenvolvimento de um discurso coerente com os desafios da própria Constituição. ${ }^{698}$

A greve é a denúncia dos efeitos dos sistemas funcionais e de suas instâncias decisórias (Niklas Luhmann e Celso Campilongo), é a resistência por parte dos trabalhadores (Márcio Túlio Viana), é a expressão da sua rebeldia (Ricardo Antunes), mas também é a estratégia de interrupção da engrenagem política e social (Walter Benjamin e Jeanne Marie Gagnebin) com a pretensão de força de lei (Jacques Derrida), na forma de protesto mediante a ruptura do cotidiano da prestação dos serviços (Viana, novamente). Em qualquer dessas acepções, o que é importante, na observação do direito de greve, a partir da Constituição de 1988, são suas múltiplas possibilidades comunicativas e seu procedimento permanentemente aberto, complexo e contingente.

\footnotetext{
697 “As multas que equivalem a um montante máximo de 500 ou 1.000 salários mínimos por dia de greve abusiva são suscetíveis de ter um efeito intimidatório sobre os sindicatos e inibir suas ações sindicais de reivindicações legítimas, e mais ainda quando o cancelamento da multa é subordinado à não realização de uma nova greve que seja considerada abusiva" (ORGANIZAÇÃO INTERNACIONAL DO TRABALHO. $O$ direito coletivo, a liberdade sindical e as normas internacionais. Vol. II, p. 165 - parágrafo 670).

${ }^{698}$ Para Florestan Fernandes, o art. $9^{\circ}$ da Constituição "está embutido em um conjunto de direitos individuais e coletivos e de direitos sociais, que armam os trabalhadores como cidadãos (não apenas como o agente econômico mais fraco, o fornecedor da força de trabalho, mercadoria manipulável ad libitum em virtude uma legislação trabalhista arcaica, com vínculos corporativos totalitários herdados do Estado Novo, e através do despotismo patronal, variável com os ramos da produção). A Constituição apenas incorpora o trabalhador à sociedade civil, dotando-o de peso e voz e em uma relação com o Estado que foi democratizada de forma parcial, graças a outros dispositivos constitucionais" (FERNANDES, Florestan. A Constituição inacabada, p. 337).
} 


\section{Conclusão}

A promulgação da Constituição de 1988 insere-se no contexto da transição brasileira em direção à democracia. A ideia de mudança, de ruptura, impregnou os discursos que circularam na Assembleia Nacional Constituinte de 1987/1988. A movimentação popular característica do período, perpassando a leitura da Carta aos Brasileiros, em 1977, e as Diretas Já, em 1984, se concentrou na Constituinte e na elaboração do novo texto constitucional. No bojo das reivindicações democráticas, a greve se consolidava como importante instrumento de participação dos trabalhadores no espaço político.

Nos discursos de constituintes e de outros atores, como representantes sindicais, vê-se o relato de práticas com as quais se buscava romper. Muitas vezes, o passado era reconstruído para indicar uma experiência que se pretendia evitar. Foi assim com as referências à Constituição de 1946 e à previsão do direito de greve, remetendo a sua regulamentação à legislação ordinária, o que veio a impedir o exercício do direito. A intervenção da Justiça do Trabalho também foi uma prática com a qual se pretendeu interromper, diante das frequentes decisões judiciais que declaravam a ilegalidade de movimentos grevistas.

Havia o anseio, na Assembleia Nacional Constituinte, de que a greve fosse assegurada, no novo texto constitucional, sem o cabimento de restrições legais e como direito autoaplicável. Tinha-se no horizonte também acabar com a proibição de paralisações nas atividades essenciais, enfatizando-se, ainda, o aspecto controvertido dessa definição. Chegouse a defender a "liberdade com responsabilidade", de maneira que seriam os próprios grevistas os responsáveis pelo atendimento das necessidades da população no caso das greves nos serviços essenciais (ou seja, rechaçava-se a intervenção das autoridades públicas).

Mas existiam vozes em sentido contrário. Para alguns constituintes, era necessário que a regulamentação do direito de greve fosse possível pela legislação ordinária, que deveria, entre outros aspectos, estabelecer quais seriam as atividades consideradas essenciais para esses fins. Havia mesmo os que defendiam a proibição da greve nesses serviços. E para outros, a possibilidade de os tribunais examinarem a legalidade de uma greve deveria ser resguardada.

Esses elementos matizaram boa parte dos debates na Assembleia Nacional Constituinte de 1987/1988 sobre o direito de greve. Subjacente estava a tensão entre continuidade e ruptura com o regime anterior. 
Na fase da Comissão de Sistematização e, em especial, das discussões no Plenário da Constituinte, os trabalhos adquiriram uma dinâmica diferente. A formação do Centrão teve um relevante impacto nas atividades da ANC, fazendo o papel de contrapeso a algumas pretensões de reconhecimento de direitos, sobretudo sociais. Além disso, as discussões e deliberações passaram a depender bastante dos acordos firmados entre as lideranças partidárias, que exerceram um papel importante no encaminhamento das votações. A despeito disso, não se deve descartar a influência que a mobilização da sociedade exerceu durante a Constituinte, seja pela participação in loco nas sessões, seja por meio das emendas populares. Não parece ser adequado entender que os debates produzidos na fase das subcomissões e das comissões temáticas tenham sido simplesmente ignorados na Comissão de Sistematização e no Plenário. A ideia de mudança e de ruptura com a ordem anterior, mesmo com as vozes em sentido contrário, perpassou todo o funcionamento da Constituinte, e não apenas algumas de suas etapas.

A disputa pelos sentidos da Constituição mostra-se presente nos discursos que tiveram lugar na Assembleia Nacional Constituinte de 1987/1988 e também nos usos que são feitos do texto constitucional a partir de sua promulgação. A ampliação do direito de greve acabou por corresponder à expansão (qualitativa) das formas de intervenção da Justiça do Trabalho nas greves. Houve uma diversificação nas respostas que a Justiça Especializada tem dado em situações de greve. A Justiça Trabalhista tem tido um papel de destaque no tratamento dos conflitos coletivos, em regra por meio da restrição ao direito de greve.

A greve dos petroleiros de 1995 permite observar esse tipo de ação da Justiça do Trabalho, em especial, do Tribunal Superior do Trabalho.

A compreensão daquele movimento demanda a investigação das negociações coletivas ocorridas em 1994 entre os petroleiros, de um lado, e a Petrobrás e o governo, do outro. Três acordos foram celebrados nesse ano, sendo um deles com o então Presidente da República, Itamar Franco. O cumprimento dos ajustes foi colocado em risco diante das vozes, do próprio governo, que viam neles uma ameaça ao Plano Real, ainda em implantação. Ao final, os ajustes não foram cumpridos pela empresa. Isso esteve na base das negociações coletivas do ano seguinte.

A greve de 1995 teve início em maio, inserida no contexto mais amplo do movimento organizado pela Central Única dos Trabalhadores - CUT, contrariamente às reformas constitucionais anunciadas pelo Presidente da República recém empossado, Fernando Henrique Cardoso. Em pouco tempo, porém, a greve dos petroleiros adquiriu protagonismo - sobretudo diante do recuo da CUT, que passa a se mostrar disposta a negociar 
com o governo as reformas antes divulgadas. Além dos acordos frustrados do ano anterior, havia a questão sensível da quebra do monopólio da Petrobrás, medida anunciada pelo governo e combatida pelos grevistas.

O governo assumiu uma postura rígida com os grevistas da Petrobrás. Não cedeu às reivindicações, não aceitou negociar, determinou o corte de ponto e, mais à frente, recorreu às Forças Armadas para ocupar quatro refinarias. A greve foi marcada pelas notícias veiculadas pela imprensa acerca dos transtornos causados. Rapidamente, o risco de desabastecimento foi anunciado. A possibilidade de racionamento de combustíveis foi admitida pelo governo. Referia-se a "sacrifícios" ao "povo brasileiro". Discutia-se se a greve teria ou não motivação política, buscando colocá-la na ilegalidade.

Como se deu a intervenção da Justiça do Trabalho nesse contexto? O Tribunal Superior do Trabalho foi provocado unilateralmente pela Petrobrás. Primeiro, em caráter liminar, a Presidência da Corte determinou a manutenção de 30\% dos trabalhadores em atividade, sob pena de multa de $\mathrm{R} \$ 100.000,00$ por dia. Foram realizadas tentativas judiciais de conciliação, todas infrutíferas. Em seguida, a Seção de Dissídios Coletivos do Tribunal julgou abusiva e ilegal a greve, determinando o imediato retorno dos grevistas à atividade e mantendo a multa anteriormente imposta. Com relação aos acordos, cujo cumprimento era visado pelos petroleiros, a Corte os reputou inválidos. É importante notar que, até aquele momento, um dos ajustes, que fora celebrado com a própria Petrobrás, não tinha sua validade questionada sequer pela empresa, que, pelo contrário, alegava que já o tinha cumprido.

Há indícios de que o governo efetivamente confiava na declaração de ilegalidade da greve pelo TST, que parecia se mostrar comprometido com a política econômica do Estado e disposto a restringir o exercício do direito de greve. Essa era uma preocupação importante: a definição de limites ao direito de greve. Como interpretar e aplicar o dispositivo constitucional que garantia, em termos bastante amplos, o recurso a esse direito? $\mathrm{O}$ julgamento pelo TST permite observar a intenção de estabelecer tais restrições. Some-se a isso a postura de uma Corte que parecia querer, com sua decisão sobre a greve, dar uma resposta "à sociedade", satisfazendo-a, como uma espécie de justificação da importância da própria existência do Tribunal.

Chama atenção, nas decisões do TST - inclusive na que julgou o recurso das entidades sindicais profissionais - a falta de referência à Constituição. Não há um discurso construído com base nas possibilidades de recurso ao direito de greve a partir do art. $9^{\circ}$ do texto constitucional. Na verdade, no julgamento do dissídio coletivo, despontou o voto enfático do Ministro Armando de Brito, para quem o texto "irresponsável" do art. $9^{\circ}$ da 
Constituição deveria ser alterado, sendo, ainda, uma questão de sobrevivência da "ordem jurídica e (...) das instituições democráticas” a proibição de greves políticas.

É certo que, antes da Constituição de 1988, já se davam as intervenções da Justiça do Trabalho nas greves. Com o novo texto constitucional, porém, essas intervenções se diversificaram e sua análise permite observar o protagonismo da Justiça Especializada no tratamento dos conflitos coletivos por parte do Estado.

A reconstrução dos debates e dos discursos presentes na Assembleia Nacional Constituinte de 1987/1988 leva à pergunta sobre os usos da Constituição. E mais do que isso: em que medida as pretensões de mudança, de ruptura, de reconhecimento de direitos se refletem nos usos que são feitos do texto constitucional pelos tribunais? O exame da greve dos petroleiros de 1995 e das decisões do Tribunal Superior do Trabalho sobre esse conflito permite verificar como o direito de greve reflete a tensão da Constituição de 1988 entre continuidade e ruptura. É emblemática a consideração da greve como uma situação que desafia a lei e a ordem.

A partir da compreensão da função da forma constitucional e, no contexto brasileiro, da Constituição de 1988 no que diz à reformulação da identidade constitucional, faz-se necessário o desenvolvimento de um discurso coerente com seu processo de elaboração, democrático, aberto, participativo e voltado para o futuro. Para tanto, os tribunais assumem um papel de relevo.

As práticas adotadas pela Justiça do Trabalho - imposição de contingentes mínimos de trabalhadores, aplicação de multas, acolhimento de pedidos em ações de interdito proibitório - evidenciam, contudo, que a edição e articulação de uma lei ordinária (a Lei 7.783/1989) tem servido, com frequência, à restrição do direito de greve previsto na Constituição de 1988. São hipóteses em que a lei adquire uma normatividade mais forte do que a do texto constitucional. A permanência da intervenção da Justiça Especializada nas greves, impedindo o desdobramento do conflito, desponta como o indício mais significativo dessa situação. Há um não uso da Constituição, diante dos inúmeros silêncios sobre o art. $9^{\circ}$. É possível se referir a um governo dos juízes se, com essa expressão, se pretender indicar que a gestão dos conflitos coletivos tem passado, em especial, pela Justiça do Trabalho.

Uma das repercussões da decisão do TST na greve de 1995 foi a provocação do Comitê de Liberdade Sindical da Organização Internacional do Trabalho. Examinando o caso, o Comitê destacou a rapidez com que a Justiça do Trabalho foi acionada, impondo condições às partes e colocando na ilegalidade a atuação dos grevistas. Foi indicado o risco ao direito de greve decorrente da possibilidade de provocação unilateral da autoridade pública para que 
essa avoque a solução do conflito. O Comitê recomendou ao governo brasileiro que alterasse a legislação de maneira a que a submissão de conflitos coletivos a autoridades judiciais dependesse de comum acordo entre as partes, ou se tratasse de serviços essenciais em sentido estrito.

Na linha da recomendação do Comitê de Liberdade Sindical da OIT, importante modificação ocorreu na redação do art. 114 do texto constitucional, que passou a condicionar a propositura de dissídio coletivo, na Justiça do Trabalho, ao comum acordo entre as partes envolvidas no conflito. Não obstante, a interpretação dada ao dispositivo tem tornado inócua a inovação. O Tribunal Superior do Trabalho tem firmado o entendimento de que a deflagração da greve, quer se trate ou não de atividade essencial, permite o ajuizamento do dissídio coletivo, independente de comum acordo entre as partes. A greve tornou-se a porta de entrada para a intervenção da Justiça do Trabalho nos conflitos trabalhistas, bastando a provocação por apenas uma das partes ou pelo Ministério Público do Trabalho. Há, pela Justiça Especializada, a rejeição do conflito na sociedade, enquanto sua atuação é justificada a partir de um interesse social criado pela própria decisão judicial e carente de verificação empírica.

É perceptível a premência assumida pela Justiça do Trabalho na solução dos conflitos laborais, que teriam como palco principal de desenlace o processo judicial. Estão implícitas relevantes conotações morais nesse entendimento, como a de que o conflito é algo ruim e que deve ser evitado. Mas os valores do sistema moral (mal/bem) não servem à reprodução do sistema jurídico, nem podem atuar como critério de fundamentação democrática, ou mesmo de preservação da "ordem jurídica".

A sociedade moderna não possui centro nem vértice. Sua característica é a existência de sistemas funcionalmente diferenciados, isto é, especializados em funções muito específicas. Inexiste, porém, uma instância condutora ou dirigente, nem um sistema que seja responsável por assegurar a "paz" na sociedade (por certo, não é essa a função do direito). A diferenciação funcional é incompatível com a imposição de valores absolutos ou superiores (como "interesse social", "segurança nacional" ou a negação de conflitos), na medida em que não há hierarquia entre os sistemas, nem existe um sistema que vincule os demais.

$\mathrm{O}$ aspecto mais relevante da garantia constitucional do direito de greve é o seu caráter procedimental. Não há definição da greve no art. $9^{\circ}$ da Constituição de 1988 . O texto assegura o procedimento de exercício do direito: compete aos trabalhadores decidir quando deflagrar a greve e quais interesses serão por meio dela defendidos. Há aqui uma importante abertura comunicativa. 
O direito de greve comporta várias leituras - direito à violência fundadora do direito, expressão da rebeldia do trabalho, direito de resistência. A greve compartilha dos movimentos sociais o fato de ser uma reação às operações dos sistemas funcionais. Essa reação é engendrada na forma de protesto, de denúncia, de crítica, de reclamação. Ela pode se voltar às organizações econômicas (como a empresa), ao sistema jurídico (sobretudo aos tribunais), à política (e ao Estado), ou a qualquer outra instância decisória. O que é decisivo, em todo caso, é a abertura a possibilidades de comunicação. A particularidade da greve é a circunstância de corresponder a uma reação às operações dos sistemas funcionais e de seus efeitos (como as exclusões, as assimetrias, as diferenças produzidas), e o fato de essa reação ocorrer mediante a ruptura do cotidiano da prestação dos serviços.

É necessário desenvolver um discurso constitucional sobre o direito de greve que seja coerente com essa abertura comunicativa. Volta-se, então, ao início: a questão que se põe diz respeito aos usos da Constituição.

A investigação histórica aqui proposta pretende contribuir com esse intento. A ideia é observar as práticas aqui examinas numa perspectiva de estranhamento.

No desenvolvimento de sua "pré-história" do estranhamento como procedimento literário, o historiador italiano Carlo Ginzburg recorre a um famoso texto de Michel de Montaigne, um ensaio intitulado "Sobre os canibais". Montaigne remete aos relatos sobre os índios brasileiros, contando a história de três deles, que foram levados à França. Ao serem indagados, indicam dois fatos que lhes impressionaram. O primeiro deles é o de que “indivíduos adultos e armados (a guarda suíça) obedecessem a um menino (o rei da França), em vez de escolherem um verdadeiro chefe". O segundo, por sua vez, é assim descrito:

[eles] perceberam que havia entre nós homens cheios até o pescoço de todo tipo de riquezas e que as metades deles estavam mendigando às suas portas, mirradas pela fome e pela pobreza; e achavam estranho que essas metades necessitadas pudessem tolerar tal injustiça e não agarrassem os outros pelo colarinho ou não tocasssem fogo na casa deles.

Em seguida, vem a observação de Carlo Ginzburg:

Os índios brasileiros, incapazes de perceber o óbvio, tinham visto algo que costuma ser ocultado pelo hábito e pela convenção. Essa incapacidade de tomar a realidade como ponto pacífico deliciou Montaigne. Ele estava pronto a se interrogar sobre tudo, incessantemente, dos fundamentos da vida em sociedade aos mínimos detalhes da existência cotidiana. A surpresa dos índios brasileiros demonstrava até que ponto a sociedade européia, marcada pela desigualdade política e econômica, estava distante daquela que 
Montaigne chamava de "ingenuidade original". "Naïf", nativus: o amor de Montaigne por essa palavra e sua respectiva aversão pela artificialidade nos levam ao âmago da noção de estranhamento. Compreender menos, ser ingênuos, espantar-se, são reações que podem nos levar a enxergar mais, a apreender algo mais profundo, mais próximo da natureza. ${ }^{699}$

Parece ser o caso de ver as práticas aqui narradas com olhos estranhados, para evitar os riscos da normalização e da banalização. Ainda como nos sugere Ginzburg, "o estranhamento é um antídoto eficaz contra um risco a que todos nós estamos expostos: o de banalizar a realidade (inclusive nós mesmos)" ${ }^{700}$ É importante voltar-se àquelas práticas e questioná-las, problematizá-las, submetê-las ao debate público e, ainda, observá-las a partir dos desafios da Constituição de 1988.

Em sua leitura do texto de Walter Benjamin, Jacques Derrida observa que a greve geral, que põe em exercício a violência fundadora do direito corresponde ao exercício de um direito concedido para contestar a ordem existente e, assim, originar uma situação na qual se cuidará de fundar um direito novo, com uma nova ordem de leitura. Esta, a estratégia de ruptura interpretativa que pode ensejar o surgimento de novas práticas, de novos discursos, de novas leituras. Nas palavras de Derrida:

(...) há uma possibilidade de "greve geral", um direito análogo ao da greve geral, em toda leitura interpretativa, o direito de contestar a ordem estabelecida em sua mais forte autoridade, o Estado. Temos o direito de suspender a autoridade legitimadora e todas as suas normas de leitura, e isso nas leituras mais finas, mais eficazes, mais pertinentes, que evidentemente se explicam por vezes com o ilegível, para fundar uma nova ordem de leitura, um outro Estado, por vezes sem o fazer ou para não o fazer.

(...)

Pois há algo como uma greve geral, e portanto algo de revolucionário em toda leitura instauradora, que permanecerá ilegível com relação aos cânones estabelecidos e às normas de leitura, isto é, ao estado presente da leitura ou àquilo que representa o Estado, com maiúscula, no estado da leitura possível. $^{701}$

${ }^{699}$ GINZBURG, Carlo. "Estranhamento - Pré-história de um procedimento literário”. In: Olhos de madeira: nove reflexões sobre a distância. Trad. de Eduardo Brandão. São Paulo: Companhia das Letras, 2001, p. 29.

${ }^{700}$ GINZBURG, Carlo. "Estranhamento - Pré-história de um procedimento literário”, p. 28 e 41.

${ }^{701}$ DERRIDA, Jacques. Força de Lei - o "Fundamento místico da autoridade”, p. 87/88. 


\section{$\underline{\text { Referências }}$}

\section{Livros e artigos:}

ABRAMO, Laís Wendel. O resgate da dignidade: greve metalúrgica e subjetividade operária. Campinas, SP: Editora da Unicamp, São Paulo, OS: Imprensa Oficial, 1999;

ALDAY, Rafael Escudero. "La sombra del franquismo es alargada: el fracaso de la llamada Ley de Memoria Histórica". In:LOPEZ, Federico Fernández-Crehuet. LOPEZ,DanielJ. Garcia (ed.). Derecho, memoria histórica y díctaduras. Granada: Editorial Comares, 2009, pp. 33-60;

ANTUNES, Ricardo. A rebeldia do trabalho - o confronto operário do ABC paulista: as greves de 1978/1980. $2^{\mathrm{a}}$ ed. Campinas: Unicamp, 1992;

ANTUNES, Ricardo. O Novo Sindicalismo no Brasil. Campinas: Pontes, 1995;

ANTUNES, Ricardo, O Novo Sindicalismo no Brasil. Campinas: Pontes, 1995;

ARENDT, Hannah. Sobre a Revolução. Trad. de I. Morais. Lisboa: Antropos, 2001;

BARBOSA, Leonardo Augusto de Andrade. Mudança Constitucional, Autoritarismo e Democracia no Brasil Pós-1964. Tese (Doutorado em Direito, Estado e Constituição). Faculdade de Direito da Universidade de Brasília. Brasília, 2009;

BAYLOS, Antonio. "Sobre el Derecho a Huelga". Entrevista concedida à Fundação Sol. Tradução livre. Disponível em http://www.fundacionsol.cl/sobre-el-derecho-a-huelga (acesso em 23.4.2011);

BENJAMIN, Walter. "Critique de la violence". In: Oeuvres. Tome I. Trad. de Maurice de Gandillac, Rainer Rochlitz e Pierre Rusch. Paris: Gallimard, 2000, pp. 210/243;

BENJAMIN, Walter. "Para una crítica de la violencia". In: Conceptos de filosofia de la historia. $1^{\mathrm{a}}$ ed. La Plata: Terramar, 2007, pp. 113/138;

BÖCKENFÖRD, Ernst-Wolfgang. "La constitución: entre la historia y el derecho". Entrevista con E-W Böckenförd, por Joaquín Valera Suanzes-Carpegna. Trad. por Benito Alaez Corral. In: Historia constitucional - revista eletrônica, $\mathrm{n}^{\mathrm{o}}$ 5, 2004 - disponível em http://hc.rediris.es/05/indice.html, acesso em 10.4.2013;

BOITO JR., Armando. O sindicalismo de Estado no Brasil - uma análise crítica da estrutura sindical. Campinas: Editora da Unicamp, São Paulo: Hucitec, 1991;

BOITO JR., Armando. "Neoliberalismo e corporativismo de Estado no Brasil". In: ARAÚJO, Angela Maria Carneiro. Do corporativismo ao neoliberalismo - Estado e trabalhadores no Brasil e na Inglaterra. Boitempo: São Paulo, 2002;

BONAVIDES, Paulo e ANDRADE, Paes de. História Constitucional do Brasil. $8^{\mathrm{a}}$ ed. Brasília: OAB Editora, 2006; 
BRASIL, Programa de História Oral do Tribunal Superior do Trabalho. Transcrição da entrevista do projeto de história oral do TST. Ministro Marcelo Pimentel. Transcrição de Luiza Brito Lemos. Brasília, 11.6.2012 (disponível em http:// www.tst.jus.br/documents/10157/3517647/Transcri\%C3\%A7\%C3\%A3o+da+Entrevista+do+ Projeto+de+Hist $\% \mathrm{C} 3 \% \mathrm{~B} 3$ ria+Oral+do+TST+- + REVISADO+PELO+Ministro+Marcelo+Pi mente+21.pdf - acesso em 13.1.2014);

BREDEKAMP, Horst. "From Walter Benjamin to Carl Schmitt, via Thomas Hobbes". Trad. Melissa Thorson Hause e Jackson Bond. In: Critical Inquiry, Vol. 25, n. 2, "Angelus Novus": Perspectives on Walter Benjamin), Winter, 1999, pp. 247/266;

CAMPILONGO, Celso. "Governo representativo 'versus' governo dos juízes: a 'autopoiese' dos sistemas político e jurídico". In: O direito na sociedade complexa. São Paulo: Max Limonad, 2000, pp. 79/87;

CAMPILONGO, Celso. Política, sistema jurídico e decisão judicial. São Paulo: Max Limonad, 2002;

CAMPILONGO, Celso. “'Aos que não vêem que não vêem aquilo que não vêem': sobre fantasmas vivos e a observação do direito como sistema diferenciado". In: DE GIORGI, Raffaele. Direito, Tempo e Memória - Apresentação. Trad. de Guilherme Leite Gonçalves. São Paulo: Quartier Latin, 2006, pp. 11/26;

CAMPILONGO, Celso. Interpretação do direito e movimentos sociais. Rio de Janeiro: Elsevier, 2012;

CARDOSO, Adalberto Moreira. A trama da modernidade: pragmatismo sindical $e$ democratização no Brasil. Rio de Janeiro: Revan: IUPERJ-UCAM, 1999;

CARVALHO NETTO, Menelick de. "A Revisão Constitucional e a Cidadania: A Legitimidade do Poder Constituinte que deu Origem à Constituição da República Federativa de 1988 e as Potencialidades do Poder Revisional Nela Previsto". In: Fórum Administrativo. Ano I. N ${ }^{\circ}$ 7. Belo Horizonte: Setembro de 2001;

CARVALHO NETTO, Menelick. "A urgente revisão da teoria do poder constituinte: da impossibilidade da democracia possível" (Prefácio). In: CATTONI, Marcelo. Poder constituinte. Belo Horizonte: Mandamentos, 2006;

CARVALHO NETTO, Menelick de, e PAIXÃO, Cristiano. "Entre permanência e mudança: reflexões sobre o conceito de constituição". In: MOLINARO, Carlos Alberto; MILHORANZA, Mariângela Guerreiro; PORTO, Sérgio Gilberto (Coords.). Constituição, jurisdição e processo: estudos em homenagem aos 55 anos da Revista Jurídica. Sapucaia do Sul: Notadez, 2007;

CARVALHO NETTO, Menelick de, e SCOTTI, Guilherme. Os direitos fundamentais e a (in) certeza do direito: a produtividade das tensões principiológicas e a superação do sistema de regras. Belo Horizonte: Fórum, 2011;

CITELLI, Adílson Odair. "Palavras de ordem: a greve dos petroleiros e a reportagem que não houve”. In: Comunicação e Educação. São Paulo (4): 82 a 89, set/dez de 1995; 
COELHO, João Gilberto Lucas. "O processo constituinte". In: GURAN, Milton (coord. editorial). O processo constituinte 1987-1988. Brasília: AGIL, 1988;

COMPARATO, Fábio Konder. Muda Brasil - uma constituição para o desenvolvimento democrático. São Paulo: Brasiliense, 1986;

CORSI, Giancarlo. "Sociologia da Constituição". Trad. Juliana N. Magalhães. In: Revista da Faculdade de Direito da UFMG. N 39. Belo Horizonte: UFMG, janeiro-junho de 2001;

COSENZA, Ana. "Representações da greve dos petroleiros de 1995 na imprensa: as referências ao período militar e à democracia no discurso jornalístico". In: Proj. História, São Paulo, (29), tomo 1, p. 303-312, dez. 2004;

COSTA, Orlando Teixeira da. "Do abuso de direito na greve". In: Revista do Tribunal Superior do Trabalho, vol. 58, 1989;

DE GIORGI, Raffaele. "Democracia, parlamento e opinião pública". In: Direito, Democracia e Risco - vínculos com o futuro. Porto Alegre: Sérgio Antonio Fabris Editor, 1998, pp. 35/47;

DE GIORGI, Raffaele. "Problemas da governabilidade democrática". In: Direito, Democracia e Risco - vínculos com o futuro. Porto Alegre: Sérgio Antonio Fabris, 1998, pp. 49/64;

DE GIORGI, Raffale. “A Memória do Direito”. In: Direito, Tempo e Memória. Trad. de Guilherme Leite Gonçalves. São Paulo: Quartier Latin, 2006, pp. 49/73;

DE GIORGI, Raffaele. "Condições de descrição da complexidade na sociedade mundial". In: Direito, tempo e memória. Trad. de Guilherme Leite Gonçalves. São Paulo: Quartier Latin, 2006, pp. 205/221;

DERRIDA, Jacques. Força de lei: o fundamento místico da autoridade. Trad. de Leyla Perrone-Moisés. São Paulo: WMF Martins Fontes, 2007;

DIPPEL, Horst. "Constitucionalismo moderno. Introducción a uma historia que necesita ser escrita”. In: Historia Constitucional - revista electrônica, n. 6, 2005 - disponível em http://hc.rediris.es/06/index.html - acesso em 10.4.2013;

FARIA, José Eduardo. A crise constitucional e a restauração da legitimidade. Porto Alegre: Sergio Antonio Fabris Editor, 1985;

FERNANDES, Florestan. A Constituição inacabada. São Paulo: Estação Liberdade, 1989;

FONSECA, Ricardo Marcelo. Introdução teórica à história do direito. $1^{\mathrm{a}}$ ed., $2^{\mathrm{a}}$ reimpressão, Curitiba: Juruá, 2011;

FRAGOSO, Christiano. Repressão Penal da Greve: uma experiência antidemocrática. São Paulo: IBCCRIM, 2009; 
FREITAS, Lígia Barros de. A consolidação institucional do Tribunal Superior do Trabalho (TST) na longa constituinte (1987-2004). Tese de Doutorado. Universidade Federal de São Carlos, 2012;

GAGNEBIN. Jeanne Marie. História e narração em Walter Benjamin. São Paulo: Perspectiva, 2007;

GINZBURG, Carlo. "Checking the Evidence: The Judge and the Historian". In: Critical Inquiry. Vol. 18, N. 1, (Outono, 1991), pp. 79/92;

GINZBURG, Carlo. The Judge and the Historian - marginal notes on a late-twentiethcentury miscarriage of justice. Translated by Antony Shugaar. New York: Verso, 1999;

GINZBURG, Carlo. "Estranhamento - Pré-história de um procedimento literário". In: Olhos de madeira: nove reflexões sobre a distância. Trad. de Eduardo Brandão. São Paulo: Companhia das Letras, 2001;

GRACIOLLI, Edílson José. Um caldeirão chamado CSN - resistência operária e violência militar na greve em 1988. Uberlândia: Editora da Universidade Federal de Uberlândia, 1997;

GRECO, Heloisa Amélia. "Esquecimento, Instituinte vs. Instituído: a luta pela Anistia ampla, geral e irrestrita". In: H. R. Kleber da Silva. A luta pela anistia. São Paulo: Editora Unesp/Arquivo Público do Estado de São Paulo/Imprensa Oficial do Estado de São Paulo, 2009;

GROSSI, Paolo. Mitologias jurídicas da modernidade. Trad. de Arno Dal Ri Júnior. Florianópolis: Fundação Boiteux, 2004;

HABERMAS, Jürgen. Direito e Democracia - entre facticidade e validade. Vol. II. Trad. de Flávio Beno Siebeneichler. Rio de Janeiro: Tempo Brasileiro, 1997;

HESPANHA, Antonio Manuel. Cultura Jurídica Européia - Síntese de um Milênio. Florianópolis: Fundação Boiteux, 2005;

HESPANHA, António Manuel. "Governo da lei ou governo dos juízes? O primeiro século do Supremo Tribunal de Justiça em Portugal”. In: História Constitucional, n. 12, 2011, pp. 203237 (disponível em www.historiaconstitucional.com - acesso em 10.4.2013);

HOBSBAWM, Eric. J. Mundos do Trabalho - novos estudos sobre história operária. São Paulo: Paz e Terra, 2005;

HONNETH, Axel. "Saving the sacred with a philosophy of history - on Benjamin's 'Critique of Violence'". In: Pathologies of Reason - On the Legacy of Critical Theory. Trad. James Ingram e outros. New York: Columbia University Press, 2009, pp. 88/125;

LE GOFF, Jacques. “As mentalidades: uma história ambígua”. In: LE GOFF, Jacques. NORA, Pierre (orgs.). História: novos objetos. Trad. Terezinha Marinho. Rio de Janeiro: Francisco Alves, 1995; 
LOURENÇO FILHO, Ricardo. Liberdade sindical: percursos e desafios na história constitucional brasileira. São Paulo: LTr, 2011;

LUHMANN, Niklas. "Causalidade no Sul". Trad. de Menelick de Carvalho Netto (para fins acadêmicos). In: Revista de Teoria Sociológica. Universidade de Bielefeld, Alemanha, s/d;

LUHMANN, Niklas. The differenciation of society. Trad. de Stephen Holmes e Charles Larmore. New York: Columbia University Press, 1982;

LUHMANN, Niklas. Sociologia do Direito. Vol. I. Trad. de Gustavo Bayer. Rio de Janeiro: Tempo Brasileiro, 1983;

LUHMANN, Niklas. Sociologia do Direito. Vol. II. Trad. Gustavo Bayer. Rio de Janeiro: Tempo Brasileiro, 1985;

LUHMANN, Niklas. "A posição dos tribunais no sistema jurídico". In: Revista da Ajuris. N. 49. Porto Alegre: Ajuris, julho de 1990. Trad. de Peter Naumann;

LUHMANN, Niklas. "El derecho como sistema social". In: No Hay Derecho. Ano V, n 11. Buenos Aires: Agosto - Outubro de 1994 (Trad. de Paulo Sávio Peixoto Maia, para fins acadêmicos);

LUHMANN, Niklas. "La costituzione come acquisizione evolutiva". In: ZAGREBELSKY, Gustavo, PORTINARO, Píer Paolo, LUTHER, Jörg (Orgs.). Il Futuro della Constituzione. Torino: Einaudi, 1996, pp. 83/128;

LUHMANN, Niklas. Teoría Política en el Estado de Bienestar. Introdução e tradução de Fernando Vallespín. Madrid: Alianza Editorial, 1997;

LUHMANN, Niklas. "Globalization or world society: how to conceive of modern society?". In: International Review of Sociology of Law, março de 1997, vol. 7, item 1 (manuscrito);

LUHMANN, Niklas, e DE GIORGI, Raffaele. Teoria della società. $11^{\circ}$ ed. Milano, Italy: FrancoAngeli, 2003;

LUHMANN, Niklas. El derecho de la sociedad. Trad. de Javier Torres Nafarrate, con la colaboración de Brunhilde Erker, Silvia Pappe y Luis Felipe Segura. México: Herder, 2005, 2a edição;

LUHMANN, Niklas. Risk: a sociological theory. New York: A. de Gruyter, 2006;

LUHMANN, Niklas. La sociedad de la sociedad. Trad. de Javier Torres Nafarrate. México: Herder e Universidad Iberoamericana, 2007;

MADDOX, Graham. "Constitution”. In: BALL, Terence; FARR, James; HANSON, Russell L. Political innovation and conceptual change. New York: Cambridge University Press, 1995;

MANGABEIRA, Wilma. Dilemas do novo sindicalismo: democracia e política em Volta Redonda. Trad. de Vera Pereira. Rio de Janeiro: Relume-Dumará: ANPOCS, 1993; 
MARTINS, Heloísa de Souza \& RODRIGUES, Iram Jácome. "O sindicalismo brasileiro na segunda metade dos anos 90". In: Tempo Social. Rev. Sociol. USP, São Paulo, 11 (2): 155182, out.1999 (editado em fev. 2000);

MARTINS, Ives Gandra da Silva. "A estabilidade das instituições e a nova Constituição". Manuscrito de 4.11.1988 (disponível em http://www.gandramartins.adv.br/artigo/index/p/137 - acesso em 13.7.2013);

MAUS, Ingeborg. "Judiciário como superego da sociedade - o papel da atividade jurisdicional na 'sociedade órfâ'". In: Novos estudos, Trad. de Martonio Lima e Paulo Albuquerque. N. 58, novembro de 2000, pp. 183/202;

MEZAROBBA, Glenda. “Anistia e reparação: uma combinação imprópria”. In: H. R. Kleber da Silva. A luta pela anistia. São Paulo: Editora Unesp/Arquivo Público do Estado de São Paulo/Imprensa Oficial do Estado de São Paulo, 2009;

MICHILES, Carlos et al. Cidadão constituinte: a saga das emendas populares. Rio de Janeiro: Paz e Terra, 1989;

MONCLAIRE, Stéphane (Coord.). A constituição desejada - SAIC: as 72.719 sugestões enviadas pelos cidadãos brasileiros à Assembléia Nacional Constituinte. Brasília: Senado Federal, Centro Gráfico, 1991;

MOREIRA ALVES, Maria Helena. Estado e Oposição no Brasil (1964-1984). Bauru, SP: EDUSC, 2005;

NEVES, Marcelo. Entre Têmis e Leviatã: uma relação difícil. São Paulo: Martins Fontes, 2006;

NEVES, Marcelo. A constitucionalização simbólica. São Paulo: WMF Martins Fontes, 2007;

NEVES, Marcelo. "The symbolic force of human rights". In: Philosophy \& Social Criticism. Vol. 33, n 4, 2007;

NEVES, Paulo S. C. "O sindicalismo na indústria petrolífera no Brasil: tendências recentes". In: Scripta Nova - Revista Electrónica de Geografía y Ciencias Sociales. Universidad de Barcelona. ISSN: 1138-9788. Depósito Legal: B. 21.741-98. Vol. VI, núm. 119 (101), 1 de agosto de 2002 (documento eletrônico);

NORONHA, Eduardo. "A explosão das greves na década de 80”. In: BOITO JR., Armando (Org.). O Sindicalismo brasileiro nos anos 80. Rio de Janeiro: Paz e Terra, 1991;

OLIVEIRA, Francisco de. "A derrota da vitória: a contradição do absolutismo de FHC". In: Novos Estudos CEBRAP, n. 50, março de 1998, pp. 13-21;

OLIVEIRA, Mauro Márcio. Fontes de informações sobre a Assembléia Nacional Constituinte de 1987 - quais são, onde buscá-las e como usá-las. Brasília: Senado Federal, Subsecretaria de Edições Técnicas, 1993; 
ORGANIZAÇÃO INTERNACIONAL DO TRABALHO. Caso número 1839 (Brasil): 300. Informe del Comité de Libertad Sindical. 264 Reunión del Consejo de Administración. Genebra: $\quad$ OIT, $1995 \quad$ (disponível em http://www.ilo.org/dyn/normlex/es/f?p=1000:50002:0::NO:50002:P50002_COMPLAINT_TE XT_ID:2903565\#1, acesso em 11.4.2014);

ORGANIZAÇÃO INTERNACIONAL DO TRABALHO. O direito coletivo, a liberdade sindical e as normas internacionais. Vol. II. Trad. e revisão técnica de Kelly Karoline Bepe Fernandes, Sandro Lunard Nicoladeli e Tatyana Scheila Friedrich. São Paulo: LTr, 2013;

PAIXÃO, Cristiano. Modernidade, Tempo e Direito. Belo Horizonte: Del Rey, 2002;

PAIXÃO, Cristiano. "Os problemas de legitimação no capitalismo tardio e a crise do Estado do Bem-Estar Social. In: SOUSA JUNIOR, José Geraldo (Org.). Na Fronteira: Conhecimento e Práticas Jurídicas para a Solidariedade Emancipatória. Porto Alegre: Síntese, 2003;

PAIXÃO, Cristiano, e BIGLIAZZI, Renato. História constitucional inglesa e norteamericana: do surgimento à estabilização da forma constitucional. Brasília: Editora UnB: Finatec, 2008;

PAIXÃO, Cristiano, e BARBOSA, Leonardo Augusto de Andrade. "Cidadania, democracia e Constituição: o processo de convocação da Assembleia Nacional Constituinte de 1987-1988". In: DIAS, Maria Tereza Fonseca. e PEREIRA, Flávio Henrique Unes. Cidadania e Inclusão Social - Estudos em homenagem à Professora Miracy Barbosa de Sousa Gustin. Belo Horizonte: Fórum, 2009;

PAIXÃO, Cristiano, LOURENÇO FILHO, Ricardo. “A greve e sua conformação pelo TST: desvelando mentalidades". In: MELO FILHO, Hugo Cavalcanti... [et. al.]. $O$ mundo do trabalho, volume I: leituras críticas da jurisprudência do TST: em defesa do direito do trabalho. São Paulo: LTr, 2009, pp. 65/76;

PAIXÃO, Cristiano, LOURENÇO FILHO, Ricardo. "Greve como prática social: possibilidades de reconstrução do conceito a partir da Constituição de 1988". In: SENA, Adriana Goulart de, DELGADO, Gabriela Neves, e NUNES, Raquel Portugal. Dignidade humana e inclusão social: caminhos para a efetividade do direito do trabalho no Brasil. São Paulo: LTr, 2010;

PAIXÃO, Cristiano, LOURENÇO FILHO, Ricardo. "Direito de greve, interditos proibitórios e a centralidade do direito de propriedade: uma visão crítica da orientação do TST" In: COUTINHO, Grijalbo Fernandes, FAVA, Marcos Neves (coordenadores). O que estão fazendo da nova competência Justiça do Trabalho? Análise crítica da jurisprudência do STF, TST e do STJ após a EC 45/2004. São Paulo: LTr, 2011, pp. 319/335;

PAIXÃO, Cristiano, e LOURENÇO FILHO, Ricardo. "Direito de greve entre afirmação e repressão: o caso CSN". In: DELGADO, Gabriela Neves, e PEREIRA, Ricardo José Macêdo de Britto (orgs.). Trabalho, constituição e cidadania: a dimensão coletiva dos direitos sociais trabalhistas. São Paulo: LTr, 2014, pp. 331/347; 
PAIXÃO, Cristiano. "Autonomia, democracia e poder constituinte: disputas conceituais na experiência constitucional brasileira (1964-2014)". In: Quaderni Fiorentini - per la storia del pensiero giuridico moderno. N ${ }^{\circ}$ XLIII, tomo I. Giuffrè Editore, 2014, pp. 415/458.

PAZZIANOTTO PINTO, Almir. "O governo, a OIT e a Justiça do Trabalho". In: Síntese Trabalhista, ano VII, nº 84, junho de 1996, pp. 126/128;

PEREIRA, Anthony. Ditadura e repressão: o autoritarismo e o estado de direito no Brasil, no Chile e na Argentina. Tradução de Patricia Queiroz Carvalho Zimbres. São Paulo: Paz e Terra, 2010;

PILATTI, Adriano. A Constituinte de 1987-1988 - Progressistas, conservadores, ordem econômica e regras do jogo. Rio de Janeiro: Editora Lumen Juris, 2008;

PIMENTEL, Marcelo. “A Nova Constituição e suas implicações na legislação trabalhista brasileira". In: Revista do Tribunal Superior do Trabalho, vol. 57, 1988, p. 69/77;

POLANYI, Karl. A grande transformação: as origens da nossa época. Trad. de Fanny Wrobel. Rio de Janeiro: Campus, 1980;

REALE, Miguel. “Ainda as greves selvagens". Manuscrito de 9.10.2004 (disponível em www.miguelreale.com.br - acesso em 13.7.2013);

REIS, Daniel Aarão. Ditadura e democracia no Brasil: do golpe de 1964 à Constituição de 1988. $1^{\text {a }}$ ed. Rio de Janeiro: Zahar, 2014;

ROCHA, Leonel Severo. "Os senhores da lei”. In: Epistemologia jurídica e democracia. 2a ed. São Leopoldo: Ed. Unisinos, 2003;

RODRIGUES, Leôncio Martins. "A composição social das lideranças do PT". In: Partidos e Sindicatos - escritos de sociologia política. São Paulo: Ática, 1990;

RODRIGUES, Leôncio Martins. "As tendências políticas na formação das centrais sindicais". In: BOITO JR., Armando (Org.). O Sindicalismo brasileiro nos anos 80. Rio de Janeiro: Paz e Terra, 1991;

RODRIGUEZ, José Rodrigo. Dogmática da Liberdade Sindical - Direito, Política, Globalização. Rio de Janeiro: Renovar, 2003;

ROMÃO, Frederico Lisboa. A greve do fim do mundo: petroleiros 1995 - expressão fenomênica da crise fordista no Brasil. Tese de Doutorado. Universidade Estadual de Campinas, Instituto de Filosofia e Ciências Humanas, [s.n.], 2006;

ROSENFELD, MICHEL. A identidade do sujeito constitucional. Tradução de Menelick de Carvalho Netto. Belo Horizonte: Mandamentos, 2003;

ROSENFELD, Michel. "The problem of 'identity' inconstitution - making and constitutional reform". Manuscrito; 
SALES, Jean Rodrigues. "Ditadura militar, anistia e a construção da memória social". In: H. R. Kleber da Silva. A luta pela anistia. São Paulo: Editora Unesp/Arquivo Público do Estado de São Paulo/Imprensa Oficial do Estado de São Paulo, 2009;

SARASOLA, Ignacio Fernández. "La historia constitucional: método e historiografía a la luz de um bicentenario Hispánico”. In: FHI-Forum historiae iuris, n.11, jun. 2009;

SCHUBSKY, Cássio, BIERRENBACH, Flávio, AFFONSO, Almino. Estado de direito já!: os trinta anos da Carta aos Brasileiros. São Paulo: Lettera.doc., 2007;

SEELAENDER, Airton Cerqueira Leite. "Juristas e Ditaduras: uma leitura brasileira". In: FONSECA, Ricardo Marcelo, e SEELAENDER, Airton Cerqueira Leite (Orgs.). História do Direito em perspectiva. Curitiba: Juruá, 2009, pp. 415-432;

SILVA, Sayonara Grillo Coutinho Leonardo de. Relações coletivas de trabalho. São Paulo: LTr, 2008;

SKIDMORE, Thomas. Brasil: de Castelo a Tancredo, 1964-1985. Trad. de Mario Salviano Silva. Rio de Janeiro: Paz e Terra, 1988;

SOREL, Georges. Reflexões sobre a violência. Trad. de Paulo Neves. São Paulo: Martins Fontes, 1992;

SOUSA, Nair Heloísa Bicalho de. "Novos sujeitos sociais: a classe trabalhadora na cena histórica contemporânea". In: SOUSA JÚNIOR, José Geraldo e AGUIAR, Roberto A. R (Orgs.). Introdução Crítica ao Direito do Trabalho. Brasília: Universidade de Brasília, 1993 (Série o direito achado na rua, vol. II);

SUANZES-CARPEGNA, Joaquín Varela. "Algumas reflexões metodológicas sobre a história constitucional”. In: RIHGB, a. 169 (440):09-28, jul/set, 2008;

SUPIOT, Alain. Critique du droit du travail. Paris: Quadrige/PUF, 2007;

TAVARES DE ALMEIDA, Maria Hermínia. Crise Econômica e Interesses Organizados: $O$ sindicalismo no Brasil nos anos 80. São Paulo: Editora da Universidade de São Paulo, 1996;

TEIXEIRA DA SILVA, Francisco Carlos. "Brasil, em direção ao século XXI". In: LINHARES, Maria Yedda (org.). História geral do Brasil. 9a ed. Rio de Janeiro: Elsevier, 1990, 15ª reimpressão;

TEUBNER, Gunther. "Self-subversive Justice: Contingency or Transcendence Formula of Law?”. In: Modern Law Review, nº 72, 2009, pp. 1-23;

VEIGA, Sandra Mayrink, e FONSECA, Isaque. Volta Redonda, entre o aço e as armas. Petrópolis-RJ: Vozes, 1989;

VIANA, Márcio Túlio. Direito de resistência: possibilidades de autodefesa do empregado em face do empregador. São Paulo: LTr, 1996; 
VIANA, Márcio Túlio. "Conflitos coletivos de trabalho". In: Revista do TST. Brasília, vol. 66, $\mathrm{n}^{\mathrm{o}} 1$, jan/mar de 2000, pp. 116/150;

VIANA, Márcio Túlio. "Da greve ao boicote: os vários significados e as novas possibilidades das lutas operárias". In: DA SILVA, Alessandro; SOUTO MAIOR, Jorge Luiz; FELIPPE, Kenarik Boujikian; e SEMER, Marcelo (coordenadores.). Direitos Humanos: essência do direito do trabalho. São Paulo: LTr, 2007, pp. 88/95;

VIANNA, Oliveira. "Exposição de Motivos da Comissão elaboradora do Projeto de Organização da Justiça do Trabalho". In: Problemas de Direito Corporativo. $2^{\mathrm{a}}$ Ed. Brasília: Câmara dos Deputados, 1983;

WEFFORT, Francisco. "Participação e conflito industrial: Contagem e Osasco, 1968". In: Cadernos Cebrap 05. São Paulo: Cebrap, 1972;

ZAGREBELSKY, Gustavo. Historia y constitución. Tradução de Miguel Carbonell. Madrid: Minima Trotta, 2005;

ZAVERUCHA, Jorge. "Relações civil-militares: o legado autoritário da Constituição brasileira de 1988". In: TELES, Edson; SAFATLE, Wladmir (Orgs.). O que resta da ditadura: a exceção brasileira. São Paulo: Boitempo, 2010, pp. 41/76.

\section{Diários:}

BRASIL. Diário do Congresso Nacional. Seção I, de 18 de abril de 1964;

BRASIL. Diário do Congresso Nacional (Seção I). Brasília, 7 de agosto de 1986;

BRASIL. Diário do Congresso Nacional (Seção I). Brasília, 19 de junho de 1987;

BRASIL. Diário da Assembleia Nacional Constituinte, vol. 330, Resolução no 2/1987, Brasília, Centro Gráfico do Senado Federal, 1987;

BRASIL. Assembleia Nacional Constituinte. Ata da $2^{a}$ Reunião da Comissão da Ordem Social. Brasília: Senado Federal, 1987;

BRASIL. Assembleia Nacional Constituinte. Ata da $3^{a}$ Reunião da Subcomissão dos Direitos dos Trabalhadores e Servidores Públicos. Brasília: Senado Federal, 1987, documento eletrônico;

BRASIL. Assembleia Nacional Constituinte. Ata da $4^{a}$ Reunião da Subcomissão dos Direitos dos Trabalhadores e Servidores Públicos. Brasília: Senado Federal, 1987, documento eletrônico;

BRASIL. Assembleia Nacional Constituinte. Ata da $5^{a}$ Reunião da Subcomissão dos Direitos dos Trabalhadores e Servidores Públicos. Brasília: Senado Federal, 1987;

BRASIL. Assembleia Nacional Constituinte. Ata da $7^{a}$ Reunião da Subcomissão dos Direitos dos Trabalhadores e Servidores Públicos. Brasília: Senado Federal, 1987, documento eletrônico; 
BRASIL. Assembleia Nacional Constituinte. Ata da $8^{a}$ Reunião da Subcomissão dos Direitos dos Trabalhadores e Servidores Públicos. Brasília: Senado Federal, 1987, documento eletrônico

BRASIL. Assembleia Nacional Constituinte. Ata da $10^{a}$ Reunião da Subcomissão dos Direitos dos Trabalhadores e Servidores Públicos. Brasília: Senado Federal, 1987, documento eletrônico

BRASIL. Assembleia Nacional Constituinte. Ata da $12^{a}$ Reunião da Subcomissão dos Direitos dos Trabalhadores e Servidores Públicos. Brasília: Senado Federal, 1987, documento eletrônico;

BRASIL. Assembleia Nacional Constituinte. Ata da $13^{a}$ Reunião da Subcomissão dos Direitos dos Trabalhadores e Servidores Públicos. Brasília: Senado Federal, 1987, documento eletrônico;

BRASIL. Assembleia Nacional Constituinte. Ata da $14^{a}$ Reunião da Subcomissão dos Direitos dos Trabalhadores e Servidores Públicos. Brasília: Senado Federal, 1987, documento eletrônico

BRASIL. Assembleia Nacional Constituinte. Ata da $16^{a}$ Reunião da Subcomissão dos Direitos dos Trabalhadores e Servidores Públicos. Brasília: Senado Federal, 1987, documento eletrônico;

BRASIL. Assembleia Nacional Constituinte. Ata da 20a Reunião da Subcomissão dos Direitos dos Trabalhadores e Servidores Públicos. Brasília: Senado Federal, 1987, documento eletrônico;

BRASIL. Assembleia Nacional Constituinte. Ata da 24a Reunião da Subcomissão dos Direitos dos Trabalhadores e Servidores Públicos. Brasília: Senado Federal, 1987, documento eletrônico;

BRASIL. Assembleia Nacional Constituinte. Ata da 25a Reunião da Subcomissão dos Direitos dos Trabalhadores e Servidores Públicos. Brasília: Senado Federal, 1987, documento eletrônico;

BRASIL. Assembleia Nacional Constituinte. Ata da $10^{a}$ Reunião da Subcomissão dos Direitos Políticos, dos Direitos Coletivos e Garantias. Brasília: Senado Federal, 1987, documento eletrônico;

BRASIL. Assembleia Nacional Constituinte. Ata da $16^{a}$ Reunião da Subcomissão dos Direitos Políticos, dos Direitos Coletivos e Garantias. Brasília: Senado Federal, 1987, documento eletrônico;

BRASIL. Assembleia Nacional Constituinte. Comissão da Soberania e dos Direitos e Garantias do Homem e da Mulher. Subcomissão dos Direitos Políticos, dos Direitos Coletivos e Garantias. Vol. 74. Brasília: Centro Gráfico do Senado Federal, 1987; 
BRASIL. Assembleia Nacional Constituinte. Comissão da Soberania e dos Direitos e Garantias do Homem e da Mulher. Subcomissão dos Direitos Políticos, dos Direitos Coletivos e Garantias. Vol. 77. Brasília: Centro Gráfico do Senado Federal, 1987;

BRASIL. Assembleia Nacional Constituinte. Ata da $12^{a}$ Reunião da Subcomissão dos Direitos e Garantias Individuais. Brasília: Senado Federal, 1987, documento eletrônico;

BRASIL. Assembleia Nacional Constituinte. Ata da 26a Reunião da Subcomissão dos Direitos e Garantias Individuais, Brasília: Senado Federal, 1987, documento eletrônico;

BRASIL. Assembleia Nacional Constituinte. Comissão da Soberania e dos Direitos e Garantias do Homem e da Mulher. Subcomissão dos Direitos e Garantias Individuais. Vol. 78. Brasília: Centro Gráfico do Senado Federal, 1987;

BRASIL. Assembleia Nacional Constituinte. Comissão da Ordem Social. Subcomissão dos Direitos dos Trabalhadores e Servidores Públicos, vol. 188, Brasília, Centro Gráfico do Senado Federal, 1987;

BRASIL. Assembleia Nacional Constituinte. Comissão da Ordem Social. Subcomissão dos Direitos dos Trabalhadores e Servidores Públicos, vol. 190, Brasília, Centro Gráfico do Senado Federal, 1987

BRASIL. Assembleia Nacional Constituinte. Comissão da Ordem Social. Subcomissão dos Direitos dos Trabalhadores e Servidores Públicos, vol. 191, Brasília, Centro Gráfico do Senado Federal, 1987;

BRASIL. Assembleia Nacional Constituinte. Ata da $2^{a}$ Reunião da Comissão da Ordem Social. Brasília: Senado Federal, 1987, documento eletrônico;

BRASIL. Assembleia Nacional Constituinte. Ata da $5^{a}$ Reunião da Comissão da Ordem Social. Brasília: Senado Federal, 1987, documento eletrônico;

BRASIL. Assembleia Nacional Constituinte. Ata da $9^{a}$ Reunião da Comissão da Ordem Social. Brasília: Senado Federal, 1987, documento eletrônico;

BRASIL. Assembleia Nacional Constituinte. Comissão da Ordem Social, vol. 183, Brasília, Centro Gráfico do Senado Federal, 1987;

BRASIL. Assembleia Nacional Constituinte. Comissão da Ordem Social, vol. 185, Brasília, Centro Gráfico do Senado Federal, 1987;

BRASIL. Assembleia Nacional Constituinte. Comissão da Ordem Social, vol. 186, Brasília, Centro Gráfico do Senado Federal, 1987

BRASIL. Assembleia Nacional Constituinte. Ata da $4^{a}$ Reunião da Comissão da Soberania e dos Direitos e Garantias do Homem e da Mulher, Brasília: Senado Federal, 1987, documento eletrônico; 
BRASIL. Assembleia Nacional Constituinte. Ata da $6^{a}$ Reunião da Comissão da Soberania e dos Direitos e Garantias do Homem e da Mulher, Brasília: Senado Federal, 1987, documento eletrônico;

BRASIL. Assembleia Nacional Constituinte. Ata da $10^{a}$ Reunião da Comissão da Soberania e dos Direitos e Garantias do Homem e da Mulher, Brasília: Senado Federal, 1987, documento eletrônico;

BRASIL. Assembleia Nacional Constituinte. Ata da $13^{a}$ Reunião da Comissão da Soberania e dos Direitos e Garantias do Homem e da Mulher, Brasília: Senado Federal, 1987, documento eletrônico;

BRASIL. Assembleia Nacional Constituinte. Comissão da Soberania e dos Direitos e Garantias do Homem e da Mulher. Vol. 66. Brasília: Centro Gráfico do Senado Federal, 1987;

BRASIL. Assembleia Nacional Constituinte. Comissão da Soberania e dos Direitos e Garantias do Homem e da Mulher. Vol. 68. Brasília: Centro Gráfico do Senado Federal, 1987;

BRASIL. Assembleia Nacional Constituinte. Comissão da Soberania e dos Direitos e Garantias do Homem e da Mulher. Vol. 69. Brasília: Centro Gráfico do Senado Federal, 1987;

BRASIL. Assembleia Nacional Constituinte. Ata da $11^{a}$ Reunião Extraordinária da Comissão de Sistematização, Brasília: Senado Federal, 1987, documento eletrônico;

BRASIL. Assembleia Nacional Constituinte. Ata da $14^{a}$ Reunião da Comissão de Sistematização, Brasília: Senado Federal, 1987, documento eletrônico;

BRASIL. Assembleia Nacional Constituinte. Ata da $22^{a}$ Reunião Extraordinária da Comissão de Sistematização, Brasília: Senado Federal, 1987, documento eletrônico (I);

BRASIL. Assembleia Nacional Constituinte. Ata da $32^{a}$ Reunião Extraordinária da Comissão de Sistematização, Brasília: Senado Federal, 1987, documento eletrônico (II);

BRASIL. Assembleia Nacional Constituinte. Comissão de Sistematização. Anteprojeto de Constituição. Vol. 219 (errata no vol. 220). Brasília: Centro Gráfico do Senado Federal, 1987;

BRASIL. Assembleia Nacional Constituinte. Comissão de Sistematização. Projeto de Constituição. Vol. 223. Brasília: Centro Gráfico do Senado Federal, 1987;

BRASIL. Assembleia Nacional Constituinte. Comissão de Sistematização. Projeto de Constituição. Vol. 226. Brasília: Centro Gráfico do Senado Federal, 1987;

BRASIL. Assembleia Nacional Constituinte. Comissão de Sistematização. Projeto de Constituição. Emendas oferecidas em Plenário (Constituintes e Eleitores). Vol. 229. Brasília: Centro Gráfico do Senado Federal, 1987; 
BRASIL. Assembleia Nacional Constituinte. Comissão de Sistematização. Emendas Populares - vol. 2. Vol. 231. Brasília: Centro Gráfico do Senado Federal, 1987;

BRASIL. Assembleia Nacional Constituinte. Comissão de Sistematização. Parecer sobre as Emendas oferecidas em Plenário ao Projeto de Constituição. Vol. 234, Brasília: Centro Gráfico do Senado Federal, 1987;

BRASIL. Assembleia Nacional Constituinte. Comissão de Sistematização. Projeto de Constituição. Primeiro Substitutivo do Relator e Parecer. Vol. 235, Brasília: Centro Gráfico do Senado Federal, 1987;

BRASIL. Assembleia Nacional Constituinte. Comissão de Sistematização. Projeto de Constituição. Segundo Substitutivo do Relator. Vol. 242, Brasília: Centro Gráfico do Senado Federal, 1987;

BRASIL. Assembleia Nacional Constituinte. Substitutivo da Comissão de Sistematização. Vol. 244. Brasília: Centro Gráfico do Senado Federal, 1987;

BRASIL. Assembleia Nacional Constituinte. Projeto de Constituição (A). Vol. 251. Brasília: Centro Gráfico do Senado Federal, 1987;

BRASIL. Assembleia Nacional Constituinte. Trabalho comparativo entre o projeto de constituição (A) com as emendas substitutivas oferecidas pelo "Centrão" e os destaques sobre o texto e as emendas individuais, populares e coletivas. Vol. 276. Brasília: Centro Gráfico do Senado Federal, 1988;

BRASIL. Assembleia Nacional Constituinte. Projeto de Constituição (B), $2^{a}$ Turno. Preâmbulo e Títulos I e II. Emendas e destaques organizados por dispositivos. Vol. 308. Brasília: Centro Gráfico do Senado Federal, 1988;

BRASIL. Assembleia Nacional Constituinte. Ata da 206 ${ }^{a}$ Sessão da Assembleia Nacional Constituinte, Brasília: Senado Federal, 1988, documento eletrônico (XIII);

BRASIL. Assembleia Nacional Constituinte. Ata da $213^{a}$ Sessão da Assembleia Nacional Constituinte, Brasília: Senado Federal, 1988, documento eletrônico (XIV);

BRASIL. Assembleia Nacional Constituinte. Ata da 307 ${ }^{a}$ Sessão da Assembleia Nacional Constituinte, Brasília: Senado Federal, 1988, documento eletrônico (XXI);

BRASIL. Assembleia Nacional Constituinte. Ata da 308 ${ }^{a}$ Sessão da Assembleia Nacional Constituinte, Brasília: Senado Federal, 1988, documento eletrônico (XXI);

BRASIL. Assembleia Nacional Constituinte. Ata da $316^{a}$ Sessão da Assembleia Nacional Constituinte, Brasília: Senado Federal, 1988, documento eletrônico (XXII);

BRASIL. Assembleia Nacional Constituinte. Ata da $318^{a}$ Sessão da Assembleia Nacional Constituinte, Brasília: Senado Federal, 1988, documento eletrônico (XXII);

BRASIL. Assembleia Nacional Constituinte. Ata da $319^{a}$ Sessão da Assembleia Nacional Constituinte, Brasília: Senado Federal, 1988, documento eletrônico (XXII); 
BRASIL. Assembleia Nacional Constituinte. Ata da 320 Sessão da Assembleia Nacional Constituinte, Brasília: Senado Federal, 1988, documento eletrônico (XXV);

BRASIL. Diário da Assembleia Nacional Constituinte. Ata da $2^{a}$ Sessão. Brasília: Senado Federal, 1987, documento eletrônico (I);

BRASIL. Diário da Assembleia Nacional Constituinte, vol. 340, Resolução no 3/1988, Brasília, Centro Gráfico do Senado Federal, 1988;

BRASIL, Diário da Câmara dos Deputados. Brasília, 5 de março de 1996;

BRASIL. Diário do Congresso Nacional (Seção I). Brasília, 7 de agosto de 1986;

BRASIL. Presidência da República. Anteprojeto Constitucional, elaborado pela Comissão Provisória de Estudos Constitucionais, instituída pelo Decreto $\mathrm{n}^{\circ}$ 91.450, de 18 de julho de 1985. Diário Oficial da União, Suplemento Especial ao nº 185, Brasília, DF, 26.9.1985;

BRASIL, Presidência da República. Mensagem de veto $n^{\circ} 260$, de $1^{\circ}$ de abril de 1996;

BRASIL, Presidência da República. Mensagem de veto $n^{\circ}$ 858, de 14 de julho de 1998;

BRASIL. Diário da Câmara dos Deputados. Brasília, 16 de março de 1999;

BRASIL, Presidência da República. Mensagem de veto nº 488, de 14 de junho de 2002.

\section{Legislação:}

- Constituições:

BRASIL. Constituição (1967). Constituição do Brasil. Diário Oficial da União, Brasília, DF, 24.1.1967;

BRASIL. Constituição (1988). Constituição da República Federativa do Brasil. Diário Oficial da União, Brasília, DF, 5.10.1988;

- Emendas Constitucionais:

BRASIL. Constituição (1967). Emenda Constitucional no 26, de 27 de novembro de 1985. Convoca Assembléia Nacional Constituinte e dá outras providências. Diário Oficial da União, Brasília, DF, 28.11.1985;

BRASIL. Constituição (1988). Emenda Constitucional no 24, de 9 de dezembro de 1999. Altera dispositivos da Constituição Federal pertinentes à representação classistas na Justiça do Trabalho. Diário Oficial da União, Brasília, DF, 10.12.1999;

BRASIL. Constituição (1988). Emenda Constitucional no 45, de 30 de dezembro de 2004. Altera dispositivos dos arts. 5 , 36, 52, 92, 93, 95, 98, 99, 102, 103, 104, 105, 107, 109, 111, 112, 114, 115, 125, 126, 127, 128, 129, 134 e 168 da Constituição Federal, e acrescenta os 
arts. 103-A, 103B, 111-A e 130-A, e dá outras providências. Diário Oficial da União, Brasília, DF, 31.12.2004.

- Leis

BRASIL. Lei $\mathrm{n}^{\circ} 4.330$, de $1^{\circ}$ de junho de 1964. Regula o direito de greve, na forma do art. 158, da Constituição Federal. Diário Oficial da União, Brasília, DF, 3.6.1964. Retificações publicadas no Diário Oficial da União, Brasília, DF, em 15.6.1964 e 19.6.1964;

BRASIL. Lei no 5.869, de 11 de janeiro de 1973. Institui o Código de Processo Civil. Diário Oficial da União. Brasília, DF, 17.1.1973;

BRASIL. Lei $n^{\circ} 7.701$, de 21 de dezembro de 1988. Dispõe sobre a especialização de Turmas dos Tribunais do Trabalho em processos coletivos e dá outras providências. Diário Oficial da União. Brasília, DF, 22.12.1988;

BRASIL. Lei $\mathrm{n}^{\mathrm{o}}$ 7.783, de 28 de junho de 1989. Dispõe sobre o exercício do direito de greve, define as atividades essenciais, regula o atendimento das necessidades inadiáveis da comunidade, e dá outras providências. Diário Oficial da União. Brasília, DF, 29.6.1989;

BRASIL. Lei no 8.880, de 27 de maio de 1994. Dispõe sobre o Programa de Estabilização Econômica e o Sistema Monetário Nacional, institui a Unidade Real de Valor (URV) e dá outras providências. Diário Oficial da União. Edição Extra. Brasília, DF, 28.5.1994. Retificado no Diário Oficial da União de $1^{\circ} .6 .1994$

BRASIL. Lei $\mathrm{n}^{\circ}$ 9.069, de 29 de junho de 1995. Dispõe sobre o Plano Real, o Sistema Monetário Nacional, estabelece as regras e condições de emissão do REAL e os critérios para conversão das obrigações para o REAL, e dá outras providências. Diário Oficial da União. Brasília, DF, 30.6.1995;

BRASIL. Lei $\mathrm{n}^{\circ}$ 9.689, de 14 de julho de 1998. Concede anistia de multas cominadas pelo Tribunal Superior do Trabalho a entidades sindicais representativas dos empregados da Empresa Petróleo Brasileiro S/A - PETROBRÁS, no período em que menciona. Diário Oficial da União, Brasília, DF, 15.7.1998;

BRASIL. Lei $n^{\circ}$ 9.842, de 7 de outubro de 1999. Revoga os arts. 723, 724 e 725 do DecretoLei no 5.452, de 1o de maio de 1943, que aprova a Consolidação das Leis do Trabalho. Diário Oficial da União. Brasília, DF, 8.10.1999;

BRASIL. Lei $\mathrm{n}^{\mathrm{o}} 10.790$, de 28 de novembro de 2003. Concede anistia a dirigentes ou representantes sindicais e trabalhadores punidos por participação em movimento reivindicatório. Diário Oficial da União, Brasília, DF, $1^{\circ}$.12.2003;

- Decretos-Lei:

BRASIL, Decreto-Lei no 2.848, de 7 de dezembro de 1940. Código Penal. Diário Oficial da União. Rio de Janeiro, DF, 31.12.1940. Retificação em 3.1.1941

BRASIL, Decreto-Lei $\mathrm{n}^{\circ} 5.452$, de $1^{\circ}$ de maio de 1943. Aprova a Consolidação das Leis do Trabalho. Diário Oficial da União. Rio de Janeiro, DF, 9.8.1943; 
BRASIL. Decreto-Lei $n^{\circ}$ 314, de 13 de março de 1967. Define os crimes contra a segurança nacional, a ordem política e social e dá outras providências. Diário Oficial da União, Brasília, DF, 13.3.1967;

\section{- Decretos:}

BRASIL. Poder Executivo. Decreto n ${ }^{\circ}$ 91.450, de 18 de julho de 1985. Institui a Comissão Provisória de Estudos Constitucionais. Diário Oficial da União, Brasília, DF, 22.7.1985;

BRASIL. Poder Executivo. Decreto $\mathrm{n}^{\mathrm{o}}$ 1.480, de 3 de maio de 1995. Dispõe sobre os procedimentos a serem adotados em casos de paralisações dos serviços públicos federais, enquanto não regulado o disposto no art. 37, inciso VII, da Constituição. Diário Oficial da União, Brasília, DF, 4.5.1995

- Medida-Provisória:

BRASIL. Medida Provisória n ${ }^{\circ}$ 50, de 27 de abril de 1989. Dispõe sobre o exercício do direito de greve, define as atividades essenciais, regula o atendimento das necessidades inadiáveis da comunidade, e dá outras providências. Diário Oficial da União, Brasília, DF, 28.4.1989;

- Mensagens de veto:

BRASIL, Presidência da República. Mensagem de veto $n^{\circ} 260$, de $1^{\circ}$ de abril de 1996. Diário Oficial da União. Brasília, DF, 2.4.1996;

BRASIL, Presidência da República. Mensagem de veto $\mathrm{n}^{\circ}$ 858, de 14 de julho de 1998 . Diário Oficial da União, Brasília, DF, 15.7.1998;

BRASIL, Presidência da República. Mensagem de veto $\mathrm{n}^{\circ}$ 488, de 14 de junho de 2002. Diário Oficial da União. Brasília, DF, 17.6.2002.

- Regimento interno:

BRASIL. Tribunal Superior do Trabalho. Resolução n. 40-A, de $1^{\circ}$ de outubro de 1993. Diário da Justiça, Brasília, DF, 23.11.1993.

\section{Processos e decisões judiciais:}

BRASIL. Tribunal Superior do Trabalho. Seção Especialização em Dissídios Coletivos. Recurso Ordinário em Dissídio Coletivo no 52547/1992. Relator Ministro Marcelo Pimentel. Diário de Justiça, Brasília, DF, 20.11.1992;

BRASIL. Tribunal Superior do Trabalho. Seção de Dissídios Coletivos. Dissídio Coletivo n ${ }^{\circ}$ 131.024/1994. Rel. Ministro Indalécio Gomes Neto. Diário de Justiça, Brasília, DF, 11.11.1994;

BRASIL. Tribunal Superior do Trabalho. Seção de Dissídios Coletivos. Dissídio Coletivo no 177.734/1995. Processo, Brasília, DF; 
BRASIL. Tribunal Superior do Trabalho. Seção de Dissídios Coletivos. Dissídio Coletivo no 177.734/1995. Notas taquigráficas da sessão de julgamento. Brasília, DF, 9.5.1995;

BRASIL. Tribunal Superior do Trabalho. Seção de Dissídios Coletivos. Dissídio Coletivo n 177.734/1995. Notas taquigráficas da sessão de julgamento. Brasília, DF, 26.5.1995;

BRASIL. Superior Tribunal de Justiça. Conflito de Competência n ${ }^{\circ}$ 15.804/SP (95/00658674), Rel. Min. Bueno de Souza. Diário de Justiça, Brasília, DF, 23.3.1998;

BRASIL. Tribunal Superior do Trabalho. Seção Especializada em Dissídios Coletivos. Recurso Ordinário em Dissídio Coletivo $\mathrm{n}^{\mathrm{o}}$ 454136-20.1998.5.01.5555. Relator Ministro Valdir Righetto. Diário de Justiça, Brasília, DF, 6.8.1999;

BRASIL. Superior Tribunal de Justiça. Recurso Especial n 186.786/SP (98/0062952-1), Rel. Min. Waldemar Zveiter. Diário de Justiça, Brasília, DF, 16.8.1999;

BRASIL. Tribunal Superior do Trabalho. Seção Especializada em Dissídios Coletivos, Recurso Ordinário em Dissídio Coletivo no 571212-31.1999.5.01.5555. Relator Juiz Convocado Márcio Ribeiro do Valle. Diário de Justiça, Brasília, DF, 15.9.2000;

BRASIL. Tribunal Regional do Trabalho da $2^{\mathrm{a}}$ Região. Medida Cautelar $\mathrm{n}^{\mathrm{o}}$ 20236200600002005. Rel. Juiz Nelson Nazar. Diário de Justiça. São Paulo, SP 20.9.2007;

BRASIL. Tribunal Regional do Trabalho da $2^{\mathrm{a}}$ Região. Dissídio Coletivo $\mathrm{n}^{\mathrm{o}}$ 20288200700002002. Rel. Juíza Sonia Maria Prince Franzini. Diário de Justiça, São Paulo, SP, 10.7.2007;

BRASIL. Superior Tribunal de Justiça. Agravo Regimental na Medida Cautelar no 15.656 DF. Rel. Min. Og Fernandes. Diário de Justiça Eletrônico, Brasília, DF, 1.7.2009;

BRASIL. Supremo Tribunal Federal. Reclamação no 6568/SP. Rel. Ministro Eros Grau. Diário de Justiça, Brasília, DF, 25.9.2009;

BRASIL. Supremo Tribunal Federal. Arguição de Descumprimento de Preceito Fundamental $\mathrm{n}^{\circ}$ 153. Rel. Ministro Eros Grau. Diário de Justiça Eletrônico, Brasília, DF, 6.8.2010

BRASIL. Tribunal Superior do Trabalho. $2^{\mathrm{a}}$ Turma. Agravo de Instrumento em Recurso de Revista $\mathrm{n}^{\circ}$ 128040-67.2005.5.03.0114. Rel. Ministro Guilherme Caputo Bastos. Diário Eletrônico da Justiça do Trabalho, Brasília, DF, 20.8.2010;

BRASIL. Tribunal Regional do Trabalho da $10^{\mathrm{a}}$ Região. Mandado de Segurança $\mathrm{n}^{\mathrm{o}}$ 046112010-000-10-00-2. Rel. Juiz Grijalbo Fernandes Coutinho. Brasília, DF, decisão de 8.10.2010;

BRASIL. Tribunal Superior do Trabalho. Seção de Dissídios Coletivos. Recurso Ordinário no 2014200-84.2009.5.02.0000. Relator Ministro Márcio Eurico Vitral Amaro. Diário Eletrônico da Justiça do Trabalho. Brasília, DF, 01.7.2011; 
BRASIL. Tribunal Superior do Trabalho. Seção Especializada em Dissídios Coletivos, Recurso Ordinário em Dissídio Coletivo $\mathrm{n}^{\circ}$ 2025800-10.2006.5.02.0000. Relator Ministro Fernando Eizo Ono, Diário Eletrônico da Justiça do Trabalho, Brasília, DF, 04.11.2011;

BRASIL. Tribunal Superior do Trabalho. $8^{\mathrm{a}}$ Turma. Agravo de Instrumento em Recurso de Revista $\mathrm{n}^{\mathrm{o}}$ 185700-73.2009.5.02.0383. Rel. Ministro Márcio Eurico Vitral Amaro. Diário Eletrônico da Justiça do Trabalho, Brasília, DF, 5.10.2012;

BRASIL. Tribunal Superior do Trabalho. Seção de Dissídios Coletivos. Recurso Ordinário no 2020800-24.2009.5.02.0000. Relator Ministro Mauricio Godinho Delgado. Diário Eletrônico da Justiça do Trabalho, Brasília, DF, 23.11.2012;

BRASIL. Tribunal Superior do Trabalho. Vice-Presidência. Cautelar Inominada $\mathrm{n}^{\mathrm{o}}$ 144577.2013.5.00.0000, Rel. Ministra Maria Cristina Irigoyen Peduzzi, Diário Eletrônico da Justiça do Trabalho, Brasília, DF, 22.2.2013;

BRASIL. Tribunal Superior do Trabalho. Seção de Dissídios Coletivos. Recurso Ordinário no 2030700-36.2006.5.02.0000, Relatora Ministra Kátia Magalhães Arruda. Diário Eletrônico da Justiça do Trabalho, Brasília, DF 10/05/2013;

BRASIL. Tribunal Superior do Trabalho. Presidência. Decisão cautelar no Dissídio Coletivo $\mathrm{n}^{\circ}$ 5842-82.2013.5.00.0000. Rel. Min. Carlos Alberto Reis de Paula. Diário Eletrônico da Justiça do Trabalho, Brasília, DF, $1^{\circ} .8 .2013$;

BRASIL. Tribunal Regional do Trabalho da $2^{\mathrm{a}}$ Região. Recurso Ordinário $\mathrm{n}^{\mathrm{o}}$ Rel. 21230920125020312. Rel. Desembargador Manoel Antonio Ariano. Diário Eletrônico da Justiça do Trabalho, São Paulo, SP, 4.10.2013;

BRASIL. Tribunal Superior do Trabalho. Seção de Dissídios Coletivos. Recurso Ordinário no 2030700-36.2006.5.02.0000. Relatora Ministra Kátia Magalhães Arruda. Diário Eletrônico da Justiça do Trabalho, Brasília, DF, 10.05.2013;

BRASIL. Tribunal Superior do Trabalho. Corregedoria-Geral da Justiça do Trabalho. Correição Parcial no 7603-51.2013.5.00.0000. Rel. Min. Ives Gandra Martins Filho. Diário Eletrônico da Justiça do Trabalho, Brasília, DF, 10.10.2013;

BRASIL. Tribunal Superior do Trabalho. Seção de Dissídios Coletivos. Recurso Ordinário $\mathrm{n}^{\circ}$ 116-89.2013.5.05.0000. Relatora Ministra Kátia Magalhães Arruda. Diário Eletrônico da Justiça do Trabalho, Brasília, DF, 15.4.2014;

BRASIL. Tribunal Superior do Trabalho. Seção de Dissídios Coletivos. Recurso Ordinário no 168400-29.2009.5.04.0000. Relator Ministro Mauricio Godinho Delgado. Diário Eletrônico da Justiça do Trabalho, Brasília, DF, 16.05.2014;

BRASIL. Tribunal Superior do Trabalho. Seção de Dissídios Coletivos. Recurso Ordinário $\mathrm{n}^{\circ}$ 51534-84.2012.5.02.0000, Rel. Ministro Walmir Oliveira da Costa. Diário Eletrônico da Justiça do Trabalho, Brasília, DF, 20.6.2014; 
BRASIL. Tribunal Superior do Trabalho. $7^{\mathrm{a}}$ Turma. Recurso de Revista $\mathrm{n}^{\mathrm{o}}$ 25384090.2006.5.03.0140. Rel. Min. Vieira de Mello Filho. Diário Eletrônico da Justiça do Trabalho, Brasília, DF, 20.6.2014.

- verbetes jurisprudenciais:

BRASIL. Tribunal Superior do Trabalho. Enunciado 316. Diário de Justiça, Brasília, DF, 29.9.1993;

BRASIL. Tribunal Superior do Trabalho. Enunciado 317. Diário de Justiça, Brasília, DF, 29.9.1993;

BRASIL. Tribunal Superior do Trabalho. Enunciado 323. Diário de Justiça, Brasília, DF, 4.1.1994;

BRASIL. Tribunal Superior do Trabalho. Seção de Dissídios Coletivos. Orientação Jurisprudencial no 15. Diário de Justiça, Brasília, DF, 27.3.1998;

BRASIL. Supremo Tribunal Federal. Súmula Vinculante no 23. Diário de Justiça Eletrônico, Brasília, DF, 11.12.2009.

\section{Periódicos:}

Folha de São Paulo;

Jornal do Brasil;

O Estado de São Paulo;

Revista Isto é;

Revista Veja.

\section{Documentários:}

$A B C$ da greve. Direção de Leon Hirszman. São Paulo: VF, 1990. DVD (85 min), NTSC, son., color. Port.;

Linha de montagem. Direção de Renato Tapajós. São Paulo: Tapiri Cinematográfica, 2007, DVD (90 min), NTSC, son., color. Port.

\section{Entrevistas:}

PASSOS, João Pedro Ferraz dos. Depoimento sobre a greve dos petroleiros de 1995. Entrevista concedida a Ricardo Machado Lourenço Filho. Brasília, 7 de julho de 2014. Arquivo M4A;

BRITTO, Cézar. Depoimento sobre a greve dos petroleiros de 1995. Entrevistador: Ricardo Machado Lourenço Filho. Brasília, 14 julho de 2014. Arquivo de som M4A;

Sítios na internet:

www.trt2.jus.br

www.tst.jus.br

http://www.cut.org.br/institucional/68/cronologia-de-lutas, acesso em 12.3.2014 
http://www.fup.org.br/2012/noticias/entrevistas/118, acesso em 12.3.2014 


\section{$\underline{\text { Anexo I }}$}

PASSOS, João Pedro Ferraz dos. Depoimento sobre a greve dos petroleiros de 1995. Entrevista concedida a Ricardo Machado Lourenço Filho. Brasília, 9 de julho de 2014. Arquivo M4A.

JOÃO PEDRO FERRAZ DOS PASSOS: (...) naquela época, antes da Constituição de outubro, eu participei muito também dos trabalhos, inclusive, da Assembleia Nacional Constituinte. Inclusive, na época, eu era presidente da Associação Nacional dos Procuradores do Trabalho e nós tínhamos um vínculo de proximidade com alguns dos que chamavam naquela época dos "notáveis" para escrever o primeiro anteprojeto da Constituição. E esse trabalho tinha sido escolhido por setores, pelos Poderes, enfim. E no Poder Judiciário ficou encarregado da divisão dos poderes, do Poder Judiciário, um dos integrantes desse grupo era o Ministro Pertence, Sepúlveda Pertence, que era Procurador Geral da República de então. Tinha uma proximidade muito grande com ele. Eu, como Presidente da Associação, fui designado pela Associação e depois por ele também para fazer o anteprojeto da nossa lei complementar, para ficar fazendo esse link dos interesses do Ministério Público com a Constituinte. Na época nós tínhamos uma associação nacional, que era a Conamp, que era muito forte, muito atuante, que nós tínhamos, na liderança da Conamp, para atender os interesses do Ministério Público, do Judiciário, etc., o Fleury, que era Procurador Geral do Estado de São Paulo e depois veio a ser governador do Estado de São Paulo.

Mas nós estávamos num período de transição onde a greve era exceção, a greve veio de um ilícito, depois para uma tolerância, depois aquela regulamentação excepcional. Uma regulamentação, não para permitir, mas uma regulamentação para coibir, para dizer: "olha, nessas atividades que são essenciais, a greve continua com essas restrições”. E dali, com a Constituinte, depois, com todas as discussões, todos os debates, a greve passou a ser um direito. Então quando vc apresenta como um direito constitucional, quer dizer, o direito de greve que era ainda regulado por exceções e apresenta como um direito constitucional, evidente que os titulares desse direito querem esse direito sem nenhum limite. Então o debate que se estabeleceu no Judiciário, se estabeleceu nas forças daquela época de Capital e Trabalho, de sindicato, nas centrais sindicais, era exatamente estabelecer um limite para esses direitos. Ao ponto de se dizer assim: todo direito, todos os direitos constitucionais tem um limite. Então, aí com a credencial constitucional desses direitos, todo mundo queria exercer o 
direito de greve sem nenhuma limitação. Até aqueles setores essenciais e tal, saúde, segurança, funcionários públicos, todos eles queriam fazer greve já escorados nessa titularidade desse direito que a Constituição veio consagrar.

E os debates se estabeleceram exatamente aí. Numa época em que nós não tínhamos ainda sequer, em relação aos servidores públicos, nós não tínhamos ainda sequer o estatuto dos servidores públicos, que estava sendo ainda escrito. E pelo mesmo, quer dizer, ... Foi um período em que, quem escreveu a Lei 8.112, se não me engano, foi o mesmo legislador constituinte e que deu o direito de organização sindical, direito de greve, direito de participar da elaboração de normas coletivas, inclusive os servidores públicos. Depois veio aquela discussão no Supremo Tribunal Federal e aquela declaração de inconstitucionalidade até. Mas por quê? Porque nós tivemos um período de muito debate, de muita dúvida. Ora, se o legislador constituinte diz que, inclusive a competência da Justiça do Trabalho, para apreciar essas controvérsias de relações de trabalho com os servidores públicos, foi colocada lá pelo legislador constituinte. E o mesmo legislador, depois transformado em legislador ordinário, faz o estatuto dos servidores públicos e garante tudo aquilo que estava na Constituição. Aí vai para a Presidência da República para sancionar o estatuto e há um veto em relação a essas disposições, esse veto é derrubado e acaba que isso foi bater no Supremo Tribunal Federal. Então, para você ver que, naquele período, nós ainda estávamos num momento fértil de discussão a respeito da extensão desses direitos, do direito de greve, do direito de participação de greve de servidores públicos, de, como diziam, negociar com os Estados.

E, no setor privado, as questões foram se acirrando muito mais, porque nós não tínhamos ainda nenhuma legislação que limitasse esses direitos, que dissesse: "olha, o direito de greve tem que ser exercido dentro desses parâmetros e tal". Não tinha nada. Então esse foi o período em que o Judiciário tinha que colocar alguns freios e tratar da ilegalidade de greve, legalidade ou ilegalidade de greve, buscando uma legislação que ainda não se sabia se estava ou se não estava recepcionada. Quer dizer, era um outro problema, o Judiciário tinha que verificar, com todo cuidado, quais as disposições, até mesmo as disposições da Consolidação das Leis do Trabalho, que tinham sido recepcionadas e a legislação da greve. Então foi um período que nós tivemos muita dificuldade com essas interpretações. Foi um período também de muita, eu diria, participação política, enfim. Todos aqueles anseios de greve que foram reprimidos durante décadas foram liberados exatamente pela Constituição de 88 .

O que que aconteceu especificamente em relação à greve da Petrobrás? Eu, como não tenho o processo, vou te dizer o que eu tenho de memória e o que eu sei de história. Evidentemente que a confirmação disso vai depender do que você vai examinar no processo. Muitas coisas 
me falham, muitas coisas eu posso às vezes estar misturando com outras ações e outros episódios. Mas, na realidade, aquela época era uma época de muita busca, nós não tínhamos ainda essa estabilidade econômico que temos agora e tal. Então as greves, elas eram muito mais por reajuste salarial do que por conquistas de outros direitos dos trabalhadores. Então a mobilização dos trabalhadores tinha um objetivo, que era o maior, que era o macro, que dominava, que era a recomposição salarial. Era só isso. Não se buscava conquistas. Não se buscava melhoria nas condições de trabalho. Se buscava recomposição salarial e isso ocorria, às vezes, sempre, independente de ter ou não ter data base, porque a inflação, naquela época, era ainda, enfim, nós tínhamos inflação de mais de $90 \%$ ao mês, então você imagina que era realmente uma busca de recomposição salarial, muito mais do que condições de trabalho. E uma resistência à política econômica do governo, que a política econômica tinha por objetivo restringir aqueles reajustes salariais, aquela recomposição salarial, para, com isso, também, ter um controle da inflação. Quer dizer, a cabeça diz o seguinte: "vamos... a gente reduz salário aí a gente controla a inflação". E aí você tinha de um lado os trabalhadores buscando, primeiro defendendo que essa não devia ser a política correta, que não era a redução salarial, que não era o arrocho salarial que devia combater a inflação. E ao mesmo tempo eles iam buscar, então eles tinham uma capacidade de mobilização muito grande por causa disso, por causa dessas questões. E o que aconteceu, em relação à greve da Petrobrás? Todas essas discussões da categoria dos petroleiros, que era dividida em várias federações de petroleiros pelo Brasil inteiro, eles não tinham sindicato nacional dos petroleiros no comando nacional. Eles tinham sindicatos e federações independentes, isso em cada região e principalmente naquelas regiões onde tinha refinaria de petróleo. Por outro lado, o polo patronal era apenas a Petrobrás, que tinha o monopólio, então não tinha o sindicato dos produtores... Você tinha uma empresa, uma empresa de economia mista, uma estatal, controlada pelo governo, que era uma das maiores, e várias federações, quer dizer, sindicatos e federações pelo Brasil afora. E tinha um comando de greve, que, nessas condições, você tendo várias federações, sindicatos, o comando de greve, sempre tem um comando mas tem suas dissidências.

E a maioria desses sindicatos, ou federações, tinha filiação com a CUT, então, da história que eu sei, que é um pouco folclórica, que deu também essa razão jurídica, é que dentro dessas postulações, desses petroleiros, e talvez do contato desse comando de mobilização de empregados, eles tinham uma vinculação à CUT também, me parece que até por intermédio, por apoio da Confederação, da CUT, da Central Única dos Trabalhadores, eles fizeram essas postulações até diretamente, junto ao Presidente da República. E o que a imprensa dizia, o que se comentava é que numa reunião, com então acho que Presidente da CUT, ou então um dos 
dirigentes da CUT que era o Vicentinho na época, teve uma reunião em Juiz de Fora, num restaurante lá, um tal de Brasão, com Itamar, que era então Presidente da República. Nesta reunião, o Presidente da República teria consentido, teria feito um acordo, uma negociação, quer dizer, que ocorreu acho que na mesa de um restaurante, e teria prometido ou teria garantido aos trabalhadores que daria um determinado reajuste. E dessa reunião parece que teria saído até um documento, uma ata, eu não tive acesso a esse documento formal, assinado pelo Presidente, mas parece que teve uma ata que parece que eles assinaram e houve a promessa de um reajuste salarial, uma vantagem salarial, pelo Presidente da República.

De posse disso, os empregados foram então pressionar a empresa, para buscar essa promessa do Presidente da República. Até então, logo, nesse período de transição, acaba o mandato do Itamar e assume, por eleição, o Fernando Henrique Cardoso, que era, na época, que foi então o Ministro da Fazenda do Itamar.

Na presidência da Petrobrás estava um cidadão cujo nome não lembro mas você tem no processo, que era daquela geração antiga, antes da Constituição...

RICARDO LOURENÇO FILHO: se não me engano, era o Joel Rennó...

JOÃO PEDRO FERRAZ DOS PASSOS: o Joel Rennó... E que na cabeça do sujeito negociar com o sindicato, negociar com empregado, era uma coisa que ainda não estava na cultura dele. Ele vinha daquela... E me parece que o Ministro de Minas e Energia, que, se não me engano, ainda era não sei se o Antônio Carlos Magalhães ou alguém da área, eu não lembro quem era o Ministro das Minas e Energia. Mas eu sei que o Joel Rennó é que assumiu toda a responsabilidade pela negociação, naturalmente com respaldo do governo, com respaldo do... E não aceitou, e não concordou em garantir aquilo que o Presidente da República teria prometido aos trabalhadores. Então, a greve teve este, mais ou menos, que se diz na época, esse leitmotiv, quer dizer, o que ocasionou a greve foi esse desconforto de ter uma promessa do Presidente da República, uma garantia do Presidente da República, numa ata assinada que daria um reajuste e esse reajuste não foi dado.

Estabeleceu-se, então, uma greve, que foi eclodindo no Brasil inteiro e essa greve já estava começando a colocar em risco inclusive o abastecimento de combustível, chegou a haver quase que um colapso no abastecimento de gás de cozinha, na época, que aí você começa a atingir as famílias, o dia a dia, a subsistência, enfim. E foi então ajuizado um dissídio coletivo. Foi feita uma representação pelos... Eu também não lembro agora se essa representação foi feita pelos empregados ou pelos empregadores, porque na época qualquer um podia fazer. Mas parece que houve um pedido de ilegalidade da greve da Petrobrás.

RICARDO LOURENÇO FILHO: Pelo que eu vi o dissídio foi suscitado pelo Petrobrás. 
JOÃO PEDRO FERRAZ DOS PASSOS: ... Pela Petrobrás pedindo a ilegalidade da greve, exatamente. Eu lembro que eu examinei na época o dissídio e eu cheguei à conclusão de que a greve era formalmente, que a greve era ilegal. A greve era ilegal porque, primeiro não se podia exigir de uma empresa de economia mista que cumprisse com o compromisso - isso era a minha, o meu entendimento - que se cumprisse um compromisso pelo Presidente da República, porque o Presidente da República não tinha poderes para decidir pela Petrobrás, embora fosse uma empresa de economia mista com a União sendo a maioria acionária. Primeiro, ele não tinha a legitimidade formal para decidir a respeito disso, mas, de qualquer maneira, a greve era ilegal, mas havia, de certa forma, no mínimo, uma dúvida razoável, na cabeça dos empregados, "olha só: o Presidente da República mandou que se estabelecesse esse reajuste, por que o Presidente da Petrobrás, que, de certa forma, é nomeado pelo Presidente da República, não cumpre essa ordem?”. Aí eu lembro que eu, como Procurador Geral, eu nem sempre fazia os dissídios coletivos. Na época, eu designei o Procurador que era o Ives Gandra da Silva Martins Filho para fazer a primeira audiência. Não se sei se está lá no processo...

RICARDO LOURENÇO FILHO: Sim, está lá...

JOÃO PEDRO FERRAZ DOS PASSOS: Eu não lembro... Isso tem 20 anos... Eu não li o processo quando você falou comigo... Pelo que eu lembro o Ives foi para a audiência e o parecer da Procuradoria naquela época foi pela legalidade da greve. Parece que o parecer do Ives, se não me engano, foi pela legalidade da greve. Foi pela legalidade da greve em cima desses pressupostos, uma vez que havia uma promessa do Presidente da República, então que era justo que os empregados reivindicassem o cumprimento daquela promessa. E, em cima disso, a greve teria sido legal. O movimento grevista então recrudesceu e nós chegamos na beira do desabastecimento. O Tribunal então foi julgar o processo, quer dizer, na... deu pela legalidade da greve da audiência. Quando o Tribunal foi julgar o processo nós já conversamos então, tinham algumas determinações do Tribunal para que houvesse um atendimento a um determinado percentual, enfim, o Tribunal já estava analisando aquela greve como uma greve numa atividade essencial à luz da legislação anterior e determinou que algumas providências fossem estabelecidas. Isso não foi cumprido e a greve recrudesceu. No julgamento, então, do dissídio em si é que o tribunal decidiu então pela ilegalidade, se não me engano no julgamento definitivo, pela ilegalidade da greve, no processo, teve amplo debate... Eu lembro que eu estava no tribunal na época. E concluiu pela ilegalidade da greve, determinou o retorno dos trabalhadores e parece que esse retorno não aconteceu... É isso?

RICARDO LOURENÇO FILHO: Exatamente... 
JOÃO PEDRO FERRAZ DOS PASSOS: Aí o Tribunal novamente se reuniu, eu lembro que na época eu fui muito pressionado para tomar providência a respeito dos trabalhadores. Naquela oportunidade - porque a história eu vou te dizer agora, nunca me foi perguntado quanto a isso -, eu tentei inúmeras vezes reunião com a Petrobrás e com o governo, naquela época. Eu era Procurador Geral, tinha uma relação boa com o Ministro do Trabalho, que na época, se não me engano, era o Paulo Paiva, o Ministro do Trabalho, e o Secretário Geral dele era o hoje governador de Minas Gerais, Anastasia. Então eu tinha uma boa relação com o Ministério e fiz algumas reuniões, algumas reuniões com o movimento grevista no meu gabinete, de Procurador Geral, tentando uma negociação. Tinha um líder do movimento grevista, que, se não me engano, era Spis o nome dele. Era um sujeito extremamente radical, dificílimo de negociar. Eu lembro que era advogado de uma das federações de petróleo o Cézar Britto, que foi Presidente da Ordem - você também se você entrevistá-lo, ele vai te contar muita coisa sobre essa greve se você quiser - e o Cézar esteve em algumas reuniões dessas que teve comigo. Mas o elemento era extremamente radical. A última tentativa de acordo antes que o Tribunal fizesse mais uma sessão para analisar o comportamento dos empregados... Eu tentei fazer um acordo e lembro que eu telefonei para o Ministro do Trabalho de então... Me parece que o Ministro da Justiça era Nelson Jobim... Então eu liguei para o Ministro do Trabalho e disse: "olha, eu estou aqui com o movimento, eu gostaria de conversar e quero conversar com a Petrobrás mas não vejo ambiente para conversar com o Presidente da Petrobrás, o Presidente da Petrobrás estava querendo realmente..." E ele disse: "olha, Procurador, eu the aconselho a não levar adiante a sua pretensão de conciliar porque a deliberação do governo é quebrar o movimento sindical". Essa foi a frase que eu ouvi, estou dizendo para você, pela primeira vez você está ouvindo isso aqui... "A deliberação do governo é quebrar o movimento sindical”. Isso foi o que eu ouvi do Ministro naquela época. Então: “o senhor não leve a frente essa sua intenção de negociar". Aí eu desisti, não vou também negociar quando um lado já foi claro a respeito da sua pretensão. Então fomos para o Tribunal e o Tribunal então impôs aos sindicatos uma multa, que eu não lembro o que era mas era uma multa para os sindicatos, uma multa pesada... Os sindicatos ainda bem desorganizados, as federações, não tinham ainda aquelas arrecadações... Depois é que eles vieram a instituir, de normas coletivas, enfim. E determinou que os empregados voltassem sob pena de multa. Mas não foi isso que fez os empregados voltarem. Eles chegaram num momento e concluíram que eles não iam conseguir, com aquela greve, nenhuma saída honrosa. Realmente, a deliberação de bater de frente com o movimento sindical era uma deliberação do governo e o governo tinha colocado todas as suas forças ali. E depois nessa negociação, de desabastecimento, de 
discussão, me parece, eu não tenho certeza, que houve até um infortúnio. Me parece que morreu um diretor da Petrobrás, que estava nas negociações... Você levantou isso?

RICARDO LOURENÇO FILHO: Levantei. Foi o Superintendente de Recursos Humanos, Clotário Cardoso...

JOÃO PEDRO FERRAZ DOS PASSOS: É... que não aguentou a pressão...

RICARDO LOURENÇO FILHO: Após uma reunião, pelo menos a notícia que saiu na imprensa... Foi num hotel no Rio de Janeiro, após uma reunião...

JOÃO PEDRO FERRAZ DOS PASSOS: Tem vinte anos isso... Mas como você falou... Eu não tive tempo de pesquisar nada... Ele morreu... E aí o movimento recrudesceu mais ainda. E a Petrobrás veio para cima. Já tinha o governo, com a Petrobrás, com essa deliberação de “quebrar o movimento sindical”... Muito bem. O Tribunal então, novamente instado a se manifestar sobre o comportamento dos empregados, que depois da greve ilegal não tinham voltado ao trabalho, ele resolveu então fazer uma sessão e impor essa multa, pela primeira vez ele impôs essa multa aos sindicatos... Lembro que na época eu... o Ministro da Justiça foi procurar o então Procurador-Geral da República, que estava lá em exercício, que era o Moacir Machado, estava lá na época, depois ele veio até a ser Procurador da União, na época atual foi até Advogado Geral agora... Mas o Moacir estava substituindo o Aristides Junqueira, não sei, na transição... E o Ministro da Justiça foi procurá-lo e eu coincidentemente estava na Procuradoria da República para tratar... E o Ministro da Justiça saiu do Ministério e foi lá na Procuradoria da República para exigir do Ministério Público que cobrasse do sindicato a multa, a astreinte, exatamente para forçar, para fazer com que os sindicatos realmente voltassem ao trabalho. Aí pressionado pelo... Já com a decisão dessa na rua, eu passei a ser pressionado pelo próprio Tribunal... O Tribunal disse: “olha, eu já impus a multa, alguém tem que executar". E a competência para executar as multas impostas pelas decisões do Tribunal são, eram na época e ainda são, do Ministério Público do Trabalho, quer dizer compete ao Ministério Público do Trabalho inclusive executar as decisões dos tribunais em dissídios coletivos. E aí eu comecei a ser pressionado por fazer a execução desses processos. Lembro que, na época, eu designei para fazer o processo da execução o que é hoje Ministro do TST, o Lélio Bentes Correa, o Ministro Lélio. Eu disse: "Lélio, olha - que na época era procurador...”. Eu disse: “olha, nós vamos ter que executar, a competência é nossa, então você faça aqui a petição, distribua, manda para os Procuradores dos Estados e exija deles que entrem com a execução contra cada uma dessas federações de petroleiros". E isso na realidade foi feito, foi implementado... Os processos chegaram a ter um andamento... E parece que depois houve uma anistia em relação a isso, do próprio governo, do próprio governo Fernando 
Henrique... Não sei se a anistia foi do Congresso, se a anistia foi do próprio Presidente da República. Acho que foi do próprio Presidente da República. Houve uma negociação e houve uma anistia dessas multas que quebravam os sindicatos...

RICARDO LOURENÇO FILHO: Pelo que eu levantei houve um projeto de lei que saiu do Congresso e o Presidente Fernando Henrique vetou... Alguns anos depois, o Congresso aprovou outro projeto e dessa vez ele...

JOÃO PEDRO FERRAZ DOS PASSOS: É, o primeiro ele vetou até porque o próprio TST, na época, ficou um pouco irritado, disse: "olha, coloca o Tribunal nessa exposição, exige que a gente tome uma posição e depois a gente decide e vocês por uma questão política vocês anistiam, e fica... Como se a Justiça do Trabalho é que fosse o algoz dos trabalhadores". Parece que esse foi o entendimento do Tribunal, o desconforto do TST naquela época. Acabou que, depois com essa anistia... Mas ali teve, claro... Durante o processo... Eu não lembro se foi nessa época que ou se foi numa época de greve de banco, mas teve uma época até que a CUT fez passeata na frente do Tribunal, amarrou um jegue na frente do Tribunal... Escreveu lá: “de quem é esse jegue?”. Inclusive, tiveram determinações internas para que houvesse inquérito para que fosse processado por difamação... Aquelas coisas todas que você... Mas parece que foi nessa época também, não sei se você pesquisou nos jornais, foi? RICARDO LOURENÇO FILHO: Eu cheguei a ver uma foto do jegue na frente do TST... JOÃO PEDRO FERRAZ DOS PASSOS: Foi na greve da Petrobrás... Depois eu até brinquei com o Zunga, um tempo depois, que eu encontrei ele... Eu sempre me dei com ele... Ele sempre frequentou a procuradoria, ele era membro presidente, diretor da CUT aqui em Brasília... Depois que passou isso tudo, veio o governo Lula, o Zunga foi receber uma comenda de ordem ao mérito do TST... Eu disse a ele: "quem devia estar recebendo essa comenda é aquele jegue que você colocou aqui”... (risos) Mas eu posso te ajudar em mais alguma coisa? Acho que historicamente... Acho que quase tudo isso está no processo, né?

RICARDO LOURENÇO FILHO: O senhor falou da postura do governo, essa ligação com o Ministro do Trabalho da época, que o senhor chegou a falar com ele... Como o senhor vê a postura geral do governo naquela greve? Até as Forças Armadas foram mobilizadas...

JOÃO PEDRO FERRAZ DOS PASSOS: Foram... Foram todas mobilizadas... Não... O governo estava realmente... Já tinha tomado a deliberação, quer dizer, o que o Ministro do Trabalho me informou foi o seguinte: “o governo já deliberou...”. Quer dizer, tinha uma deliberação interna, reunião de ministros, tinha ouvido todo mundo, e o governo já tinha deliberado: "vamos enfrentar o movimento sindical, vamos derrubar...". A intenção do governo era naturalmente passar por cima do movimento sindical. Não do movimento 
sindical, mas daquela facção do movimento sindical que estava apoiando a greve, que era realmente a CUT, a Central Única dos Trabalhadores, porque o braço sindical do governo era outro. O braço sindical do governo já era, sei lá, não sei se naquela época era o que é hoje a Força Sindical, que depois teve uma tentativa de criar uma outra central, Central, acho que Social...

RICARDO LOURENÇO FILHO: ... Houve uma dissidência... Nessa época até a Força Sindical ameaçou fazer uma greve a favor do governo...

JOÃO PEDRO FERRAZ DOS PASSOS: Sim. Naquela época... Depois eles acabaram... Houve uma dissidência da Força Sindical, da que é hoje Força Sindical, parece que era CGT, Central Geral dos Trabalhadores, era a CGT, e depois eles estavam numa dissidência... Acho que saiu o Alemão da CGT e foi a criar a Central Socialista Sindical, uma coisa assim, não é isso? Lá em Pernambuco, começou a criar lá em Recife, tem uma sede... Saiu o Alemão, saiu José Ibrahim, que eram as pessoas que estavam dentro da CGTB, ainda assessorando o Medeiros, que era o Presidente na época. Então houve essa dissidência, mas esse era o braço sindical do governo na época, entendeu? Se contrapondo à CUT. Claro que o governo queria quebrar aquele movimento sindical, aquela greve, aquele movimento de trabalhadores que estavam sendo apoiados pela CUT. Não era contra todos os trabalhadores, era contra aquele movimento sindical para naturalmente se sobrepor. Então a ideia era essa.

RICARDO LOURENÇO FILHO: Pelo que eu levantei, houve muita discussão sobre esse acordo que o Presidente Itamar teria feito...

JOÃO PEDRO FERRAZ DOS PASSOS: Sim, a discussão que se estabeleceu em termos jurídicos era o seguinte: pode um Presidente da República conceder um reajuste salarial a empregados de uma empresa pública? Foi aí que a Petrobrás resistiu e disse: “olha, não pode. Quem dá aumento salarial é a Petrobrás, tem que ouvir o Conselho de Acionistas, tem que ouvir o...” Tinha, naquela época, um Comitê de Controle das Estatais, que era CCE, se não me engano. Era um comitê, que depois ele foi sendo desfeito por ato, foi modificado, etc. Mas era um comitê de controle das estatais e as estatais não podiam negociar, não podiam conceder nenhum reajuste salarial se não tivesse a autorização daquele conselho. Então o conselho colocava um limite. Depois acabou que não funcionou. Nós tivemos até algumas ações aí, ações rescisórias de grandes processos... Teve um que terminou até pouco tempo aqui, na $10^{\mathrm{a}}$ Região, que era uma ação até da Eletronorte, que ela perdeu um processo, um processo alto que dava um valor significativo e entrou com uma ação rescisória e uma das discussões... Isso foi discutido aqui na $10^{\mathrm{a}}$ Região... Era se... A ação rescisória era porque aquela norma coletiva não valia, porque... aquele acordo não valia porque não tinha tido autorização do controle das 
estatais, que depois acabou perdendo a sua importância e hoje não valia mais. Mas um dos fundamentos pela ilegalidade da greve, inclusive, e pela... que justificava a não concessão do aumento é que o Presidente da República não tinha poderes para... de gestão da Petrobrás, embora tivesse gestão, como chefe de governo e chefe de Estado, ele não tinha poderes numa empresa de economia mista. Primeiro. Segundo que isso não teria passado pelo Comitê de Controle das Estatais, que era esse CCE, e por isso a greve seria ilegal. Esses seriam os fundamentos da ilegalidade da greve.

RICARDO LOURENÇO FILHO: À época também tinha a questão da inflação, estava no contexto de implementação do Plano Real, no final do governo Itamar, o que foi até um aspecto importante para credenciar o Fernando Henrique a se tornar Presidente. O senhor acha que isso influenciou de alguma forma na época?

JOÃO PEDRO FERRAZ DOS PASSOS: Sim, sim, influenciou, porque o governo estava extremamente preocupado em controlar todos os índices de inflação. Ele estava primeiro fazendo uma análise de tudo que estava ocorrendo na economia e de todos... fazendo um diagnóstico para saber quais eram as causas que impediam o governo de fazer o controle da inflação, que era uma coisa perseguida há muito tempo, perseguida há muitos anos. Tivemos aí... A gente estava saindo àquela época do que se chamava de vários planos econômicos e que começou com o Cruzado, que era o Plano Cruzado do Sarney, que a inflação... os preços foram congelados e os salários eram reajustados automaticamente sempre que a inflação atingisse $20 \%$ de patamar. Então a gente tinha aquele reajuste de $20 \%$ quase que... Chegou uma época que era mensal... Enfim... Então ele tinha dificuldade, mas nós não estávamos ainda... Se não engano, naquela época, da... que era, não chegou a ser... foi uma moeda que foi estabelecida, um reajuste que foi estabelecido antes do Plano Real...

(...)

RICARDO LOURENÇO FILHO: O senhor acha que isso pressionou o TST de alguma forma? O governo pressionou o TST?

JOÃO PEDRO FERRAZ DOS PASSOS: Não, isso especificamente não. Quer dizer, a pressão do TST... A pressão no TST era sempre, por quê? Porque existia uma limitação do Tribunal de conceder reajustes salariais, de conceder a correção salarial, mas sempre respeitando a política econômica estabelecida pelo governo, inclusive tinha, na época, o Ministério Público tinha o dever de recorrer de todas as decisões... Quer dizer, era um recurso, que era obrigatório para o Ministério Público, dele recorrer sempre que as decisões do TST concedessem reajuste além da política econômica do governo. Então tínhamos essa obrigação de recorrer independente de acharmos que estava certo ou não. Ultrapassou a política 
econômica... Então, o Ministério Público, na época, era também um fiscal da política econômica do governo.

RICARDO LOURENÇO FILHO: O senhor vê algum componente político na greve dos petroleiros?

JOÃO PEDRO FERRAZ DOS PASSOS: O componente político que tinha na época era o componente político que temos hoje. O movimento sindical é envolvido também na política partidária e no interesse dos seus candidatos. Isso naturalmente que tinha naquela época. Como a greve era de um setor que estava sendo comandado pela CUT, então você tinha lá, hoje, o PT, que antigamente era um partido onde predominavam as lideranças sindicais, o movimento de trabalhadores, evidente que sufocar as greves apoiadas pela CUT naquela época era sufocar a outra linha partidária ideológica. Não tem dúvida que, claro que teve, teve muito dessa...desse interesse político de, na época, também fazer com que uma determinada, um determinado segmento sindical fosse sufocado para enfraquecer a política partidária de outros candidatos. Porque a oposição na época era uma oposição de... muito mais áspera do que a que vê hoje. O Lula era na época o líder dos trabalhadores do PT e era um líder dos trabalhadores que ele fazia uma oposição muito, muito severa... ele fazia uma oposição muito severa. Aquela oposição mesmo de assembleia de trabalhador. Ia para a porta do Congresso, ia para a porta do Ministério e tal. E naturalmente que isso ia irritando o governo. E é difícil você separar interesse que é meramente dos trabalhadores dos interesses políticos, principalmente quando esses interesses estão no centro do movimento sindical, como algumas greves que ocorreram de Correio. Não se você viu, no paralelo, se você viu o reflexo dessa greve da Petrobrás na greve dos Correios, na greve de Banco. Tudo isso. As de banco, muito antes, eram greves também que paravam o país. No momento em que você tinha, às vezes, no Banco do Brasil, toda a movimentação de conta do tesouro nessa época. E você tinha também o Banco do Brasil e os bancos particulares todos envolvidos nas mesmas negociações coletivas. Depois é que o Tribunal Superior do Trabalho, por um entendimento jurisprudencial que até hoje não me convenceu, a dizer que o Banco do Brasil, por ser um banco que tem quadro de carreira a nível nacional, tem os seus dissídios coletivos decididos pelo Tribunal Superior do Trabalho. Então nós vamos dizer que... E os bancos particulares? Se o Bradesco tiver um quadro de carreira a nível nacional, o Itaú... Então todas as greves bancárias vão... Todas as empresas. Mas isso é uma jurisprudência que praticamente só se aplicou por setor bancário, e não se aplicou para mais nada. Claro, você tem Petrobrás, tem nível nacional, é evidente. Caixa Econômica é nível nacional, é evidente, porque ela está num setor de economiários. Mas você tem muitos segmentos que... Principalmente segmento 
bancário. Todos os bancos estão organizados a nível nacional. Quer dizer, o mesmo quadro de carreira do Bradesco que funciona em São Paulo funciona na Bahia, funciona... E por que que o dissídio coletivo é ajuizado, por Bradesco, Itaú, etc., e não vai para o Tribunal Superior do Trabalho? Então são decisões que cunho político. Não tem dúvida nenhuma que são decisões de cunho político, numa época em que nós não tínhamos ainda - e aí não tem nada a ver com a sua tese - esses acessos aos tribunais superiores não eram compartilhados, por exemplo, por lista tríplice do tribunal... quer dizer, nomeação direta pelo Presidente da República. Então ficava aquela influência muito maior, que hoje eles não tem, porque você dilui, vai nomear um ministro você tem uma lista com vários ministros, faz uma lista pelo tribunal, você manda para lá para escolher um, vai para os advogados você tem a lista da Ordem, depois transforma... Ministério Público é a mesma coisa... Naquela época não, antes da Constituição, a nomeação dos ministros era de livre escolha do Presidente da República. Então esses ministros sofriam uma influência política, não tem a menor dúvida, muito mais... Embora fossem vitalícios, etc., mas tinha uma influência política... Vinham de um regime em que eles não tinham nenhuma liberdade de... Ficavam decidindo o dissídio coletivo, mas sempre atrelado e aplicando a política econômica do governo. Quer dizer, nunca ultrapassavam isso. Então claro que o movimento, as greves, elas tinham também um componente político, não tinha dúvida nenhuma. Independente disso era gancho para você fazer movimentos políticos pelo Brasil inteiro. 


\section{$\underline{\text { Anexo II }}$}

BRITTO, Cézar. Depoimento sobre a greve dos petroleiros de 1995. Entrevistador: Ricardo Machado Lourenço Filho. Brasília, 14 de julho de 2014. Arquivo de som M4A.

CÉZAR BRITTO: (...) Por que a Constituição não muda? Todo aquele arcabouço que vem da Era Vargas, que sobrevive à ditadura militar, sobrevive pós 46 e pós ditadura militar, de que era preciso suavizar a exploração, nunca acabar com a exploração mas suavizar, mas castrar o movimento sindical. Por que não houve a mudança quando a Constituição fala: liberdade estatuária, direito de greve, proteção aos trabalhadores como princípio fundamental? $\mathrm{Na}$ minha compreensão é a de que é muito mais fácil mudar uma Constituição, uma lei, do que mudar a cabeça do homem. E toda a ideologia brasileira de compreensão dos movimentos dos trabalhadores como coisa anarquista, comunista, petistas e outros "-istas" permaneceu nos julgadores. Nós fizemos no Brasil uma transição sem mudanças. Quem estava no sistema anterior continuou pós-88. Os governantes eram os mesmos. O Presidente da República era o Sarney, foi Presidente da ARENA. Os militares eram os mesmos. Os julgadores eram os mesmos. Então não houve mudança substancial. Então essa ideologia de repressão aos trabalhadores, às organizações de trabalhadores, permaneceu intacta, mesmo com a expressa vontade da Constituição de mudar, mesmo em reconhecimento aos trabalhadores do $\mathrm{ABC}$, mas que fizeram o Brasil mudar. É por isso que a liberdade estatutária, que nós pensávamos que conquistávamos, o TST vem decidir depois que permanece os sete dirigentes sindicais. As greves que eram ilegais ou legais passaram a ser abusivas e não abusivas, com os mesmos fundamentos. Então não houve modificação. E uma das formas mais inteligentes que se encontrou para manter esse distanciamento do mundo do direito do mundo sindical foi exatamente não permitir que o mundo do direito estudasse o mundo sindical. Até hoje não se ensina direito sindical nas universidades brasileiras. Isso significa que juízes, promotores e advogados não cuidarão da matéria. Uma outra tentativa também foi dizer que a Justiça que cuida do "capital-trabalho" é Justiça menor, secundária, sem importância. Para que desestimule as pessoas que se sintam inteligente de ir para essa Justiça pequenininha, sem força. Isso é perceptível até nas composições nas mesas, nas solenidades no Brasil. O mundo do trabalho é chamado depois do mundo civilista, sempre. A dificuldade que nós temos de se ter... colocar pessoas especializadas no mundo do trabalho na Corte Suprema. Então essa ideologia do afastamento do mundo do direito do mundo sindical, do mundo dos 
trabalhadores resulta na manutenção da mesma legislação de Vargas, ou da mesma legislação antes de Vargas. Essa compreensão que não pode permitir aquelas que possam acabar com o lucro, com a mais valia, fortalecer aqueles que possam acabar com o lucro, com a mais valia. Essa para mim é... Uma outra forma também de repressão é retirar o direito de defesa dos trabalhadores. A Justiça do Trabalho não permite o direito de defesa do cidadão. Ele teria que ir para um ambiente que não é seu, com roupas que não é dele, com conhecimentos que não tem, para combater o outro lado, que geralmente comparece com seus advogados. O mesmo raciocínio de exclusão que posteriormente é repetido no Juizado Especial, que é a Justiça dos pobres. Retira-se dos pobres o direito de defesa. E do outro lado no Juizado Especial, exatamente os mesmos clientes da Justiça do Trabalho, os bancos, as empresas de telefonia, todos acompanhados de advogado. E mais uma vez um desrespeito à Constituição, porque a Constituição já tinha dado solução para isso, para a Justiça para os pobres, os advogados chamados defensores públicos. Então não se deu defensor público e ainda retirou o direito de defesa. Tanto no Juizado Especial, quanto na Justiça do Trabalho. Eu lembro, em Sergipe uma pesquisa que você pode até aprofundar no caminho - Sergipe resolveu retirar o ius postulandi das partes. Logo depois, um Presidente que substitui aquele que tinha retirado o ius postulandi tinha me dito que estava pensando em voltar o sistema anterior porque os juízes estavam se queixando porque as reclamações trabalhistas estavam mais aprofundadas e isso estava dificuldade o julgamento. E eu disse: "Presidente, vocês deviam raciocinar que foram anos de reclamações não formuladas corretamente, foram anos de violação de direito. Porque você procura quem não conhece, você vai pedir, horas extras, férias e equiparação salarial. Quando você procura advogado vem danos morais, danos coletivos... Mostra claramente esse exemplo de que foi proposital a retirada do direito de defesa técnica dos trabalhadores. Isso eu ponho alguma coisa no livro...

(...)

Você está escrevendo sobre o livro que eu queria escrever, que é a aventura de Fernando Henrique de privatizar a Petrobrás. A greve de 1995 tem esse conteúdo. Quando Fernando Henrique quis privatizar a Petrobrás, criou a Petrobrás... Por que ele criou a Petrobrás se ele mudou a cor da Petrobrás? É a mesma razão que ele quis acabar com os petroleiros. A Petrobrás, para o brasileiro, é uma propriedade pessoal, o Brasil se sente dono da Petrobrás. A cor verde e amarela, o nome, Petróleo brasileiro, a campanha do monopólio que resultou na propriedade fez com que nós incorporássemos a Petrobrás como algo nosso. Então a estratégia de privatizar a Petrobrás era um pouco mais delicada do que nas outras empresas. Por isso mudar o nome, de Petrobrás, de Petróleo brasileiro, para Petrobráx, tirar a cor a verde 
e amarela, vai ser azul, e acabar com a resistência dos trabalhadores petroleiros. Eu advogo para os petroleiros há 28 anos e não conheço uma categoria que se sente mais proprietária da empresa do que a Petrobrás. Eu tenho um processo que é um exemplo disso. Depois lhe dou o número do processo, eu tenho até cópia dele lá em Aracaju.

Existia uma subsidiária da Petrobrás chamada Nitrofértil. Ela entrou no rol das empresas privatizadas por Collor. Quando Collor assume e vem o Plano Collor - aquele 84,32\% -, eu ingresso na Justiça com ação pedindo, não só os 84,32\%, mas, havia um acordo coletivo assinado no sistema da Petrobrás dizendo assim: que a empresa se compromete a reajustar os salários nos termos, critérios, índice da lei do IPC. Aí eu peço 84,32\%, de abril... Daria um reajuste de quase $250 \%$ na remuneração dos petroleiros da Nitrofértil. À época, o nosso tribunal era vinculado à Bahia. O processo vai para a Bahia, depois, com o desmembramento, vai para Sergipe e a Petrobrás não percebe. Ganha o processo em Aracaju. Eles não recorrem, porque não perceberam a mudança. O processo transita em julgado. Mais ou menos uns 200 milhões de dólares. Logo a seguir, se tenta privatizar a empresa, efetivar o que Collor tinha posto, no governo Fernando Henrique mais à frente. Mas tinha essa dívida de 200 milhões. O que que os trabalhadores fazem? Renunciam aos 200 milhões de dólares para a empresa não ser privatizada. A empresa passar a ser incorporada à Petrobrás, deixa de ser Nitrofértil e passa a ser Petrobrás. Abriram mão de 200 milhões de dólares, eu abri mão dos 20 milhões de dólares dos honorários sucumbenciais, contratuais. Mas esse processo demonstra o amor que tinham à empresa. Quando Fernando Henrique, mais à frente, quis privatizar a empresa, não podia, porque tinha uma cláusula que teria que pagar o processo, os 200 milhões de dólares. Então, esse amor é muito forte nos petroleiros. E era preciso quebrar essa estrutura. Daí a greve de 1995. Como é que surge? Aí vou dizer na ótica dos trabalhadores e do advogado que participou dela. Porque eu integrei o núcleo jurídico da greve, como advogado dos petroleiros de Sergipe e Alagoas, embora não tenha sido eu o advogado central, era Boechat. Mas eu participava das negociações, eu participava do núcleo de defesa do processo.

Havia uma greve anterior que se reivindicava um reajuste salarial. Não sei se houve paralisação de um dia ou dois. Só sei que os trabalhadores sentaram com Itamar, que era Presidente da República, e se negociou esse reajuste salarial e algumas condições de trabalho diferenciadas. O encontro é presenciado por vários ministros. O Itamar assina o acordo. Demora mais um tempo e não se implementa o acordo. Os trabalhadores ameaçam entrar em greve e esse acordo é ratificado pelo Ministro de Minas e Energia e pelo Superintendente da Petrobrás, Clotário - esse nome é importante porque ele morre durante a greve - Clotário, que era Superintendente da Petrobrás e encarregado do Recursos Humanos. Ele quem fazia as 
negociações em nome da Petrobrás. Mais à frente, o governo Fernando Henrique assume e resolve descumprir o acordo. Então o acordo é... A greve é para que se cumprisse o acordo assinado pelo Presidente da República, pelo Ministro de Energia e pelo Diretor de Recursos Humanos da Petrobrás, o Clotário. Evidentemente que aí não se chega a um acordo. Estourase a greve e aí instaura-se o dissídio coletivo - que é o que lhe interessa...

O dissídio coletivo começa a ser julgado pela abusividade ou não do direito de greve. E aí começa a se mostrar como o TST estava a serviço do governo Fernando Henrique, especialmente seu Ministro, porta voz lá dentro, que era o Ministro Almir Pazzianotto. Eu falo porque Pazzianotto, embora não relator, não sendo o relator, ele que negociava conosco no TST algumas saídas jurídicas para o processo. Quando começa o julgamento, a primeira preliminar que é posta pelos trabalhadores era a exclusão do Sindicato de Pernambuco da decisão do dissídio. Porque a assembleia de Pernambuco tinha decidido expressamente não aderir à greve. Você viu isso lá no acórdão. Ora, se ele não tinha aderido à greve, qualquer julgamento sobre abusividade, não poderia atingi-lo. $O$ Tribunal rejeita a exclusão ao argumento de que os sindicatos não podem, não tem legitimidade para atuar perante os tribunais superiores, portanto, não poderia pedir exclusão, porque não tem legitimidade, somente a Federação podia fazê-lo. O que gerou depois um outro absurdo: a condenação por ato dos sindicatos que não foram parte do processo. Ora, se o Tribunal tinha dito que a Federação é que era representativa e os sindicatos não poderiam apresentar sua defesa, não poderia ser também objeto da condenação. Ainda assim o Tribunal condena os sindicatos, inclusive o Sindicato de Pernambuco.

Prossegue-se o julgamento. E nesse dia, o relator começa a desmontar a tese de que o acordo assinado com o Itamar e o Ministro de Energia, e esquecia a presença do Clotário assinando o acordo, não tinha a forma de acordo coletivo de trabalho a justificar a paralisação por descumprimento de acordo coletivo, que é uma das regras que permitiria, na legislação pósConstituição, o exercício do direito de greve. E aí ele... que não era acordo, não era acordo. O Procurador à época, Ives Gandra, estava num dia muito feliz, decerto que também estava convencido de que a greve era legal, ou não abusiva, porque exigia o cumprimento... O Ives Gandra pede a palavra e diz o seguinte: "se os senhores estão dizendo que o documento assinado pelo Presidente Itamar não tem validade, e nem o Ministro da Justiça, eu vou ter que processá-los criminalmente. Na nota taquigráfica não está esse diálogo não...

RICARDO LOURENÇO FILHO: Acho que não...

CÉZAR BRITTO: Pois é... Ele diz assim: "então vou ter que processar o Presidente da República, o Ministro também, por ter induzido uma categoria a erro, assinado documentos 
que não tem competência para assinar, causando esse prejuízo para o Brasil. Nisso, o Ministro Pazzianotto faz uma intervenção e diz: "Não, eu não estou dizendo que não vale. Não vale enquanto acordo coletivo, mas tem força política e tem força moral. Mas não vale enquanto acordo coletivo".

Prossegue o julgamento. É rejeitada qualquer discussão sobre a validade ou não do acordo coletivo porque tinha ficado implícito que ele teria força moral e força política mas não teria então força enquanto acordo coletivo de trabalho a justificar, o descumprimento, a greve. Aí o processo vai seguindo. Era Ursulino o relator. E quando chega em um dos Ministro, não lembro, não recordo qual... Talvez a nota taquigráfica possa dizer. Ele começa a dizer assim: “Espera aí, mas eu tinha uma dúvida. A Federação dos petroleiros existe ou não existe?

RICARDO LOURENÇO FILHO: Acho que foi Pedrassani...

CÉZAR BRITTO: Foi Pedrassani... Eu confundo porque teve um outro que fez uma outra observação depois de Pedrassani. Então foi ele mesmo. "Eu tenho uma dúvida...” Por que essa dúvida? Porque, nessa época, em 1995, os tribunais estavam relutantes em aceitar as novas federações, que eram federações mais avançadas, que eram contrárias a algumas federações cartoriais e arrecadatórias. Então havia uma tentativa de manter o sistema federativo anterior, mesmo pós-Constituição ter criado a pluralidade no sistema federativo, e a unicidade apenas nos municípios. Então havia essa vontade. Ele começa a folhear o processo. Quando ele está folheando o processo, o Ives Gandra de novo disse: "Mas gente, não há litígio sobre essa parte, a Petrobrás que ingressou com o dissídio contra a Federação". Aí Pazzianotto faz a intervenção dura de novo contra... "Mas por acaso a Petrobrás é cartório? A Petrobrás é Ministério do Trabalho?” E, de novo, ele bate em cima do Ministério Público para dizer que essa argumentação estava equivocada. Aí, quando estava nesse debate, eu chamo os advogados, para uma reunião, e propus que a gente reconhecesse na tribuna que a Federação não estava registrada no Ministério do Trabalho. Aí os caras: "Você está maluco, Cézar". Aí eu: "Confia em mim, confia em mim e vá para a tribuna dizer que não está registrada". Aí Boechat vai para a tribuna: "Excelência, não precisa procurar nos autos não. A Federação dos petroleiros não está registrada no Ministério do Trabalho. Está em andamento, mas não está deferida ainda a carta sindical". Aí foi um sorriso geral dos ministros. Ursulino retoma a palavra para acrescer ao voto a afirmação de que aí que o acordo não valia, porque subscrito por entidade que não estava... por entidade sindical que não está registrada. Aí todo mundo quis me linchar, né? Piorei o julgamento. Quando retoma, aí vai esse outro Ministro que eu não lembro quem é. Ele fez... Por isso nós queríamos as notas taquigráficas, por causa desse Ministro. Porque ele fez: "Espera aí, tem algo errado. Tem algo errado. Se eu disser que a 
Federação dos Petroleiros não existe, vamos ter que anular o processo todo, inclusive a abusividade da greve, porque a Federação não existindo não poderia ser ré no processo. Tínhamos que anular e chamar a Confederação dos trabalhadores. Como é que eu vou explicar ao governo que a greve não acabou por questão jurídica?” Então ele faz essa afirmação e causou aquele silêncio lá no Tribunal E o povo viu que eu tinha razão na estratégia de reconhecer a inexistência. Como que o Tribunal ia se sair disso? Se a Federação não existia todo processo teria que ser anulado, ganharíamos mais 15 dias, até intimar a Confederação, nova audiência de conciliação, novo julga...mas a greve prosseguiria. Aí inventaram uma nova teoria, que está lá no acórdão, que a ementa do acórdão, que a Federação dos petroleiros não existe, como confessou o advogado da tribuna, porém, neste caso específico, tem legitimidade de fato. E aí que foi o acórdão que ficou. Veja o raciocínio que determinou no Tribunal... Por isso que o TST é condenado na OIT, o Estado brasileiro, já que ele é integrante do Estado. Um órgão que não existe, não tem personalidade jurídica pode deflagrar uma greve, ser parte num processo e o efeito do julgamento desse processo atingir os sindicatos que o próprio Tribunal diz que não tinham legitimidade para atuar. Então foi uma das grandes aberrações jurídicas. Mas não acaba aí.

Quando termina o julgamento, os trabalhadores permaneceram em greve mas procuraram uma saída jurídica. Foi aí que nós começamos a conversar com os Ministros do TST. A saída foi dar provimento parcial ao nosso recurso para reconhecer que o acordo tinha efeito político possível, embora não tivesse o efeito nenhum enquanto acordo coletivo de trabalho. Se reconhecesse que teria efeito moral ou cível a Petrobrás daria o reajuste e nós acabaríamos a greve, as multas podiam ser pagas ou discutidas. Isso foi mais ou menos acordado em reuniões em que participou o Ministro Pazzianotto. Quando estávamos certo que teríamos mais ou menos isso, o Palácio mudou de novo o entendimento e, quando nós fomos para o julgamento, o que já tinha sido acordado, que daria provimento para esclarecer essa matéria nem essa matéria foi esclarecida.

Durante a greve morre o Clotário, de tão desautorizado que foi e se expressou que ele não tinha poder nenhum para fazer o acordo e ele termina morrendo durante a greve. E é nesse momento em que o TST nega qualquer perspectiva de saída jurídica para a greve que os trabalhadores resolvem colocar o jegue na porta do TST. E aí com essa atitude dos trabalhadores, gerou um acirramento maior ainda dos ânimos e do próprio Tribunal, que passa a executar todo o processo, nos autos do dissídio, pendente de recurso e se penhora os bens dos sindicatos todos no Brasil. E os sindicatos ficam sem recurso. Daí que, nesse período, os sindicatos adoram algumas medidas muito importantes para reagir. Medidas judiciais, como a 
denúncia do caso à OIT, que resultou depois na condenação do governo brasileiro e obrigou o governo brasileiro a adotar uma lei de anistia, primeiro para as multas depois uma lei de anistia para os trabalhadores. Acho que é a Lei Zica, a Lei Zica. No campo da luta política, outras medidas foram tomadas. Os sindicatos decidiram, já que as contas estavam penhoradas, as mensalidades, em assembleia, reduziram o desconto da mensalidade, de $1 \%$ para $0,1 \%$. E essa diferença de $0,9 \%$, os trabalhadores depositaram em associações de fundos de greve que foram criadas nesse período. Então os trabalhadores voluntariamente depositavam na conta do banco esse dinheiro para manter a estrutura sindical e manter os dirigentes. Mas tem uma declaração do Ministro de Minas e Energia de Fernando Henrique, publicada na Veja, que nós utilizávamos na defesa dos trabalhadores, que bem simboliza. Eu vou lhe dar depois a Veja, a página, para você procurar. O Ministro de Minas e Energia dizia assim, era Raimundo Brito: "que adotei na Petrobrás uma prática terrorista. Demiti os melhores trabalhadores e os piores, para criar um clima de medo, terror e desorientação". Aí mostra qual foi de fato a posição do governo Fernando Henrique em relação aos petroleiros. Criar um clima de medo, terror, para que depois se privatizasse a empresa.

RICARDO LOURENÇO FILHO: Eu me deparei com essa reportagem. Achei impressionante também.

CÉZAR BRITTO: Você tem ela, né? Da Veja, né?

RICARDO LOURENÇO FILHO: O relato do Ministro é impressionante. É bem frio... É "demitimos inclusive trabalhadores que não estavam envolvidos com a greve..."

CÉZAR BRITTO: Ele botou assim: "trabalhadores padrão, para criar um clima de medo, terror”. Então o cara não estava demitido por causa da greve, ele estava... A greve é que foi um objeto para dizer: "cara, não resistam mais porque eu vou privatizar sua empresa, se não vocês vão perder seus empregos". Foi um período de... duro na vida dos trabalhadores. E graças a essa fórmula, de você criar um fundo de greve, a OIT, o Brasil teve que se ajustar...

RICARDO LOURENÇO FILHO: Nessa postura do TST, na reação do TST, tem a questão da privatização da Petrobrás... Alguma questão econômica influenciou? O Plano Real?

CÉZAR BRITTO: Não, porque, não acho que a questão econômica foi relevante porque a Petrobrás concordava com o aumento. Tanto concordava com o aumento que deu o aumento. Ela concordou com o aumento antes. Portanto que o Clotário falava pela empresa. Deu aumento antes, concordou no meio da greve de reajustar e depois de cessadas essas discussões todas, o aumento veio. Então nunca foi uma questão econômica. Sempre foi uma questão política, contra o movimento sindical e a resistência que os petroleiros sempre tiveram em relação a qualquer medida de desgaste da empresa, pela paixão que eles tem. 
RICARDO LOURENÇO FILHO: Eu li em alguns jornais, principalmente no ano anterior, depois do acordo com Itamar, que dentro do próprio governo surgiram alguns questionamentos e muitos diziam que o acordo talvez pudesse colocar em risco o Plano Real... CÉZAR BRITTO: Não, porque, se a empresa propôs, se havia depois a saída... houve reajustes, então não tinha porque... A ideia mesma essa que o Ministro Raimundo Brito colocou: criar um clima de medo. Ora, se não tinha mais a força... E foram várias as medidas... Isso você mostra com a virulência com que é atacada a estrutura sindical, com confisco de bens, penhora, demissão de líderes...

RICARDO LOURENÇO FILHO: Na sua visão, o TST tinha uma informação do governo sobre essa postura quanto ao movimento sindical?

CÉZAR BRITTO: Tinha porque o Ministro Pazzianotto conversava o tempo todo com o governo. E isso não era negado nem pelo Ministro Pazzianotto. Porque nas reuniões que nós tínhamos com ele, ele dizia que estava conversando o tempo todo. (...) Conversando com alguns procuradores da época, que estavam vendo também o outro lado, todos sabíamos que a regra era mesmo acabar com o movimento sindical. Parecia ser essa a... E a frase do Raimundo Brito era muito clara. A gente muito isso na defesa dos trabalhadores. Para mostrar: olha, havia uma intenção clara, ruim ou não, pouco importa se o demitido era ruim ou bom, até porque ele podia ser o bom. Nós dizíamos que ele era o bom. Diziam que o padrão estava demitido. Então foi uma intenção muito clara de privatização. 